SUSTAINABLE HERITAGE

MANAGEMENT PRACTICES AT

VISITED HERITAGE SITES IN DEVON AND CORNWALL

\author{
Darlow, Susan Elizabeth Joan
}

http://hdl.handle.net/10026.1/482

http://dx.doi.org/10.24382/1568

University of Plymouth

All content in PEARL is protected by copyright law. Author manuscripts are made available in accordance with publisher policies. Please cite only the published version using the details provided on the item record or document. In the absence of an open licence (e.g. Creative Commons), permissions for further reuse of content should be sought from the publisher or author. 
*

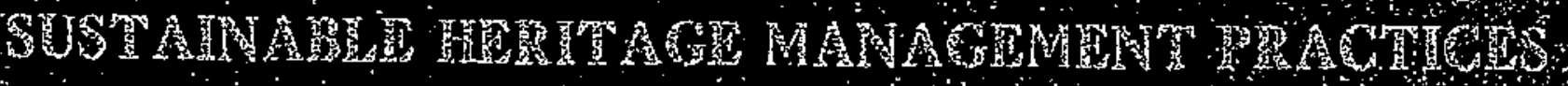

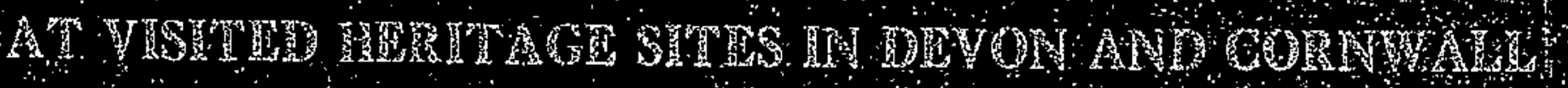

\section{BA}

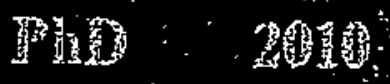




\section{Copyright}

This copy of the thesis has been supplied on condition that anyone who consults it is understood to recognise that its copyright rests with its author and that no quotation from the thesis and no information derived from it may be published without the author's prior consent. 


\title{
SUSTAINABLE HERITAGE MANAGEMENT PRACTICES \\ AT VISITED HERITAGE SITES IN DEVON AND CORNWALL
}

by

SUSAN ELIZABETH JOAN DARLOW

A thesis submitted to the University of Plymouth

in partial fulfilment of the degree of

\author{
DOCTOR OF PHILOSOPHY.
}

School of Geography, Earth and Environmental Sciences

Faculty of Science and Technology 


\section{Susan Elizabeth Joan Darlow \\ Sustainable Heritage Management Practices \\ at Visited Heritage Sites in Devon and Cornwall \\ ABSTRACT}

Sustainability is one of the key challenges facing society in the twenty-first century. The adoption of sustainable practices in the heritage sector resonates with its long-established objectives to conserve and enhance the historic environment, although its implementation can also present significant dilemmas for the commodification, integrity, authenticity, accessibility and viability of these resources, particularly where sites are tourist attractions. The aim of this thesis was to investigate progress in the adoption of sustainable practices in heritage properties and sites in Devon and Cornwall. The findings were based on the compilation of an inventory of selected heritage resources; an extensive questionnaire survey of managers of historic houses and castles, historic churches, and museums and archives (416 responses), which investigated the extent of, and opinions about, sustainable management approaches; and semistructured, face-to-face interviews with eight heritage managers, which probed key issues in much greater depth.

The results of the research demonstrated some similarities with the adoption of sustainable practices in other sectors, such as the practical issues associated with costs and lack of knowledge. There were also some heritage-specific issues, such as perceived conflicts with protection duties, the consequences of being largely dependent upon volunteer staffing, and the institutional role of larger parent organisations, which have been overlooked in previous research. Most significantly, the results indicated that very few heritage sites produced 
sufficient surpluses to facilitate investment in sustainable practices that might ultımately enhance their financial viability and fund enhanced conservation activities Future strategies for the sector as whole must therefore not only deal with capacity-butding, such as access to information and training on sectorspecific sustanable management, but also address the institutional factors governıng heritage in the UK, such as strategic leadershıp, the most effective models for governance and funding mechanısms for sustanability, and the creation of local and regıonal heritage networks. 


\section{Contents}

Abstract

Contents . . iii

List of Figures ix

List of Tables xvii

List of Abbreviations $\quad x x i$

Acknowledgements xxiii

Author's Declaration $\quad$ xxivi

CHAPTER 1. THE SUSTAINABILITY OF HERITAGE AND HERITAGE TOURISM 1

1.1 Introduction 1

1.2 Growth of interest in heritage and heritage visiting 3

$\begin{array}{ll}\text { 1.3 Defining heritage and heritage resources } & 7\end{array}$

1.4 Scholarly interest in heritage 14

1.5 Theoretical debates in heritage studies and sustainability 16

$\begin{array}{ll}\text { 1.5.1 Conservation theory } & 19\end{array}$

1.5.2 Commodification theory and economic sustainability 24

$\begin{array}{ll}\text { 1.5.3 Authenticity theories } & 27\end{array}$

1.5.4 Elitist/Social exclusion theory 29

1.5.5 Interpretation theories 32

1.5.6 Segmentation and visitor profiling theories 37

1.5.7 Environmental sustainability theories 38

1.6 Sustainable management policies $\quad \cdot \quad 39$ 
162 English Heritage

1.6.3 The Historic Houses Association

164 The Church of England

16.5 The Churches Conservation Trust

1.6.6 The Museums, Libraries and Archıves Councll 
3.2.1 Defining and Classifying the Southwest's Visited Heritage 144

3.2.2 Phase 1: Inventory Stage - Design, Development and Pilot 149

3.2.3 Phase I: Inventory Stage - Populating database

3.4 Phase III: Sustainable Management Research Stage (In-depth Interview Stage)

3.4.3 Interview schedule and design 
CHAPTER 4. ENVIRONMENTAL, SOCIO-CULTURAL, AND ECONOMIC SUSTAINABILITY IN THE MANAGEMENT OF VISITED HERITAGE IN DEVON AND CORNWALL.

193

40 Introduction 193

4.1 Sustannable Management of Heritage 195

4.2 Environmental Sustainability 197

4.22 Adoption of Environmental Measures The Implementation Gap

202

42.3 Constraints on the implementation of sustanability measures in heritage sites

213

43 Socio-cultural Sustainability 224

4.31 Provisıon of Heritage Interpretation 225

4 3.2 Engagement with the Local Community 244

4.4 Economic Sustannability 249

4.41 The Means of Income Generation 254

44.2 Expenditure 257

4.4 3 Profitablity 259

4 4.4 Barriers to Profitability 263

4.45 Maximising Income from Heritage Visitors: Market Research 265

4 4.6 Examples of Successful Profit Generation 272 
5.1 Outcomes in Relation to the Aims and Objectives of the Research

5.2.1 Objective 1: Awareness of heritage managers of sustainability issues and attitudes towards the adoption of sustainable management practices.

5.2.2 Objective 2: Priorities accorded to, and implementation of, various kinds of sustainable management.

5.2.3 Objective 3: Barriers to the implementation of environmentally sustainable policies and/ or financially robust management, and the delicate balance between public access and conservation/ custodianship

5.2.4 Objective 3: Perceptions and opinions about the benefits, problems and barriers to the implementation of sustainable management.

5.2.5 Objective 4: The extent of commodification and its implications for sustainability and heritage places that do not easily lend themselves to direct commodification.

2.2.6 Objective 5: The role of larger parent organisations in the implementation of sustainable management practices.

295

2.2.7 Objective 5: Evidence of existing dissemination of good practice, expertise and knowledge within and across the categories. 297

2.2.8 Objective 5: Modelling progress towards the sustainable management of Devon and Cornwall's heritage resources. 298 
532 Establishing the best model for 'governance' of heritage resources

533 Management Train!ng

309

534 Applying for Grants and Support

535 Improvements in access to information on Sustainable Management

536 Radical Suggestions

54 Critique of Research and Research Design

541 Methodological Limitations

542 Conceptual Issues

5.43 Geographical Limitatıons

5.4.4 TIme and cost constrants

322

5.5.1 Research in other regions

552 Industrial heritage in Devon and Cornwall

553 Historic houses and castles

5.5.4 Linear or progressive adoption of sustainable management

555 Cross-cultural comparison

5.5.6 Attıtudes of the heritage visitor

557 Sustanable transport

5.5.8 The sustannability agenda and other key stakeholders

559 Evaluation of the cost and benefits of sustanable management 


\section{APPENDICIES}

Appendix 1. Listed Building Status Explained

Appendix 2. Conservation Area Status Explained

Appendix 3. AONBs, SSSI and National Parks

Appendix 4. The Heritage Lottery Fund

Appendix 5. Quantitative Survey

Appendix 6. Survey Cover Letter

Appendix 7. Semi-Structured Interview Questions 388

Appendix 8. Interview Transcripts A-H 394

Appendix 9. Publications 


\section{List of Figures}

Figure 2.1 St German's Church, Cornwall. The magnificent Romanesque doorway was described by Samuel Rowe in his 1821 guidebook.

Figure 2.2 Areas of Outstanding Natural Beauty

Figure 2.3 The Forrabury open field 'stitches', Cornwall. A small surviving area of open field strip farming.

Figure 2.4 Tor Royal farmhouse, Princetown, Dartmoor. The house was built as part of Sir Thomas Tyrwhitt's reclamation project in the lateeighteenth century.

Figure 2.5 Emmet's Grange farmhouse, Exmoor. One of the new farms created in the former Royal Forest as part of its reclamation by John and Frederick Knight in the early nineteenth century

Figure 2.6 The traditionally managed hay meadows on the Duchy farm holding at Dunnabridge, Dartmoor (a) butterfly orchid (b) common spotted orchid.

Figure 2.7 Bronze Age remains at Merrivale, Dartmoor (a) stone rows (b) house remains.

Figure 2.8 Bronze Age megalith, Men-an-Tol, West Penwith, Cornwall. 77

Figure 2.9 Iron Age stone-built village remains at Chysauster, Cornwall.

Figure 2.10 Dartmoor Medieval Settlement of Houndtor, Dartmoor.

Figure 2.11 Dartmoor Medieval Settlement of Hutholes, Dartmoor. 80

Figure 2.12 Dartmoor Medieval Farmstead of Dinna Clerks, Dartmoor. 80

Figure 2.13 Lydford, aerial view of the ninth-century 'Alfredian' burh. 
Figure 216 Exeter Cathedral, displaying Romanesque, Early Gothıc, Decorated and Perpendicular architectural elements.

Figure 2.17 Churchi of St Grada, Ruan Mınor, Cornwall. A Grade I listed Church on the Lizard Penınsula. One of hundreds that exıst across Devon and Cornwall

Figure 218 St Andrews Church Aveton Giffard The original church comprised a cruciform medieval structure until it was heavily damaged by bombing in the Second World War The church was rebult as a copy of the medieval original but has additional heritage significance as a result of its wartime damage and post-war restoration.

Figure 221 United Methodist Church, Bodmin Street, Holsworthy This enormous Edwardian buldıng was completed in 1910 but it occuples the site where a Methodist place of worship has stood since 1841 . The building is normally locked and cannot be easily visited by heritage tourists

Figure 222 St Nicholas's Priory, Exeter. This Benedictıne priory became a home after the Dissolution and is now managed by the Royal Albert Memorial Museum and is open to visitors on certain days.

Figure 223 Buckland Abbey. National Trust Historic House site located on the edge of Dartmoor. After the Dissolution of the Cistercian monastery of Buckland, the property was purchased by the Grenville family and converted Into a domestic residence. When Francis Drake returned from his circumnavigation of the globe (1577-1580), newly knıghted and enrıched with looted Spanish 
gold, he invested his acquired wealth by purchasing property. Amongst his new houses was Buckland, which he bought from Sir Richard Grenville.

Figure 2.24 Monastic barn of the Cistercian Abbey of Buckland.

Figure 2.25 Monastic ('Spanish') Barn of the Premonstatensian Abbey of Torre

Figure 2.26 Remains of the great Benedictine Abbey at Tavistock

92

Figure 2.27 Buckfast Abbey: rebuilt by Benedictine monks in the latenineteenth and early twentieth centuries on the site of the medieval Cistercian monastery.

Figure 2.28 Higher Uppacott: a medieval Dartmoor longhouse which still has its cattle byre or 'shippon' intact.

Figure 2.29 Sanders, Lettaford: a large, stone-built Dartmoor cross-passage longhouse which still has its large shippon intact.

102

Figure 2.30 Totnes Castle: A Norman motte and bailey Castle 102

Figure 2.31 Cotehele, St Dominic, Cornwall: a late-fifteenth century house set in an extensive estate.

104

Figure 2.32 The Guildhall, Exeter. The original medieval structure was rebuilt in the 1590s.

Figure 2.33 The 'House that Moved' at the foot of Stepcote Hill, Exeter. Threatened by demolition to allow for road improvements, it was moved on rollers to this position in 1961.

Figure 2.34 The Tudor Merchant Houses in High Street, Exeter. While the buildings behind these conserved facades have been entirely rebuilt, the conservation of the structures has preserved a glimpse of the dwellings of the wealthier sort in the seventeenth-century city. 
Figure 235 Tudor shops/houses at the foot of Stepcote Hill, Exeter, demonstrate the problems of finding appropriate uses for heritage bullings.

106

Figure 2.36 Godolphın House, Cornwall. Acquired by the Natıonal Trust in 2000 and now undergong costly conservation

108

Figure 237 The Baroque Gateway of the Royal Citadel on Plymouth Hoe, completed in 1670

108

Figure 238 Barnfield Crescent, Exeter. A very fine example of the graceful elegance of Georgian provincial architecture.

Figure 2.39 Exeter's Victorian Market Building in Queen Street, completed in 1838.

Figure 2.40 The Royal Albert Memorial Musuem, Queen Street, Exeter, completed in 1868.

Figure 241 The Rougemont Hotel, Exeter, completed in 1878.

Figure 2.42 Nineteenth-century agricultural estate workers cottages at Dartıngton

Figure 243 Fitzford, Tavistock. Miners' cottages, bult by the Bedford Estate in the 1860 s

Figure 244 West Exe, Tiverton: Lace factory workers cottages bult by John Heathcoat in the 1840s

Figure 245 Tamar View (now know as the Horn of Plenty), near Tavistock, bult by the Devon Great Consols Mine for its mine manager in 1866

Figure 246 Saltram House, near Plymouth. A largely eighteenth-century house but with some Tudor elements surviving in the inner court. In the early nineteenth century, John Foulsdon, the local architect, designed the somewhat heavy porch. 
Figure 2.47 Tinside Lido Plymouth: first opened in 1935 and described at that time as 'one of the finest open-sea bathing centres in the country (BBC 2006), Plymouth's pool is built in the fashionable Art Deco style with a classically proportioned sem-circular pool. It closed in 1992 and in 1998 the pool became a Grade $\mid \mathrm{f}$ listed building and has since been fully restored at a cost of $£ 3.4 \mathrm{~m}$.

Figure 2.48 Holsworthy: Art Deco façade of former cinema; conserved in 2002 and now home to the town's amateur theatre company.

Figure 2.49 The Ten Designated Mining Landscapes of the 2006 Cornwall and West Devon World Heritage Site.

Figure 2.50 Botallack Mine 'count house' (National Trust)! ?

Figure 2.51 The Levant Engine Houses (National Trust), West Penwith

Figure 2.52 Morwellham, Devon. The quayside buildings.

Figure 2.53 Tuckers Hall, Fore Street, Exeter: the restored façade of part of the building of the city's medieval Tuckers, Shearers and Fullers Guild.

Figure 2.54 Remains of an Arsenic Calciner, Blanchdown Woods, Tavistock. This is an area of toxic ground and other hazards. 125

Figure 2.55 The Gunpowder Testing Mortar at Powder Mills, Dartmoor. 125

Figure 2.56 Postbridge, Dartmoor Clapper Bridge.

Figure 2.57 Former Turnpike Tollhouse (on A379), now used as private house, but displaying board showing charges or tolls for users of the thoroughfare in the turnpike era.

Figure 2.58 Derriton Viaduct, Holsworthy, completed in 1898 and restored as a footpath and cycle track with Heritage Lottery Fund support in 2007.

Figure 2.599 Holsworthy's older railway viaduct, completed in 1879 . 
Figure 2.60 Totnes, Devon, one of the surviving Engine Houses of Brunel's Atmospheric Rarlway.

Figure 261 The Historic Harbour of llfracombe

Figure 2.62 Ilfracombe's Heritage Harbour.

Figure 2.63 Steam Locomotive belonging to the South Devon Rallway

Figure 264 Totnes termınus of the South Devon Railway and the Rare Breeds Farm

Figure 2.65 Plymouth Museum, Plymouth: A museum with layered hentage significance The Plymouth museum holds extensive and diverse displays of heritage giving it significant heritage significance Additionally, the building has significant hentage value in its own right.

Figure 2.66 The National Maritıme Museum, Falmouth.

Figure 31 Process map of Inventory creation.

Figure 3.2. Spatal representation of the museum database category

Figure 33 . Spatial representation of the historic house and/or castle database category.

Figure 34 . Spatıal representation of the religious sites database category.

Figure 35. Spatial representation of the archaeological sites database category.

Figure 3.6 Spatal representation of the Marine and Martıme sites database category.

Figure 4.1. Percentage of respondents identifying their top, or joint top, operating priority. 
Figure 4.2. The perceived importance of operating in an environmentally friendly manner.

Figure 4.3. Reasons that make it important to operate in an environmentally friendly manner.

Figure 4.4. Percentage of respondents who identified that they had implemented the measures described to reduce resource consumption .

Figure 4.5. Percentage of respondents identifying that they have implemented the given measures to reduce waste production.

205

Figure 4.6. Sites that have identified that they have an environmental strategy or policy.

207

Figure 4.7. Site identifying whether they have, or have not, reviewed their environmental performance.

Figure 4.8. Percentage of respondents who did or did not make changes as a result of their environmental review.

214

Figure 4.9. Percentage of respondents identifying the barriers which they ranked as primary reason for not implementing environmentally friendly measures.

216

Figure 4.10. Perceptions of the impact that implementing environmentally friendly measures has on the conservation of heritage sites.

220

Figure 4.11. Perceptions of the impact that implementing environmentally friendly measures has on the visitor experience at heritage sites.

Figure 4.12. The percentage of sites providing interpretive material for visitors. 
Figure 4 13. Percentage types of interpretive information provided at heritage sites

Figure 4.14 Perceptions of respondents as to which is the most, or joint most, cost effective means of providing interpretation

Figure 4 15. Perceptions of respondents as to which is the most, or joint most, effective means of securing visitor interest.

Figure 4.16 Update cycle by type of interpretive provision

Figure 417 The percentage of heritage sites whose interpretive material is produced by external consultants or professional designers.

Figure 4.18 The percentage of stes that target their interpretive material at a particular audience group

Figure 4 19. Respondents perceptions as to which is the group that exerts the most influence on the interpretive information they provide.

Figure 420 Respondents perceptions as to which is the group that exerts the most influence on the interpretive information they provide.

Figure 4.21. Patterns of expenditure 258

Figure 4.22 The percentage of sites identifyng that they generated a profit or broke even in that last financial year

Figure 423 Percentage of respondents identifying the methods used to measure visitor numbers and types.

266

Figure 424 . Average (mean) percentage of origins of visitors by geographical area as Identified by sire manager/ custodian.

268

Figure 4.25. Percentage break-down of the main, or joint main, visitor groups by herttage category. 


\section{List of Tables}

Table 1.1. Yale's Typology of Heritage Tourism Attractions.

Table 1.2. Prentice's Typology of Attractions.

Table 1.3. Timothy and Boyd Classification of Heritage Resources. 12

Table 1.4. Leask and Yeoman's Classification of Heritage Visitor Attractions (HVAs).

Table 1.5. Simplified description of the sustainable development spectrum proposed by Hunter (1997).

Table 1.6. International Council of Monuments and Sites (ICOMOS) Charter on the Interpretation and Presentation of Cultural Heritage Sites.

Table 1.7. The Minimisation of Environmental Impacts by the National Trust (1992).

Table 1.8. Seven Market Segments Identified by the National Trust (2006b).

Table 1.9. English Heritage's Six High-Level Principles for the Sustainable Management of the Historic Environment.

Table 1.10. Potential energy and cost savings through the adoption of sustainable energy practices in Church of England properties.

Table 2.1 National Trust Houses and Gardens in Devon.

Table 2.2 National Trust Houses and Gardens in Cornwall.

Table 3.1 Southwest Heritage classification.

Table 3.2 Sources used to populate the selected heritage resource categories.

Table 3.3 Questionnaire's circulated and associated response rates. 182 
Table 3.4 Number and percentage of respondent to question concerning participation in interview phase of research.

Table 35 Sample frame for interviews.

Table 36 Sample frame description of interviewees.

Table 41 Local Community Involvement in the Natıonal Trüst Quay Museum at Cotehele, Cornwall

Table 42 Main, or joint main, sources of income identified by respondents

255

Table 4.3 Reasons given for a lack of enterprise activity and an enterprise ethos by Devon and Cornwall heritage providers.

264

Table 51 Modelling a progressive route to the sustainable management of heritage 
List of Abbreviations

3BL Triple Bottom Line

ACNY A Church Near You

AONB Areas of Outstanding Natural Beauty

CMAMA Cornish Mining Attractions Marketing Association

CofE Church of England

CROW Countryside and Rights of Way

CSR Corporate Social Responsibility

DCLG Department for Communities and Local Government

DCMS Department for Culture, Media and Sport

DEFRA Department for Environment, Food and Rural Affairs

EH English Heritage

HBMC Historic Buildings and Monuments Commission

HELM Historic Environment, Local Management

HLF Heritage Lottery Fund

ICIP International committee on Interpretation and Presentation of

Cultural Heritage Sites

ICOMOS International Council on Monuments and Sites

LNR Local Nature Reserve

MLA Museums and Libraries and Archives Council

NNR National Nature Reserve

NERC Natural Environment and Rural Communities

NHMF National Heritage Memorial Fund

NP National Parks

NT National Trust

ONS Office of National Statistics 
PRISM Fund for the Preservation of Industrial and Scientific Material

RAMM Royal Albert Memorial Museum

RDPE Development Programme for England

SAC Special Areas of Conservation

SENDA Special Educational Needs and Disability Act

SPA Special Protection Areas

SPSS Statıstıcal Package for Social Sciences

SSSI Sites of Special Scientific Interest

SWRDA South West Regional Development Agency

UN United Nations

UNEP United Nations Environment Programme

UNESCO United Natıons Economic, Scientific and Cultural Organısation

UV Ultra Violet

WCED World Commission on Environment and Development

WHS World Hertage Site 


\section{Acknowledgements}

There are many individuals that I would like to recognise for their support and assistance during the completion of this thesis. I would like to thank all those within the School of Geography, Earth and Environmental Sciences at the University of Plymouth who have supported me in my research. In particular, I would like to thank my supervisory team, especially Professor Mark Brayshay as my Director of Studies: He provided unerring support, continuous encouragement, much needed constructive feedback and numerous cups of tea. I am also grateful to Prof. Mark Brayshay for permission to use images from his personal collection in Chapter 2. Dr Stephen Essex went above and beyond as my second advisor, with continuous input and detailed feedback which helped me to improve not only my thesis, but also my skills as a researcher and an author. Without their guidance, this thesis, and my experience as a postgraduate student, would have been poorer. My thanks also go to the cartographers, support staff and the postgraduates in Geography who have made the last few years both supportive and productive.

I would like to thank my family, and Neil, for their continued and invaluable contributions. Without their support, encouragement, proof reading, visits, weekly phone calls, and much needed distraction, none of this work would have been possible. Particular thanks go to my parents for supporting my decisions, encouraging me to succeed, and providing the guidance that I so often need.

Finally, I would like to thank all of the heritage managers and custodians who contributed to this research. Many of their insights were invaluable and their dedication to conserving valued historic sites is evident. 


\section{AUTHOR'S DECLARATION}

At no time during the registration for the degree of Doctor of Philosophy has the author been registered for any other University award without pror agreement of the Graduate Committee.

The fees for the first three years of this study were provided by SERIO, University of Plymouth

Relevant seminars and conferences were attended at which work was often presented. Two papers were prepared for publication.

Publications (or presentation of other forms of creative and performing work)

Darlow, S (2007) Constructing Heritage Geographies Mapping valued sites in Devon and Cornwall Proceedings of the 2007 Postgraduate Symposium.

Faculty of Social Science and Business. University of Plymouth, pp 176-189

Darlow, S and Hunt, R. (2010) The Re-development of Cotehele Quay Museum Report and Transactions of the Devonshire Associatıon, 142, pp

Presentation and Conferences Attended:

Darlow, $\mathrm{S}$. The Re-development of Cotehele Quay Museum. $150^{\text {th }}$ anniversary conference for the Devonshure Association. $5^{\text {th }}$ June 2010

Darlow, S. Sustanable Heritage Management Practices in Devon and Cornwall. Human Geography Postgraduate Symposıum, University of Plymouth May 2010

Darlow, S. Economic Sustanability of Heritage resources for tourism. Postgraduate Lunchtime Seminar Series. University of Plymouth Sept 2009

Darlow, S. Sustainable Heritage Management Royal Geographical Society Postgraduate mid-term conference March 2009.

Darlow, S. Constructıng Herıtage Geographıes. Mappıng valued sites in Devon and Cornwall 2007 Postgraduate Symposium. University of Plymouth. $3^{\text {rd }}$ March 2007

\section{External Contacts:}

National Trust: Rachel Hunt provided collaborative assistance in the production of a paper for Transactions of the Devonshire Association. 
Word count of main body of thesis: 67,519

(including tables, figures, and captions)

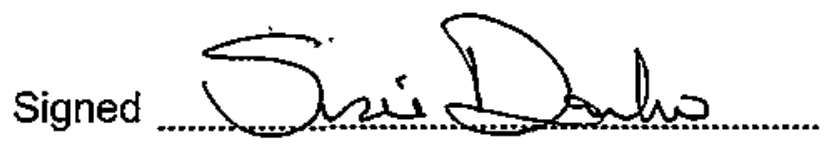

Date $30 / 3 / 2011$ 
xxvi 


\section{CHAPTER 1}

\section{THE SUSTAINABILITY OF HERITAGE AND HERITAGE TOURISM}

\subsection{Introduction}

Sustainable development has become one of the key challenges facing society in the twenty-first century. The concept is commonly defined as "development that meets the needs of current generations without compromising the ability of future generations to meet their own needs' (Brundtland Report, 1987.54). It represents a reaction to the growing environmental crisis arising from, inter alia, the depletion of non-renewable resources, pollution, species extinctions, and climate change, and has led to the establishment of a new paradigm for development, which incorporates economic, social and environmental considerations into decisions about the future. Through either the force of law or exhortations urging voluntary action, both businesses and wider society have been required to integrate environmentally sustainable practices, such as energy and water conservation, alternative energy production and carbon offsetting, within their normal operations and routines. No sector has remained exempt from the new mantra of sustainability.

The adoption of sustainable practices into the heritage sector resonates with its long-established objectives to conserve and enhance the historic environment. Both terms are associated with inheritance, namely the transfer of something from one generation to another (Nuryanti 1996, 249). However, the alignment is not as clear as might be expected and a number of significant challenges to the achievement of sustainability in the heritage sector have emerged. First, the 
adoption of sustainable practices in the management of historic buldings and structures can require modifications to their fabric which pose threats to the building's integrity and authenticity. Purısts tend to resist making fundamental changes to the fabric of a bullding that might reduce or compromise its historical legitmacy. The sustannabilty challenge is compounded when the heritage site is open to the public as a tourist attraction. For example, the introduction of alternative energy sources or energy conservation measures can involve the physical modification of properties as well as altering the appearance of the structures

Second, some goals of sustanability, such as restnctions on the use of private cars and the provision of car parks, can be counterproductive to heritage properties. Much heritage is not easily accessed by public transport, but depends on the arrival of paying visitors as a critically important income stream to fund their conservation remit As a result reducing private transport could detrımentally impact on economic viability Another example is the adoption of energy-efficient light bulbs, which can prove detrimental to the conservation of fabrics and other artefacts in heritage properties because low energy lighting emits higher levels of ultra violet (UV) light than conventional lighting High levels of UV are known to lead to fading and disintegration of fragile historic fabrics.

Third, not all heritage properties have the financial resources and expertise to respond fully to the sustarnabilty agenda, even though the actions themselves and the potential for cost-savings from the adoption of sustainable management practices could well contribute to the costs of the property's conservation and 
protection. Properties managed by organisations with 'corporate' sustainability policies, such as the National Trust and English Heritage, tend to fare better in this regard than other heritage resources owned by groups with non-heritage objectives. In this instance, historic churches represent a considerable heritage asset within the local scene, yet their sustainable management is made difficult because they inevitably privilege their role as places of worship rather than as revenue-generating tourist attractions.

The aim of this thesis is to investigate progress in the adoption of sustainable practices in heritage properties and sites in a particular region of England, namely the two south-western counties of Devon and Cornwall, and to evaluate some of the fundamental challenges and contradictions involved in the achievement of sustainability in this sector. The purpose of this chapter is to review the growth of public interest in heritage, its definition and classification, the evolution of heritage as an academic discipline and the main themes emerging from the academic discourse relevant to the sustainable management of heritage.

\subsection{Growth of interest in heritage and heritage visiting}

An interest in heritage, and the material items and representations of the past, has a deeper history than most contemporary commentators usually acknowledge (Harvey 2001, 2008). Heritage tourism certainly existed in the ancient world; Romans are known to have visited the Athens of Pericles and of Alexander the Great and, by the third and fourth centuries, Roman travellers were beginning to seek out their own heritage, such as Hadrian's villa at Tivoli 
or his great wall bounding the northern edge of empire in Britain By then, the sacred spring and temple complex of Aqua Sulis (Bath) in Britaın was attractıng many toursts from across the Roman Empire. By late antıquity, a strong link between Christian plgrimage and visıtıng heritage sites had become established (Dietz 2004). Indeed, the word hertage orıgınally meant the Inheritance or representation of relıgious faith and, although heritage tourism today is overwhelmingly secular, the connection with pilgrimage has never entirely been lost (Smith 1992) Thus, visits to the great religious heritage sites such as Jerusalem, Rome, Santiago de Compostela, Lourdes, Walsingham, Glastonbury or Canterbury may still be made for a mix of both secular and spıritual reasons (Graham and Murray 1997) The conflıctıng motivations of pilgrims and tourists to places which are symbols of all of the world's great religions have existed sınce at least the medieval period (Digance 2003).

Though the active or conscious conservation of heritage was rare in the ancient and medieval periods, the level of any threat to the sustainability of key sites was relatively low. Desplte the remarkable numbers of pilgrims and visitors known to have journeyed to certain herıtage places, ${ }^{1}$ in general, opportunities for extensive travel, either for tourism or to engage in pilgrimage, were avallable to a farrly small proportion of the population. However, both heritage tounsm, and modem commercial tourısm in its widest sense, began to grow significantly In the era of the so-called Grand Tour, a phenomenon that emerged amongst the elite in Britain and other parts of northern Europe, especially from the sixteenth century onwards Before the elghteenth century, the British elite tended to travel within Europe but, in the 1700s, the Grand Tour saw the

\footnotetext{
1 For example, an estımated $1 / 2$ million were visitıng Santiago de Compostella by the 1250 s Today, the site attracts well over 5 milion tourists and pigrims
} 
horizons of travel extended even further: into Egypt, Turkey and India. By then, strongly aligned with the educational ideas that were shaped by Enlightenment thinking, heritage tourism became a significant cultural phenomenon (Cohen 1992; Chaney 1998; Black 2003). While providing entertainment and social betterment through contact with fashionable society elsewhere; a Grand Tour was also essentially a scholarly pilgrimage to the great cultural and historical cities of Europe and beyond. Thus, for most, a visit to Rome was seen as important in providing an opportunity to observe and understand at first hand the physical legacies of classical antiquity in one of the great crucibles of Western culture (Hibbert 1987; Creed 2002). Grand Tours were usually lengthy episodes of heritage tourism. Travellers might be away from home for a few months; some were absent for several years (Arentz 1998; Black 1992; 2003). Their purchase of works of art as souvenirs, and their experiences of historic places elsewhere, which influenced architectural taste in Britain, substantially augmented the collection of heritage buildings and artefacts that survive in this country and are cherished today.

While extensive and lengthy European heritage tours remained prevalent amongst the richer classes during the Victorian era (Pemble 1988), the expansion of large-scale rail travel in the 1840 s provided for the beginning of a new era of mass domestic tourism within Britain. A growth in interest was stimulated across a broader section of society in the nation's antiquities and historical sites. Thus, the rich architectural, archaeological and cultural heritage of Britain came increasingly to be recognised, cherished, celebrated and visited by ordinary people. Indeed, the conscious imperative to safeguard and record the nation's heritage gained a new urgency within the context of the rapid 
changes occurring in the era of nıneteenth-century modernity (Barthel 1996) This gathering awareness culmunated in 1895 when the National Trust for Places of Historic Interest or Natural Beauty was founded (Cannadine 1995). At first armed at combating threats to the English landscape, the Trust was soon also Involved in the protection of historic buildings and their contents (Jenkıns 1994). Moreover, in the twentieth century, especially in the post-war perıod, and as a result of a marked growth in lessure time, nising levels of disposable Income, better education, and access to transport, heritage tounsm at last became fully accessible to those of modest means (Aplin 2002; Timothy and Boyd 2003).

Alongside these main drivers, which explain the expansion in the populanty of heritage tourism, hertage commentators also point to an acutely heightened desire, especially since 1945 , to engage tangibly and personally in an expression of nationhood and identity. Such urges were, of course, founded in (and reinforced by) the threats posed to the country's survival during both world wars. People have increasingly been drawn to the places and sites that embody their shared history and culture (Prentıce 2004). Natıonal, regional and local representations of the past have thus been increasingly perceived as highly Important to the national sense of well-being and 'rootedness'.

Inevitably, the growth in interest in heritage led to stronger and more comprehensive moves to conserve and preserve umportant buldıngs, collections, archaeological sites, and expressions of culture that had been at risk of annihilation by enemy action during the Second World War, and were subsequently threatened by demolition during the post-war appetite for the 
renewal and reconstruction of Britain (Starn 2002). Palmer (2003, 429) argues that those who had been 'prepared to die for their country' now wanted to understand and relate more closely to what it was that they had been 'trying to protect'. In essence, there was a growth not only in understanding the history of Britain, but in taking ownership of, and identifying directly with, that history. At the core of Palmer's thesis is the notion that heritage sites have the capacity to encapsulate 'a past that people can recognise as belonging to them'; heritage, she contends 'unites [people] and is timeless' (Palmer 1999, 315; 2003, 428).

The decline, in more recent decades, of extractive and manufacturing industry in Britain has also contributed to the encouragement of tourism in general, and heritage tourism in particular. As Edwards and Llurdés (1996) note, in postindustrial Britain, the commercialisation of heritage places has been seen to offer an alternative means to generate income and provide employment. Moreover, as Palmer (1999, 315) notes, obsolete industrial sites have themselves come to be seen as heritage; "the heritage label has become an important means of attracting visitors to a variety of places, from industrial manufacturing sites to the homes of writers and poets'.

\subsection{Defining heritage and heritage resources}

Palmer's choice of the phrase 'heritage label' is significant. As either noun or adjective, the word 'heritage' (rather like the words 'national' or 'royal') conveys a particular embedded message. Although its meaning is in fact somewhat slippery and vague, the label 'heritage', perhaps in place of 'old' or 'aged', imbues an object or place with an extra cachet of reverence that requires 
admiration and attention in recent years, the marketing industry has enthusiastıcally adopted the word heritage, and attached it to almost anything, as a means of adding a kind of phoney kudos to a product (Johnson and Thomas 1995). Inevitably, therefore, one of the fundarnental issues emerging from the heritage Itterature is a contınuing lack of an agreed definition of what constitutes 'herıtage' (Graham ef al. 2000, Aplın 2002, Edwards and Llurdés I Colt 1996, Garrod and Fyall 2001; Ashworth and Larkham 1994). Graham et al (2000) contend that the historic overlap between heritage and other disciplines, prior to the 1980 s, resulted in a very loose definition of heritage Nevertheless, many authors now recognise that there are two broad strands of heritage definition: 'heritage as a set of ideals, and heritage as thıngs' (Aplın 2002, 15). Smith (2006, 11-16) emphasised that heritage is as much about a set of 'meanings and values' as it is about a set of tangible 'things'

Heritage 'as thıngs' refers to any kınd of past event, historical place or historical object Yale $(1991,21)$ defined hentage as that which is 'centred on what we have inherited, which can mean anything from historic buildings to art works, to beautiful scenery' Many of the classifications and typologies of heritage are based on these conceptions. For example, Yale's (1991) typology incorporated 11 categories that are present in all regions, including museums, stately homes and the arts (Table 11) Prentıce's (1993) 23-category model represents a detailed picture of the types of heritage sites that it is possible to visit (Table 1.2) Timothy and Boyd (2003) used a different means of classifying heritage resources (Table 13). resources that are 'tanglble' ( 1 e buldıngs and fixed sites) or 'ıntangıble' (e.g festivals, events and ceremonies) 
Type

The museums

Stately homes

Religious

Heritage

Other historical attractions

The Arts

Industrial

heritage

Transport

heritage

Countryside attractions

Wildlife attractions

Miscellaneous attractions

Events attractions

\section{Attractions included}

Local museums (comprehensive and specialist), History and archaeology museums, science and technology, natural history, ethnography, open-air, film/ photography, fine arts, industrial heritage, historical/ literary, archaeology, children and toys, military, transport, specialist, private collection

Stately homes, Castles, places and gardens, the royal family, royal parks,

British cathedrals, churches, special events, redundant churches, chapels, churchyards and cemeteries, abbeys and priories, ruins.

Archaeological sites, ancient monuments, Military manoeuvres sites, listed buildings, conservation areas, heritage centres, heritage trails and guided walks, homes of the famous, historic public buildings, British battlefield sites, other monuments

Att galleries, art displays, temporary exhibitions, works of art in situ, the crafts, theatres, plays, musical entertainment, dance companies, cinemas, art festivals

Mines and quarries, the mills, wind and watermills, the public utilities, other industrial remains, model towns, dockland revival schemes, the potteries, engineering projects

The railways, railway museums, stations, other buildings, other leisure possibilities, the canals, ships, roads and road transport, carriages, veteran and vintage cars, public transport, road structures, air

National parks, AONB, SSSI, Nature reserves, country parks, Coastal scenery, Heritage coasts, marine nature reserves, forest and woodland, forest parks, community parks, paths and trails, mountains, caves, water attractions,

Zoos, Aquaria, Safari parks, animal encounters, wildfowl and wetland trust reserves, Falconry centres, other bird attractions, rare breed farms, city farms, heavy horse attractions, trout farms, butterfly farms, local wildlife trusts, other specialist wildlife attractions

Waxworks, leisure and theme parks, seaside resorts and piers, towns, spa towns, shops, film and television studios,

Traditional ceremonies, sports events, festivals of music, drama and film, food and drink festivals, flower and garden festivals, religious events, political events, markets, illuminations, circuses.

Source: Adapted from Yale, 1998. 


\begin{tabular}{|c|c|}
\hline $\begin{array}{l}\text { Type of } \\
\text { Attraction }\end{array}$ & Description \\
\hline $\begin{array}{l}\text { Natural History } \\
\text { attractions }\end{array}$ & $\begin{array}{l}\text { Nature reserves, nature trails, aquatic life displays, rare breeds } \\
\text { centres, wildlife parks, zoos, butterfly parks, wateifowl parks, } \\
\text { geomorphologic and geological sites, including caves, gorges, cliffs } \\
\text { and waterfalls }\end{array}$ \\
\hline $\begin{array}{l}\text { Solence based } \\
\text { attractions }\end{array}$ & $\begin{array}{l}\text { Science museums, technology centres, 'hands on' science centres, } \\
\text { 'alternative' technology centres. }\end{array}$ \\
\hline $\begin{array}{l}\text { Attractions } \\
\text { concerned with } \\
\text { primary production, }\end{array}$ & $\begin{array}{l}\text { Agncultural attractions, farms, daines, farmıng museurns, vineyards, } \\
\text { fishıng, mınıng, quarryıng, water Impoundıng reservoırs }\end{array}$ \\
\hline $\begin{array}{l}\text { Craft centres and } \\
\text { craft workshops }\end{array}$ & $\begin{array}{l}\text { Attractions concerned with hand-made products and processes, } \\
\text { including water and windmills, sculptors, potters, woodcarvers, hand- } \\
\text { worked metals, glass makers, silk working, lace making, handloom } \\
\text { weaving, craft 'villages'. }\end{array}$ \\
\hline $\begin{array}{l}\text { Attractions } \\
\text { concerned with } \\
\text { manufacturing } \\
\text { industry }\end{array}$ & $\begin{array}{l}\text { Attractions concerned with the mass production of goods pottery and } \\
\text { porcelain factories, breweries, cider factories, distilleries, etc }\end{array}$ \\
\hline $\begin{array}{l}\text { Transport } \\
\text { attractions, }\end{array}$ & $\begin{array}{l}\text { Transport museums: raslways, canals, civi shıppıng, clvic aviation, } \\
\text { motor vehicles. }\end{array}$ \\
\hline $\begin{array}{l}\text { Socio-cultural } \\
\text { attractions }\end{array}$ & $\begin{array}{l}\text { Archaeological and histonc sites and displays (domestic houses, } \\
\text { museums of social history, costume, regalla, furnishıngs museums, } \\
\text { chidhood and toys. }\end{array}$ \\
\hline $\begin{array}{l}\text { Attractions } \\
\text { associates with } \\
\text { historic persons }\end{array}$ & Sites and areas associates with writers and panters \\
\hline $\begin{array}{l}\text { Performing arts } \\
\text { attractions, }\end{array}$ & $\begin{array}{l}\text { Theatres, street-based performıng arts, performıng arts workshops, } \\
\text { circuses. }\end{array}$ \\
\hline Pleasure gardens, & Ornamental gardens, period gardens, arboreta, model villages \\
\hline Theme parks & $\begin{array}{l}\text { Nostalgia parks, 'historic' adventure parks, faırytale parks (but } \\
\text { excluding amusement parks). }\end{array}$ \\
\hline Galleries & Art gallemes \\
\hline $\begin{array}{l}\text { Festivals and } \\
\text { pageants }\end{array}$ & $\begin{array}{l}\text { Historic fairs, festivals 'recreatıng' past ages, countryside festivals of } \\
\text { 'rural' activities }\end{array}$ \\
\hline Field sports & Traditional fıeld sports, Includıng fishıng, hunting, shootıng , stalkıng. \\
\hline $\begin{array}{l}\text { Stately and } \\
\text { ancestral homes }\end{array}$ & Palaces, country houses, manor houses. \\
\hline $\begin{array}{l}\text { Religious } \\
\text { attractions }\end{array}$ & $\begin{array}{l}\text { Cathedrals, churches, abbeys, prories, mosques, shrınes, wells, } \\
\text { springs }\end{array}$ \\
\hline Military attr & $\begin{array}{l}\text { Castles, battlefields, military arfields, naval dockyards, prisoner of war } \\
\text { camps, military museums. }\end{array}$ \\
\hline
\end{tabular}


Genocide

monuments

Towns and

townscape,

Villages and

hamlets

Countryside and treasured

landscapes

Seaside resorts

and 'seascapes',

Regions
Sites associated with the extermination of other races or other mass killings..

Historic townscapes, groups of buildings in an urban setting.

Rural settlements, usually of pre-twentieth century architecture.

National parks, other countryside amenity designations; 'rural' landscapes.

Seaside towns of past eras and marine 'landscapes'.

'Pays', 'lande', counties, or other historic or geographical areas.

Source: Adapted from Prentice, 1993, 39-40. 
Table 1.3. Timothy and Boyd Classification of Heritage Resources

\begin{tabular}{ll}
\hline \multicolumn{1}{c}{ Tangible resources } & \multicolumn{1}{c}{ Intangible resources } \\
\hline A: Tangible immovable resources: & $\bullet$ Value \\
\hline - Buildings & $\bullet$ Customs \\
- Rivers & - Ceremontes \\
- Natural areas & - Lifestyles \\
\hline B: Tangible moveable resources & experienced as festivals, arts and \\
\hline & \\
\hline
\end{tabular}

Source Adapted from Timothy and Boyd, 2003, 3.

Rather than ciassifying resources only by theır characteristics, Tımothy and Boyd's model distınguishes between tangıble 'things' and intangible experiences. Leask and Yeoman's (1999) classification of hentage visitor attractions incorporates different geographıcal scales (natıonaliregional, area and site) and three key categories of heritage namely, 'living heritage (cultural)', 'built environment heritage' and heritage relatıng to the 'natural environment' (Table 1.4)

There have been studies of the less-tangible aspects of cultural heritage such as folk dance, song, ritual and taboos (Segadıckı 2006), and the stagıng of events as a means of expressing ancestral links (Chhabra, Healy and Sills, 2003). Studies of heritage as 'meanıng' have also extended to examınations of literary places and the 'writers country' landscapes of England (Herbert 2001) Structures and places as objects and spaces are also used by some in 
Table 1.4. Leask and Yeoman's Classification of Heritage Visitor Attractions (HVAs)

\begin{tabular}{|c|c|c|c|}
\hline & 'Built' heritage & 'Natural' heritage & 'Living' heritage \\
\hline Nation/Region & Cities & Landscape/sea & People \\
\hline \multirow[t]{3}{*}{ Area } & Historic towns & National Parks & Traditional food \\
\hline & Seaside resorts & Heritage Coastlines & Festivals \\
\hline & $\begin{array}{l}\text { Conservation } \\
\text { areas }\end{array}$ & AONBs & Markets \\
\hline \multirow[t]{7}{*}{ Site } & Museums & $\begin{array}{l}\text { Towns and country } \\
\text { parks }\end{array}$ & $\begin{array}{l}\text { Public } \\
\text { houses/cafes }\end{array}$ \\
\hline & Art galleries & Botanic gardens & Craft centres \\
\hline & Historic buildings & Historic gardens & Farms \\
\hline & $\begin{array}{l}\text { Historic } \\
\text { sites/monuments }\end{array}$ & Nature reserves & \\
\hline & Heritage centre & Countryside centres & \\
\hline & $\begin{array}{l}\text { Heritage theme } \\
\text { parks }\end{array}$ & Country parks & \\
\hline & Transport & Forest & \\
\hline
\end{tabular}

Source: Leask and Yeoman, 1999, 9.

memorialising particular kinds of past lives and former neighbourhoods, linking the tangible with the intangible (Fotsch 2004; Uriely et al. 2002).

However, irrespective of the typology used, the important point to consider is that all these heritage 'things' have been deliberately and selectively saved from change by a society which has privileged a particular set of meanings and values (Aplin 2002). In this respect, heritage is a 'selective valuing (or using) of 
aspects of the past' (Graham et al 2000,2). Smith (2006) discusses what she refers to as 'authorized hertage discourse' which focuses on the objects, sites, and places that an elite group of experts and authorties have defined as those which must be protected and revered. Thus, heritage is not synonymous with 'the past' or with 'history', but refers to aspects of the past that are selected and valued by particular individuals and groups. Clearly, this reference to selective valuing underlmes the fact that heritage is not a neutral construct (Tunbridge 1998; O'Nerll 2006). Busby $(2008,76)$ asserts that 'heritage is not value-neutral; It has different meanıngs for different people' Ashworth and Larkham's (1994, 13) work stressed the link between heritage, history and a sense of place, suggesting that 'the occurrences of the past, are widely used to fulfil a number of major modern functions, one of which is shaping socio-cultural placeIdentities in support of particular state structures'.

The key message to emerge from a close reading of all the literature on how heritage should be defined, and how heritage resources should be classified, is that the subject is still in an emergent phase. As it matures, and a stronger body of theory is established, wider and more solid agreement on definitions and classificatıons may well develop

\subsection{Scholarly interest in heritage}

Aplin (2002) justifies the scholarly study of heritage by arguing that heritage represents a part of society's past, and it 'enriches our lives' He adds that heritage studies help increase awareness of heritage values and the ways in which heritage can contribute to a richer life in a more meanıngful society' The 
need, he suggests, for heritage in modern-day society has been instrumental in the evolution of heritage as a discipline that is 'valued by society, or parts of society, [and] is worth studying" (Aplin 2002, 16).

Although, as already noted, a concern with heritage and the practice of heritage tourism have much deeper histories than the emergence of heritage studies as a field of academic enquiry (Harvey 2008, 19-21), authors such as West and Ansell (2010), Aplin (2002), Timothy and Boyd (2003), Graham et al. (2000), and Howard (2003) all show that heritage as a scholarly subject began to emerge in the 1970s and 1980s. However, Howard (2003, 14-31) argues that, insofar as it existed at all, the study of heritage until the later 1980s was 'embedded within other disciplines' (history, art history, cultural studies, archaeology, geography and predominantly tourism) when, following the publication of pioneering works on the heritage industry by Lowenthal (1985) and Hewison (1987), it came to be seen for the first time as a separate discipline in its own right.

The empirical and theoretical literature clearly shows that both heritage as a field of study, and heritage-visiting as a popular phenomenon, continue to expand and accelerate at an extraordinarily rapid rate. The growth of interest in heritage tourism was emphatically underlined by the launch of the International Journal of Heritage Studies in 1995 and the Journal of Heritage Tourism in 2006. The spread of scholarly concerns related to heritage and heritage tourism continues to grow and mature. 


\subsection{Theoretical debates in heritage studies and sustainability}

Although direct use of the word sustainability in the heritage studies literature remains remarkably rare, some of the long-standing theoretical debates about the management of heritage resources are relevant to the sector's response and adaptation to the sustainability agenda: namely conservation, commodification, ${ }^{2}$ authentıcity, interpretation and elitist/social exclusion Moreover, some of the theorles advanced to explain the adoption of environmentally sustainable practıces by busınesses provide a framework for examınıng the process of 'greenıng' the management of hertage.

The concept of sustanability is now commonly presented as consisting of economic, social and environmental dimensions. In the business sector, links between these dimensions are envisaged within the theory of Corporate Social Responsibulity (CSR) (Kotler 1991), which models the activities of businesses in a manner that maintains or improves both the customer's and society's wellbeing. Henderson $(2007,228)$ proposes that CSR theory 'is favoured by many as a philosophy and policy which benefits the economy, society and environment based on the idea that companies have wider responsibilities beyond commerce' Nevertheless, these objectives are not easy to achieve and can often conflict Different businesses interpret the theoretical concept in different ways, with some emphasising the conservation of natural resources while others privilege economic returns (Mather and Chapman 1995; Hunter 1997; Bell and Morse 1999) Hunter (1997) identified a theoretical spectrum of sustainability positions from 'very weak' to 'very strong', and he has outlined the

\footnotetext{
${ }^{2}$ Alternatively, the word 'commoditisation' is used Both commodification and commoditisation are unattractive, new 'coinages', but both are now frequently encountered in the literature on heritage tourism and heritage marketıng.
} 
defining characteristics of each (Table 1.5). In the case of 'very weak' CSR, profit is ranked above all else. Some care would be expected to be devoted to the protection of ecosystems where CSR is just 'weak', but environmental concerns are treated separately from the (usually stronger) drive to secure economic returns. As CSR becomes 'stronger', much more of an equal balance is sought between economic, environmental and social considerations; and where it is 'very strong', Hunter (1997) suggests that a business will begin to subscribe to the Gaia principle (which stresses the complete interdependence and interconnectedness of all the elements in the system), and will show concern regarding the use of non-renewable resources and the integration of social considerations within their business model.

Henderson (2007: 230) explains that extra spending is often required to implement sustainable or CSR initiatives and that 'there might be fundamental tensions between commercial priorities and a social and environmental orientation'. She emphasises that companies must strike an appropriate balance in the degree of their commitment and avoid 'excessive involvement which detracts from the pursuit of vital corporate goals' (Henderson 2007, 230). Other factors in the adoption of sustainable practices include the capabilities for innovation and learning (Merritt, 1998; Johannson 1997; Carlsen et al 2001; Lee 2009; Haden et al. 2009). Theoretical ideas regarding such compromises are also relevant in the management of heritage properties.

A further refinement of the Corporate Social Responsibility (CSR) ideas is the Triple-Bottom-Line (3BL) theory, advanced in 2005 by Kleindorfer, Singhal and Van Wassenhove. 
Table 1.5 Simplified description of the theoretical sustainable development spectrum proposed by Hunter (1997)

\begin{tabular}{cl}
\hline $\begin{array}{c}\text { Sustainability } \\
\text { position }\end{array}$ & \multicolumn{1}{c}{ Defining Characteristics } \\
\hline Very Weak & $\begin{array}{l}\text { Anthropocentric and utiltarian, growth onented and resource } \\
\text { exploitative, natural resources utilised at economically optımal rates } \\
\text { through unfettered free markets operatıng to satisfy individual }\end{array}$ \\
& $\begin{array}{l}\text { consumer choice; infinite substifution possible between natural and } \\
\text { human-made capital, contınued well-being assured through } \\
\text { economic growth and technical innovation }\end{array}$
\end{tabular}

Weak

Anthropocentric and utiltarian, resource conservationist, growth is managed and modified; concern for distribution of development costs and benefits through intra and intergenerational equity, rejection of infinite substitution between natural and human-made capital with recognition of some aspects of natural world as critical capital (e.g ozone layer, some natural ecosystems); human-made plus natural capital constant or rising through time; decoupling the negative environmental impacts from economic growth

Strong (Eco)systems perspective; resource preservationist; recognises primary value of maintaining the functional integrity of ecosystems over and above secondary value through human resource utilisation, interests of the collective given more weight than those of the individual consumer, adherence to intra- and intergenerational equity, decouplıng important but alongside the belıef in a steadystate economy as a consequence of following the constant natural assets rule, zero economic and human population growth

Very Strong Bioethical and ecocentric, resource preservatıonist to the point where uttlisation and natural resources is mınımısed, nature's right or intrinsic value in nature encompassing non-human living organisms and even abıotıc elements under a literal interpretatıon of Garanısm; anti-economıc growth and reduced human population

Source Hunter (1997) adapted from Turner et al. (1994) 
This 3BL theory of management envisages the complete integration of economic, socio-cultural and environmental sustainability objectives in a strategic manner. The three dimensions are seen as being enmeshed in a symbiotic relationship where no one form of sustainability takes precedence over the others.

\subsubsection{Conservation theory}

Achieving a harmonious balance between the imperative to protect and conserve heritage and the desire to make it accessible to visitors and financially profitable has attracted attention in the research literature (Graham, et al. 2000, 167-71). Landorf (2009) asserts that conservation is intrinsic to the sustainability of heritage. Aplin $(2002,69-74)$ describes conservation as 'all the processes of looking after a place so as to retain its cultural significance'. It includes 'preservation', which is the least-invasive continuous protective care of the fabric, contents and settings of a place in their existing state with the aim of retarding any further deterioration. Conservation can, however, also include 'restoration, 'reconstruction' and 'adaptation'. Restoration involves the returning of the fabric of a place to a known earlier state by removing accretions, reassembling existing components, and repairing the structure(s) and materials. Reconstruction, a more radical approach, also means the returning of a place as nearly as possible - to a known earlier state, but often it requires the use of new materials to replace those that have decayed or disappeared. Adaptation means modifying a place in order to render it compatible with a new or modern use. Commonly, conservation involves a combination of more than one of these various levels of intervention to ensure the continued survival of a building or 
artefact in as good a state as possible Quntessentlally, therefore, the conservation of hertage is about ensuring its sustamability

Conservation, in the sense of the legally enforced protection and safeguarding of designated heritage that is deemed to be important, is discussed by West and Ansell (2010). In examıning the international conservation bodies formed, and agreements made, since 1922, they assert that, "following the Second World War, the canonical approach to listing becomes globalised' (West and Ansell 2010,37) They explain, in partıcular, the influence of the United Nations Educational, Scientific and Cultural Organısation (UNESCO) as the executive body for the elected members of the World Heritage Committee. Under the auspices of UNESCO, in 1964, the International Councll on Monuments and Sites (ICOMOS) was founded as a non-governmental agency (funded by the UN), and the International Charter for the Conservation and Restoration of Monuments and Sites - known as the 'Venice Charter' - was drawn up to articulate a philosophy and a set of specific recommendations for the protection of historic resources. With its recommendations regarding the need for careful research on evidence of the original and subsequent 'physical states' of heritage and careful decisions about the 'state' that should be conserved, expert judgements about how to conserve (how to repair, what materials to use, etc), and emphasis on respect for the historic and aesthetic attributes of heritage, the Venice Charter remains as a fundamental benchmark for the professional care of all heritage places (Larkham 1995; Donnachie 2010).

In the UK, the 1882 Ancient Monuments Protection Act ranks as the first plece of heritage 'sustaınability' legıslation. Under its provisions, a list or 'schedule' of 
medieval or earlier monuments and buildings, that were thought worthy of government inspection and monitoring, was to be drawn up and thereby afforded legal protection from all unauthorised alteration and development. In total, since 1882, some 22 Acts of the UK Parliament have addressed, to a greater or lesser extent, the protection and conservation of heritage. ${ }^{3}$ In addition to the 1882 Act, perhaps another seven may be regarded as highly significant milestones: the 1947 Town and Country Planning Act; the 1967 Civic Amenities Act; the National Heritage Acts of 1980, 1983 and 2002 (the 1983 Act provided for the establishment of English Heritage and the 2002 Act expanded its remit to include marine heritage within the country's territorial waters); the 1990 Planning (Listed Buildings ${ }^{4}$ \& Conservation Areas ${ }^{5}$ ) Act; and the Museums and Galleries Act 1992 (which established boards of trustees at some larger national sites, allowing them more control in the management of their own operations)(Delafons, 1997$){ }^{6}$

Further legislation (i.e. the 1995 and 2006 Environment Acts, and the 2006 Natural Environment and Rural Communities Act) have acknowledged the

${ }^{3}$ It should be noted that the precise approaches and details of the national legal instruments for the protection and conservation of heritage enacted in different countries vary considerably, giving rise to rather different outcomes. For example, Soane (2002) showed the conservation practices of post-war Germany led to the complete re-building of historic structures lost as a result of enemy action, which in England might be regarded as pastiche.

${ }^{4}$ A description of Listed Building designations is given in Appendix 1.

${ }^{5}$ A description of the Conservation Area designation is given in Appendix 2.

6 Separate legislation affords protection for Scotland's heritage: the 1991 Natural Heritage Act (Scotland); and the 1997 Planning (Listed Buildings \& Conservation Areas Act) (Scotland). These laws created Scottish Heritage as an organisation which parallels English Heritage, and recognised the need for separate Scottish heritage listings. 
Importance of heritage by stipulating a requirement for hertage bodies to be included in decision-making processes. However, these particular laws do not address heritage protection or management in significant detat Notably, the 1967 Civic Amenttes Act and the 1990 Plannıng (Listed Buildıngs \& Conservation Areas) Act dealt with the designation of conservation areas and thereby addressed the sometımes contested Interface between planning and heritage While conservation areas have their critics (Magean and Hulmes 2000), the protection afforded to heritage by its inclusion within them can do much to ensure that the wider setting and local environmental quality of historic bulldings is properly considered

A common criticism of the heritage sector is that the 'traditional curatorial approach' to management remains dominant in the contemporary utilisation of heritage assets (Garrod and Fyall 2000,691). While this emphasis ensures the protection of the built and cultural environment for future generations, the approach ignores two important aspects of sustainability. First, if the protection of a heritage asset prevents its utilisation, then the resource will be deprived of a 'human dimension, identity and relevance' (Garrod and Fyall 2000, 693) In other words, its social and cultural sustanability will be lost Second, the conservation of heritage assets is expensive and requires considerable financial support With the decline of public expenditure, heritage managers have developed alternative income streams, particularly from tourism Economic sustainability is therefore often a precondition for achieving other forms of sustannabllity although attempts to generate income from heritage can be detrimental to the historic resource itself. The resolution of these conflicts lies at the heart of the challenge for sustannable management in the heritage sector. 
A key criticism of both the legislation and the guidance regarding the conservation and management of heritage is that it remains intractably elitist and top-down in its approach. In discussing the UK's most recent Heritage White Paper, Waterton and Smith (2008) thus point out the stark disconnect between its stated 'inclusiveness' aspirations and its heavy reliance on elite professional opinion in the framing of new objectives and policies. The White Paper's aim of offering a pathway towards a simplified and unified system of heritage management practices may thus be a laudable objective, but Waterton and Smith believe it will continue to be driven from 'the top' and it will not be inclusive. Good practice guidance may thus simply not reach the managers of small-scale, independent heritage attractions.

Effective heritage management and heritage conservation therefore faces a myriad of economic, political, environmental and socio-cultural challenges but the high costs involved and the general scarcity of funding are particularly highlighted by Timothy and Boyd $(2003,119-120)$. A key danger is that available finance is used for short-term benefits, such as providing better ancillary facilities for tourists or investing in media promotion, rather than for high-quality, technically-expert conservation, 'which might better ensure the long-term viability' of a visited heritage attraction. These arguments would appear further to support the notion that a comprehensive management approach, which seeks the intelligent integration of all the dimensions of sustainability, is desirable. 


\subsubsection{Commodification theory and economic sustainability}

Graham, Ashworth and Tunbridge (2000) offer three theoretıcal models that explain the direct exploitation of the economic potential of heritage: the windfall gain model, the turnstile model, and the commodification model. The windfall gain model, they contend, is the most widespread and it assumes that the herttage resource already exists to satisfy some other purpose but can accommodate an additional revenue-generating income Access for visitors to parısh churches, when not in use for relıgıous worshıp, provides an Illustration of this theory in practice; this windfall gain approach is especially the case when guldebooks, postcards and other souvenırs are on sale The theory assumes, however, that the extra economic function can be added without threatenıng the existing uses or historical integrity of the heritage, and that the existing users positively welcome the extra demand that the added economic function Inevitably generates.

Graham et al (2000) explain the theory of the turnstile model, whereby visitors pay an entrance fee to gain access to heritage and, once inside, they derive whatever 'buyer benefits' they seek Many of the outdoor archaeological sites in the care of English Hertage for which an entry fee is levied provide examples of the turnstile theory in practice The turnstle model equips the custodian of the heritage with the means to regulate demand by adjusting the admission price but success in doing so depends critically on knowledge of the market and its expectations

In order to achieve more control and stablity (1 e economıc sustainabillty), Graham et al. (2000) show that heritage is capable of being commodified. 
Commodification theory is a further elaboration on the ideas of the windfall gain and the turnstile models and it envisages that heritage is deliberately packaged, presented, interpreted and marketed in a manner that appeals to potential visitors or 'consumers' and thereby generates an income to facilitate the protection and management of that heritage (Leask and Yeoman 1999). Britain 'occupied royal palaces', open to the visiting public, provide a tangible example of commodification theory in practice. Managers of the heritage are able to construct, or package, a directly 'saleable' product that matches with, or responds to, the consumer demands of their perceived market or market segments. For heritage managers with a curatorial approach, the fear is that heritage can be reduced to 'just another commodity to be bought and sold', and evaluated primarily in terms of its exchange value in a context of trade (Goulding 2000, 836-7). Scholarly credibility and historic integrity are sacrificed in favour of a sanitised, distorted, trivialised and inauthentic view of history in order to guarantee financial viability. Provided, however, that commodification is managed carefully and sensitively, the packaging and presentation of heritage as an appealing tourism product can help to optimise revenues and therefore fund both environmental sustainability and the vital preservation and conservation work that protects and safeguards the continued survival of the resource.

In order to maximise the consumption of heritage as a commodity, heritage is often presented in a way that ensures the widest possible appeal. Drummond and Yeoman (2003) suggest that economic sustainability can only be attained by ensuring that the site meets 'the increasingly sophisticated demands of the expanding, discerning tourist market'. The 'commodity' must therefore present 
an attractive image (via effective marketing), it must be accessible, it must offer high-quality amenttes on site; and it must provide the best-possible level of visitor service They suggest that maintenance of sufficient income not only helps to make the resource sustanable, but also supports the cost and retention of expert staff whose contribution can further enhance the quality and attractiveness of the product which is offered

According to Smith (2006, 37-38), in commodifying hertage, a narrative that chimes with the values of society's dominant groups, often emphasising the use of 'heritage as a symbolisation of power', will frequently be adopted. However, thıs approach can risk the alienation and marginalısatıon of visitors for whom a particular narrative or standpoint is skewed or partial, and might have a deleterious effect on the site's historic value and cultural meanıng Conflicts that may arise as a result of the different emphases favoured in the processes of commodifying heritage are commonly referred to as expressions of 'dissonant heritage'. a phrase first coined by Ashworth and Larkham (1994)

Du Cros $(2001,2008)$ suggests that many heritage managers are forced to make decisions that are based too heavily on the priority of generating income. Thus, they may offer particularly long openıng hours or extended opening seasons, even though doing so might threaten the heritage resource with excessive wear and tear, and other negative visitor impacts. Other research has suggested that admission prices to heritage attractions do not reflect the true costs of opening to the publıc Unrealistıcally low entrance charges can lead to high demand, physıcal pressures on the fabric of the site and underınvestment In conservation work Nevertheless, Inflated admıssion pricing is often counter 
to the fundamental mission of heritage attractions (Garrod and Fyall 2000,703) and remains a controversial aspect of achieving sustainability in heritage management. The introduction of carefully considered sustainable practices on the site might therefore be seen as a means of achieving a better balance between the profit imperative, on the one hand, and the demands and desirability of conservation on the other.

Commodification can also involve changes and modifications to the fabric of historic buildings and sites through the introduction of additional on-site facilities, such as restaurants and gift shops, in order to increase visitor spending. Investment in such facilities can also divert resources from conservation work. In a similar way, the adoption of sustainable practices to reduce costs might also be perceived as a damaging adaptation of the site. The adaptation of heritage resources to incorporate environmentally or economically sustainable practices can encroach upon the historical authenticity and integrity of a property or site.

\subsubsection{Authenticity theories}

Some literature draws a distinction between the theory of historical authenticity of a heritage site, and the authenticity of the tourist experience (Goulding 1998; Wang, 1999). However, these two dimensions of authenticity are inextricably linked. One of the key challenges for managers of commodified heritage attractions open to visitors is to ensure that the site remains authentic and accurate to its history and does not drift into staged authenticity or a distorted representation of the past (MacCannell 1973). Achieving this goal is not as easy 
as might appear. First, heritage, by its very nature, is usually a re-creation of a selective past consistıng of those elements that soclety values or that time has allowed to survive (TImothy and Body 2003, 237). Second, as already noted, the extent of commodification of a heritage resource can affect the perceived and actual hıstorical authentıcıty and integrity of the site dependıng upon the emphasis placed on market orientatıon Taken to extremes, however, commodification can risk the 'Disneyfication' of heritage for mass tourism in a manner that compromises and damages the historical legitımacy and value of the resource (Waltt 2000; Choay 2001) Cultural exaggeration and gigantism can occur where there is the alm to entertain or maximise the market appeal of a heritage site. In extreme situatıons, there can be heritage attractions developed around ımagınary places (for example, literary associations within a place, (such as the Land of $\mathrm{Oz}$ in Kansas), Invented places (for example, Ballykıssangel (Avoca) in Ireland or Aıdensfield (Goathland in north Yorkshire)), and inauthentic locations (for example, relocated sites or new constructions within open-air museums) (Timothy and Boyd 2003). Hewison (1987) suggests that heritage often creates a fantasy world that never existed and replaces true history with more comfortable and nostalgic forms.

Handler $(1986,2)$ describes the search for an authentıc cultural heritage experience as a quest for 'the unspoilt, pristıne, genuine, untouched and traditional'. Perceptions that an experience was real or authentic have been shown to be a significant Influence on visitor satisfaction (Moscardo 1996; Pearce 1996; Yeoman et al 2007), although the extent to which all visitors are able to distinguish historical authentıcity from a staged but real experience has also been questioned (Robb 1998; Hall 2007) For local populations, customs 
and traditions can lose their true meaning if they become scheduled and paid spectacles for tourists. Ultimately, the balance achieved will not only influence the value and integrity of what is being protected and sustained, but the relevance it has to the local society and culture as well as its commercial viability. These aspects are therefore relevant to the achievement of sociocultural sustainability.

\subsubsection{Elitism and social exclusion theory}

Another issue with of the commodification of heritage lies in its appeal to the visitor market. Research on heritage visitor markets has found consistently that those who enjoy and seek to engage with heritage tend to come predominantly from white collar, business and professional groups of people, making the demand rather elitist and rather socially exclusive. In consequence, the achievement of socio-cultural sustainability is impaired. Lowenthal (1985) suggests that this concentration of demand in the 'middle classes' represents a shift away from the dominance of the 'upper class' elite 'heritage tourist' travellers of the Georgian period. In fact, as already noted, the heritage tourism phenomenon - as an activity of the elite - stretches back to at least the sixteenth century, and later flourished noticeably as the Georgian Grand Tour. While class categorisation of visitors has largely been replaced by representations of socio-economic groupings (ONS 2001), the findings from research based on either class categorisation or socio-economic groupings still suggests that heritage is predominantly the preserve of the professional, white collar, or the upper and middle classes. Lowenthal (1985) and Prentice et al. (1993) suggested that these visitor groups represent those better able to draw links between their own life experiences and the heritage displayed. 
One reason for this perpetuation of class division is highlighted by Timothy and Boyd $(2006,7)$ who suggest that heritage sites have historically focused on 'artefacts associated with royalty, nobility or other elites', usually at the expense of the 'heritage of the ordinary' While Timothy and Boyd recognise that this bias Is changing and a trend has been established whereby providers seek to embrace more diverse and inclusive narratives, they suggest that there remains a 'major unrepresentative Imbalance in the heritage industry' $(2006,7)$. English Heritage's national visitor surveys from 2000 suggest that these are nationally occurring trends, with limited recorded visits from lower soclo-economic groupings (English Heritage 2000). The white-collar visitors of today represent a breed of heritage visitors who are able to appreciate heritage on an intellectual level (Lowenthal, 1985). The interests of these groups will be reflected in the value placed on different forms of hertage and ultimately in what is deemed worthy of protection and conservation.

Hale $(2001,191)$ argues that 'while heritage [Is] used to legitımıse and renforce power structures', and may thus be socially exclusive, it can also 'be used to subvert them'. Her work on Cornwall's heritage highlights strong local objections to the hegemony of national 'hertage' agencles that operate in the regions and Cornish resistance to the 'expert' interpretations of the county's heritage Caffyn and Lutz (1999) examine the development of Soho House (the elghteenth century home of industrial pioneer Matthew Boulton) in Birmingham's Handsworth as the core of a heritage tourism project In this case, the risk of excluding significant groups of residents of Afro-Caribbean and Indian ethnic ongin was recognised and ways were devised to provide opportunities for the partıcular narratives and other representations of the heritage of migrant groups 
to be presented within the building. Such cases of social inclusiveness are, however, seemingly rather rare and, echoing the Cornish case, the work of Pritchard and Morgan (2001) offers another example of metropolitan inspired heritage interpretation in Wales that fails to include the narrative of the ordinary working-class Welsh.

Origin and social class clearly appear to be defining variables in heritage audiences. However, work by O'Neill (2006) in Glasgow suggests that belonging to a lower social class does not necessarily limit participation in heritage. Evidence from the Glasgow example suggests that some workingclass communities have developed a tradition of visiting heritage as a means of educating their families through enriching their lives. O'Neill $(2006,38)$ summarises this activity as 'contributing to the betterment of their children and grandchildren'. While this case may not conform to national trends, it does imply that differences in social construction, community development, and ingrained attitudes to history can influence the type of visitor that engages with heritage.

In any case, attempts to broaden the appeal and market of heritage sites have sometimes been seen in a negative light. Mellor (1991, 98), for example, suggests that 'heritage has become a little too inclusive' and he expresses a concern, shared by some others, that the growing popularity of heritage and heritage tourism might become problematic. Indeed, both Mellor and Lowenthal foresaw some of the pressures of over-visiting of heritage sites that have now become all too familiar (Du Cross 2008). Nevertheless, the limited appeal of heritage within society constrains the achievement of economic and social 
sustainability, although (because it keeps visitor volumes in check) it is perhaps arguably beneficial to environmental sustainability

\subsubsection{Interpretation theories}

Theories regarding the interpretation of heritage regard it as the process of communicatıng or explaining the significance of a place to visitors (Timothy and Boyd, 2003) It is an educational activity that reveals meaning and relationships through the use of objects, by direct experience, and by instructive media, rather than simply to communicate facts and figures (Tilden, 1977) Its theoretical relevance to the sustanable management of heritage attractions is four-fold. First, by presenting the selective narrative with the greatest market appeal (economic sustainability), interpretation is part of the commodification of a site. Indeed, learning about the historical significance of a site can add to the quality of the visitor experience and enjoyment by broadening horizons and the Imagination. Nevertheless, there are also dangers in takıng this approach by elther makıng the interpretation far too scholarly or taking it into the realms of entertainment, where the history is misrepresented for the sake of spectacle, thrills and/or the adoption of new technology. The staging of historical reenactments of events at heritage attractions using actors or volunteers as an attempt to appeal to visitors is often criticised for this reason

Second, interpretation can be an important means of achieving authentic appeal and relevance to contemporary soclety (soclal sustainablity), although selected narratives can also be potentially value-laden, partial and contain hidden agendas (Busby, 2008). In fact, Shackley $(2001,18)$ suggests that interpretation might not be a suitable tool for presenting heritage, arguing that the visitor 
experience should be 'uncontaminated by technical and commercial realities'. Moscardo (2001) highlights another complexity involved in providing interpretation when he suggests that the use of information to decode heritage artefacts relies on heritage users having sufficient cultural capital to understand the material that is presented.

Community involvement in the development of interpretation at heritage sites has the potential to promote social sustainability. Conflict can arise between the owners and managers of heritage sites and a local community where there is disagreement and a lack of collaboration over the themes presented to visitors. In her work in Cornwall, Hale (2001) addressed the potential impact of conflicts that have arisen between owners and managers of the county's heritage sites and the local community. She noted that issues of the socio-cultural sustainability of interpretation must be addressed collaboratively in order to secure community support and to attract heritage visitors seeking a genuine Cornish experience. Hale's work highlights the dissonance between English Heritage's elitist and Anglicised version of Cornwall's past and the, predominantly working class, industrial heritage seen as important by members of today's Cornish community. She argued that small-scale locally driven initiatives can help to address the problem whereby working-class cultural histories are thought to have been ignored or excluded. Indeed, Hale contended that 'delivering distinct difference' (Hale 2001, 194) and marketing the unique, authentic heritage of Cornwall in fact adds to its national and international appeal. 
Cheung's (1999) work in Hong Kong further demonstrates this point Using the example of the Cantonese community, whose members feel that the heritage of Hong Kong is presented in a manner which marginalises them and favours the former colonial occupants, Cheung argued that the interpretation is skewed and therefore socially unsustannable. He suggested that the falure to offer interpretation that resonates with the narratives of all potential visitors is a source of conflist and, in cases where it is not resolved, it can result in the closure of the resource Palmer (2003) raised further socio-cultural dimensions that should be considered when she discussed the issue of attracting people through emphasising their social link to the site, providing a level of interpretation that allows people to connect to, or see the value of, the resource, and also in sustaining this social link through changing this approach in the light of the demographic for which the site caters. It is therefore essential that a heritage attraction attempts to work in harmony with the local community and ensures that visitors are not afforded use of the heritage asset at the expense of the locals (Garrod and Fyall 2000, 691)

The third way in which interpretation can be relevant to the sustainability of heritage is its use as an important management tool for the control of the movement and environmental Impact of visitors (environmental sustainability) (Pretes, 2002, Palmer, 2005) Laws (1998) employed the concept to develop his blueprinting theory as a means of understanding the typical visit to Leeds Castle In Kent He showed how interpretation can be used as one of the technıques avalable to managers to determine how their heritage product is consumed. Interpretation is thus an Important means of managing visitors and controlling 
their impact on the site; people can be directed to less sensitive or crowded areas by offering alternative routes and attractions.

Fourth, interpretation can also act directly as education. Precisely how this is achieved is one of the most keenly debated issues in the theoretical literature on heritage management. Interpretation is seen by many commentators as a means of presenting heritage stories, and making heritage intellectually accessible to visitors by decoding complex issues (Fotsch 2004; Kolar and Zabkar 2010; Moscardo 1996; 2001; Palmer 1998; 2003; 2005; Prentice et al. 1998; Pretes 2002; Shackley 2001; Uriely et al. 2002). However, as already noted, conflicts can occur because of the potentially value-laden, partial and hidden agendas of interpretive materials (Busby 2008). Nevertheless, it is argued by some authors that by increasing visitors' understanding and appreciation of the heritage being presented, long-term changes in attitude and behaviour can be secured which can reduce pressures and threats to heritage sites. Moscardo (1996) developed the theory of the 'mindfulness' of visitors, whereby 'consumers' can be responsibly led through a site by interpretation aimed at an appropriate level, thus mitigating detrimental impacts on the heritage resource.

In addition to these four ways in which interpretation theory is relevant to the sustainability of heritage sites, it should be noted that materials and activities need to be designed to be long term and capable of being maintained. The International Council of Monuments and Sites (ICOMOS), which is an international body of professionals which advises the World Heritage Committee (of UNESCO) on the conservation of cultural heritage, has formed an 
International committee on Interpretation and Presentation of Cultural Heritage Sites (ICIP). The committee has drafted a charter (the Ename charter), ratified In September 2008, as a new standard for professional standards. The charter lists seven key principles which are recommended to guide the development of good interpretation (Table 16) Significantly, amongst the Ename Charter principles, plannıng for sustarnability is explicitly noted.

Table 1.6 International Council of Monuments and Sites (ICOMOS) Charter on the Interpretation and Presentation of Cultural Heritage Sites

\begin{tabular}{l}
\hline Key Principles \\
\hline - Access and understanding \\
- Information sources \\
- Attention to setting and context \\
- Preservation and authentıcity \\
- Planning for sustamability \\
- Importance of research, trainıng and evaluation \\
Source ICOMOS ICIP (2008) The ICOMOS Charter for the Interpretation and \\
Presentation of Cultural Heritage Sites (Ename Charter) [online]
\end{tabular}
Presentation of Cultural Heritage Sites (Ename Charter) [online]

In elaborating these principles, the text of the ICOMOS charter explicitly noted that interpretation activities need to be designed to be long term and maintaned In a socially, financially and ecologically sustainable manner.

Clearly, the theoretical Iterature pertaining to heritage interpretation has focused strongly on the importance of adopting correct, authentic and inclusive interpretive material. While the role that interpretation could play in managing visitor numbers has been alluded to, there is very little evidence in existing 
research of work that seeks to locate the provision of interpretation in the broad context of sustaining heritage resources environmentally, socio-culturally and economically.

\subsubsection{Segmentation and visitor profiling theories}

Theoretical discussions regarding the analysis of heritage visitor characteristics and its importance for the success of heritage marketing have been common in the literature since the 1990s. An important study by Hall and McArthur (1998) developed a model that combined an analysis of the demographic, geographic and socio-economic attributes of visitors with information about their motivations, expectations, and preferred heritage experiences. Psychographic profiling theory, of the kind first developed and described by Plog (1973; 1991), emphasises the importance of understanding the behavioural characteristics of potential visitors. His 'life-style model', for example, distinguished between 'risktakers' who seek challenge and adventure, at one end of the spectrum, with those, at the other extreme, who prefer much more passive and unthreatening situations. Perhaps the key point of relevance in the context of this thesis, however, is that theoretical discussions have stressed the importance for the successful and profitable management of heritage of securing a detailed and comprehensive knowledge of the characteristics, motivations and expectations of potential visitor groups. There has, however, been relatively little empirical work that explores the extent to which heritage providers are systematically conducting research of this kind on their 'market'. 


\subsubsection{Environmental sustainability theories}

The response of heritage providers to the sustanability agenda is a largely unexplored area of research. However, a number of theoretical models from previous research, which attempt to conceptualise the process of adoption of environmental sustaınab!lity withın commercial businesses, appear to be relevant. The transferability of such theories to the heritage sector is, of course, complicated by the conservation imperatives and protected nature of the resources under consideration, which were outlıned earlier in thıs chapter Nevertheless, theories about the adoption of environmental sustannability have commonly envisaged a linear or tterative transformation of behaviour, values and strategies which, over tıme, seek to reconcile environmental and economic priorities. Progress is influenced by a number of factors, such as societal and scientific perceptions of the need for environmental sustainability (Roome 1992), market opportunities that may arıse as a result of adopting sustanable practices (Steger 1993), calculations about the financial relevance of any Innovation, and the extent of managerial discretion (Walley and Whitehand 1994) It has been argued that variations in the strengths of these influences will give rise to different levels of adaptation to the environmental sustannability agenda from an essentially very weak appreciation of the need to operate in a more sustannable manner, to a much deeper awareness that prompts significant changes in practice

Theories on the so-called voluntary 'greening' of business thus appear to resonate with investıgatıons of the sustannable management of heritage. For example, the notion of the linear or continuum model (Hass 1996), which envisages a gradual process of adoption of environmentally friendly measures 
and, at each stage, an assessment being made of how the new practice will mesh with other imperatives in the business, appears to be directly applicable to an analysis of sustainable heritage management. Hass (1996) also described an alternative, so-called 'categorised model' where the critically strategic role of an influential individual in an organisation is decisive in assessing opportunities, identifying risks, and determining the formulation of policies and projects for the further adoption of environmental sustainability. While evidence from the literature on business offers very few examples of the empirical testing of these theories, they clearly provide a useful conceptual framework within which to monitor the 'greening' of heritage management.

\subsection{Sustainable management policies}

The extent to which the challenges to sustainable heritage management have been recognised by the main owners and managers of heritage sites in the UK is also an important consideration in this analysis. This section reviews the sustainability policies of the main statutory heritage agencies and organisations.

\subsubsection{The National Trust}

The Trust's approach to heritage custodianship aims to safeguard heritage 'for ever, for everyone' (National Trust 2007). It is responsible for protecting and opening over 300 historic houses and gardens, 49 industrial monuments, mills, 'forests, woods, fens, beaches, farmland, downs, moorland, islands, archaeological remains, castles, nature reserves, villages' (National Trust 
2010) The National Trust, established (as already noted) in 1895, is a charity that is completely independent of government. This independence means that income is not derved in the same way as other government-supported organisations (e.g English Heritage). The Natıonal Trust relıes for income on membershtp fees, donations and revenue rassed from commercial operations.

Evidence of the increasing importance of the sustannability agenda in the work of the National Trust was reflected in its Environmental Impact Assessment in 1992 and an associated statement of environmental principles (National Trust $2009 a, 2009 b)$. These principles focused primarly on the impact of heritage visits on the natural environment. The National Trust thus began takıng actions to mınımıse the environmental ımpacts of buildıngs, energy, transport, waste and water at their resources (see Table 17) While these actions demonstrated progress towards identifying and mutigating some of the key issues of sustainability at National Trust resources, it did not encompass issues of sociocultural or economıc sustannability.

The National Trust bult on its 1992 Environmental Impact Assessment when it produced its 2001 Rural Sustainablity - A Rural Policy Framework and the 2006(a) Towards Sustamable Land Management report. The 2001 Rural Policy Framework was produced to demonstrate how the Trust, through sensitive Investment in places, people and ideas, could develop and promote sustannable solutions for social and environmental wellbeing. In words that echo the Brundtland report, the National Trust thus declared that it takes account of the 'cultural, economic, social and environmental interest of people today, while planning for the wellbeing of future generatıons' (National Trust 2001). 
Table 1.7. The Minimisation of Environmental Impacts by the National Trust (1992)

\begin{tabular}{|c|c|}
\hline Area & Impact \\
\hline Buildings & $\begin{array}{l}\text { Impact of building materials and } \\
\text { energy efficiency }\end{array}$ \\
\hline Energy & $\begin{array}{l}\text { Impact of carbon dioxide emissions, } \\
\text { impact of climate change }\end{array}$ \\
\hline Transport & $\begin{array}{l}\text { Impact of congestion, emissions, } \\
\text { intrusion of car parks, need for } \\
\text { expansion }\end{array}$ \\
\hline Waste & $\begin{array}{l}\text { Impact of litter on wildlife, need for } \\
\text { landfill, impact of pollution e.g. } \\
\text { contaminated water }\end{array}$ \\
\hline Water & $\begin{array}{l}\text { Impact of climate change and } \\
\text { associated water shortage, } \\
\text { subsidence, water supply charges. }\end{array}$ \\
\hline
\end{tabular}

Source: Adapted from National Trust (2009a) [online]

The framework also focused on a holistic view of sustainability and defined 17 policies to maintain heritage resources in an environment of climate change, economic development and agricultural reform.

While the 2001 framework provided an idea of what the Trust sees as its position on sustainability, and provided policies that it aims to implement, the document failed to detail specific actions, or examples of good practice, for managers or providers of heritage. As a result, in 2006, another document was issued, entitled Towards Sustainable Land Management. This document included examples of the use of sustainable management techniques at National Trust properties. As well as providing case studies of applied good practice, the document also articulated the 'conditions for performance 
objectives to have impact', 'principles of progress', and Included a section entitled 'steps in the right direction' In 2006, the Natıonal Trust reported market research to identify their key visitor groups The Trust's Head of Membership explanned the two-fold purpose of undertaking this 'segmentation' analysis as (1) to secure long-term financial sustainability of the Trust by attracting more vIsitors, and (2) by finding out 'what they want', to enhance the Trust's relationship with its core supporters (National Trust 2006b, 4). The research revealed seven target audience groups (Table 1.8) from whıch two national prıority groups were identffied Explorer Families and Curıous Mınds (orıginally called Grey Matter). The managers of Trust properties have since been encouraged to identify therr own prionty group from amongst the seven 'audiences' that the research identified. As a means of Improving both the economic sustainability and socio-cultural appeal of the heritage offering, local managers have been advised to target their marketing and interpretive provision at their own priority audience Clearly, in the past few years the National Trust has made significant progress in developing policy that introduces socio-cultural sustianability into therr working practices.

The National Trust has promoted a range of schemes to promote environmental sustainabilty in ts properties and estate, including lightbulb replacement schemes and also the introduction of more energy-efficient heatıng systems at many of its historic houses. The Trust's lightbulb replacement scheme began in June 2008 and involved the replacement of 40,000 light bulbs in nearly 500 of their properties 


\begin{tabular}{|c|c|c|c|}
\hline Segment & Description & $\begin{array}{c}\text { No. in } \\
\text { segment } \\
\text { nationally }\end{array}$ & $\begin{array}{c}\text { Spend } \\
\text { per NT } \\
\text { visit }\end{array}$ \\
\hline $\begin{array}{l}\text { Explorer } \\
\text { Families }\end{array}$ & $\begin{array}{l}\text { Self Starters. Proactive. Enjoy adventure as an } \\
\text { entire family. Into castles and ruins, high users of } \\
\text { the internet, less likely to spend on } \\
\text { catering/souvenirs, self sufficient. Active attendance } \\
\text { to NT properties in last twelve months }\end{array}$ & 7.7 million & High \\
\hline $\begin{array}{l}\text { Out and } \\
\text { About }\end{array}$ & $\begin{array}{l}\text { Moochers, doing things together is more important } \\
\text { than what they are doing. The Trust is a backdrop } \\
\text { for socialising. Go where the fancy takes them. } \\
\text { Picturesque towns and villages interest them; and } \\
\text { art and architecture. Like to dip in and out of } \\
\text { information and experiences }\end{array}$ & 8.7 million & Low \\
\hline $\begin{array}{l}\text { Grey Matter } \\
\text { (later } \\
\text { renamed } \\
\text { 'Curious } \\
\text { Minds') }\end{array}$ & $\begin{array}{l}\text { Majority } 65+\text {, active minds. Highest proportion of } \\
\text { members. Deliberate visits to well researched } \\
\text { places. Fascinated by people stories. Seek peace } \\
\text { and relaxation, likely to be members of other like- } \\
\text { minded organisations }\end{array}$ & 5.6 million & Low \\
\hline $\begin{array}{l}\text { Young } \\
\text { experience } \\
\text { seekers }\end{array}$ & $\begin{array}{l}\text { Eclectic, under } 30 \text {, no children, high ethnicity, like } \\
\text { new experiences, travel, some want an adrenalin } \\
\text { fix. Group visitors for interest, exercise and } \\
\text { challenge - ending in the pub. }\end{array}$ & 1 million & Medium \\
\hline $\begin{array}{l}\text { Home and } \\
\text { Family }\end{array}$ & $\begin{array}{l}\text { Know what they like and like what they know. } \\
\text { Lowest income segment, largest groups of } \\
\text { extended family and friends, most interested in } \\
\text { spending time together. Enjoy shopping. Visits likely } \\
\text { on high days and holidays. Entertainment and value } \\
\text { important, want affordable catering rather than } \\
\text { having to take a picnic. }\end{array}$ & 4.9 million & High \\
\hline $\begin{array}{l}\text { Kids First } \\
\text { Families }\end{array}$ & $\begin{array}{l}\text { Want to be certain they will have a good time. Likely } \\
\text { to attend Halloween, Christmas. Large Groups. } \\
\text { Want packaged experiences and familiarity. Visit } \\
\text { country parks and estates, wanting entertainment. } \\
\text { High spenders but infrequent visitors }\end{array}$ & 3.8 million & High \\
\hline $\begin{array}{l}\text { Live Life to } \\
\text { the Full }\end{array}$ & $\begin{array}{l}\text { Full-on, into everything. Self sufficient. Proactively } \\
\text { seek experiences. Highest level of special interest. } \\
\text { Avoid crowds. Confident, sophisticated, young at } \\
\text { heart, unlikely to buy souvenirs, Frequent days out } \\
\text { takers, above average visits to stately homes }\end{array}$ & 3.1 million & Medium \\
\hline
\end{tabular}

Source: Adapted from: National Trust 'Trust You', National Trust Magazine, September 2006b, 4-5). 
The Trust realised that they could not simply replace all existing lighting with conventional energy saving bulbs, 'not only because of the murky green light they emit but also because they emit more ultraviolet light which is damaging to historic fabrics, wallpapers and watercolours" . The manufacturer, Philıs, was therefore persuaded to customise IIght bulbs that emit less ultraviolet (UV) light than either incandescent or compact flourescent lıght (CFL) bulbs', resultıng in the procurement and installation of specially designed low energy halogen bulbs $^{8}$ The initiative produced a cost saving of $£ 431,000$ from an initial Investment of $£ 189,853$, which was the equivalent of $£ 4192$ saving per bulb (Telegraph 2008). While cost was seen as the prıncipal driver for this exercise, the project was also reported to bring other benefits to the organisation, such as an increased attractiveness to visitor groups seeking more environmentally friendly visitor expenences and a clean organisational ethos among staff and VIsitors The Trust recognised that it was able to implement these changes without damaging the integrity of its sites.

At the Castle Drogo estate in Devon, an oll-powered boiler was replaced, 'saving some $£ 35,000$ a year as well as greatly reducing Drogo's carbon footprint and improving wildlife habitats on the estate' (National Trust 2009c). These well-publicised schemes have helped other heritage managers to recognise the environmental and financial benefits that might be secured by the adoption of green technologies The Trust also manages waste management using reedbed systems, produces electricity generated by old milis and, as far as possıble, makes purchases from local producers. It is clear that the National

\footnotetext{
${ }^{7}$ A point noted in section 11

Bhttp / www telegraph.co uk/earth/3345054/The-National-Trust-sees-the-eco-llght.htm! (2008) 
Trust is responding to the sustainability agenda in a number of ways and beginning to gain some credentials in leading these innovations.

\subsubsection{English Heritage}

English Heritage acts as the government's advisor on the historic environment and is funded by a grant from the Government's Department of Culture, Media and Sport (75 per cent) together with revenue earned from its own heritage resources (25 per cent). The English Heritage funding settlement agreed in 2008 , for the three-year period $2008 / 9,2009 / 2010$ and $2010 / 2011$, shows that annually some $£ 132.7$ million is drawn from public funds, and another $£ 48.1$ million comes from revenue generated by its own heritage resources.

English Heritage began as three separate Historic Buildings Councils created by the Historic Buildings and Ancient Monuments Act, 1953: one for England, Scotland and Wales. The Historic Buildings Council for England was abolished by Section 39 of the National Heritage Act 1983 (mentioned above) and replaced by the Historic Buildings and Monuments Commission for England, also known as English Heritage. At this time, English Heritage subsumed the functions that were formerly the responsibility of England's Ancient Monuments Board. The body aims both to ensure the conservation of heritage and to encourage people to enjoy and appreciate it.

Given its overall responsibility for the nation's historic environment, as well as its own estate, the approach of English Heritage to the sustainability agenda has been more strategic and slower than that of the National Trust. It has 
tended to view climate change and the growing demands for energy efficiency in buildings as a long-term threat to the historic environment. The effects of climate change are recognised as being both direct, through damage or destruction of historic assets, and indirect, through the impact of adaptation and mitigation on historic buldıngs, sites and landscapes. Both effects will impair the ability of future generations to understand and enjoy their cultural heritage (English Heritage, 2008a). In terms of Improving the energy efficiency of buildings, it recognises that many historic buildings often perform well in this respect because of their thick walls and small windows Small improvements sympathetic to the historic character of buildings can be implemented, such as draught-proofing, Improved insulation and bringing internal shutters back into use. Nevertheless, English Heritage suggest that any sustannablity appraisal of the historic building stock should be informed by a wider range of factors other than just energy efficiency, such as the cultural and social significance of the existing stock and its exıstıng and future functionality (English Heritage, 2008b) English Heritage have published guldance notes for owners of heritage properties on the implementation of renewable energy technologres $(2008 \mathrm{c})$, bjomass crops (2006a), micro-generation technologies (2008d), energy conservation and energy saving measures (2008e) In 2004, English Heritage also launched HELM (Historic Environment, Local Management), a web-based resource amed at providing 'accessible Information, trainıng and guldance to decision makers in local authorities, regional agencies and national organisations whose actions affect the historic environment' (English Heritage 2010a) The aim of HELM is to work with key partners to provide tools to manage change in the historic environment The HELM website contains some IImited guidance for local authorities on how to manage historic sites; 
information on heritage reform; case studies on good practice; and information about relevant training opportunities. HELM's role as a tool for local authorities is reflected in the training provision and guidance that it provides focused on the environmental sustainability of built resources.

The organisation's most recent strategic document, Conservation Principles: Policies and Guidance for the sustainable management of the historic environment, was published in 2008 (English Heritage, 2008f). It was produced as a philosophical foundation for the improved legislative framework being formulated for the management of change in the historic environment in the twenty-first century (draft Heritage Protection Bill 2008). It will guide the agency in the management of its own estate as well as other actors involved in the historic environment, such as planning officers, councillors, developers, professional agents and amenity societies. The central focus of the document is on six high-level principles (see Table 1.9), which are supported by detailed policies and guidance on how to reach decisions on a wide range of situations involving repair, new development, alteration and restoration. One of the fundamental changes in policy is that 'owners and managers of significant places should not be discouraged from adding further layers of potential future interest and value, provided that recognised heritage values are not eroded or compromised in the process' (English Heritage 2008f, 43). Unfortunately, the Heritage Protection Bill was dropped from the legislative programme in both the 2008-2009 and the 2009-2010 Parliamentary Sessions as more pressing matters arose relating to the global financial crisis and economic recovery. 
Table 1.9. English Heritage's Six High-Level Principles for the Sustainable Management of the Historic Environment

\section{Principles}

- The historic environment is a shared resource

- Everyone should be able to partıcipate in sustaining the historic environment

- Understanding the significance of places is vital

- Significant places should be managed to sustain their values

- Decisions about change must be reasonable, transparent and consistent; and

- Documenting and learning from decisions is essential.

Source: English Heritage (2008f, 19-24)

The Bill currently remains in draft form and has been proposed for the 20102011 legislative programme ${ }^{9}$

\subsubsection{The Historic Houses Association}

The HHA represents 1,500 historic houses, castles and gardens in private ownership throughout the UK. Around 350 of these properties are open to the public, and attract about 12 million visitors per year. The Association lobbles government for concessions to improve the viablity of owning historic houses and estates, such as taxatıon relıef for maintaining hıstoric properties Its most recent policy document, entitled Insprrational Places: the value of Britain's historic houses, was published in 2010 (Historic Houses Association 2010).

\footnotetext{
${ }^{9}$ The change of government in May 2010 might, however, further affect the prospects of the legislation
} 
Essentially, the document continues to make the usual case for special treatment given the back-log in essential repair work, but does also specifically refer to aspects of sustainability. The adoption of low-cost efficiency measures by members has reduced energy use in historic houses by $15-25$ per cent. About 20 per cent of HHA members have invested in renewable energy sources, 60 per cent have installed low-energy light bulbs, and 50 per cent have installed more efficient heating systems. Substantial progress towards sustainability in heritage properties is evidently being achieved, despite the inherent challenges posed within the sector.

\subsubsection{The Church of England}

The Church of England is a major owner of heritage properties, which includes 44 cathedrals, 16,000 churches, 4,700 schools and colleges, and three Archbishops' palaces (Church of England, 2010). In 2006, it launched its national environmental campaign, Shrinking the Footprint. The environmental consultants AECOM (Architecture, Engineering, Consulting, Operations, and Maintenance) produced technical reports to encourage the environmental management of churches, cathedrals, schools and clergy housing. The Shrinking the Footprint report evaluated a range of issues including environmental problems in historic churches, low-carbon lighting alternatives for cathedral buildings, and identifies impacts associated with the Church of England's desire to reduce carbon emissions. The report showed that the carbon footprint of cathedrals and church buildings could be reduced by as much as 20 per cent by using energy more efficiently (see Table 1.10). 
Table 1.10. Potential energy and cost savings through the adoption of sustainable energy practices in Church of England properties

\begin{tabular}{|c|c|c|c|}
\hline $\begin{array}{c}\text { Description of } \\
\text { action }\end{array}$ & Capital cost $£$ & $\begin{array}{l}\text { Typical energy } \\
\text { saving as } \\
\text { percentage of } \\
\text { annual heatıng, } \\
\text { electric or total bill }\end{array}$ & $\begin{array}{c}\text { Typical annual } \\
\text { cost-saving from } \\
\text { heatıng or electric } \\
\text { bill }\end{array}$ \\
\hline $\begin{array}{l}\text { Implement-an energy } \\
\text { saving regume }\end{array}$ & Low-or no cost & $515 \%$ total & £280 total \\
\hline $\begin{array}{l}\text { Improve boiler } \\
\text { controls }\end{array}$ & $£ 1,000-£ 5,000$ & $5-10 \%$ heat & $£ 300-£ 1,000$ heat \\
\hline $\begin{array}{c}\text { Insulate hot water } \\
\text { prpes }\end{array}$ & $£ 10-£ 30$ per metre & $5 \%$ heat & $£ 200-£ 350$ heat \\
\hline $\begin{array}{l}\text { Install draught } \\
\text { proofing }\end{array}$ & $£ 200-£ 5,000$ & $25-10 \%$ heat & $£ 50-£ 700$ heat \\
\hline $\begin{array}{l}\text { Reduce heat loss } \\
\text { associated with } \\
\text { windows }\end{array}$ & $£ 250-£ 1,000$ & $1 \%$ heat & $£ 0-£ 100$ heat \\
\hline $\begin{array}{l}\text { Replace lighting } \\
\text { Installation }\end{array}$ & $£<100-£ 4,000$ & $3-50 \%$ electrıc & $£ 15-£ 800$ electric \\
\hline Replace boiler & $£ 2,000-£ 15,000$ & $15-25 \%$ heat & $£ 200-£ 1,000$ heat \\
\hline
\end{tabular}

Source Harden (undated, based on AECOM report for Church of England)

From 1 July 2010, churches are being encouraged to record their electricity, gas and oll usage by means of an onlıne facility as well as a sımple energy audit to Identify action that need to be taken.

In 2009, as part of the Shrinking the Footprint Campargn, the Church of England introduced a seven-year plan on climate change and the envronment called Church and Earth 2009-2016 (Church of England 2009). Church and Earth 2009-2016 (Church of England 2009) builds on the original Shrinking the Footprint reports, establıshıng a basis for environmental action at Church of England owned sites The plan summarises the key environmental concerns for the Church, identrfying the main challenges for the organısatıons. It also 
provides a set of key principles by which churches should endeavour to operate and also suggests a set of milestones against which engagement with environmental issues will be assessed. In addition, the plan provides examples of past and present good practice activities from different Church of England sites.

At a local level, the Church of England monitors their actively used historic churches through a rolling programme of assessment. The rolling programme involves five-yearly inspections by Church-employed architects who produce a summary of church condition and a long and short-term plan for work that needs to be carried out. The reports provide a short-term list of actions that those managing the church must address, and a longer-term two, to five-year plan of work. Through this process, the Church is able to monitor the condition of their properties and ensure that the physical structure retain their historic integrity. Advice can also be sought from the architect as to acceptable approaches to implementing environment sustainability in historic churches. While the architects do not commission work, they are able to monitor its progress and provide information to the wider church as to the quality, condition and environmental implementation at individual sites.

\subsubsection{The Churches Conservation Trust}

The need to preserve redundant churches (those with no active congregation) was recognised in the 1968 Pastoral Measure: Ecclesiastical, by the formation of the Churches Conservation Trust. Now over 40 years old, the Trust is a national charity that protects historic churches at risk from failing congregations. 
They have so far saved over 340 special buldings which attract more than 15 million visitors a year, keepıng them open, in use and free to all The Trust aıms to encourage local communities to preserve important historic churches that are now redundant, by encouraging them to use and care for buldings and engage with points of interest, with the aim of conserving the historical, archaeological and socio-cultural value Both this organisation, and the more recent addition of the Historic Chapels Trust, aim to make historic churches more sustannable However they make little or no reference to economic or environmental sustanabılity, referrıng predomınantly to the importance of sustaınıng the sociocultural relevance of their sites In addition, in the past few years, English Heritage has recognised the urgent need to conserve historically important (but all-too-often endangered) parish churches. Thus, in 2006, it launched its 'Inspired Campaign' to encourage historic churches to diversify their activities and to attract visitors and tourists as a means to secure income English Heritage estımates that vital mantenance on historic parish churches across the country urgently currently requires around $£ 1$ billion: there could hardly be a clearer case for exploring sustainability issues than there is in the context of parish churches

\subsubsection{The Museums, Libraries and Archives Council}

The Museums, Libraries and Archives Councll (MLA) is an organisation Inked to the government Department for Culture, Media and Sport that offers tranning, advice and funding to its members. In July 2009 , the MLA released a strategy document entitled Leading Museums, A Vision and Strategıc Action Plan for English Museums, which addresses (In a sector-specific context) the Issues and 
challenges raised in Understanding the future (DCMS 2006) to provide an action plan of 'ten key action points, underpinned by three main aims: supporting excellence; promoting partnerships; and building capacity' (MLA $2009,3)$. The report highlighted the need for curators and managing agencies to seek out entrepreneurial partnerships and focus on effectively meeting visitor needs in order to remain sustainable. However, the report represents a general statement of direction for the MLA, and provides little or no guidance for curators or managers of individual sites. The MLA relies on local managers of museums/archives to implement and develop their own policies, but it does offer a central source of assistance similar to the National Trust.

While the 2007 Government White Paper, the 2008 Draft Heritage Protection Bill, and associated policies put forward by English Heritage and the National Trust, together represent significant progress in the recognition of the need to sustain heritage, it is clear that many of the proposed actions still await implementation. The range of heritage resources across the country means that methods needed to address the issues will be complex and diverse.

While this discussion highlights that some large organisations have taken significant steps towards incorporating sustainability into their roles as custodians of heritage, it also indicates the complexities involved in the implementation of policies. With limited government guidance, in documents such as Energy Conservation in Traditional Buildings and Developing Best Practice Guidance for Local Heritage Assets, targeted directly at the managers and custodians of heritage, and an historic lack of consideration of sustainability beyond that of green issues, it is evident that sustainable heritage management 
has nether been fully appreciated nor researched. Where any research and policy exists, it refers solely to the larger providers and custodians of heritage with little or no mention of smaller providers and little guidance avallable for providers lookıng to manage their resources sustannably.

\subsection{Key themes, research aims and objectives}

It is apparent, from the review presented so far, that the implementation of sustannable hertage management is fraught with problems, conflicts and apparent contradıctions A decade ago, Garrod and Fyall's $(2000,702)$ study of heritage management revealed that a greater emphasis is generally placed on curatorial Issues, conservation and education, than on the contemporary use of, and local community engagement with, heritage resources than is evident in most other interpretations of the sustainability imperative. It appears that there may not yet have been very much change in this emphasis since 2000 and the application of ideas about sustaınable development in the heritage sector is still In Its infancy

Considerably more research is required into the degree of engagement with the sustannabllity agenda on the part of heritage providers The overall alm of this research is therefore to contribute to a better and fuller understanding of the scope for sustainable development in the heritage sector, and the current application and Implementation of sustainable management practıces 


\subsubsection{Main research objectives}

The main research objectives comprise two categories. The first category, which includes two objectives, labelled below as (a) and (b) includes basic research that was found to be necessary in order to establish a basis for a later detailed exploration of the current awareness and adoption of sustainable management within the heritage sector in Devon and Cornwall. A survey of the diversity, character and economic significance of publicly accessible heritage provision in the two counties was needed in order to justify the focusing of the research on Devon and Cornwall. Investigations were also needed to establish whether a comprehensive and reliable listing of heritage sites for the region existed and, if no satisfactory classified listing was identified, to seek to create one for a small group of visited heritage types. A database of this kind was deemed essential to provide a sampling framework for the later empirical enquiries undertaken in this research project. In detail, therefore, for the first category of objectives, the study will:

a. Survey the broad diversity, range, and character of heritage in Devon and Cornwall, and the extent of attention paid to it by previous authors, in order to establish its importance to the local economy and justify its choice as a potential area of focus for the study.

b. Formulate an effective means of identifying and categorising heritage, customised for application in Devon and Cornwall, and develop a comprehensive database of publicly visited heritage sites within the two counties as a sampling frame for an investigation of sustainable management practices in a selection of different heritage categories. 
Drawing on the evidence and data generated as a result of achieving the research objectives (a) and (b), the second category of objectives, numbered below as 1-6, comprises specific enquiries designed to explore and examine the sustainable management of visited heritage in Devon and Cornwall These objectives have been formulated to achieve the key overall alm of the research, namely to contribute to an enhanced understanding of attitudes towards, and the practise of, sustainable management in Devon and Cornwall's heritage sector (as already outlined fully in Section 17) In detall, therefore, the study will go on to

1 Assess the awareness of heritage managers of sustannablity Issues, and their attitudes towards the adoption of sustannable management practices.

2. Establish the extent of adoption, priorities accorded to, and the degree of Implementation of sustainable management (environmental, sociocultural and economic).

3 Investigate perceptions and opınıons about the potential benefits, problems and barriers in the implementation of sustanable management

4. Evaluate the extent of any commodification and its implications for sustainablity at heritage sites

5. Examıne the role of larger parent organisations in the dissemınation of good practices, the availabulity of guidance, and the sharing of 
investment costs between sites for the implementation of sustainable management practice.

6. Formulate policy recommendations in relation to key research findings.

\subsection{Structure of Thesis}

Chapter 1 has reviewed the literature and theoretical background of heritage studies; it has also shown that the relative dearth of studies on the sustainable management of heritage resources represents a gap in the existing body of research; and it has also outlined the aims and objectives of this research. The thesis hereafter comprises another four chapters.

In order to justify the selection of the two Southwest counties as a study area for this investigation, Chapter 2 reports on the review undertaken of the range, diversity, and quantity of heritage in Devon and Cornwall. It also evaluates the extent to which the region has been the focus of analytical studies of heritage. Thereafter, Chapter 3 discusses the methods employed to probe in detail the extent and character of sustainable heritage management practised in the sample of cases representing the chosen heritage categories. The selection of a sample of heritage resource categories for the research is then explained, and the methods used to establish the number and location of all the sites in the chosen categories are outlined, and the findings are presented. The chapter also describes the questionnaire survey and interviews that were conducted in order to explore sustainability in heritage management in Devon and Cornwall's historic houses/castles, museums/archives, and historic churches. 
Chapter 4 presents an account and analysis of the findings derived from the results of the questionnarre survey and interviews with respect to environmental sustainablity, socio-cultural sustanability, and economic sustanability. In partıcular, it examines hentage managers' awareness of sustannabilty issues, provides an assessment of their attitudes towards sustainable management, establishes the extent to which these management technıques have been adopted and discusses the perceptions of benefits and barriers in the Implementation of these approaches. The Chapter also evaluates how levels of commodification, the role of larger parent organisations and the balance between paid staff and volunteers impacts on the implementation of sustarnable management.

The final chapter of the thesis explores the policy Implications and wider significance of the findıngs of the research and makes recommendations about the prospects for achieving enhanced environmental, socio-cultural, and economic sustanabulity at heritage sites in Devon and Cornwall. The Chapter Indicates future directions that now need to be adopted by all the relevant stakeholders to improve heritage sustainability. Finally, a research agenda is suggested to examıne further the sustainability of heritage in the Southwest in partıcular, and in the country as a whole 


\section{CHAPTER 2}

\section{HERITAGE IN DEVON AND CORNWALL}

\subsection{Introduction}

This chapter aims to examine the heritage of the two counties of Devon and Cornwall and to justify their selection as the focus of research on sustainable management practices. Tangible legacies of the past are abundant in the Southwest and the attractiveness of the region's heritage makes a major contribution to the appeal of Devon and Cornwall as tourist destinations. The range and quality of heritage in the two counties will therefore be reviewed.

\subsection{An Overview of Devon and Cornwall Heritage}

The rich, varied, and deeply layered heritage of Devon and Cornwall has attracted visitors for more than five centuries. From the late-fifteenth century, it has drawn the attention of generations of scholars and writers who recorded and described the historical features which they observed. By the end of the eighteenth century, and with gathering momentum in the nineteenth century, heritage tourism in the Southwest was underway. Despite the serious damage inflicted in episodes of Second. World War aerial bombardment, in keeping with the rest of England, Devon and Cornwall have been spared, for almost a millennium, the destructive effects of a land invasion and the two counties thus possess representations of human occupation and activities that stretch back to the Palaeolithic. The impacts of post-war planning and other pressures to [re]develop have been lamented and strongly criticised by, amongst others, the 
lumınary W. G. Hoskıns (writıng about England as a whole, and Devon in particular 1955, 231-235, 1978, 132), but a huge abundance of hertage nonetheless survives as a tangible, physical legacy of the region's historical experience

\subsubsection{Devon and Cornwall Visitors and Recorders of Heritage}

Although none would have recognised that their activities amounted to heritage tourism, the early visitors to the two counties in the far south-west of England, who left accounts of therr experiences, were in effect engaged in exactly that. in 1478, William Botoner, also known as 'Willam of Worcester', undertook a journey from Norwich to St Michael's Mount in Cornwall and, on the way, recorded the 'castles, churches, havens and ports' that he encountered (Brayshay 1996, 4) A tradition thereby began that has come to be known as topographical and antıquarian writing The genre was greatly influenced by the much fuller commentarles of John Leland who is known to have 'explored the Westcountry twice' first in 1542, and again in etther 1544 or 1545 (Chandler 1996, 36) Leland's descriptions of what would now be referred to as the 'bult heritage' of the two counties may perhaps be regarded as the beginnıngs of travel for the purpose of 'consuming' England's history (Chandler, 1993) The castles, great houses, ancient bridges, towns and antıquities, as well as other manifestations of heritage in Devon and Cornwall, are later described in works by Willam Camden and William Harrison, which were natıonal-scale surveys camed out in the Elizabethan period However, the county-scale surveys of Rıchard Carew (Cornwall) and John Hooker (Devon) provide considerably more local detall and manifest the considerable interest and pride taken by both men 
in the history (and its physical legacies) of their home area (Brayshay 1996). Others who followed in the late-sixteenth and early seventeenth centuries include Thomas Westcote, Tristram Risdon, and William Pole (Youings 1996).

Interest in visiting and recording archaeological monuments flourished in the later seventeenth and eighteenth centuries. For Cornwall, the work of William Borlase stands out. Borlase pursued both the topographical approach of Leland and Camden, and conducted meticulous investigations into the county's antiquities (Borlase 1754; 1758). Richard Polwhele wrote a three-volume history of Devonshire between 1793 and 1797, and produced a similar work on Cornwall in 1803. These 'studies of Devon and Cornwall assemble information which is not easily obtainable elsewhere' and, as eye-witness accounts of the heritage and the contemporary late-Georgian landscapes of the two counties, 'they scarcely have an equal' (Brayshay 1996, 16). The well-known travel . journals of Celia Fiennes and Daniel Defoe contain, amongst a great deal of other material, brief descriptions of historical sites in Devon and Cornwall which they encountered during their country-wide tours. However, the diaries of the Revd John Swete (1789-1804) provide a richer (and most beautifully illustrated) commentary on both the antiquities (i.e. the heritage) and the 'modern' phenomena that he encountered in the two counties (Gray 2000).

By the later Georgian era, the descriptive tradition continued, but new publications were increasingly being aimed at readers who themselves might expect to visit the places and the buildings that were presented. Victorian writers later began to produce detailed guidebooks which would be of use to what, effectively, were heritage tourists intent on visiting particular areas. Thus, 
In 1848, the Revd Samuel Rowe published his Perambulation of the Ancient Royal Forest of Dartmoor, which is a guide to the Moor of such great value that It was only superseded in 1909 by Willam Crossing's masterly Guide to

\section{Dartmoor}

Samuel Rowe's earlier tourısts guide to Plymouth and its neıghbourhood mıght well be regarded as an early example of a hertage visitors' handbook. For example, his description of the magnificent Romanesque doorway of the east Cornwall church of St German's is as useful today as it was almost two centuries ago (Fig 2.1)

Between [the] two towers is the ancient entrance door-way, which is a very fine circular receding arch, with four pillars on each side, having plan square bases and capitals, and being contaned in semi-cırcular niches. The arch displays seven mouldings, with alternate zigzag ornaments, which also occur between the pllars. Over the arch is a pediment, with a cross at the top, resembling an heraldic cross (Rowe $1821,242-243)$.

Thıs kınd of highly informative and detailed descriptive approach was emulated by the Handbooks for Travellers published by John Murray between 1851 and 1905 Perhaps Indıcatıng the partıcular attractiveness of Devon and Cornwall as a region whıch was likely to appeal to tourists, a volume devoted to the two counties was the first in Murray's series The handbook contanns a great deal of information on the abundant heritage of the far Southwest Twentieth-century tourısts benefited from an outpouring of publications which aimed to draw their attention to the interestıng, aesthetically pleasing, picturesque and memorable places in a locality. 


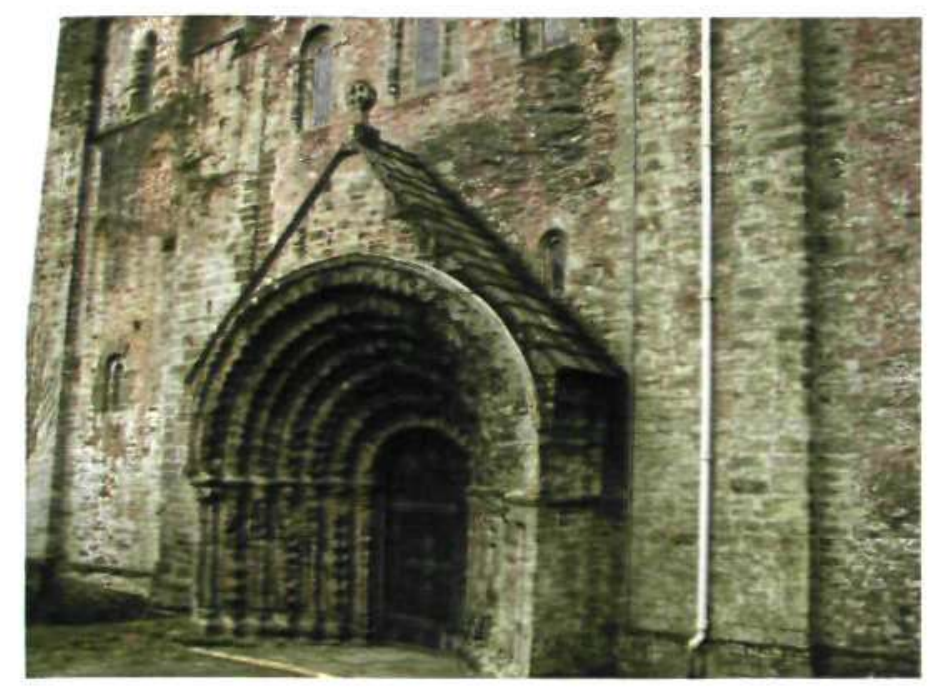

Figure 2.1 St German's Church, Cornwall. The magnificent

Romanesque doorway was described by Samuel Rowe in his 1821 guidebook.

The Penguin Guides series exemplifies the kind of material on offer. Both volume 3 (Cornwall) and volume 4 (Devon) were issued in 1939. While these guidebooks were not exclusively focused on 'heritage', it was a theme which formed a key element in their descriptions; and the popularity of the series immediately before, and certainly after, the Second World War underlines not only the increased personal mobility of ordinary people in mid-twentieth century Britain, but also (as noted in chapter 1 ) the growing appetite to identify with the nation's past.

\subsubsection{Caring about Heritage in Devon and Cornwall}

In the 1950s, the increased engagement with, and enjoyment of, the historic English landscape in general, and the landscapes of Devon and Cornwall in particular, mirrored a burgeoning academic interest in its detailed study. The doyen of the study of landscape history in the post-war era was undoubtedly 
Willıam Hoskıns, Devon-born, and author of semınal works on Devon (1954) and on the making of the English landscape (1955). Hoskins Inspired a new generation to care about the landscape as a repository of history. While he did not at first use the word 'heritage', his descriptions of the history of England's, and Devon's fields, farms, villages, towns, roads, canals, and traditional crafts and industries amounted to an eloquent (and highly effective) clarıon-call to the nation to understand, respect, protect, and cherish the physical expressions of Its past

By the 1970s, Hoskıns had become a television favourte, presenting two serres of programmes, which each generated a slım volume (Hoskıns 1973, 1978). The final chapter of the second of these two books, 'Devon Land of my fathers' (Hoskıns 1978, 128-142) amounts to evocative praıse of Devon's heritage He ends the chapter appropriately in Exeter, the city of his birth, and a place for which his love was undısguised Yet here he delivered crticisms so stinging about the threats to, and damage inflicted upon, the historic fabric of the city, that it must have caused a stir in local government circles both in Exeter and in Devon County Hall 'Here and there', he wrote, 'scattered about it are liftle enclaves that have escaped the eye of the planner and the engineer ... I put the road engineer as a worse menace than the planner' While he rejolced at the fallure of the Germans to destroy Exeter completely in May 1942, he commented that, 'since then, the city councll, to my mind, has nearly finished the job off' (Hoskins 1978, 132)

Within two years, the County Councll sponsored the publication of a slim volume, Archaeology of the Devon Landscape (1980), edited by Peter 
Beacham, which catalogued and reviewed Devon's archaeological heritage. In this book, the word heritage was liberally used and the contents encompassed not only the renowned antiquities of the county, but also castles, churches and historic towns. Simon Timms, then a planning officer, opened the volume and considered 'why we should conserve the past'. A gathering momentum for much more interest to be taken in the county's heritage, and a more concerted approach towards its protection, are thus clearly discernible. In 1982, Beacham edited a second volume, again published by the County Council; this time, it was on Devon's Heritage: Buildings and Landscape: A collection of essays on the conservation of Devon's environment. Significantly, Professor Hoskins was invited to write the introduction; in it, he commented on 'our great building heritage in Devon' (Beacham 1982, vi), and he called for a 'complete survey, not just picking out particular buildings, as we do here in this book, but a bringing together of all the historic features of a particular local landscape'. Almost thirty years on, such comprehensive surveys remain remarkably rare, but Hoskins and Beacham had at least begun the process of further raising the profile of heritage in the county. Beacham drew expert attention to the 'great heritage of historic buildings which Devon is so fortunate to possess'. He wrote that the county 'is rich both in the quantity and diversity of buildings of all kinds' (Beacham 1982, 72). By the early 1980s, therefore, and coinciding with the formation of heritage studies as an emergent and separate academic discipline, the drive to look after Devon's historic treasures was being pursued with new vigour and purpose. 


\subsubsection{Landscape and Coastal Heritage}

Although little of the landscape and coastal heritage of Devon and Cornwall is directly commodified in order to yleld admission-charge income, its extent and quality represent a key ingredıent in the overall attractiveness and appeal of the two counties to visitors, and make an undoubted contribution to the sense of wellbeing for local inhabitants. Research by Tourism Associates for the National Trust in 1999 estımated that there were 6.7 millon holiday trips to Devon and Cornwall motivated by the counties' conserved landscapes (broadly 67 per cent of the total number of trips to the two counties). These trips equated to $408 \mathrm{~m}$ nights with a visitor spend of $£ 1,488 \mathrm{~m}$ and 44,800 full tıme equivalent (FTE) jobs (Tourısm Associates, 1999) A measure of the amount of land in Devon that is recognised for the importance of its natural heritage is that over 50 per cent of the county is covered by environmental designations These include Dartmoor Natıonal Park ${ }^{10}$ and part of Exmoor National Park, and with five Areas of Outstanding Natural Beauty (AONBs), which together account for 35 per cent of Devon's area The rest comprises the World Heritage Sites on the East Devon 'Jurassic' coast, and the West Devon mınıng landscapes, plus a 'blosphere reserve' of 4,453 ha focused on Braunton Burrows in north Devon. Devon also currently contains 211 Sites of Special Scientific Interest (SSSIs).

Both Exmoor and Dartmoor are internationally renowned for their archaeological monuments, but 144 of the county's scheduled ancient monuments are located In the five Devon AONBs (Fig. 2.2).

${ }^{10}$ An explanation of the National Park, Area of Outstanding Natural Beauty, and Sited of Special Scientific Interest designations are given in Appendix 3. 


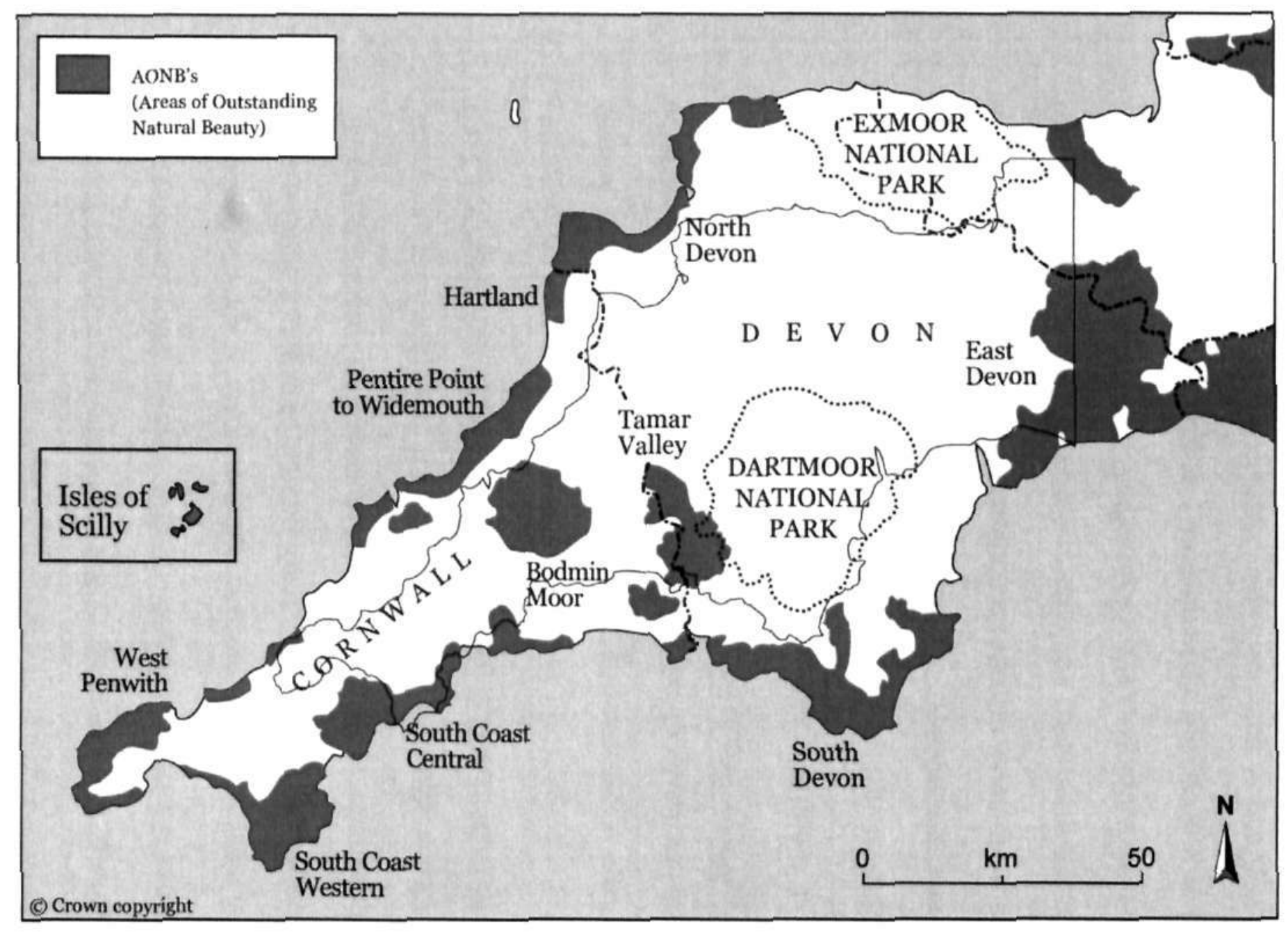

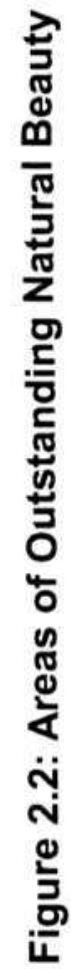


The AONBs together cover a total of $1,336 \mathrm{~km}^{2}$ (and include areas in North Devon, the Blackdown Hills, East Devon, the Tamar Valley and South Devon).

Although there is no National Park in Cornwall, the county's AONB, first designated in 1959, covers $958 \mathrm{~km}^{2}$ and comprises 12 separate areas: the coastal and estuarine areas of Hartland; Pentire Point to Widemouth; the Camel Estuary; Trevose Head to Steppe Point; St Agnes; Godrevy to Portreath; West Penwith; the Lizard to Marazion; Mylor to Roseland and onward to Porthpean; Par Sands to Looe; and Rame Head. The only inland tract of land in the Cornwall AONB is Bodmin Moor. There are also some 166 SSSIs in Cornwall.

Overall, the National Trust is now by far the largest single landholder in Devon and Cornwall and possesses over 15,000 ha. of farmland and another 3,000 ha. of woodland across the two counties. Approximately 4,000 ha. of the Trust's lands lie within the National Parks of Dartmoor and Exmoor. In addition to the important natural habitat heritage within its land portfolio, the Trust is also responsible for important archaeological assemblages and monuments ranging from Neolithic burial monuments such as Lanyon Quoit and Chun Quoit in the far west of Cornwall, to the Bronze Age stone rows, cists and menhirs such as those of Holne Chase and Trowlesworthy Warren on Dartmoor. The economic impact of tourism at National Trust properties in Devon and Cornwall was estimated to be $5.6 \mathrm{~m}$ visitor days, which induced $£ 142 \mathrm{~m}$ of tourist spending including $£ 6.8 \mathrm{~m}$ at National Trust sites. Total employment linked to the activities of the National Trust was estimated to be 3,571 FTE jobs or 5,071 actual jobs (Tourism Associates, 1999). 
Coastal landscape and marine heritage is abundant in Devon and Cornwall. The National Trust currently owns $595 \mathrm{~km}$ ( 370 miles or 36 per cent) of the coastline of the two counties and protects a large proportion of the most spectacular and important stretches of the $1,014 \mathrm{~km}$ (630 mile) South-West Coastal Path, which is the longest national trail in the country (Peel 2010). The stretch of Dorset and East Devon coast designated as a World Heritage Site by the United Nations Educational, Scientific and Cultural Organisation (UNESCO) in 2001 extends for $155 \mathrm{~km}$ (95 miles) from Exmouth in Devon to Studland Bay in Dorset, encompassing both the cliffs and the foreshore. This so-called 'Jurassic Coast' was the first World Heritage Site to be proclaimed in the far Southwest and it records 185 million years of the Earth's history (Edmonds 2005). A World Heritage Site Management Team is financially supported by the Devon and Dorset County Councils and further funding has been secured from the Heritage Lottery Fund ${ }^{11}$ and the South West Regional Development Agency (SWRDA). The cost of high-quality interpretation materials (for example, in Sidmouth Museum and elsewhere) has thus been met. Commodification, in the sense of generating income from the site, has been achieved by producing the Official Guide to the Jurassic Coast (Brunsden, 2003), which had sold 27,000 copies by June 2005 (Edmonds 2005, 61; 63). A 'Jurassic Coast Bus' service, supported by the Rural Bus Challenge Fund, and operated by drivers trained to offer a commentary during the trip, represents a form of indirect commodification (Edmonds 2005, 61-63). Outside these designated areas the nature and quality of regional coastal resorts is varied (Gale 2007). The work of Williams and Shaw (1997) and Shaw and Agarwal (2007) have shown that these variations are often linked to complex global and local issues, but their

${ }^{11}$ A description of the Heritage Lottery Fund is given in Appendix 4. 
heritage character undoubtedly contributes significantly to their appeal and popularity

As a particular example of an inland natural heritage site, the oaks of Dartmoor's Wistmans Wood are noteworthy. In fact, Wistmans Wood is a very rare primeval woodland community, which has been studied and monitored since at least the 1920s (Harris 1921, Christy and Worth 1922, Spooner, et al 1980, Mountford et al. 2001) Part of Wistmans Wood is, however, now fenced (maınly agaınst damage by grazıng animals): an intrusıon 'enabled by the designation of the site as an SSSI, whIch provides for its managed conservation by English Nature' but has excluded visitors (Howard 2003, 201).

The farmed landscapes of Devon and Cornwall have, of course, never been an Immutable entity, they have been subject to dynamıc and often radical change. However, the agricultural land of the far Southwest is an extraordinary palımpsest upon which vestıges of virtually all past perıods of cultıvation, from the Bronze Age to the present, may be found (Turner, 2004) The substantial areas of small, irregular, stone-walled enclosures of the extreme west of Cornwall are a famous survival of Bronze Age and Celtıc farmıng, and the fossilised strip lynchets on the sloping ground at Challacombe, in Manaton parısh, have been recognısed since the 1930s as medieval in origın (Shorter, 1938). Early enclosure, in relatively small parcels, of some areas of former open field has also frequently preserved the elongated shapes of pre-existing bundles of unfenced strips. Moreover, Devon and Cornwall possess two of England's very few surviving patches of open-field arable land, still worked (more or less) according to traditional common farming practices Devon's 'Great Field' at 
Braunton is much the larger, but the strips or 'stitches', separated by their distinctive turf balks, at Forrabury near Boscastle in Cornwall (Fig. 2.3) are also important (Brayshay and Kelly 1988; Herring 2006).

The reclamation of parts of Dartmoor's Duchy lands under the auspices of the private secretary of the Prince of Wales, Sir Thomas Tyrwhitt, especially around his newly founded settlement of Princetown and farm of Tor Royal (Fig. 2.4) encapsulate the 'Georgian improvement era' heritage. Reclamation also occurred around Postbridge (Havinden and Wilkinson 1970). Comparable reclamation, in fact on a much more comprehensive scale, of the Forest of Exmoor by father and son, John and Frederick Knight (after its disposal by the Crown in the early nineteenth century) has there left behind a rich patchwork of Georgian farmhouses (Fig. 2.5) with their surrounding, characteristically large, rectangular fields enclosed within impressive beech-topped hedgebanks (Orwin and Sellick 1970).

There are just a few places where traditionally managed hay meadows survive in Devon and Cornwall. Their preservation is regarded as highly important because of the habitat for rare flora that they offer. For obvious reasons, visitors are not actively encouraged and the old orchid-rich hay meadows, such as those at Dunnabridge on Dartmoor (Fig. 2.6) are an example of superb natural heritage that does not lend itself to commercial commodification or access for consumption by tourists. 


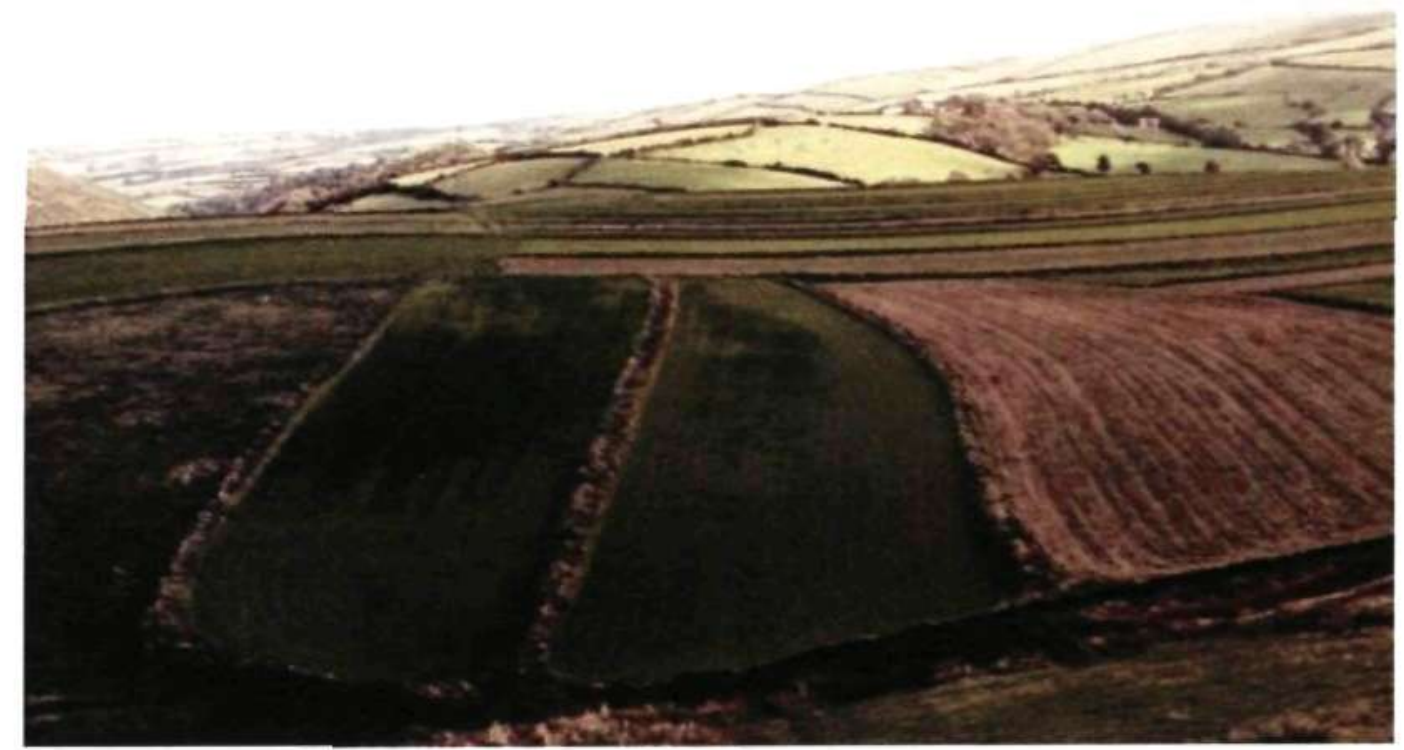

Figure 2.3 The Forrabury open field 'stitches', Cornwall. A small surviving area of open field strip farming.

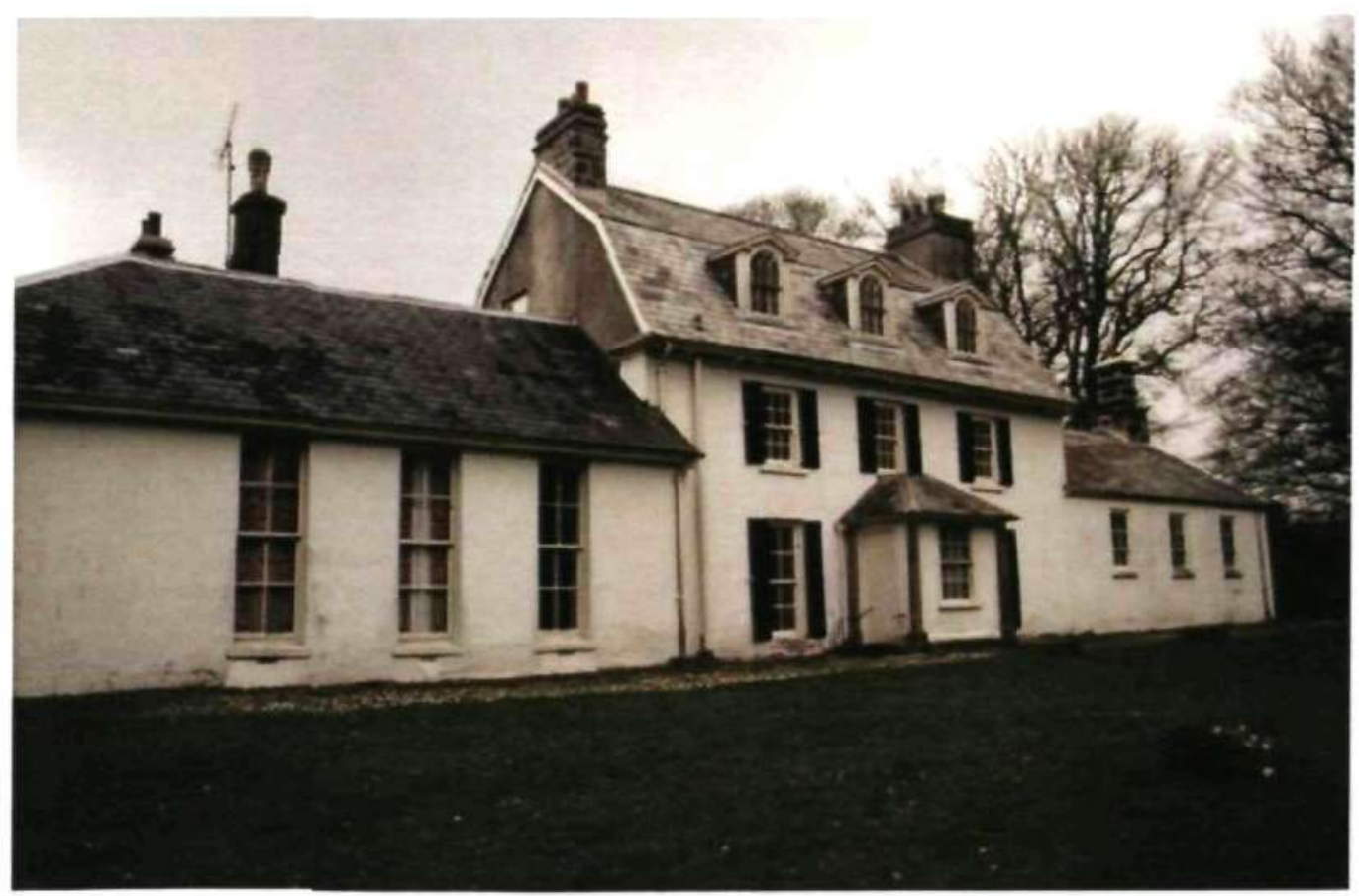

Figure 2.4 Tor Royal farmhouse, Princetown, Dartmoor. The house was built as part of Sir Thomas Tyrwhitt's reclamation project in the lateeighteenth century. 


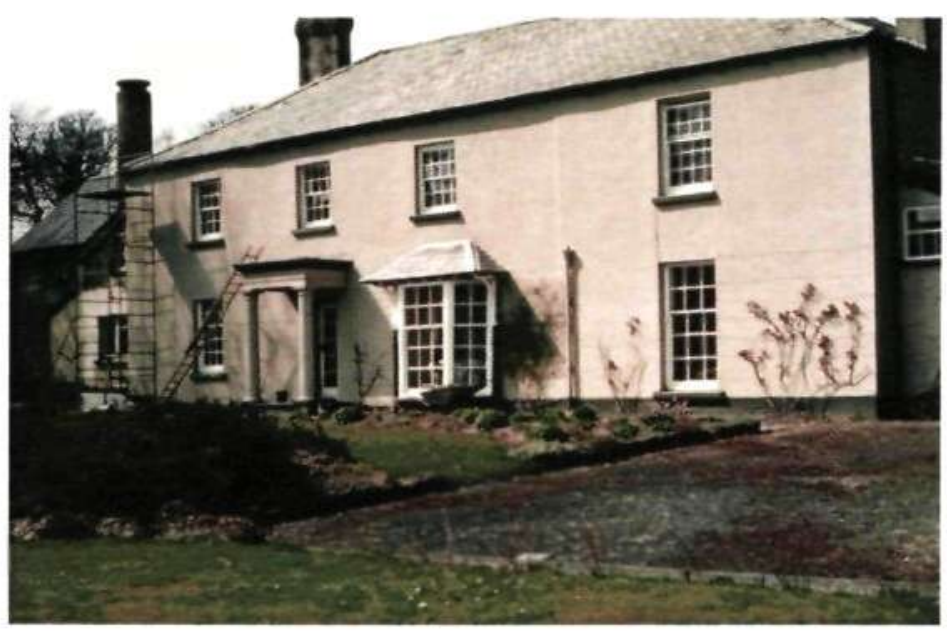

Figure 2.5 Emmet's Grange farmhouse, Exmoor. One of the new farms created in the former Royal Forest as part of its reclamation by John and Frederick Knight in the early nineteenth century.
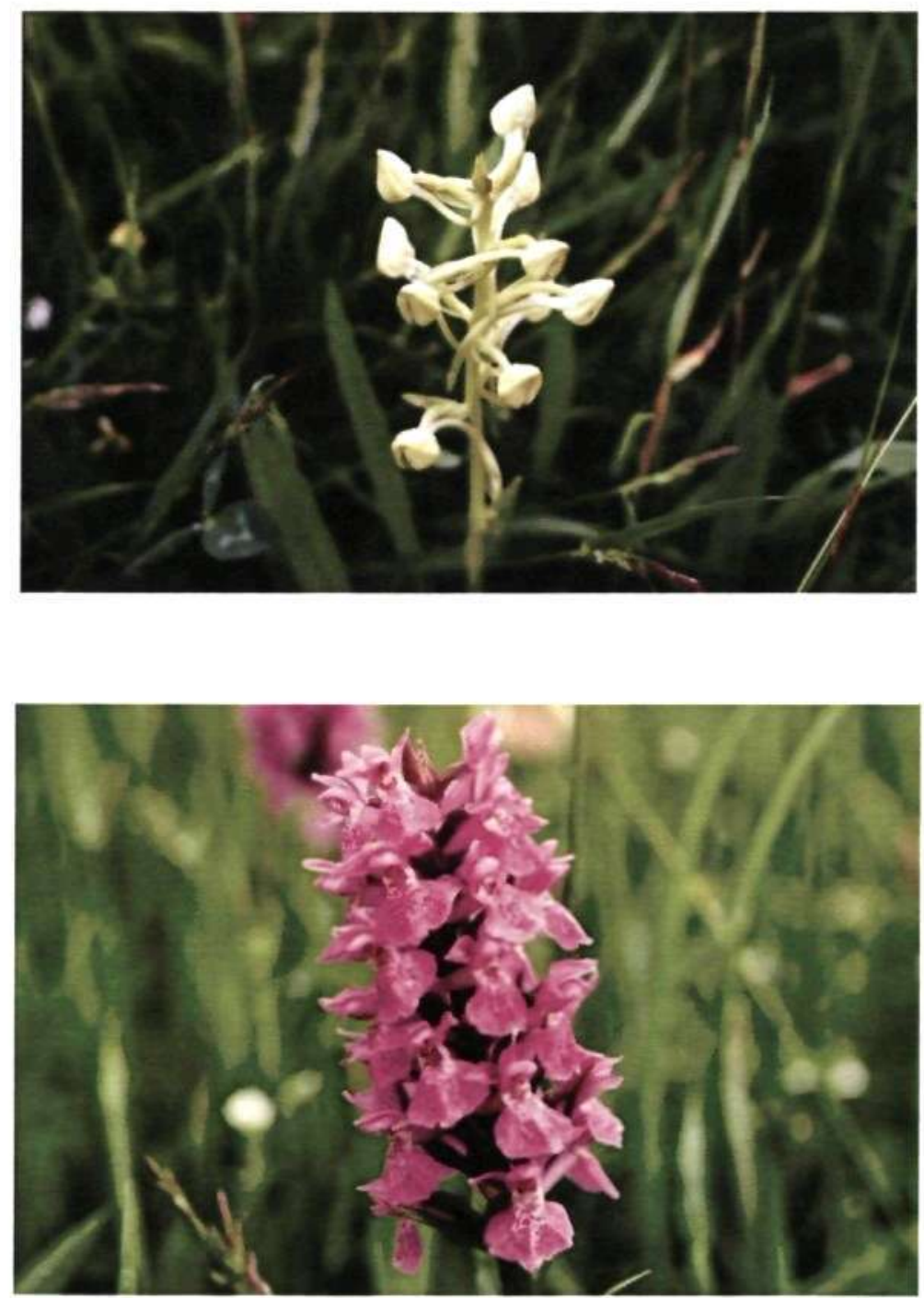

Figure 2.6 The traditionally managed hay meadows on the Duchy farm holding at Dunnabridge, Dartmoor (a) butterfly orchid (b) common spotted orchid. 
Large heritage gardens in Devon and Cornwall are, on the other hand, very frequently commodified and made accessible to paying visitors and subscribing members. The mild climate of the Southwest provides conditions that permit tender plants to thrive, thereby adding greatly to the botanical range and abundance to be found in the two counties. The historic gardens of the region are very popular tourist attractions and those in the care of the National Trust, including Trelissick and Trengwainton in Cornwall, and Overbecks in Devon, are examples of commodified heritage which successfully draws in significant numbers of visitors.

In addition, there are privately owned heritage gardens including, for example, the Trevarno Country Estate Garden, near Helston, which was opened in 1998. While the property has been known since 1296, when Randulphus Trevarno built a house there, and it was later owned successively by the Killigrews, the Carminows and the Courtneys; the present house dates only to 1839 . Nevertheless, it is an example of the work of Plymouth architect, George Wightwick, who is also remembered for the development of the distinctive Victorian villas and terraces near to the Hoe. Perhaps better known is Bicton Park, which occupies 156 ha. (63 acres) in Colaton Raleigh, north of Budleigh Salterton, and claims to present 300 years of horticultural history (Lambert and Lovie 2006). Its so-called Italian Garden, confusingly said to be modelled on the Versailles creation of André Le Nôtre, was made in 1735, while the Palm House was erected in the early 1820 s. The so-called 'Bicton orchid' grows in this building and has done so since 1836. Bicton also has a museum of historic machinery, tools, tractors and rural life ephemera (James 2007). Hosting 
weddings, private parties, and an extensive season of concerts and other events, the property is heavily commercialised.

The marketing potential of another heritage garden - that at Heligan, near Pentewan, in Cornwall - has been equally exploited. Occupying 2,471 ha. $(1,000$ acres $)$, the estate that had for four centuries been the seat of the Tremayne family, had been abandoned for over 70 years when a restoration project commenced in 1991. The house is (unusually for the Southwest) a mainly brick-built William and Mary period structure, completed in 1692. However, the heritage focus of the site is the garden where around 198 ha. (80 acres) have so far been restored. Indeed, Heligan claims to be the largest garden restoration project in Europe. A selling point is the claim that much of the vast collection of original plants had miraculously survived and was rescued (Johnson 2000; Smit 2000; Warner 2004).

Although difficult to categorise and perhaps possessing only limited credentials as a heritage site, it is nonetheless inevitable that mention should be made of the Eden Project at Bodelva, near St Austell. Winning the competition for funding as one of the designated UK Landmark Millennium Projects in 2000, the old china clay-quarry has been transformed as a series of biomes (high-tech greenhouses) where plants, that thrive in various climatic conditions, such as the tropics, are cultivated (Smit 2001).

Serious horticultural enthusiasts are drawn to the Royal Horticultural Society's (RHS) gardens at Rosemoor, near Great Torrington. Originally the home of the Earl and Countess of Orford, the estate was gifted in 1988 to the RHS by their 
daughter (the owner), Lady Anne Palmer (Hellyer 1986). At that time, there were just 20 ha. ( 8 acres) of gardens and another 79 ha. (32 acres) of pasture, which was rented out as keep. The property now extends over 160 ha. (65 acres) and it has all been made into gardens. The name of the RHS president in 1989 is commemorated in Rosemoor's 'Robin Herbert Visitor Centre' where a shop, plant-sale centre, restaurant and lecture theatre are housed. There is also a horticultural library. As in other commodified heritage gardens, Rosemoor can be hired for weddings and other kinds of events and holiday apartments in the house can be booked.

\subsubsection{Archaeological Heritage}

The abundance of archaeological heritage in Devon and Cornwall is so great that any attempt at a brief survey is likely to prove inadequate. From the Palaeolithic and Mesolithic, with nationally important sites such as Kent's Cavern in Torquay and Dozmary on Bodmin Moor, through every cultural phase until the present, the richness and range of monuments and remains in the two counties is unsurpassed. In addition to some Neolithic sites, such as the barrow at Coringdon Ball, near South Brent, the uplands of Dartmoor possess one of the densest and most important complexes of Bronze Age settlement, burial and ritual sites in Western Europe (Fig. 2.7) (Butler 1991-1997).

A cluster of Neolithic tombs exists in the far west of Cornwall. For example, Zennor Quoit and Sperris Quoit are very close together. As already noted, Lanyon Quoit and Chun Quoit are both in the care of the National Trust. 

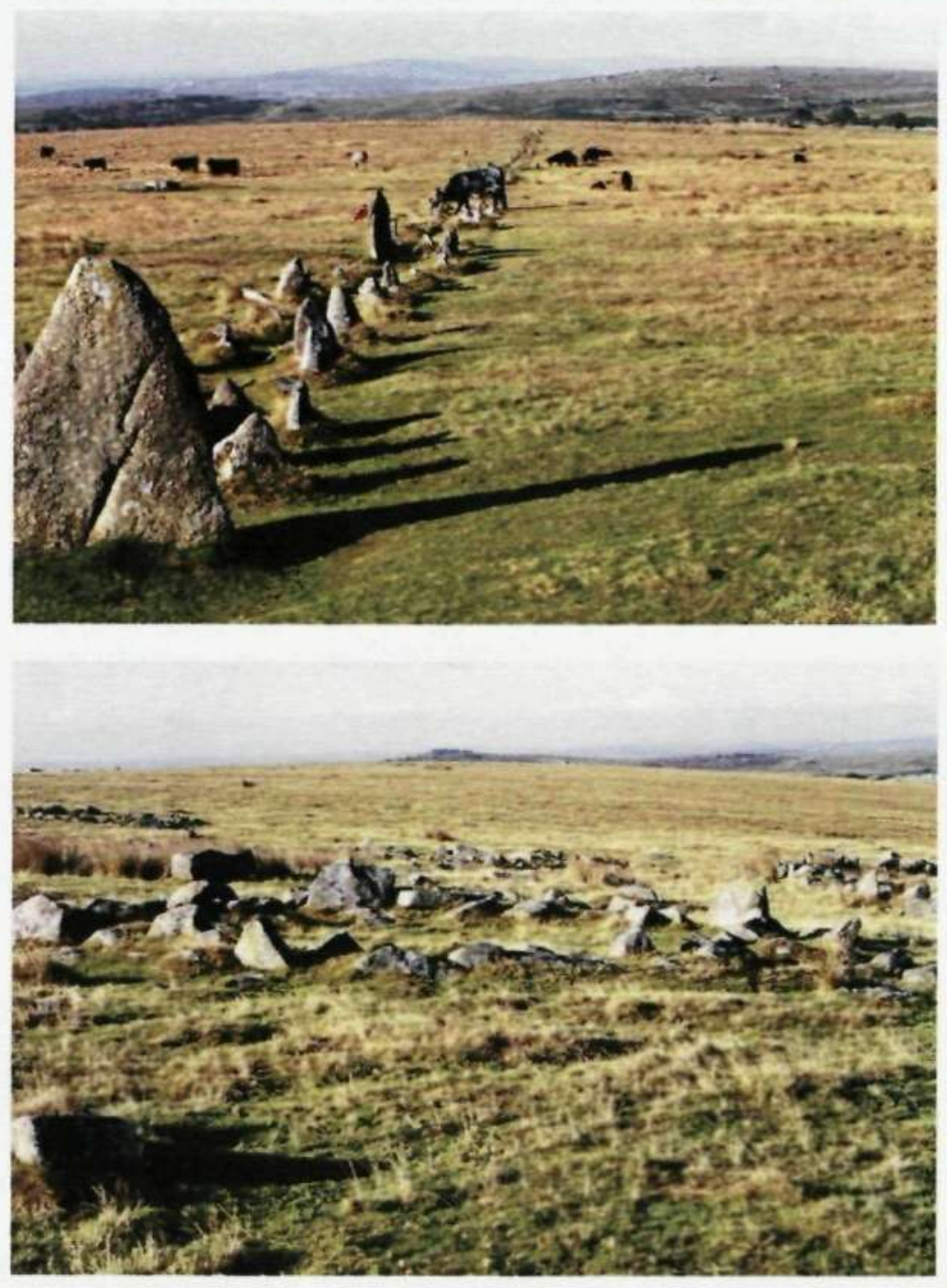

Figure 2.7 Bronze Age remains at Merrivale, Dartmoor (a) stone rows (b) house remains.

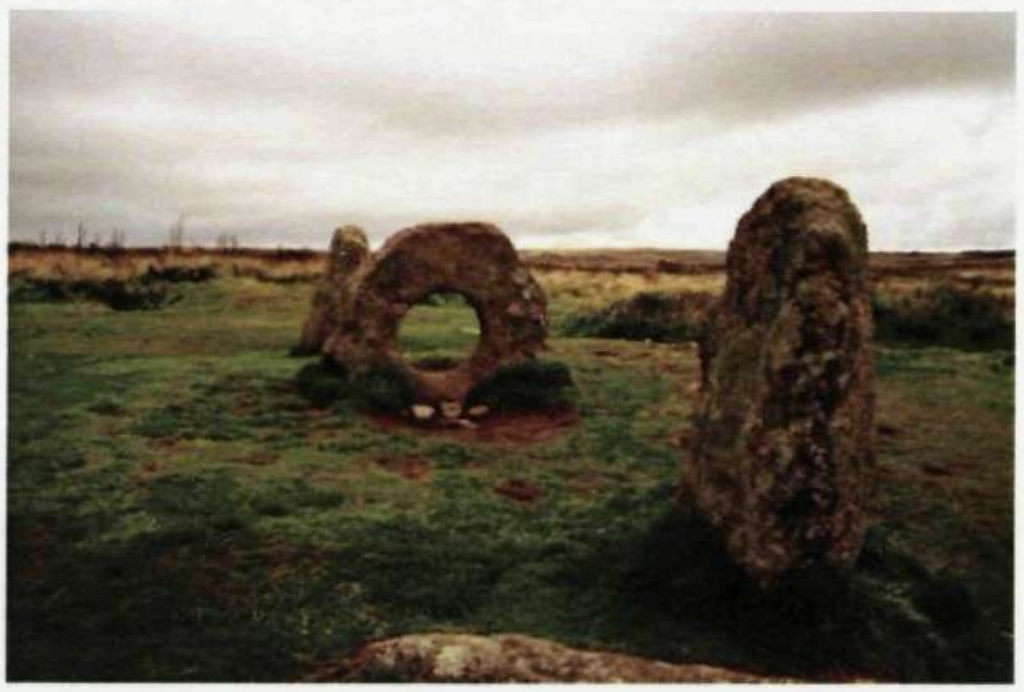

Figure 2.8 Bronze Age megalith, Men-an-Tol, West Penwith, Cornwall. 
Together with the dolmens and stone circles, such as those at Tregeseal, Boskedan and at the Merry Maidens, there are also Bronze Age cairns. However, it is perhaps the curious Bronze Age megalithic ritual monument known as Men-an-Tol, which has no match anywhere else in the two counties, that attracts most attention (Fig. 2.8). The remarkable remains of Iron Age, stone-built villages in West Penwith are immensely important; those at Chysauster (Fig. 2.9) and Carn Euny are particularly well-maintained by English Heritage for visitors, but they are not commercially exploited. Iron Age hill forts and, especially, the numerous coastal promontory forts are a particularly distinctive and sometimes dramatic heritage feature of the Southwest peninsula.

Exeter has remarkable stretches of well-preserved city walls and there are landscape remains of military camps, such as those close to the north Devon coast at Martinhoe and Old Burrow, that represent Roman-period heritage. However, compared with other parts of England, Roman heritage in Devon and Cornwall is sparse. Medieval archaeology, on the other hand, is abundant. The Dartmoor sites of abandoned farmsteads, of which there are well over 100, are striking legacies of upland farming on marginal sites in the era before the midfourteenth century. Only a few have been completely investigated. Those excavated by E. M. Minter in the 1960 s and 1970s at Houndtor, Hutholes and Dinna Clerks (Figs 2.10-2.12) are maintained by Dartmoor National Park on behalf of English Heritage, whereby the structures have been conserved and bracken infestation is controlled. However, in line with National Park policy regarding the minimal use of information boards on the open moor, only the site at Hutholes is provided with any interpretive material for visitors. All, however, are freely open to visitors. 


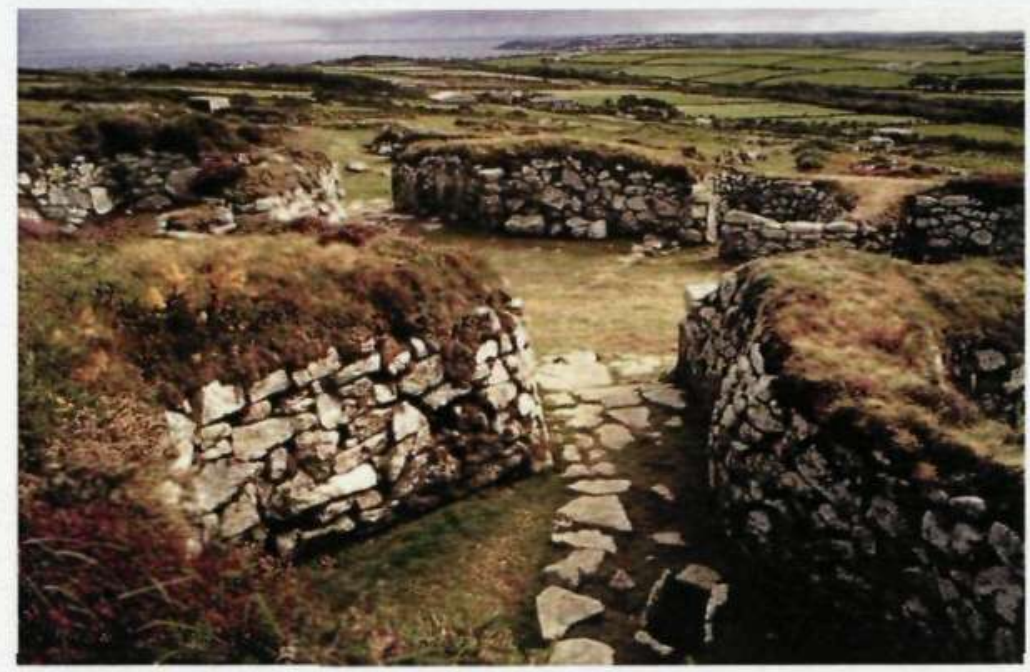

Figure 2.9 Iron Age stone-built village remains at Chysauster, Cornwall.

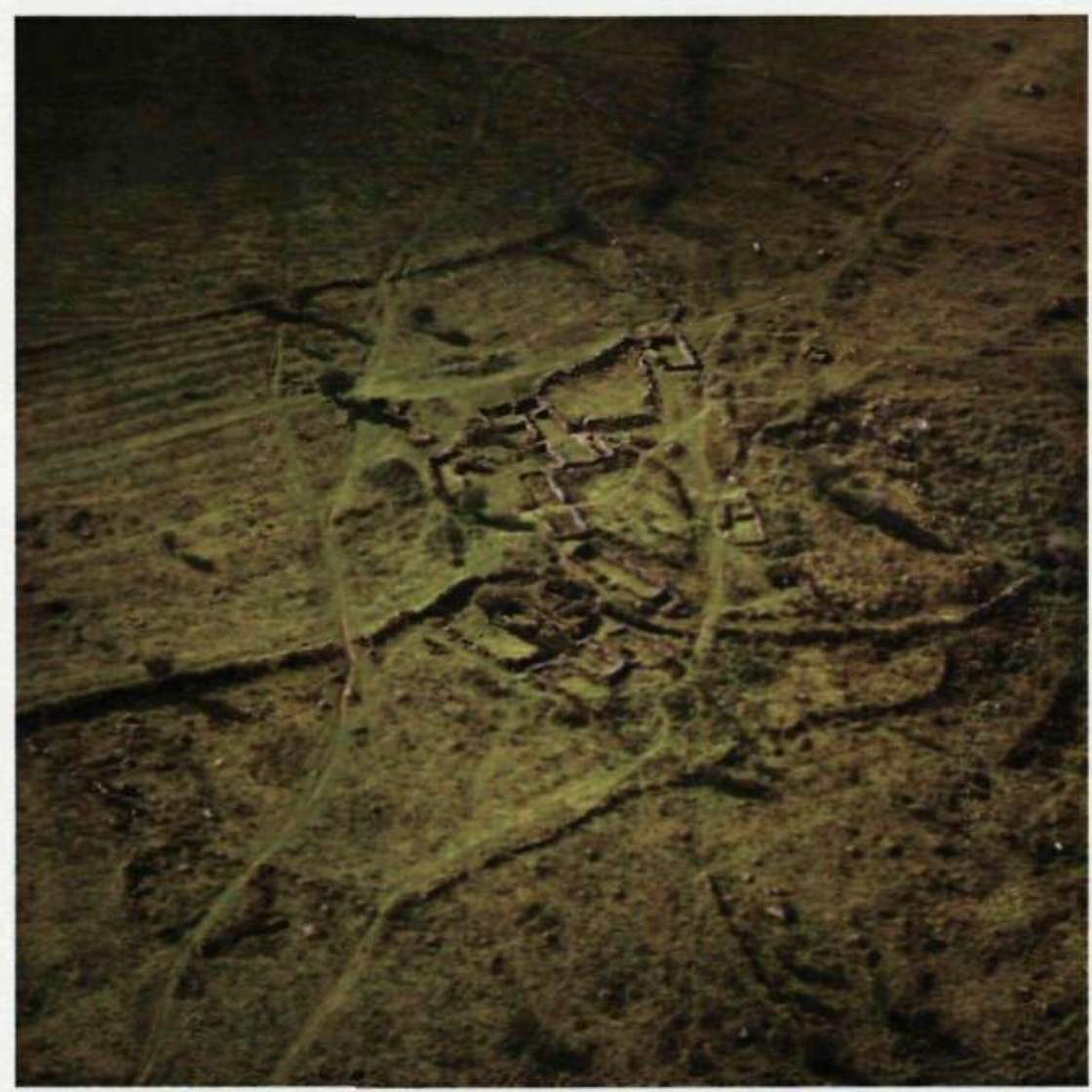

Figure 2.10 Dartmoor Medieval Settlement of Houndtor, Dartmoor. The picture shows, in the bottom left-hand corner, the remains of a much earlier, large Bronze Age house (partly damaged by the walls of the medieval paddock, adjacent to the largest longhouse). Beyond the remains of the 11 medieval buildings, the clear evidence of ploughing the strips of the 'in-field' has survived. The site thus encapsulates the fragile landscape heritage of two quite distinct episodes of human settlement on the high moorland of Devon. Source: courtesy of the University of Cambridge Air Photo Collection, AC350218. 


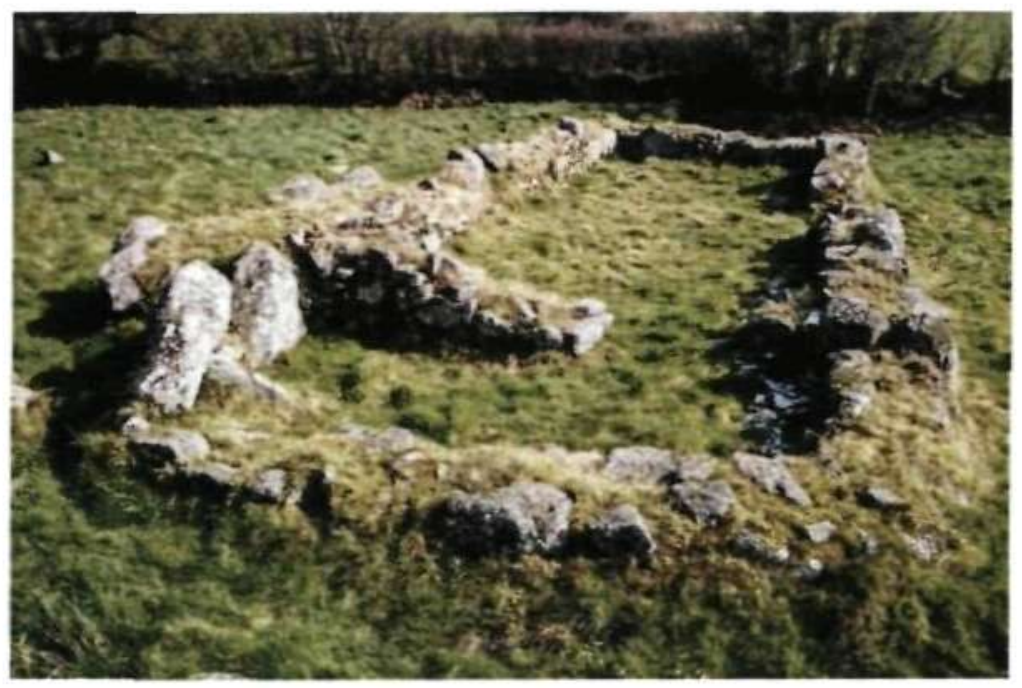

Figure 2.11 Dartmoor Medieval Settlement of Hutholes, Dartmoor.

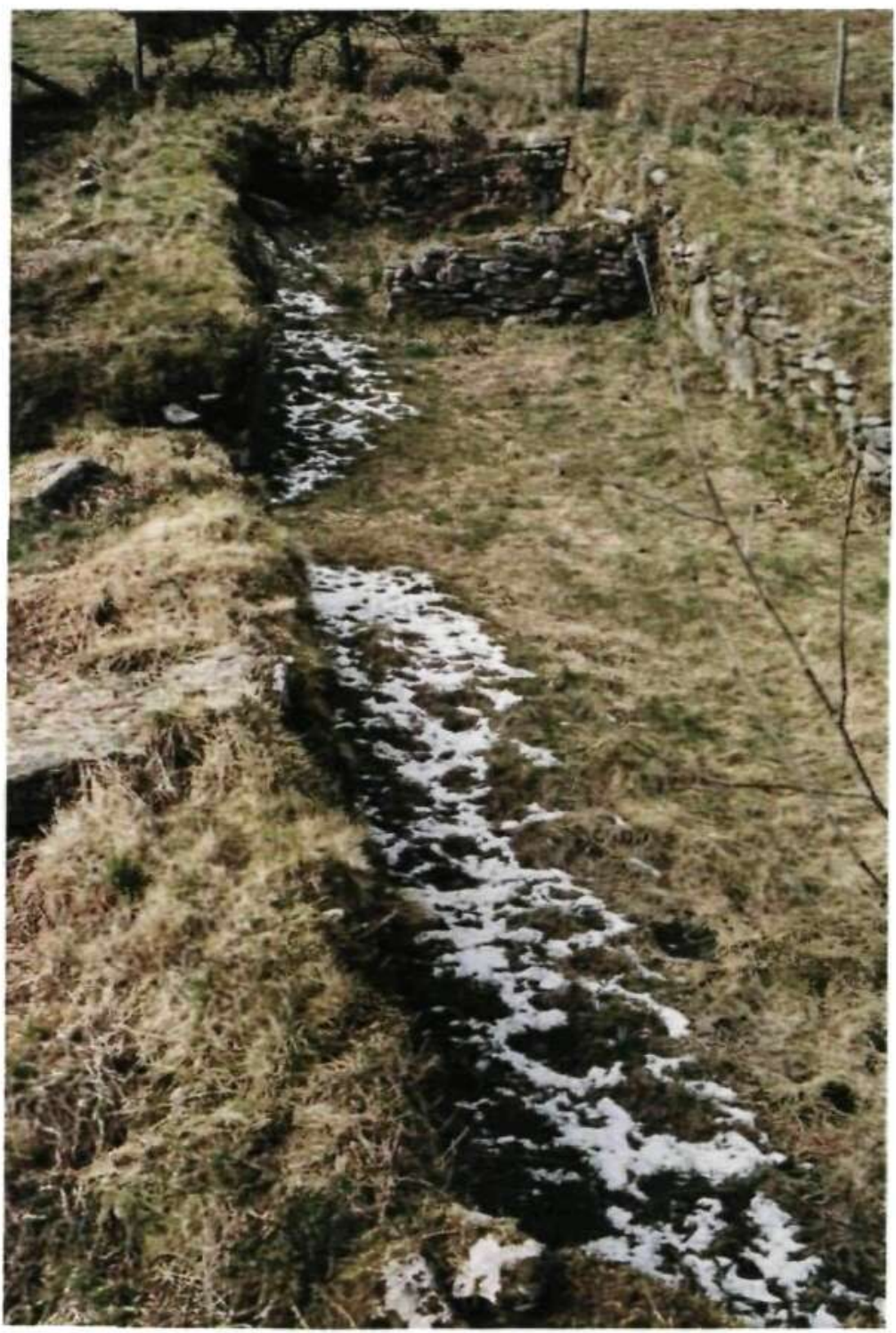

Figure 2.12 Dartmoor Medieval Farmstead of Dinna Clerks, Dartmoor. 
In general, it would appear that the early archaeology of Devon and Cornwall is the least directly commodified heritage in the region. It might be argued that opportunities to construct a commercial product are being missed. For example, Lydford, Devon has one the best-preserved of the 20 or so fortress towns, or burhs, built across Wessex in the reign of Alfred the Great to defend his Beleaguered kingdom against the Danes (Fig. 2.12). With its easily discerned, ninth-century, formal layout and impressive earthen banks protecting the site on its eastern side, it is a rare and important historical survival. There are also later earthworks of an early Norman motte; there is an important historic church dedicated to St Petrock (Fig. 2.14); and the imposing so-called 'castle' (Fig. 2.15) is, in fact, a twelfth-century stannary gaol (i.e. it was built to detain those who transgressed the laws of the tinners). Interpretation in the village is slight and commodification is non-existent.

\subsubsection{Heritage Churches}

The showpiece Church of England heritage in Devon is, of course, the exceptionally fine Cathedral in Exeter (Fig. 2.16). Set within one of the most beautiful closes in England and manifesting architectural elements in the Romanesque (Norman), early Gothic, Decorated and Perpendicular styles, St Peter's Cathedral Church is an immensely important asset both for the city and for the county (Kelly 1991). It is also commodified in the sense that visitors are

charged an entrance fee (currently: $£ 5.50$ for adults and $£ 3.00$ for those with concessions). There is also a shop, selling (amongst other items) souvenirs and guide books. 


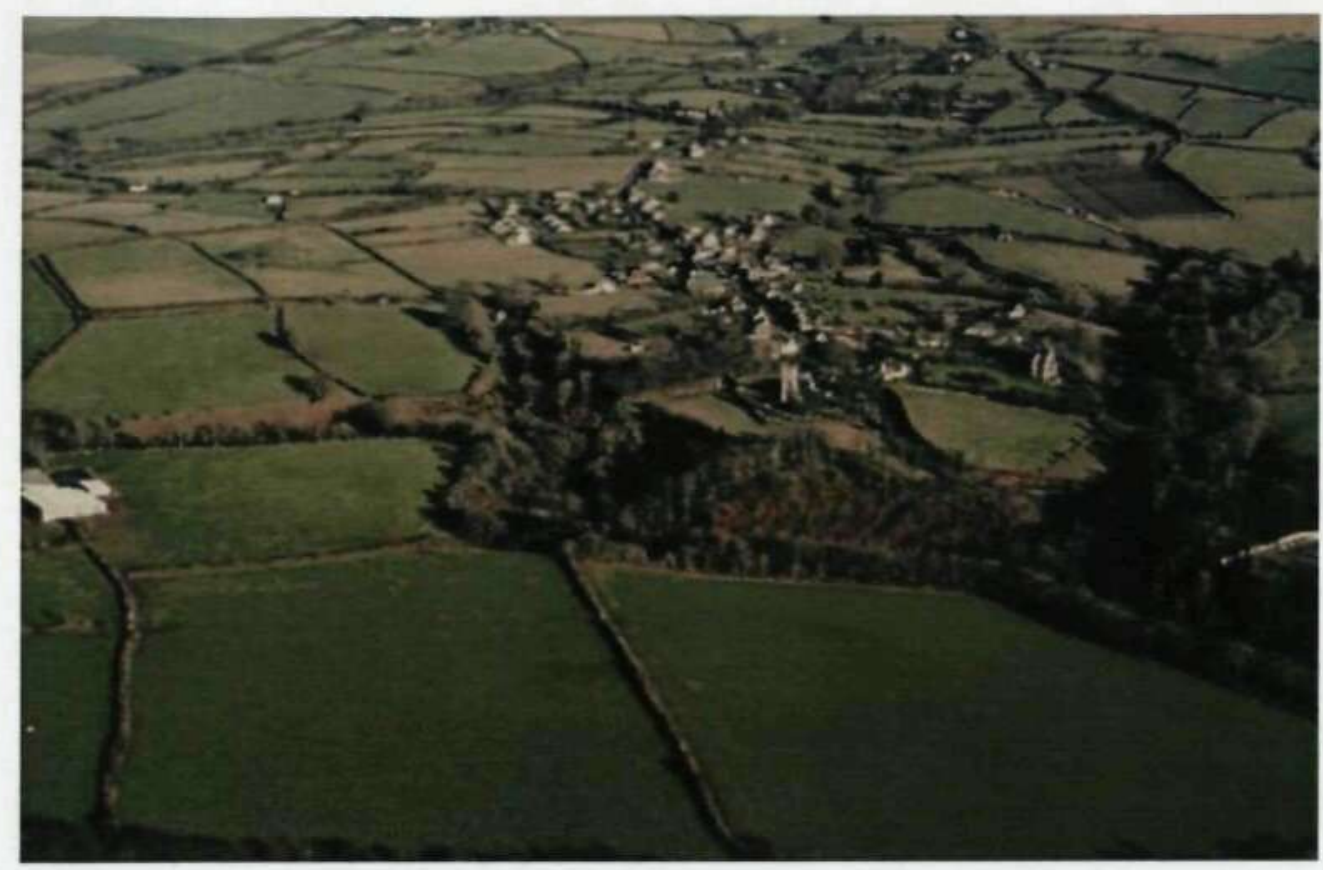

Figure 2.13 Lydford, aerial view of the ninth-century 'Alfredian' burh. (Source: Mark Brayshay and Stephen Johnson)

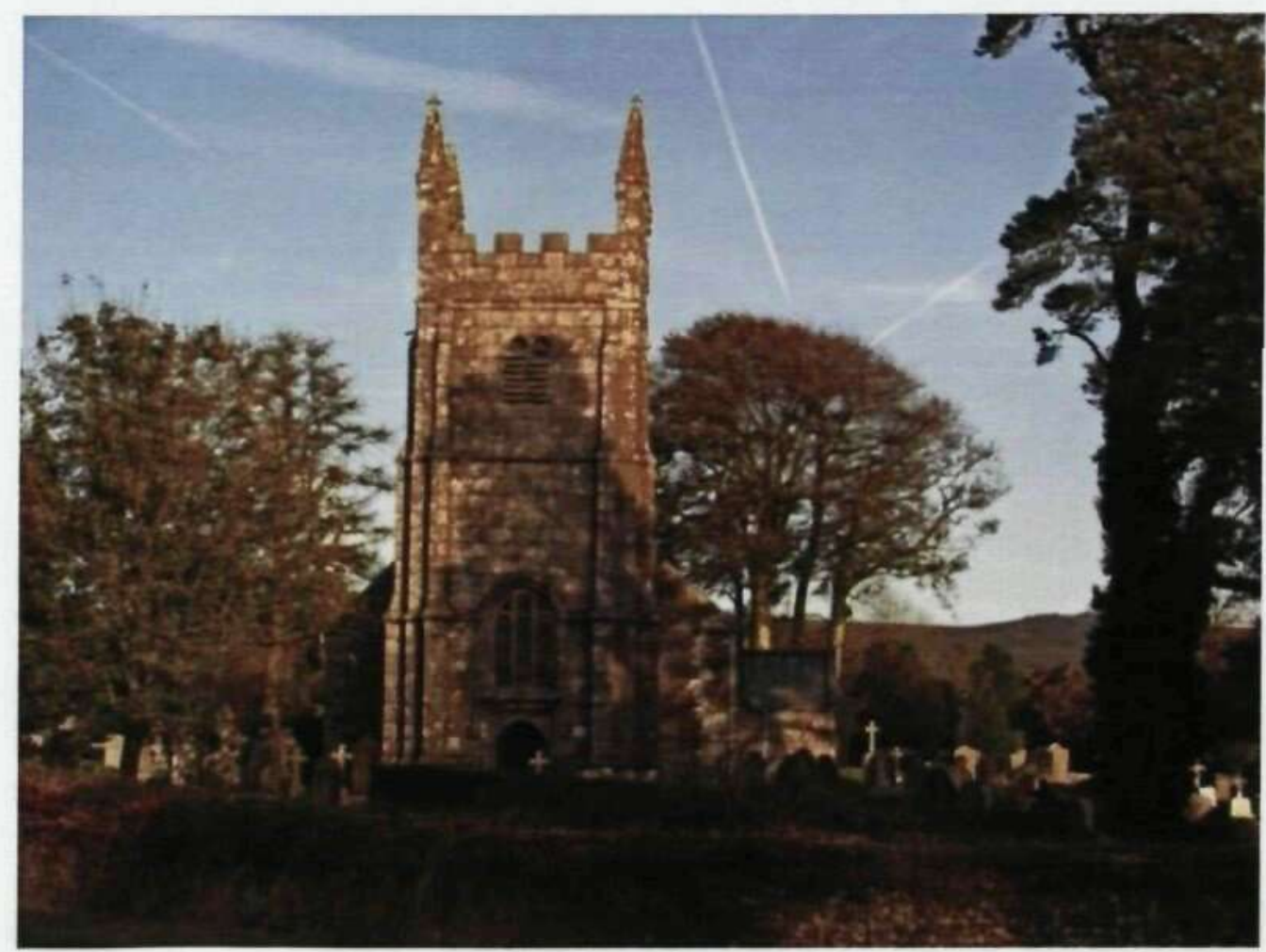

Figure 2.14 Lydford, Parish Church of St Petrock 


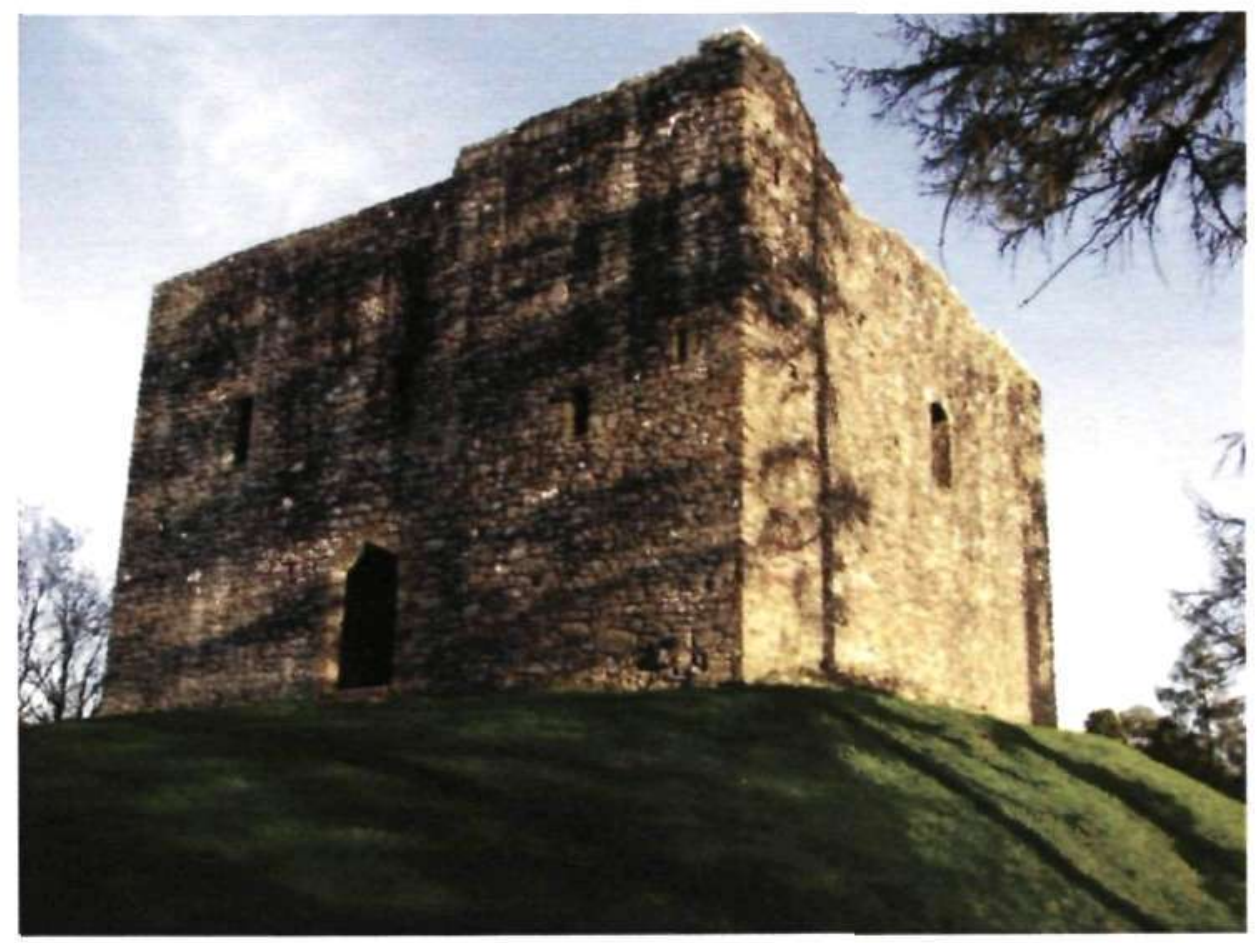

Figure 2.15 Lydford Castle, the twelfth-century stannary gaol.

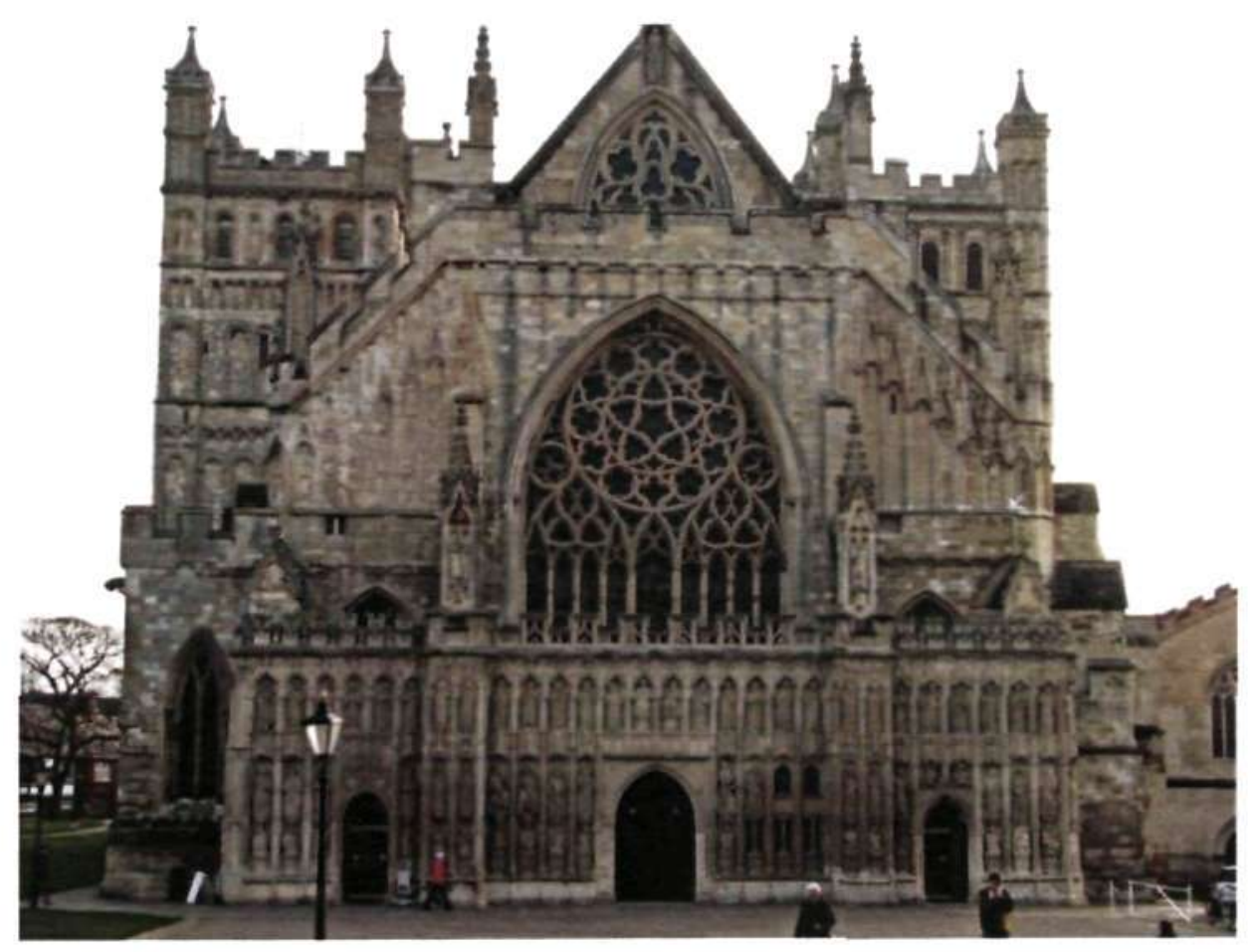

Figure 2.16 Exeter Cathedral, displaying Romanesque, Early Gothic, Decorated and Perpendicular architectural elements. 
A café/restaurant in the cloister area serves refreshments and meals. Points of interest within the Cathedral are easily identified: the 'astronomical' clock; the seventeenth-century organ; the minstrels' gallery; the medieval glass/windows; the exceptionally fine vaulted roof; and the really lovely cloisters. The Victorian Cathedral, dedicated to the Blessed Virgin Mary, and located in the centre of Truro, is one of the prominent heritage landmarks in Cornwall. When it was consecrated in 1877, it was the first cathedral in England to be built on a new site since the building of Salisbury's cathedral in the 1220s. It is in 'Gothic revival' style with some strong French influences. The central spire soars to $76 \mathrm{~m}$ giving the building a stronger presence than might otherwise have been achieved in such a small 'footprint'. Commodification has been approached in a slightly different way compared with Exeter. Thus, there is no admission charge, but the shop (and its range of merchandise) is more strongly promoted. The drive to secure $£ 4 \mathrm{~m}$ to fund the restoration of eroded stonework on the three spires and elsewhere in the Cathedral's fabric has involved some ingenious commercial ventures. Amongst these, the 'organ discovery day', in May 2010, for which there was a charge of $£ 5$ a head, capitalised on the so-called Father Willis organ and combined an opportunity to try out the organ and to hear a recital of 'popular' music. In June 2010, the celebrity chef, Rick Stein (of Padstow) cooked a special gourmet dinner (in aid of the appeal) in the Cathedral's Chapter House Restaurant at a cost of $£ 65$ a head. However, a recent study by Barker (2007) on the library of books bequeathed to Truro by Bishop Phillpotts of Exeter discusses an example of heritage as both blessing and burden. Comprising more than 2,000 volumes and once considered a treasure in the Cathedral's possessions, the books are now much less celebrated and their custody is seen as a burden. 
It is an extraordinary fact that, in addition to the two county cathedrals, Devon and Cornwall have several hundred historically valuable parish churches (Fig. 2.17). As Harvey $(2006,76$ ) comments, 'almost every rural church throughout Devon and Cornwall was established by the fifteenth century'. Even those that have been 'restored' in Victorian times, or rebuilt for example following wartime damage, embody heritage narratives that attract many visitors (Figs 2.18-2.20).

Moreover, the region possesses a highly distinctive Celtic Christian legacy. Together with dedications to little-known Celtic saints, and many shrines, crosses and holy wells, this legacy is manifested in numerous physical landscape remains (Turner 2006). However, more than two-thirds of the religious buildings in Devon and Cornwall are not Anglican. A great many chapels are 'witness to the remarkable success of Methodism in the Southwest' (Harvey 2006, 83). Indeed, Thorne $(1980,54)$ estimates that in Devon alone 'there are probably more than 1,000 buildings ... that are, or have been, chapels belonging to one or another of the nonconformist denominations'. While some occupy very imposing buildings (Fig. 2.21), none can compare in age or historical or architectural importance with the older parish churches of the County, but they deserve to be recognised as an integral part of the heritage of Devon and its people. There are also Roman Catholic churches, synagogues, and mosques; though, broadly speaking, comparatively few of these have important historic buildings. However, taken together, places of worship, as a heritage category, represent easily the most numerous, but (seemingly) only very weakly commodified, set of historic attractions. 


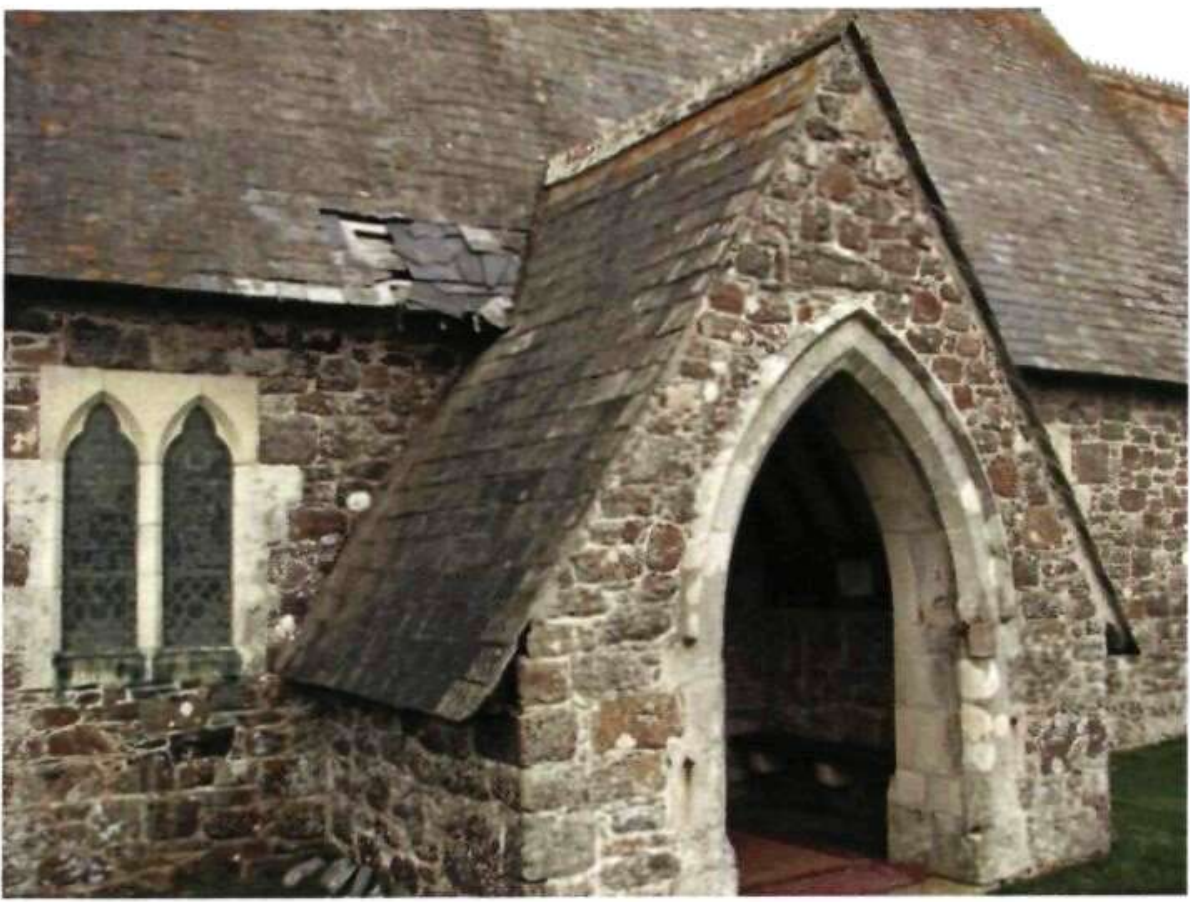

Figure 2.17 Church of St Grada, Ruan Minor, Cornwall. A Grade I listed Church on the Lizard Peninsula. One of hundreds that exist across Devon and Cornwall.

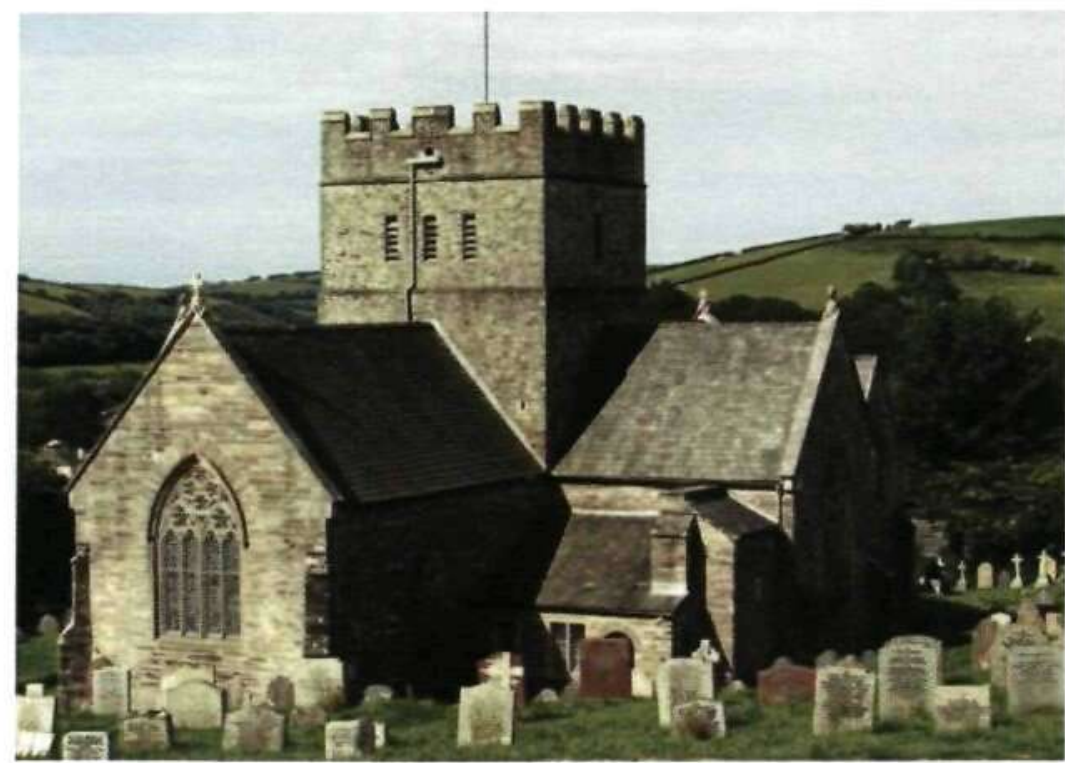

Figure 2.18 St Andrews Church Aveton Giffard. The original church comprised a cruciform medieval structure until it was heavily damaged by bombing in the Second World War. The church was rebuilt as a copy of the medieval original but has additional heritage significance as a result of its wartime damage and post-war restoration. 


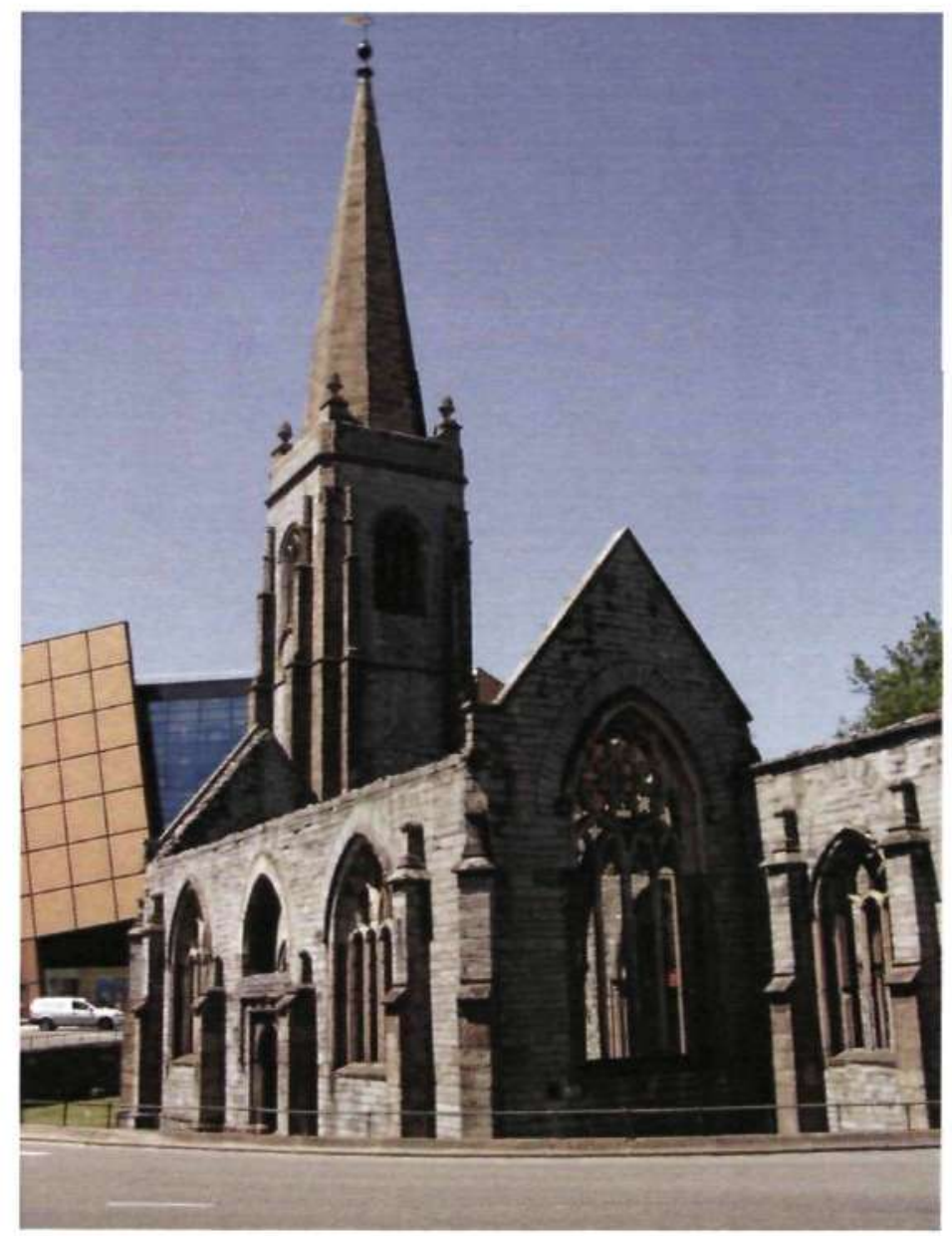

Figure 2.19 Charles Cross, Plymouth

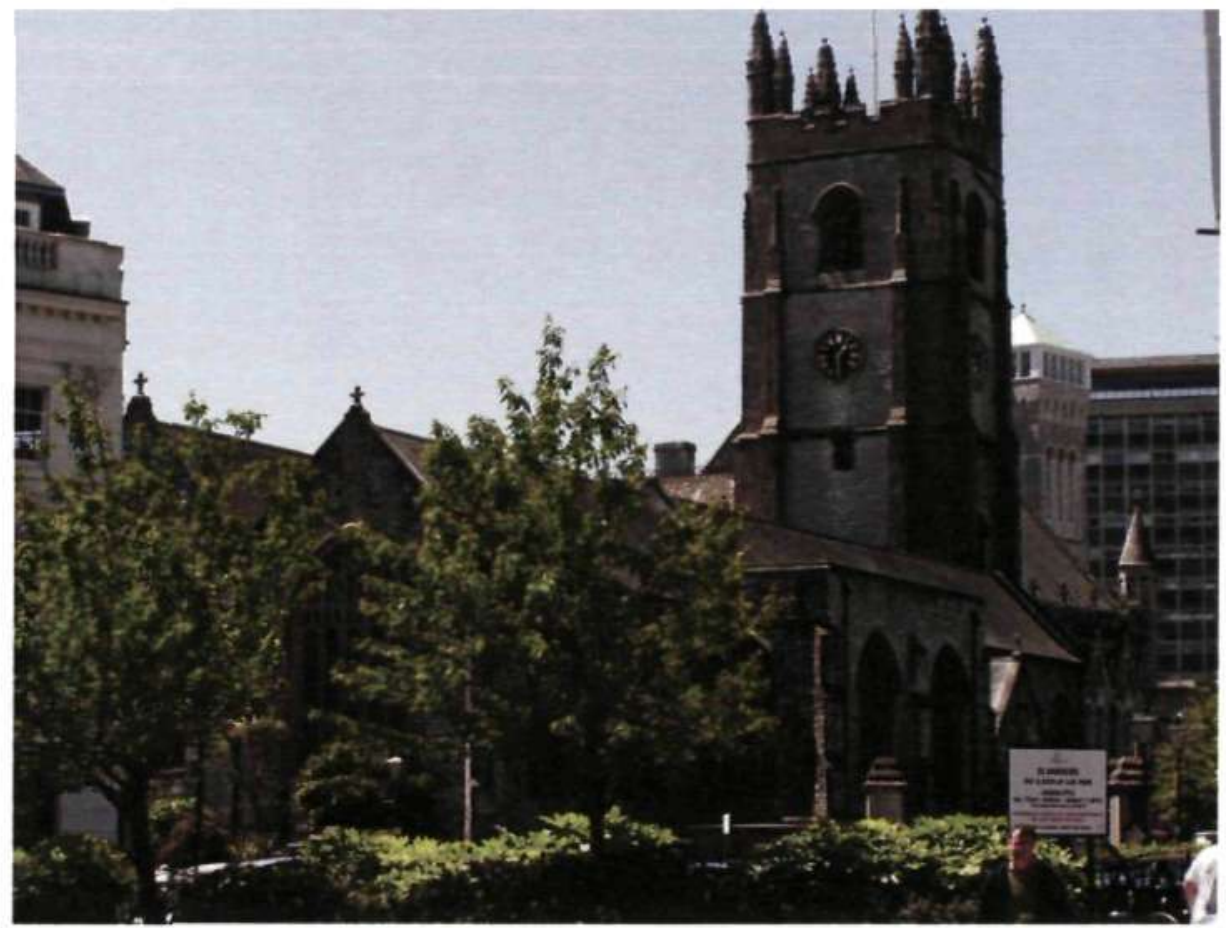

Figure 2.20 St Andrews Minster Church, Plymouth 


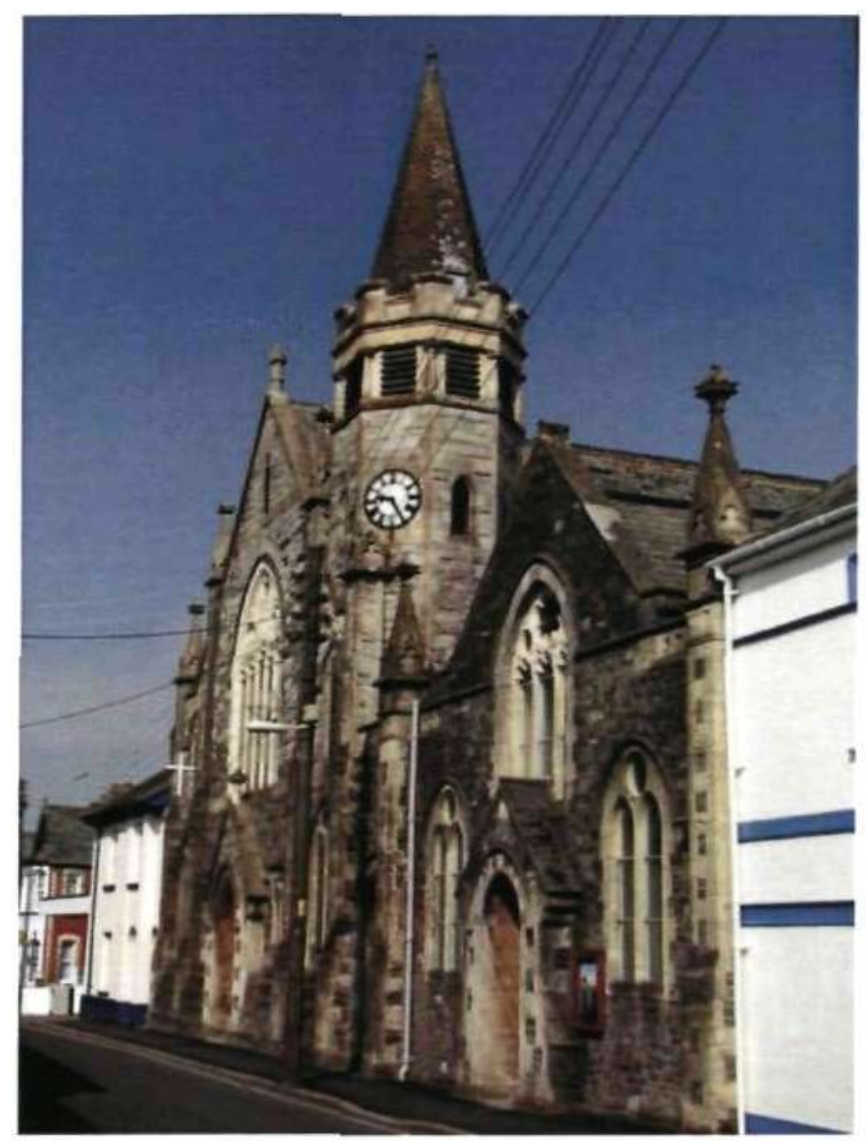

Figure 2.21 United Methodist Church, Bodmin Street, Holsworthy. This enormous Edwardian building was completed in 1910 but it occupies the site where a Methodist place of worship has stood since 1841. The building is normally locked and cannot be easily visited by heritage tourists.

Although Devon and Cornwall do not have the spectacular monastic ruins that exist as heritage attractions elsewhere in England, the remains of dissolved religious houses survive, amongst other places, in Totnes, Barnstaple, Exeter and Bodmin. St Nicholas's Priory survived destruction at the dissolution and was converted into a Tudor home (Fig. 2.22). The Cistercian monastery of Buckland and the Premonstratensian house at Torre (Torquay) were also both converted into private homes after their sale by the Henrician Court of Augmentations and, in their new incarnation, they exist today as major Devon heritage attractions (Fig. 2.23). 


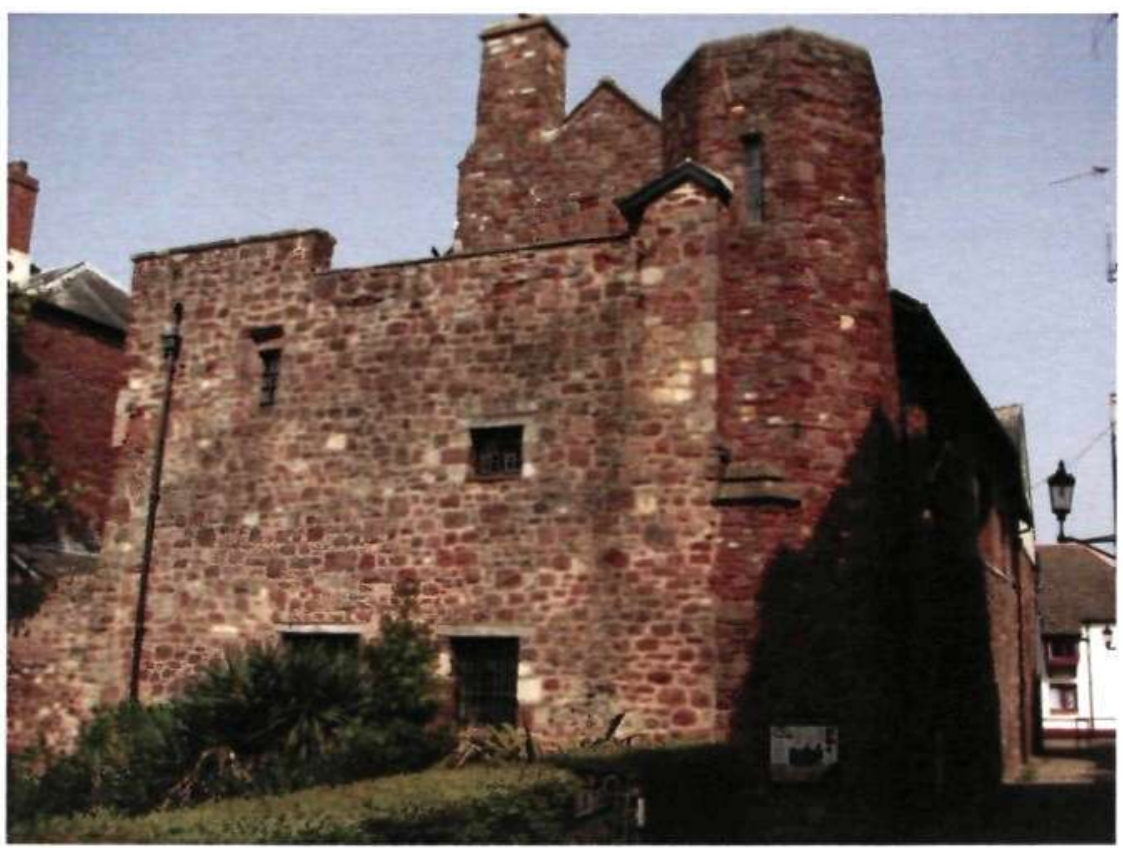

Figure 2.22 St Nicholas's Priory, Exeter. This Benedictine priory became a home after the Dissolution and is now managed by the Royal Albert Memorial Museum and is open to visitors on certain days

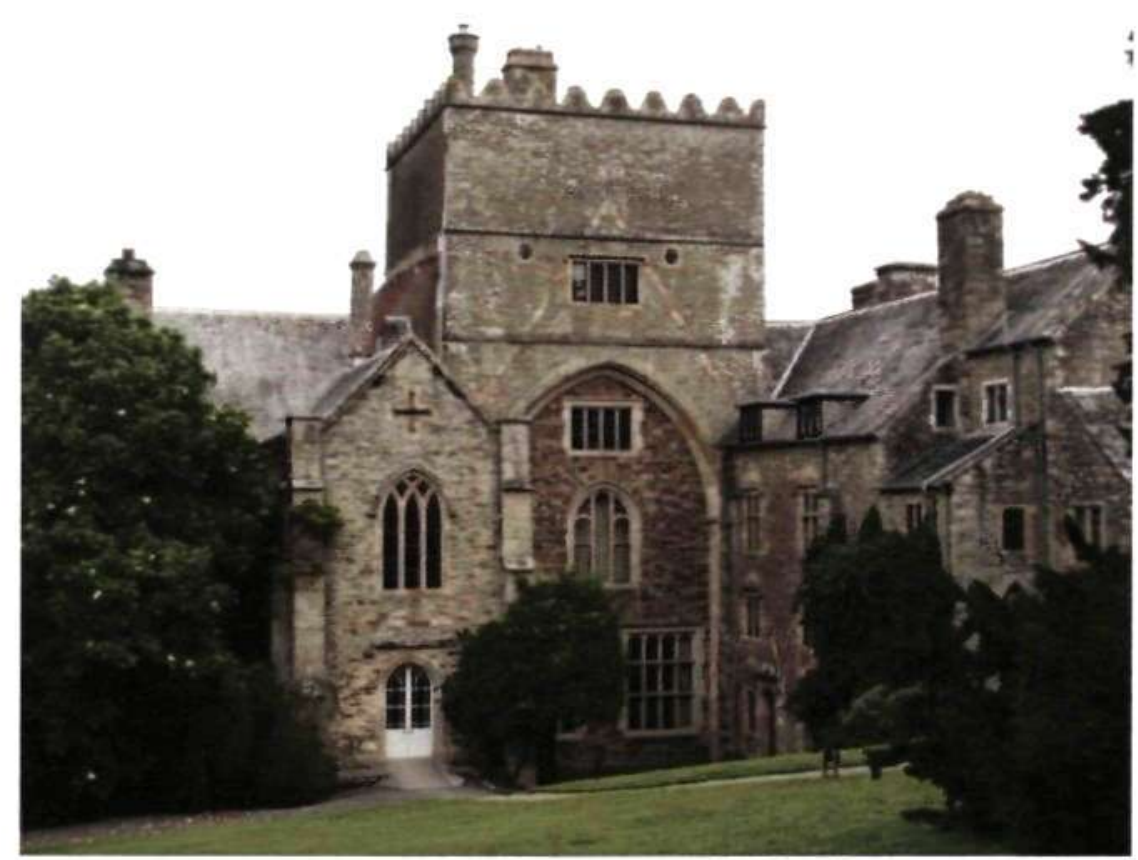

Figure 2.23 Buckland Abbey. National Trust Historic House site located on the edge of Dartmoor. After the Dissolution of the Cistercian monastery of Buckland, the property was purchased by the Grenville family and converted into a domestic residence. When Francis Drake returned from his circumnavigation of the globe (1577-1580), newly knighted and enriched with looted Spanish gold, he invested his acquired wealth by purchasing property. Amongst his new houses was Buckland, which he bought from Sir Richard Grenville. 
In both cases, splendid Abbey barns remain intact (Fig. 2.24 and Fig. 2.25). Nothing of note remains of the Augustinian Priory at Plympton and only small scraps of the once-wealthy Benedictine Abbey at Tavistock survive (Fig. 2.26). Nothing remains of Hartland Abbey in North Devon, but elements of the former priory perched on St Michael's Mount in Cornwall survive as part of the complex of buildings which, after a brief period as a military garrison, became the home of the St Aubyn family soon after the restoration in 1660 .

The case of Buckfast Abbey in Devon is, however, very unusual (Fig. 2.27). The monastery today stands out as a successful and distinctive example of commodified heritage focused on a Benedictine community, which today comprises just 22 monks. ${ }^{12}$ Visitors are drawn to Buckfast to engage with its remarkable monastic heritage: a story in two distinct parts. The first part saw Buckfast founded as a Benedictine abbey in 1018 by King Cnut. The monastery became Savignac under King Stephen in 1136, and Cistercian in 1147, when those two orders merged. A peak of medieval prosperity - mainly through the trade in woollen fleeces - was achieved in the thirteenth century. The last Abbot before the dissolution under Henry VIII was Gabriel Donne who, in return for an unusually comfortable pension of $£ 120$ per year, apparently colluded with Thomas Cromwell in bringing about the suppression of Buckfast on 25 February 1539. The Abbey's manorial lands were sold; the plate was confiscated; the lead was melted down; the monastic precincts were dismantled and the buildings gradually fell into ruin.

\footnotetext{
${ }^{12}$ Note: The bulk of the detail about Buckfast Abbey was provided by Father James, a member of the Benedictine Community and the Abbey's Bursar (Finance Officer) in the Autumn of 2009. Thanks are also due to Alison Gagg, the Education Officer at the Abbey.
} 


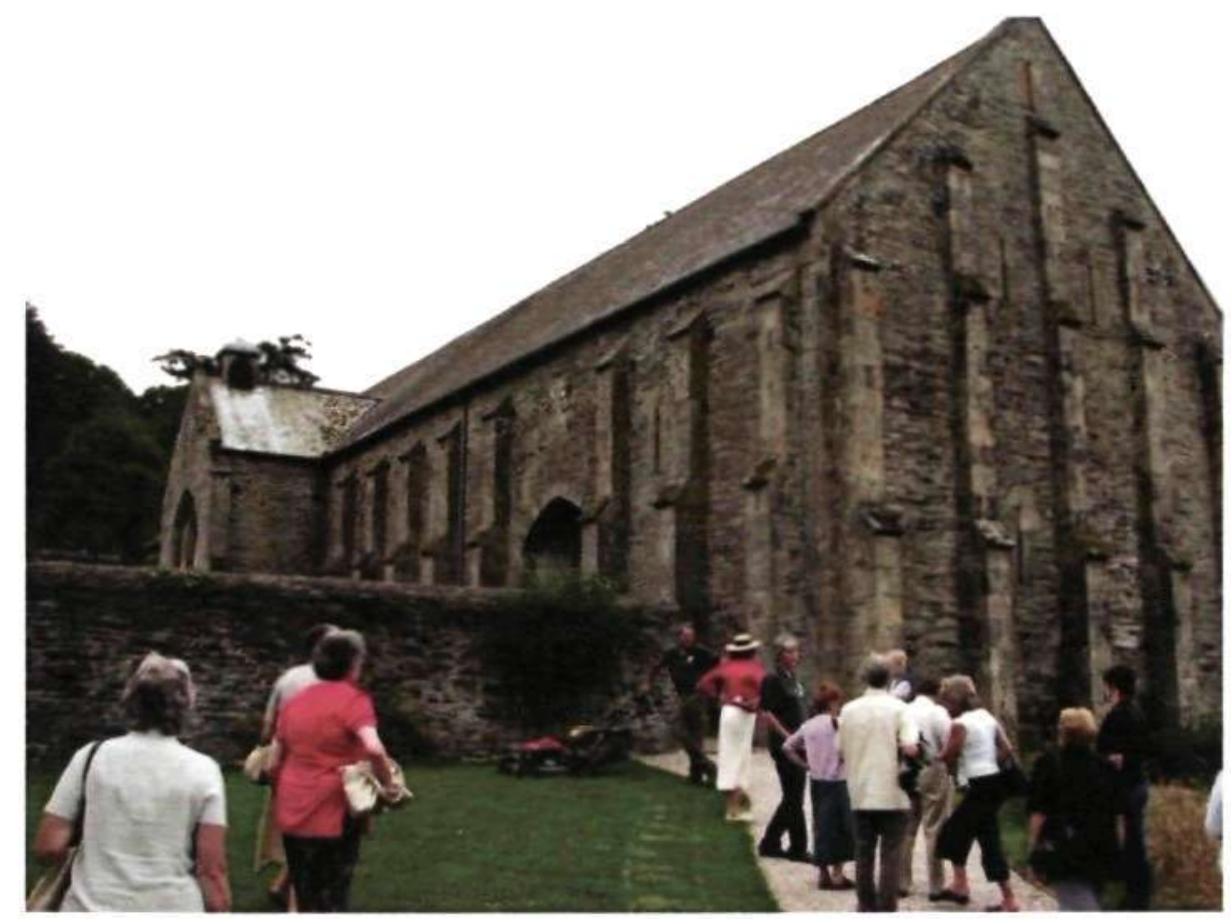

Figure 2.24 Monastic barn of the Cistercian Abbey of Buckland.

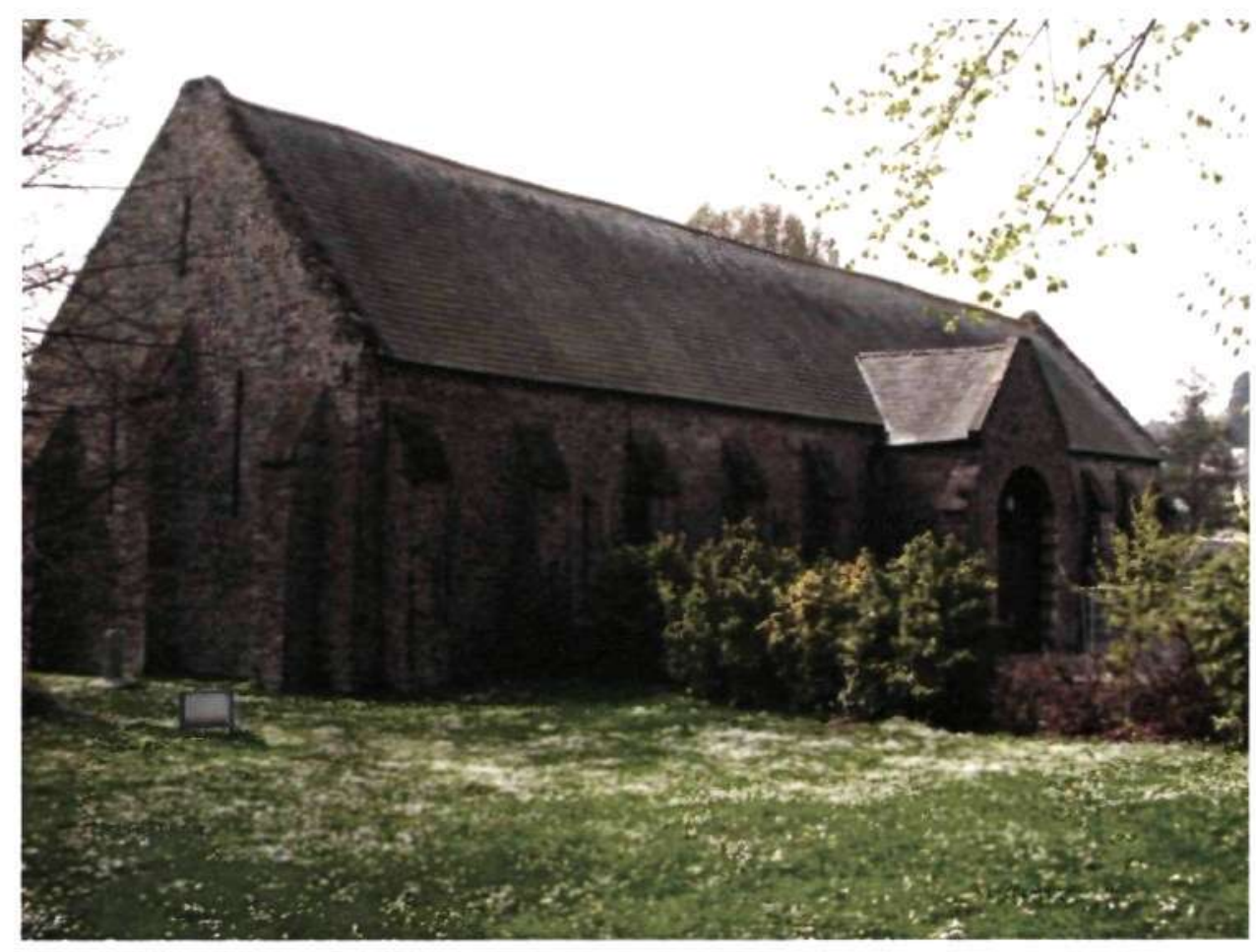

Figure 2.25 Monastic ('Spanish') Barn of the Premonstatensian Abbey of Torre 


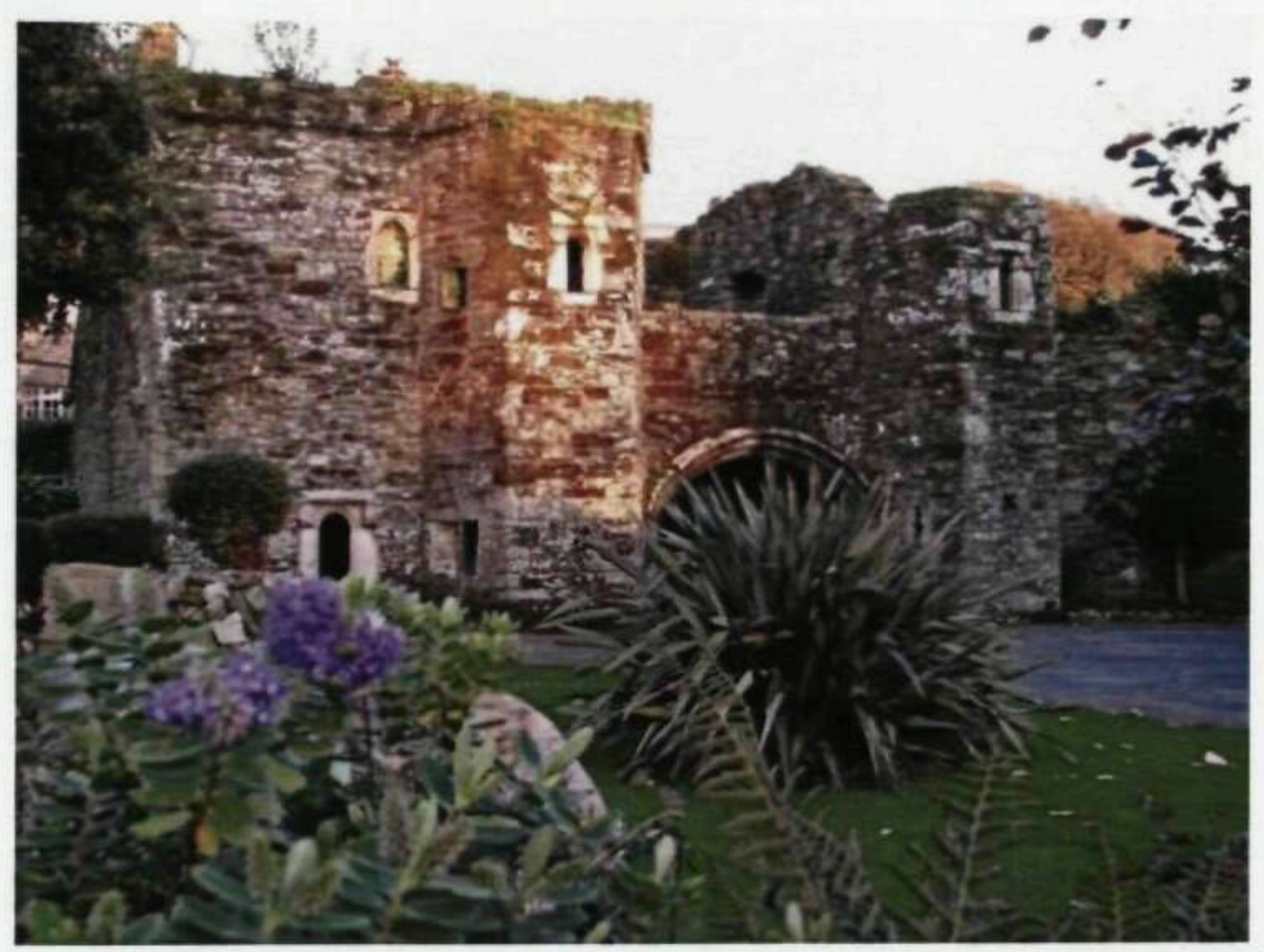

Figure 2.26 Remains of the great Benedictine Abbey at Tavistock

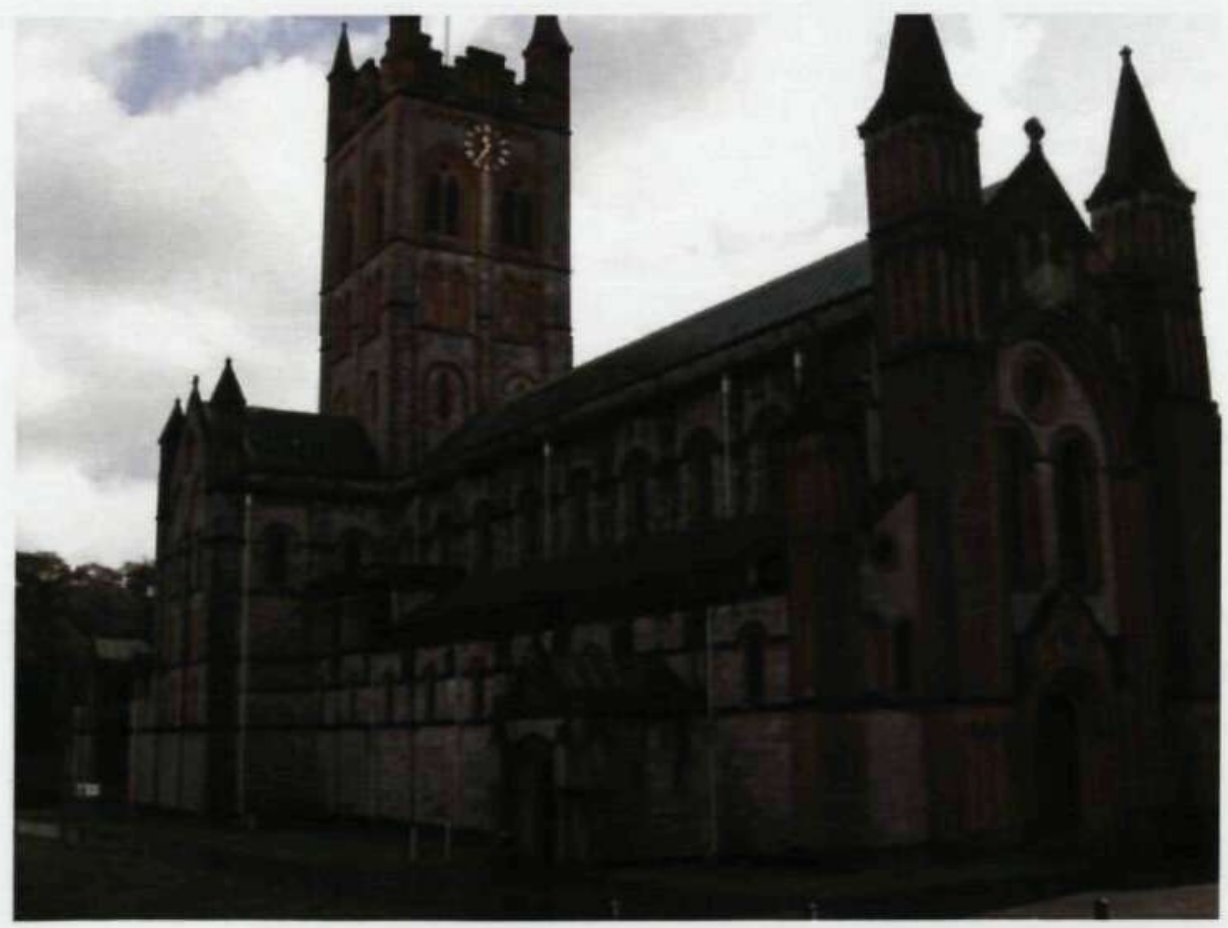

Figure 2.27 Buckfast Abbey: rebuilt by Benedictine monks in the latenineteenth and early twentieth centuries on the site of the medieval Cistercian monastery. 
By the beginning of the nineteenth century, much of that which remained was cleared away to make way for a new house. However, in 1882, the owner sought to sell the house and the old Abbey estate to a religious community. A group of around 30 French Benedictines purchased the property for $£ 4,700$ in 1883. So began the second part of Buckfast's extraordinary story. The new occupants formulated plans to rebuild the medieval Abbey and began to raise funds. Excavations located the entire ground plan of the twelfth-century monastery and work to rebuild began. By 1902, the monastery was recognised as an independent community and the first abbot of the modern era, Dom Boniface Natter, was installed on 24 January 1903, some 365 years after Abbot Donne infamously signed the deed of surrender. The foundation stone of the Abbey was laid on 5 January 1907, and work was sufficiently advanced for the consecration ceremony to take place on 25 August 1932 . The building was topped off on 24 July 1937. All of the work had been undertaken by the monks themselves and, as it proceeded, Buckfast Abbey attracted increasing numbers of visitors. The growing availability of motor coaches and privately owned cars was significant. Indeed, the scale of early heritage tourism at the Abbey attracted local criticism. In 1928, the Western Morning News published a letter of complaint sent in by a resident of the adjacent village of Buckfastleigh:

The inhabitants of Buckfastleigh, Protestant and Catholic alike, find themselves, and their children, in danger every moment from the neverending train of motor cars and charabancs.

Deriving their income mainly from donations, sales of vegetables from their gardens, milk from their dairy cattle, honey from their bees, pork from their pigs, and (from 1897) their well-known tonic wine, the monks embarked on the commodification of their heritage appeal by opening tea-rooms adjacent to the 
North Gate of the Abbey precincts The vigorous marketing of the tonic wine and honey led to considerable success Beekeeping expertise, especially that of Brother Adam Kehrle, further strengthened the Buckfast enterprise and Its unıque brand

During the abbacy of Dom Leo Smith (1976-1992), very considerable additions were made at Buckfast, which transformed its quality as a heritage tourism attraction. Preceded by careful archaeological investigations, in 1982, a large new car and coach park was built. In 1983, a purpose-bult gift shop was completed and a very large restaurant was added in 1991 (to replace the existing wooden café) An exhibition that tells the story of Buckfast was opened In 1982 in the crypt of the Chapel of the Blessied Sacrament and, three years later, an Education Officer was appointed to run school and college visits and an audio-visual show was inaugurated. However, there is no doubt that part of the attraction of Buckfast is the magnificent rebult Abbey and the fact that behınd it there are precincts that are home to a community of monks. Indeed, the chances of encountering and speaking to one of the monks adds considerably to Buckfast's huge appeal.

Abbot Leo added a residential complex in the early 1990s, ingentously capitalising on the hertage resonances of the monastery's medieval role as the provider of hospitality by partly utilising the surviving remains of the latemedieval South Gate guest hall. By then, total annual visitor numbers to the Abbey were close to one third of a million In 2008-2009, the estimated number stood at over 400,000 In addition, another 12,000 came to the Abbey on educational trips Fully accurate figures are, however, not avallable in keeping 
with the monastic tradition, there is no admission charge at Buckfast, and the car park is free. Estimates of the total number of visitors are therefore based on the totals counted periodically in the café/restaurant. As not all visitors go to the Grange restaurant, it is likely that this method a gauging numbers yields totals below the actual figure. Paradoxically, as one of the most successful, popular and highly commodified heritage tourism sites in the Southwest, by offering free entry, the Abbey is disqualified from membership of (and being listed by) the Devon Association of Tourism Attractions.

Alongside the monks, the Abbey employs 120 'lay' staff. However, unlike a majority of heritage sites in Devon and Cornwall, there are no volunteers at all working at Buckfast. Nevertheless, there is clear evidence of entrepreneurial acumen. The restaurant, bookshop, giftshop, and the shop selling goods and gifts made in other monasteries across Europe, all yield an income. The Abbey's conference centre now has residential facilities for up to 100 people. Accommodation is also offered for those on 'retreats' and for educational groups. Weddings solemnised amidst the splendour of the Abbey also yield a healthy income. Ordained monks belonging to the community serve as Catholic priests is nearby parishes, such as South Brent, where congregations provide another source of income for Buckfast.

The tonic wine production business is highly lucrative. A $75 \mathrm{cl}$ bottle retails at £6.50. External marketing is managed for the monastery by an agency and, notwithstanding some negative recent publicity, there are customers across the UK. Commercial honey production - once a thriving part of the operation - has recently been reduced and will be phased out. The high cost of Buckfast honey 
(over $£ 6$ for a 45 gram pot) compared with cheaply produced blended honey from other parts of Europe, which is on sale in local supermarkets, has severely Impacted turnover and, along with its catchy slogan on the label 'a little gift from Buckfast', it will soon disappear. The breeding and sale of Buckfast bees will, however, contınue and honey for the monks' use will be produced Docle, disease resistant, slow to swarm, and highly productive, the Buckfast bee strain Is highly prized by beekeepers in Britain and across Europe.

Commenting on heritage tourism at Buckfast, Father James said that it had been relatively easy for the monks because the Abbey, and its story, "became part of the tourism industry in Devon just as it was growing up'. The development of the 'facilities for visitors', he said, 'were just an organic part of that growth' ${ }^{13}$ Certanly, observations at Buckfast, and the comments made by Father James, indicate that the conflicts (alluded to by some heritage tourısm authors) between pilgrıms and secular visitors at spirtual sites are minımal and the Abbey ranks as one of Devon's foremost and most successful heritage places

\subsubsection{Architectural and Built Heritage}

Religrous buldıngs are, of course, important examples of architectural and bult heritage, but secular structures of great historic importance add significantly to the total that survives in the Southwest. In all, Devon has 19,000 listed buildings - more than any other single county, while Cornwall has another 12,490 Devon

${ }^{13}$ Father James of Benedictıne Communty at Buckfast, personal comment, October 2009. 
and Cornwall together have 415 designated Conservation Areas. The properties of the National Trust in Devon and Cornwall (Tables 2.1 and 2.2) include houses in almost every architectural genre from the late-medieval to the era of Art Deco and beyond. Representatives of virtually every architectural period exist in Devon and Cornwall.

The importance of the two cathedrals and hundreds of churches has already been mentioned. In terms of secular buildings, some are in styles or materials that are distinctive to the Southwest. Cob and thatch structures are traditional in Devon and, though demanding in their conservation requirements, they are much treasured. The Dartmoor 'longhouses', many dating to the medieval period, are equally valued. Originally these comprised living quarters at one end (usually upslope) and a cattle byre or 'shippon' at the other end. Animals and human occupants shared a common doorway. A little altered survivor of this kind of vernacular farmhouse, with its shippon intact, is that at Higher Uppacott, which is maintained by Dartmoor National Park and occasionally open for visiting groups (Fig. 2.28). The same basic form lent itself to larger, stone-built and more impressive versions. The two-storey longhouse at Lettaford (Sanders) is a good example where, again, the byre has survived unaltered (Fig. 2.29). Grander medieval structures also, of course, survive. The wave of castle building in the wake of the Norman Conquest left splendid legacies at Totnes (Fig. 2.30) and Launceston. 


\begin{tabular}{lcl}
\hline \multicolumn{1}{c}{ Devon } & \multicolumn{1}{c}{$\begin{array}{c}\text { Date } \\
\text { Acquired }\end{array}$} & \multicolumn{1}{c}{ Heritage } \\
\hline A la Ronde, Exmouth & 1991 & $\begin{array}{l}\text { Sixteen-sıded, late-eighteenth century } \\
\text { house }\end{array}$ \\
$\begin{array}{l}\text { Arlington Court \& } \\
\begin{array}{l}\text { Natıonal Trust Carriage } \\
\text { Museum, near Barnstaple }\end{array}\end{array}$ & 1949 & $\begin{array}{l}\text { Regency house, Victorian gardens and } \\
\text { parkland beyond; major collection of } \\
\text { horse-drawn vehicles }\end{array}$ \\
$\begin{array}{l}\text { Bradley, Newton Abbot } \\
\text { Branscombe Old Bakery, }\end{array}$ & 1938 & $\begin{array}{l}\text { Medieval manor house (occupled) in } \\
\text { meadowland and woodland }\end{array}$ \\
$\begin{array}{l}\text { Manor \& Forge, near } \\
\text { Seaton }\end{array}$ & $\begin{array}{l}\text { Complex of thatched buldings } \\
\text { includıng working mill and forge }\end{array}$ \\
\hline
\end{tabular}

\section{Buckland Abbey, near Yelverton}

Castle Drogo, near

Drewsteıgnton

The Church House, Widecombe-In-the-Moor

Coleton Fishacre,

Kingswear

Compton Castle, near

Marldon, Pargnton

Finch Foundry,

Stıcklepath, near

Okehamton

Greenway, Galmpton, 2000 near Brixham

Killerton House, Budlake Old Post Office, Clyston Mill; Marker Cottage,

1948
Thirteenth century Cistercian abbey converted into home in later Tudor period, medieval tithe barn, gardens and parkland overlookıng River Tavy

Sir Edwin Lutyens granite-built medieval revival castle bult for Juluus Drewe in interwar perıod

Sixteenth-century church house, used for parish events and church 'ales'

Art Deco style house and 12-hectare garden

Medieval fortified home of the Devon Glberts

Water-powered forge, tilt hammer, grindstone

Private holiday home of author, Agatha Christie, furnished in 1950 s style Gardens overlookıng River Dart

1944 Georgian style house of Devon Aclands Garden created by John Veitch. Thatched former village post 
Broadclyst, near Exeter

Knighthayes Court,

Bolham, near Tiverton

Lundy, Bristol Channel

Overbecks, Salcombe

Saltram, Plympton,

Plymouth

Watersmeet, Lynmouth office. Medieval cob-built cottage

Gothic revival mansion designed in 1869 by William Burges for lace-maker John Heathcoat. Large garden

1969 Small village, inn, church and thirteenth-century Marisco Castle

1937 Edwardian house of Otto Overbeck set in extensive exotic gardens overlooking Salcombe estuary

1957 Eighteenth and early nineteenth century home of Parker family set in extensive park overlooking River Plym $1955 \quad$ Nineteenth-century fishing lodge set in wildlife landscape 
Table 2.2 National Trust Houses and Gardens in Cornwall

\begin{tabular}{|c|c|c|}
\hline Cornwall & $\begin{array}{c}\text { Date } \\
\text { Acquired }\end{array}$ & Heritage \\
\hline Antony House, Torpoint & 1961 & $\begin{array}{l}\text { Classical-style house of Carew } \\
\text { Pole family set in Humphry } \\
\text { Repton park }\end{array}$ \\
\hline $\begin{array}{l}\text { Cornish Mines and Engines, } \\
\text { Pool, near Redruth }\end{array}$ & 1967 & $\begin{array}{l}\text { Two beam (steam) engines } \\
\text { preserved in engine houses }\end{array}$ \\
\hline $\begin{array}{l}\text { Cotehele and Cotehele Mill, St } \\
\text { Domınick }\end{array}$ & 1947 & $\begin{array}{l}\text { Medieval/Tudor house, mill, } \\
\text { Tamar quay, museum, } \\
\text { gardens, mother orchard, } \\
\text { Georgian folly }\end{array}$ \\
\hline $\begin{array}{l}\text { Glendurgan Gardens, Mawnan } \\
\text { Smith, near Penzance }\end{array}$ & 1962 & $\begin{array}{l}\text { Gardens extending over three } \\
\text { valleys; the creation of the Fox } \\
\text { famuly }\end{array}$ \\
\hline $\begin{array}{l}\text { Godolphin, Godolphin Cross, } \\
\text { near Helston }\end{array}$ & 2000 & $\begin{array}{l}\text { Seventeenth century house } \\
\text { and earlier gardens and } \\
\text { stables }\end{array}$ \\
\hline Lanhydrock, near Bodmın & 1953 & $\begin{array}{l}\text { Seventeenth century } \\
\text { elements, but mostly late } \\
\text { nineteenth century country } \\
\text { house set in large park }\end{array}$ \\
\hline Lawrence House, Launceston & 1964 & $\begin{array}{l}\text { Mid-eighteenth century town } \\
\text { house (leased to town councl } \\
\text { as museum and civlc centre) }\end{array}$ \\
\hline $\begin{array}{l}\text { Levant Mine and Beam Engine; } \\
\text { Botallack Count House, } \\
\text { Trewellard, Pendeen, near St Just }\end{array}$ & 1967 & $\begin{array}{l}\text { Restored and workıng beam } \\
\text { engine, on original site, engine } \\
\text { houses, short underground dry } \\
\text { tunnel }\end{array}$ \\
\hline $\begin{array}{l}\text { St Michael's Mount, near } \\
\text { Marazion }\end{array}$ & 1954 & $\begin{array}{l}\text { Medieval church and castle, in } \\
\text { parts datıng to thirteenth } \\
\text { century; home of the St } \\
\text { Aubyns }\end{array}$ \\
\hline Tintagel, Old Post Office & 1903 & $\begin{array}{l}\text { Fourteenth-century yeoman } \\
\text { farmer's house (used as post } \\
\text { office in Victorlan era) }\end{array}$ \\
\hline
\end{tabular}


Trelissick Gardens, Feock, near 1955 Truro

Trengwainton Gardens, Madron, 1961 near Penzance

Trerice, Kestle Mill, near Newquay 1953
Extensive gardens, woodlands and four summerhouses

Ten-hectare garden stocked with exotic plants overlooking Mounts Bay; restored walled kitchen garden

Elizabethan manor house little altered since 1600 s

Sources: Peel, L., (2010), 32-107; 


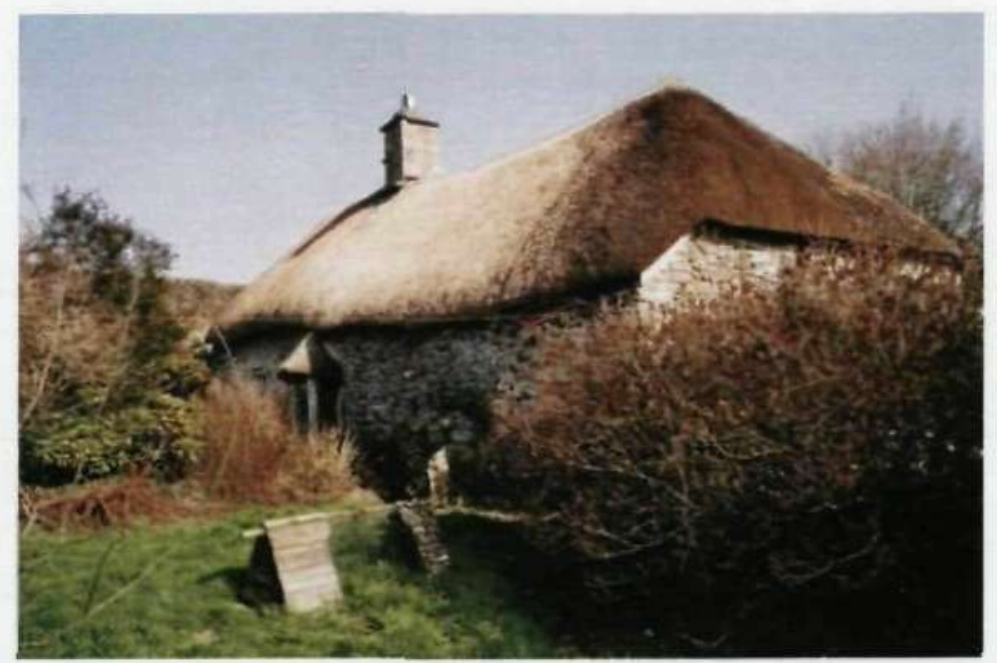

Figure 2.28 Higher Uppacott: a medieval Dartmoor longhouse which still has its cattle byre or 'shippon' intact.

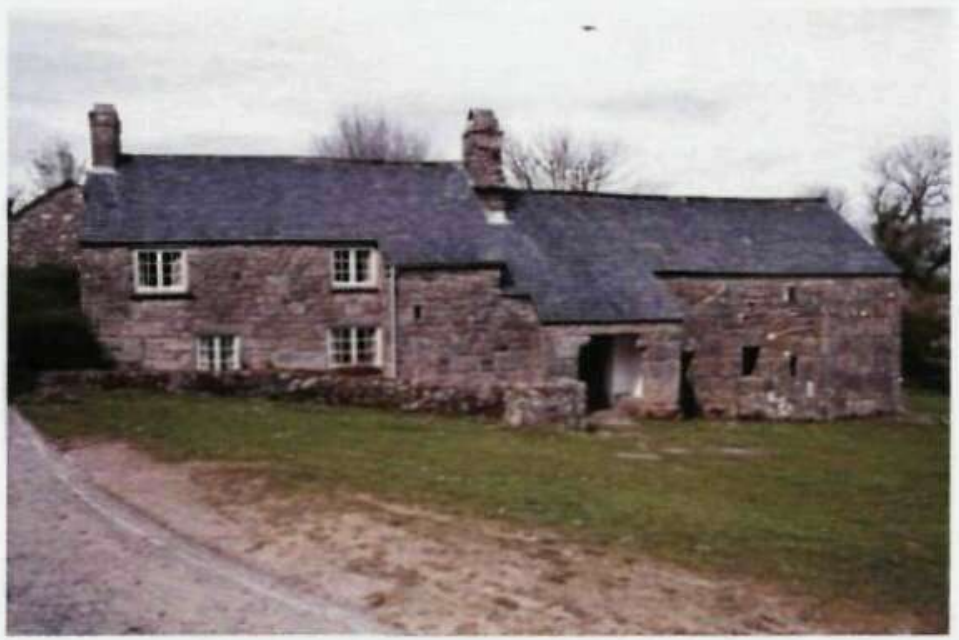

Figure 2.29 Sanders, Lettaford: a large, stone-built Dartmoor crosspassage longhouse which still has its large shippon intact.

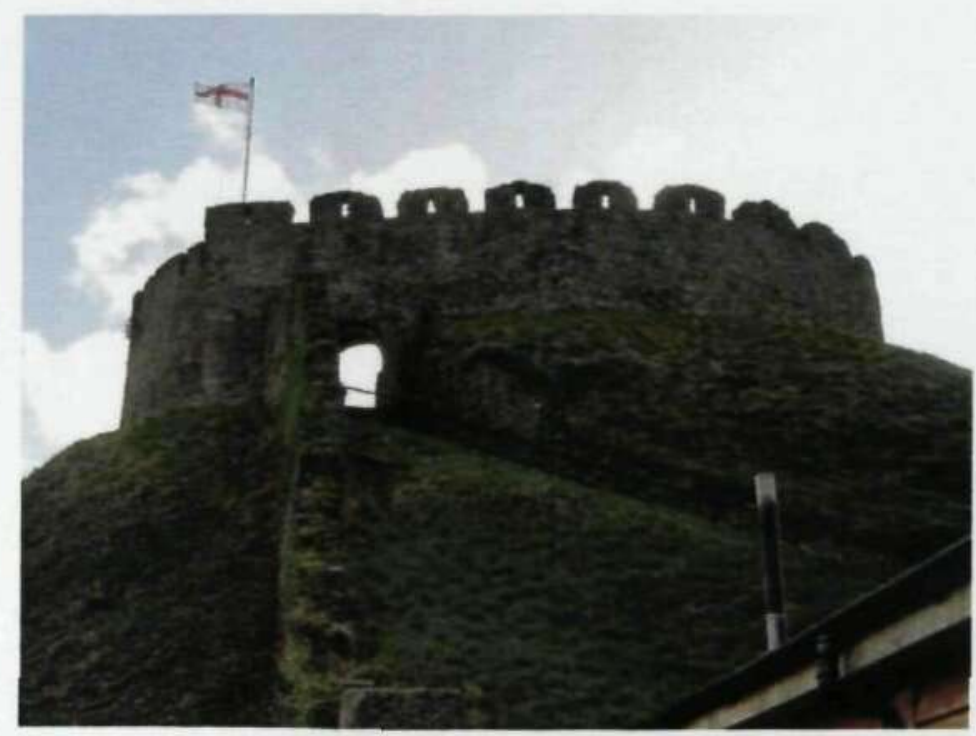

Figure 2.30 Totnes Castle: A Norman motte and bailey castle, managed by English Heritage. 
Both are managed by English Heritage and admission charges are levied on visitors. Plympton's Norman castle was virtually demolished in the English Civil War, though the motte and the bailey area have been retained within a park. The remnants of Exeter's Rougemont Castle are similarly contained within parkland, but the original Norman structure was in any case much altered in later centuries. The complex castle at Okehampton is another commodified medieval heritage structure in the heart of Devon.

Domestic buildings belonging to the wealthy in late-medieval times are represented in Cornwall by Cotehele, which has been in the ownership of the National Trust since 1947 (Table 2.2). Although there have been many later additions, elements of the house date to the fifteenth century (Fig. 2.31). In Devon, the fortified manor house of the Gilberts, Compton Castle, is even older. It was, however, in the growing prosperity of the Tudor era that architecture of striking quality began to be erected in Devon and Cornwall. Wealthy towns such as Dartmouth, Plymouth, and Totnes grew rapidly and fine town houses were erected. Some survive as testament to the drive and dynamism of the era. However, it was perhaps in Exeter that the fullest expression of sixteenth and seventeenth century economic buoyancy and demographic expansion was manifested. Although much has been lost, the city still has a wonderful heritage of Tudor and Stuart architecture. The city's Guildhall, re-fronted in the early 1590s (Fig. 2.32) makes a powerful statement about the wealth and prestige of late-Elizabethan Exeter. Rescue and conservation of the built heritage of the city is exemplified in the little Tudor-date building at the foot of Stepcote Hill 'The House that Moved', which was saved from demolition and moved on rollers to its present site in 1961 (Fig. 2.33). 


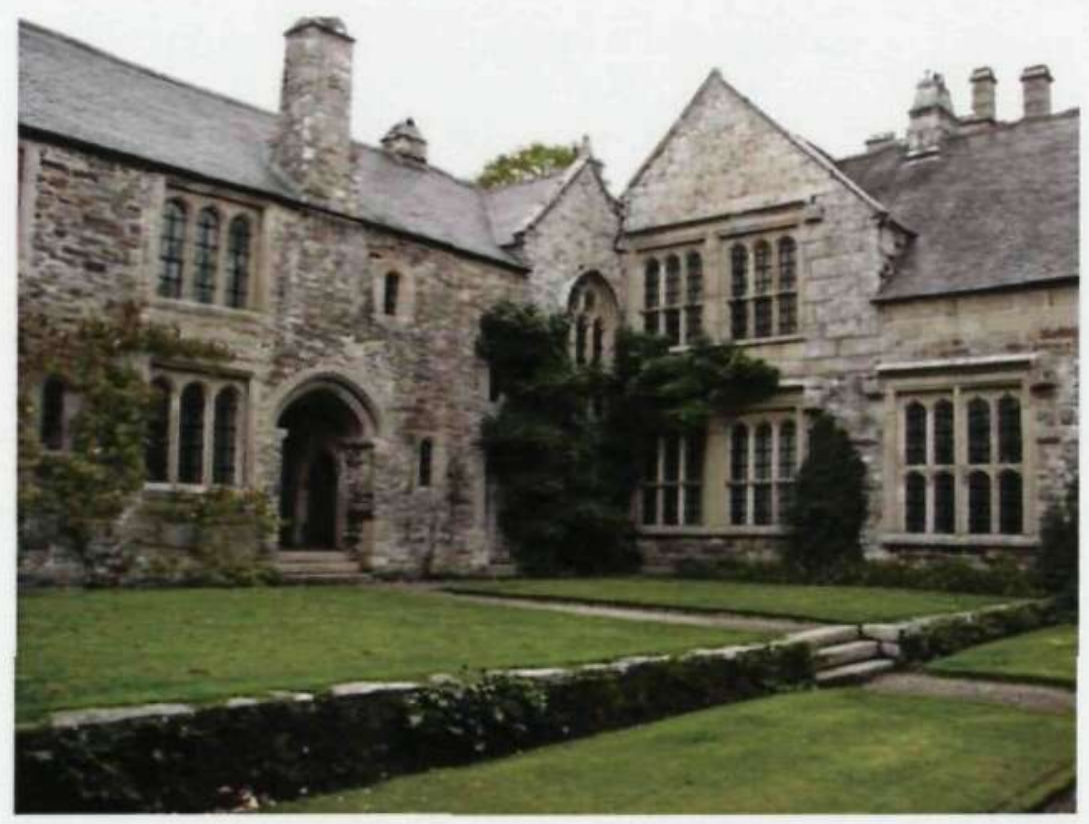

Figure 2.31 Cotehele, St Dominic, Cornwall: a late-fifteenth century house set in an extensive estate.

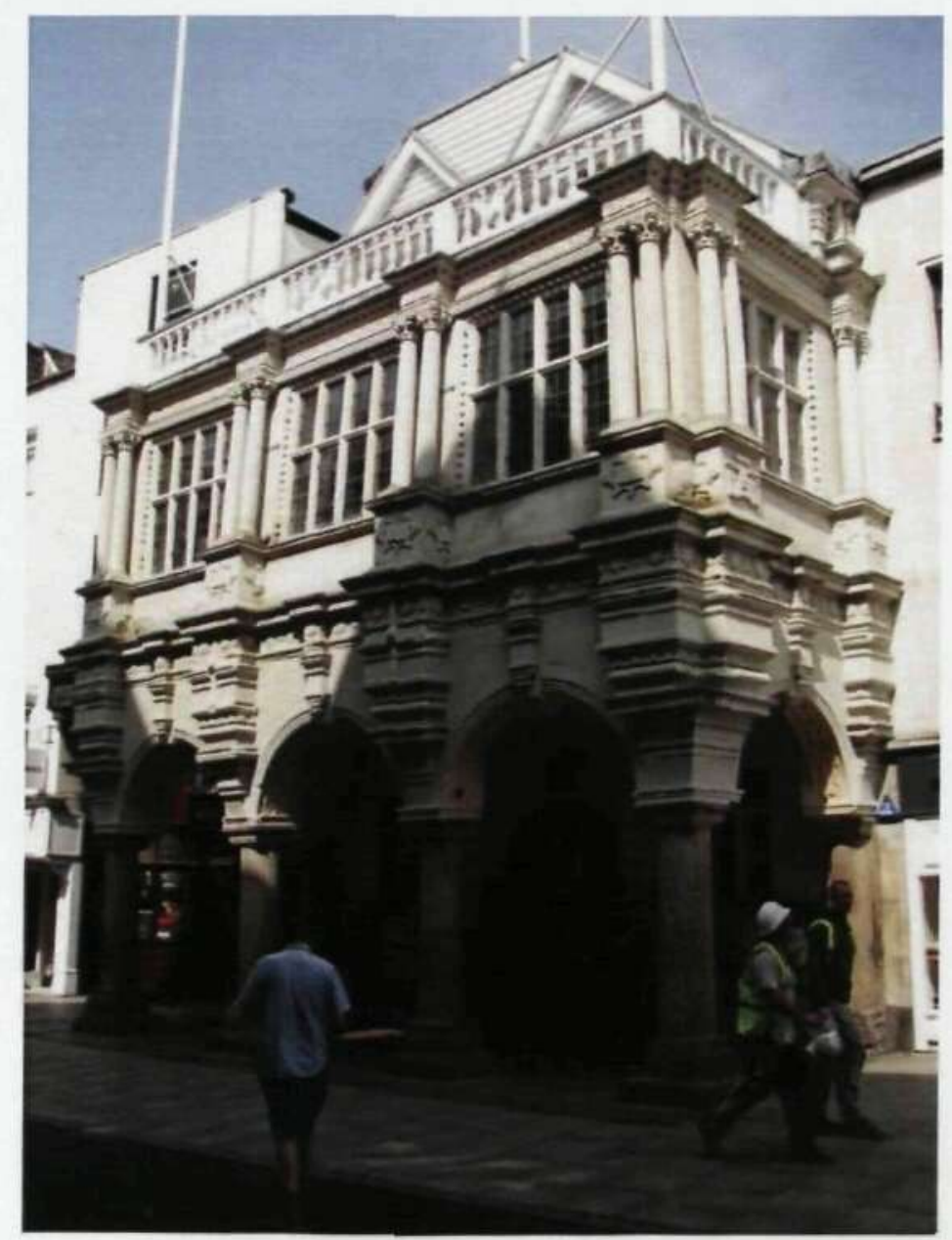

Figure 2.32 The Guildhall, Exeter. The original medieval structure was rebuilt in the 1590 s. 


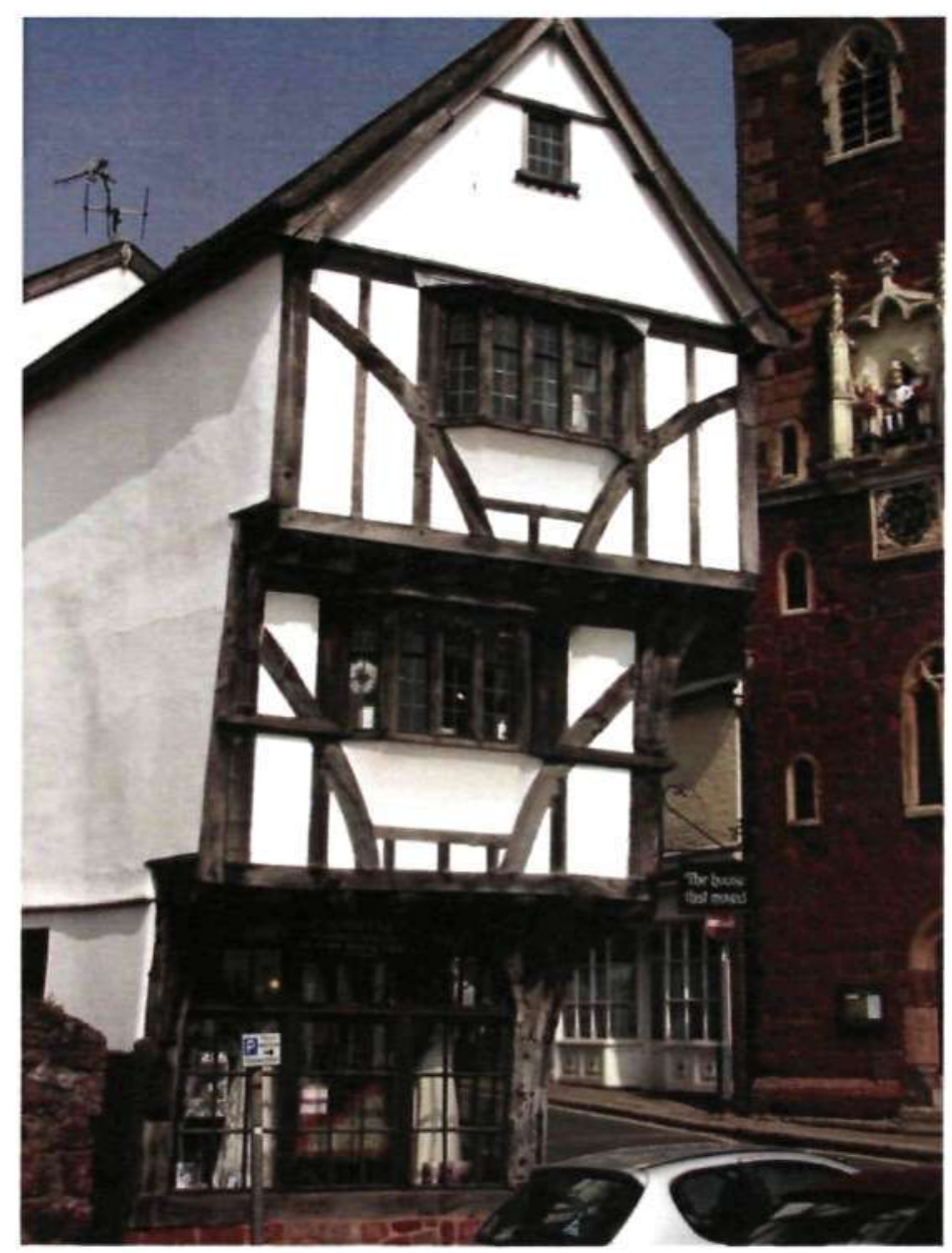

Figure 2.33 The 'House that Moved' at the foot of Stepcote Hill, Exeter. Threatened by demolition to allow for road improvements, it was moved on rollers to this position in 1961.

In Exeter's High Street, the exceptional façades of Tudor merchants' houses have been retained and conserved, even though the buildings behind are total replacements, and there is no doubt that the heritage streetscape of the city is considerably enhanced by their presence (Fig. 2.34). However, heritage buildings pose difficult problems for commercial occupants as the photograph of the shops that occupy the other Tudor buildings at the foot of Stepcote Hill make clear (Fig. 2.35). 


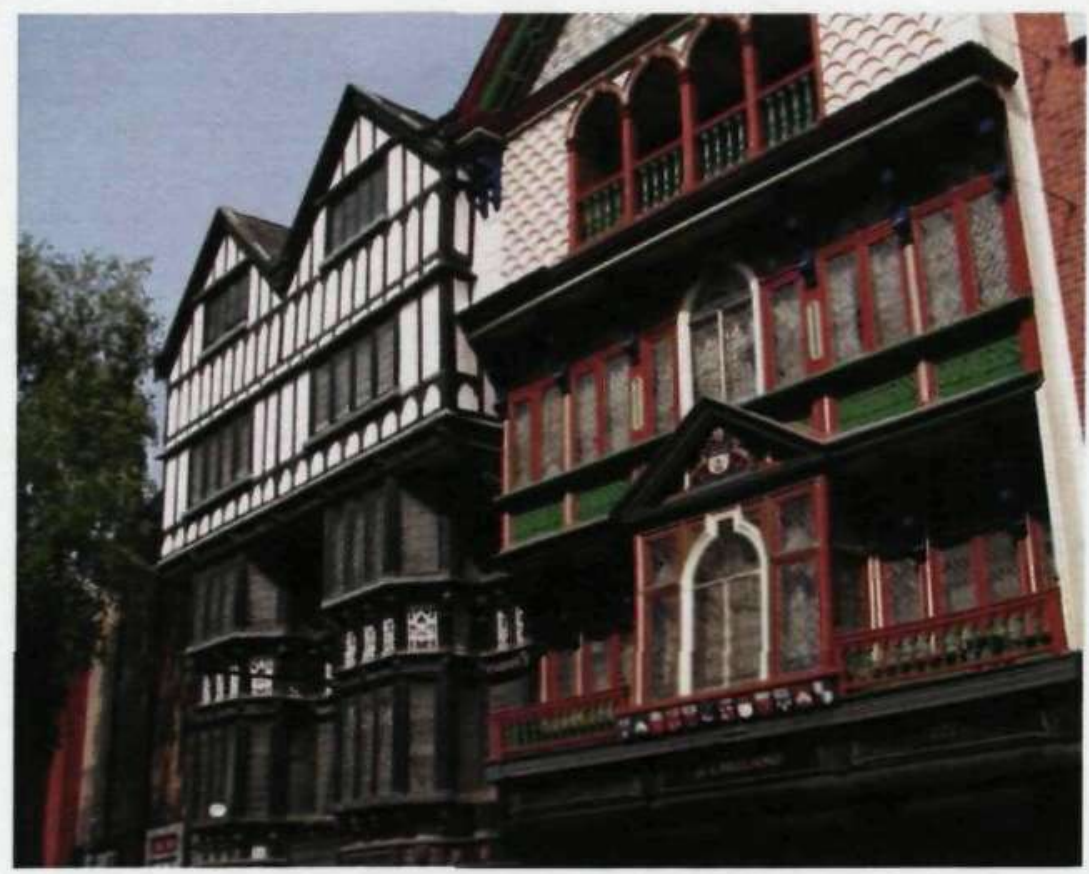

Figure 2.34 The Tudor Merchant Houses in High Street, Exeter. While the buildings behind these facades have been entirely rebuilt, the conservation of the structures offers a glimpse of the dwellings of the wealthier sort in the seventeenth-century city.

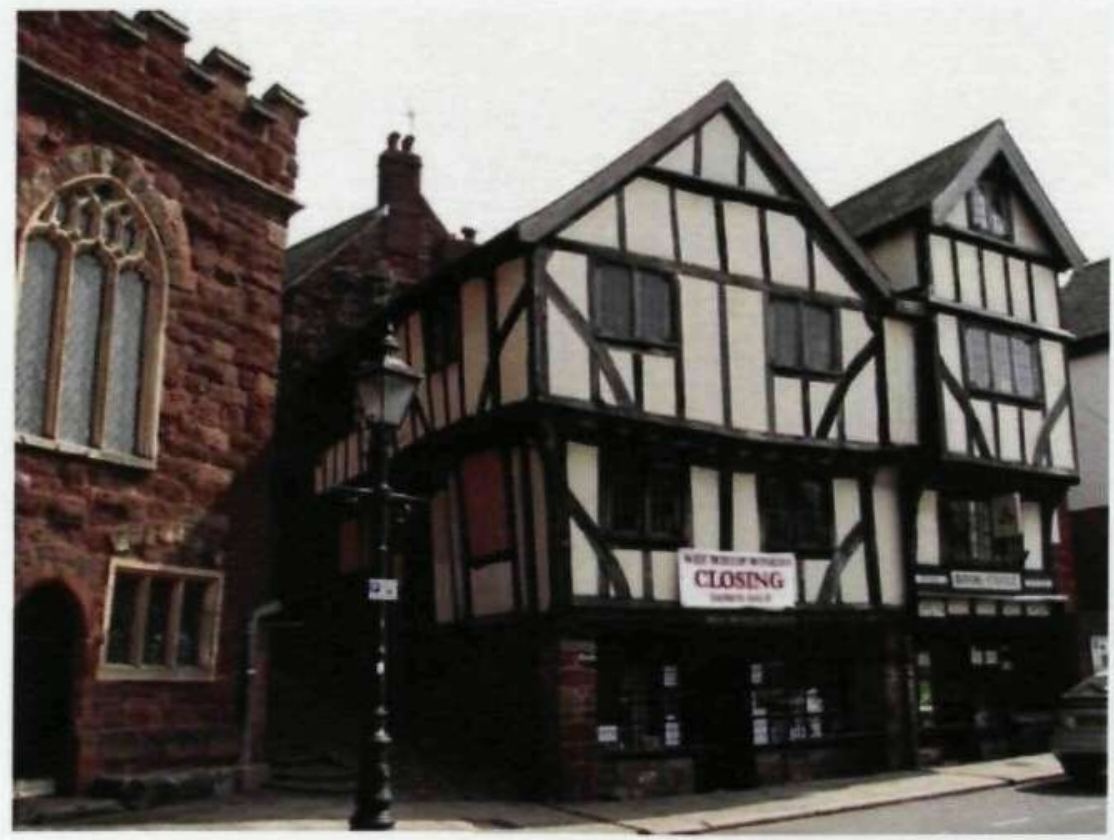

Figure 2.35 Tudor shops/houses at the foot of Stepcote Hill, Exeter, demonstrate the problems of finding appropriate uses for heritage buildings. 
The country homes of the wealthier sort, such as Trerice and Goldolphin (Fig. 2.36) in west Cornwall, both belonging to the National Trust, provide a glimpse of even grander Tudor and Stuart architecture.

The wave of activity in the Tudor period to provide coastal defences has left a considerable contribution to the heritage of military architecture in Devon and Cornwall. Most notable, of course, is Pendennis Castle, with its partner at St Mawes, constructed in the 1540 s to provide protection for Carrick Roads and the port of Falmouth. Both are in the care of English Heritage and are examples of extensively commodified castle heritage in the county.

One of the rare examples outside London of the English Baroque style is the main gateway to Plymouth's Royal Citadel, which was completed in 1670 (Fig. 2.37). The Citadel is garrisoned by the Royal Artillery, but guided tours are offered to the public throughout the year and musical events are occasionally staged within its precincts; in that sense, the structure might be regarded as commodified heritage.

The grace and elegance of Georgian and Regency architecture is found in abundance in Devon and Cornwall. The National Trust properties of Arlington Court, Killerton, Saltram, and Antony are fine examples and all have been commodified as heritage attractions. In urban settings, eighteenth and early nineteenth-century buildings add greatly to the overall heritage appeal. (Fig. 2.38). Until fairly recently, the restrained and harmonious signature of the Georgian style was preferred over the more eclectic, revivalist taste of the Victorians. 


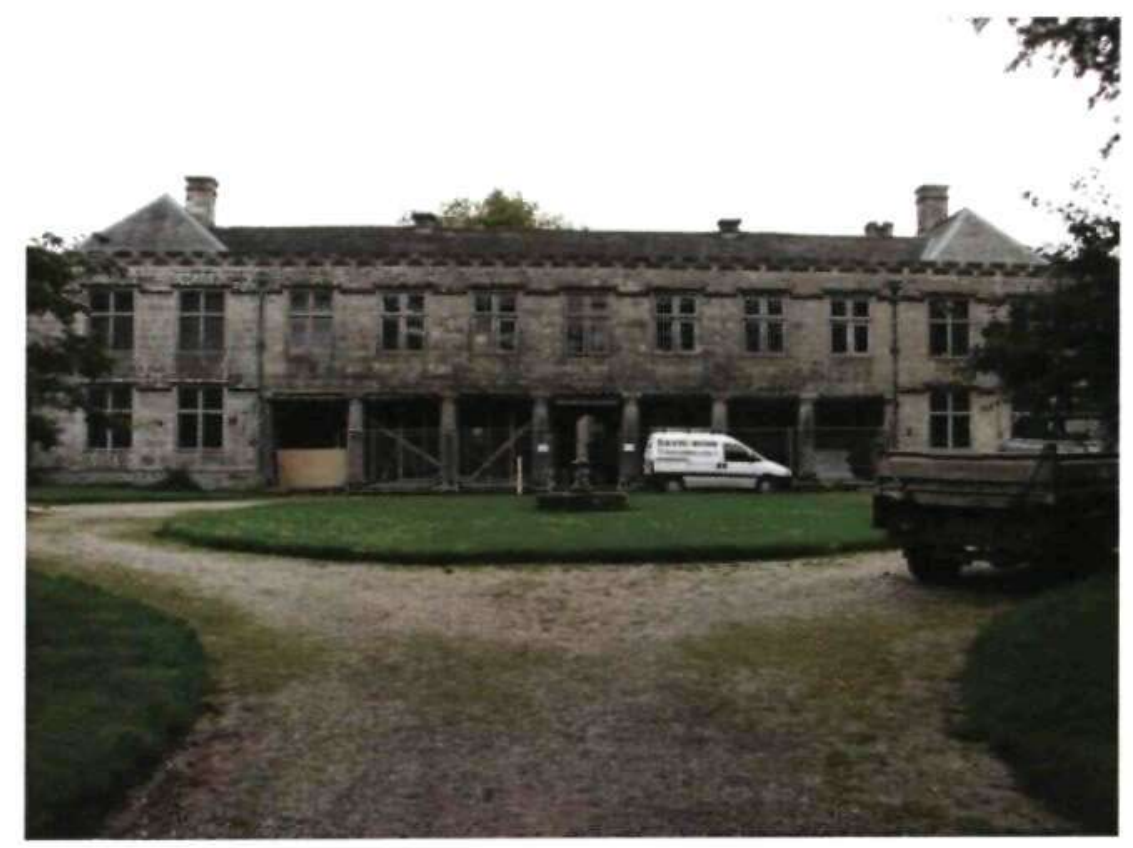

Figure 2.36 Godolphin House, Cornwall. Acquired by the National Trust in 2000 and now undergoing costly conservation.

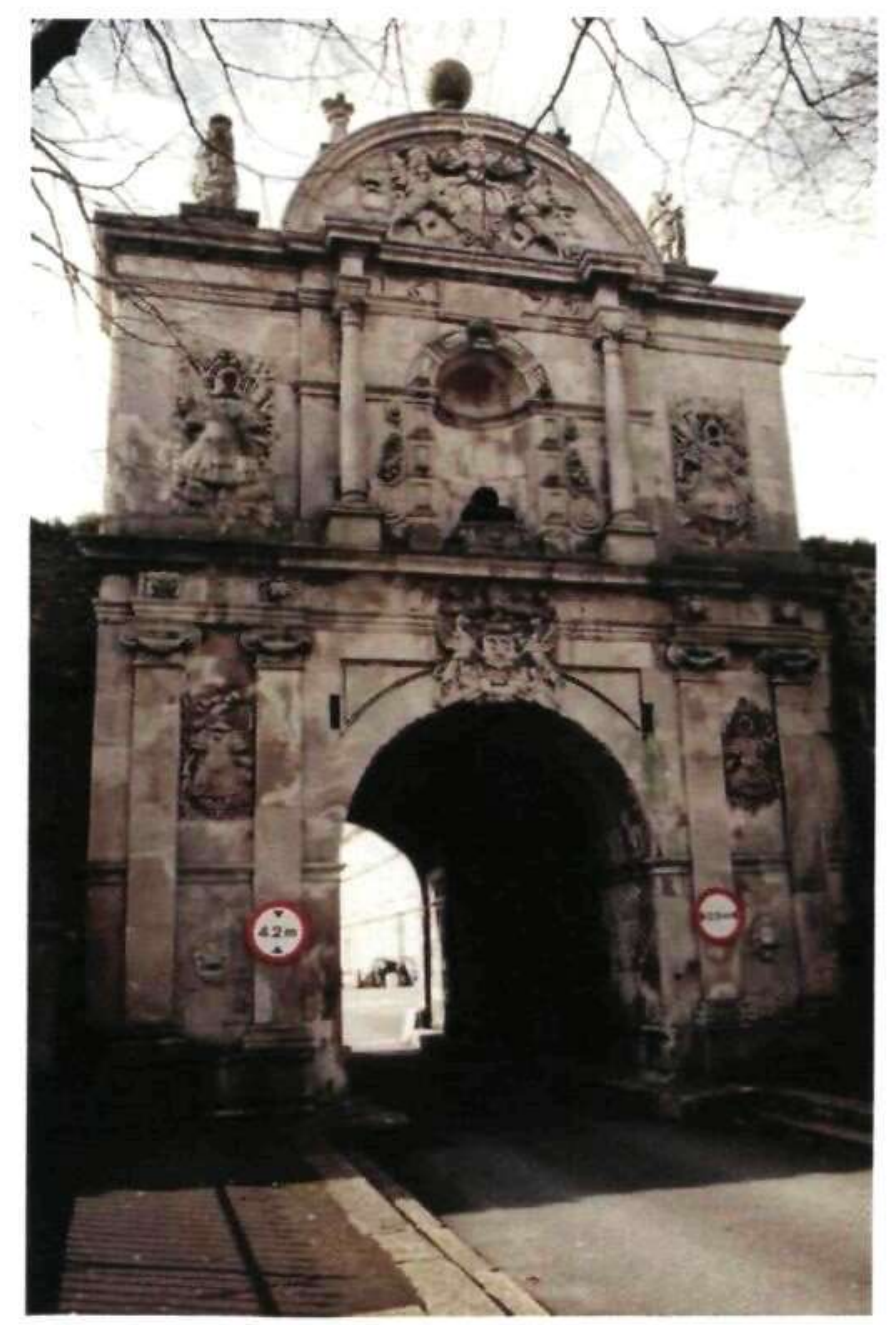

Figure 2.37 The Baroque Gateway of the Royal Citadel on Plymouth Hoe, completed in 1670 


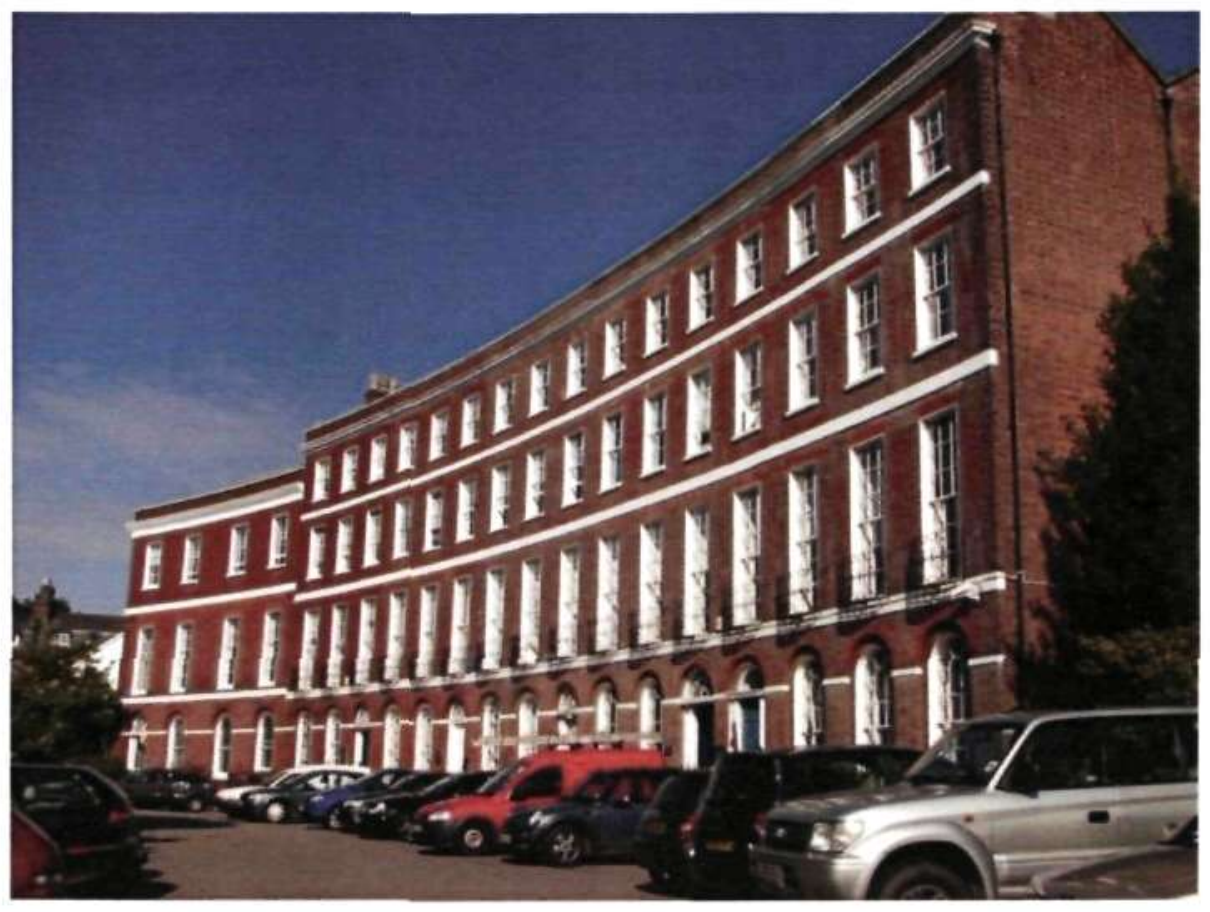

Figure 2.38 Barnfield Crescent, Exeter. A very fine example of the graceful elegance of Georgian provincial architecture.

However, appreciation of Victorian heritage buildings is now well established. Exeter's Queen Street offers some splendid examples. The Market Hall, recently restored as the frontage of to the modern Guildhall Shopping precinct, marks the start of Queen Victoria's reign and was completed in 1838, within a year of the accession (Fig. 2.39). The neo-classical building contrasts markedly with the flamboyant Royal Albert Memorial Museum of 1868 (Fig. 2.40) and the two neatly sandwich a period of thirty years in which almost every past style was revived (and often unashamedly mixed) in an outpouring of self-confident, bold and striking architecture. In 1878, when the imposing Rougemont Hotel was opened (opposite Exeter's Central Station), an unmistakeable Victorian urban style had crystallised (Fig. 2.41). 


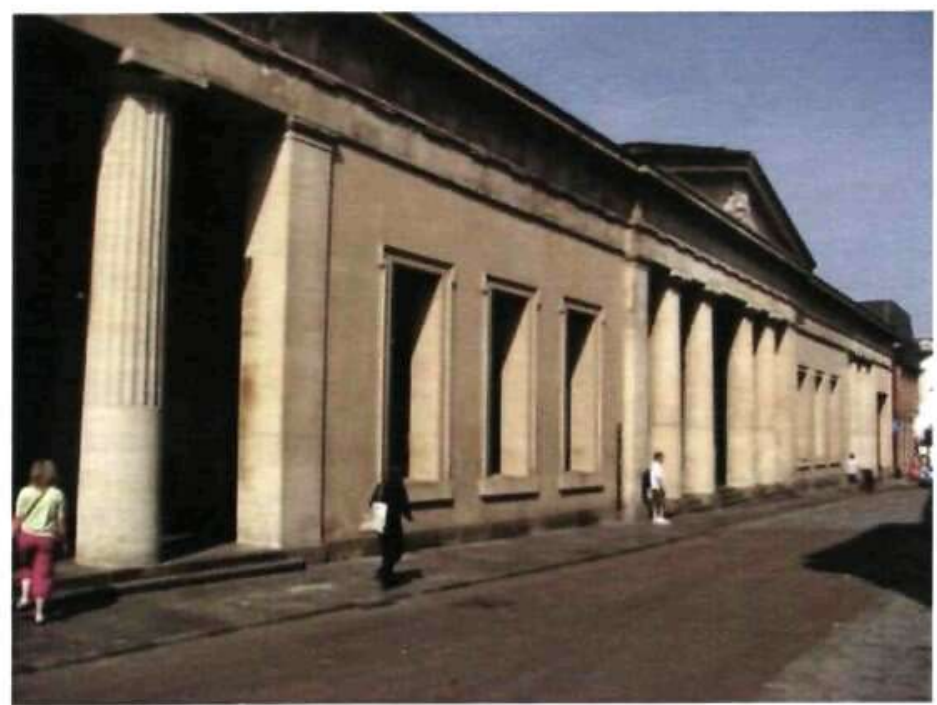

Figure 2.39 Exeter's Victorian Market Building in Queen Street, completed in 1838 .

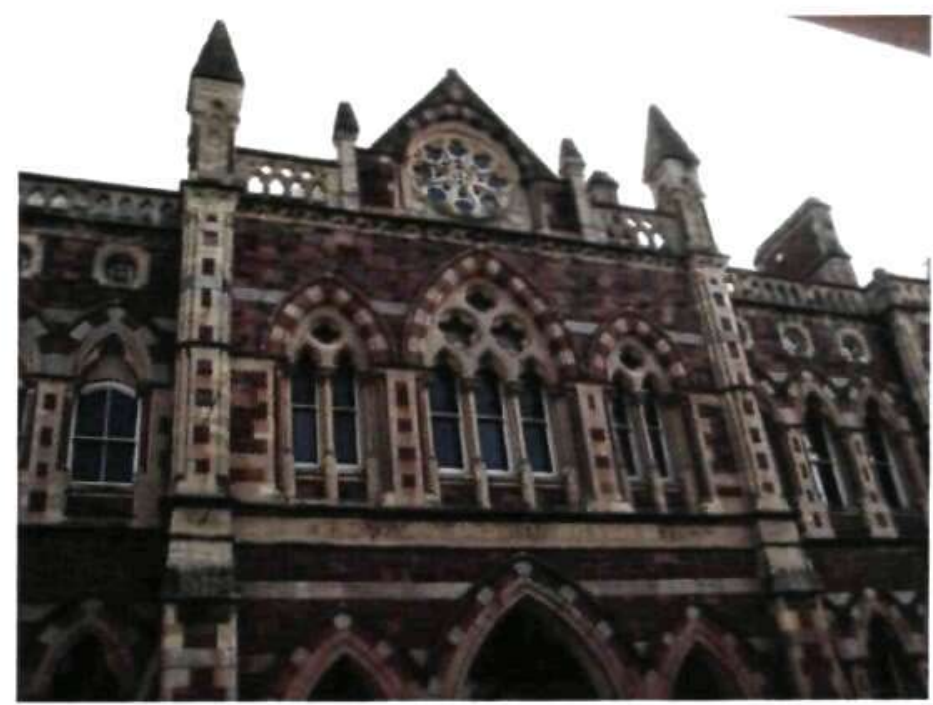

Figure 2.40 The Royal Albert Memorial Musuem, Queen Street, Exeter, completed in 1868.

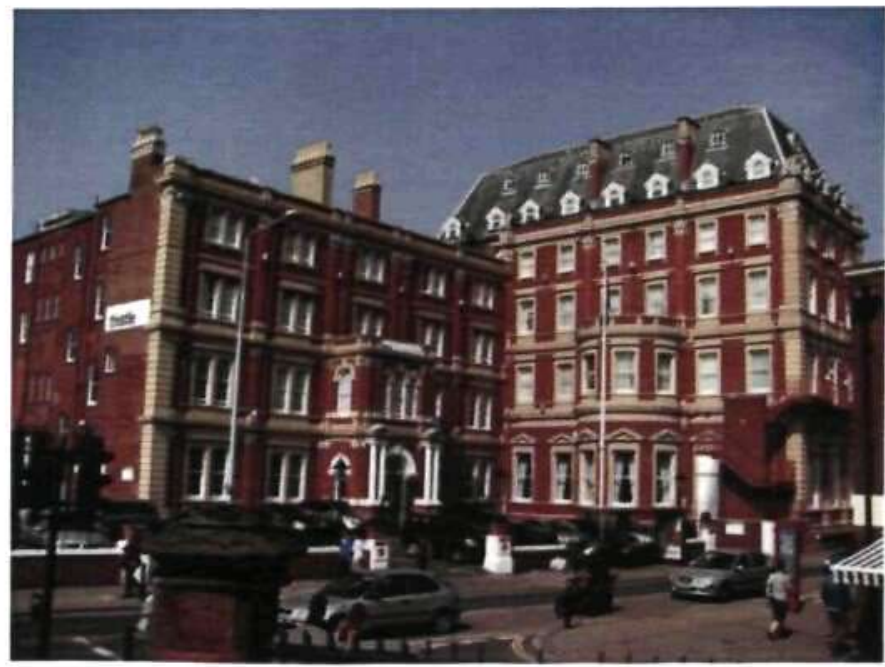

Figure 2.41 The Rougemont Hotel, Exeter, completed in 1878. 
In rural locations, the distinctively robust and high-quality architecture of some 65 Victorian model farms survive in Devon and Cornwall (43 and 22 respectively).

Amongst the most impressive for its layout and high-quality architecture is the complex of model farm buildings erected at Kilworthy near Tavistock on the west Devon estate of the Duke of Bedford in 1851. The best 'Cornish example is Trebartha Barton, built by the Rodd family' in the parish of North Hill (Overton $2006,119-210$ ). More modest cottages for farm workers have also survived. The agricultural estate workers cottages at Dartington are a fine example of the genre (Fig. 2.42). These share characteristics in common with the industrial workers housing erected by mine owners such as the Duke of Bedford in Tavistock (Fig. 2.43) and industrialists such as John Heathcoat in Tiverton (Fig. 2.44). Better paid mine employees were provided with more imposing dwellings; the house erected for the mine manager of Devon Great Consols, known originally as Tamar View, and now the restaurant, the Horn of Plenty, is an excellent example (Fig. 2.45) (Goodridge 2008).

The homes of wealthy Victorian families of Devon and Cornwall also embody the architectural tastes of the era. Saltram, near Plymouth, now in National Trust care, manifests the elegance of eighteenth century style but with the addition of a rather heavy early nineteenth century porch (Fig. 2.46). 


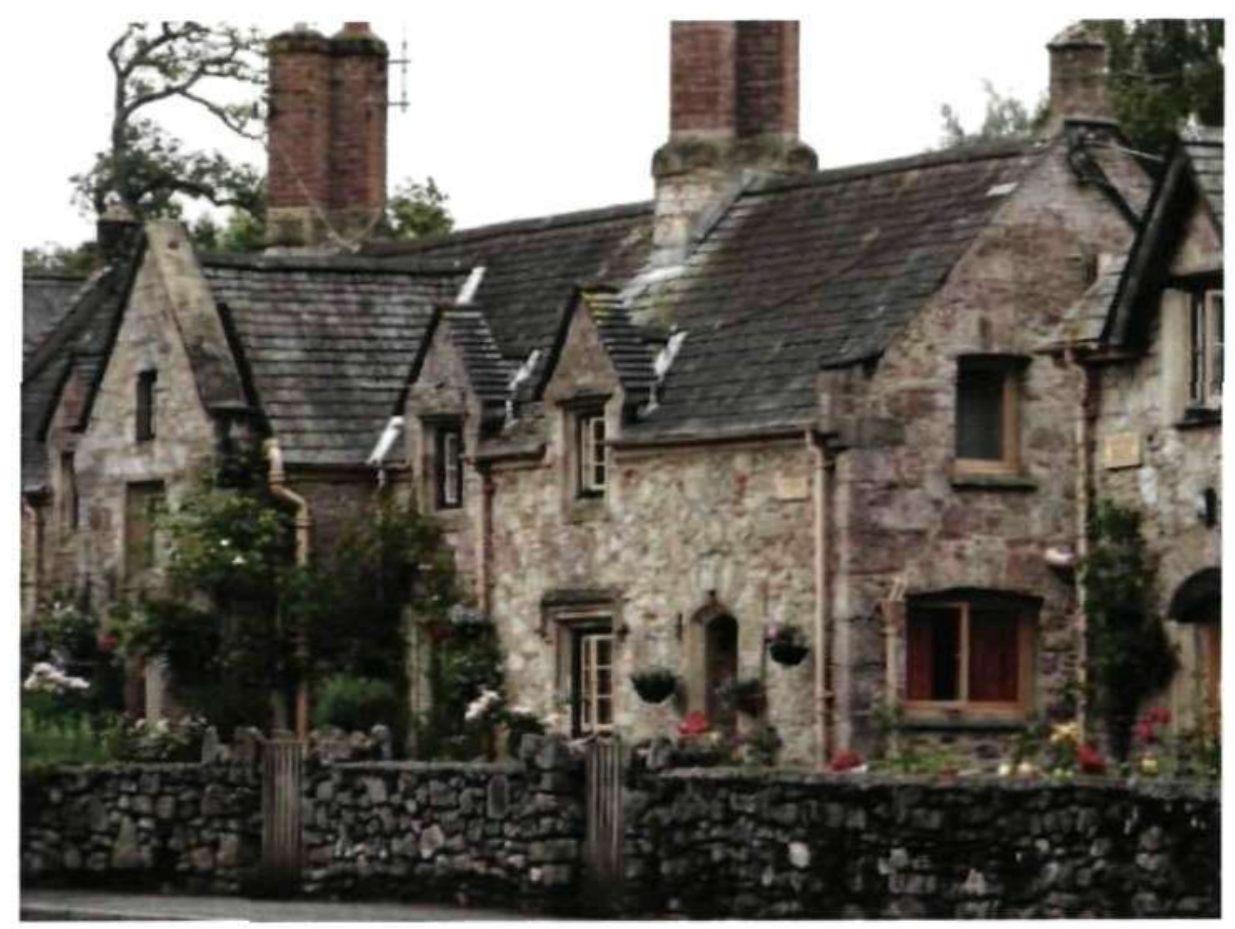

Figure 2.42 Nineteenth-century agricultural estate workers cottages at Dartington.

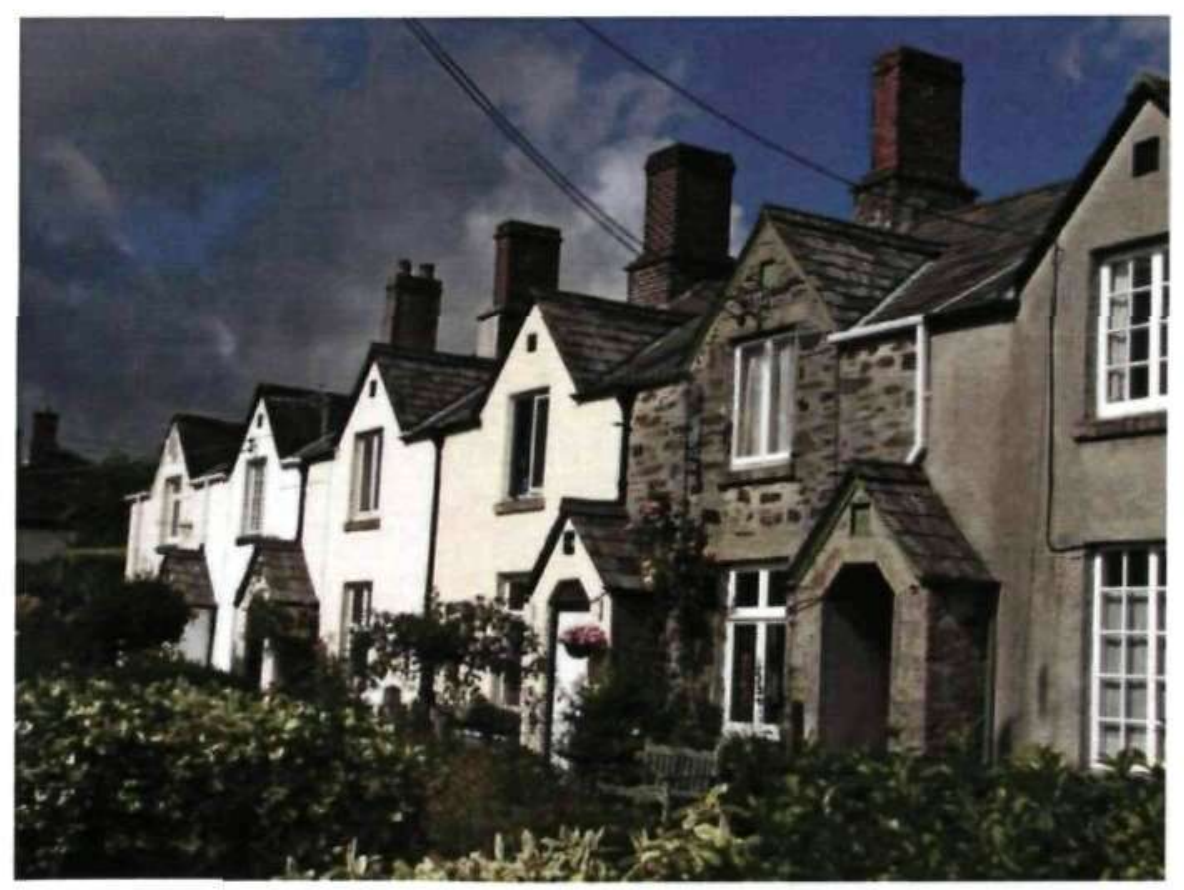

Figure 2.43 Fitzford, Tavistock: Miners' cottages, built by the Bedford Estate in the 1860s 


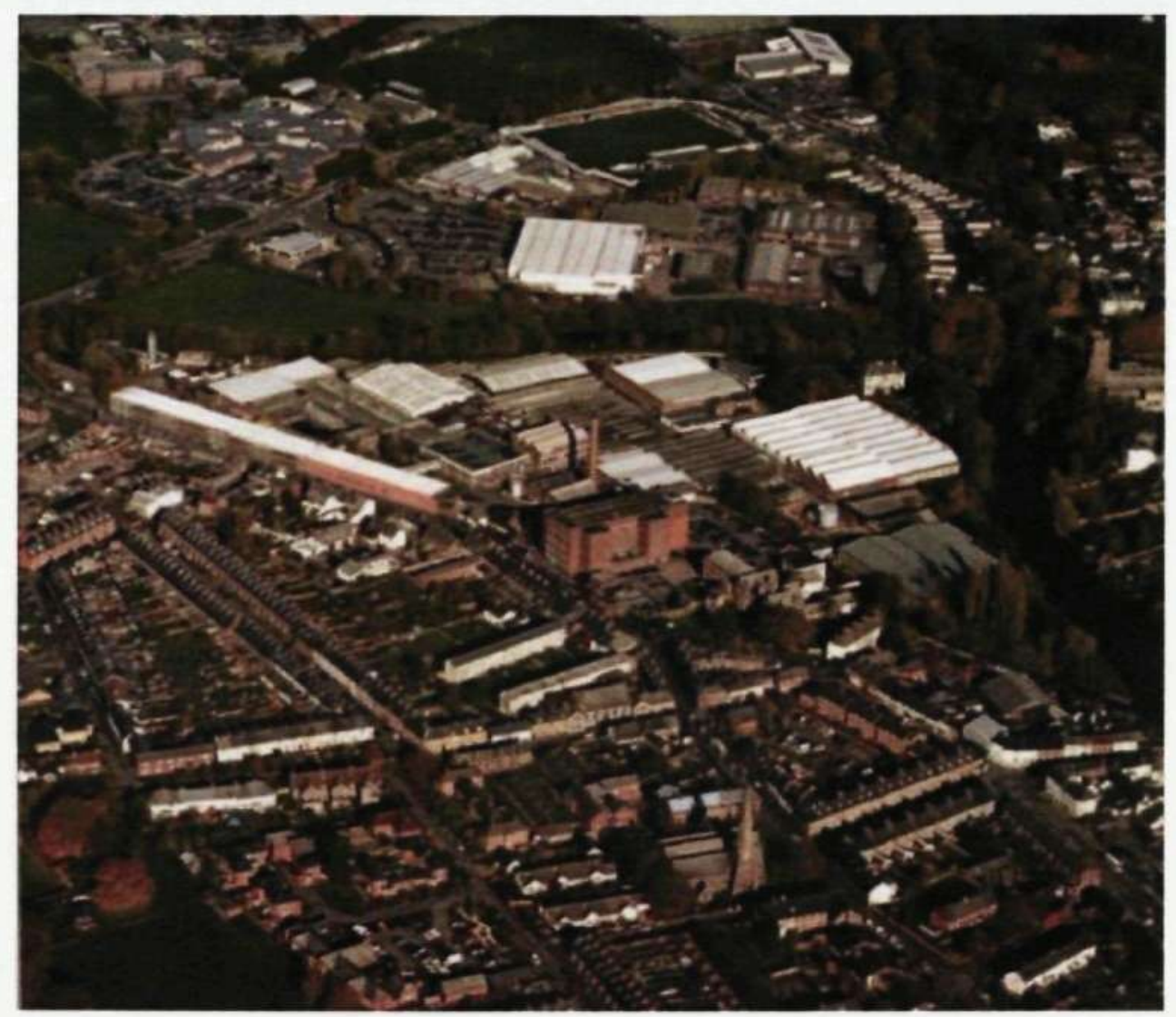

Figure 2.44 West Exe, Tiverton: Lace factory workers cottages built by John Heathcoat in the 1840 s. The photo shows workers' housing with good-sized gardens, a working men's institute, a school amongst other things. Most of it built between 1840 and 1870 (Source: English Heritage).

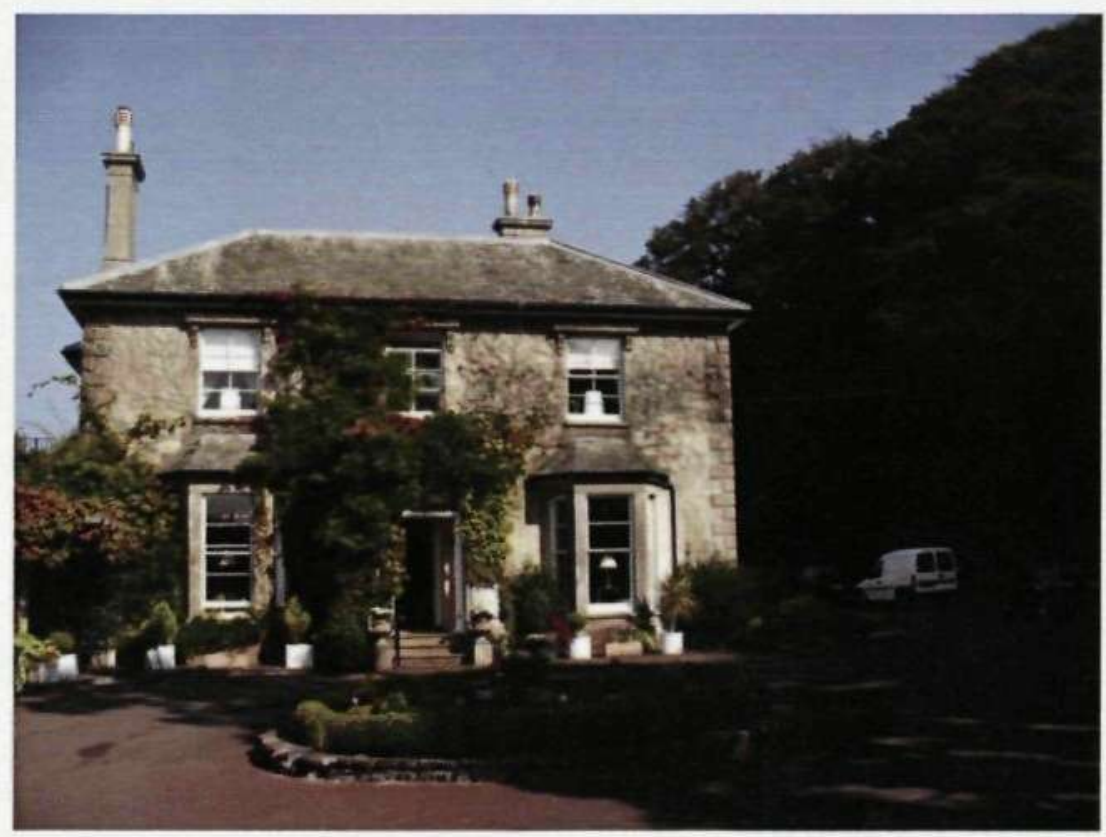

Figure 2.45 Tamar View (now know as the Horn of Plenty), near Tavistock, built by the Devon Great Consols Mine for its mine manager in 1866. 


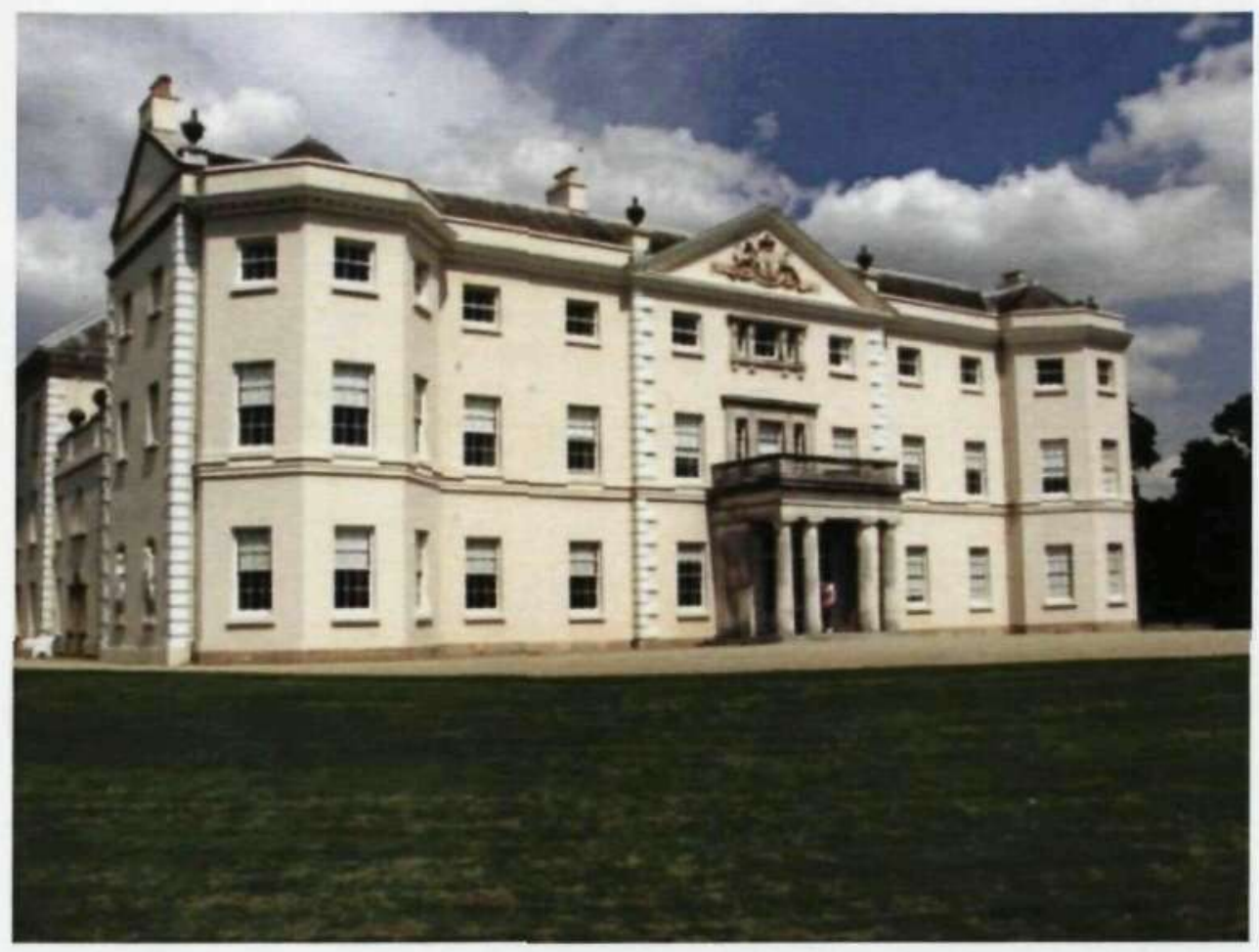

Figure 2.46 Saltram House, near Plymouth. A largely eighteenth-century house but with some Tudor elements surviving in the inner court. In the early nineteenth century, John Foulsdon, the local architect,designed the somewhat heavy porch.

Knightshayes Court near Tiverton in Devon, and Lanhydrock in Cornwall, are also amongst the great heritage houses owned by the National Trust; in these cases, exuberant high-Victorian style is on display. Castle Drogo in Devon, another Trust property, offers a glimpse of the continuing taste for revivalist architecture amongst some of those who possessed considerable wealth. It was here that Edwin Lutyens designed his extraordinary medieval revival building for the retailing tycoon Julius Drewe. 
Examples of twentieth-century built heritage also exist in the two counties. Amongst these, the exceptional Art Deco Tinside Pool on Plymouth's waterfront may be identified (Fig. 2.47). Art Deco architecture can be found unexpectedly in unlikely locations such as the former cinema, now a small theatre run by an amateur company in Holsworthy (Fig. 2.48).

While such a brief survey cannot encapsulate the entire stock of architectural and built heritage in the two counties, it is clear that Devon and Cornwall are richly endowed. Some of the most striking examples of past styles are publicly accessible. However, a great deal is obviously not in any way directly commodified and its conservation must therefore depend on other means of support.

\subsubsection{Industrial Heritage}

Devon and Cornwall are remarkably rich in industrial heritage. Studies by Booker (1967) of the Tamar Valley, by Harris (1968) of Dartmoor, and by Todd and Laws (1972) of Cornwall did much to kindle popular interest in the rich legacy that survives in the region of past industrial activity. That interest has been growing ever since. An new overview of Cornwall's industrial heritage was produced by Stanier in 2005; while Newman has done much in recent years to record and describe the industrial heritage of Dartmoor (see Newman 2006). 


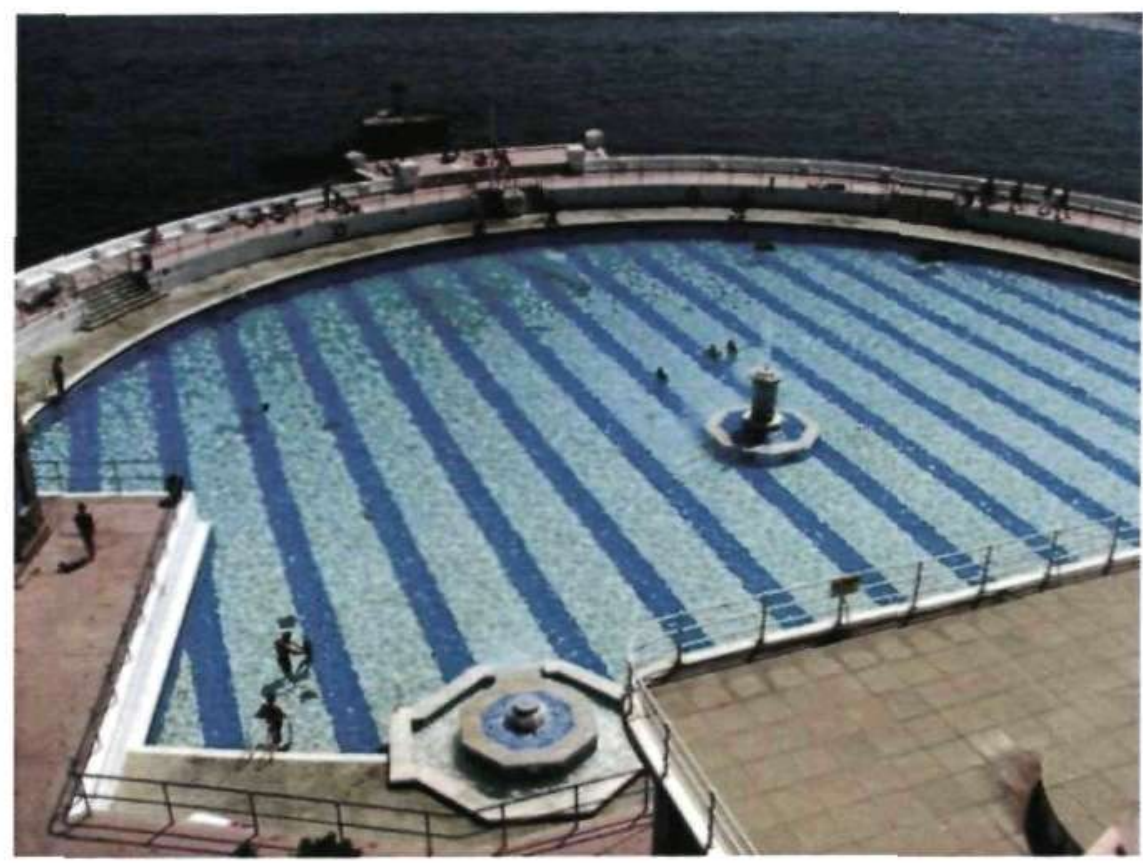

Figure 2.47 Tinside Lido Plymouth: first opened in 1935 and described at that time as 'one of the finest open-sea bathing centres in the country (BBC 2006), Plymouth's pool is built in the fashionable Art Deco style with a classically proportioned sem-circular pool. It closed in 1992 and in 1998 the pool became a Grade II listed building and has since been fully restored at a cost of $£ 3.4 \mathrm{~m}$.

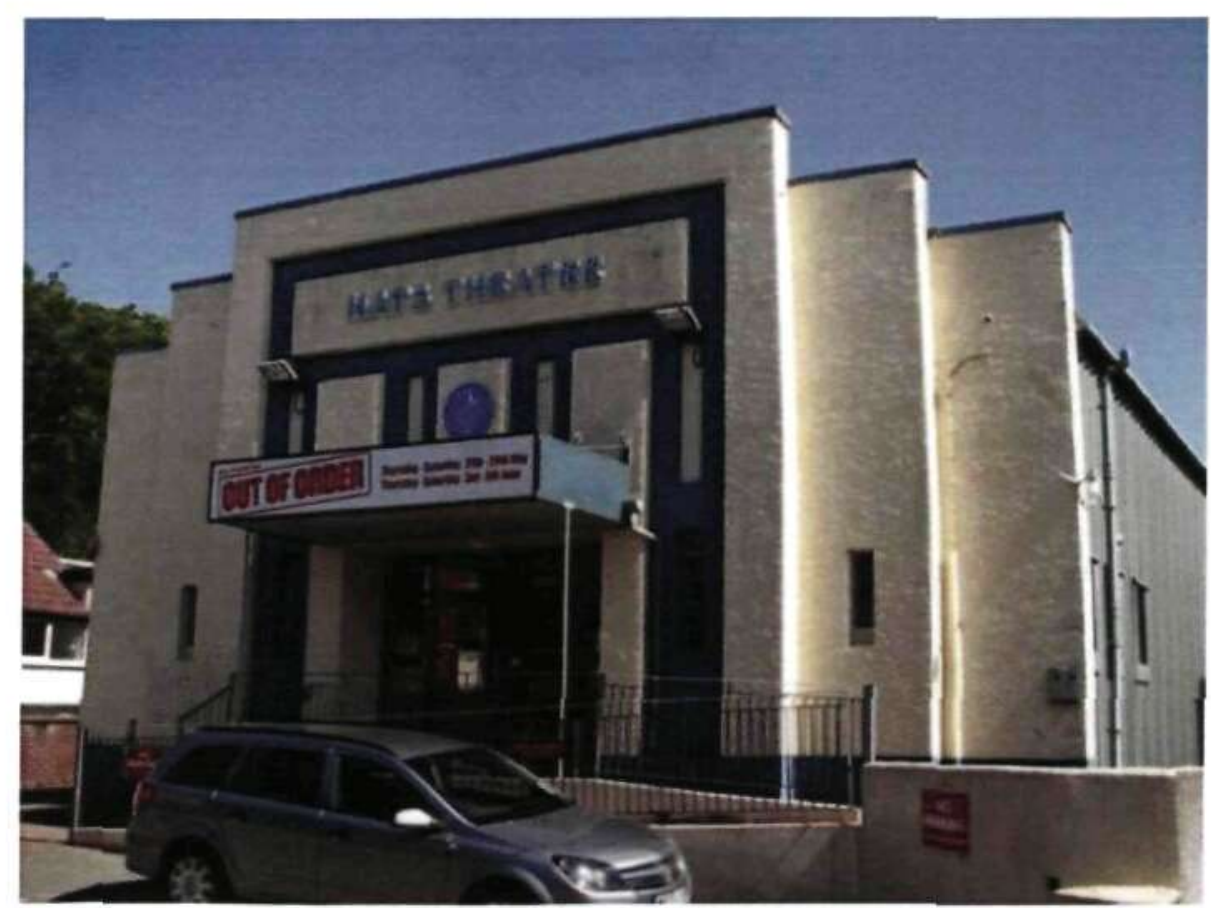

Figure 2.48 Holsworthy: Art Deco façade of former cinema; conserved in 2002 and now home to the town's amateur theatre company. 
On 13 July 2006, ten selected mining landscapes in Cornwall and west Devon were inscribed as a World Heritage Site by UNESCO. The ten areas are the mining districts of St Just-in-Penwith, Tregonning and Trewavas, Wendron, Camborne and Redruth, Gwennap (including the Kennall Vale and Perran Foundry), St Agnes, and Caradon. Also included are the port town of Hayle, the Luxulyan Valley and the port of Charlestown, and (spanning the county border with Devon) the Tamar Valley and the Tavistock district (Fig. 2.49).

Well before the World Heritage designation, some Cornwall mining heritage had already been conserved and, in some cases, extensively commodified as a visitor attraction. Before its closure as a working tin mine in 1990, Geevor at Pendeen, near St Just-in-Penwith, offered tours of the ore-dressing complex. In the past 20 years, the site has become an industrial heritage attraction that, in addition to the ubiquitous café facilities, includes underground tours, a "hard rock' mining museum, a 'miners dry' (changing room and washing facilities), and a mineral-panning shop. Towards Botallack and the ruined, but still stunning Crowns engine houses, perched precariously on the edge of the cliffs, there is a superb restored mine 'count house' (now in the care of the National Trust) where the mine records were once kept, bargains struck, and monthly payments transacted (Fig. 2.50).

A few Cornish steam engines, housed in their distinctive 'houses', and formerly used for raising the ore and/or the miners, as well as pumping water from the deeper levels of the tin and copper mines, have been preserved and are open as visitor attractions. 


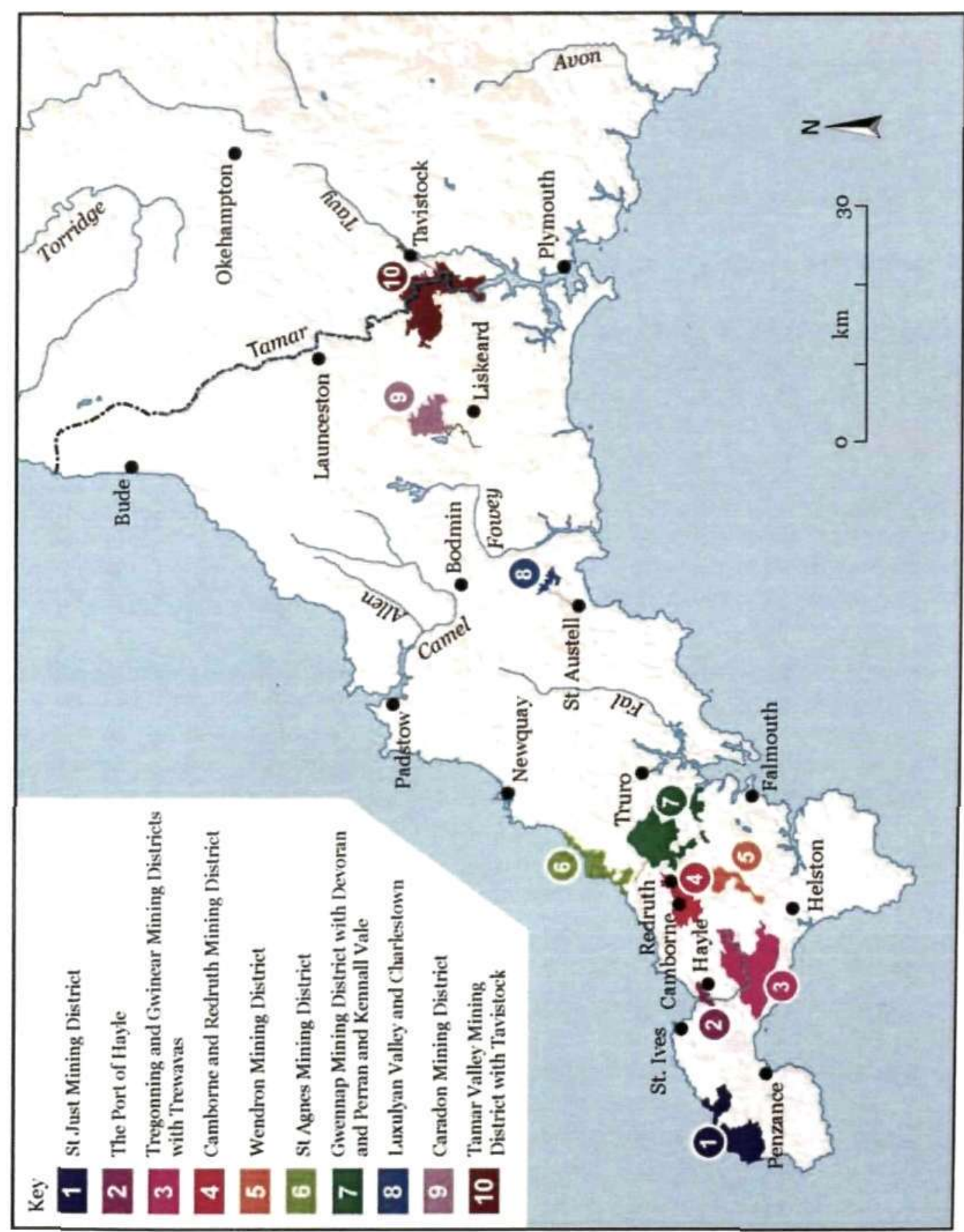

Fig 2.49 The Ten Designated Mining Landscapes of the 2006 Cornwall and West Devon World Heritage Site. 


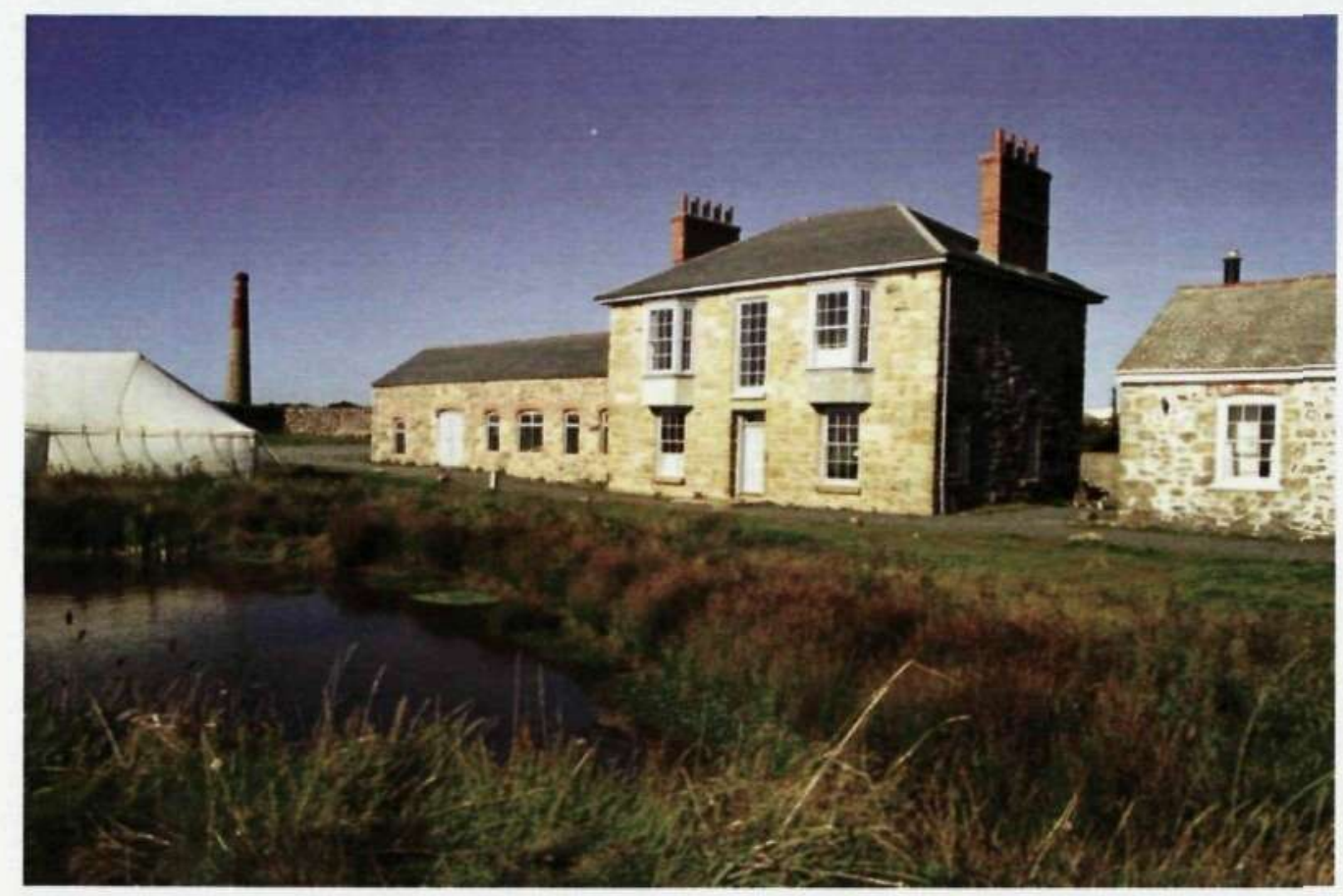

Figure 2.50 Botallack Mine 'count house' (National Trust).

The beam engines at Pool near Camborne (in the care of the National Trust) have been open for over 40 years but, in more recent years, the restoration of the Levant engine houses at the edge of the Penwith cliffs, and the loving refurbishment of one of the steam engines by local enthusiasts known as the 'greasy gang', has added a spectacular and poignant addition to Cornwall's range of industrial heritage attractions (Fig. 2.51). In October 1919, the lifting gear failed and 31 miners were killed in one of the county's most remembered mining disasters. The Levant workings extended well beyond the coast, beneath the sea; they were deep and difficult, and prone to flooding. Although the mine closed in 1930, its levels were drained by neighbouring Geevor in the mid 1960 s to allow the latter access to usually flooded but otherwise workable seams of tin ore. 


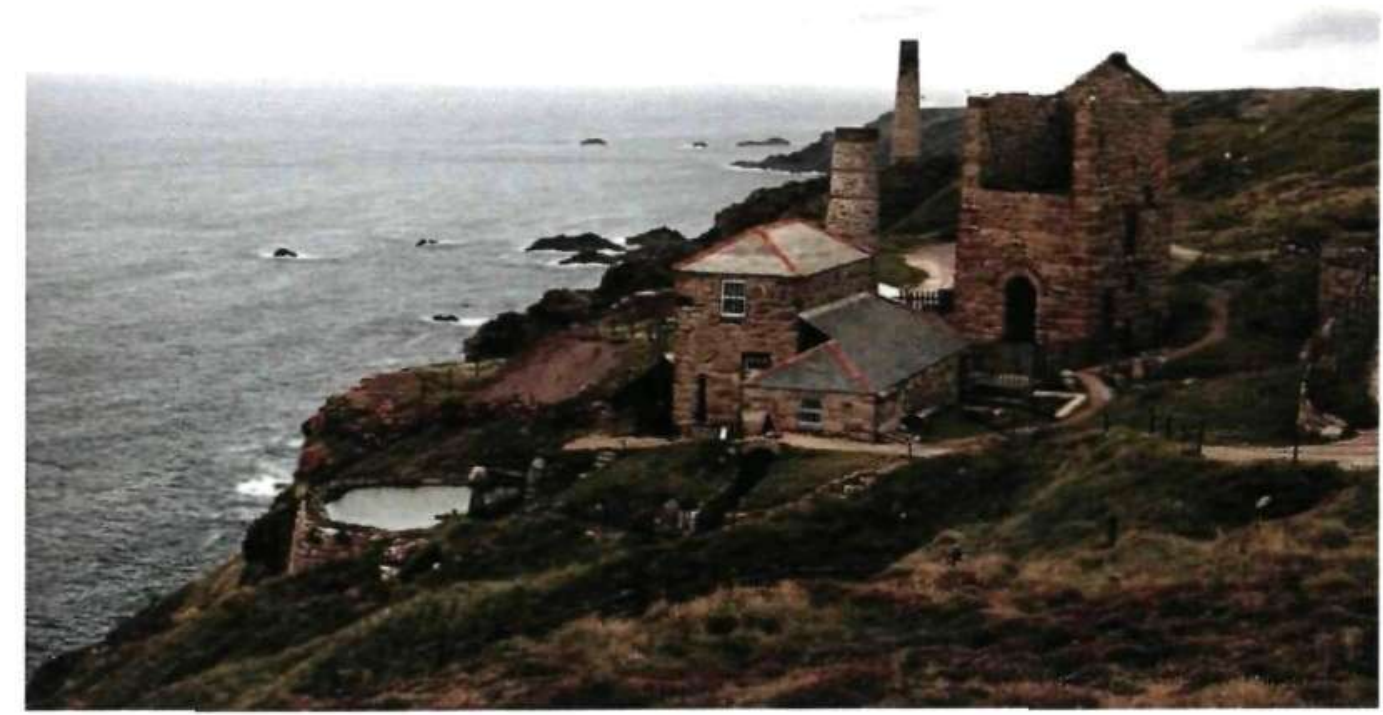

Figure 2.51 The Levant Engine Houses (National Trust), West Penwith

Tolgus Tin, located between Redruth and Portreath, is a tin streaming works, where the tin ore was separated by floating off other materials on specially designed tables. It is an example of extensive commodification for tourists and visitors, whereby activities never practised there have been introduced to appeal to its customers. Thus, panning for gold, 'find a diamond', dousing for water, wood-turning and candle-making are all offered. There is also a children's play area. The site is available for hire as a wedding venue and for private parties. Those seeking an authentic mining-related heritage site might find such additional attractions somewhat intrusive. By contrast, the Poldark Mine, located at Wendron, near Helston, strikes a different balance and its mine tour has been commended as one of the most atmospheric of its kind in Europe. King Edward Mine at Troon, near Camborne, boasts the most complete complex of mine buildings in Cornwall. However, at present, the only use made 
of the exceptional suite of Grade II $^{*}$ listed buildings for heritage tourism is the mining museum on the site.

Mine engineering as a past industrial activity is even less commodified than the tangible remains of the extractive processes; however, the cottage at Penponds that was the home of perhaps the best-known of Cornwall's inventors and engineering geniuses, Richard Trevithick, is (rather infrequently and partially) opened for visits by its National Trust tenants.

China clay mining heritage at The Wheal Martyn Museum and Discovery Centre, at Carthew near St Austell, which has backing from Imerys (the China Clay company) and Restormel Borough Council is another long-established and comprehensively commodified attraction. Grants have been secured from the Heritage Lottery Fund. The Wheal Martyn museum complex of 64 ha. (26 acres) is set within a SSSI and nearly all of the buildings and the machinery are scheduled as an ancient monument. In addition to the historic tools and equipment, there are geological specimens and ceramic items on display. Moreover, Wheal Martyn has a large archive of documents and photographs, as well as some movie film of the industry and the local community.

The Tamar river port of Morwellham (Fig. 2.52), which ceased to operate commercially in 1903, was first rescued from decay in 1969 and subsequently became a tourist attraction where visitors could experience not only the history of a thriving community clustered around the quay where copper and tin ores, lime, arsenic, small amounts of silver, and a range of other commodities were loaded, but also a trip inside the adjacent mine. 


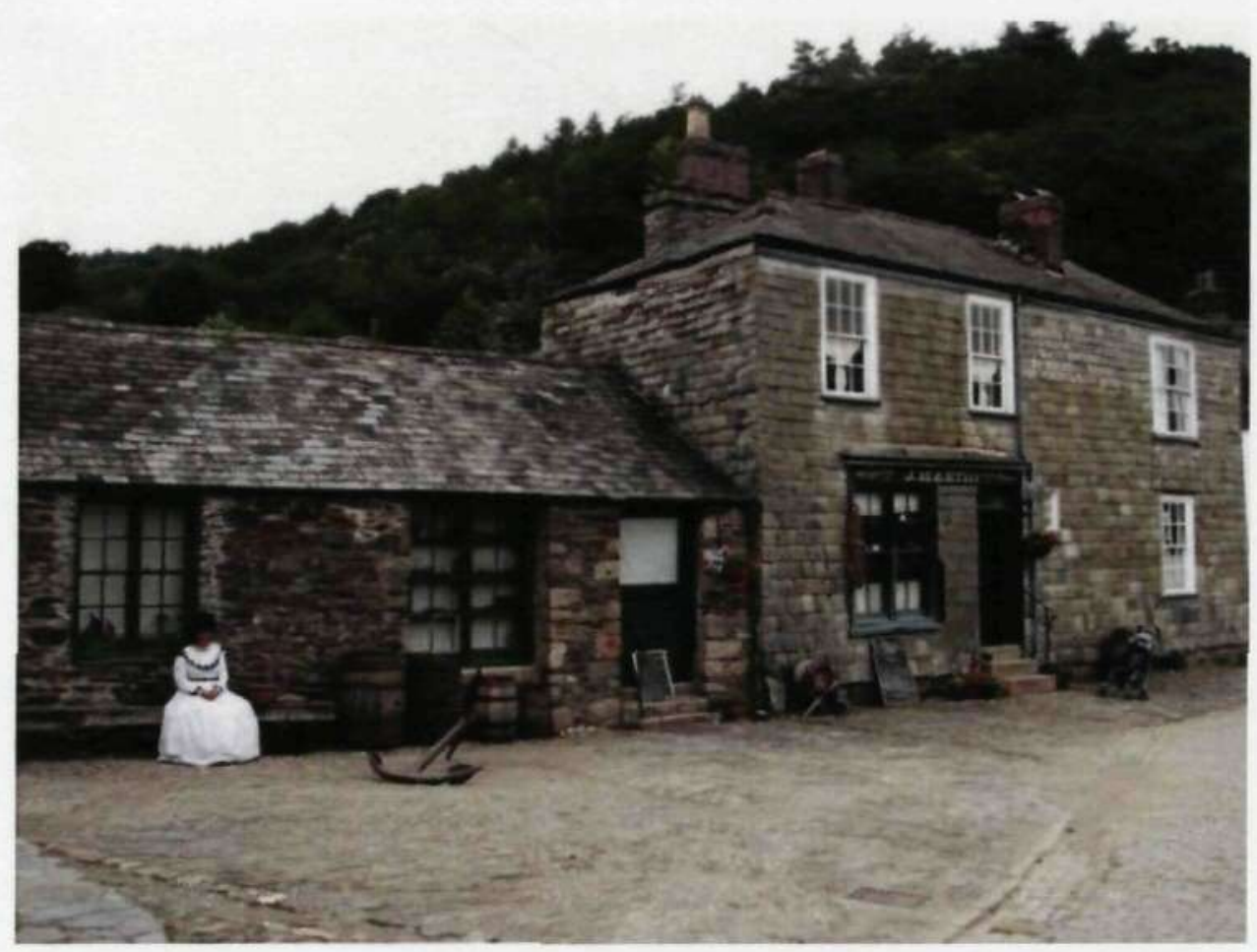

Figure 2.52 Morwellham, Devon. The quayside buildings.

At the peak of its popularity, annual visitor numbers exceeded 170,000 . However, in the autumn of 2009 , with numbers falling below 50,000 per year, and after three years survival on loans from Devon County Council totalling more than $£ 1.2 \mathrm{~m}$, the debt-ridden heritage site was forced into administration. Although it was announced on 15 April 2010 that the site had been purchased by Simon and Valerie Lister, who run the Bicton Park botanical gardens in Colaton Raleigh, the bankruptcy of Morwellham in 2009 certainly raises sharp and important questions about the financial security and profitability of even the largest and most high-profile heritage attractions in Devon and Cornwall.

Against the sobering story of Morwellham's demise and its abandonment by Devon County Council, it should be noted that the designation of the Cornwall and West Devon World Heritage Site has begun to catalyse the flow of awards 
from other sources. For example, £2 million of European Union and DEFRA funding, channelled through the Rural Development Programme for England (RDPE), is supporting the 'Discover the Extraordinary' project. This venture aims to 'enhance the visitor experience in the World Heritage Site and at partner attractions'. ${ }^{14}$ It is seeking to boost the number of tourists from outside Devon and Cornwall who are attracted to the Heritage Site areas. Plans for enhanced interpretation of the World Heritage landscapes and attractions, comprising new displays, trails and audio tours (for use with mobile phones) are being designed. A new interactive Cornish Mining website portal is to be produced, which will contain information about the World Heritage Site and will interface with online 'regional destination management systems' that allow people to plan their holidays and book accommodation. The project includes a scheme to install a number of touch-screen kiosks where visitors will be able to obtain information about all the Devon and Cornwall World Heritage Sites. The budget will provide for enhanced marketing of the attractions both in the region and elsewhere in the UK. A campaign to target international visitors is also envisaged. The proposals and plans have been formulated in partnership with organisations including Visit Devon, Visit Cornwall and the Cornish Mining Attractions Marketing Association (CMAMA). The CMAMA was set up in 2006 in order to ensure that the potential of the World Heritage Site is maximised for the benefit of the wider community and economy.

Although, in general, there are fewer tangible legacies of the Southwest's woollen industry, and its heritage is only weakly commodified, some notable buildings survive. For example, in Exeter, Tuckers' Hall, which was the chapel

\footnotetext{
${ }^{14}$ Cornish Mining World Heritage; World Heritage Site News, http://www.cornishmining.org.uk/news/news.htm (accessed 17 May 2010)
} 
of the guild of fullers, still stands in Fore Street (Youings 1968) (Fig. 2.53). Woollen manufacturing heritage is extensively displayed at the Coldharbour Mills site in Uffculme. As Brayshay $(2006,139)$ notes, the mill is 'still partly powered by water and steam. Originally built in $1799 \ldots$ to spin woollen, and later, worsted yarn, it survives as a heritage tourism attraction and an important example of Georgian architecture, industry and enterprise'.

The Finch Foundry at Sticklepath near Okehampton was also originally a (water-powered) woollen mill but was converted for the production of metal tools in 1814. Now in the care of the National Trust, the foundry preserves the heritage of edge tools (mainly for agricultural use) which was once widespread across Devon and Cornwall. The establishment houses two very unusual 'trip' hammers and 'shears' - all worked by a single waterwheel.

While a host of other industries (for example, paper making, leather tanning, glove making, lace manufacture, carpet manufacture, and lime burning) once flourished in Devon and Cornwall, tangible evidence of their stories is accessible only to those with plentiful prior knowledge and the ability to recognise decaying, and usually unmarked, remains. Sometimes the heritage is, of course, physically hazardous. Thus, the processing of arsenic in calciners in Blanchdown Woods near Tavistock, using the material mined at Devon Great Consols, has bequeathed not only the ruins of the buildings, but also areas of highly toxic ground (Fig. 2.54). The manufacture of gunpowder was also once fairly common; indeed at the isolated site of Powder Mills on Dartmoor, one of the mortars, formerly used for testing the quality of the explosives, may be viewed, but such survivals are rarities (Fig. 2.55). 


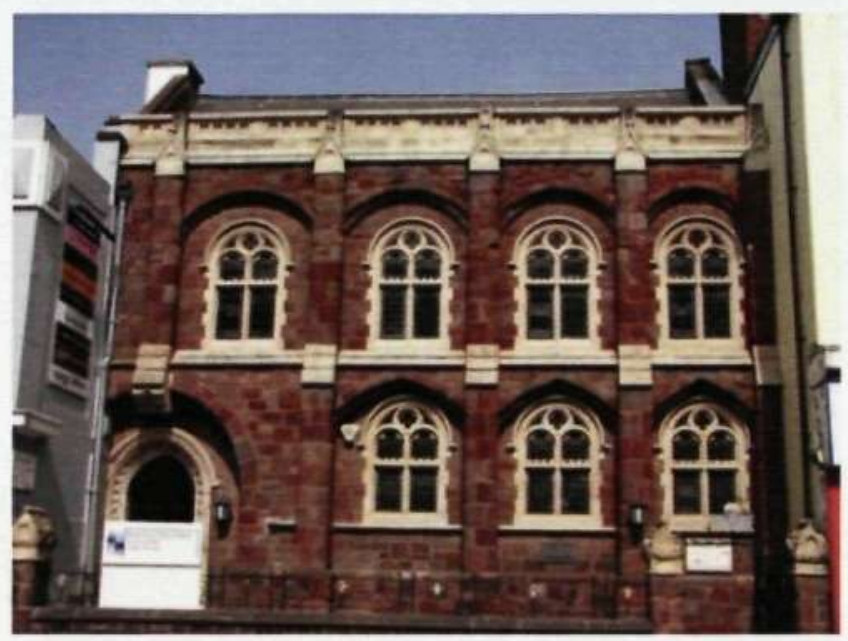

Figure 2.53 Tuckers Hall, Fore Street, Exeter: the restored façade of part of the building of the city's medieval Tuckers, Shearers and Fullers Guild.

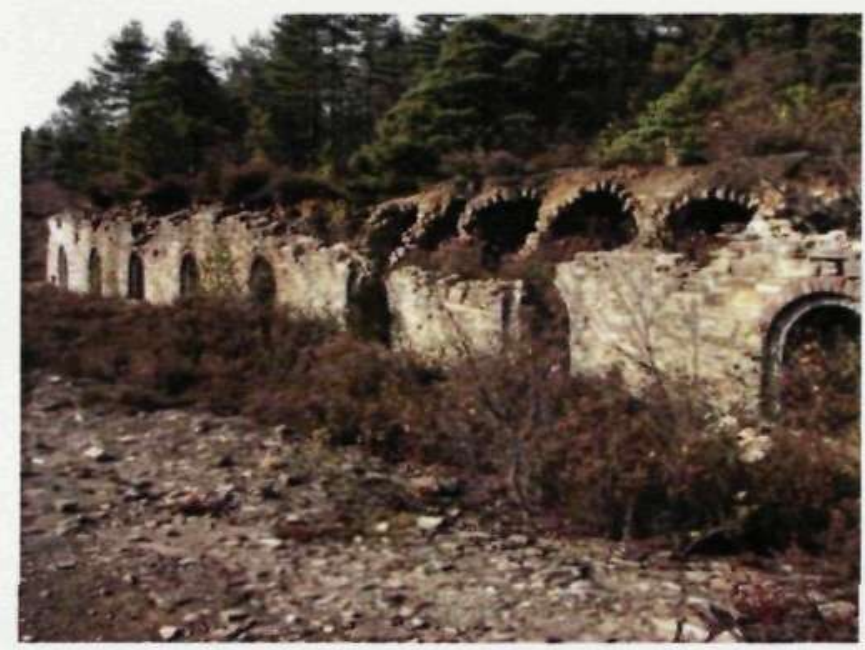

Figure 2.54 Remains of an Arsenic Calciner, Blanchdown Woods, Tavistock. This is an area of toxic ground and other hazards.

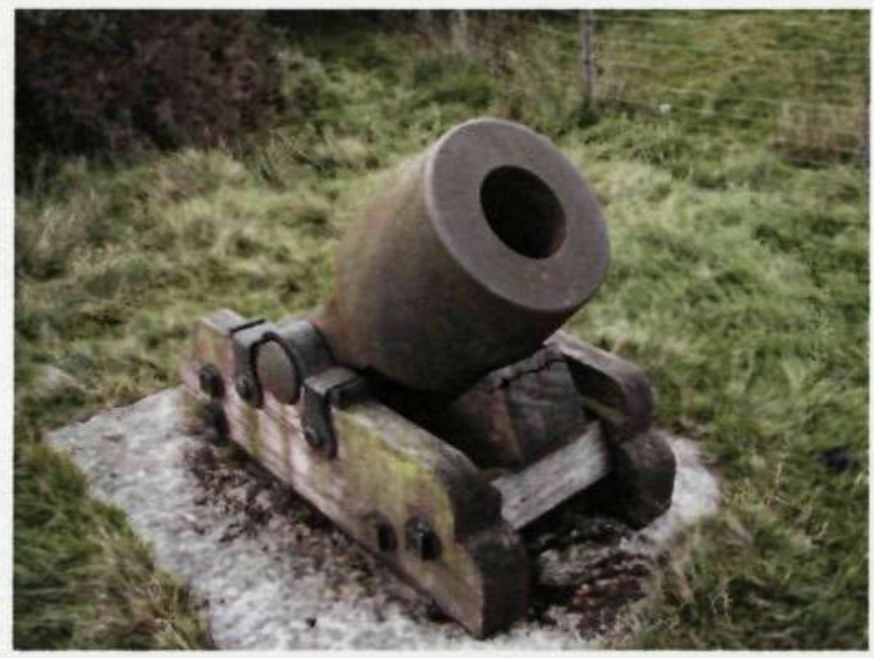

Figure 2.55 The Gunpowder Testing Mortar at Powder Mills, Dartmoor. 


\subsubsection{Transport Heritage}

Although Devon and Cornwall possess abundant examples of transport heritage, a good deal of it cannot easily be made into commodified attractions. Most of it is on view for no payment and, where funding is required for its conservation, revenues must come indirectly from other sources. For example, the distinctive and much-loved 30 Dartmoor clapper bridges are a tourist attraction, but their maintenance is supported from general National Park monies (Fig. 2.56). Some 80 toll houses of the 400 or so built in Devon in the turnpike era survive (Fig. 2.57) but, again, such heritage cannot easily be commodified. The heritage credentials of Devon and Cornwall's railway structures are widely acknowledged. In some cases, Heritage Lottery Fund support has been won in order to conserve and make accessible the exceptional railway viaducts that once carried lines that fell victim to the Beeching cuts of the 1960s. An excellent example is the Derriton viaduct, built in 1898 in pre-cast concrete blocks to carry the Okehampton to Holsworthy branchline onwards to Bude (Fig. 2.58). The track-bed now serves as a path and cycle track. Holsworthy's older stone viaduct, on the south-east side of the town, finished in 1879 has yet to receive similar support and (in 2010) remains inaccessible to visitors (Fig. 2.59).

The extraordinary experiment in 'atmospheric' railway locomotion conducted by Isambard Kingdom Brunel in the 1840s is memorialised in the survival of a few structures erected to house the engines that created the vacuums in pipes laid on the track bed. The buildings at Starcross and Totnes (Fig. 2.60) are easily visible from the trains that travel the route between Exeter and Plymouth but interpretation is scarce and the legacy is virtually ignored. 


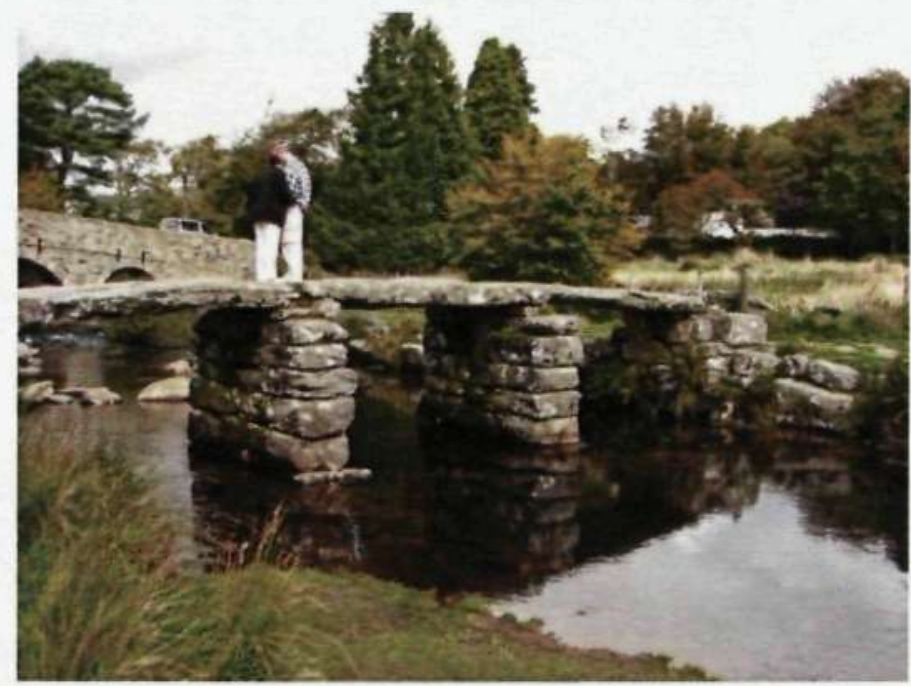

Figure 2.56 Postbridge, Dartmoor Clapper Bridge.

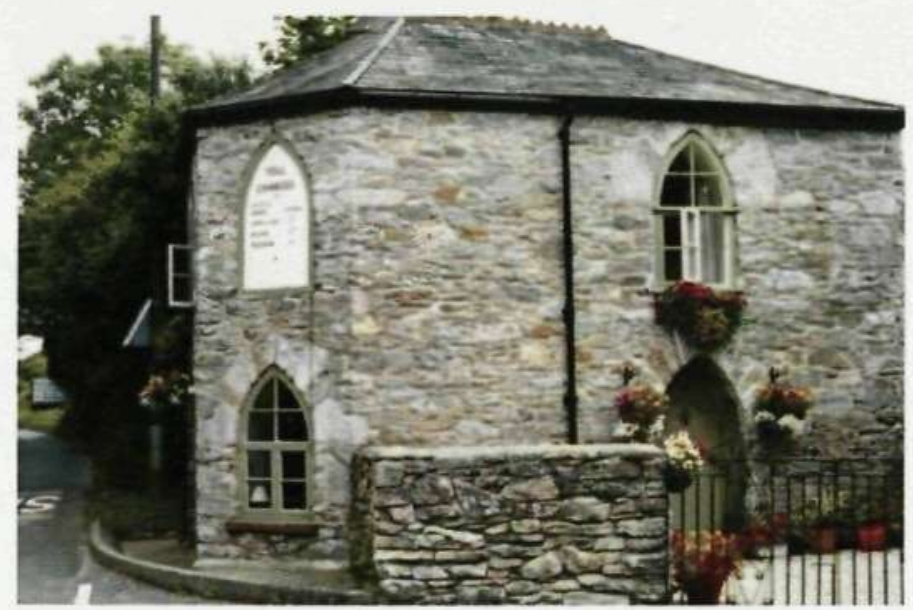

Figure 2.57 Former Turnpike Tollhouse (on A379), now used as private house, but displaying board showing charges or tolls for users of the thoroughfare in the turnpike era.

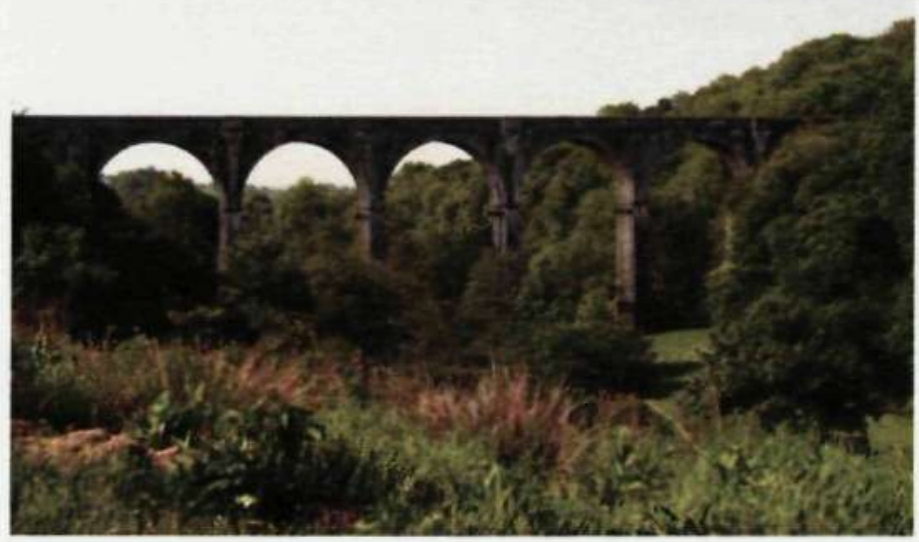

Figure 2.58 Derriton Viaduct, Holsworthy, completed in 1898 and restored as a footpath and cycle track with Heritage Lottery Fund support in 2007. 


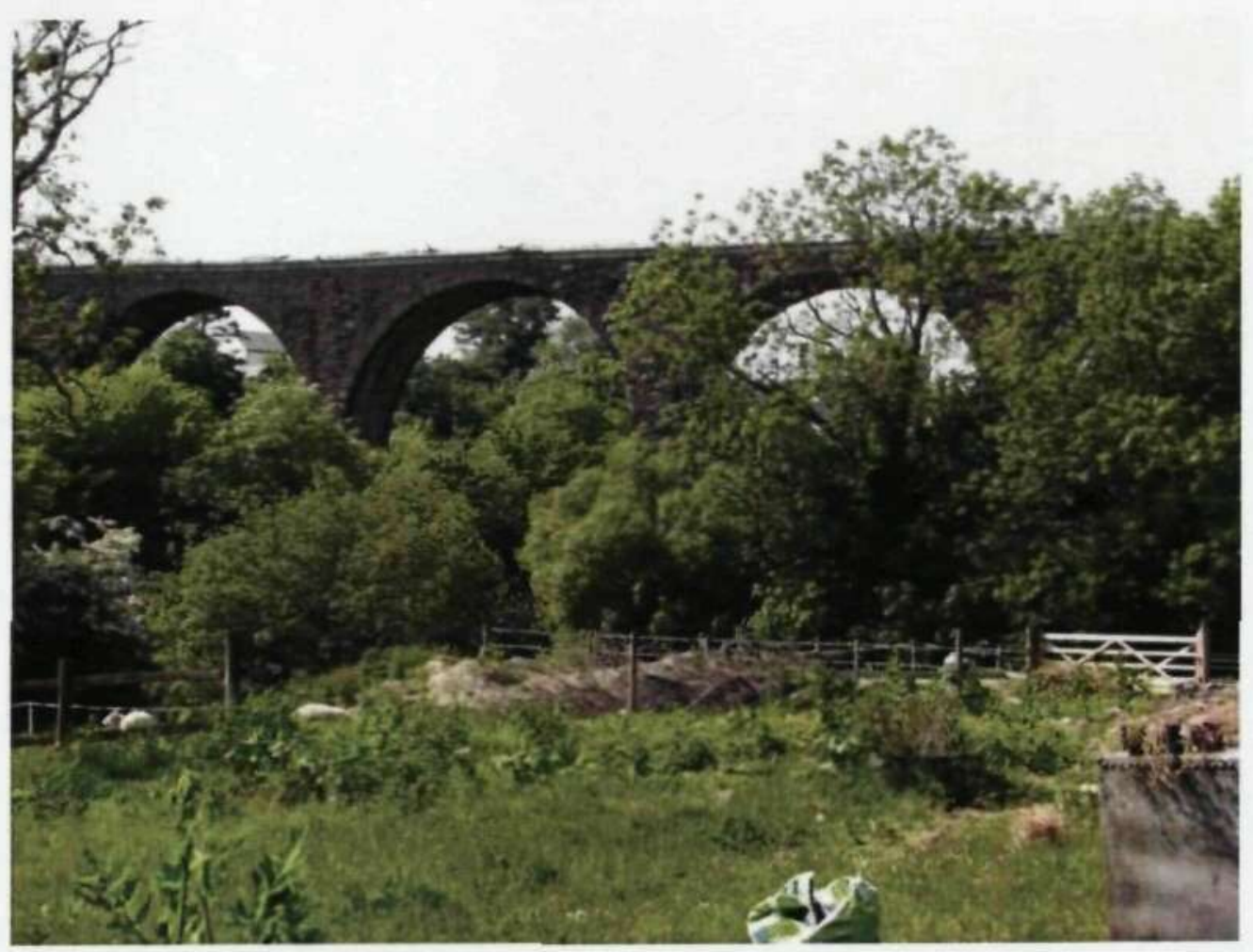

Figure 2.59 Holsworthy's older railway viaduct, completed in 1879.

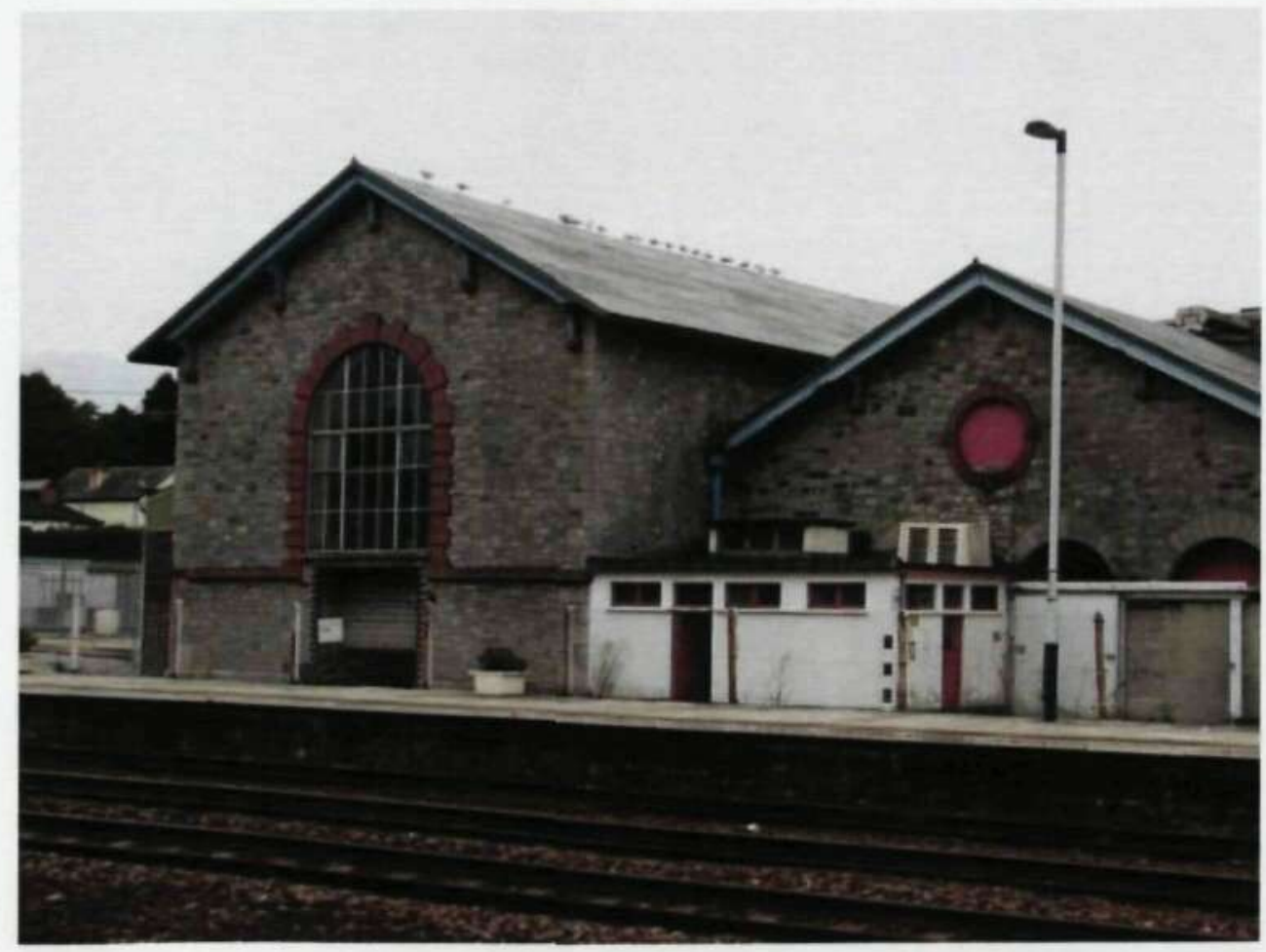

Figure 2.60 Totnes, Devon, one of the surviving Engine Houses of Brunel's Atmospheric Railway. 
Brunel's spectacular railway bridge across the Tamar at Plymouth is one of the most important civil engineering achievements of the nineteenth century. It is, of course, still in use, but it is heritage nonetheless. The same might also be said for the Tamar road bridge, which, though just short of 50 years old, ranks as a piece of transport heritage.

Numerous small ports, many with harbours dating to the medieval period, abound in Devon and Cornwall. Some are beginning to capitalise on their undoubted heritage appeal. Ilfracombe, in north Devon, is an excellent example (Figs 2.61-2.62). In a resort that possesses exceptional Victorian architecture (Laithwaite 1992), investment in conservation and the enhancement of environmental quality has added greatly to the appeal of the 'heritage harbour' and the cafés, restaurants, public houses, shops and other businesses in the vicinity benefit from increased trade as visitor numbers increase.

However, one of the most successful examples of commodified transport heritage in Devon and Cornwall is the seven-mile stretch of the South Devon Railway between Buckfastleigh and Totnes, which runs along the banks of the River Dart via Staverton Halt. The route occupies most of the original Totnes to Ashburton line, which was opened in 1872 but closed as part of the Beeching cuts on 7 September 1962; by then, passenger numbers had fallen well below 8,000 per annum. As a result of the endeavours of a small group of steamrailway preservation enthusiasts, the line was acquired and re-opened as a heritage railway on 5 April 1969. 


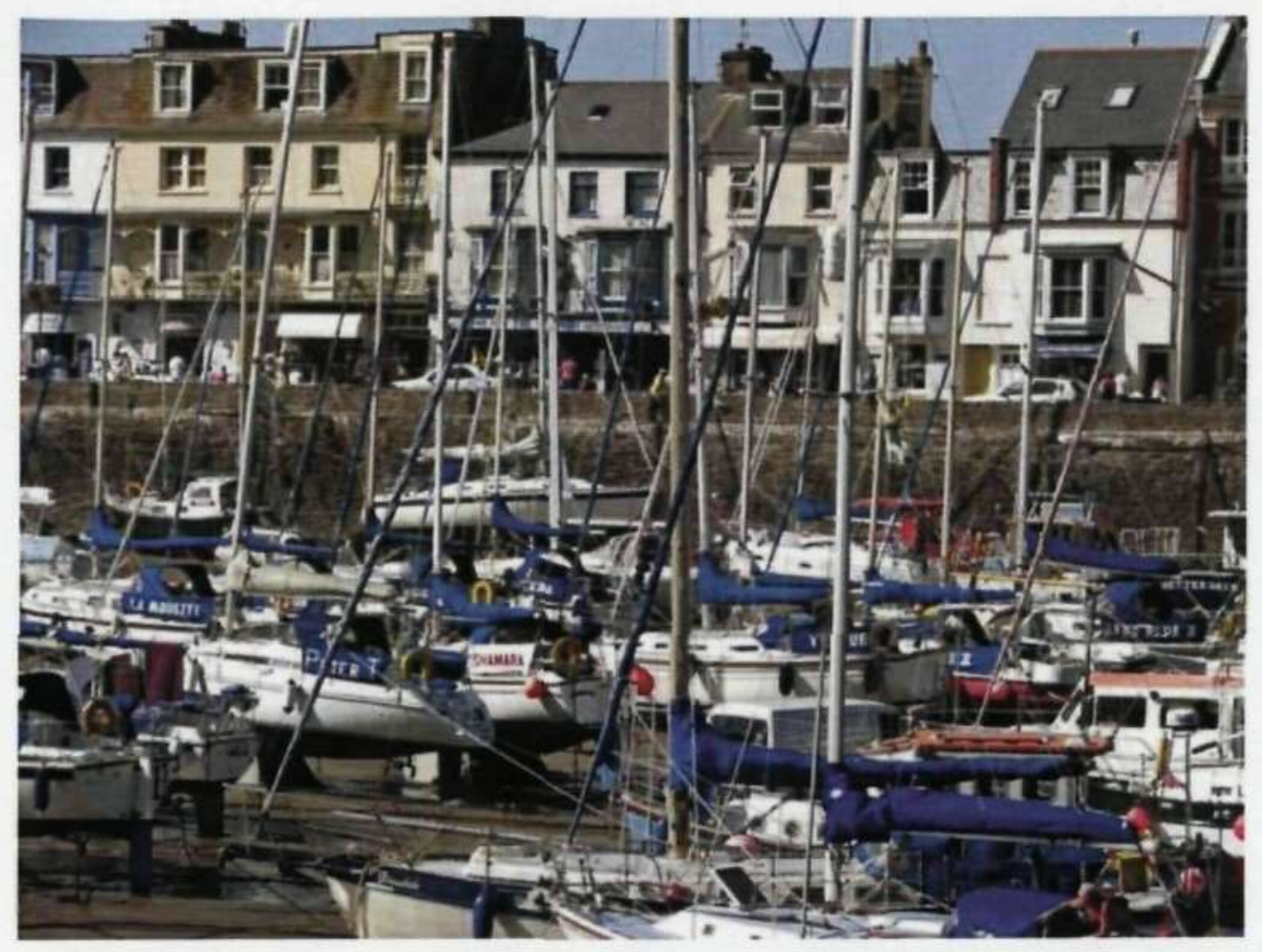

Figure 2.61 The Historic Harbour of Ilfracombe.

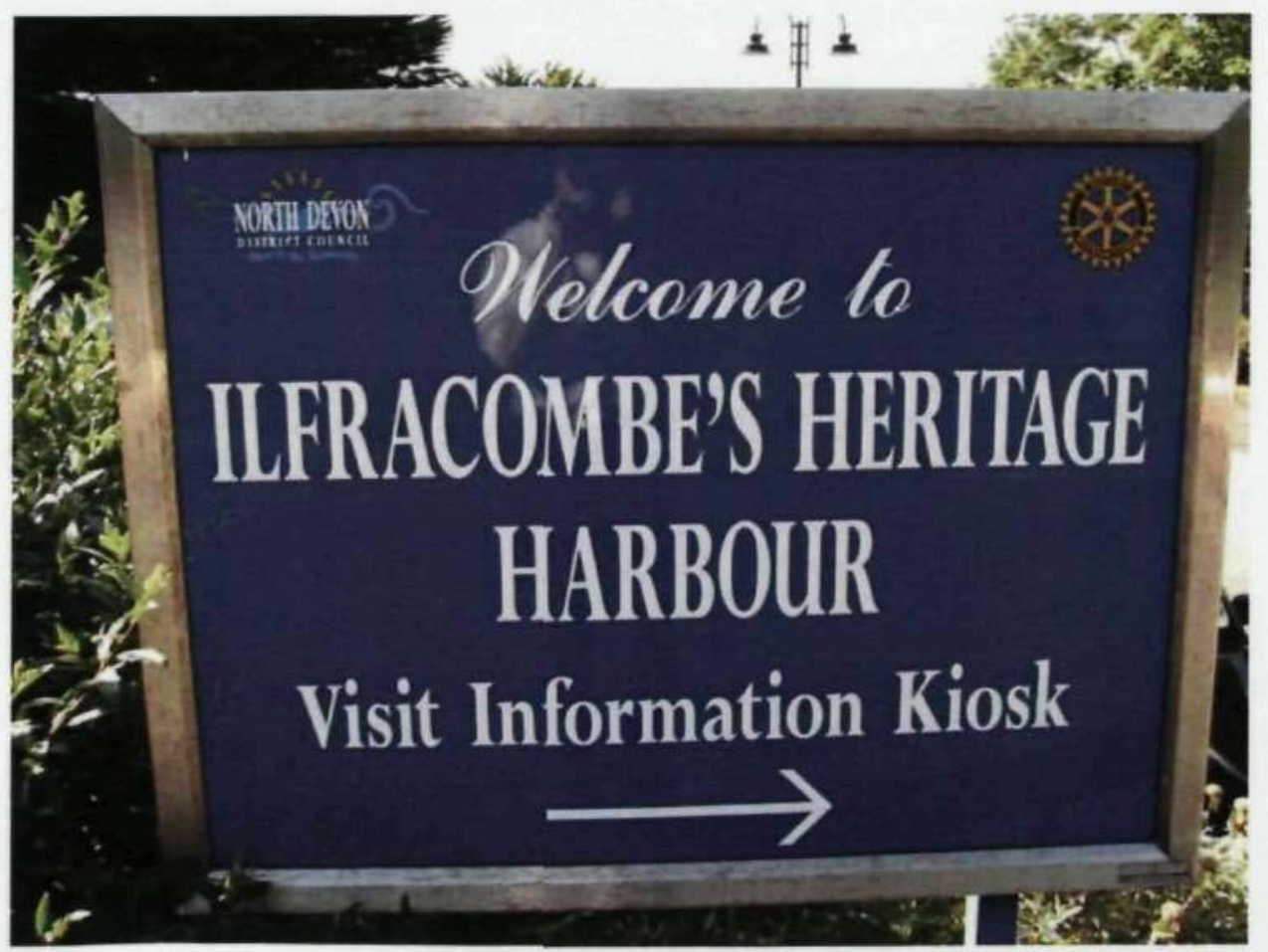

Figure 2.62 llfracombe's Heritage Harbour. 
Its story provides a lesson in the successful operation of a heritage attraction. Originally known as the Dart Valley Railway, since 1991, it has been managed as the South Devon Railway Charitable Trust and, during 2008-2009, the turnover was $£ 1.75 \mathrm{~m}$. Ticket sales yielded $£ 680,000$; other enterprises earned the remainder. ${ }^{15}$ Profitability is secured in part because of very low wage costs. The South Devon employs only 12 full-time staff (in administration, the giftshop, the café, the museum, and the engineering workshop). There are no paid staff at all working on the trains. Some 450 volunteers (including 20 retired railway engineers) form the backbone of the workforce. Indeed, the ratio of volunteers to paid staff in the South Devon Railway $(38: 1)$ is almost four times greater than the average ratio in UK heritage railways as a whole (which rely on 16,291 volunteers and employ 1,694 paid staff; a ratio of around 10:1).

Considerable income is accrued from contracts awarded to the South Devon's engineering workshop. For example, in the six months between May and October 2009, income of over $£ 290,000$ was earned from other heritage railways and Network Rail, mainly for replacing the metal tyres on locomotive and rolling-stock wheels. Work on the copper components needed for the restoration of the Flying Scotsman locomotive was also carried out in the Buckfastleigh workshop and the expertise of the South Devon's engineers is very widely respected and sought-after. The South Devon currently owns 14 locomotives; and, at any one time, four working engines are in use (Fig. 2.63).

\footnotetext{
${ }^{15}$ Note: All of the details about the South Devon Railway were obtained from $\mathrm{Mr}$ Richard Elliott, retired General Manager, who first joined the South Devon Railway in 1965 as a volunteer and worked with others to secure its reopening four years later. $\mathrm{He}$ retired in 2009.
} 


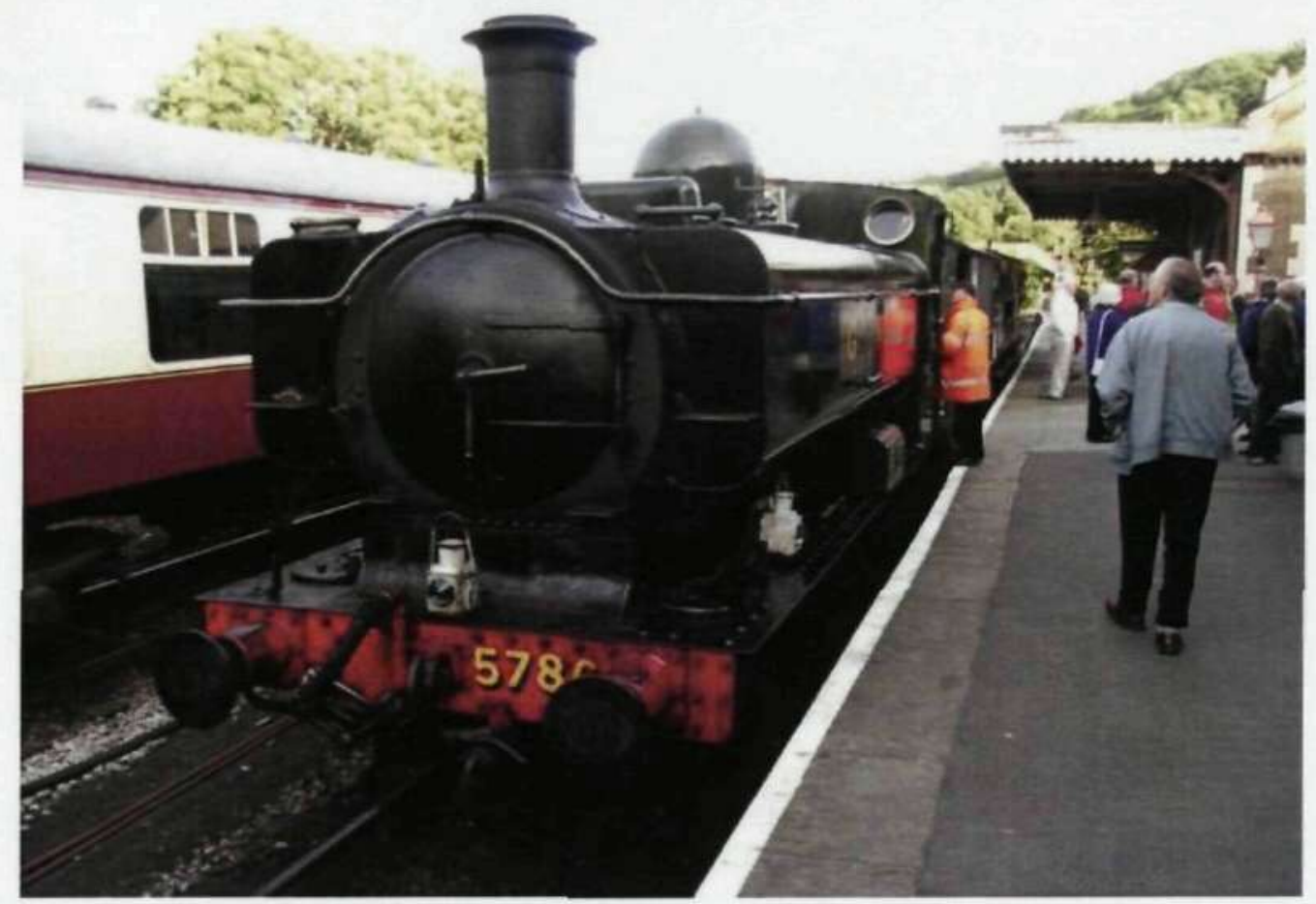

Figure 2.63 Steam Locomotive belonging to the South Devon Railway

In addition to its regular timetable, the South Devon Railway runs 'dining trains' on Friday evenings in the summer season, using its restored Great Western Railway special saloon carriages, which can seat 50 people. The same rolling stock is available for charter for special occasions such as birthday parties and wedding receptions. All the catering is provided by the South Devon at an average cost of $£ 42.50$ per head. Steam locomotive devotees can enrol on 'footplate experience' courses (giving training in driving both steam and diesel locomotives), which are offered twice a month. The cost is $£ 310$ per student, but the four places on offer per course are readily snapped up, thereby yielding additional income of $£ 2,480$ in each month that they operate.

The South Devon's entrepreneurship extends still further. Some of the land they have at Buckfastleigh is occupied by two other tourist attractions: a butterfly 
farm and an otter sanctuary, both paying rent to the Railway Trust. In summer, a free bus link is provided to bring visitors to and from nearby Buckfast Abbey. The South Devon Railway funds 95 per cent of the cost (the Abbey pays the remaining 5 per cent), but the bonus is that considerably more visitors are tempted to combine a trip to the Abbey with a return ride on the heritage railway. Adjacent to the South Devon's station in Totnes, there is a rare breeds farm, and the two attractions have united to offer a combined ticket, which enables visitors to travel to and from the farm by train. An entire 'day out' is thereby feasible: comprising the gift shop, café, museum and railway workshops at Buckfastleigh, the train ride to and from Totnes, and a visit to the farm, which site also offers a café (Fig. 2.64).

When the South Devon Railway Charitable Trust was formed, annual passenger numbers were already 57,000. In 2008, despite the severe difficulties engendered for tourism enterprises generally by the global economic recession, some 99,500 passengers were carried. In 2007, numbers were well over 100,000 . The South Devon values its links with coach-holiday operators, such as Shearings, who bring an average of five groups per week for an inclusive trip on the train during the operating season. Marketing comprises brochures, leaflets and an attractive web site. In October 2009, a new General Manager had been appointed whose past experience had been in marketing. However, outside agencies had hitherto been engaged to assist with the design of the printed materials and the web site, but the contents of these publications are produced by employees and volunteers, thereby minimising cost. 


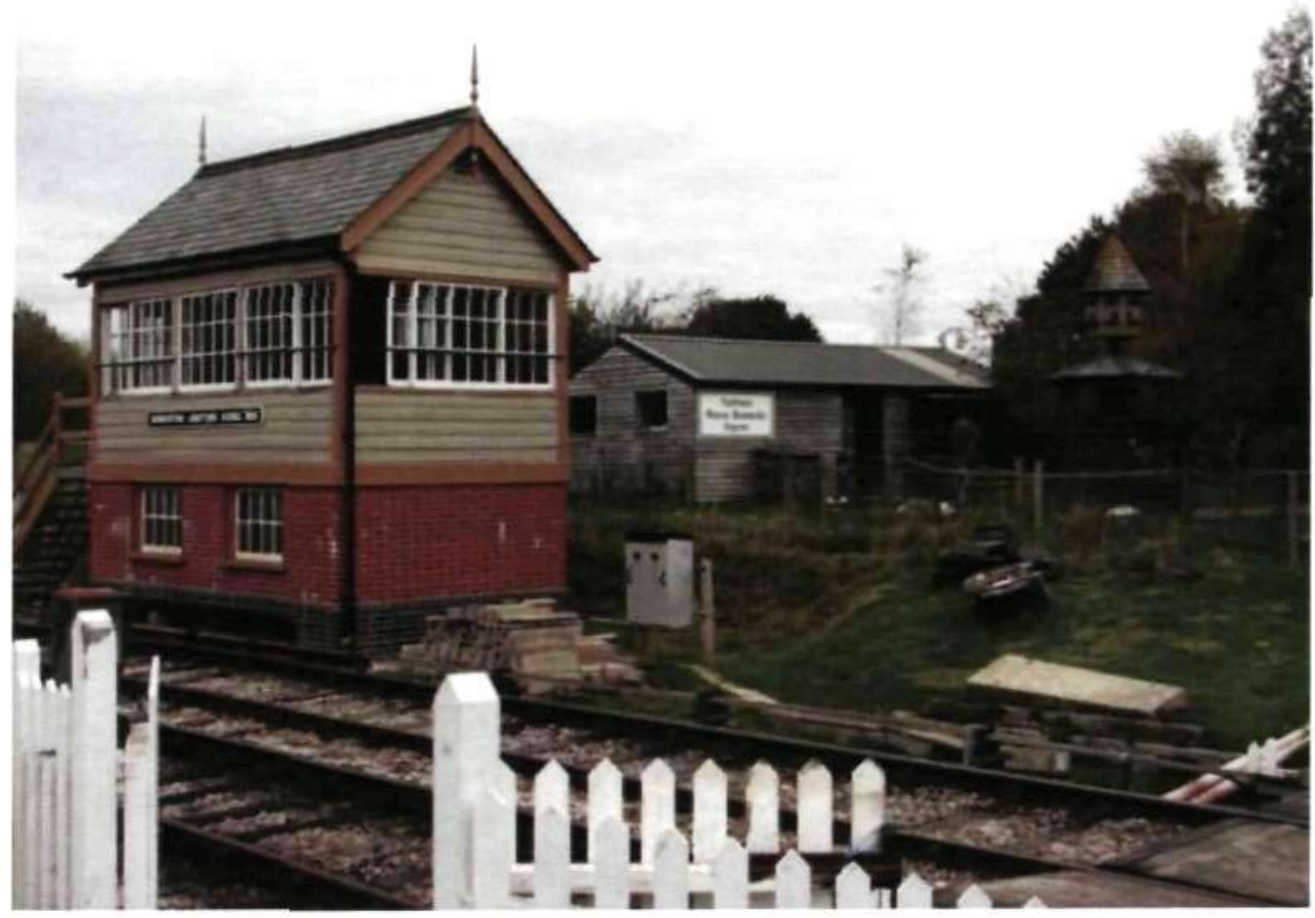

Figure 2.64 Totnes terminus of the South Devon Railway and the Rare Breeds Farm.

\subsubsection{Cultural Heritage}

The Southwest in general, and particularly Cornwall, has a strong cultural heritage. Cornwall's separate language and Devon's distinctive dialect to a greater or lesser extent set the region apart from the rest of England. A rich heritage of folklore is a further asset in the two counties. Associations with artists, for example the so-called Newlyn School, and the local roots of some nationally recognised painters such as Joshua Reynolds, add further depth to the cultural history of the Southwest. Examples of 'literary places' of the kind described in other parts of the country by authors such as Herbert (2001) can be identified in Devon and Cornwall. In some cases, a location featured in a 
story might attract attention. Daphne Du Maurier's Jamaica Inn on Bodmin Moor is perhaps the best known of these. Otherwise, the home of an author, or a place with which a writer had a connection can attract the attention of heritage visitors. The summer home of Agatha Christie at Greenway on the River Dart, acquired by the National Trust in 2000 , strongly capitalises on its association with the author in promotional literature and it has been furnished as a 1950s dwelling in order to evoke the era when she wrote her novels there. St Juliet's Church in Cornwall draws visitors because Thomas Hardy, when practising as an architect, worked there in 1870 on plans for its restoration and met the daughter of the vicar, Emma Gifford; and she later became his first wife.

\subsubsection{Museums and Visitor Centres}

The Royal Albert Memorial Museum in Exeter (RAMM) was opened in 1868 following a public subscription to mark the life of the Prince Consort which was launched seven years earlier. The building that resulted is one of the most striking and exuberant of Exeter's Victorian gothic-revival structures (see previous Fig. 2.39).

Plymouth City Museum and Art Gallery was completed in 1908 in imposing Edwardian Baroque-revival style (Fig. 2.65). It is particularly noted for its large natural history collection and Dartmoor archaeological artefacts. There is also a small collection of early William Cookworthy porcelain. The art collection contains works from the Newlyn School and, within the Cottonian Collection, there are very large numbers of important works of art. 


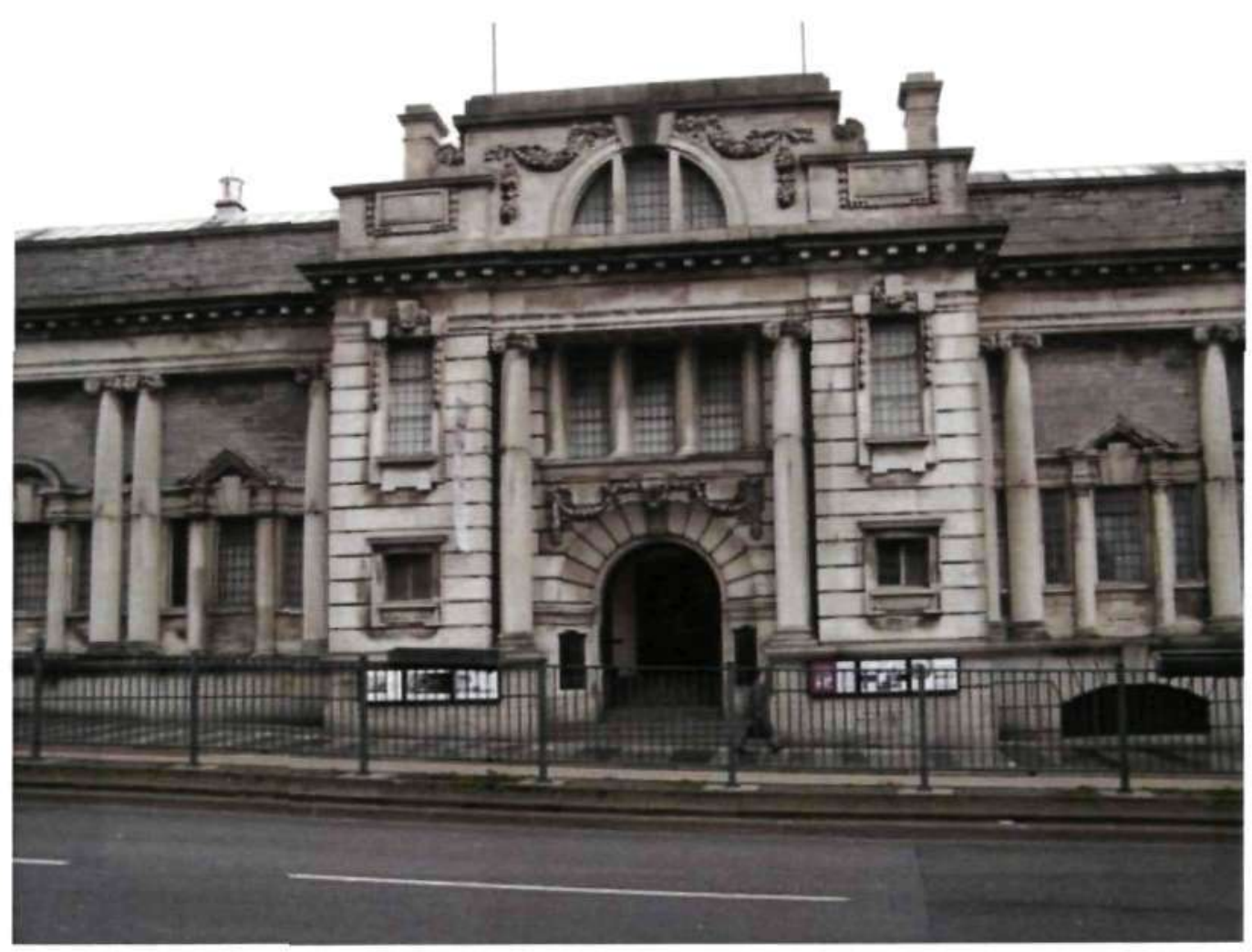

Figure 2.65 Plymouth Museum, Plymouth: A museum with layered heritage significance. The Plymouth museum holds extensive and diverse displays of heritage giving it significant heritage significance. Additionally, the building has significant heritage value in its own right.

The Tudor town houses, open to the public as the Elizabethan House in New Street, and the Merchant's House in St Andrew's Street are under the purview of the city's Museum.

The National Maritime Museum in Falmouth, opened in 2002, heads a list of scores of other heritage museums and archives in Devon and Cornwall (Fig. 2.66). It is both a major tourist attraction and an important educational facility. The collection is, of course, its main appeal, but the Falmouth Museum includes the Bartlett Library which holds a large book collection and a significant body of archival material such as the Falmouth Harbourmasters' journals and all the records of the Falmouth and District Pilot Boat Association. 


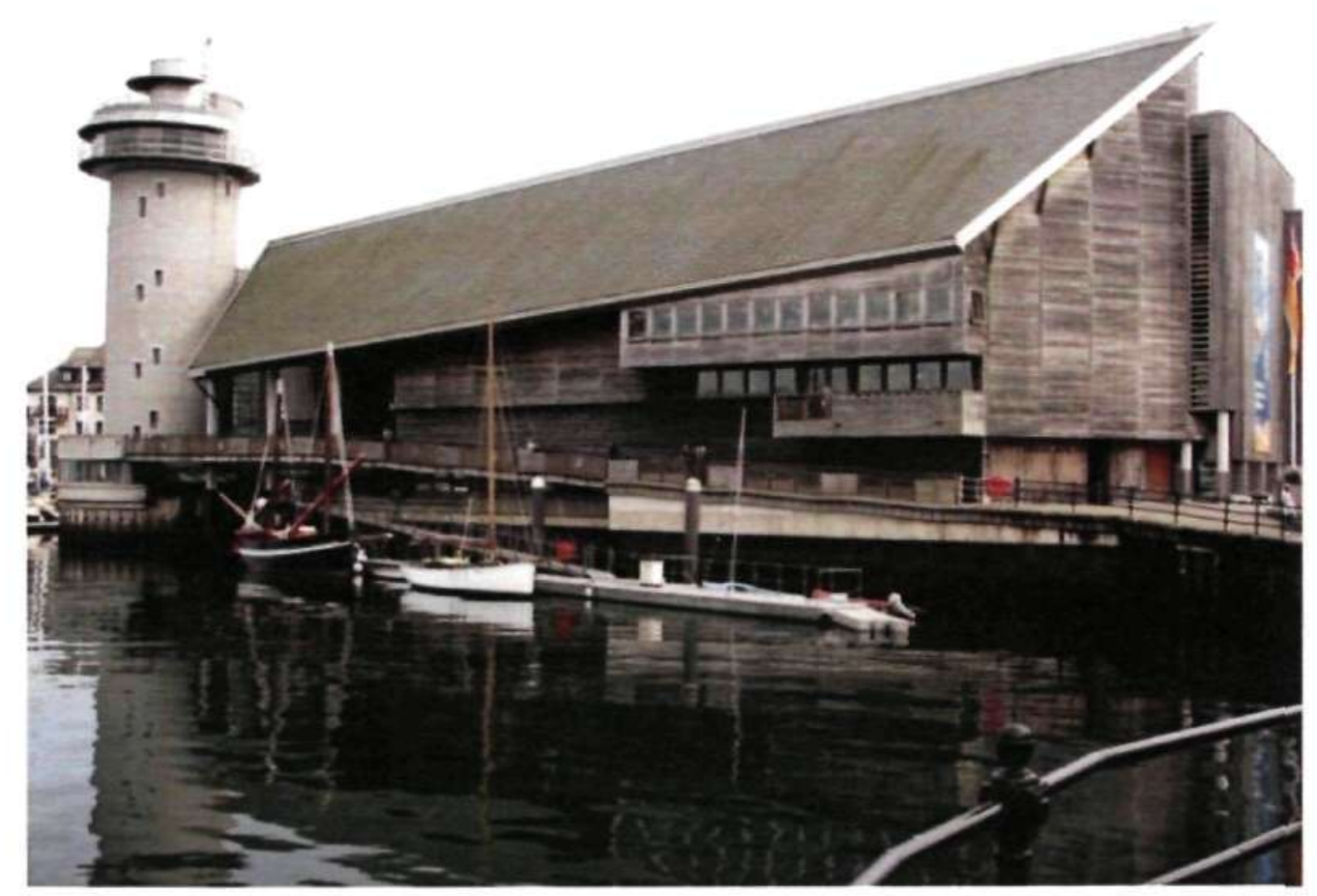

Figure 2.66 The National Maritime Museum, Falmouth

Its holdings of Fox's Shipping arrivals in the port, unbroken for the period since 1880 , are clearly of great heritage significance.

Plymouth's National Marine Aquarium, opened in 1998, is difficult to categorise and may, in any case, not be regarded by purists as a heritage resource. Nevertheless, its existence in the heart of the historic old port of Plymouth, and its strong focus on marine education and research, further underlines the prominence in the far Southwest of maritime heritage and maritime museums.

Small maritime museums are also present across Devon and Cornwall, the majority of these are either dedicated to the local history of either shipping or fishing. Examples of shipping museums include the Charlestown Shipwreck and Heritage Centre and the Fowey Museum in Cornwall and the Salcombe 137 
Maritime and Local History Museum in Devon. While examples of fishing museums are also found in both Cornwall (Polperro Museum of Smuggling and Fishing and the Mevagissey Museum) and Devon (Brixham Museum).

A host of small, specialist museums exist in Devon and Cornwall. Many not only possess internationally important collections, but are also housed in historically valuable buildings. Although it is managed as a subsidiary of the Royal Albert Memorial Museum, an example of a specialist museum is Rougemont House in Exeter, which is located in a fine eighteenth-century building and holds one of Britain and Europe's most extensive collections of lace (including Honiton lace) and Victorian costumes.

There are numerous visitor centres in the Southwest; and some are accommodated in fine heritage buildings. Foremost amongst these is the High Moorlands Visitor Centre at Princetown on Dartmoor. This large centre lies in the converted, historically significant old 'Duchy Hotel'. Although the displays attempt to tell Dartmoor's story, as Howard $(2003,264)$ points out, some are static and others make use of old technology in a time when 'people's expectations are such that they expect a video presentation' to be a 'Hollywood standard production' (Howard 2003, 266).

\subsection{Studies of Heritage Management Issues in Devon and Cornwall}

Although studies that simply describe the important heritage of Devon and Cornwall are clearly abundant, rather less attention has been paid to the two counties by authors seeking to analyse heritage, and to explore heritage 
tourism issues. However, there are, of course, some notable contributions that focus on heritage sites in this region. The work of Hale $(2001 ; 2005)$, which analyses responses in Cornwall to the English Heritage 'imposed narrative' of Cornwall's history was discussed in Chapter 1 . Her study ranks as an important contribution to work on dissonant and contested heritage.

The issue of 'disneyfication' was addressed in a Cornwall context by Kennedy and Kingcome $(1998,45)$ who wrote about 'ersatz cultural artefacts and guidebook representations' that raise the 'spectre of a sanitised, Disneyesque, 'Kernowland', shrink-wrapped, preserved, and furnished with fudge for the consumption of visitors and locals alike'. Romanticised, mythologised and oversimplified representations of the county's past that are used to construct Cornwall's presumed identity were examined. The disconnect between the perceptions of heritage tourists and those of the native Cornish was highlighted. They showed that the past can be adulterated and cheapened by commercial pressures. Although the authors acknowledged that in the final analysis it doesn't matter whether simulations and representations are real or not', because 'what matters is their implications for the confidence, identity and economic well-being of the community' (p. 59), their powerful critique certainly threw some uncomfortable light on a corner of 'theme-park' Britain.

Links between heritage studies, landscape archaeology and oral history within a Devon context are studied by Riley and Harvey (2005). Their work draws attention to the importance of local, direct knowledge - in this case, of midtwentieth century farming practices - in the identification and revision of heritage narratives. The study highlights the danger of over-reliance on elite 
interpretations of the rural landscape and rural life in the past and makes a case for an inclusive and broader approach to heritage practıce. Gendered heritage has been examined by Pearce (1999) who asserts that A la Ronde in Devon, now a property of the National Trust, strongly evokes a particular eighteenthcentury feminine approach to the decoration and presentatıon of a domestic space

Critiques of the successes and shortcomings of the conservation of particular heritage bulidıngs in Devon and Cornwall, often carried out by architectural historians, represent another strand in the analytical research that has taken particular places in the two study countles as a focus. An example is the work of Davies (2008), which examınes the 'Red Store' in Lerryn, Cornwall. The value of the study lies in the way that it addresses the problem of finding an appropriate new function for an historically important, albeit modest, riverside buldıng In this case, the conserved building was made 'sustaınable' as resource centre and craft workshop for the local community.

Busby's work on the heritage tourism potential of Cornwall's historic churches (2002) examined visitor types at a range of visited Cornish churches His research suggests that existing visitor groups are, as anticipated, quite narrow, attracting predominantly retıred people and those with high household incomes The key conclusion drawn from this research was that Cornwall does not need to 'reinvent' itself as a destination, rather it needs to improve the marketing to promote extant hertage (Busby 2002, 371) Busby illustrates this assertion with an examination of different visitor characteristics at churches withın the Southwest region His later $\mathrm{PhD}$ research (2006) examined the visitor 
experience at churches in Cornwall. Both of these pieces of research articulate Busby's contention that the Southwest has a diverse and attractive range of historic church sites, but that visitors are drawn from a very small visitor segment. The need to secure the long-term sustainability of existing resources by expanding their appeal and awareness is a thread that runs through all of these pieces of research.

Although Howard $(2003,24-25)$ comments that 'green tourism and heritage tourism are now much discussed features of tourism [and are] more closely related than one might gather from most of the literature', there are no previous studies of the management of heritage for environmental sustainability in a Devon and Cornwall context. While Howard (p. 25) asserts that both green tourism and heritage tourism wish to "tread lightly on the environment and to. leave the local culture undisturbed', their successes and failures in Devon and Cornwall do not seem to have been analysed.

There is, moreover, no evidence of work that examines the economic and socio-cultural sustainability of heritage management practice in the Southwest. This absence of research is, as has been outlined in this chapter, a significant and curious omission given the importance of heritage in the region to both historical legacy and the contemporary economy. Although the financial difficulties of the Tamar port of Morwellham came to light some considerable time after this research project began, the plight of this west Devon heritage attraction firmly underlined the validity of exploring the financial stability of heritage resources and further exposed the dearth of previous studies. This chapter has revealed the richness of the heritage of Devon and Cornwall. It has 
also noted its importance to the local economy of the two countres. The relative lack of attention paid to Devon and Cornwall heritage in previous analytical work in general, and the absence of any previous studies on the sustannable management of heritage resources in the two counties in particular has also been noted The next chapter therefore represents a starting point for more systematic research into the sustainability of heritage management in the South West 


\section{CHAPTER 3}

\section{METHODOLOGY}

\subsection{Introduction}

The purpose of this chapter is to assess critically the methodological approaches used in this research. A mixed-method research strategy was adopted to examine the aims of the thesis, comprising three sequential phases: the creation of an inventory tool for visited heritage, the design and sampling for a questionnaire survey of managers of a sample of heritage resources, and the completion of a series of semi-structured in-depth interviews with a selection of heritage managers. As the basis for the sampling strategy for the original data collection surveys, the first part of the chapter explains the design and construction of a region-specific typological database of heritage sites. The particular challenges encountered in populating a sample of five of the proposed categories of heritage in Devon and Cornwall are evaluated and a technique for their geospatial presentation is explained.

The categorisation, inventory and geospatial referencing of the sites provides the sampling frame for the second part of the original data collection, which focuses on an investigation of the evidence of sustainable management practices by those who run heritage sites. The second part of the chapter evaluates both the questionnaire-based survey of all of the heritage sites within the five selected categories, and the series of in-depth interviews with managers across the different heritage types. The chapter describes and 
evaluates the efficacy of each of these methods to investigate the research questions formulated earlier in the thesis

\subsection{Creating an inventory of visited heritage in South west England}

\subsubsection{Defining and classifying the Southwest's visited heritage}

Despite the rich history and tremendous diversity of heritage resources in Southwest England, as outlined in Chapter 2, there is no agreed, comprehensive and publicly accessible inventory of these resources within the region (or indeed the country) Such an omission presents obvious limitations for the protection and planning of heritage, as well as for the promotion of heritage tourism. The Heritage White Paper in 2007 confirmed that heritage information in the UK is still fragmented and inconsistent. The importance of creatıng a co-ordinated resource was recognised as one of the key provisions of the Draft Heritage BIll in 2008 (DCMS 2008) However, to date, no progress has been made. The task, after all, is netther simple nor straighforward. First, an agreed classification of regional resources amongst the relevant stakeholders has to be established As discussed in Chapter 1, the varrety of classifications already devised illustrates the difficulties in creating a typology that will be relevant across different regions and have utlity amongst all the many relevant stakeholders and users. Second, there are inherent issues of integrating Information about sites and properties from the diverse and multiple sources that have already been devised Some sources, such as the websites of English Heritage and the National Trust, are relatively detalled and complete, while other sources, such as local tourist information and local museum sites, are 
fragmented and incomplete. The websites of English Heritage and the National Trust already provide map-based tools, which are designed as information and marketing tools. They help potential visitors to find locations and link to practical useable information about the site. However, such information very rarely conveys the full historic importance of any particular heritage site or the issues related to its sustainability.

One of the main aims and contributions of this research, therefore, is to develop a comprehensive database of visited heritage sites within Devon and Cornwall. The primary function of this database is as a sampling frame for an investigation of sustainable management practices across different types of heritage site. However, with modifications, the database might have other functions, such as a tool in local and national planning and as a means by which visitors can make informed decisions about the heritage sites that they wish to visit.

Timothy and Boyd (2003) recognised that classifications of heritage should reflect regional manifestations of cultural heritage. The unique qualities of Devon and Cornwall were felt to justify the creation of a new typology. However, ideas drawn from a range of existing classifications have been incorporated in the scheme proposed for use in this research (Table 3.1). The typology developed for Devon and Cornwall has its basis in the typologies devised by Prentice and Yale. Six categories were adapted from Yale's work, namely: industrial heritage, transport heritage, historic house and/or castle sites, historic churches, arts and crafts, and museums and archives. 


\section{Table 3.1. Southwest Heritage classification}

\section{Category Description}

Natural heritage resources

Socio-culturall Human landscape heritage resources

Industrial hentage

Transport heritage

Histonc Houses and/ or Castles

Famous person influenced sites

Marıne and maritume hertage

Military heritage

Historic Churches/ religious sites

Science based heritage attractions

Heritage theme parks

Arts and Crafts

Festivals, field sports, markets and farrs

\section{Museums and} Archives

Archaeological Sites
Resources/ Sites and attractions in which natural landscapes and nature form the basis of the resource

Other landscape features affected by human influencel includes other non designated treasures landscapes. Resources/ sites/ displays which demonstrate human existence in defined periods of history This can include historic townscapes and grouped buildings in urban and rural areas Focus on architecture, bult environment, and geography of settlement

All resources/sttes/ displays and museums linked to Industry including impact of industry on society

All resources/sites/ displays and museums linked to Industry including impact of transport on society

Including ornamental gardens, period gardens, arboreta and including palaces, country houses, manor houses

A site or resources viewed as having value due to its inferred or actual relationshıp to a historic person or persons

All heritage resources and attractions based within the marine environment (beach to natronal offshore extent)

Including castles and fortıfications, battlefields, military arfields, naval dockyards, prisoner of war camps, miltary museums displays, exhibitions and memorabilia resources

Including cathedrals, churches, abbeys, prones, mosques, shrines, wells, springs

Including science museurns, technology centres, 'hands on' science centres, 'alternative' technology centres

Including nostalgia parks, 'hıstoric' adventure parks, fairytale parks for children (but excluding amusement parks, where the princıple affractions are the excitung rides and the like). Sites are usually highly commodified and can be Inauthentic

Including theatres, street-based performıng arts, performıng arts workshops, circuses, art galleries and attractions concerned with handmade products and processes, including water and windmills, sculptors, potfers, woodcarvers, hand worked metals, glass makers, silk workıng, lace makıng, handloom weaving, craft 'vilages'

Includıng histonc fars, festivals 'recreatıng' past ages, countryside festivals of 'rural' activities Traditional field sports, including fishıng, huntıng, shootıng, stalkıng

Museums based on or hostung specfic or generalised historic displays. Can be seen as an aspect of every category rather than a classification of its own

Visited sites of archaeological interest Including, abandoned villages, stone rows, ancient monuments and other inhabited landscapes where archaeological remans are present 
A furrther eight categories were adapted from Prentice's typology, namely: natural heritage resources (thereby amalgamating Prentice's countryside and wildlife categories), socio-cultural/human landscape resources (combining Prentice's settlements and treasured landscapes categories), famous person influenced sites, marine and maritime heritage (including seaside resorts), military heritage, science based attractions and festivals, field sports, markets and fairs (combining Prentice's festivals and pageants and fieldsports categories, and aspects of Yale's events attractions category).

Categories, such as historic houses and museums, were included to reflect existing typologies for national heritage (as detailed in Chapter 1). In addition however, further categories were also included to reflect the particular character of the study area. While some of these categories do feature in existing national typologies they are given a greater prominence in this research. For example, the special richness of Devon and Cornwall's historic churches, marine and maritime, and industrial heritage sites mean that they are accorded special recognition.

Some types of heritage could be categorised in more than one way. For example, although maritime heritage museums could be either a museum and archive site, or an example of marine and maritime heritage clear decision was made about which category it was included in. For the purpose of this research, it was deemed important to provide an accurate count of heritage sites within the study area. Each heritage type was allocated to one heritage category, based on an evaluation of its key features, characteristic, primary function and use for visitors. The process avoided double counting and ensured that each 
heritage site was allocated correctly In order to ensure that the database was fully comprehensive an explanation box was included to cross reference a site within another category

\section{Creating an inventory database tool}

Several processes are involved in the creation of a database capable of being searched and interrogated Thus, the database must contain recognisable classifications locational data and detals about the resources Some of this information is held withın existing fragmented data sources and must be assembled in order to create an effective and searchable inventory. The following section describes the process by which information was drawn from the already avallable, though fragmented, resources; how information was checked and verified, and how it was supplemented by the inclusion of other detalls in order to ensure each category contained useable information.

\section{Formatting and piloting an inventory tool}

The desire to create an accessible tool, capable of being interrogated and useful at a range of different levels, Imposed a number of key demands. Above all, the database had to be functional, use readily avalable software (of the kind that other general users would be able to operate), and have an accessible 'front end' Although hosting the tool in Microsoft Excel had the attraction of ease of use and wide familiarty, the option was rejected. The Excel format provides neither the 'front end' functionality nor the ability to lock the onginal dataset to prevent the corruption of its contents 


\subsubsection{Phase l: Inventory Stage - Design, Development and Pilot}

Microsoft Access was instead considered a better choice, because this software is not only reasonably easy for computer-literate users to navigate and interrogate, but also offers the functionality necessary to create the inventory tool.

Heritage museums and historic churches were chosen as pilot categories to test the process of assembling relevant data to populate the datasets. Although it was known from the evidence of the survey of Devon and Cornwall heritage, presented in the previous chapter, that these two categories are abundant in the two counties, the primary problem encountered at this preliminary stage was that full information on every site is not obtainable from single existing sources or listings. The realisation of this major methodological issue meant that the population of all fifteen inventory categories would represent a difficult and exceptionally time-consuming process. For this reason, it was therefore decided that a more manageable number of key heritage categories would be fully researched and populated within this research project. The decision was taken to populate one third (five) of the total number of inventory categories, that way endeavouring to explore a diverse range of category types while ensuring that there was enough time to address any potential methodological barriers that arose. Of course, it is recognised that by limiting the inventory creation to the five chosen groups, the choice of the categories which would be the subject of the questionnaire survey and the in-depth interviews would be prefigured.

Clearly, therefore, the justification of the five chosen groups was of some significance to the findings of the thesis as a whole. The five categories 
selected were historic houses and/or castles, museums and archives, historic churches, archaeological sites and marıne and maritıme site The chorce of these five particular categories was made for a range of particular reasons which are set out below.

1. The previous chapter shows that some exceptionally fine historic houses and castles exist in Devon and Cornwall. Moreover, as elsewhere in the country, historic houses and castles are amongst the most commercialısed and visited kınds heritage. Their appeal and popularity is considerable. Moreover, they are strongly marketed in the tourism advertising for the far Southwest. While there are some notable privately-owned historic houses and castles in Devon and Cornwall, many are managed by the larger national providers, such as English Heritage and the National Trust, and the group in general was therefore lıkely to act as a contrast to other categories of heritage site which are dominated by the small-scale, independent owners and charitable trusts Historic houses and castles are also a type of heritage which is the most frequently discussed in academic literature. Their inclusion in this research will not only contribute to the growing body of sustainable management literature concerning these types of site, but will also provide evidence which could, in future, augment and update prevous studies For these reasons, it was deemed essential to include this highprofile type of heritage site in the present investigatıon.

2. Museums and archives are also closely associated with what the public perceive as important national and local heritage resources. Museums 
and archives are distinctive in that their heritage value lies, more often than not, in both their tangible moveable collections and the historic building in which they are located. There are, of course, some examples in the two counties of historic collections being housed in relatively new buildings. The National Maritime Museum in Falmouth, which was mentioned in the previous chapter, is perhaps the most well-known case of a collection accommodated in modern premises. In fact, however, a majority of Devon and Cornwall museum and archival collections are based in old buildings which are often just as historically important as the artefacts on display within. A further strong justification for the inclusion of the museums and archives category in this research is that they are another example of a heritage type that has featured in academic discourses. Guidance for the improved management of museums and archives emerged in heritage literature in the 1990s, largely relating to socio-cultural issues of interpretation, inclusion, and authenticity. As guidance has been available to providers of this form of heritage for a relatively long period, they present the possibility of making interesting comparisons with other categories of heritage in the context of progress made towards socio-cultural sustainability.

3. Historic churches are included in the database for two key reasons. First, historic churches are a much-cherished and visible heritage feature in most local communities throughout the two counties. As noted in the previous chapter, Devon and Cornwall are especially rich in exceptionally fine parish churches, many being medieval in origin. A great many are both architecturally and culturally significant in the heritage landscapes of 
the two counties. Not only are these spaces still actively used for worship and other activties by their congregations and local groups, thereby embodying an Immensely important 'heritage of practice and tradition', but they are also often one of the only physical expressions of a community's shared history and lineage. Second, historic churches represent a very particular kind of heritage the great majority tend not to be fully commodified heritage places, yet hundreds are made publicly accessible for visitors. Indeed, visitors expect to be able to go inside a church and view its interior. Those most associated with the running of an historic church tend often to have ambivalent feelings about its role as a heritage tourism destınation and the potential for contestation is perhaps greater than in the case of other heritage places. However, funding for the maintenance of historic churches almost always depends, in large measure, upon the voluntary collections made amongst the local congregation and (often rather limited) fund-rassing within the parısh. Church attendance is declining nationally and, as a result, the stream of core funding needed to provide for the upkeep of old churches is scarce. While access is taken for granted by the population at large, historic churches which can no longer sustain a large congregation are often at acute risk of closure and/or neglect.

Utilsation of their appeal to heritage visitors as a means of securing investment in historic churches has only recently begun to emerge as a theme in the herıtage literature. For example, prelımınary studies such as those by Watson (2007) for doctoral research at the University of York, by Gibson (2004) for a Nottıngham Trent PhD (Gibson 2004) and by 
Busby (2006) for his Exeter PhD have all pointed to the dual value of historic churches to their local communities and to heritage visitors. Each of these studies focuses on aspects of historic church sustainability, predominantly examining issues of socio-cultural sustainability such as presenting authentic and appealing narratives (Gibson 2004) and addressing the needs of the visitor (Gibson 2004; Busby 2006). In these studies, the research concentrates almost exclusively on gauging visitor motivation, and whether their needs are being met. Limited consideration is given to the way that the upkeep of churches is funded or how their income contributes to the site's ability to engage in suitable visitor provision. However, these authors recognise the need to sustain historic churches.

Although there are, of course, a great many buildings belonging to other post-Reformation Christian denominations, as well as those of other faiths, in the two counties, a decision was taken in this research to focus only on the Anglican churches. As noted in Chapter 2, even when a nonconformist denomination possesses an historically important building (and there are many of these, especially in Cornwall), they tend to be much less frequently open for general visitors than is the case with Anglican churches. The heritage potential of chapels and other places of faith in Devon and Cornwall could perhaps form the focus of another future study.

4. Marine and maritime sites are of particular importance to Devon and Cornwall. As coastal counties, marine and maritime heritage represents 
an Important component of the heritage offering which is relevant to host communities as representative of their lived and shared experiences in this research project, a decision was taken to explore marıne and maritıme heritage rather than perhaps the more obvious choice of the well-known Industrial heritage of Devon and Cornwall As revealed in the previous chapter, although the landscapes of both counties are abundantly littered with the remains of the region's industrial past, there are in fact still only a handful of publicly accessible and actively managed Industrial sites in the region However, this situation is changing: prompted by the UNESCO inscription of the Cornwall and West Devon mınıng landscapes as a World Herıtage Site In July 2006 Nevertheless, for three reasons, a prmma facie choice was made to investıgate marıne and marıtıme heritage sites. First, they are an unmistakeable Ingredient In the wider heritage image of the Southwest penınsula Second, there appeared to be more commodified and publicly accessible resources than is the case for industrial heritage. Thırd, there is little previous Itterature on the marıne/maritıme category (less than on Industrial heritage sites). These factors supported the need to develop further research in this area.

5. Archaeological sites have been selected for inclusion in this research for many of the same reasons as the marine and maritime category it was noted in Chapter 2 that Devon and Cornwall are particularly rich in archaeological sıtes In partıcular, the preserved landscapes of Dartmoor, Exmoor and Bodmın Moor represents a concentration of archaeological sites of immense importance As previously mentioned, Dartmoor 
National Park contains the largest concentration of Bronze Age archaeology in the country (Dartmoor National Park, 2004). With such a resource in the study area, this type of heritage was thought to offer a unique opportunity to investigate the extent and sustainability of these very ancient visited sites. However, it may be noted that there was a risk in choosing archaeological heritage as one of the five categories. It was clear that commodified archaeological sites were not abundant. Most conserved and accessible archaeology tends to be open to visitors at no charge. Nevertheless, the importance of the resource and the relevance of sustainability issues in the case of the archaeological category determined that it would be included in the inventory and survey.

\subsubsection{Phase I: Inventory Stage - Populating database}

The sequential process used to populate the inventory is shown in Fig. 3.1, which charts the initial identification of sources of information through the population of the inventory to the creation of mapped categories of data. Constant re-examination of the sources used and the resultant information, as well as revisions of the database format, were necessary as the work progressed.

\section{Populating the inventory - Category variation and complexity}

The five chosen heritage categories were populated to test the functionality of the inventory tool, while also providing a platform from which phases 2 and 3 of the research could be based. 


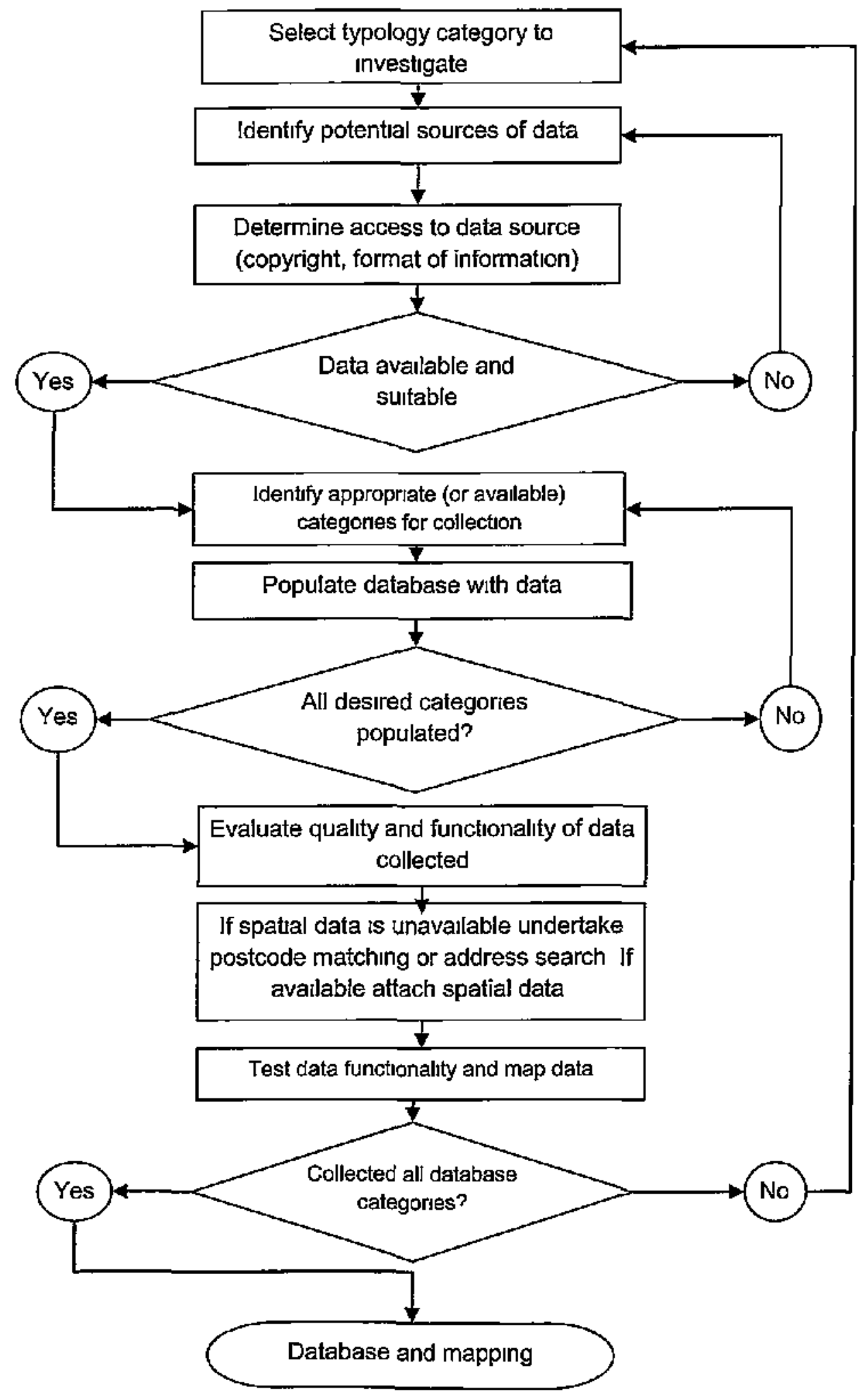

Figure 3.1. Process map of Inventory creation. Source: Author 
Of the five categories, two (historic houses and castles; and museums and archives) were sourced from relatively low complexity, coherent, informationrich sources. In contrast, the information for historic churches, marine and maritime sites, and archaeological heritage sites was not as coherent and involved a process of high complexity. In order to secure the appropriate level of information for these latter three types of site, including accurate addresses and site descriptions, it was necessary to consult a wide range of sources. Table 3.2 summarises the sources used and the variables recorded in the inventory.

In order to obtain the required co-ordinate information, two alternative methods were used. First, where postcode information was available, a matching query identifying the centroid co-ordinate of the postcode was undertaken using the Code-point Ordnance Survey tool. This approach was also used for sites where an address was provided, but a postcode was absent. Associated postcodes could be accessed from an online resource (such as the 'Royal Mail address finder' where addresses are used to capture postcode information) and then used to create a matching query. The second method was employed if fragmentation of address data was more pronounced (or if the address information was incomplete). For example, where a road name was given with no indication of specific location, or where a site name was given with no corresponding address information, a web-based map finder, such as the www.streetmap.co.uk resource, was utilised. In these cases, the more fragmented data could be used to find the 'nearest postcode', and associated co-ordinates could be extracted using online Ordnance Survey tools such as Code-point and the online co-ordinate batch converter (found at http://search.ordnancesurvey.co.uk/query). 
Table 3.2 Sources used to populate the selected heritage resource categories

\begin{tabular}{|c|c|c|}
\hline $\begin{array}{l}\text { Hentage } \\
\text { category }\end{array}$ & Sources used & Varlables recorded \\
\hline $\begin{array}{l}\text { Museum and } \\
\text { archives }\end{array}$ & $\begin{array}{l}\text { Museums, Libraries and } \\
\text { Archives Council and } \\
\text { information from local tourism } \\
\text { web sites in Devon and } \\
\text { Cornwall }\end{array}$ & $\begin{array}{l}\text { Site name, ownership, type } \\
\text { (museum types and content } \\
\text { description), address, postcode, } \\
\text { website address, email address, } \\
\text { name of manager/curator }\end{array}$ \\
\hline $\begin{array}{l}\text { Histonc houses } \\
\text { and castles }\end{array}$ & $\begin{array}{l}\text { Websites of Englısh Heritage, } \\
\text { National Trust, local tourısm } \\
\text { Information and other local } \\
\text { sites }\end{array}$ & $\begin{array}{l}\text { Site name, ownership, type } \\
\text { (subcategorles of historic house, } \\
\text { castle), address, postcode, } \\
\text { webpage (withsn wider } \\
\text { organisational framework) or } \\
\text { website, e-mail address (where } \\
\text { provided) }\end{array}$ \\
\hline Historic churches & $\begin{array}{l}\text { Diocesan directories of the } \\
\text { Church of England (hard copy), } \\
\text { Church of England 'A Church } \\
\text { neat You' (ACNY) website, } \\
\text { English Heritage IIsted } \\
\text { churches, and Pastscapes } \\
\text { facility. Streetmap website }\end{array}$ & $\begin{array}{l}\text { Pansh name, church name, } \\
\text { name and address of clergy for } \\
\text { church, address of church } \\
\text { (ACNY only), postcode } \\
\text { (transformed from EH and ACNY } \\
\text { information using Streetmap } \\
\text { facility) }\end{array}$ \\
\hline Archaeology & $\begin{array}{l}\text { English Heritage, Devon } \\
\text { County Council, academic } \\
\text { publications (Grinsell, 1970, } \\
\text { Claire, 1982) Websites of Visit } \\
\text { England, Visit Southwest, } \\
\text { Discover Devon, Cornwall } \\
\text { Tourist Board. }\end{array}$ & $\begin{array}{l}\text { Name of site, description, grıd } \\
\text { reference, directions to site } \\
\text { Nearest postcode (transformed } \\
\text { from academıc publıcatıons } \\
\text { using Streetmap facility) }\end{array}$ \\
\hline $\begin{array}{l}\text { Marıne and } \\
\text { maritime heritage }\end{array}$ & $\begin{array}{l}\text { Englısh Herıtage Pastscapes } \\
\text { website, Diving club websites } \\
\text { (providıng Information about } \\
\text { wreck locatıons), local tourist } \\
\text { information websites }\end{array}$ & $\begin{array}{l}\text { Description of site, map } \\
\text { reference. Where land-based } \\
\text { nearest postcode (transformed } \\
\text { from EH Pastscapes using } \\
\text { Streetmap facility) }\end{array}$ \\
\hline
\end{tabular}

Source Author 
The large-scale nature of the mapping required that, in order to display sites at a regional or sub-regional scale, the corresponding symbol for each site was displayed at a scale of approximately one kilometre. In addition to this spatial information, the database was also populated with other variables, although. these were dependent on the level of detail held within the associated data source. These variables, where available, included a combination of the following: contact details, manager name, opening times, facilities available and site description. A more detailed explanation of the processes involved in populating each of the heritage categories follows, together with a brief analysis of the geography of the five heritage categories in Devon and Cornwall.

\section{Category 1: Museums - Low complexity}

As an example of a low-complexity dataset the museums and archives inventory was constructed from two sources that list all the region's sites. These. sources were the Museums, Libraries and Archives (MLA) website and tourist information websites provided by VisitBritain (www.VisitDevonandCornwall .com). The MLA facility only included information about establishments that were subscribing members of the organisation. In order to complete the selection of appropriate sites within this category, the tourist information was utilised. The total number of museums and archives in Devon, Cornwall ${ }^{16}$ (183 museums) is relatively small, and detailed descriptive information for each

museum and archives site was derived from the two sources. However, it should be noted that this information was not available for download and it was

${ }^{16}$ This includes the Isles of Scilly 
necessary to transcribe manually all the information into the Access database from both the MLA and tourist websites.

The analysis of the spatial distribution of the museum and archives category Indicates that the 183 sites are distributed farly evenly across the whole study area (Fig. 3 2) However, there are clusters in the urban areas, especially around Plymouth, Exeter and Torquay. There are also striking numbers of museums located in coastal towns and villages. These findings suggest that, while Inland towns frequently possess a smail museum (which often also has an archival collection), significant numbers of the museums in Devon and Cornwall are located in the urban and coastal areas of the two counties and they are therefore prominent in tourist areas. Analysis of survey responses indicated that the majority of sites are indeed small, employing etther one or two paid staff (34.1 per cent), or three to five pard staff (220 per cent). The majority of museums are owned or managed by charttable organisations (66.4 per cent), with small proportions being privately owned ( 15.3 per cent) or are run by, or in collaboration with, local councils (less than 15 per cent) 


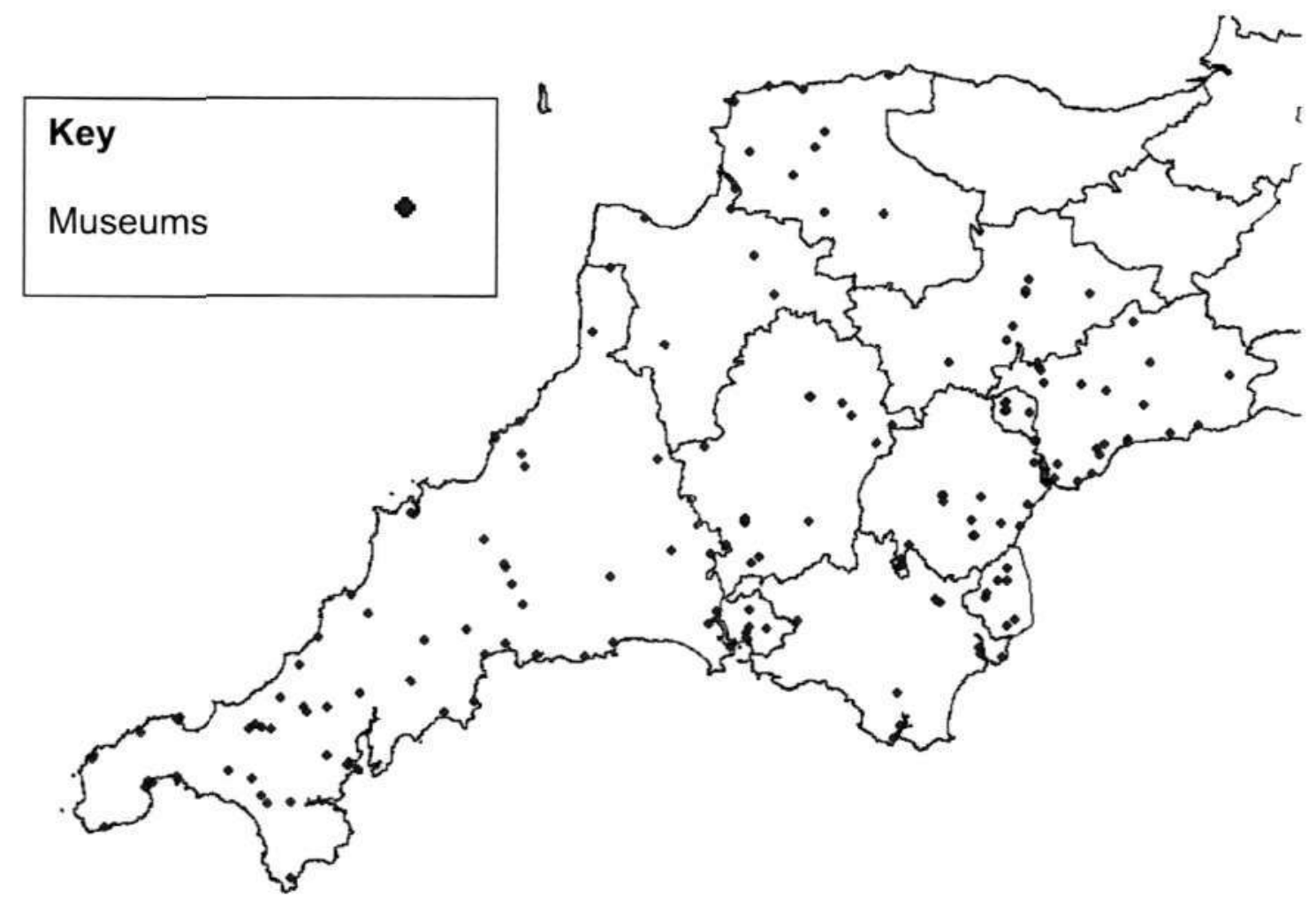

Figure 3.2. Spatial representation of the museum database category

\section{Category 2: Historic House and/or Castle category - Low complexity}

Much like the museums and archives example, information concerning the location of historic houses and castles can be sourced relatively easily. Within the study area, there are 22 castles and 28 historic houses. A large proportion of these sites are owned and managed by two large national providers of heritage, English Heritage (18 sites) and the National Trust (21 sites). The remaining sites (10) are independently owned or owned by charitable trusts.

Information about the English Heritage and National Trust sites was readily available, published online, on the web sites of each organisation. The presence of detailed sources of information from these providers was thereafter supplemented by gathering data from tourist information providers and the web 
sites of privately managed houses and castles. Each of these sources contained full address and postcode data, making the analysis of site location relatively easy. The web sites also contained site descriptions, ownership details, information about the historical characteristics of each place, and the tourist facilities that are available.

The analysis of the spatial distribution of the sites within this category indicates that the 50 publicly accessible sites are not distributed evenly across the study area (Fig. 3.3). In part, this geography depends on whether a house or castle has been opened for visitors. Many fine historic houses in both Devon and Cornwall are still occupied as homes. It is important therefore not to read too much into the distributional pattern. Nevertheless, it may be noted that those historic houses and castles that are accessible are mostly concentrated in the southern half of the two counties, with some clusters adjacent to the urban areas, especially Plymouth and Torbay. There also appears to be spatial variation between houses and castles, with a larger number of historic houses located in Devon, and very few castles being located on or around the north Devon coast. In this category, site choice was linked to the strategic positioning of castles at defensive locations, while historic houses were often fairly close to key routes and the centres of trade and local markets. The original location of many of these sites within their own expansive estates means that their predominantly rural location has implications for the sustainability of visitor access and transport to the sites. 


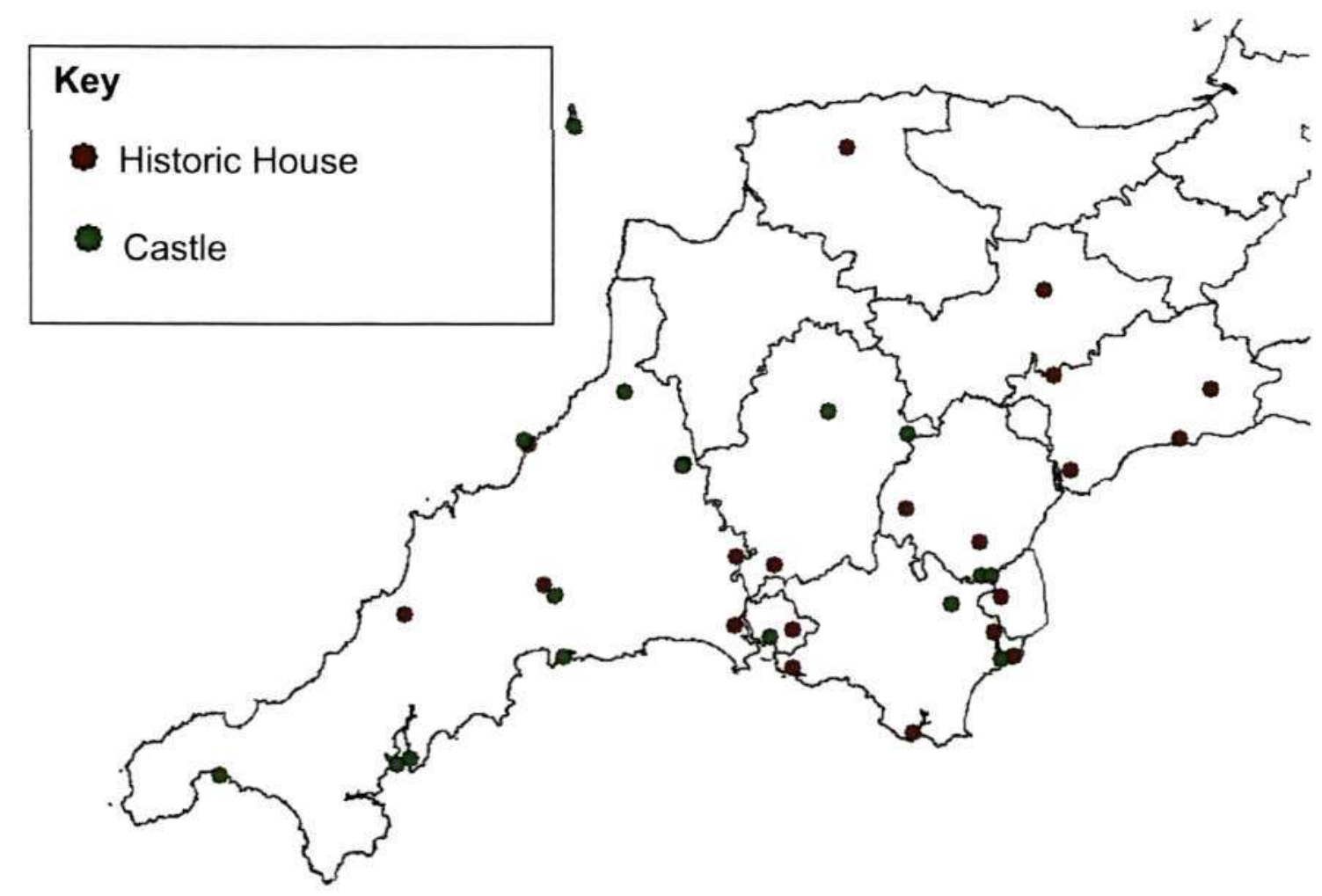

Figure 3.3. Spatial representation of the historic house and/or castle database category

\section{Category 3: Historic Churches - High-complexity}

In sharp contrast to the previous datasets, the gathering of detailed information on the historic churches of Devon and Cornwall proved to be much more difficult. As previously mentioned, it was decided to focus this investigation on the most easily accessible type of church: namely the parish churches of the Church of England. While it is recognised that some sites belonging to other Christian denominations and other faiths may have heritage importance (perhaps especially the Methodist chapels of Cornwall and west Devon), as previously noted, very few are regularly unlocked for visitor access. Nonetheless, it is recognised that their approaches to sustainable management ought to be investigated and, while time and resource constraints prevented a 
wider survey in this research project, the possibility of addressing this issue in future remains.

Even focusing exclusively on Anglican parish churches, the category remains extensive with a large number of recorded sites (929 churches in Devon and Cornwall). However, the main difficulty in populating the inventory with information about these sites was the absence of a single source of detailed information about historic churches. It was essential to combine information drawn from a range of sources. Foremost amongst these was the Diocesan Directories of the Church of England, which were used as a starting point. These directories are available only in hard copy and were purchased direct from each diocese. Both booklets contained limited, but frustratingly inconsistent information. The parish and church name, and the name and address of the clergyman was, however, nearly always recorded. Information in the directories about the heritage attributes of individual churches was very limited ${ }^{17}$.

Supplementing this source was essential to achieve the level of detail and the quality of data required in the inventory. The Church of England's on-line facility 'A Church Near You (ACNY)' provided some further, though still limited, data. In the case of churches within Cornwall (the Truro Diocese), for example, some postcodes and additional detail about the historic character of churches was provided. There was no further information available from the Diocese of Exeter. However, English Heritage publishes information on all churches with

\footnotetext{
${ }^{17}$ Since the data on churches were collected for this study a new guide to Devon's churches has been produced to mark the $1,100^{\text {th }}$ anniversary of Exeter Cathedral's foundation (Orme et. al, 2008). Had the guide been available, it would have proved invaluable as a source of information for the inventory of Devon (but not Cowall) historic churches.
} 
'listed' status within their 'Pastscapes' web site facility. This source was employed to cross-reference and identify historic churches, and to fill in as much 'missing' information as possible. Moreover, by consulting the English Heritage source, as well as the list of buildings in the care of the Churches Conservaiton Trust, it was possible to add further cases to the inventory, including redundant church buildings that possess 'listed' status.

A cross-check between the information contained in the ACNY resource and English Heritage listings revealed inaccuracies and inconsistencies in approximately 10 per cent of the entries. These inconsistencies included the incorrect spelling of a site name, the assigning of the wrong name to the site in the English Heritage listings or, most commonly, conflicting information about the listed status of the site. Where listings or name disagreed, the diocesan directories, ACNY site, and 'Pastscapes' sites were supplemented with information from online mapping resources and, where available, individual church web sites in order to establish the best information to include in the inventory. The fragmented nature of sources of information and suspicions about the reliability of data held in some listings meant that further research was essential. This research included searching texts describing the historic character of the regions churches, seeking specific reference to missing or fragmented data. In most cases, this information was available in volumes in the Buildings of England, series:

1. Pevsner, N. (2002) The Buildings of England: Cornwall. Yale University Press. London 
2. Cherry, B. \& Pevsner, N. (2004) The Buldings of England Devon. Yale University Press. London

As might be expected, there is an even distribution of historic churches across the Devon and Cornwall study area (Fig. 3.4) reflecting the distribution of parishes. Clusters of newer 'non-listed' churches occur in the larger urban areas, like Plymouth and Exeter, especially reflecting the Victorian and early twentleth-century expansion of these areas when the need to serve the demand for places of worship of the growing population was acute and new churches were bult

The two most populous categories listed in the inventory are Grade 1 and Grade $2^{*}$ listed sites, which underlines the point that a very large proportion indeed of the active Anglican churches in Devon and Cornwall are highly valued historic sites worthy of inclusion in this research. 


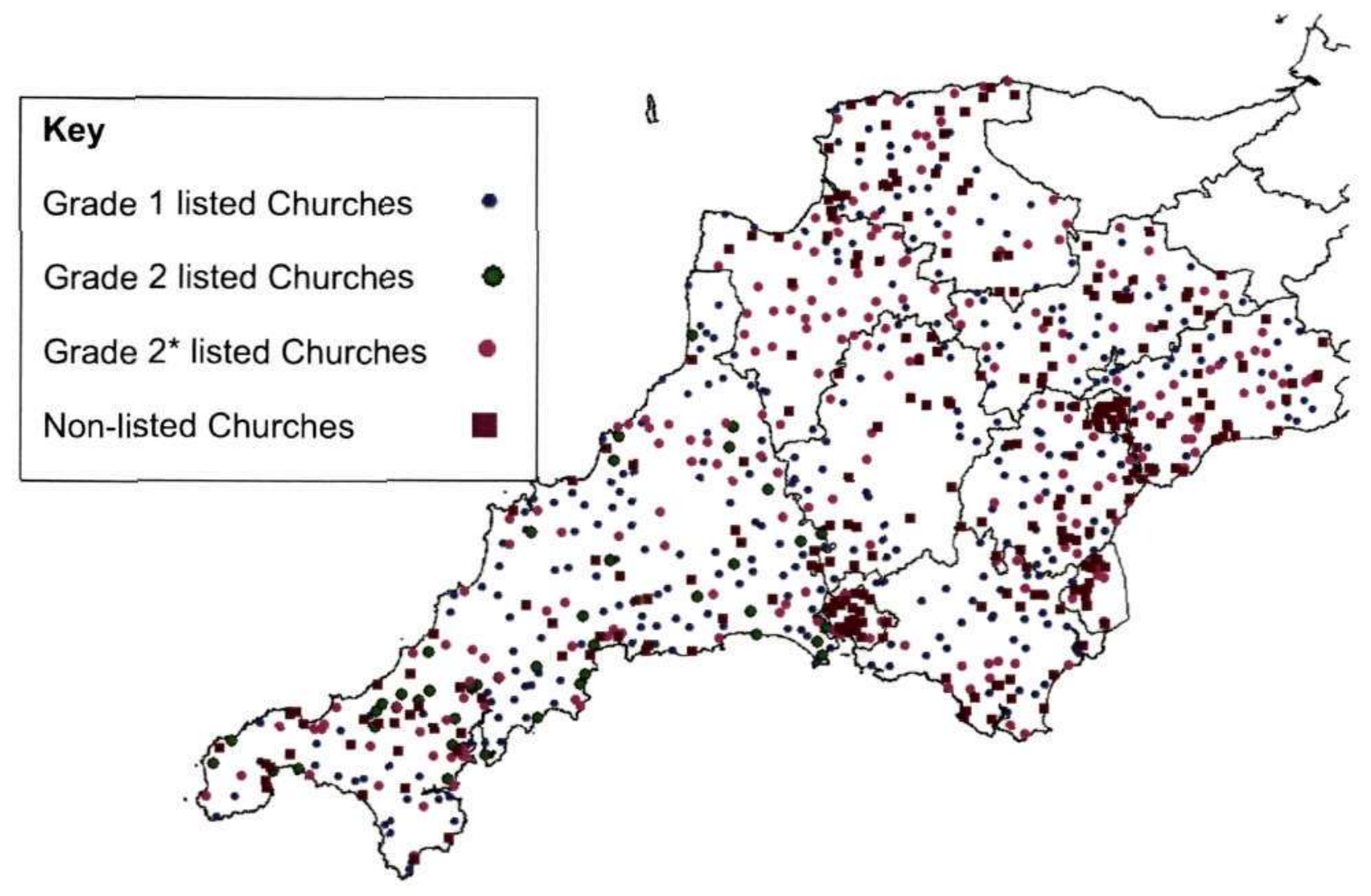

Figure 3.4. Spatial representation of the religious sites database category.

Source: Author

\section{Category 4: Archaeological sites - High complexity}

Obtaining information about the archaeological sites in the study area also proved to be surprisingly complicated. While local authorities and English Heritage hold databases on the name, type and location of archaeological sites, these data are held in such a way that it is impossible to identify which sites are publicly accessible.

In order to try and supplement this information, details of archaeological sites were requested from Devon County Council, Plymouth City Council and 
Cornwall County Council. Responses from these authorities revealed that they hold spatial information concerning sites within their area. However, they too hold limited detail on public accessibility, and what little information is available is held in a database that is not available to the public. Information on individual sites is available to the public on request, but only in hard copy, which makes the process of obtaining data cumbersome and of no use at all to the ordinary heritage visitor. Visiting council offices is the only means by which the information can be obtained. A key reason why the lists are available only in this exceptionally awkward format is their sheer size. For example, Devon County Council estimates that there are in excess of 70,000 archaeological sites in the county. On investigation, it became clear that the vast majority of these sites represented single, small, inaccessible points of interest, including wall fragments, historic stones, and other features that would merit some interest. However, the majority of these points of interest would not represent a visitable heritage site, holding little interest beyond the recognised need for protection. As the databases held by the Councils were unable to differentiate between these minor details and archaeological sites that are accessible for public visits, a decision was made to explore alternative means of securing usable information

Due to the complexities outlined so far, the database for the archaeological category was constructed using a further range of sources. Two key academic texts proved essential foundations for the database:

1. Grinsell, L. (1970) Discovering Regional Archaeology South Western England. Shire Publications, Tring, Herts. 
2. Claire, T. (1982) Archaeological sites of Devon and Cornwall. Moorland Publishing Ltd, Derbyshire.

Each entry identified in these sources was updated and cross-checked with the information drawn from national, regional and county-based tourist information boards (Including EnjoyEngland, VisitDevon, VisitCornwall). Combining these sources, and adding information from tourist information leaflets, resulted in the identification of just 106 sites which are accessible to the public. This greatly reduced figure demonstrates the extent of inaccessible and non visited points of archaeological interest within Devon and Cornwall and suggests that further research would be required to establish the potential to use the many thousands of unexplored sites in a visited heritage context. The combination of the information from these sources provided the name, description, grid reference and directions to each of the identified sites.

As anticipated, the main cluster of visited archaeological sites in the two counties is on Dartmoor (Fig. 3.5). There are smaller clusters of sites on Bodmin Moor and in the West Penwith area of Cornwall. The largest Moorbased clusters represent the concentrations of Bronze Age sites with a small number of earlier Neolithic and later Iron Age sites that have survived in the protected landscapes of the Moors. Often found on open-access areas of the moorland, the sites have not been developed or affected by intensive farming and, as a result, they are readily accessible to the public. Unlike other types of site reported in the inventory, there are (inevitably) very few sites in urban areas. 


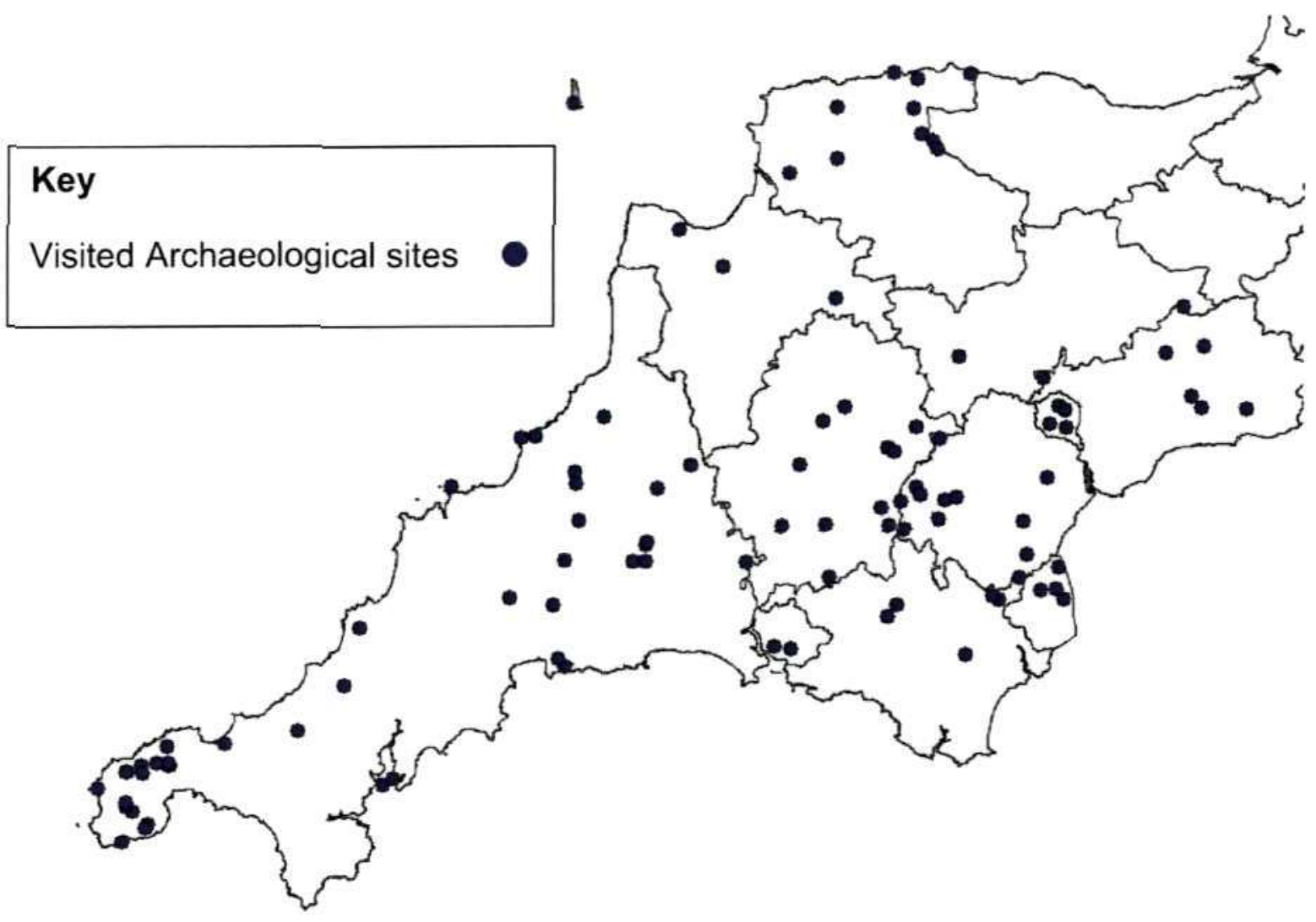

Figure 3.5. Spatial representation of the archaeological sites database category. Source: Author

\section{Category 5: Marine and Maritime - High complexity}

The final database category to be populated was the marine and maritime category, which also drew upon information contained in a range of data sources. The foremost source for this category was, once again, the English Heritage 'Pastscapes' online facility, which provides 'an inventory of archaeological sites and historic buildings in England' (English Heritage 2007). This facility was useful in providing a basis for marine-oriented searching, and gave a brief description and a map references for most marine and maritime 
heritage sites. However, little or no detail was included about addresses, custodianship, or whether it is a visited heritage resource. The English Heritage resource also categorised all marine and maritime features within a close proximity as separate features, or separate points of interest, while a visitor may consider these individual features as part of a single area's heritage appeal. For example, the slipway, harbour wall and historic docking area of one village are categoriesed separately instead of as adjoining features. While this aspect of the database is essential for identifying all the different features that are of interest in the area (i.e. harbours, quays, mooring posts, slipways), it adds a further layer of complexity when trying to identify visited heritage sites. Additionally, there was found to be significant overlap between the marine and maritime category, identified by English Heritage, the churches category, with particular reference to former coastal mission buildings, and also with the military resources category, in particular where coastal sea defences and military outposts were listed. As previously described, these sites were assigned to the marine and martime category where features and primary function indicated that it was appropriate to do so. With all of these factors taken into account, 450 land-based marine and maritime visited heritage resources were identified in Devon and Cornwall.

In order to map and record these sites, additional information from tourist information guides, describing site characteristics and detailing the facilities provided, was used to supplement the rather sparse information provided in the English Heritage source. One key area of visited marine heritage was not recorded by the English Heritage online facility. This key area was accessible shipwrecks, which are in fact popular attractions for divers. Information about 
Devon and Cornwall's 14 accessible shipwreck sites was therefore derived from numerous professional diving organisations, such as the UK Diving organısations (www.ukdiving.co.uk), whıch contains detals of all the wreck sites In the UK and Ireland, and the European based Wreck Site (www.wrecksite eu), which lists the UK's and Europe's wreck sites. Both sources provided descriptıons of the sites and gnd references for each wreck

It is hardly a surprise to find that the majority of marine heritage resources in Devon and Cornwall are found in the coastal areas, around the ports and the coastal communties Accessıble shıpwreck sites are predominantly clustered in locations close to the south coasts of the two counties (Fig 36). This concentration of shipwreck sites is thought to reflect greater military and naval activity off the south coasts, with particular emphasis on the wrecks dating from the Second World War period (examples of visited wrecks from this period include the James Egan Layne and S S. Persıer) Divers are also able to see the evidence of much earlier naval engagements, Including cannonballs from the Spanish wars of the Elizabethan period Some sites are also located inland. On examınation, many of these occur adjacent to rivers, lınking them to Industries or to nearby locations on the coast. In some cases, these sites represent historic vessels moored in a more sheltered environment Some of the sites also represent former marıne industries, which have been converted to heritage attractions For example, in Cornwall, the Charlestown Shipwreck and Heritage Centre is located in an old China Clay shipping bujlding on the quayside 


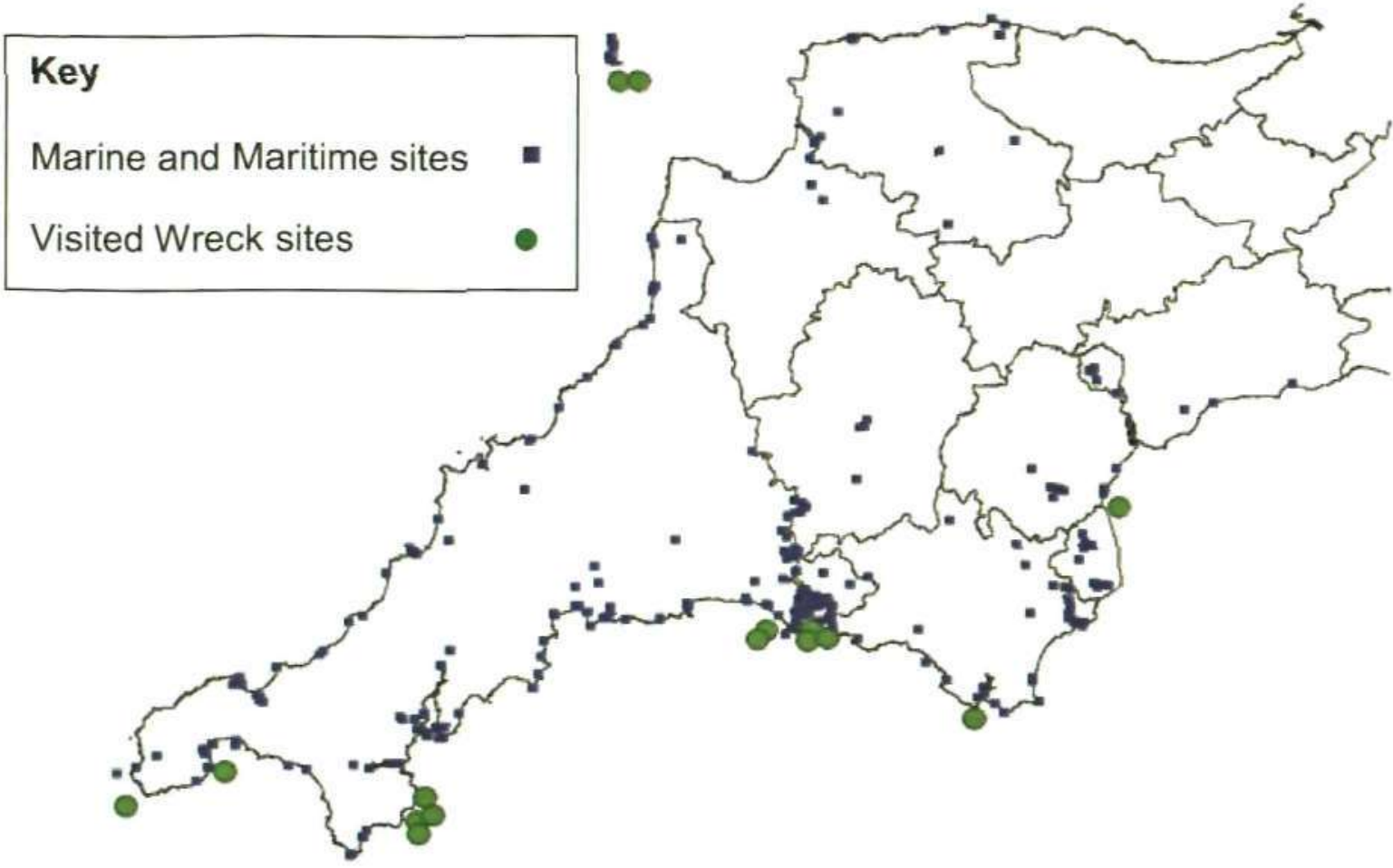

Figure 3.6. Spatial representation of the marine and maritime sites database category. Source: Author

The creation of an inventory of heritage resources fills a recognised gap in the tools available for the management and understanding of heritage resources. Primarily, the development of a spatially referenced database, which draws together a diverse range of existing information, offers a range of functions that are likely to be valuable to conservation policy makers, educational users, and even visitors/tourists in search of heritage places that are of particular interest to them. Further practical applications could be envisaged. For example, the managers of heritage resources might use the database to identify all similar, complementary (or even contrasting) resources in their surrounding area, thereby perhaps creating opportunities for networking, clustering and the sharing of good practice. 
The database is also capable of being built upon by the addition of other relevant variables and data fields, which would perhaps extend its utility to an even broader range of users. However, for the purpose of this research, the inventory has been created as a high-quality sampling frame for further survey Investıgations into sustainable management practices in heritage The following section therefore examines the methodological approaches adopted in the second phase of this research, where the database was used to develop and disseminate a survey to managers and custodians of the five populated hentage categories

\subsection{Phase II: Questionnaire Survey Phase}

As already mentioned, the main part of this research project involved a survey of management practices of 'Heritage Resources' in the Cornwall and Devon study area, with a particular focus on sustamable practices and actions This phase of the research was accomplished using a postal survey sent to heritage managers within the five selected heritage categories in the two counties

\subsubsection{Survey delivery}

Questionnaire design and implementation can take many forms postal, telephone, on-line, self completion and researcher completion. Different types of questıonnaire gathering approaches offer distınct advantages, such as higher response rates; as well as disadvantages, such as cost and time (Wheeler, et al. 2004; Oppenhelm 1999, Willams 2001) This research adopted a postal survey approach, relying on self-completion of the questionnaure by the 
respondents. This method was chosen as it offered a better chance of obtaining replies from the intended respondents because completion was flexible around their commitments. A face-to-face interview survey was not practicable - in terms of cost, time and logistics - across a large geographical region such as Devon and Cornwall. The practical probiems of contacting and negotiating an appointment with busy managers were also considered to be a potential barrier to securing a large sample. Telephone surveys were not considered the best means of securing a higher response rate as the time taken to undertake (potentially) over a thousand telephone interviews was not feasible. Consideration was also given to the possible use of on-line surveys. However, when building the inventory for this research, it became clear that a high proportion of potential respondents, especially those from the historic churches category, had no easy access to the internet or email. The inventory tool developed in Phase 1 of this research had recorded the names, addresses and postcodes of the sites in the five categories. The postal option therefore seemed to represent the most practicable and financially affordable option available to the researcher.

The postal survey was conducted using the complete population of the five database categories rather than a sample from these groups. Ultimately, the initial sample would be influenced by a level of self-selection of respondents, but the approach was viable in terms of administration and distribution. 


\subsubsection{Questionnaire design}

The questionnaire was constructed in order to include a range of questions identifying not only key characteristics of the site, such as heritage category, age of site or collection of objects, ownership, staff and visitor numbers, levels of profitability and facilites provided by the site, but also a framework of questions probing the extent of implementation of sustannable management practices, management attitudes towards sustainability ISsues, and organısational approaches to site and staff management. The final part of the questionnaire examıned a range of standard variables relating to the site manager (or respondent), which included age, gender, qualifications and key responsibilities. These more personal questions were located at the end of the questionnaire in the hope that the preceding lines of questionıng had 'convinced the respondent that the inquiry was genuine' (Oppenherm 1992132 ).

The questionnarre comprised a range of 'closed' and 'open' question formats. The alm of this approach was to capture easily-analysed and comparative data, while also providing the respondent with opportunities to ralse and comment upon issues that were not specifically addressed in the questions. The questionnaire was presented in an intuitive format At the start of each major section, a brief explanation of the importance of the questions was given. The survey comprised 60 questions presented in a booklet format ${ }^{18}$. It was printed in 12-point Arlal font to ensure that it was suitably SENDA compliant. ${ }^{19}$ A covering

\footnotetext{
${ }^{16}$ Appendix 5 contains a copy of the questionnarre used in this research

19 SENDA - The Special Educational Needs and Disability Act, 2001
} 
letter $^{20}$ explained the purpose of the survey and emphasised the confidential nature of the survey.

The first part of the questionnaire established the type, age, location, staffing levels, and ownership of each heritage site. Questions within this section were presented in a simple and accessible format, with the aim being to ensure consistency of completion and the acquisition of detailed comparative data.

The second part of the questionnaire was entitled 'Management of heritage sites' and aimed to probe the issues of approaches and barriers to sustainable management of heritage sites. This part was subdivided into four sub-sections associated with the issues analysed in Chapter 1 . The first section, 'Visitors and Visitor Management', aimed to capture information relating to socio-cultural sustainability. This section incorporated ideas from existing work on visitor characteristics (Moscardo 1996, Swarbrooke 2002, Poria, Biran and Reichel 2006), the production and consumption of interpretive materials (Samuel 1994, Light 1995, Uzzell 1996, Brethnach 2006) and community engagement with heritage sites (Hitchcock and Darma Putra 2005, Aas, Ladkin and Fletcher 2005, Hampton 2005). The second section was entitled 'Environmental Management'. As studies concerning environmental management of heritage are negligible, examples of existing research from other, related, disciplines was explored (Johannson 1997, Merritt 1998, Carisen et al., 2001). Questions were formulated to identify levels of awareness of issues of environmental sustainability and existing levels of adoption of environmental practices.

${ }^{20}$ Appendix 6 contains a copy of the cover letter 
Barriers to implementation and the impacts of implementation were also explored

The third section, entitled 'Financial Management', aimed to probe sources of income, profit generation, and expenditure Questions in this section were designed to buld on the limited existing literature relating to the profitable management of heritage (Cole 2004) and to provide evidence of barriers and stımulı to the economıc sustainability of heritage sites The fourth section, entitled 'Advice, Guidance and Staff Tranning', aimed to probe differences in levels of support and training offered to staff at the different types of heritage site The final part of the questionnaire, entitled 'About You', probed Issues relating to the roles, responsibilities and characteristics of heritage managers in order to gauge whether or not these factors influenced the implementation of sustaınable management practices.

\subsubsection{The Pilot Study}

The wordıng and format of the questionnalre design was tested by undertakıng two pilot surveys. Veal (1997) suggests that a pllot is necessary not only to test the sequencing, response tıme, and clarity of wording and layout, but also as a means of testing the effectiveness of the analytical framework. The first of two pllot surveys was undertaken with a single heritage professional from the National Trust. Feedback on the types of questions, the flow of the questions, and the appropriateness of the line of questioning was obtained. In additson to makıng some suggestions regarding minor changes to question wording, the heritage professional regarded the survey as being constructed to a high 
standard and suitable for circulation to heritage managers. In detail, the feedback included the need to reduce the amount of text in the question describing visitor types (Q18), thus making identification easier for the respondent. The feedback also suggested that while the introductory paragraphs placed before each section were useful in explaining the relevance of the research, a more comprehensive covering letter, addressed specifically to the respondent, would improve the questionnaire format and response rate. In light of these comments, question 18 was redrafted to achieve a clearer version and a more comprehensive covering letter was composed. These revisions were re-approved by the heritage professional.

The second pilot survey then was sent to eight sites, selected by stratified random sampling from within the five populated heritage categories. In this way, four historic churches, two museums and archives, two marine and maritime sites, two archaeological sites, and one historic house and/or castle were contacted. Pilot responses were received from one historic house and/or castle, one archaeological site and two historic churches.

As a result of the feedback received from the recipients, a number of further changes were made to the survey. Although the questionnaire was always intended to be anonymous, it was decided for administrative reasons to include a specific identifier on each questionnaire that would allocate replies to each specific category of heritage and specify the type of site. Such an identifier would allow analysis by heritage types and enable late responses to be reminded about completion. It was found that two specific questions in the pilot had not been completed by any of the pilot survey respondents. Both questions 
asked the respondent to rank the importance of different types of interpretatıon In achieving environmental sustanability and socio-cultural/economic sustannability Seemingly, the relative complexity of this question discouraged a response As a result, the two 'problem' questions were reviewed and then replaced with stmplified alternatives which still aimed to achieve a useful response In the case of environmental sustanability, the question was changed to ask the respondent to Identify the type of interpretation that they felt exerts the least environmental impact (Q22), while the other problematic question was simplified to reduce confusion about the ranking of variables (Q21) The pllot also identified that more space was needed to allow respondents to comment and elaborate on therr responses Further space was therefore provided in all of these cases

\subsubsection{Sampling methods, strategy and validity}

With the comprehensive listing of all heritage sites based in the five different heritage categories undertaken in Phase 1 of this project, the total number of sites for survey was counted In total, some 1,734 sites were identified across these five categories. The questionnaire was therefore posted to all the heritage sites concerned. It was known that surveys of this type usually produce a response rate of only 25 per cent (Holbrook, et al. 2007). While higher percentage responses have historically been seen by many to represent a reduction in sample bras (Aday 1996, Rea and Parker 1997), more recent research contests this assertion, suggestıng that in some cases lower response rates were only marginally less accurate (Holbrook et al. 2007). However, it is 
recognised that, while a lower response rate does not automatically mean that findings will be less reliable, the risk of bias in the results is higher.

In this research, a response rate of 24.3 per cent $(421 / 1734)$ was ultimately achieved (Table 3.3). Unfortunately, however, responses rates were not distributed evenly across the categories, with considerably higher rates from historic churches and museums and archives. The response from archaeological sites and marine and maritime sites were exceptionally and disappointingly low. It emerged that the main reason for the lack of any response from these groups was that many of their sites are not actively managed and so there are no staff regularly available to deal with matters such as making responses to questionnaires. With hindsight, although none of the information sources used to compile the database included appropriate details, it is clear that it would have been helpful to have somehow ascertained in advance whether or not there might be an appropriate person to respond at all the sites earmarked for inclusion.

As a result of the lack of response from two of the categories (marine and archaeology), it was decided with some regret to exclude them from further analysis in this research. However, once these two 'problem' categories had been excluded, the overall response rate for the remaining categories rose to 35.7 per cent. Nevertheless, as Table 3.3 shows, the response rate from historic houses and/or castles was still only 22.0 per cent. In consultation with a heritage professional from the National Trust, it was decided that an attempt to boost this response rate by sending a second batch of surveys was unlikely to improve the situation. 
Table 3.3. Sampling strategy and associated response rates

\begin{tabular}{lccc}
\hline \multicolumn{1}{c}{ Site types } & $\begin{array}{c}\text { Number of site in study } \\
\text { area with addresses } \\
\text { (from inventory) }\end{array}$ & $\begin{array}{c}\text { Number of } \\
\text { questionnaires } \\
\text { sent }\end{array}$ & $\begin{array}{c}\text { Number of } \\
\text { responses }\end{array}$ \\
\hline $\begin{array}{l}\text { Historic Church } \\
\text { sites }\end{array}$ & 931 & 931 & $345(37.3 \%)$ \\
$\begin{array}{l}\text { Museum and } \\
\text { Archive sites }\end{array}$ & 183 & 183 & $60(32.8 \%)$ \\
$\begin{array}{l}\text { Historic House and } \\
\text { or Castle sites }\end{array}$ & 50 & 50 & $11(220 \%)$ \\
$\begin{array}{l}\text { Archaeological } \\
\text { sites }\end{array}$ & 106 & 106 & $1(1.0 \%)$ \\
$\begin{array}{l}\text { Marne and } \\
\text { mantime sites }\end{array}$ & 464 (Including visited & 450 (excluding & \\
wreck sites) & visited wreck site) & $0(0 \%)$ \\
Unknown & 0 & 0 & 4 \\
Total & 1734 & 1734 & $421(24.3 \%)$ \\
\hline
\end{tabular}

Source: Author

*Note. Many publicly accessible heritage sites are not actively managed and so were not in a position to respond. In these cases addresses of the organisation responsible for their management were used

The capacity amongst site managers for participatıng in this type of research is IImited and so a lower sampie rate simply had to be accepted. Future research Into the sustainability of heritage would need to consider these very considerable barriers to the completion of this kind of enqurry. Importantly, it was recognised that the results would need to be interpreted with care in the knowledge that some of the information might be skewed and unrepresentative. 
However, backed up by further in-depth evidence acquired during face-to-face interviews, every effort has been taken to ensure that the analyses offered in the next chapter are as robust and meaningful as possible.

An assessment of measures of validity were used to assess the methodological approach taken. These measures were based on internal (Robson 1993), content (Neuendorf 2002) and construct (Ryan 1995) validity. In these cases, construct validity is high as whole populations are being used rather than a limited sample. However, low response rates in some categories reduced construct validity. Content validity is also high as concepts have been explored broadly and probed in detail, building on existing literature. Also, internal validity is high as questions were designed to reflect causal relationships in the data, allowing statistical analysis to accurately observe difference. In order to analyse the responses to the questionnaire, the data processing package of SPSS (Statistical Package for Social Sciences) was used.

\subsection{Phase III: Sustainable Management Research Stage (In-depth Interview Stage)}

Phase 3 involved personal in-depth interviews with a selection of those involved in managing and running heritage resources. Inevitably, interviewees were self selecting on the basis of expressions of willingness to participate. However, the aim was to choose representatives of all three types of site and the different ownership and management techniques. 


\subsubsection{Interview method}

An In-depth interview approach was chosen for use in this research as it offered the most effectrve means of augmentıng the data derrived from the questionnaire and probing associated issues For example, it offered the opportunity to explore reasons for non-Implementation in greater detall The data offered by interviewees are regarded as useful because it provides ' .. nch Insights into people's biographies, experıences, opınıons, values, aspiratıons, attltudes and feelıngs' (May 2001, 120). Due to the diversity of heritage sites and managers within the sample, and the anticipated range of issues present at different types of heritage site, a semi-structured interview format was adopted as the most effective means of gathering the most useful and fullest information. In practice, the approach enabled the researcher not only to base the interview on a pre-determıned ist of questions (supporting the need to make comparısons and to link the evidence with the results of the main questionnaıre survey), but also to encourage interviewees to engage in an open and free dialogue that might explore areas of specific concern and relevance May $(2001,123)$ highlighted the benefits of this technique when stating that '. these types of intervew are said to allow people to answer more on their own terms than the standardized interview permits, but still provide a greater structure for comparability over that of the focused interview'.

\subsubsection{Sampling frame}

When designing the survey phase (phase 2) of this research, it was decided that participation in the in-depth interview stage (phase 3) would only be undertaken with questionnasre participants who had clearly identified that they 
would be happy to participate further. While this decision does mean that the sample for interview is self selecting, it was made principally because these parties were found to include both adopters and non-adopters of sustainable practices. The number of potential and willing respondents for this stage of the research was high (Table 3.4 and 3.5 ), but were dominated by respondents from historic churches and museums and archives. Disappointingly, there were no willing respondents from historic houses (and predictably none from archaeological sites and marine and maritime sites). As it had already been decided to exclude marine and maritime and archeological sites from later stages of this research, they were not considererd for interview. However, in order to address the lack of interviewees from the historic houses and/ or castles category, the researcher contacted sites that had indicated that they would like to know more, and sought to explain the nature of the interview and its purposes. Through this method, agreement to participate was secured from one major historic house site. The final sample for the interviews included representatives from five historic church sites, two from museums and archives and one from a historic house and/or castle site (see Table 3.6).

\subsubsection{Interview schedule and design}

The development of an interview schedule was undertaken following the initial analysis of the results of the survey phase on the research. The interview schedule was designed in two sections: for those who had adopted sustainable practices and those who had not. 
Table 3.4. Number and percentage of respondent to question concerning participation in interview phase of research

\begin{tabular}{|c|c|c|c|c|c|}
\hline & 'Yes' & 'No' & $\begin{array}{l}\text { 'I would like } \\
\text { to know more } \\
\text { before saying } \\
\text { yes" }\end{array}$ & $\begin{array}{l}\text { Did not } \\
\text { respond }\end{array}$ & Total \\
\hline \multirow[t]{2}{*}{$\begin{array}{l}\text { Historic } \\
\text { Church sites }\end{array}$} & 48 & 193 & 73 & 31 & 345 \\
\hline & $(139 \%)$ & $(55.9 \%)$ & $(21.2 \%)$ & $(90 \%)$ & $(100.0 \%)$ \\
\hline \multirow{2}{*}{$\begin{array}{l}\text { Museum and } \\
\text { Archive sites }\end{array}$} & 12 & 23 & 16 & 9 & 60 \\
\hline & $(200 \%)$ & $(38.3 \%)$ & $(26.7 \%)$ & $(150 \%)$ & $(100.0 \%)$ \\
\hline \multirow{2}{*}{$\begin{array}{l}\text { Historic House } \\
\text { and or Castle } \\
\text { sites }\end{array}$} & 0 & 8 & 3 & 0 & 11 \\
\hline & $(00 \%)$ & $(72.7 \%)$ & $(273 \%)$ & $(0.0 \%)$ & $(1000 \%)$ \\
\hline \multirow{2}{*}{$\begin{array}{l}\text { Archaeological } \\
\text { sites }\end{array}$} & 0 & 0 & 1 & 0 & 1 \\
\hline & $(00 \%)$ & $(0.0 \%)$ & $(1000 \%)$ & $(00 \%)$ & $(100.0 \%)$ \\
\hline \multirow{2}{*}{$\begin{array}{l}\text { Marrne and } \\
\text { martime sites }\end{array}$} & 0 & 0 & & 0 & 0 \\
\hline & $(0.0 \%)$ & $(0.0 \%)$ & $(0.0 \%)$ & $(0.0 \%)$ & $(0.0 \%)$ \\
\hline \multirow{2}{*}{ Unknown } & 1 & 3 & 0 & 0 & 4 \\
\hline & $(250 \%)$ & $(750 \%)$ & $(00 \%)$ & $(00 \%)$ & $(1000 \%)$ \\
\hline \multirow{2}{*}{ Total } & 61 & 53 & 93 & 40 & 421 \\
\hline & $(14.5 \%)$ & $(12.6 \%)$ & $(221 \%)$ & $(9.5 \%)$ & $(100.0 \%)$ \\
\hline
\end{tabular}

Source. Author 
Table 3.5: Sampling frame for interviews

\begin{tabular}{|c|c|c|c|c|}
\hline & $\begin{array}{l}\text { Total number } \\
\text { of 'yes' or } \\
\text { 'would like to } \\
\text { know more' }\end{array}$ & $\begin{array}{l}\text { Percentage of } \\
\text { respondents } \\
\text { from all } \\
\text { categories }\end{array}$ & $\begin{array}{l}\text { Eight in- } \\
\text { depth } \\
\text { interviews } \\
\text { (proportional) }\end{array}$ & $\begin{array}{l}\text { Number of } \\
\text { agreed } \\
\text { interviews } \\
\text { from each } \\
\text { category }\end{array}$ \\
\hline $\begin{array}{l}\text { Historic Church } \\
\text { sites }\end{array}$ & 121 & $79.1 \%$ & 6.3 & 5 \\
\hline $\begin{array}{l}\text { Museum and } \\
\text { Archive sites }\end{array}$ & 28 & $18.3 \%$ & 1.5 & 2. \\
\hline $\begin{array}{l}\text { Historic House } \\
\text { and or Castle } \\
\text { sites }\end{array}$ & 3 & $2.0 \%$ & 0.2 & 1 \\
\hline $\begin{array}{l}\text { Archaeological } \\
\text { sites }\end{array}$ & 1 & $0.7 \%$ & 0.1 & 0 \\
\hline $\begin{array}{l}\text { Marine and } \\
\text { maritime sites }\end{array}$ & 0 & $0 \%$ & 0 & 0 \\
\hline Unknown & 0 & $0 \%$ & 0 & 0 \\
\hline Total & 153 & $100 \%$ & 0 & 8 \\
\hline
\end{tabular}

Source: Author 
Table 3.6: Sample frame: description of interviewees

\begin{tabular}{|c|c|c|c|c|}
\hline $\begin{array}{l}\text { Interviewee } \\
\text { Number }\end{array}$ & $\begin{array}{l}\text { Inventory } \\
\text { Category }\end{array}$ & $\begin{array}{l}\text { Location } \\
\text { (urban/ } \\
\text { rural/ } \\
\text { coastal) } \\
\end{array}$ & County & Description of heritage site \\
\hline A & $\begin{array}{l}\text { Museum } \\
\text { and Archive } \\
\text { site }\end{array}$ & Urban & Devon & $\begin{array}{l}\text { Small urban museum. } \\
\text { independently financed Single } \\
\text { paid member Support from } \\
\text { volunteers. Seasonal opening }\end{array}$ \\
\hline$B$ & $\begin{array}{l}\text { Historic } \\
\text { Church site }\end{array}$ & Urban & Devon & $\begin{array}{l}\text { Medium sized urban church. Large } \\
\text { congregation Declining quality of } \\
\text { building. Managed by volunteer } \\
\text { wardens. Low visitor/ tourist } \\
\text { numbers }\end{array}$ \\
\hline C & $\begin{array}{l}\text { Historic } \\
\text { Church site }\end{array}$ & Rural & Cornwall & $\begin{array}{l}\text { Small rural church. No electricily } \\
\text { One resident living in parish. } \\
\text { Managed by volunteer wardens. } \\
\text { Seasonal tourist/ visits. }\end{array}$ \\
\hline $\mathrm{D}$ & $\begin{array}{l}\text { Historic } \\
\text { Church site }\end{array}$ & Rural & Cornwall & $\begin{array}{l}\text { Medium sızed rural church Local } \\
\text { community support Undertakes } \\
\text { tncome generating activities. } \\
\text { Managed by volunteer wardens }\end{array}$ \\
\hline$E$ & $\begin{array}{l}\text { Historic } \\
\text { Church slte }\end{array}$ & Coastal & Devon & $\begin{array}{l}\text { Small rural church based in AONB } \\
\text { High visitor number, minimal } \\
\text { revenue generatıng activities } \\
\text { Managed by volunteer wardens }\end{array}$ \\
\hline$F$ & $\begin{array}{l}\text { Historic } \\
\text { Church site }\end{array}$ & Urban & Cornwall & $\begin{array}{l}\text { Large urban church, high visitor } \\
\text { numbers Multıple revenue } \\
\text { generating activities. High levels of } \\
\text { volunteers }\end{array}$ \\
\hline G & $\begin{array}{l}\text { Historic } \\
\text { House } \\
\text { and/or } \\
\text { Castle }\end{array}$ & Rural & Cornwall & $\begin{array}{l}\text { Large rural historic house Owned } \\
\text { and managed by large, national, } \\
\text { heritage provider High numbers of } \\
\text { staff and volunteers. Profitable site } \\
\text { with high visitor numbers }\end{array}$ \\
\hline $\mathrm{H}$ & $\begin{array}{l}\text { Museum } \\
\text { and Archive } \\
\text { site }\end{array}$ & Urban & Devon & $\begin{array}{l}\text { Medium sized urban museum High } \\
\text { visitor numbers. Financially viable. } \\
2 \text { paid staff and high numbers of } \\
\text { volunteers }\end{array}$ \\
\hline
\end{tabular}

Source: Author 
Questions within these two schedules were, however, very similar and were based around the three areas of the survey: namely, issues of economic, sociocultural and environmental sustainability.

The interview schedules aimed to identify the drivers for the implementation of sustainable techniques and barriers to their implementation, as well as uncovering unique problems or innovations present at each site. The full interview schedule is included in Appendix 7.

The interview schedule was planned to require between 30 and 45 minutes. In practice, the meetings tended to take considerably longer and conversations ranged very widely over all issues related to the running of heritage places and looking after structures and collections that have historical importance. Where requested, a summary of the key themes was sent to the participant in advance. In order to reflect the comments and statements given by the interview participants accurately, each interview was recorded on a dictaphone. Consent was sought from all interviewees regarding the use of recording equipment, and all further associated ethical issues were discussed with the interviewees. The interviews were completed in accordance with the agreed University of Plymouth ethical approval process. Each of the taped interviews was later manually transcribed in full by the researcher. The transcriptions of these interviews are included in Appendix 8. 


\subsubsection{Interview analysis framework}

Analysis of interview data was undertaken by transcription and through nonstatıstıcal content analysıs Software, such as Nvivo, were considered for this process, but discarded as their function is often more effective with much larger datasets and more relevant to statıstical content analysıs. Key themes were based on question responses to form a categorical approach to analysis. Responses were analysed and themed on the basis of their reference to issues of socio-cultural, economic and environmental sustainability and were interrogated to identify information in support of, or in opposition to, the results of the initial survey Case studjes relatıng to models and examples of practice were also Identified and drawn from the interviews Due to the varlations between issues discussed by managers/custodians from different types of heritage, the transcripts were divided into groups relating to their heritage category types before the analysis was undertaken In this way, a better understanding of the simılar and contrasting issues of different heritage types could be achieved

\subsection{Conclusion}

This chapter has sought to justify and evaluate the methodological process adopted in all three phases of the research project The starting point of the enquiry was the formulation of a region-specific typology of heritage resources, which acted as the framework for the inventory/database The population of the database with relevant information proved difficult and time-consuming, so completion of all heritage categones was not feasible. Instead, five heritage 
categories were entered into the inventory, which served to illustrate both the difficulties of using multiple sources to compile a meaningful dataset and its potential utility for a range of stakeholders in heritage management. Moreover, for the purpose of this research, the database enabled the representativeness of the postal survey to be guaged by providing a complete sampling frame. The postal questionnaire investigated the extent of, and opinions about, sustainable management approaches at visited heritage sites in Devon and Cornwall. On the basis of the results, a further phase of the research involved semistructured, face-to-face interviews with a small number of heritage managers which enabled an exploration to be made of key issues in much greater depth. Through the linking of quantitative and qualitative methods, in a way that recognised their respective strengths and limitations, the scope of this study was extended both in breadth and depth. The following chapter, Chapter 4, discusses the results from this research.

It is acknowledged that while data gathering for the research project has generally been satisfactory, there have been some unforseen disappointments. Ideally, the investigation should have surveyed representatives of all fifteen categories of heritage place, but it became apparent that an enquiry on such a huge scale - even for just two counties - was simply not practicable. A survey of a third of the range (i.e. five of the categories) was deemed to be achievable. Immensely careful thought was given to the choice of those five categories. The selection of historic churches appears to have been sound. Churches represent a neglected type of heritage resource and their inclusion in this research sheds some new light on their sometimes ambivalent and problematic role within the sector. In view of their almost automatic association with the notion of heritage 
In the minds of tounsts and popular Imaginatıon, historic houses/castles were thought to be a critical category, but it proved in practice to be immensely difficult to secure the partıcipation of a significant number of those represented in Devon and Cornwall. Well-endowed with a great many small museums/archives, more often than not accommodated in historically important premises, the selection of that category seemed obvious; and proved to be a worthwhıle choice However, the partıcular quality of archaeological heritage, and marıne and maritme heritage in Devon and Cornwall proved in fact to be a seductive, but ultımately perfidıous reason for choosing those categories to complete the five. The fact that the sites are publicly accessible did not mean that many are commodified and staffed. With hindsight, alternative categories would have been better. Notwithstanding these critical reflections on the data gathering phase of the research, it is important to re-emphasise that the analysis presented in the next chapter is based on a dataset that comprised $416^{21}$ questionnaire responses and the detalled evidence gathered in eight lengthy, in-depth interviews The findings to be discussed in Chapter 4 are therefore well-founded on a body of new evidence and the conclusions that are drawn, it is contended, can be regarded as valuable.

\footnotetext{
${ }^{21} 421$ responses were recelved from the postal questionnare However, five of these responses were from categories with very low response rates. For this reason these five sites were removed from further analysıs, leaving a total of valid responses 


\section{CHAPTER 4}

ENVIRONMENTAL, SOCIO-CULTURAL, AND ECONOMIC SUSTAINABILITY

IN THE MANAGEMENT OF VISITED HERITAGE IN DEVON AND CORNWALL.

\subsection{Introduction}

This chapter presents the findings and analyses of both the 416 questionnaires and the eight in-depth interviews carried out with representatives of the sample of heritage churches, museums/archives, and historic houses/castles in Devon and Cornwall. ${ }^{22}$ Respondents were questioned about the factors that either facilitated or impeded the sustainable management of heritage resources whether economic, socio-cultural or environmental. Theoretically, if implemented correctly, all three forms of sustainability are mutually supportive. If a site is achieving its socio-cultural goals, then visitor satisfaction ought to be secured. Healthy visitor numbers contribute to the economic sustainability of the site, which can be further improved by environmental measures. Environmental sustainability also enhances socio-cultural sustainability through its care of the local environment and resources. Investment costs incurred as sustainable practices are adopted are later likely to be recouped by the cost-savings envisaged; and, if increased admissions result, the expense of making

\footnotetext{
${ }^{22}$ As described in Chapter 3, the sample of 416 respondents to the questionnaire survey comprises three main response groups: historic churches (345 responses; response rate of 37.3 per cent); historic houses and/or castles (11 responses; response rate of 22.0 per cent) and museum/archives (60 responses; response rate of 32.8 per cent). While higher response rates would have been desirable, those obtained in this survey lie within the acceptable range for social science investigations (Holbrook et al. 2007). The in-depth interview respondents were selected in order to provide a proportionate representation of each of the categories.
} 
Improvements to meet visitor needs will be recovered This so-called 'triple bottom line' (3BL) approach integrates economic, socio-cultural and environmental sustanability objectives in a strategıc manner (Kleındorfer, Singhal and Van Wassenhove 2005). As explanned in Chapter 1, the 3BL approach resembles the Idea of corporate social responsiblity (CSR) that exists in the world of commerce and business (Henderson 2007). Although it might be argued that other forms of sustannability are made possible and feasible in those operations which are economically sustainable, in this symbıotic relationship, no one form of sustainability takes precedence over the others.

The chapter outlines the environmentally sustanable practices that operators of heritage attractions have been able to introduce, together with a review of the main drivers and motivations for such actions. Additional dimensıons of sustanability, such as the socio-cultural and economic aspects, are then evaluated. From this analysis, a number of constraints on the ability of heritage providers to respond to the sustanability agenda are discussed Throughout the discussion, variations between the sustanability performance of museums/archives, histonc houses/castles, and histonc churches in the Implementation of sustanable management practices (economic, environmental, and socio-cultural) are noted. In the case of historic churches, it is important to re-emphasise that because therr primary function is not that of tourist attractions (but as places of worship), it is therefore inevitable that a lower priority is currently given by them to issues of sustainability in terms of the policy implications of this research, examples of effective sustainable practices that are revealed might offer potentially useful and practical insights that could be shared more widely to help those who manage hentage in Devon 
and Cornwall to develop more coherent, co-ordinated and profitable approaches.

\subsection{Sustainable Management of Heritage}

The heritage places included in the survey clearly assign very different levels of priority to aspects of sustainable management: namely, economic, environmental and socio-cultural sustainability. Moreover, there is considerable variation between the categories (Fig. 4.1). The type of sustainability which was most commonly ranked as the top or joint-top operational priority across all forms of heritage in the questionnaire sample was socio-cultural ${ }^{23}$ (67.8 per cent). Some 31.1 per cent of respondents ranked economic sustainability as their top or joint-top priority, although this concern was highest amongst the museums/archives (48.1 per cent). The lowest priority across all types of heritage was accorded to environmental sustainability (2.5 per cent $\left.{ }^{24}\right)$, although it was clear that the historic houses/castles group had, by some margin, given this concern more attention than the other types (12.5 per cent as opposed to 1.8 per cent in churches and 3.8 per cent in museums/archives). In most cases, the respondents are responsible for conserving artefacts of historic interest and so their management practices might be expected to align with environmental responsibility and the broad ethos of sustainability.

\footnotetext{
${ }^{23}$ Socio-cuitural sustainability was defined in Chapter 1

${ }^{24}$ Low average value for ail three groups are caused by low values within the most dominant group. As such these are viewed in conjunction with individual group values to ensure variations are shown
} 

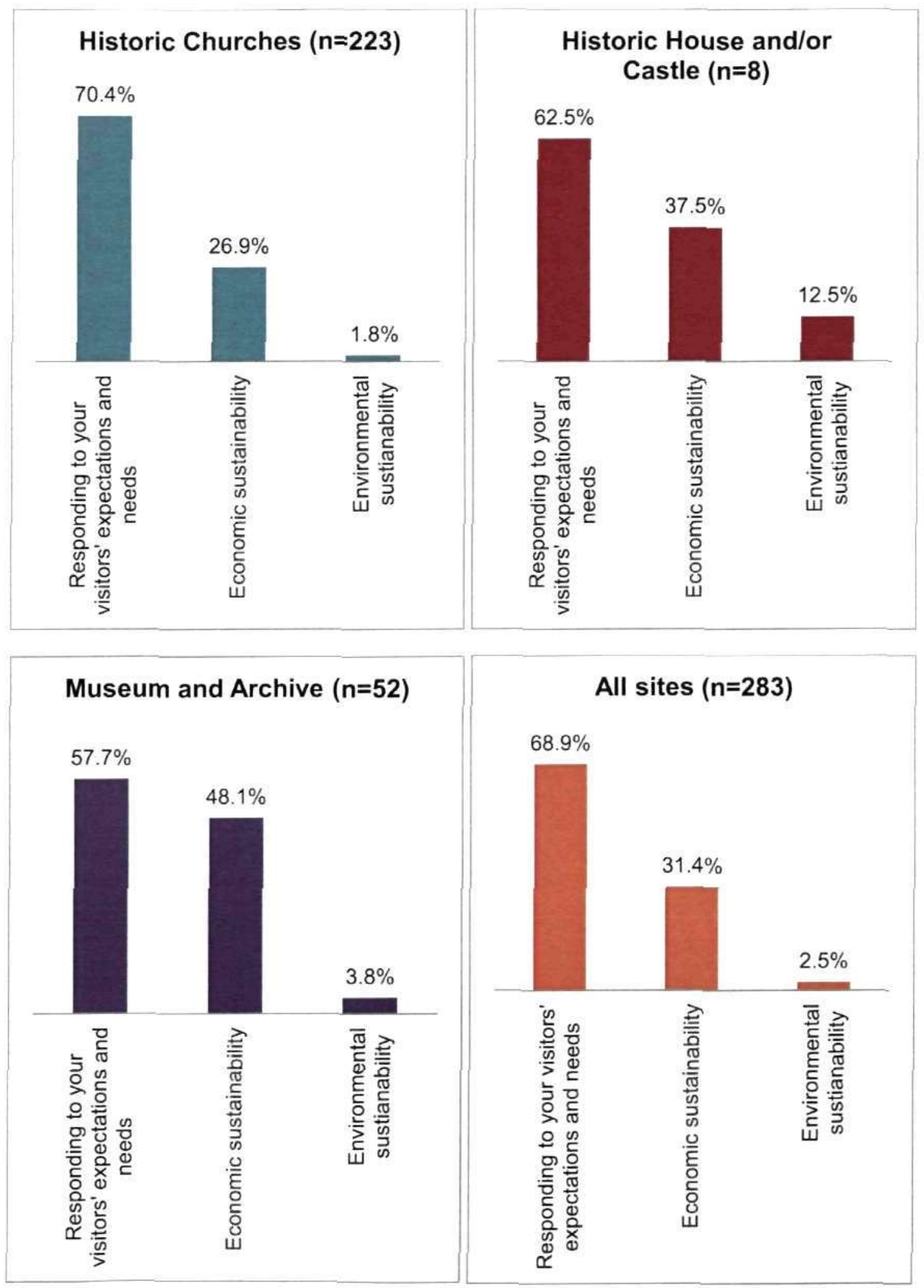

Figure 4.1. Percentage of respondents identifying their top, or joint top, operating priority. Source: Author. 
Instead, the results suggest that, amongst the heritage attractions surveyed in this research, environmental sustainability is accorded the lowest priority, whereas profitability and engagement with local communities, which have been longer-established management concerns and are now [re-]presented under the new nomenclature of 'sustainability', are given much higher priority. Explanations for the balance of sustainability priorities reported by the questionnaire respondents will be sought in the analysis and discussion that follows.

\subsection{Environmental Sustainability}

Despite the low priority given to environmental sustainability, a large percentage of respondents in the survey said that operating in an environmentally friendly manner was either 'important' (42.7 per cent) or 'very important' (40.3 per cent) (Fig. 4.2). Indeed, the proportion of heritage respondents stating that operating in an environmentally friendly manner was either 'important' or 'very important' (83.0 per cent) was higher than that found in a comparable study of tourism businesses in the Caradon district of Cornwall (Vernon, Essex and Pinder $2002)^{25}$. However, some variations clearly exist between different types of heritage site. A larger percentage of historic houses/castles regarded environmental friendliness as 'very important' (72.7 per cent) than is the case for museums/archives (46.2 per cent) or for historic churches (37.7 per cent). The reasons given by respondents for the importance accorded to the aspiration of environmental friendliness are shown in Fig 4.3.

\footnotetext{
${ }^{25}$ In the Caradon survey, the comparable percentage was 77 per cent
} 

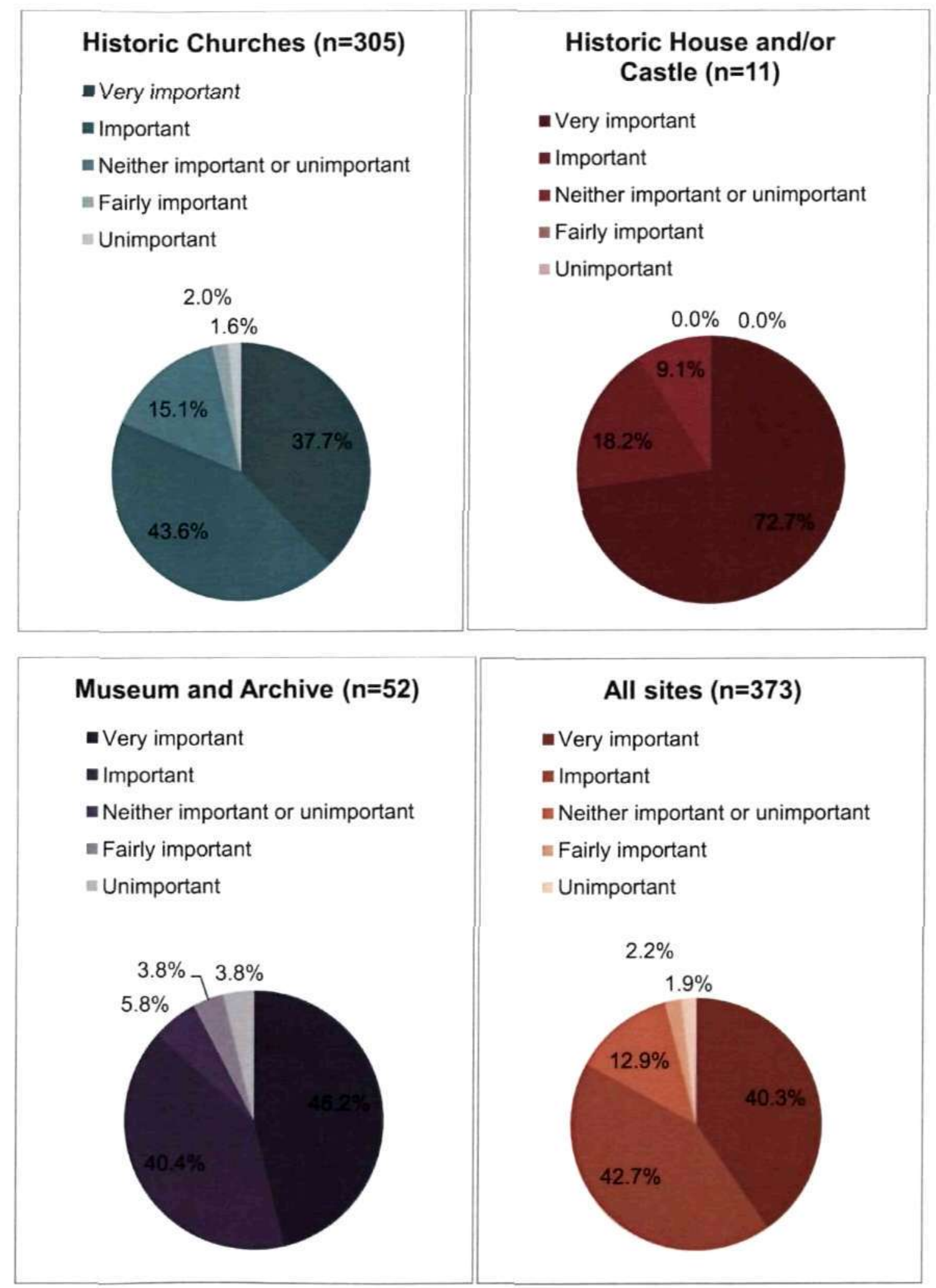

Figure 4.2. The perceived importance of operating in an environmentally friendly manner. Source: Author. 


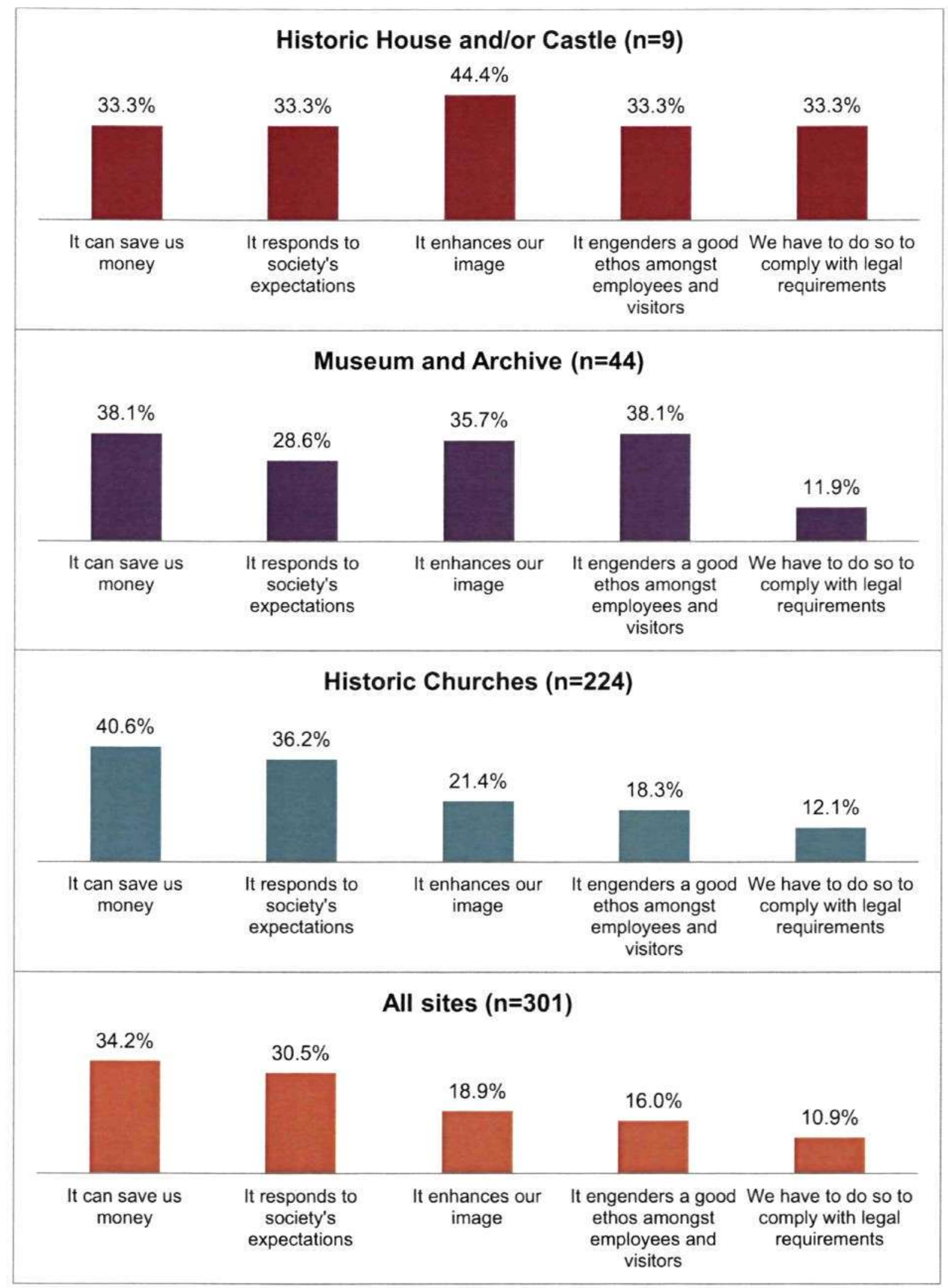

Figure 4.3. Reasons that make it important to operate in an environmentally friendly manner. Source: Author. 
For all three heritage categories, 'saving money' (34.2 per cent) and 'responding to society's expectations' (30.5 per cent) emerged as the two most prominent motivations. Compliance with legal requirements was the least important (10.9 per cent). Although broadly similar findings were reported in the 2002 survey of tourism business in Caradon (Vernon, Essex and Pinder 2002), slightly lower percentages of the heritage providers regarded 'improved image' (18.9 per cent) and 'responding to society's expectations' (30.5 per cent) as being important than was the case amongst the tourism businesses surveyed in Caradon (42 and 53 per cent respectively). Amongst the providers of heritage attractions, the imperatives of caring effectively for their site and preserving its integrity outweigh concerns about constructing a good external image or privileging the demands made by wider society. This finding supports Garrod and Fyall's 2000 contention that the curatorial drive remains dominant.

Both the questionnaires and the interview responses clearly showed that cutting costs was a key motivation for the adoption of environmentally sustainable practices and highlighted the interconnections between the different forms of sustainability. One interviewee pointed out that:

We are rethinking these things constantly and looking for ways in which we can improve our efficiency because, basically, it boils down to money... and anything we can do to reduce costs is beneficial (Interviewee E).

Undoubtedly influenced by the widespread publicity now given to environmental issues, the economic gain that might be made by adopting 'green technologies' (including low-energy light bulbs and fuel-efficient boilers), was underlined by several interviewees in the survey. For example, Interviewee D commented that 
'we need to use energy-saving bulbs ... we like to think we could reduce our electricity bill long term'. Compared with the other two heritage categories, historic houses/castles accorded more importance to environmentally friendly practices as a means to enhance their public image (Fig. 4.3). In doing so, they recognise the interconnections between environmental sustainability, economic sustainability, and socio-cultural sustainability. Indeed, acknowledging the priority that his organisation attached to 'image', Interviewee $G$ (who represented a National Trust property) noted that environmentally friendly operations are 'a bit of a no-brainer because of the type of organisation we are ... looking after incredibly beautiful places forever and for everyone'. Looking after a place forever to him meant looking after it in a sustainable manner. Moreover, Interviewee $\mathrm{G}$ directly mentioned the National Trust's 'Triple Bottom Line' (3BL) approach whereby economic, socio-cultural and environmental sustainability practices are regarded as intimately interlinked (Kleindorfer, Singhal and Van Wassenhove 2005).

We have a Triple Bottom Line approach ... we look at it in financial, environmental and social terms. Sometimes the environmental and social measures come out as a higher priority than financial returns, and it is still justified (Interviewee G).

Although representatives of the management of historic houses/castles have appreciated that social and economic benefits can be secured by adopting environmentally sustainable practices, comparably sophisticated, integrated sustainable management approaches do not yet appear to be widespread in the historic churches and the museums/archives heritage categories. While some evidence was found, especially amongst some managers of museums/archives, of an understanding that environmentally friendly practices might help to 
enhance their public image, few showed a full or convincing appreciation of the Interconnections. Interviewee A (representing a museum) claimed that 'making money and satısfying the market' were more important drivers than environmental sustainability because 'not many people in the museum world are interested in environmental issues'. Interviewees representing historic churches generally saw 'the environment' as 'important' to their staff, visitors and congregations. Thus, Interviewee B sald 'most people in the church are quite environmentally conscious'. Persuasive evidence of etther aspirations or the adoption of environmentally friendly measures as a means of promotıng a 'good practice' Image was not found A respondent from a church noted that: 'We just get together with the congregation and ask for volunteers and take it from there on a farly ad hoc basis' (Interviewee E).

\subsubsection{Adoption of Environmental Measures: The Implementation Gap}

So far it has emerged that many of the representatives of the heritage sites in this survey understand the importance of operatıng in an environmentally friendly manner; moreover, just a few have also recognised the beneficlal lınkages between 'saving money', 'responding to society's expectations, and 'being green' Nevertheless, a considerable proportion has yet to mplement any environmentally friendly measures (Fig. 44 ). Notwithstanding the $70+$ per cent of respondents who reported that low-energy light bulbs had been fitted, the take-up of other measures was strikıngly modest. 


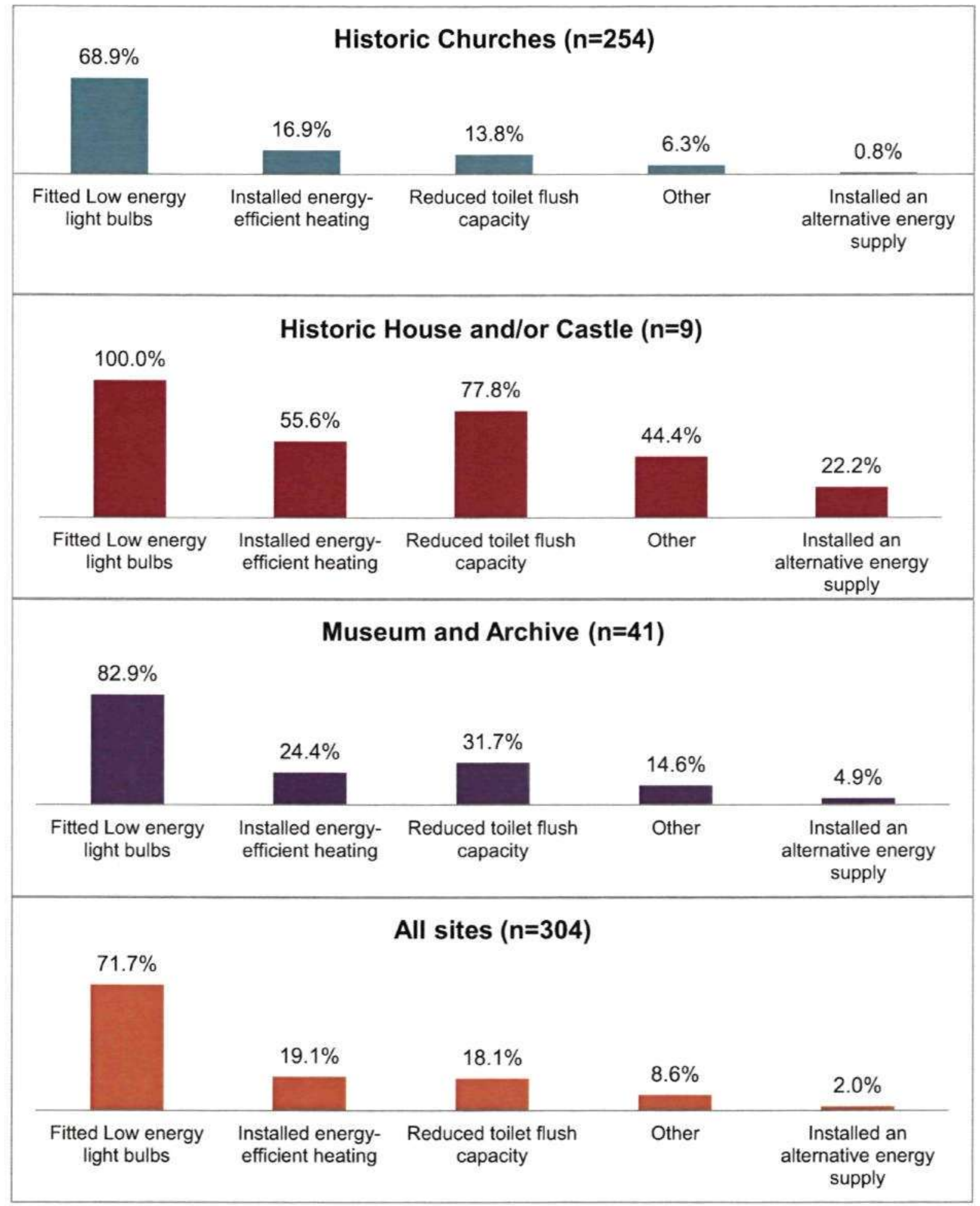

Figure 4.4. Percentage of respondents who identified that they had implemented the measures described to reduce resource consumption. Source: Author. 
Less than 20 per cent have installed energy-efficient heating; only two per cent have added an alternative means of supplying energy (such as solar panels); and less than 20 per cent have fitted water-efficient lavatories. Changing light bulbs is cheap and relatively easy and is generally regarded as accepted conventional practice.

Measures to reduce waste production and to engage in recycling similarly appear generally to have been taken up by a somewhat modest percentage of heritage providers in the survey. Only the recycling of paper/cardboard was found to have been implemented in more than two-thirds (67.6 per cent) of the cases (Fig. 4.5). Recycling of glass and plastic, and composting garden and kitchen waste was practised by just less than 45 per cent of respondents. However, in line with previous findings, the record of the historic houses/castles was better than that of the other categories. Nevertheless, the relatively modest take-up figures overall for reducing resource consumption and waste production do not apparently square with the expression of clear support for environmental sustainability identified in section 4.2. There appears to be an implementation gap between the stated aspirations of the providers and the reality of what has been achieved to date.

Indeed, only 12.9 per cent of providers stated that they had in place an environmental sustainability strategy or policy (Fig. 4.6). Amongst the historic churches, just 8.7 per cent reported the existence of such a strategy. 

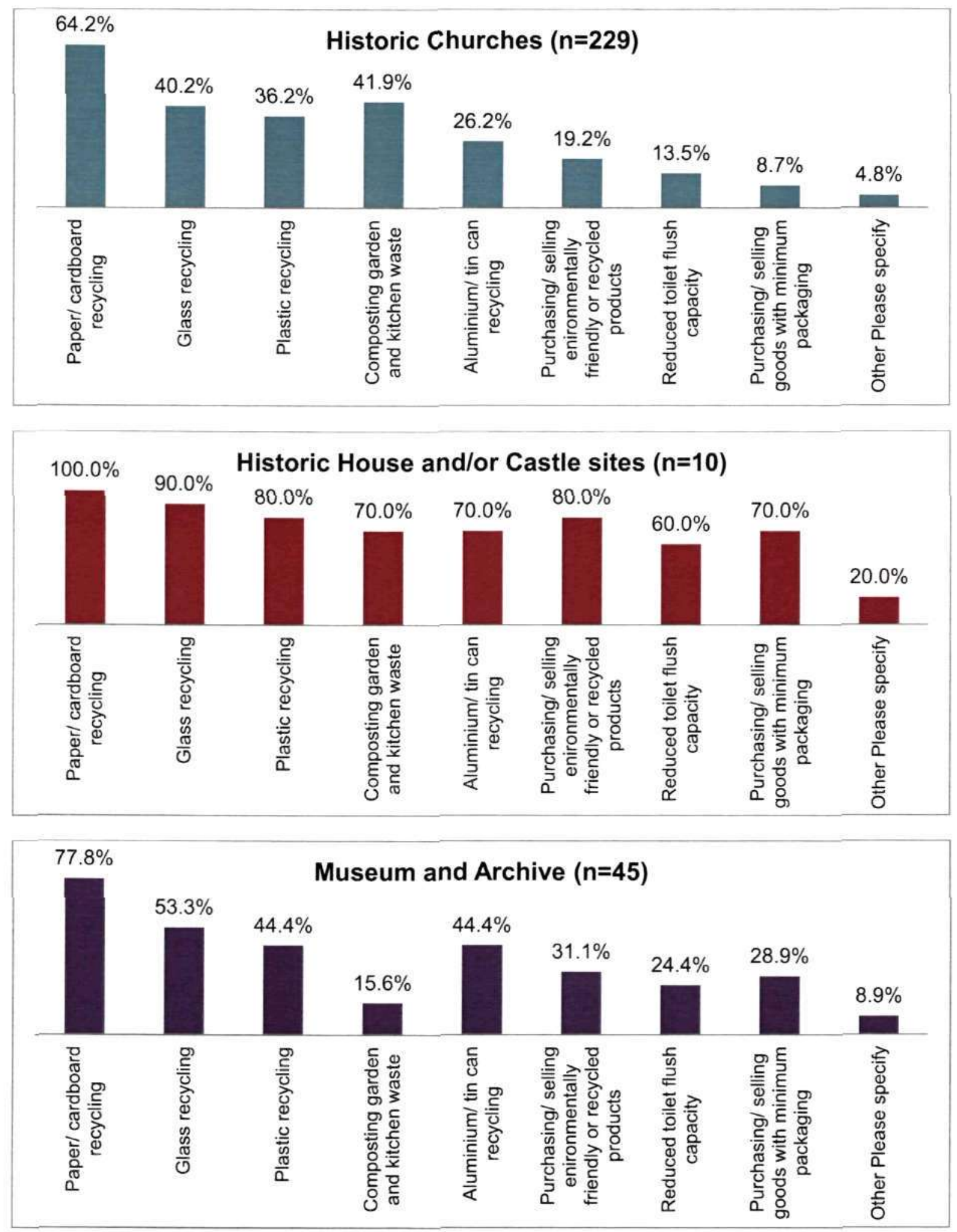

CONTINUED ... 


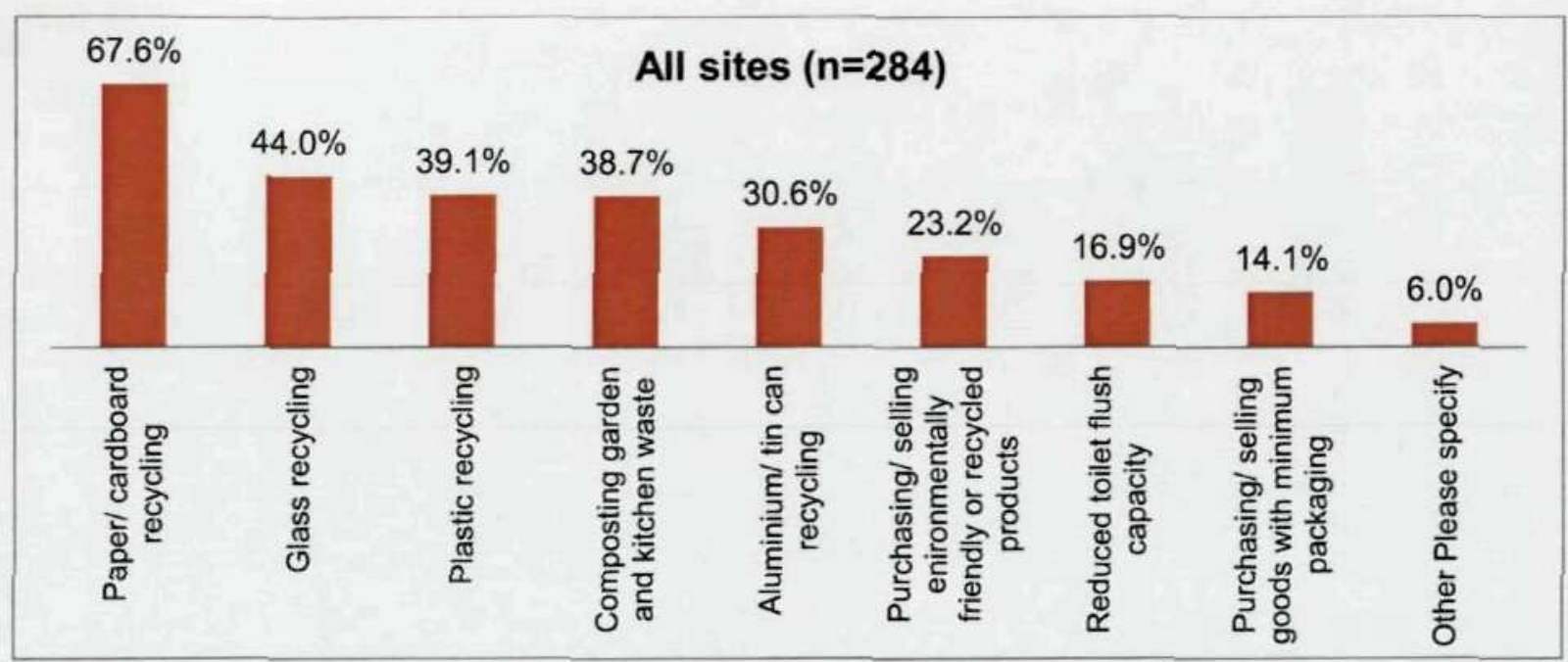

Figure 4.5. Percentage of respondents identifying that they have implemented the given measures to reduce waste production. Source: Author. 

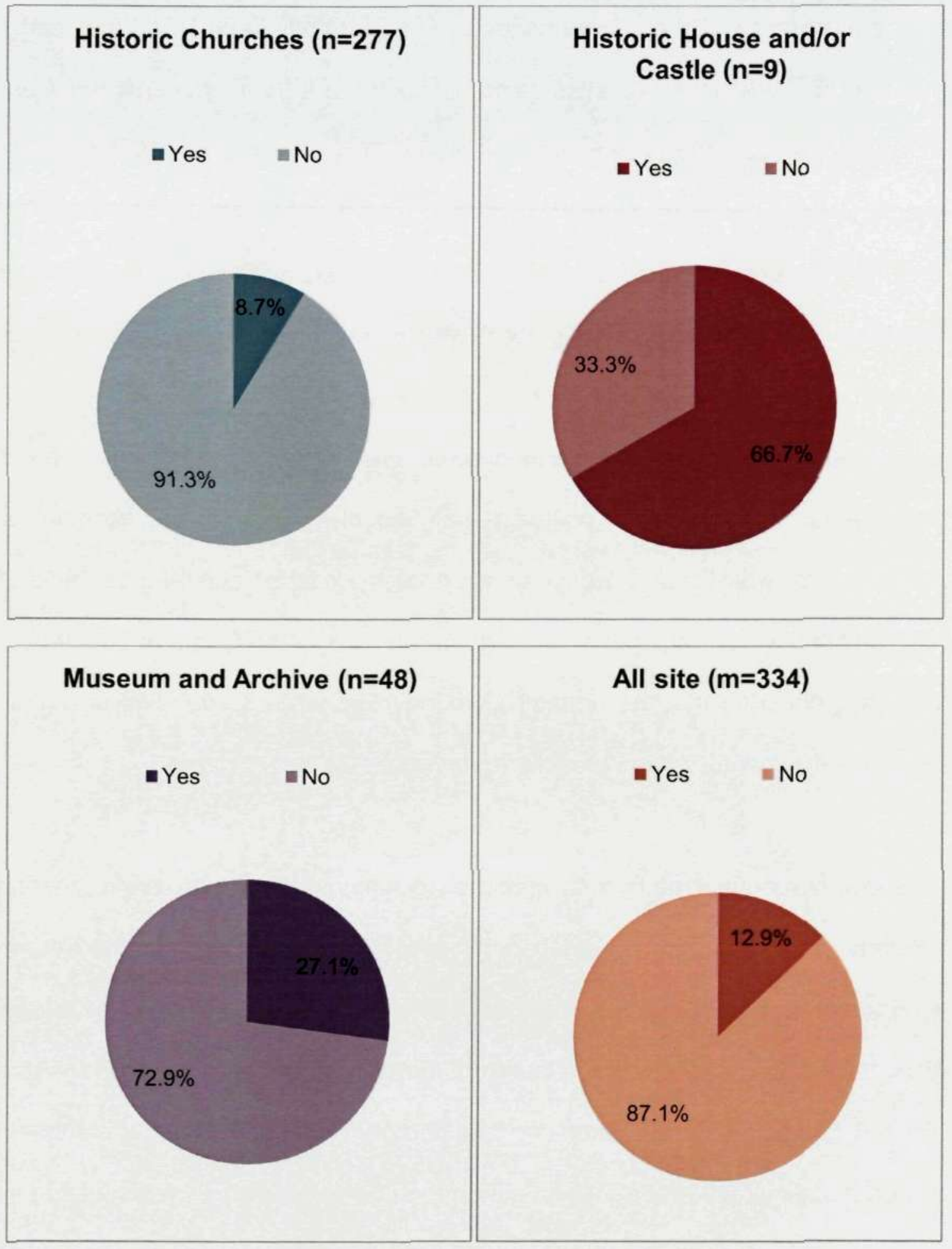

4.6. Sites that have identified that they have an environmental strategy or policy 
The performance of the museums/archives was rather better (27.1 per cent). However, historic houses/castles stand out, with more than two thirds (66.7 per cent) saying that they possessed a strategy. This category included a higher proportion of sites that belonged to larger, parent organisations. As might be expected, therefore, these organisations operate specific, well-communicated environmental strategies. Interviewee $\mathrm{G}$ stated that 'when this new strategy was introduced ... for me it was: well that's what we should be about as an organisation'. This interviewee added comments on the long-term character of the strategic environmental planning that had been undertaken, like that at 'Wicken Fen, which has a 100-year vision for the site'. A central imperative of the National Trust strategy is 'financing our future, so achieving that 20 per cent net gain, ensuring that the amount of money that we are spending is slightly less than the money we are making' (Interviewee G).

The low percentage of historic churches claiming to have an environmental strategy requires further examination. It has already been noted that the Church of England does have a coherent and well-articulated environmental strategy: Church and Earth 2009-2016 (Church of England 2009) and, prior to this, the Church had launched its Shrinking the Footprint national strategic campaign (Church of England 2006a), which aimed to address environmental issues in all church buildings in the country. However, 91.3 per cent of the respondents from the Devon and Cornwall historic churches included in this survey thought that the Church of England did not have a strategy. Their answers suggest that the Church's central policy is either not being effectively communicated or it is seen to have little direct relevance. The latter supposition is underlined in a comment made by Interviewee A. Though aware of the Shrinking the Footprint strategy, 
he nonetheless contended that it had not been implemented in their church. He added that 'a lot of [what we do] is just off our own bat, and a lot of the congregation wouldn't know anything about that'.

All interviewees representing historic churches also mentioned the Church Architects: a body which inspects and reports on a church's physical condition, and requires the devising of a maintenance plan for a five-year (quinquennial) period. Such maintenance plans are devised to ensure that historic buildings remain structurally sound, both inside and outside. They are not concerned per se with achieving environmental sustainability.

Museums/archives reported that they receive advice and guidance from many sources and actively pursue cost-saving ideas themselves. One interviewee mentioned the Museums, Libraries and Archives Council (MLA), as well as local government, as providers of advice on energy saving together with some training and funding. In Chapter 1 of the thesis, the 2009 a strategy document entitled Leading Museums: A Vision and Strategic Action Plan for English Museums, which provides guidance on sustainable approaches to curatorship was described. The MLA relies on local managers of museums/archives to implement and develop their own policies, but it does offer a central source of assistance similar to the National Trust, as well as providing some competitively allocated grants. ${ }^{26}$ Advice is also available from regional or county bodies such

\footnotetext{
${ }^{26}$ The MLA offers two specific types of funding to organisations within their sector: (1) The Fund for the Preservation of Industrial and Scientific Material (PRISM) provides grants to help in the acquisition and/or conservation of any object or group of objects illustrating the history of any branch of science, industry or technology (MLA 2010). An annual total of $£ 250,000$ is divided between all successful applicants; (2) The Purchase Grant Fund, administered by the Victoria \& Albert Museum, offers grants for the
} 
as, for example, the Devon Museum Group, which can provide funding to pilot the use of energy and cost-saving technologies. One respondent stated that 'I talk to everybody, initially through the Museum Trust and the Society ... they are the managing trust for the museum, and I share it with others [through] them' (Interviewee A).

The organisational structure, the quality of internal communication and the priority given to 'green' policies within the parent body to which a particular heritage site belongs are clearly important factors in determining whether or not a centrally-devised strategy is effective. 'Buy-in' by staff is obviously important in developing and adopting an environmentally sustainable approach. While research carried out elsewhere has highlighted the importance of volunteers in the effective management of visited heritage, some studies have indicated that poorly instructed, untrained, and mostly part-time volunteers seem often to be less-able or less-motivated to engage (Shackley, 2006; Rhoden et al. 2009). However, Interview $F$ provided evidence of a very effective contribution made by well motivated volunteers.

Long-term planning for environmentally sustainable management is vital. However, just two respondents in the sample (both representing museums) reported that their environmental strategy had been in place before the year 2000. Another 16 said that their strategy had been implemented between 2000 and 2008. Clearly, the formulation of environmental strategies by these heritage 
providers, where it is happening at all, is very recent indeed and, in most cases, it is producing modest outcomes.

In addition, nearly three quarters (74.2 per cent) of sites had never reviewed their environmental performance (Fig. 4.7). This finding further reinforces previous comments regarding an 'implementation gap' but, once again, a larger percentage of historic houses/castles (60.0 per cent) and museums/archive sites (36.0 per cent) report that a review has been completed than is the case for historic churches (22.6 per cent). Historic houses/castles can draw on a larger paid staff and are usually better resourced, that other site, for undertaking review.

Between 10 and 14 per cent of historic churches and museums/archives that do not have an environmental strategy or policy in place nonetheless state that a review of their environmental performance has been undertaken. Further, indepth enquiry would be required to establish precisely why no strategy emerged from the review that was apparently conducted, but it is perhaps another indication that the adoption of environmentally friendly approaches is not yet well or widely developed across the entire heritage sector in Devon and Cornwall. Historic churches, though increasingly dependent on exogenous sources of income, understandably privilege their role as places of worship and lag well behind other kinds of visited heritage in the sophistication of their sustainable management. 

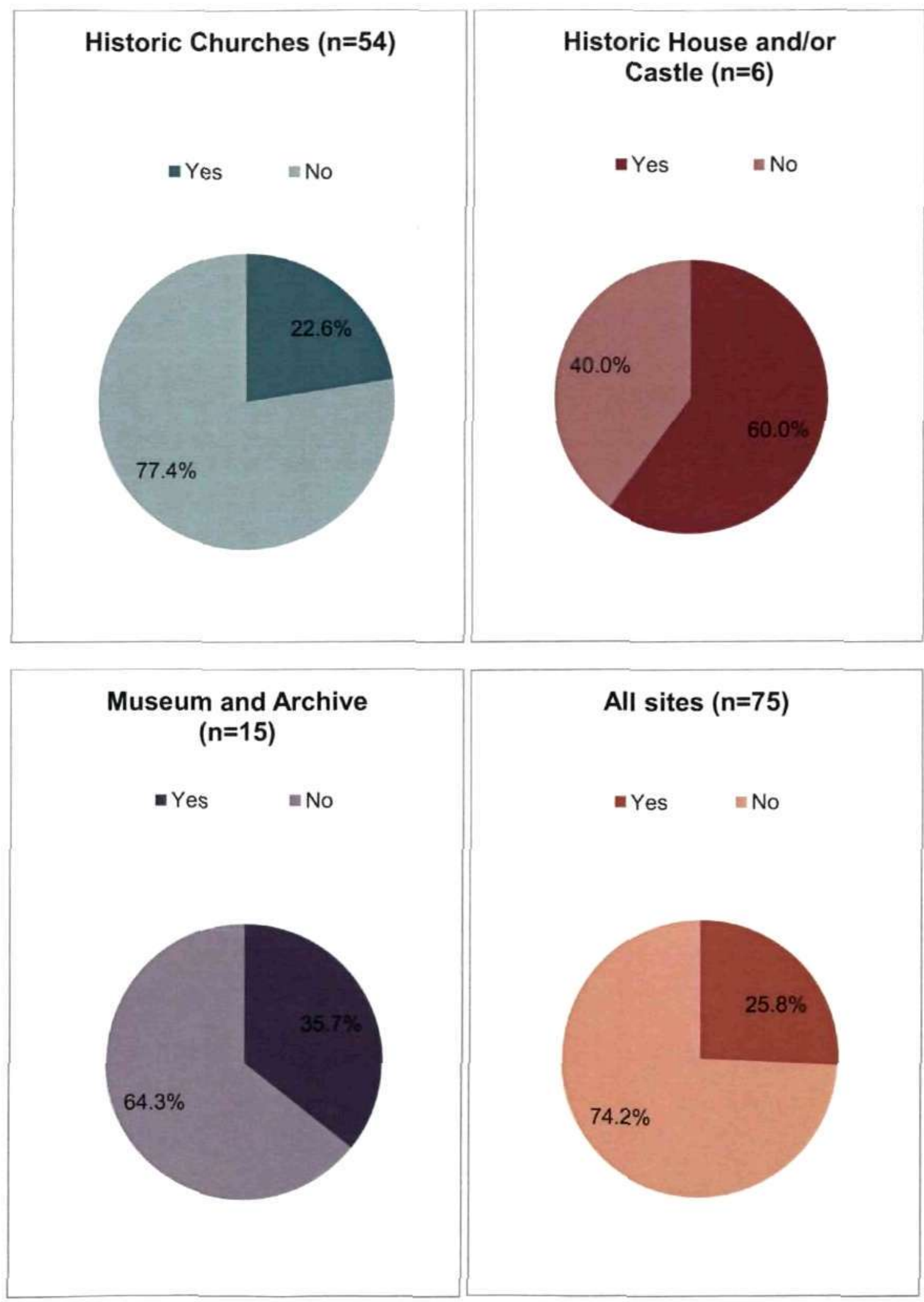

4.7. Site identifying whether they have, or have not, reviewed their environmental performance 
Respondents stating that an environmental review had been undertaken were further asked whether any changes in management policy had been made as a result. Overall, in 22.7 per cent of cases, no changes had reportedly been made. Most of the apparent 'inaction' occurred among the historic churches category (29.6 per cent). Indeed, all those responding on behalf of historic houses/castles reported that changes had been made as a result of the review (Fig. 4.8).

The low take-up of sustainable practices detected in this survey does appear to match the 'modest level of adoption of sustainable practices' reported for Caradon tourism businesses (Vernon, Essex and Pinder 2002). However, given the considerable popular attention now focused on environmental sustainability, it might have been expected that - some six years after the Cornwall research was published - a greater level of adoption might have existed than is, in fact, the case. Heritage sites in Devon and Cornwall seem to be no more environmentally sustainable than general tourism businesses in the Caradon district of Cornwall were several years ago.

\subsubsection{Constraints on the implementation of sustainability measures in heritage sites}

The survey probed opinions regarding barriers that explain the 'implementation gap' that clearly exists, especially regarding the adoption of environmental sustainability measures by the heritage providers in the sample. 

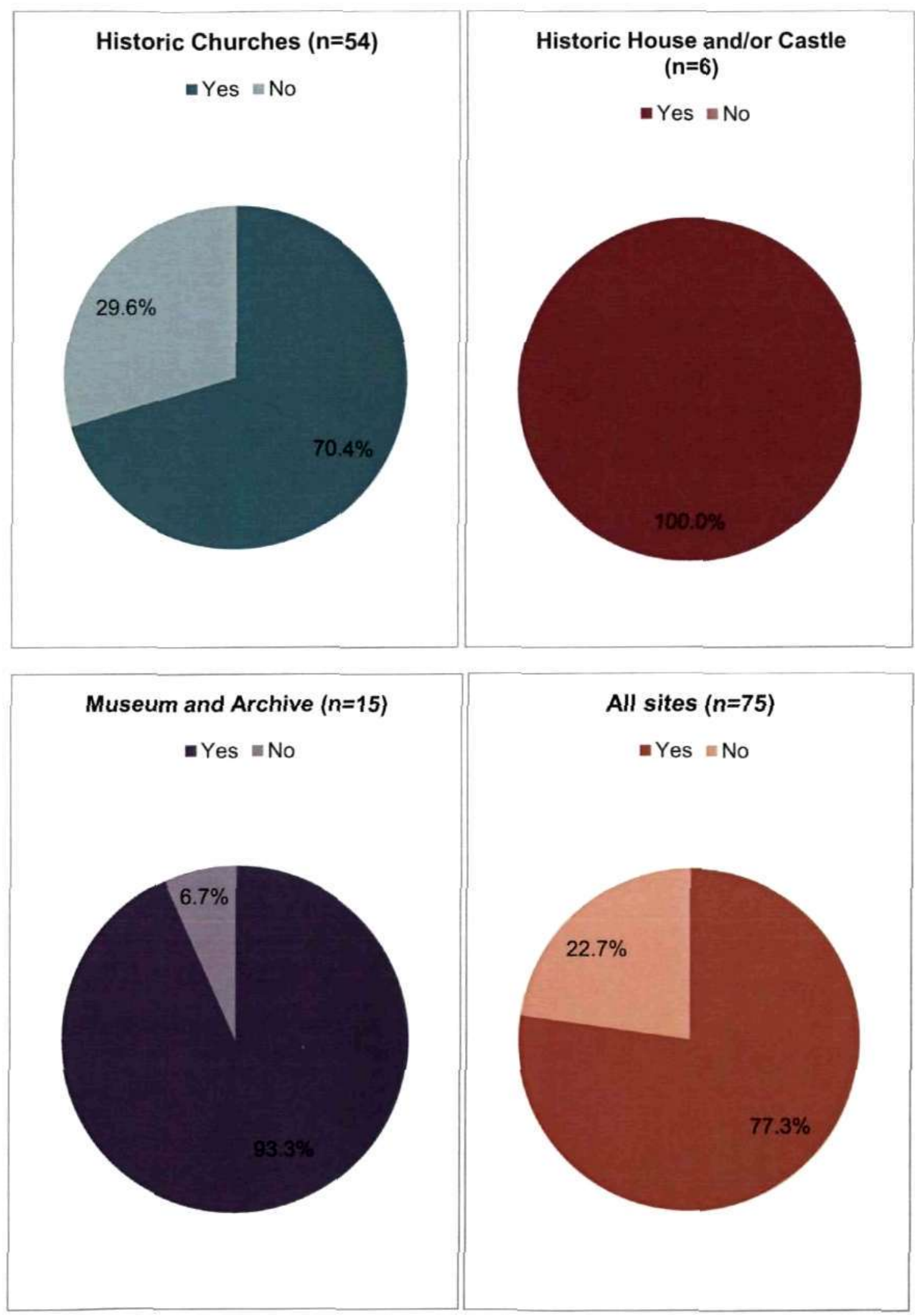

Figure 4.8. Percentage of respondents who did or did not make changes as a result of their environmental review 
Unfortunately, a mere 25.4 per cent of respondents answered questions relating to constraints on the implementation of environmentally friendly practices. Amongst those who did respond, 88.4 per cent reported no problems in undertaking the measures that they had implemented. Of course, it has already been established that a majority had done little more than change light bulbs or recycle glass and paper, which are conventional practices and are unlikely to create problems! It would therefore seem that the lack of adoption might be explained by broader structural considerations within the sector.

Problems of adoption: The problems experienced by those who have implemented environmentally friendly measures (i.e. by the 25.4 per cent who chose to answer the question) range widely from a lack of knowledge of what might be done, to concerns about the costs, to insufficient time, and to concerns about adverse impacts on the historic conservation of the site (Fig. 4.9). When asked to identify their main, or joint-main, barrier to introducing environmental measures, professing a lack of knowledge and expertise was an especially common response (particularly among the custodians of historic churches). Overall, 31.3 per cent expressed a lack of knowledge about the options ('we do not know what more we could do'), with a further 16.5 per cent noting that they were 'already doing enough'. Predictably, 28.1 per cent felt that actions were 'not cost effective'. All these responses suggest, in line with research on the adoption of sustainable practices in related sectors, that managers of heritage sites, amongst other factors: lack the information, expertise and resources required to take appropriate actions to address the sustainability issue. 


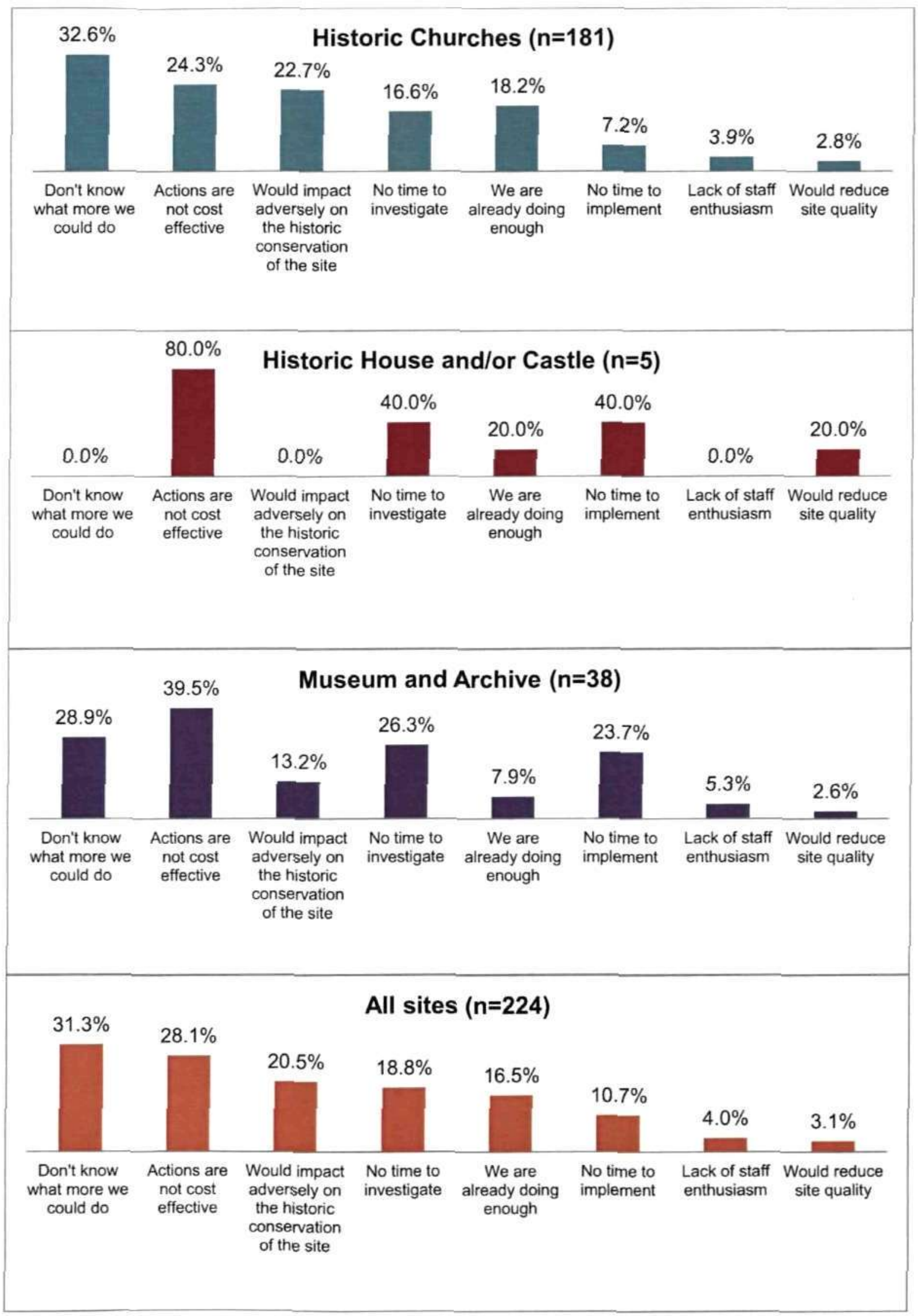

Figure 4.9. Percentage of respondents identifying the barriers which they ranked as primary reason for not implementing environmentally friendly measures. Source: Author. 
Clash with heritage protection: The protection of the sometimes fragile fabric of a heritage site and retaining its attractiveness to visitors were also highlighted by one fifth of the respondents in the sample (20.5 per cent) as critically important considerations that preclude the adoption of certain kinds of environmentally friendly measure. For example, a curator of a museum occupying a Grade 1 building remarked that enquires about the installation of solar panels on the roof had met with an immediate refusal by English Heritage and the local planning authority. While none of the representatives of historic houses/castle noted these latter concerns, those looking after historic churches, and museums/archives housed in historically important buildings, frequently did so. ${ }^{27}$

One environmentally sustainable practice that appeared to create some problems in heritage management was the suitability of new energy-saving lighting. A museums/archives representative (Interview A) reported on his experience as manager of installing a new energy-efficient lighting system, which proved to be more than simply replacing light bulbs. On the individual initiative of the manager, the installation had involved the replacement and testing of all lighting systems within the building. The manager's personal interest in environmental sustainability and the need to save money drove the project. Economically marginal, a need to cut utility bills was seen as critical, 'I have to do something about the energy bill or the museum will fail financially; it is on a knife-edge now; it always has been; it has always teetered on the edge of affordability'. The manager was 'an electronics engineer from previous

\footnotetext{
${ }^{27}$ Constraints of that kind were not encountered amongst those managing general tourism businesses surveyed by Curry et al. in 2002 .
} 
experience, so it was an obvious move'. However, the main barriers to overcome concerned both the intial investment cost and the potentially detrimental effect of conventional energy-saving light bulbs on the integrity of their collection 'Because of the nature of the collection ... we have, until now, had to use incandescent lightıng - halogen lightıng - whıc̣h is very energy intensive But commercial low-energy lighting is fluorescent ... it is ultra-violet heavy and you can't blast the collection with that textiles, materials and colours - it kills pigments, hardens materials and does lots of horrible things to paper Items'. New LED lighting technologies overcome the problem and bring both a saving on costs and 'the bonus of zero UV', and it is better (1.e brighter) than the old lighting However, the investment cost is high. 'Incandescent light bulbs cost $56 p$ each and last about a year. For LED lightıng, one bulb costs $£ 18$ and the holder to put each one in for the experıment cost $£ 7$ or $£ 8^{\text {' }}$

Funding to support the project was secured from the Devon Museum Group and paid for a trial of the system in just one room of the museum. However, if the trial proved successful, then the system will be gradually installed throughout the bulding, thus phasing the high implementation expenditure. 'We can gradually change over to LED lighting on a replacement basis for the whole museum' Recognising the value of the project, the funder is now keen to promote it as an example of good practice. Indeed, a condition for receipt of financial support has been to publicise it through forums like the Devon Museum Group and the Museum Trust However, expertence of speakıng at meetıngs of colleagues suggests that, because of insufficient tıme, money or Interest in environmental sustainability issues, there is as yet very little enthusiasm in other Devon museums and archives to follow a sımilar strategy. 
In another example, a historic church (Interviewee E) had implemented two major environmental measures: the installation of conventional low-energy lightbulbs and an energy-efficient boiler. At first, the new lighting had an impact on the integrity or 'feel' of the church because of the slow speed in reaching full intensity, but made 'a lot of difference to the bills'. Located within an Area of Outstanding Natural Beauty (AONB), in sight of a public footpath, and on the horizon of the surrounding National Trust owned land, solar panels were not practicable because there is no 'position where we could put them that would be out of sight of the public and therefore out of site of the AONB that we are in'. Weekly running costs of around $£ 1,800$ prompt the church constantly to rethink its management and seek ways to improve efficiency. 'Anything we can do to reduce our costs is beneficial'. However, it was clear that no measures to improve sustainability would be taken if they risked the historical integrity of the building.

Given the priority accorded to protecting the physical fabric of some heritage buildings in the survey, an investigation was made of the environmental measures that were thought to pose the most significant threat either to the historical integrity and conservation of the site, or the quality of the visitor experience (Figs 4.10 and 4.11). Paradoxically, the results indicate that respondents across the board felt that environmental measures either enhanced, or had no effect on the visitor experience or the conservation on site. In light of the misgivings expressed by those managing historic churches and museums/archives in answers to previous questions, the responses seem inconsistent. 


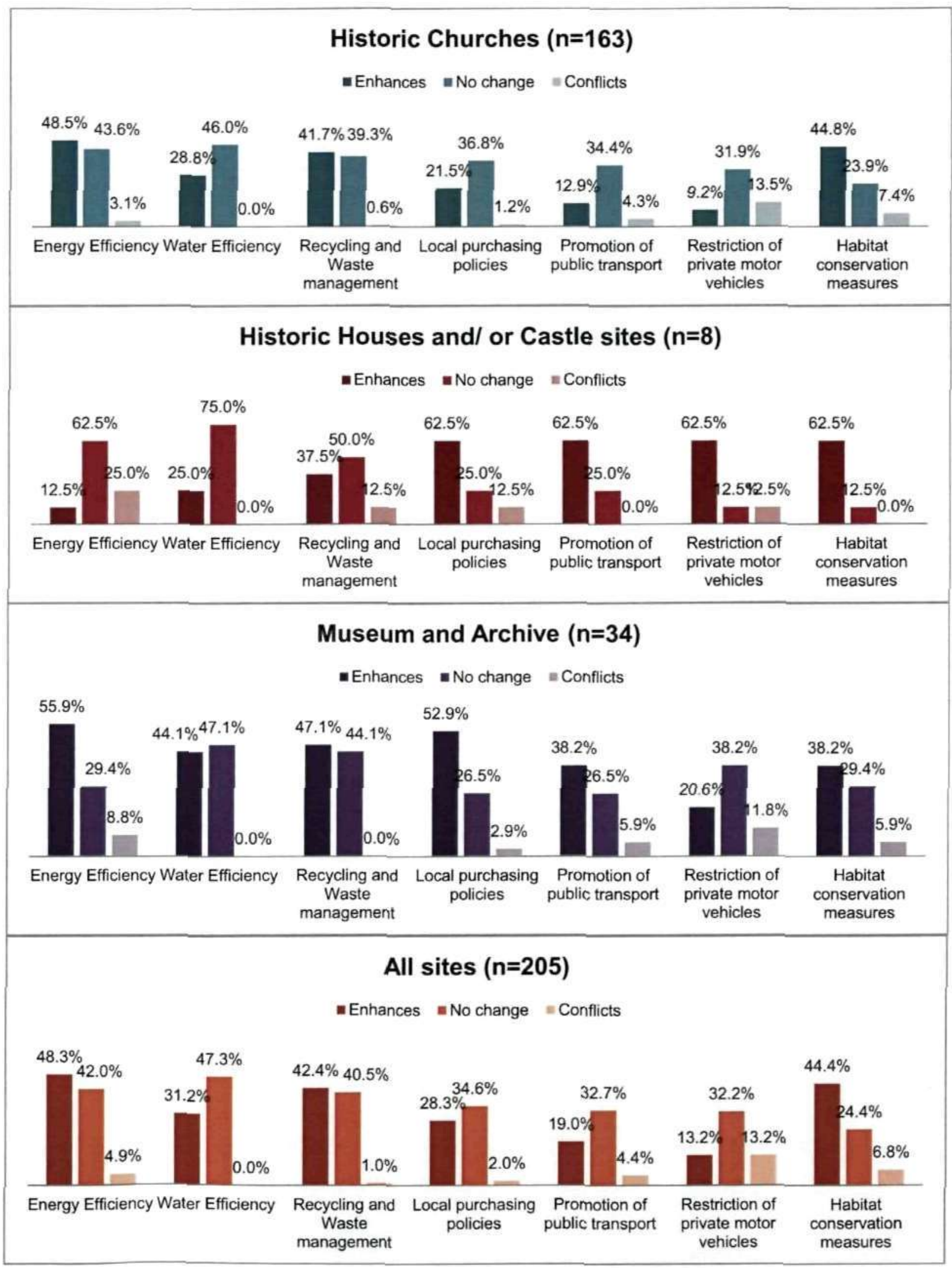

Figure 4.10. Perceptions of the impact that implementing environmentally friendly measures has on the conservation of heritage sites. Source:

Author. 


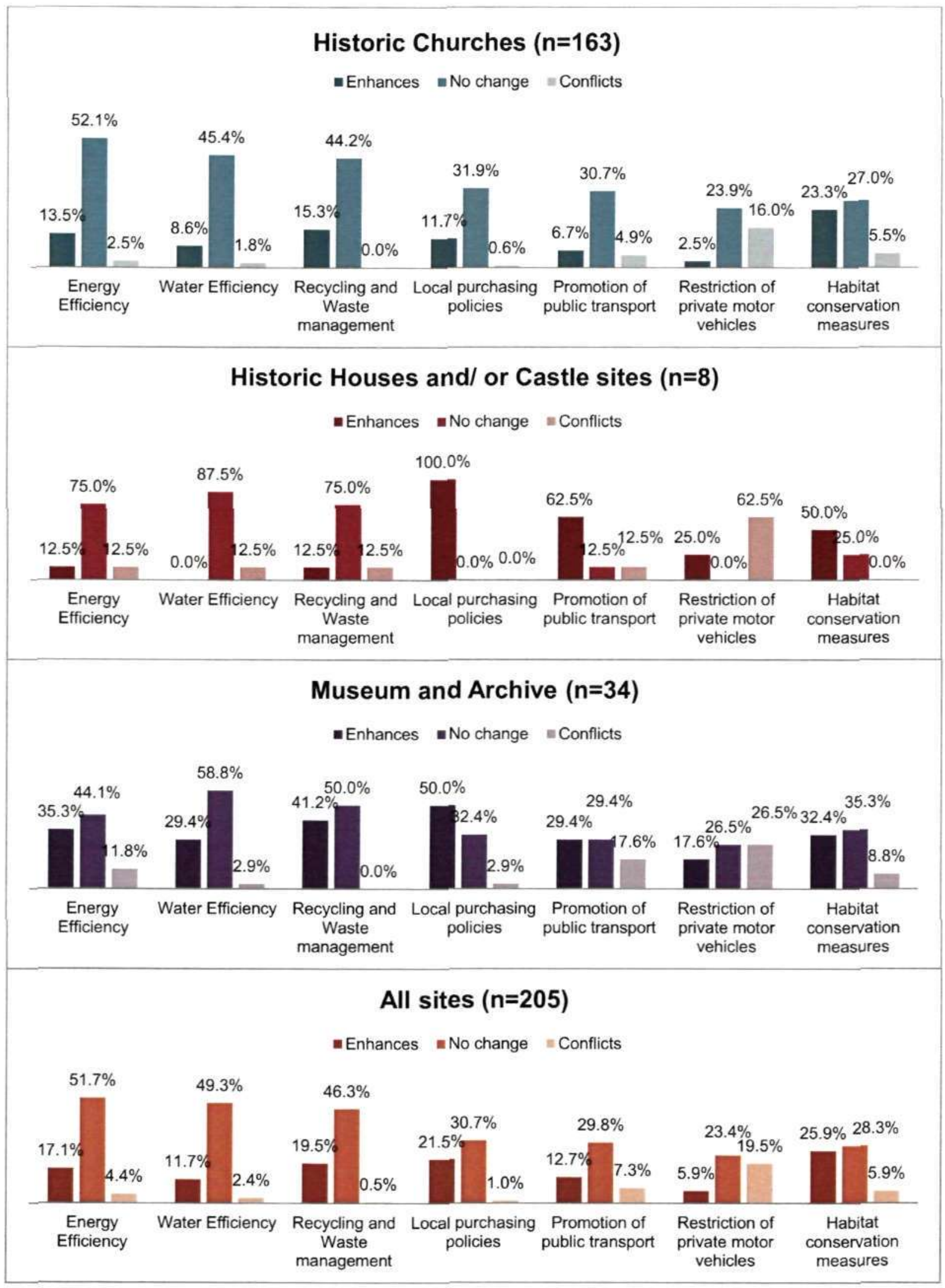

Figure 4.11: Perceptions of the impact that implementing environmentally friendly measures has on the visitor experience at heritage sites. Source:

Author. 
The apparent contradictions underline a general lack of knowledge and uncertainty with regard to the issue of the intrusiveness or otherwise of sustainable management.

Role of volunteers: Many of the issues related to the lack of expertise amongst the heritage providers is compounded by a shortage of staff and the prevalence of volunteers in their operation. Compared with the other two categories, historic houses/castles employ the highest numbers of paid staff and have larger numbers of volunteers. Museums/archives in the survey are typically supported by just one or two paid staff plus a group of volunteers, while the management of the historic churches depends almost exclusively on volunteers. The only paid personnel are the clergy, whose main role is pastoral and the ministry of the Church.

The more economically marginal cases in the sample relied almost entirely on volunteers. While volunteers are crucial to the management and maintenance of visited heritage, they are constrained in the amount of time they can commit to such work. Some respondents said they were unaware of what further initiatives they could pursue, and others said that heritage management was not part of their main role.

Existing research suggests that volunteers are less likely to possess any management qualifications (unless specifically recruited because of their particular skills) (Rhoden et al. 2009) and tend to be less-willing to undertake training, are more resistant to change, and are reluctant to implement new practices (Jabbour and Santos, 2009). Of course, properly trained, well- 
organised and well-informed (but unpaid) volunteers can sometimes make a vital contribution to the successful management of visited heritage and Cole's (2004) work shows that they contribute to the profitability of mining heritage sites by reducing overheads and expenditure. Indeed, instances have been found in the present survey where the volunteer custodians are certainly capable of adapting to change, do possess appropriate skills, and do display considerable commitment. But lack of time is their main constraint. Thus, the finding, from this research, that there was a single case of a volunteer who was able to devote an unusually large amount of time to a particular heritage property and, acting like a full-time employee, even took on responsibility for the organisation of a sizeable group of other helpers, was very much a rarity. However, further research would be required to explore the impact and role of volunteers in managing heritage.

Transport considerations: Paradoxically, amongst many of the heritage providers in the sample, a considerable threat was perceived to be posed to their survival from moves towards more sustainable transport. In a region such as Devon and Cornwall, where many heritage sites are remotely located and public transport provision is poor, a sizeable proportion of respondents to the questionnaire picked out potential restrictions on the use of motor vehicles as potentially damaging to the quality of the visitor experience. Puzzlingly, some also saw such measures as a threat to conservation. One-to-one interviews revealed insights into the thinking that had led to these responses. Interviewee G, for example, said that any restrictions on visits by private car would deter tourists from visiting remote heritage attractions. The negative impact of a reduction in visitors on income flow would be disastrous, cutting off funds for 
conservation and operational viability For some, the Idea of 'green transport' is therefore seen not as an advantage, but more of a threat. Such a threat could be countered only if public transport provision was made as reliable, frequent and convenient as travel by private car

\subsection{Socio-cultural Sustainability}

The adoption of more broadly defined sustainable practices, such as sociocultural sustanability in the form of interpretation and community engagement, provide a more optımistic perspective on the implementation of sustanable management measures by the Devon and Cornwall heritage providers. In this Investigation, 67.8 per cent of the combıned sample placed 'respondıng to their visitors' needs and expectations' ( 1 e socio-cultural sustamability) as their top or joint-top proorty (Fig. 4.1.). Arguably, these concerns are more aligned with the traditional management roles of heritage managers and are well withın their 'comfort zones'. The questionnarre responses showed that it was the top or Jont-top pronity for 704 per cent of the historic churches ${ }^{28}, 62.5$ per cent of the historic houses/castles, and $\mathbf{5 7 . 7}$ per cent of the museums/archives

Interpretation allows visitors to gain a better understanding of the heritage significance of the site and so enhances the quality of their experience and, arguably, instils an appreciation and respect that might then influence behavour through direct and indirect support Engagement with the local community can create a similar effect from the neıghbouring communities and residents In

\footnotetext{
${ }^{28}$ It is, of course, obvious that many of the historic churches respondents were conflating their responses regarding the needs of their heritage visitors and the rather different responses they make for their congregations.
} 
many respects, such activities are well-established practices in the management of heritage attractions and certainly pre-date the policy mantra of sustainability, which has currently 'hijacked' these particular aspects. This point might explain why the socio-cultural aspects of sustainability appeared more prevalent than those relating to environmental sustainability.

\subsubsection{Provision of Heritage Interpretation}

Overall, more than two-thirds of the sites in the Devon and Cornwall sample were found to provide some kind of interpretive material (70.7 per cent) and the overwhelming majority of both historic houses/castles ( 88.9 per cent) and museums/archives (90.7 per cent) were found to do so (Fig. 4.12). Even amongst the historic churches in the sample, some 66.4 per cent reported that interpretational material is produced for visitors.

Types of Interpretation: Amongst those providers that reported offering interpretive material, printed leaflets were found to be the most common medium; 76.1 per cent of the sites in the sample claimed to produce some kind of leaflet for their visitors (Fig. 4.13). Thereafter, in rank order of frequency: information boards/panels (58.5 per cent); guide books (55.1 per cent); signs/labels (26.5 per cent); guided tours (16.9 per cent); and models/reconstructions (14.0 per cent) were cited. Film/video presentations and self-guided audio tours were mentioned, but by a relatively modest percentage of the overall sample (9.2 per cent and 2.6 per cent, respectively). In general, there was a strong emphasis on the traditional 'passive' forms of interpretation such as signs, leaflets, and guidebooks. 

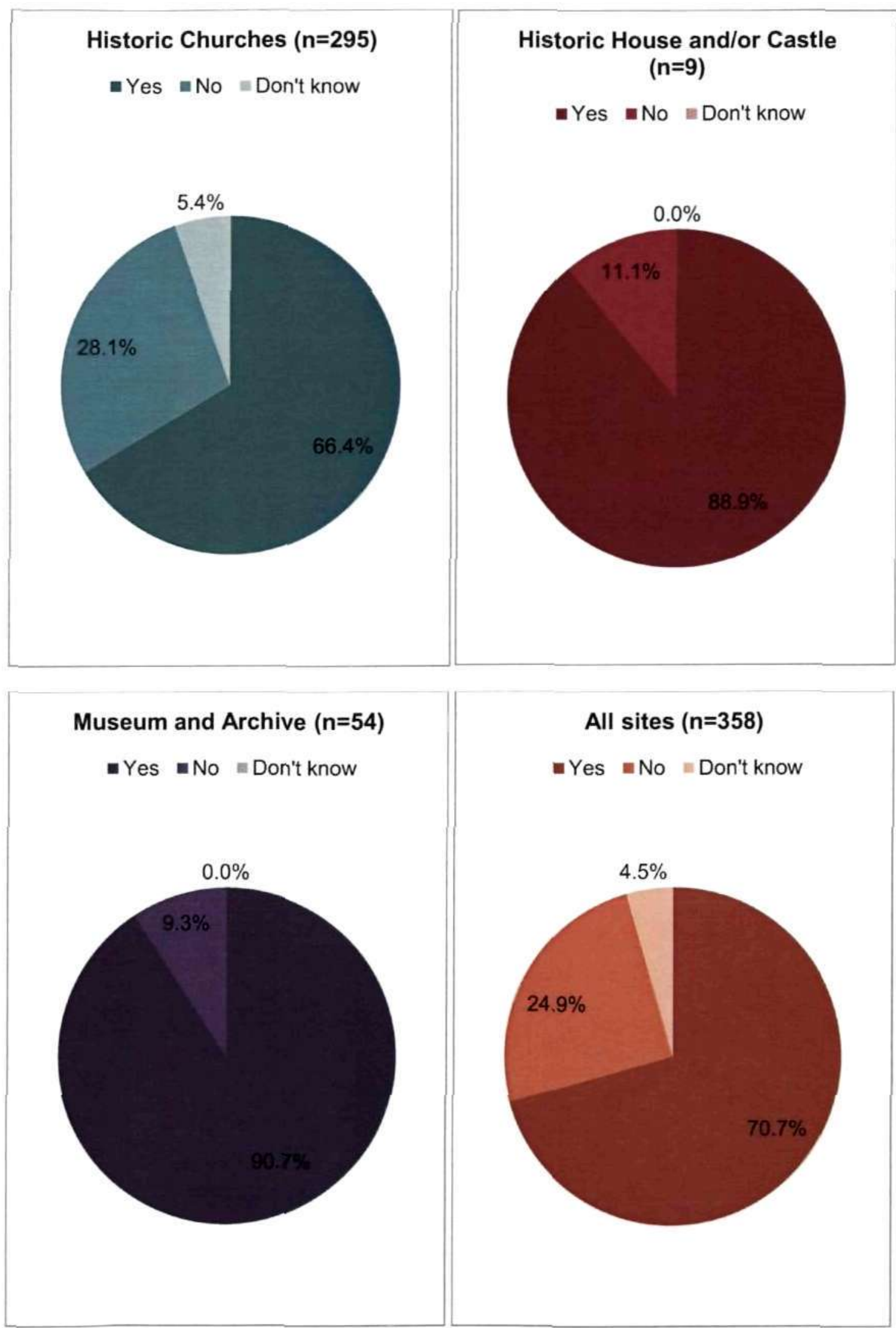

Figure 4.12. The percentage of sites providing interpretive material for visitors. Source: Author. 
There was much less evidence of 'active' forms of interpretation, such as guided tours and video presentations. However, considerable variation was found between the three heritage categories. Historic churches generally offered the narrowest range of materials. Indeed, anecdotal findings from the interviews suggested that some custodians of heritage churches have yet to be fully convinced that any increase in, or improvement to, the materials that they offer would be worthwhile. One heritage church respondent said:

We have thought about it ... it might attract some [visitors], but I do not think there is a huge interest (Interviewee B).

In addition to leaflets, information boards, guide books, and signs/labels, Fig. 4.13 shows that museums/archives and historic houses/castles were more likely (than the historic churches) to offer guided tours and/or have models or reconstructions on display. Moreover, only they reported the existence of film/video presentations; no historic church claimed to have one. Thereafter, the provision of guide books and information boards/panels was seen as offering broadly similar levels of cost effectiveness. In the case of 'active' forms of interpretation, guided tours were perceived as the top, or joint-top, most costeffective form of provision (Fig. 4.14). No doubt reflecting the high initial investment costs involved, film/video presentations and self-guided audio tours were perceived as the top or joint-top most cost effective form of interpretation by only a very small percentage of the respondents. 


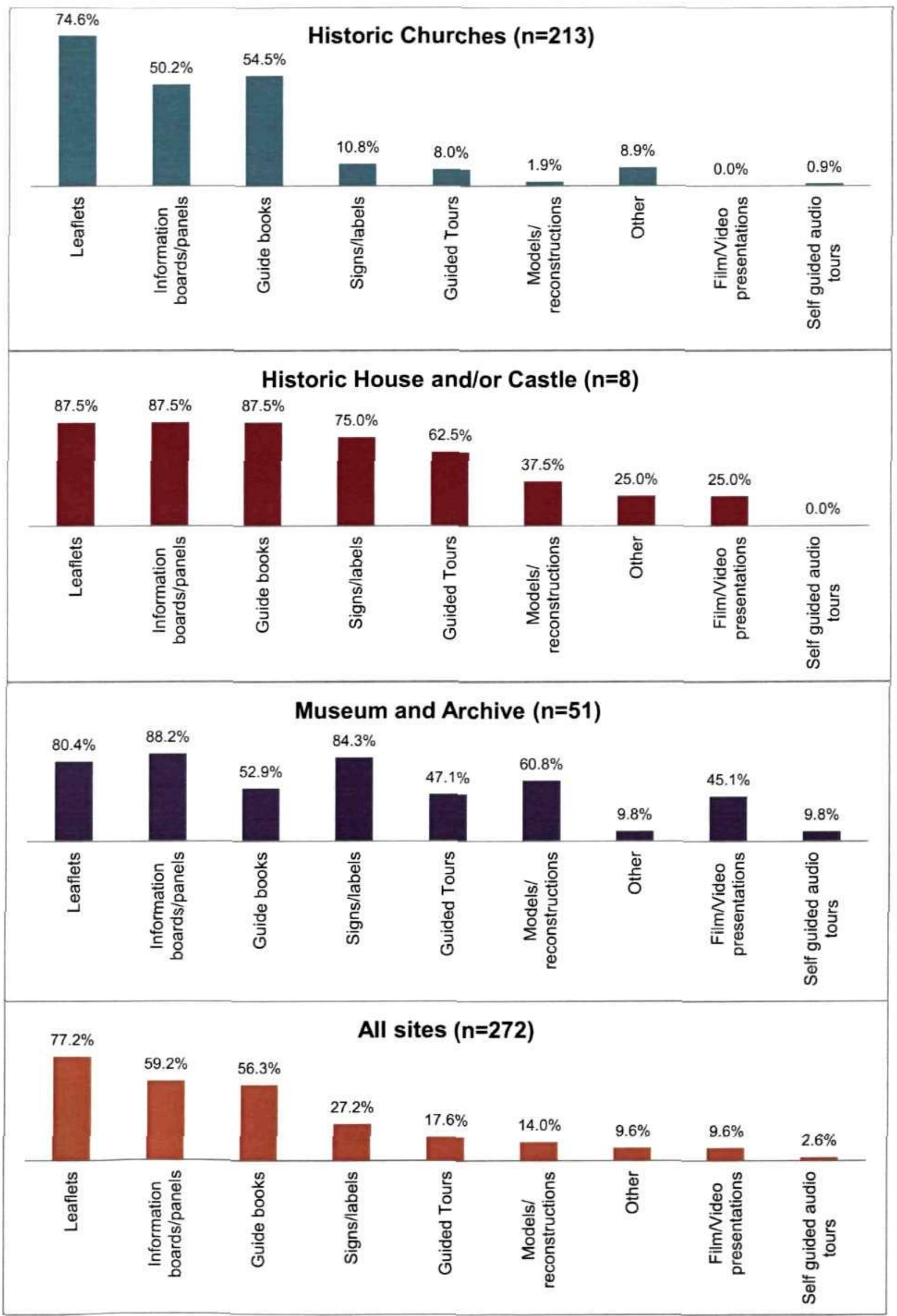

Figure 4.13. Percentage types of interpretive information provided at heritage sites. Source: Author. 


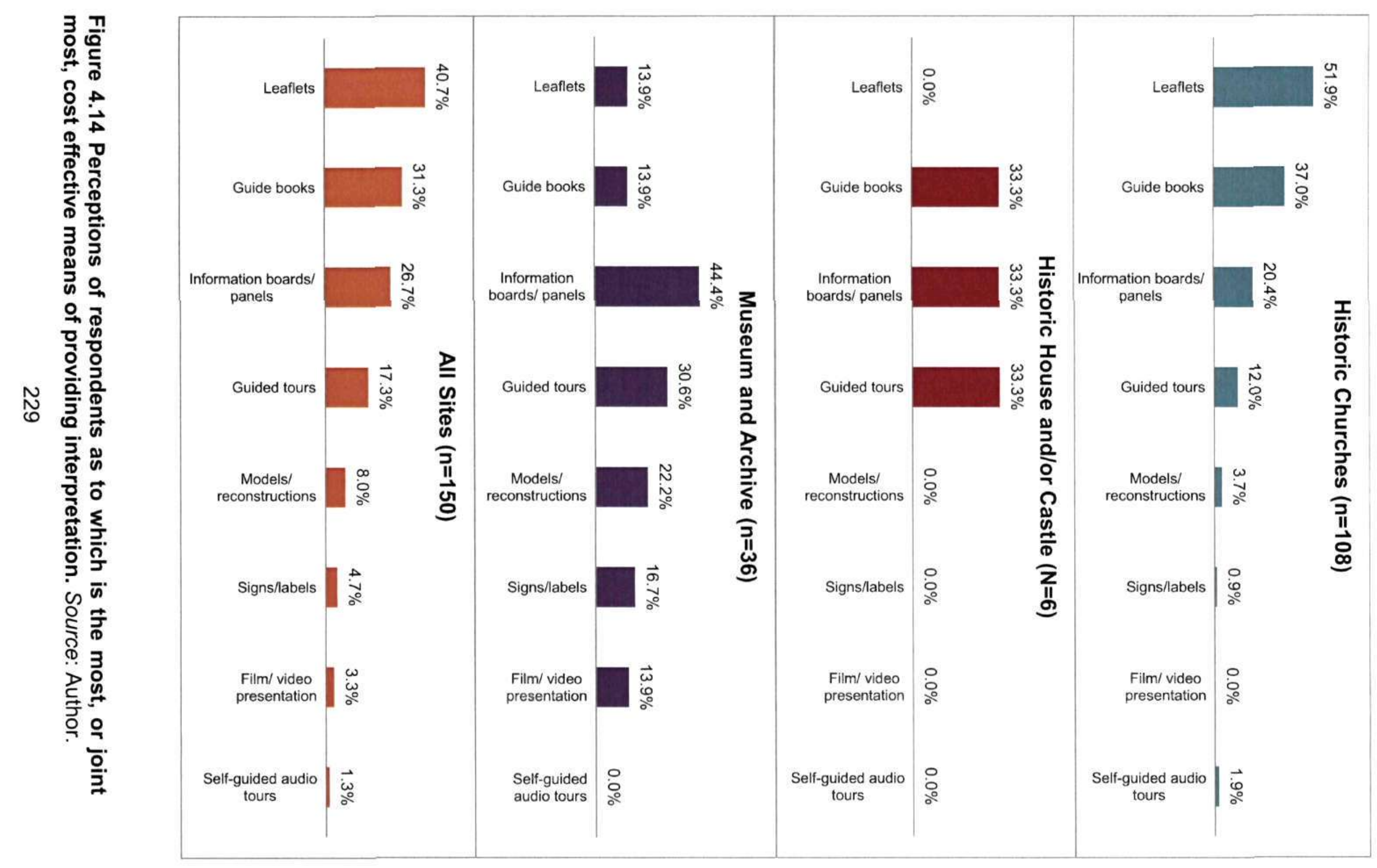




\section{Effectiveness of Interpretative Materials in Securing Visitor Interest ${ }^{29}$ :}

Overall, a high proportion of questionnaire respondents (38.8 per cent) who provided interpretive information perceived guided tours to be the top or jointtop most effective way to secure visitor interest (Fig. 4.15). Those responding specifically on behalf of historic houses/castles, however, were apparently less convinced: only 20.0 per cent of that group placed guided tours as their top, or joint-top, most-effective means of engaging the attention of their visitors. Leaflets and information boards/panels were ranked second and third in terms of being perceived as the top or joint-top most effective means of securing visitor interest. Relatively cheap and easy to produce, these two forms of interpretation were found to be ubiquitous at the sites surveyed. Providers are perhaps justifying their use of this form of interpretation by claiming that it is what their visitors respond to best. Interpretive materials in use at the sample sites are generally rather conventional in style and, although some providers appeared to appreciate that 'active' forms of interpretation can be more successful in securing visitor interest, implementation was constrained by factors such as inadequate staffing or money. For example, volunteer-led sites, such as the historic churches, were much less-able to provide guided tours.

In contrast, larger providers, employing a mix of paid and unpaid staff, were in a position to offer at least some visitor-targeted 'active' interpretation. Even so, although recognised as effective in stimulating interest and achieving visitor satisfaction, self-guided audio tours and film/video presentations were infrequent in the sample.

\footnotetext{
${ }^{29}$ Again, the data are based on responses from heritage providers who actually reported that interpretive material is supplied.
} 


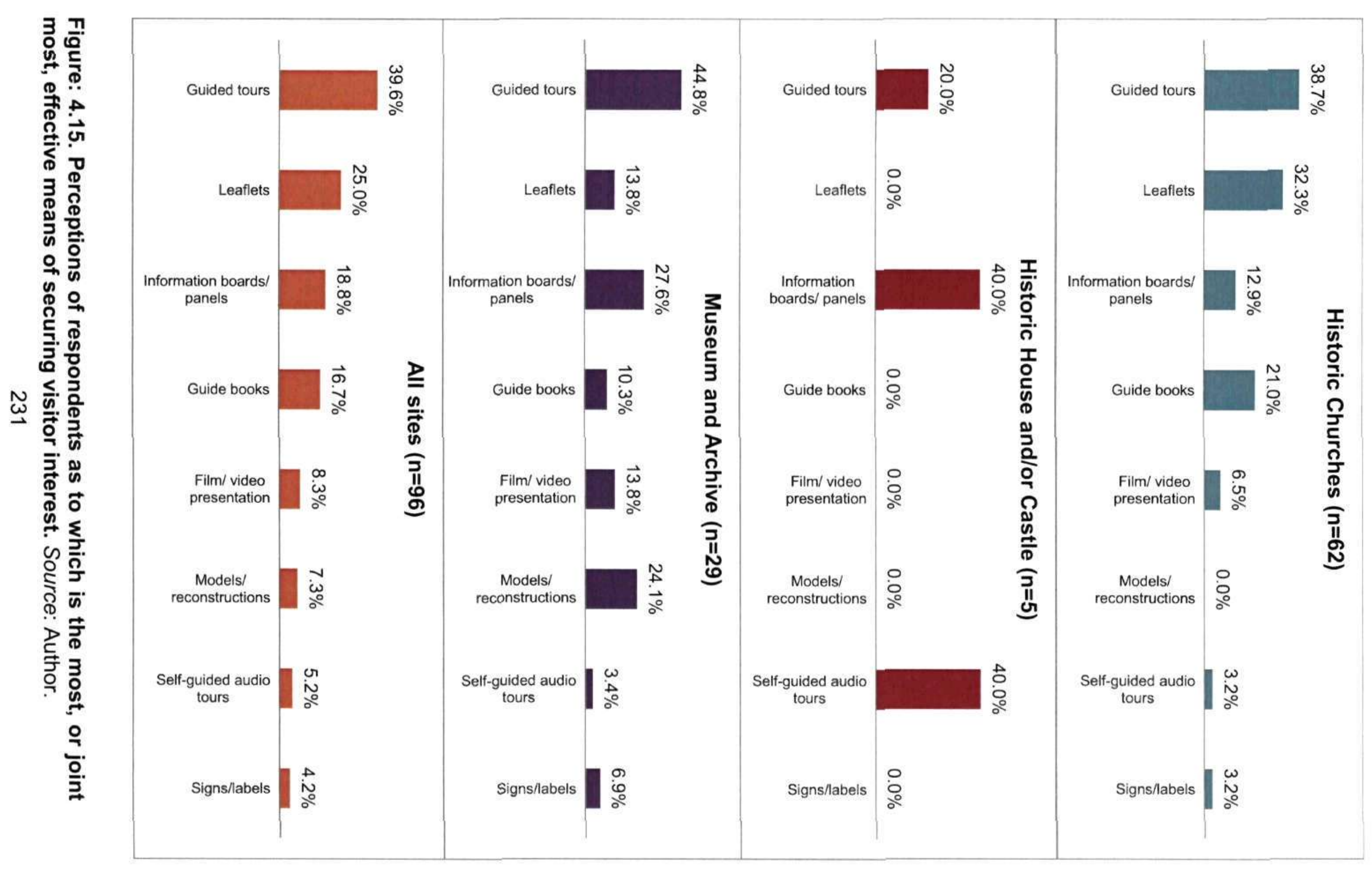


No respondent from the historic houses/castles group - a category which might have been expected to have possessed sufficient funds to meet the necessary set-up costs - regarded such provision as cost-effective (Fig. 4.14). Heritage managers balance their socio-cultural provision against practical concerns about high initial investment costs, doubts about the prospects for pay-back, and the limitations imposed by a shortage of staff. Thus, for a majority of respondents in this survey, even in cases where the potential exists for more sophisticated interpretation to increase visitor interest, the result has usually been the selection of the cheapest and most easily produced materials.

Up-dating Interpretive Materials: Interpretive materials - particularly those of a 'passive' kind - require regular refurbishment, refreshment and up-dating. Tired, dog-eared, old leaflets; guidebooks written several decades ago; and yellowing sign all tend to lack appeal and rarely generate visitor interest or any propensity to make a purchase. The up-dating cycle for interpretive materials is thus crucial for the maintenance of the attractiveness of publicly visited heritage. A key question in this investigation, therefore, is the frequency and extent of updating and renewing of interpetational material that is undertaken by the sample of heritage providers in Devon and Cornwall. Unfortunately, only a small proportion (26.4 per cent) of the respondents in fact chose to answer the question which focused on up-dating interpretation. This lack of replies itself conveys a message regarding the importance attached to the issue by many of those who have been surveyed in this research. As the number of answers on which the statements in this section are based is very small, the data do need to be viewed with extra caution. 
Amongst those who did reply to the question, it emerges that those caring for historic houses/castles and museums/archives sites were, in general, more likely to have up-dated their interpretive material on an annual basis than the custodians of historic churches. Indeed, a few of those responding on behalf of historic churches admitted that their interpretive materials had never been updated at all!

The up-dating cycles in operation varied from one type of intepretive material to another (Fig. 4.16). Overall, relatively few respondents reported that they updated their 'passive' materials (leaflets, guide books, information boards/panels, and signs/labels) on an annual basis. Some 'active' forms of interpretation (e.g. the scripts for guided tours and self-guided audio tours) were said to be updated every year. Others, such as film/video presentations, which are often very expensive to make, were never said to be annually up-dated.

The in-depth interviews shed further light on attitudes amongst those caring for historic churches. It was observed that the provision of interpretive information was not regarded as a major concern and that much of what was on offer was out-of-date. There was no evidence that materials were being compiled according to good-practice advice offered by organisations such as the Society for the Interpretation of Britain's Heritage. ${ }^{30}$

\footnotetext{
${ }^{30}$ For example, Feehally, M. (1984) Helping the Stones to Speak: simple ways to tell visitors about your church, Kenilworth, Society for the Interpretation of Britain's Heritage; or Dymond, D. (1986) Writing a Church Guide, London, Church House.
} 


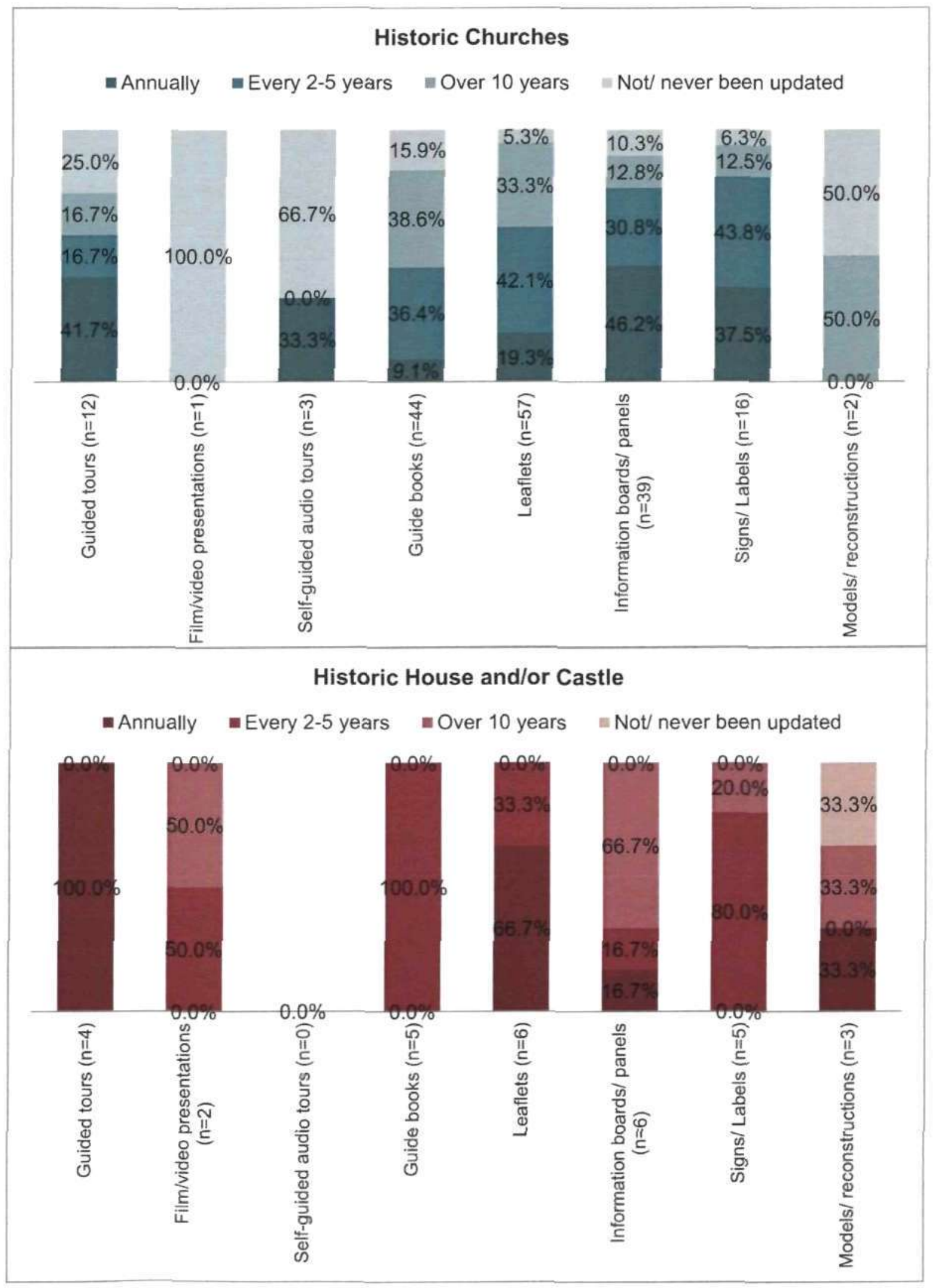

CONTINUED ... 


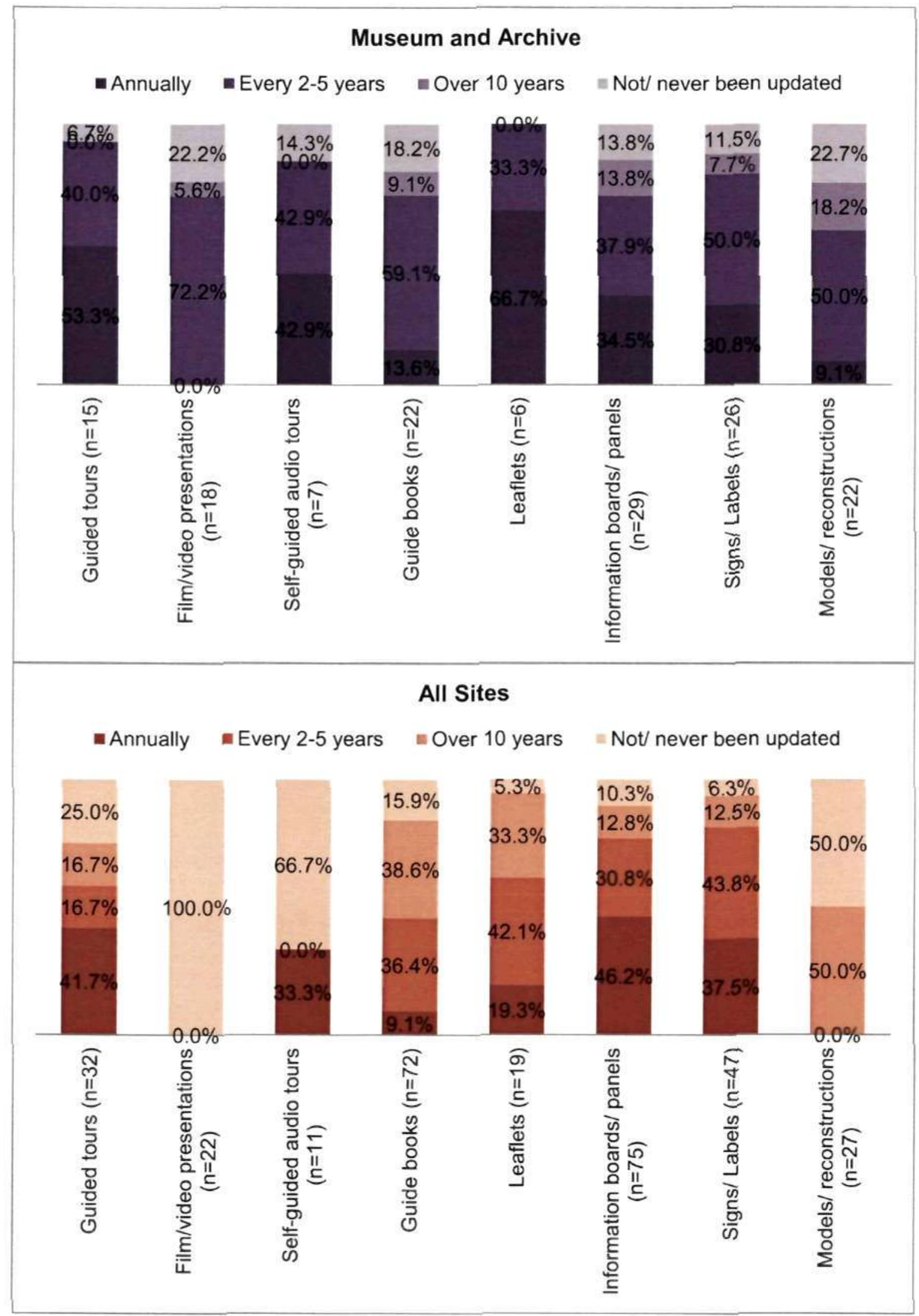

Figure 4.16. Update cycle by type of interpretive provision. Source: Author. 
One interviewee (F) acknowledged that their interpetation was not up-dated often enough and that it really needed:

... to be worked on now ... the text has been there for a long time ... and a lot of our visitors these days do not want such a great level of detail (Interviewee F).

Those who were interviewed at the historic churches which report making good profits also recognised that some of their publications were either out-of-date or out-of-print and therefore unavailable. One claimed that the material was about to be improved and said, "it is out-of-print at the moment, but the vicar ... is going to revamp it' (Interviewee C).

At another church, the interviewee said, '... it is at the printers now; it is an upgrade of the history of [the] church to incorporate newer things (Interviewee E). $\mathrm{He}$ also remarked that the up-dating cycle was limited because of the high cost of producing the material (leaflets and a guidebook). Revisions would be made more often if they could be afforded. However, he noted that the matter is considered:

... on a regular basis, though it hitherto depended on how much of the old stock had been sold. We have now decided, however, that we want to try and up-date these items every three years - so that we can print a large enough quantity to enable us to negotiate a reasonable price. If you order very small print runs, it makes each copy much more expensive (Interviewee E).

In an interview with the custodian of a small urban museum, it emerged that the up-dating of the leaflet and guide book was considered unnecessary because they rarely had any repeat visitors! The assumption was that, once a visitor had 
been to that museum, they were unlikley to return because 'museums are not expected to change very much'. When publications had been revised, he said it had been done 'usually on a whim ... and the ladies do the lion's share of the work' (Interviewee A). Discussions with a representative of another museum revealed that attempts had been made to up-date the interpretation and the displays, but a lack of time had been the major contraint: 'the curator does shift things around, but probably not as much as he should ... because of the extra work it involves' (Interviewee H).

The representative of a large National Trust site, by contrast, reported that the interpretive material is frequently up-dated - either annually or on a regular, rolling programme. Leaflets, for example, are reviewed every year and the question is asked; 'can we improve that? Can we make it better?' (Interviewee G). The need to retain visitor interest and attract higher visitor numbers was the key driver. Taking into account the opinions of the visitors was seen as critical: 'we try to encourage discussion and to listen to what the visitor is actually telling us. We tend to be led by that'. He recognised the importance of offering interpretation to meet the changing needs of the visitors and of avoiding the trap of providing materials that they think the public wants. He put it as follows:

The danger is that we can be 'led by ourselves'. We might desperately want to tell people every last snippet of information in a highly intellectual way that visitors actually find very boring. We know we have to be really careful not to do that (Interviewee G).

Professionally Produced Interpretive Material: While clear recognition existed amongst respondents to either the questionnaire or the in-depth 
Interviews of the Importance of high-quality interpretatıon for maintainıng visitor appeal, a minority of the providers in the sample sard that their materials were

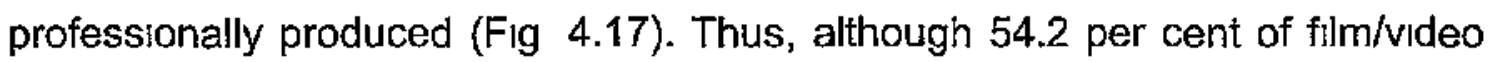
presentations were reported to have been made by professionals, the percentages for other media were considerably lower Just 16.9 per cent of the guide books, 184 per cent of the leaflets, and 313 per cent of the information boards/panels were said to have been externally produced by, for example, design agencies or consultants. The historic churches stand out as the least likely to 'out-source' the production of their interpretive materials In their case, Just 135 per cent reported that their guide book was the work of a professional, and a mere 45 per cent said their leaflet had been similarly produced. Of course, 'In-house' production may be the only affordable option for volunteermanaged heritage sites. However, there is a risk of negative consequences because amateurısh materials tend not to appeal to heritage tounsts; visıtors will not buy them; and the absence of good-quality information will exert a detrımental impact on the overall satisfaction of a visit.

None of those participating in an interview on behalf of a historic church had employed a professional company to produce elther their leaflet or their guide book In contrast, professionally produced materials were more commonly noted by those running historic houses/castles and museums/archives Organısations lıke the National Trust are, of course, well known for publishing their own extensive and high-quality range of guıde books and leaflets, which all conform to the easily recognised corporate style. High production standards are expected and relatively high prices are thus commanded 


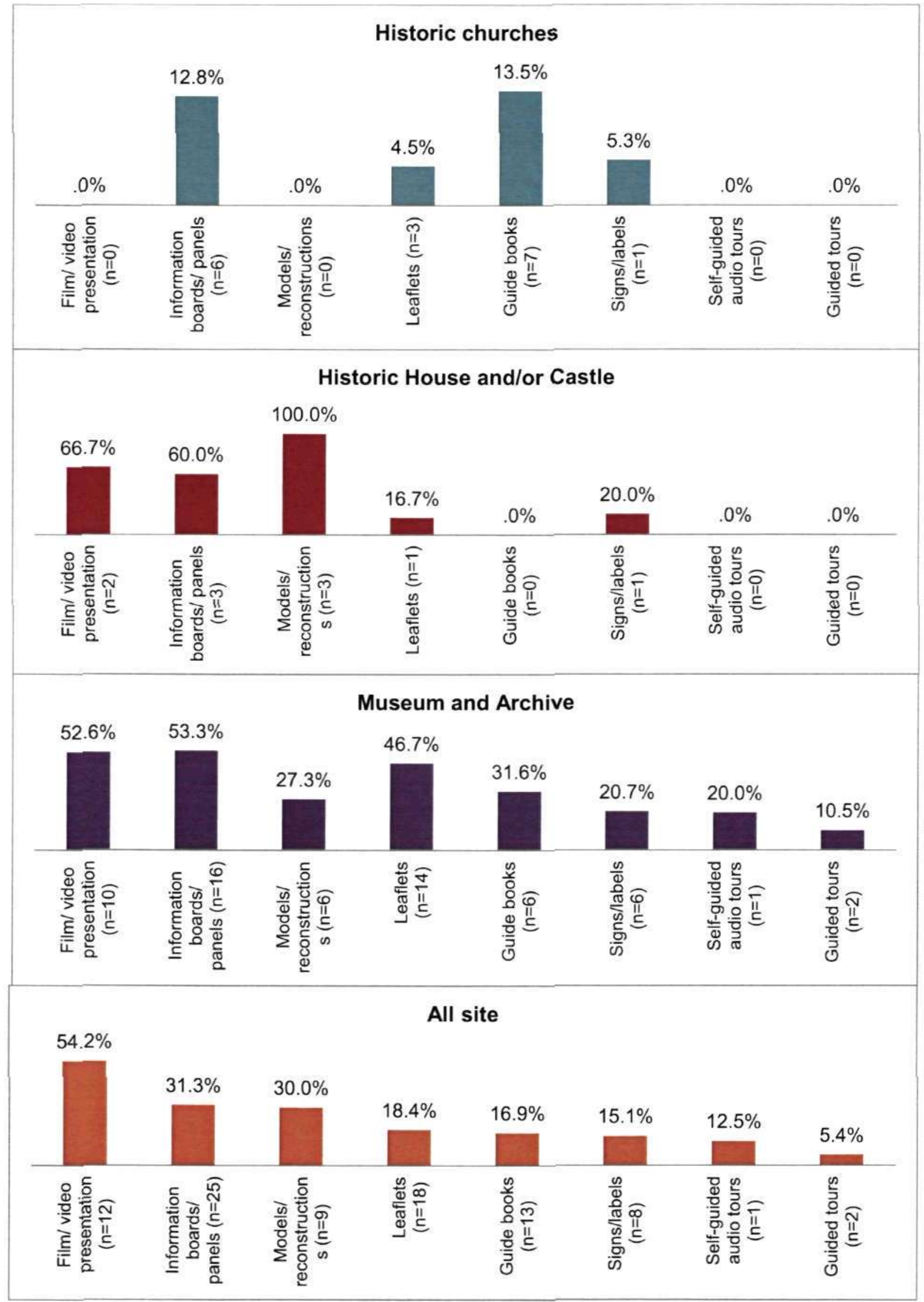

Figure 4.17. The percentage of heritage sites whose interpretive material is produced by external consultants or professional designers. Source: Author. 
In one interview with a representative of an urban museum, it became clear that professional consultants had been engaged with success to redesign the interpretive information and displays in one room:

About three or four years ago, we employed a professional company, ImageMakers, who did a very good job (Interviewee $\mathrm{H}$ ).

Whilst avoiding any impact on the day-to-day work of the existing staff and the running of the museum were seen as critical, the aim in this case had been to increase their appeal by enhancing the manner in which their collection of heritage objects and artefacts was displayed and explained, and thereby to attract new interest and boost their visitor numbers.

Interviewee (G) at the National Trust property described the work of professional design consultants who had been engaged to help with the development of a new 'discovery centre'. It was emphasised, however, that the consultancy company was responsible only for the physical design of the centre; all the interpretive material was created by the permanent staff in line with the principles and wider framework of the National Trust. The support of a large parent organisation and the local availability of highly qualified staff in the production of high-specification interpretation was clearly significant.

There is no doubt that, by employing the services of professional designers and consultants, top-quality interpretive material can be produced; but it is relatively uncommon for heritage providers in Devon and Cornwall to do so. Without skilled professional help, much therefore depends on the availability of paid staff or volunteers with some aptitude and experience. In the absence of both, the 
standard of interpetation is often relatively poor and unappealing with the implication that it does little to boost either numbers or profits, or to contribute to the enhancement of the visitor experience.

Targeted Heritage Interpretation: Only 30.7 per cent of the providers said their interpretive material was targeted at any particular audience groups (Fig. 4.18). This proportion is lower than that reported by Cole (2004) in work focused on mining heritage attractions. ${ }^{31}$ The lowest level of targeted interpretation was encountered amongst the historic churches (26.8 per cent); while for both historic houses/castles and museums/archives it was markedly higher (44.4 per cent and 43.5 per cent respectively).

Approximately half of the respondents to the questionnaire reported that they provide interpretive material which is accessible to all their visitors. Amongst the rest, interpretive material was noted that aimed (1) at school-age children, or (2) at those seeking factual information, or (3) at those with specialist interests in an historical aspect of the site. Interviews yielded further insights into the issue of targeted interpretation.

Discussions with Interviewee $\mathrm{H}$, who represented a museum/archive in a coastal town, indicated both an understanding of their usual visitors' characteristics and expectations, and the ways that had been found to respond in a broad manner to the perceived needs of that diverse group.

${ }^{31}$ Cole's work showed that 58 per cent of the larger attractions targeted educational visitor groups segments. However, on 25 per cent of the smaller attractions produced targeted interpretive materials. 


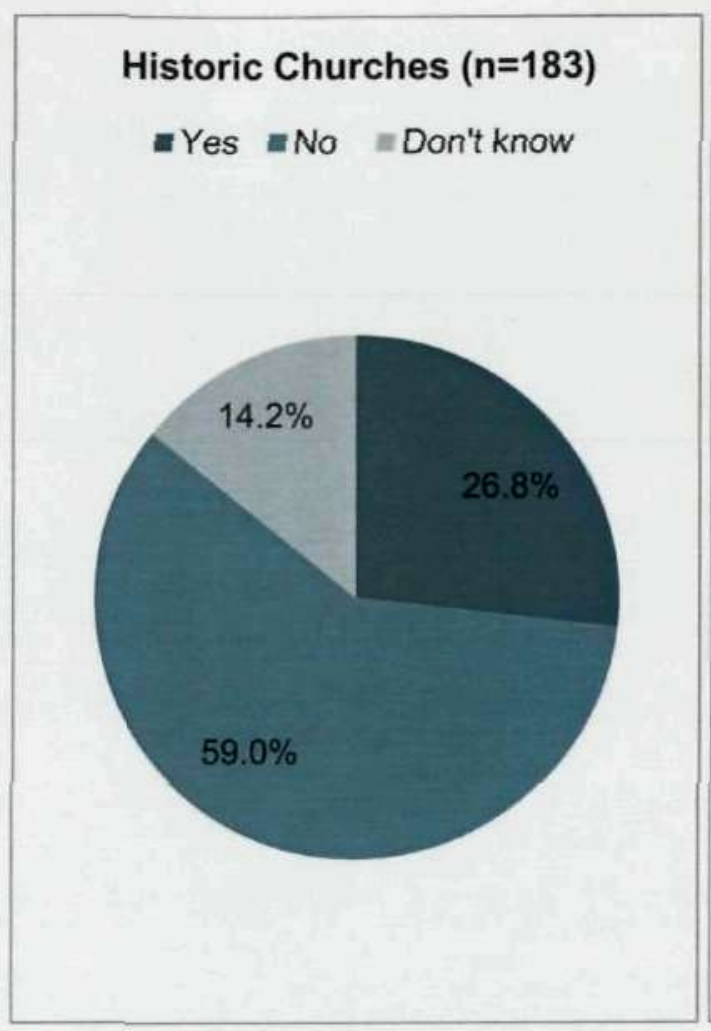

\section{Historic House and/or Castle}

$(n=9)$

-Yes $=$ No $=$ Don't know

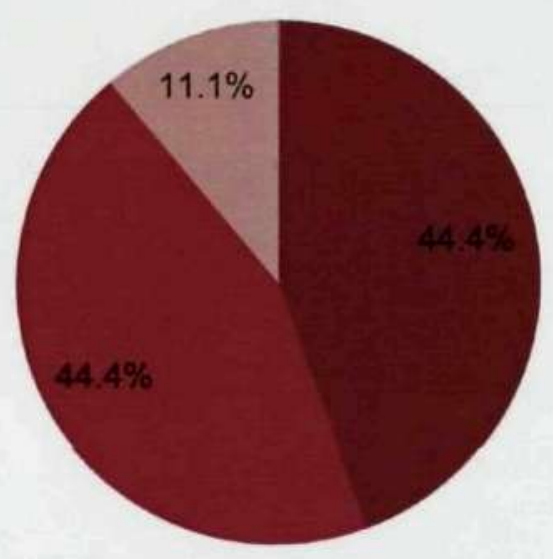

Museum and Archive $(n=46)$

-Yes $=$ No $=$ Don't know

All sites $(n=238)$

-Yes $\equiv$ No $=$ Don't know
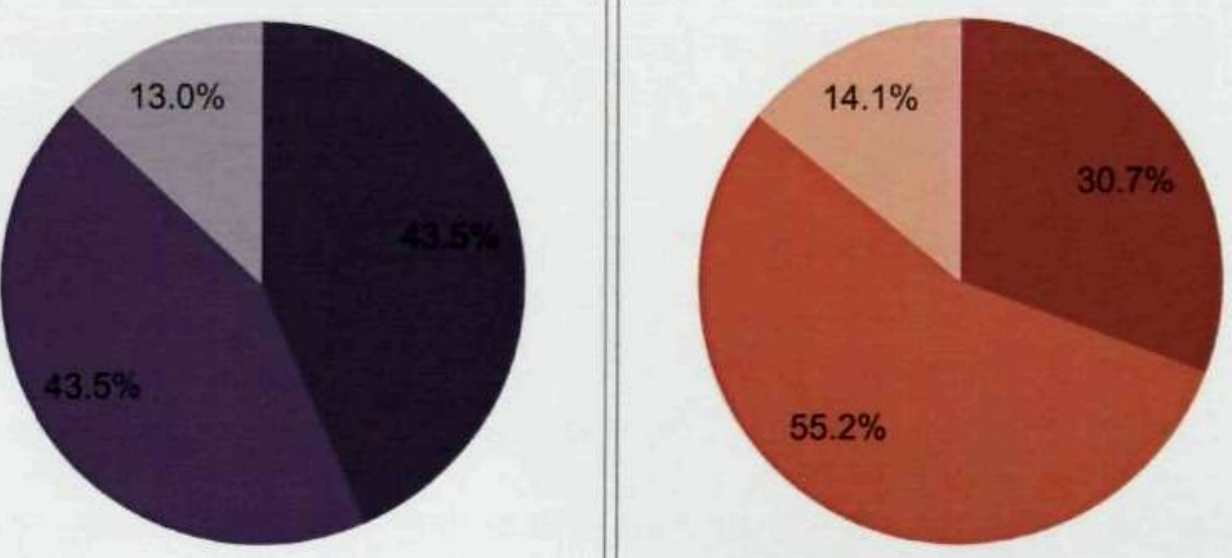

Figure 4.18. The percentage of sites that target their interpretive material at a particular audience group. Source: Author. 
He reported that the museum/archive attracted not only serious researchers, but also those with a very general interest in naval and sea-faring history. Visitors ranged from:

... senior-citizen groups which visit as part of their excursion to the town, to educational groups, to children on holiday in the summer (Interviewee $\mathrm{H}$ ).

Too much targeting (on any one particular group) of the interpretation that was offered was considered by the interviewee to risk narrowing the appeal of the museum.

In an interview with a representative of a historic house, it was stated emphatically that their interpretation was all specifically targeted at their main visitor groups:

... it is aimed at our main visitors and we always have those particular groups in mind (Interviewee G).

In another interview, this time with the custodian of a historic church site, the telling comment was made that their approach was all 'a bit haphazard'. In general, it was found that there is little recognition that other interpretations might broaden the appeal of visited heritage sites, and therefore their market. A certain degree of complacency was detected. There is perhaps a need to seek a means for sharing the good ideas and the good practices which are apparent amongst a few providers of heritage in Devon and Cornwall regarding targeted interpretation that could help to broaden the appeal and increase the visitor numbers of those which currently struggle. 


\subsubsection{Engagement with the Local Community}

The extent to which the local community within which a heritage site is located is actively involved in devising its interpretation and presentation can make an important contribution to its socio-cultural acceptability and therefore its overall sustainability. Local communities often feel a strong sense of ownership of their heritage. In some cases, personal artefacts may have been donated to a collection that is on display. In other contexts, a contribution might have been made to the development of a narrative: the 'story of the place'. Members of the local community also sometimes engage with heritage as regular visitors, or as members of groups who make use of the facilities for other purposes.

Local Community Influence on Interpretive Material: Some 34.3 per cent of respondents to the questionnaire indicated that their local community exerted the most influence on the interpretive information which they provided (Fig. 4.19). Some 36.4 per cent of the historic churches reported that the local community was the strongest influence on the interpretive information. In contrast, only 16.7 per cent of the historic houses/castles and 29.0 per cent of the museums/archives sites said the local community exerted the most influence on their interpretive information.

While some previous work alleges that the National Trust and English Heritage often present historical narratives at heritage sites that fail to engage with local sentiments and local perspectives (Hale, 2001), in recent years, efforts appear to have been made by these and other heritage bodies to address this issue (Caffyn and Lutz 1998). 


\begin{tabular}{|c|c|c|c|c|c|c|c|c|c|}
\hline \multirow{2}{*}{$43.2 \%$} & \multicolumn{8}{|c|}{ Historic Churches $(n=123)$} & \multirow[b]{2}{*}{$0.8 \%$} \\
\hline & & & $1.5 \%$ & $0.8 \%$ & $0.8 \%$ & $1.5 \%$ & $0.8 \%$ & $0.8 \%$ & \\
\hline$\frac{\frac{0}{0}}{\frac{0}{50}}$ & 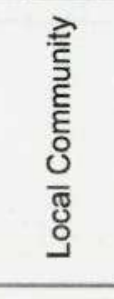 & 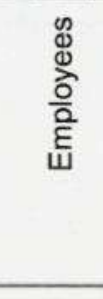 & 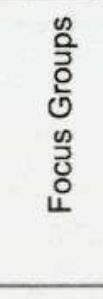 & 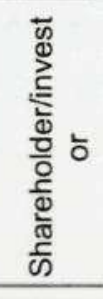 & 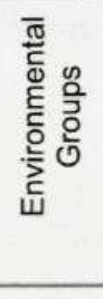 & 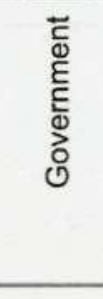 & 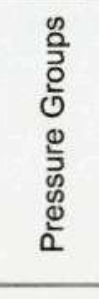 & 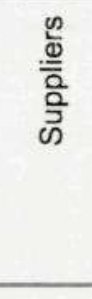 & 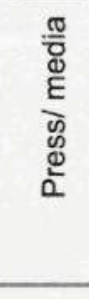 \\
\hline \multirow[t]{3}{*}{$50.0 \%$} & \multicolumn{8}{|c|}{ Historic House and/or Castle $(n=6)$} & \\
\hline & $16.7 \%$ & & $16.7 \%$ & & & & & & \\
\hline & & $0.0 \%$ & & $0.0 \%$ & $0.0 \%$ & $0.0 \%$ & $0.0 \%$ & $0.0 \%$ & $0.0 \%$ \\
\hline$\frac{\frac{0}{0}}{\frac{0}{50}}$ & 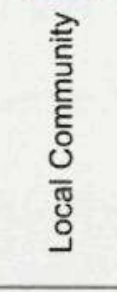 & 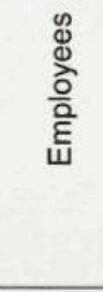 & 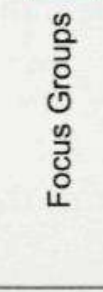 & 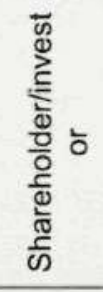 & 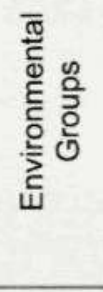 & 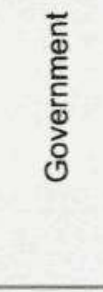 & 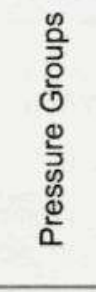 & 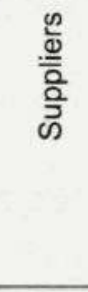 & 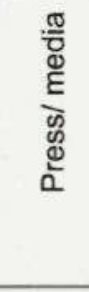 \\
\hline \multirow[t]{2}{*}{$74.2 \%$} & \multicolumn{8}{|c|}{ Museum and Archive $(n=24)$} & \\
\hline & $29.0 \%$ & $19.4 \%$ & $12.9 \%$ & $6.5 \%$ & $6.5 \%$ & $0.0 \%$ & $0.0 \%$ & $0.0 \%$ & $0.0 \%$ \\
\hline$\frac{\frac{0}{0}}{\frac{0}{00}}$ & 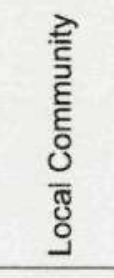 & 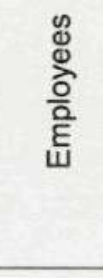 & 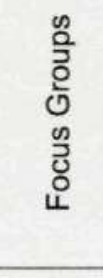 & 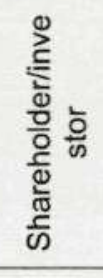 & 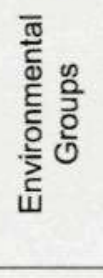 & 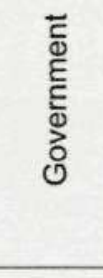 & 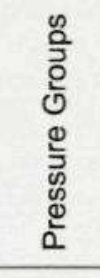 & 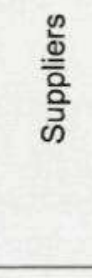 & 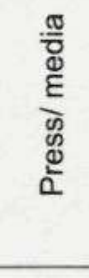 \\
\hline \multirow[t]{2}{*}{$49.7 \%$} & \multicolumn{8}{|c|}{ All sites $(n=153)$} & \\
\hline & & & $4.1 \%$ & $1.8 \%$ & $1.8 \%$ & $1.2 \%$ & $0.6 \%$ & $0.6 \%$ & $0.6 \%$ \\
\hline$\frac{\frac{0}{0}}{\frac{20}{50}}$ & 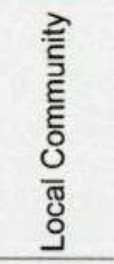 & 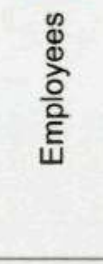 & 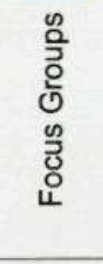 & 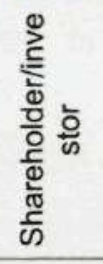 & 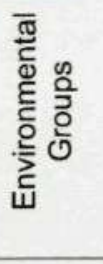 & 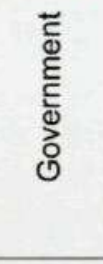 & 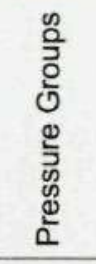 & $\begin{array}{l}\frac{n}{0} \\
\frac{\circ}{0} \\
\frac{2}{3}\end{array}$ & 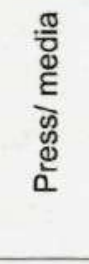 \\
\hline
\end{tabular}

Figure 4.19. Respondents perceptions as to which is the group that exerts the most influence on the interpretive information they provide. Source: Author. 
A representative of the National Trust's property at Cotehele in Cornwall, Interviewee G, commented on efforts that were being made as part of the adoption of the new '3BL' approach to management to combat accusations that they are an elitist organisation and to engage more actively with their neighbouring communities.

In a major project to up-grade, re-design and broaden the appeal of a small, run-down quayside museum that belongs to the estate, a deliberate policy of local community engagement had been adopted. The interviewee described their approach as a 'classic example of socio-cultural sustainability in action', which was very much in line with the Trust's drive to improve its local community engagement. He commented that the Trust has 'got better at community engagement, and we try to do more of it'. In the specific case of the Cotehele Quay Museum, in addition to gathering the views of visitors regarding the character and appeal of the existing museum, members of the local community were invited to a series of 'open evenings' and strongly encouraged to contribute their ideas, perspectives and opinions (Table 4.1). Thereafter, local people were invited to be members of several project groups and become directly involved in creating new interpretive materials. The wider locality was meanwhile kept informed of progress by newsletter, which publication also encouraged them to send in further views about what was being proposed. Although the Trust's staff reserved the right to make final decisions about the display of the museum's collection of heritage artefacts, as well as all the information that was to accompany them, the participation process proved to be very successful. 
Table 4.1 Local Community Involvement in the National Trust Quay

Museum at Cotehele, Cornwall

- Views of existing visitors about displays in museum canvassed

- Local community views sought at open evenings

- Newsletters produced to provide information on plans and seek feedback

- Members of the local community invited to participate as members of project groups on the design and presentation of new interpretive material

Source: Author

Local people were given a means to tell their stories and to indicate the narrative that resonated most closely with their own life and experience.

In order to appreciate more fully the practical application of the Trust's policy, and to experience 'from the inside' the way in which the local Tamar Valley inhabitants were actively engaged in the re-making of Cotehele's quayside museum, the author of this research decided herself to participate as a member of the local community design project groups. This participation was preceded by attendance, and observation of the proceedings, at the open evenings. By these means, it was possible to witness the manner in which local people 
contributed both to ideas for the design of the space, and to the formulation of Interpretative material The enjoyment, the notion of 'playing a useful part' in the creative process, and the sense of ownership of the heritage that was thereby engendered was striking However, it was also clear that the management of local community participation in heritage interpretation is very far from easy. The wider the consultation, the more complex becomes the task of satisfying all those who wish to contribute. Heritage $\mathbf{I S}_{\mathrm{z}}$ after all, essentially a socially constructed phenomenon it can mean markedly different things to different people and no single interpretation or narrative will satısfy everyone Local community engagement of the kind practised in the Cotehele case depended crucially on the patıent, skiful and diplomatic management of the project leaders Discussions were witnessed which were sometımes heated and occasionally passionate and overwrought There were instances when the loud voices of a minority threatened to 'drown out' legitımate views being expressed more quietly by others Interviewee $G$ indeed noted that much had been learned as a result of undertaking such extensive community involvement - both postive and negative - but, on the whole, the exercise had proved how much could be achieved; and it had underlined how much there is potentially to be garned by drawing on the knowledge and Ideas possessed by those who live in a locality ${ }^{32}$

Provision for Using Heritage Site as a Community Resource: Respondents to the questionnaire were asked whether their heritage site was made avallable for use by local community groups Of course, there will have been a great

\footnotetext{
${ }^{32}$ A fuller account of the Cotehele case is reported in Darlow, $S$ and Hunt, R. (2010) The Re-development of Cotehele Quay Museum, Rep. Trans. Devon Assoc. Advmnt Scl., 142, forthcoming
} 
many cases where such provision will simply not have been practicable. Heritage buildings are often fragile and cannot support the wear and tear that can result from community use. Collections of artefacts usually need protection and security. Lack of staff, fire risks, and the need for expensive additional insurance cover were also raised as major obstacles. Overall, therefore, such provision was made in only 15.8 per cent of cases in the sample (Fig. 4.20).

Provision for use by local community groups was reported by the custodians of historic churches in just 17.0 per cent of cases. There may be many more such heritage buildings that could offer their accommodation - in return for payment - for appropriate 'other' uses. The extent to which such opportunities exist should be further explored. In interviews, it was said that the cost of opening up, staffing and heating the church exceeded the income which any activities generated. However, no convincing data were offered to support this contention. In any case, another interviewee (D) commented that by increasing their provision for the local community, they were actually encouraging more people to join their Sunday congregation, and the extra hire-fee income had become fundamental to their sustainability.

\subsection{Economic Sustainability}

The final dimension of sustainability to be considered in this analysis is economic. Commercial imperatives in heritage circles have often been neglected in the past as the conservation and curatorial role is considered to be the central priority of the profession. 

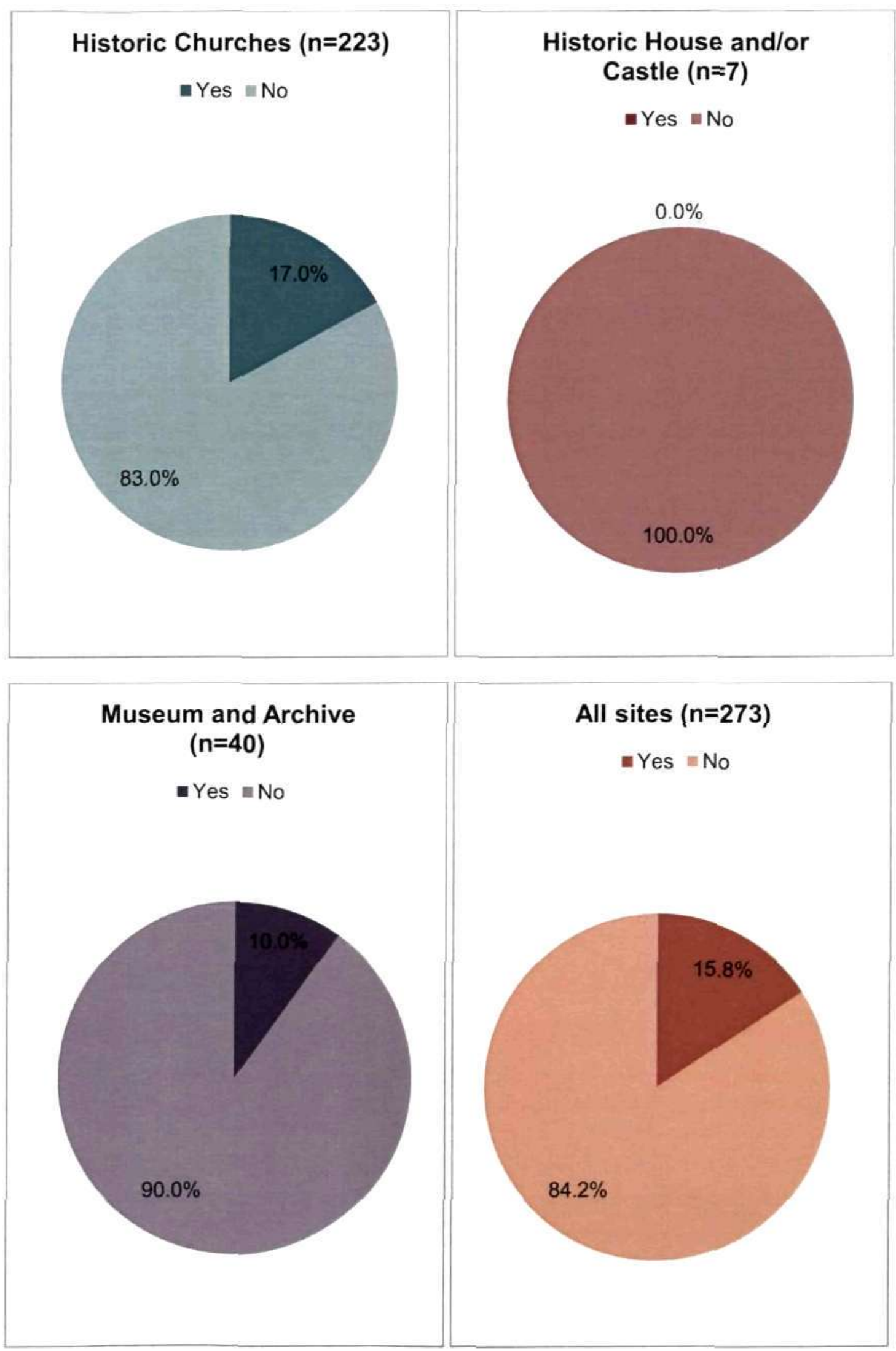

Figure 4.20. Percentage of respondents identifying that they make provision for use by local communities. Source: Author. 
In this research, nevertheless, it is argued that the existence of a robust business model lies at the heart of the successful management of a heritage attraction and should therefore be central to any consideration of long-term sustainability. Many of the findings from the analysis so far can be related to the lack of economic viability of the heritage resource itself. Unsustainable finances have management implications: first, for the care that can be given to oftenfragile heritage buildings or collections of artefacts; second, for the protection of the historical integrity and authenticity of heritage; and third, for the maintenance of the quality of the heritage experience for potential visitors.

In this survey, less than one-third (31.1 per cent) of respondents to the questionnaire survey ranked economic sustainability as their top or joint-top priority (Fig. 4.1). There was considerable variation between the different categories of heritage covered in this Devon and Cornwall study, although there was no apparent link between the priority attached to economic sustainability and the extent of adoption of sustainable practices.

Museums/Archives: The highest priority accorded to economic sustainability was demonstrated by the museums/archives. Some 48.1 per cent of the respondents representing heritage museums/archives made economic sustainability their top or joint-top priority. A majority of the 60 establishments surveyed are small, independent museums. In these cases, income sufficient to cover outgoings, and thereby enable continued operation, is vital. Many are exceptionally marginal enterprises and have no available surplus to pay for improvements that might attract more visitors. One interviewee made clear the constraint under which his establishment operates. 
If you stop the public coming in to view [the collection] while you make improvements, you cut off all your income This is a major dilemma for local, small, volunteer-run museums like ours . It is crippling (Interviewee A)

Lackıng the support of a large parent organisation, heritage sites of this kınd are obviously unable to adopt the 3BL approach of some historic houses/castles included in this survey.

Historic Churches The second highest priority expressed for economic sustarnability was the historic churches While a majority of the 345 historic churches in the sample are subject to the central governance of the Church of England, they are mostly managed by local parochial church councils (PCCs) and each one is expected not only to cover its own costs but also to make regular payments known as the diocesan share ${ }^{33}$ However, even though there was widespread recognition of the need to meet their expenses, only 269 per cent of historic-church respondents in this survey viewed economic sustainability as their top or joint-top priority Understandably, no matter how important the bullding might be as an example of architectural or cultural heritage, the role of the church as a place of worship takes precedence. Nevertheless, comments made by interviewees indicate a general realısation that the overdependence of many churches on (sometimes dwindling) offerings deposited in the collection-plate by their congregation, coupled with the need to maintain fragile historic bullings, now renders their position precarious in one case, the conflict between historıc churches as heritage sites and their spiritual and community role was made very clear:

\footnotetext{
${ }^{33}$ Amongst other things, the diocesan share imposed on Anglican churches funds clergy stipends, pensions, non-church diocesan property, and contributes towards the cost of the Cathedral.
} 
In a church like ours, with lots of voluntary work, that is what people want to spend the money on - actually ministering to those in need. [Maintaining] the building takes resources away from that (Interviewee B).

However, the conservation and maintenance of the buildings that will allow them to remain open for worship and as venues for various church social and cultural activities, requires a sufficient flow of income. While their role as tourist attractions is frequently seen as a secondary (often unimportant) function, it is clear that the community as a whole risks losing important built heritage if historic churches are unable to cover their costs.

Historic houses/castles: Only 37.5 per cent of those responding on behalf of historic houses/castles made economic sustainability their top or joint-top priority. The sample of 11 mostly included large properties in the care of the National Trust or English Heritage and is thus skewed towards providers enjoying access to the shared resources of a national organisation. Financial losses can thus be cushioned and local property managers are not necessarily obliged to balance their books. One interviewee mentioned that the Trust would ensure their financial viability, even if they failed locally to earn any surplus:

If we were generating a deficit instead of a surplus every year, we would then be taking our money from the general pot and saying we need help (Interviewee G).

Results from the questionnaire survey in fact indicate that a significant number of heritage sites in the sample that belong to a large parent body are not locally yieiding any profit and do therefore depend on a regular central 'bail out' of a 
kınd that independent operators simply cannot access. ${ }^{34}$ Property managers in the National Trust are encouraged to look beyond short-term financial shortfalls in order to achieve destrable environmental or social goals which, in due time, will contribute towards redressing the deficit Interviews with National Trust representatives indicate that the organisation's national strategy is clearly understood at local level in Devon and Cornwall:

We have a national strategy that focuses the mind there are four elements: financing our future; improving and tracking our conservation; environmental performance; and Improving the knowledge we have of our assets (Interviewee $\mathrm{H}$ )

\subsubsection{The Means of Income Generation}

For all three categories of heritage combıned, the three matn means income generation stated by respondents to the questionnaire survey were donations, membership subscriptıons, and admıssıon charges (Table 42 ). The domınance of donations is explained by the overwhelming dependence of historic churches (numerically, much the largest group in the survey) on income given by their parishioners or voluntary contributions made by visitors. Donations are, of course, a precarıous and unpredictable source of income They represent a passive means of raising revenue. Nelther churchgoers nor heritage visitors are compelled to contribute

\footnotetext{
${ }^{34}$ Four out of five of the National Trust's historic houses open to the public run at a loss. The deficit is made up from central funds See http /www.nationalitrust org.ukJ mann/w-trust/w-thecharity/w-what_we_do/w-factsabouttrust.htm (accessed 26 April 2010). 
Table 4.2. Main, or joint main, sources of income identified by respondents.

\begin{tabular}{|c|c|c|c|c|}
\hline & $\begin{array}{l}\text { Historic } \\
\text { Churches } \\
(n=303)\end{array}$ & $\begin{array}{l}\text { Historic House } \\
\text { and/or Castle } \\
\quad(n=10)\end{array}$ & $\begin{array}{l}\text { Museum and } \\
\text { Archive }(n=54)\end{array}$ & $\begin{array}{l}\text { All sites } \\
(n=367)\end{array}$ \\
\hline Donations & $\begin{array}{c}254 \\
(83.7 \%)\end{array}$ & $\begin{array}{c}1 \\
(10.0 \%)\end{array}$ & $\begin{array}{c}14 \\
(25.9 \%)\end{array}$ & $\begin{array}{c}269 \\
(73.6 \%)\end{array}$ \\
\hline Membership & 29 & 5 & 16 & 50 \\
\hline subscriptions & $(9.6 \%)$ & $(50.0 \%)$ & $(29.6 \%)$ & $(13.6 \%)$ \\
\hline $\begin{array}{l}\text { Admission } \\
\text { charges }\end{array}$ & $\begin{array}{c}3 \\
(1.0 \%)\end{array}$ & $\begin{array}{c}4 \\
(40.0 \%)\end{array}$ & $\begin{array}{c}21 \\
(38.9 \%)\end{array}$ & $\begin{array}{c}28 \\
(8.2 \%)\end{array}$ \\
\hline $\begin{array}{l}\text { Regular local } \\
\text { authority } \\
\text { payments }\end{array}$ & $\begin{array}{c}1 \\
(0.7 \%)\end{array}$ & $\begin{array}{c}0 \\
(0 \%)\end{array}$ & $\begin{array}{c}6 \\
(13.0 \%)\end{array}$ & $\begin{array}{c}7 \\
(2.5 \%)\end{array}$ \\
\hline National & 2 & 0 & 7 & 9 \\
\hline Lottery grant & $(0.7 \%)$ & $(0 \%)$ & $(9.3 \%)$ & $(1.9 \%)$ \\
\hline $\begin{array}{l}\text { One-off local } \\
\text { authority } \\
\text { grants }\end{array}$ & $\begin{array}{c}5 \\
(1.7 \%)\end{array}$ & $\begin{array}{c}0 \\
(0 \%)\end{array}$ & $\begin{array}{c}2 \\
(3.7 \%)\end{array}$ & $\begin{array}{c}7 \\
(1.9 \%)\end{array}$ \\
\hline Retailing & $\begin{array}{c}1 \\
(0.3 \%)\end{array}$ & $\begin{array}{c}2 \\
(20 \%)\end{array}$ & $\begin{array}{c}5 \\
(11.1 \%)\end{array}$ & $\begin{array}{c}9 \\
(2.7 \%)\end{array}$ \\
\hline Catering & $\begin{array}{c}4 \\
(1.3 \%)\end{array}$ & $\begin{array}{c}1 \\
(10.0 \%)\end{array}$ & $\begin{array}{c}5 \\
(1.9 \%)\end{array}$ & $\begin{array}{c}6 \\
(1.6 \%)\end{array}$ \\
\hline $\begin{array}{l}\text { Media, film use } \\
\text { of site as 'sets' }\end{array}$ & $\begin{array}{c}1 \\
(0.3 \%)\end{array}$ & $\begin{array}{c}0 \\
(0 \%)\end{array}$ & $\begin{array}{c}1 \\
(1.9 \%)\end{array}$ & $\begin{array}{c}2 \\
(0.5 \%)\end{array}$ \\
\hline Conferences & $\begin{array}{c}1 \\
(0.3 \%)\end{array}$ & $\begin{array}{c}0 \\
(0 \%)\end{array}$ & $\begin{array}{c}0 \\
(0 \%)\end{array}$ & $\begin{array}{c}1 \\
(0.3 \%)\end{array}$ \\
\hline
\end{tabular}

Source: Author 
The museums/archives and historic houses/castles in the sample clearly rely much more on membershıp subscriptions and admission charges, which are direct and usually more lucrative sources of income. Secondary-spend activities (such as catering and retailıng) were also noted as Important, but they do not appear to be a main source of income generation for respondents from any of the three heritage attraction categories in this survey. Some similar findings were reported by Cole (2004) who studied mınıng heritage sites and stated that larger enterpnses tend to rely more heavly on admission charges and secondary spending (In shops and cafés), while small sites are more dependent on donations Professionally staffed, larger heritage sites are generally better placed to maximıse income from admıssion ticket sales and retall spending The results from this research seem to support, to some extent, Cole's assertion that larger sites with more opportunities for secondary spend are more profitable This finding appears to be reflected in the higher levels of direct income, and secondary spend income, being generated at the more commercial histonc house/ castle sites.

In this project, interviews conducted with representatives of heritage sites that claim to be profitable indicate clearly that they engage in a wider and more ımagınative range of ıncome-generatıng activities than those sites whıch report runnıng at a loss Successful enterprises, such as hosting season festivals, holding raffles, and capitalising (in the case of one very beautiful medieval church) on high levels of demand to use it as a venue for weddings, were thus encountered (see Section 4.4.6) In most cases, profitable sites employ a mix of admıssion charges, retaling, and caterıng provision to achıve their success. 
An interview conducted with a representative of a historic house underlined the importance of viewing finances holistically:

It is not just down to the people in catering or the shop to make money for their own operation because they know that their profits are needed to support the main house and the gardens (Interviewee $\mathrm{H}$ ).

The generation of a profit from their existing activities has enabled some providers to invest in additional opportunities for 'secondary spend', thereby expanding their operation. Thus, in the case of one of the historic churches included in the sample, it had proved possible to establish a small gift shop:

It is not an enormous shop, but it brings in a steady turnover ... we are looking at several thousand pounds profit each year ... and it all helps (Interviewee $\mathrm{G}$ ).

Loss-making providers, by contrast, lack the resources to break into 'secondary spend' activities that could solve their problem. The dilemma of finding sufficient funds to invest in secondary spending opportunities is acute in the case of many small heritage sites in Devon and Cornwall (4.4.3).

\subsubsection{Expenditure}

Patterns of expenditure vary considerably between the three categories of heritage surveyed in this research (Fig. 4.21). Respondents representing historic houses/castles clearly spend a much larger percentage (90.0 per cent) of their income on staff training and wages than either museums/archives $(37.0$ per cent) or historic churches (16.1 per cent). 


\section{Historic Churches $(n=309)$}

a Building/ maintaining visitor facilities

= Staff costs (wages and training)

- Other

- Conserving historic nature of the site

= Updating on-site interpretation

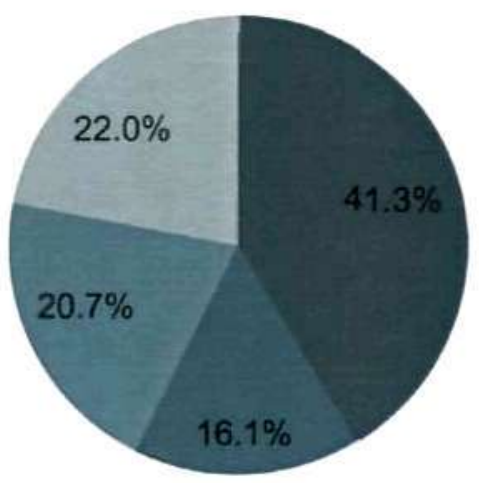

Historic House and/or Castle $(n=10)$

- Building/ maintaining visitor facilities

- Staff costs (wages and training)

- Other

m Conserving historic nature of the site

Updating on-site interpretation

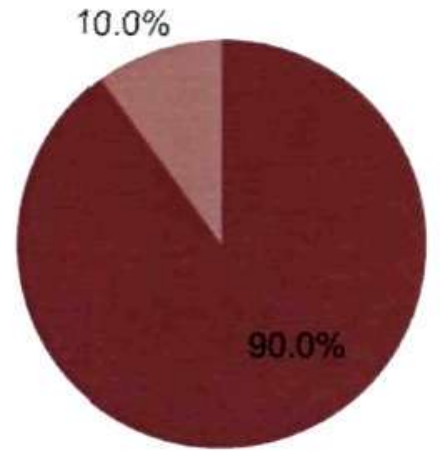

\section{Museum and Archive $(n=54)$}

- Building/ maintaining visitor facilities = Staff costs (wages and training)

Other

= Conserving historic nature of the site

= Updating on-site interpretation

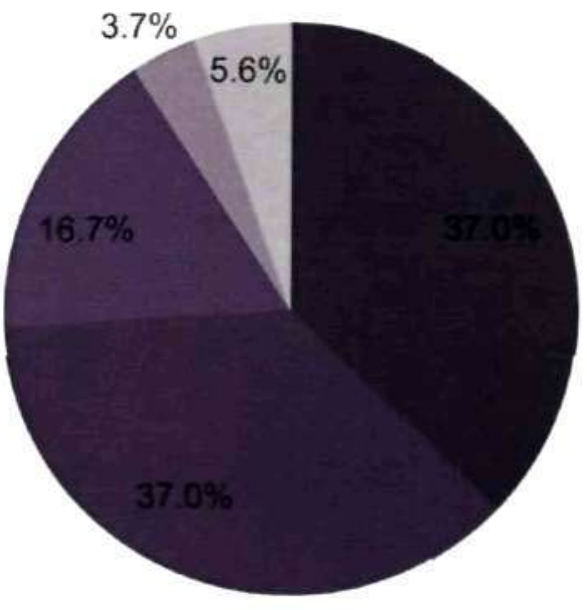

\section{All sites $(n=373)$}

- Building/ maintaining visitor facilities = Staff costs (wages and training)

- Other

= Conserving historic nature of the site - Updating on-site interpretation

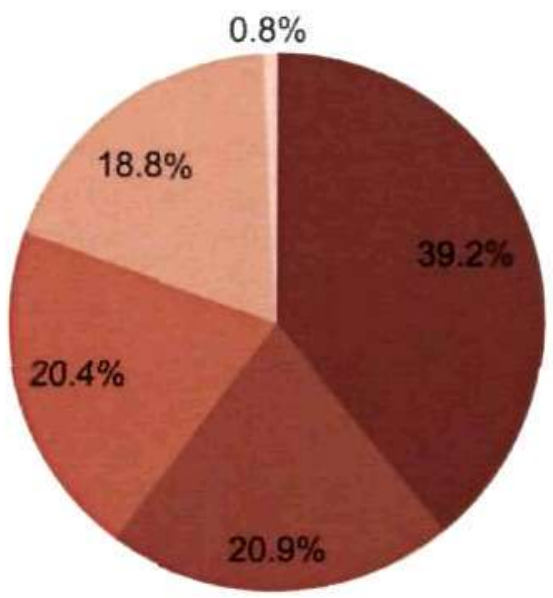

Figure 4.21. Patterns of expenditure. Source: Author. 
In fact, for historic churches, the largest percentage of respondents (41.3 per cent) stated that the costs of building maintenance and visitor facilities represented their largest area of expenditure. The interview evidence showed that the burden and responsibility of conserving and caring for the fabric of ancient churches weighed very heavily indeed. Moreover, the problem is exacerbated by the difficulty faced in meeting the diocesan share. While this cost does not link directly to the historic churches' activities as visited heritage attractions, its adverse impact on the ability of parish churches to meet their other outgoings, and perhaps invest in new means of generating income, is extremely important. One interviewee remarked that "this year the diocesan share is somewhere in the region of $£ 54,000$; so, more than $£ 1,000$ per week' (Interviewee E). Others similarly drew attention to the burden of the diocesan share as the principal reason for their failure to make a profit.

A majority of the historic houses/castles included in the sample charge an admission fee; some also have a shop and/or a café. Inevitably, therefore, the cost of wages for staff dominates their outgoings. In the case of the museums/archives, frequently staffed (at least partly) by volunteers, a wider pattern of expenditure was reported.

\subsubsection{Profitability}

Based on the knowledge and perceptions of the respondents, a remarkably small percentage (31.8 per cent) of the heritage sites included in the survey had

either 'broken even' or generated a surplus in the previous financial year (Fig. 
4 22) Clearly, 682 per cent therefore operated at a loss. Past studies have not examıned unprofitable, margınally sustaınable heritage.

The percentage of providers reporting that they were profitable or broke even in the past financial year does, of course, vary amongst the three main categories of heritage providers surveyed in this project. Thus, as might perhaps have been predicted, historic houses/castles displayed higher levels of profitabılity (55.6 per cent), while the least economically viable are the historic churches, just 288 per cent of the latter stated that they make a profit. Again, it should be noted that no matter how precious they might be in terms of their architectural heritage, churches are primarily places of worship and few custodians regard their commodification 'into marketable heritage products' (Leask and Yeoman 1999) as an overriding goal. However, the increasingly burdensome cost of maintaning the fabric of hertage churches is well understood by their custodians In interviews, it also became very clear that there is an awareness of a lack of the necessary expertise to help realise the potential of the church as an income-generating heritage attraction These are issues that will be considered more fully in section 446

The eight face-to-face interviews underlined the point that providers and custodians of heritage in Devon and Cornwall earnestly want to operate in an economically sustainable manner However, only four reported being in surplus. These were a museum/archive, a historic house, and two heritage churches The proportions thus broadly matched the overall proportions shown in the 'all sites' ple chart in Fig. 4.22 

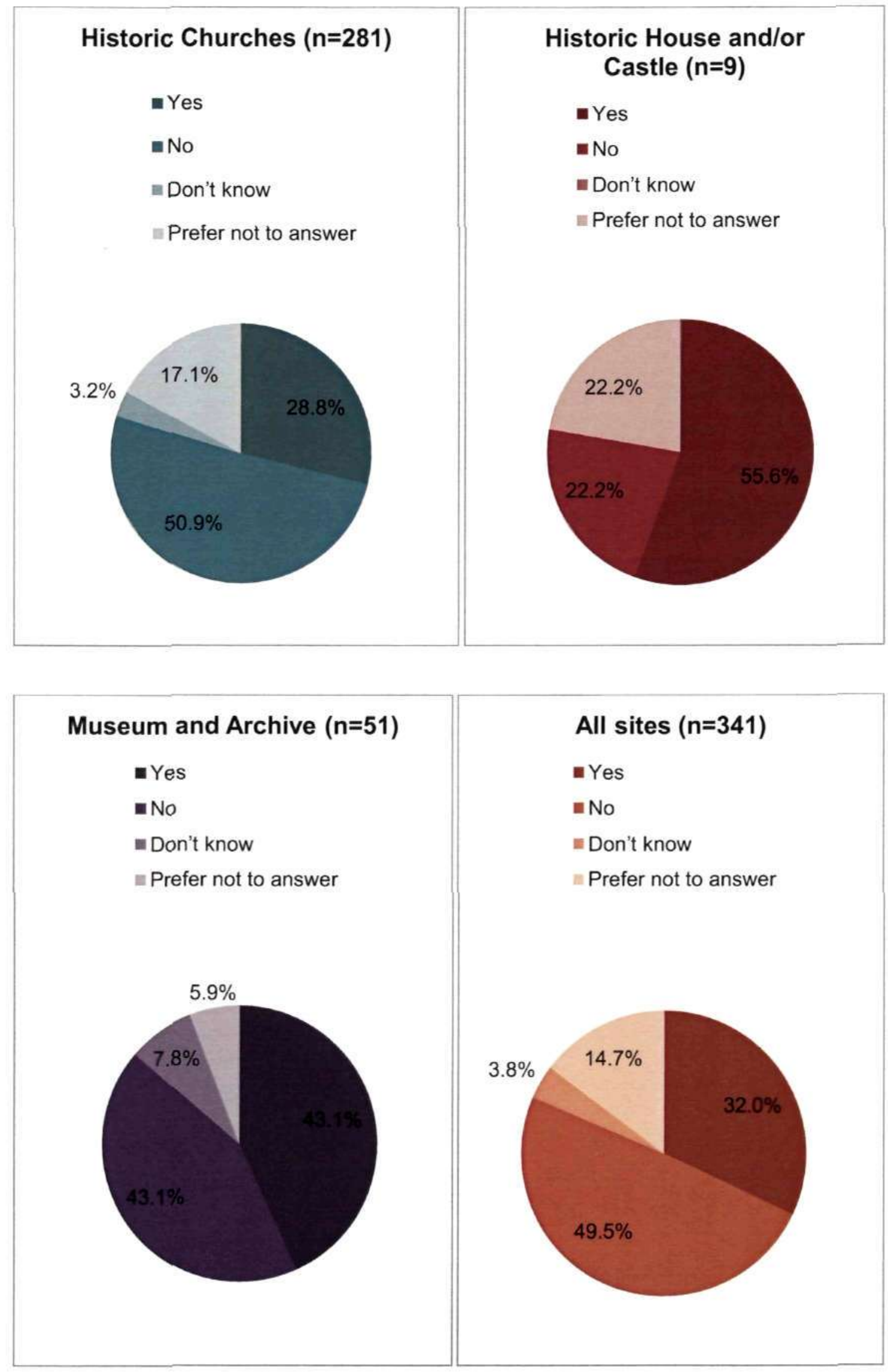

Figure 4.22. The percentage of sites identifying that they generated a profit or broke even in that last financial year. Source: Author. 
The four interviewees whose heritage site runs at a loss recognised their dilemma and the difficulty of finding a remedy. A typical remark was that:

... if you can't balance the books, you have a dead business ... you could argue that, if the money going out exceeds the money coming in, you are bankrupt and ... the public are not going to get into see it [i.e. the heritage attraction] (Interviewee A).

Another interviewee saw his predicament in stark terms:

Our income is $£ 18,000$ and our expenditure is $£ 21,000$; so every year we lose between $£ 2,500$ and $£ 3,000$, and we have a limited amount of money in our deposit account ... which is going to run out in two years time (Interviewee D).

In some cases, it was noted that accumulated savings and endowments, or the generosity of owners and benefactors could be drawn upon. Of those surveyed in the questionnaire, 72.2 per cent stated that their site belonged to a larger organisation. As previously mentioned, some (though not all) of these parent bodies will cross-subsidise loss-making properties in their care. In contrast, the weak business models of independently owned heritage attractions have no cushion, and their management style is more likely to result in their decline and eventual closure.

In general, the small, independent heritage sites (in this research, mostly comprising museums/archives and historic churches) are particularly vulnerable. Their marginal finances mean that even small increases in, for example, utility prices, or meeting the expense of unavoidable remedial repairs, could force them to close. Comments made during interviews highlight the precariousness: 
Sooner or later there will be a big problem with the roof or something like that, and then that will be horrendous! (Interviewee C).

Our inability to meet large costs prevents us from modernising and renovating (Interviewee D).

I guess that, in the long-term, the church will go into even more decay (Interviewee B).

The problems of financial security and the reconciling of commercialisation with concerns about the fragility and integrity of a heritage resource are most acute for those site that are not part of a larger organisation. Even in cases where financial losses can be borne by their parent body, sooner or later, they must face questions about their sustainability. After all, no organisation can survive indefinitely unless a majority of its activities pay their way.

\subsubsection{Barriers to Profitability}

A range of issues explain the general lack of enterprise activity and an enterprise ethos amongst many of the heritage providers included in this survey (Table 4.3). The key prohibiting factors include lack of time, the formidable barrier of set-up costs, and the usual scarcity of skilled people to help with initiatives. Of these three, the limited time that volunteers could devote to such activities was seen as the paramount constraint.

When asked if they had considered setting up a shop, many respondents stated that they were simply unable adequately to staff such a facility, so it would not be a viable proposition. 
Table 4.3 Reasons given for a lack of enterprise activity and an enterprise ethos by Devon and Cornwall heritage providers

- Low visitor numbers

- Lack of skills to develop projects or to produce interpretive material (this is a partıcular issue for volunteer-led heritage sites)

- Lack of tıme to develop or Implement initiatıves (once again, a severe constrant at places dependent on volunteers)

- Concern that activities might jeopardise the integrity of the site or interfere with its existing uses

- Lack of initial set-up funds to launch new

Source Author

Simularly, only 563 per cent sell interpretive literature Some acknowledged that the avallable material is out-of-date and perceived as rather unappealing and uninteresting by visitors The high up-front costs of revising (or even just reprinting) such material was the reason why materials were not being replaced However, lack of time and skill to target their audience and promote and sell the material were also mentioned as barriers to action. 
In those cases where reasonably good-quality material was produced and made available, a further pertinent point made by more than one interviewee was that the items were offered for purchase by means of an 'honesty box' and that only minimal monitoring was possible of the payments actually being made.

\subsubsection{Maximising Income from Heritage Visitors: Market Research}

The assertion that profiling and segmentation analysis can enable heritage providers to 'generate extra business and income' and to 'spread their market base' (Light 1996), points to its critical importance for managers of visited heritage who seek to make their operations sustainable. The monitoring of the numbers, characteristics, geographical origins and expectations of visitors, yields information upon which to base plans for the improvement and better targeting of facilities and interpretative materials. Ways to appeal to new market segments might thus be found. In general, however, the evidence of the sample indicates that a large proportion of the heritage providers in Devon and Cornwall do not undertake a formal survey of either their visitor numbers, or their visitor characteristics. The questionnaire responses showed that, overall, only 9.6 per cent of the respondents had undertaken any formal market research (Fig. 4.23). This sample-wide percentage is, however, considerably depressed by the inclusion of the historic churches for which a mere 1.1 per cent reported undertaking formal market research. Instead, the churches reported their much greater dependence on 'informal information and experience'. Of course, the accurate monitoring of visitor numbers requires adequate staff time and commitment, which most churches do not possess. 

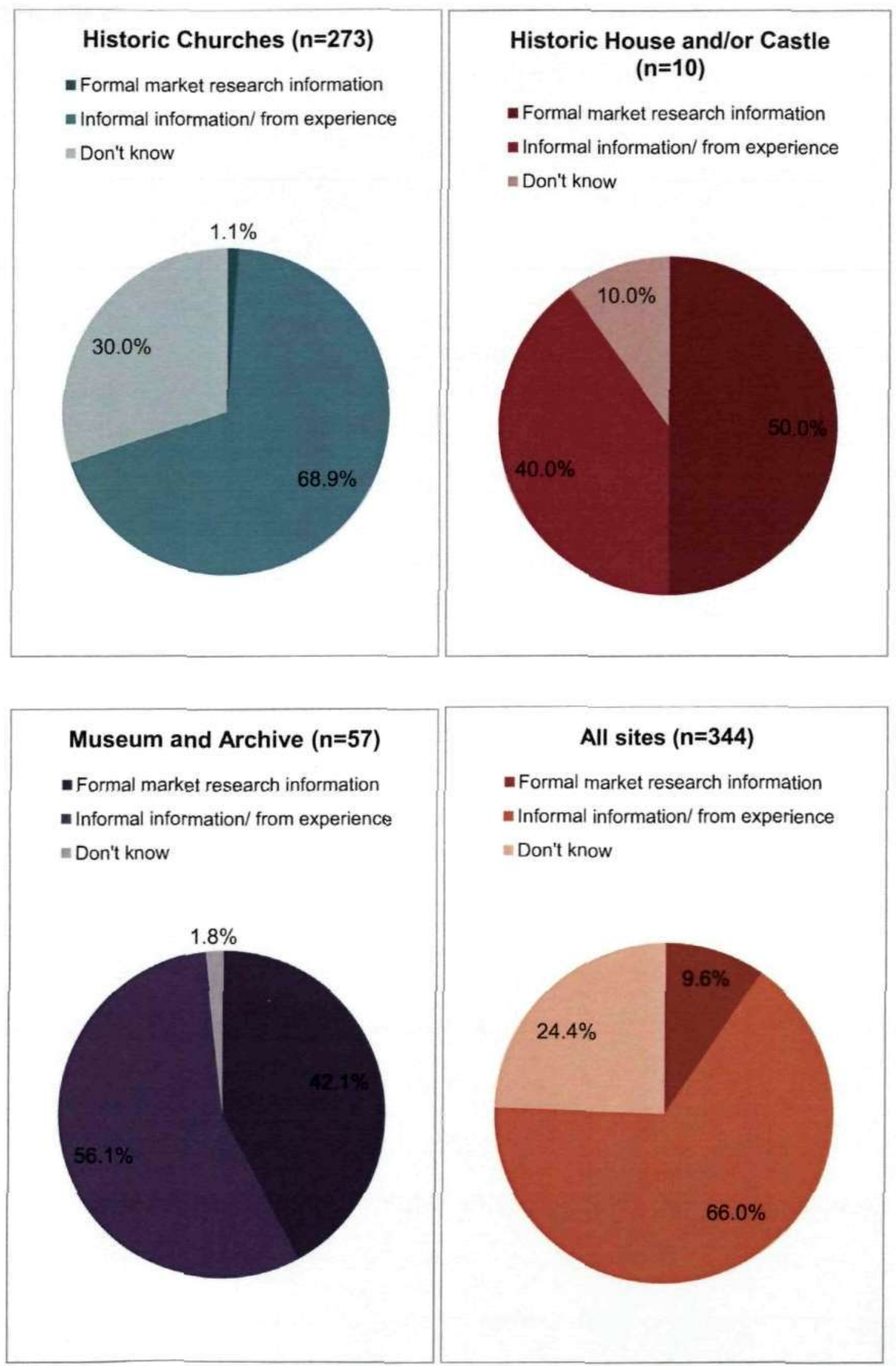

$$
\text { All sites }(n=344)
$$

m Formal market research information w Informal information/ from experience $=$ Don't know

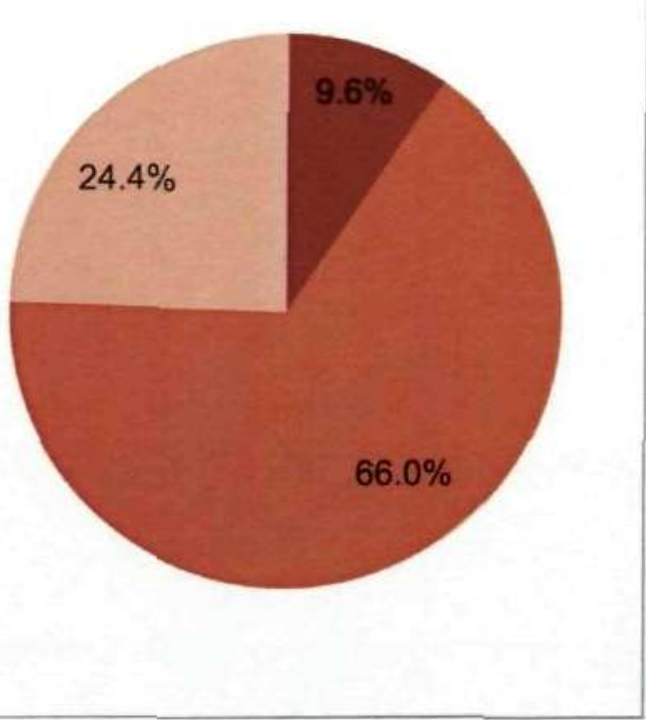

Figure 4.23. Percentage of respondents identifying the methods used to measure visitor numbers and types Source: Author. 
However, inferences and rough totals derived from entries made in visitors' books are unlikely to be reliable. In one interview, for example, it was stated that:

We do have a visitors' book, but I have come in during the day and there have been 20 or 30 people here, yet there have been no entries made in the book (Interviewee E).

In marked contrast to the very low percentage of churches that formally monitor their visitors, some 50.0 per cent of the historic houses/castles, and 42.1 per cent of the museums/archives reported that they did so. Moreover, of the historic houses in the ownership of the National Trust, and therefore able to draw on the professionally organised support of the parent organisation, some 75.0 per cent recorded their visitor numbers and had analysed visitor characteristics; and, of the museums/archives owned or managed by local authorities, some 57.1 per cent had undertaken some visitor monitoring.

Geographical Origins: The questionnaire respondents who were able to monitor their visitor numbers were, in many cases, also able to identify visitor characteristics. When asked to indicate the percentages of their visitors from different geographical catchments, responses were varied (Fig. 4.24). For all types of heritage, visitors from the immediate locality dominate (40.7 per cent). Another 25.3 per cent come from elsewhere within the UK, and just 7.8 per cent were international visitors. The high proportion of local visitors perhaps indicates that Devon and Cornwall heritage providers are engaging effectively with their local communities. 

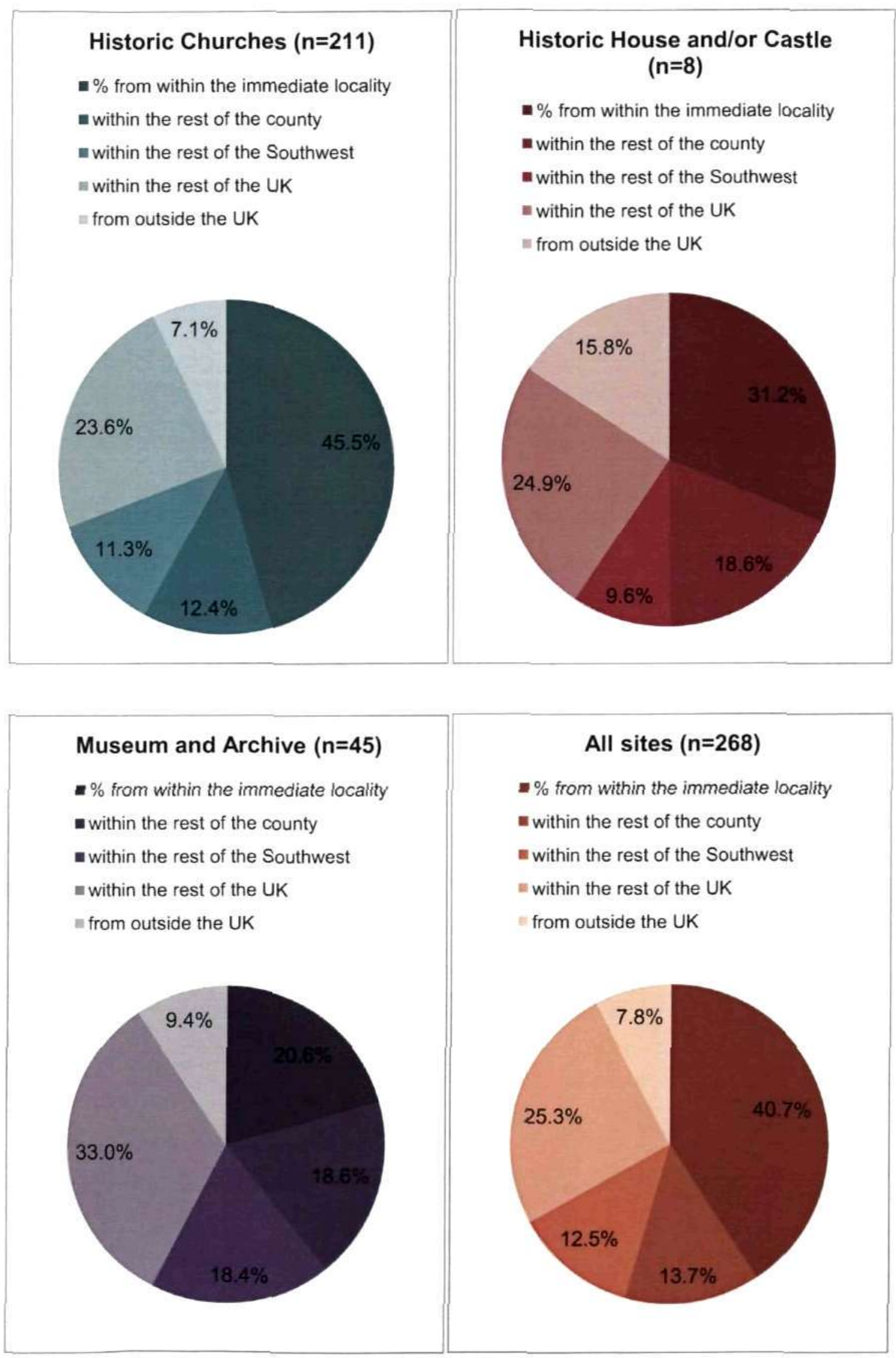

\section{All sites $(n=268)$}

" $\%$ from within the immediate lacality

within the rest of the county

w within the rest of the Southwest

w within the rest of the UK

vfrom outside the UK

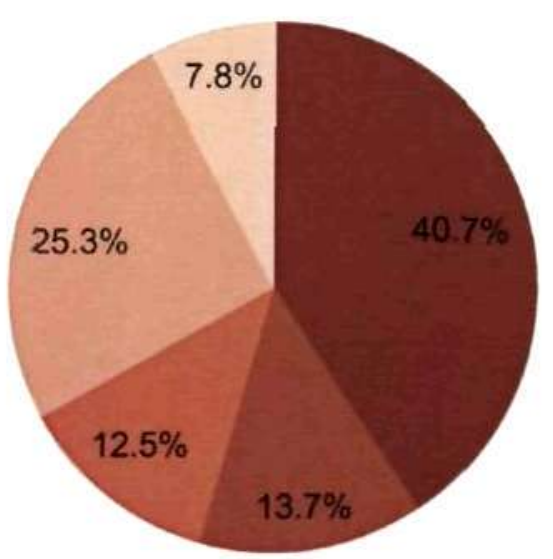

Figure 4.24. Average (mean) percentage of origins of visitors by geographical area as identified by sire manager/ custodian. Source: Author. 
On the other hand, the data indicate that considerable scope exists to appeal rather more to visitors from outside the immediate region, as well as overseas. Museums/ archives appear to receive visitors from the broadest geographical range. One third of their visitors are drawn from locations beyond the south west, and another 9.4 per cent are international visitors. The relatively high international visitor component to museums in the sample reflects the particular appeal of some of the collections and better marketing amongst overseas tourists. For example, Interviewee G pointed to the United States visitors who are attracted to see artefacts connected with the voyage of the Mayflower, and that the specific promotion of the collection drew in significant numbers of international visitors.

Motivations for Visiting: In examining motivations for visiting the heritage sites in the sample, the dominant category was reported to comprise 'people who just want a day out' (50.5 per cent). However, 41.4 per cent of the respondents also noted that their visitors were those 'seeking lots of factual information'. The pattern of motivations was similar for each of the three heritage types (Fig. 4.25). Young people, and those with young families, were found to be the two least-represented groups (Fig. 4.25). Opportunities to broaden significantly the appeal of Devon and Cornwall heritage to these two important market segments are not being sufficiently taken.

In recent years, the National Trust has spearheaded a new drive amongst some managers of heritage to undertake sophisticated visitor profiling. 


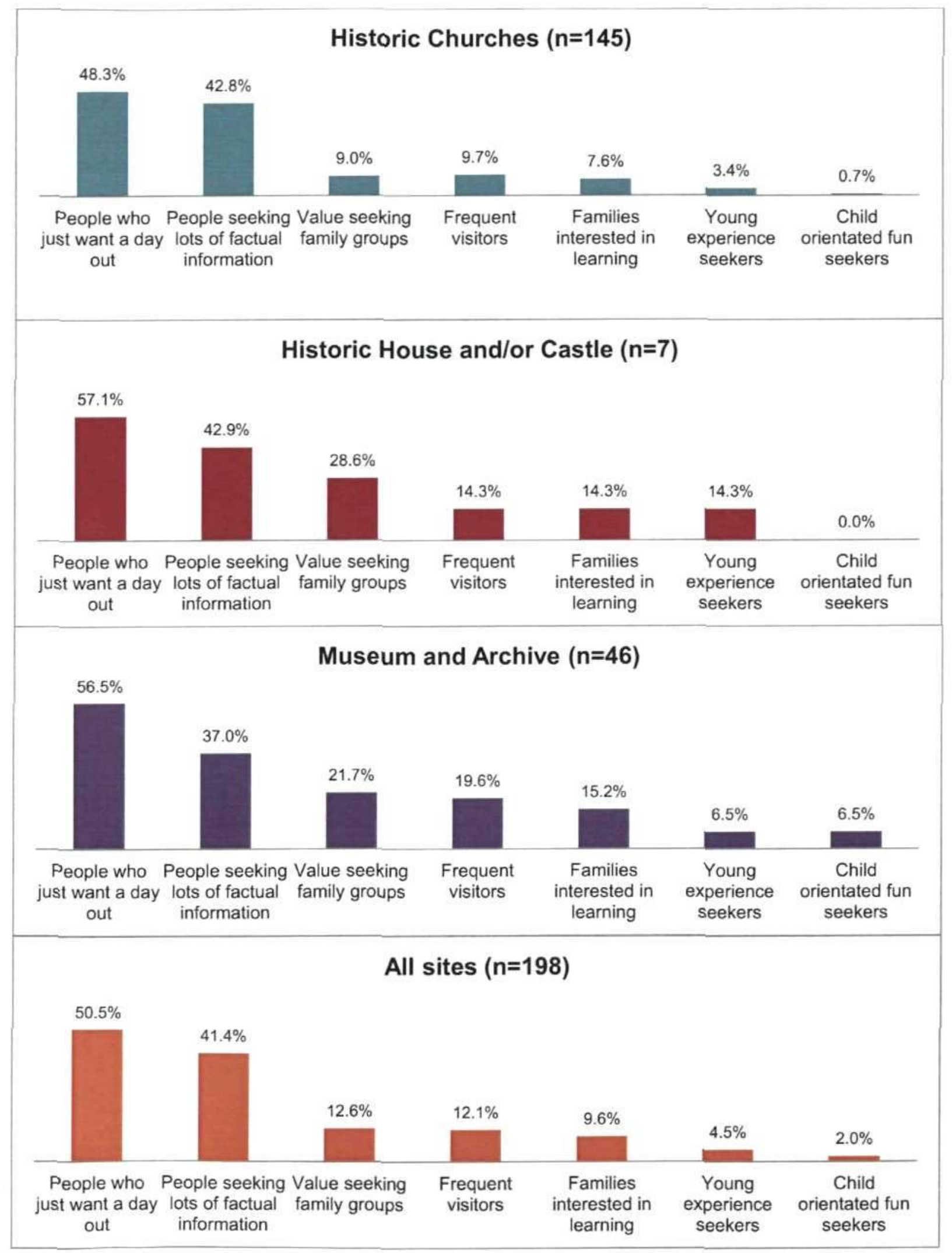

Figure 4.25. Percentage break-down of the main, or joint main, visitor groups by heritage category. Source: Author. 
As a result, a segmentation approach has been increasingly promoted by the Trust whereby interpretation and facilities that appeal to their well-established core visitor groups are continued and protected, but new ways are sought to appeal to market sectors that have hitherto been underrepresented. An in-depth interview conducted in this investigation explored the operation of the policy in one of Devon and Cornwall's large National Trust properties. The interviewee said that their local monitoring activities had been developed by the National Trust's head office; he commented that it is 'totally driven from the centre'. The respondent then pointed out that:

We look very carefully at their [i.e. the visitors'] motivations for coming here ... and we try to define which [groups] we attract; we target our work, our interpretation, and the visitor experience at those individuals (Interviewee G).

He thus stressed that a balance was sought whereby the property remained attractive to its core audience but, at the same time, found new ways to appeal to untapped, potential visitor groups. It should be noted that comparably sophisticated, research-based initiatives, of the kind implemented by the National Trust, were not encountered either in the questionnaire survey or at other heritage sites included in the in-depth interviews in this study. A major question therefore is whether, in future, more providers might recognise the value - and be capable of undertaking - profiling analyses of a similar kind and whether, in doing so, new visitor groups might be identified.

It is apparent from this analysis that many heritage providers could do more to ensure the overall economic viability of their site. Although such an approach might be alien to many managers and present a potential threat to the heritage 
qualities of the site, without this essential pre-condition, there are doubts about their ability to survive let alone introduce other forms of sustainability.

\subsubsection{Examples of Successful Profit Generation}

Interviewees who participated in this survey were able to identify a number of successful ways of generating income that have been implemented without compromising the integrity of the resource itself. Three cases in particular seem to provide evidence of 'best practice', which might act as inspiration to other sites in the region. The first is a small historic church which has perfected one additional income-generating activity. The second is a larger historic church that relies on volunteers to run several income-generating activities. Finally, the third is a large National Trust property which maximises its income through a diversity of means.

Historic Church (Interviewee E): The representative of the custodians of this small medieval Devon church said income is generated chiefly through donations. However, one other highly profitable activity has been developed: the remarkably picturesque coastal location and beautiful medieval building mean that the church is much in demand for weddings. We had 72 weddings here last year ... and, in doing that, generated additional revenue'. The average Church of England wedding costs $£ 313.50$ for the reading of banns and the service, from which $£ 127$ is taken by the $P C C .{ }^{35}$ Extra income comes from

\footnotetext{
${ }^{35}$ The wedding service itself costs $£ 247$, of which $£ 120$ is taken as the stipend to the incumbent and the remaining $£ 127$ goes to the PCC and for the management of the church. It is therefore likely that this church secures profits well in excess of $£ 10,000$ per year from the weddings it celebrates.
} 
charges for bell ringing, the cost of the choir and also for the church organist. Donations made by wedding guests are often also significant. 'We have also now noticed that it has started to "snowball" because those couples who get married, a few years down the line, bring their children back for baptisms ... as well as recommending the church to other couples as a venue for their wedding'. Unlike other possible activities, this lucrative means of increasing income is seen to exert no adverse impacts on the integrity or main function of the church; in fact, it is perceived to have a beneficial impact not only for the church but also by generating business for the local car-hire company and the hotel.

While the church in this case is profitable, it is obvious that other opportunities exist for the further commodification of its potential as a tourist attraction. 'We are flexible, but we have to stick to agreed criteria. We vet everything very carefully and make sure it doesn't demean the church in any way, shape, or form ... we have to be very careful on that'. A good-quality, full-colour guide booklet, plus other publications (postcards; parish recipe booklet) are produced and yield a good profit. 'We are talking in terms of $£ 2,000-£ 2,500$ in a threeyear period'. Payment for these items depends entirely on the honesty of visitors. 'We work totally on trust here, [but] I don't think we lose out ... I'm sure we don't ... but it's a bit of an unknown factor'. The church possesses many attractive attributes such as its supposed pre-Conquest origins, dedication to a Celtic saint, some early-modern monuments to local gentry families, as well as nineteenth-century embellishments (such as the font, pulpit and lectern). It has a fine collection of sixteenth- and seventeenth-century communion plate and a ring of six bells, four of which date to 1552 . These assets, together with its 
location and the exceptional quality of the church, may well indicate that further opportunities to attract heritage tourists are being missed.

Large Urban Historic Church (Interviewee F): In this case, several enterprises exist that specifically target the tourists who visit the locality. For example, a highly popular 'tourist trail' has been developed, which includes the church and thereby helps to encourage visits to its attractions as well as to other interesting places lying nearby. Activities in the church include concerts, conferences, corporate lunches, summer fêtes, and a December Christmas-tree festival. Individually these enterprises do not yield large income streams but together they are significant. Another successful venture has been the small shop, manned by volunteer stewards and open from 11.00 am until $3.00 \mathrm{pm}$ between April and September. The shop attracts additional visitors and has a steady turnover of souvenirs, postcards, plants, and gifts (including branded bookmarks and stationery). A guidebook to the church is also sold as well as leaflets printed in five different languages, 'because we get many international visitors'. Sensitive consideration has been given to the historical integrity of the church and the requirements of potential visitors and yet imaginative ways of generating income have been found.

Historic House (Interviewee G): Owned by the National Trust, this large historic house property undertakes a diverse range of enterprises that yield a sizeable income. Apart from the share of admissions income and membership subscriptions that are devolved from the centre, the property's café/restaurant and shops are highly profitable. Nevertheless, some further revenue and investment funding is also secured from external bodies. Emphasis is placed on 
boosting entry-fee income by encouraging visitors to authorise Gift Aid claims from H.M. Customs and Revenue (which add 28 per cent to the income derived from any ticket sold to an income-tax paying visitor). The parent organisation allows the local management to 'keep 80 per cent of our gift aid money ... so it is useful'. From time to time, regional 'pledger' and 'legacy' days are held when a group is invited to the property for an exclusive tour, talks and a lunch; information about pledging a donation or making a bequest is given on these occasions, but it is also found that participants frequently return for visits in the ordinary way.

A range of further small-scale profitable enterprises exists. Indeed, the Trust offers positive support and encouragement for local, small-scale money-making activities. Thus a second-hand book shop facility generates 'anywhere between $£ 8,000$ and $£ 10,000$ a year'. All monies raised by such initiatives are retained locally. Raffles are also held by the Trust and 'for every £1 raffle ticket we sell, we get $£ 2$ from head office'.

\subsection{Conclusions}

In presenting the detailed analysis of the questionnaire and interview data gathered from Devon and Cornwall visited heritage, a number of critically important findings have emerged that shed light on the extent and the effectiveness of the sustainable management practices that are currently operated. A summary of ten key points is presented below and these will form the basis for the development of broader policy recommendations that are presented in the final chapter of the thesis. 
1. Although there is variation between the categories of visited heritage that were examined, the evidence suggests that, across the entire sample, the highest priority is given to socio-cultural sustainability; and the lowest to environmental sustainability. Because of the strong imperative to privilege the conservation and protection of the historical integrity of the sites in their care, heritage providers appear to attach a lower priority to being 'green' than is the case amongst ordinary tourism businesses. Moreover, some aspects of environmental sustainability, such as discouraging the use of private cars, clearly conflict with aims to maximise visitor numbers to Devon and Cornwall heritage sites that are remote or inaccessible using public transport.

2. Despite the more obvious relevance to the remit of heritage providers of adopting 'green' measures, in practice, it has been shown that, overall, there is actually not much difference between the level of take-up they actually claim, and that claimed by small tourism businesses.

3. Of the heritage providers who report the implementation of 'green' measures, a majority have done nothing more than adopt low-energy light-bulbs or similarly unsophisticated and modest changes. Even though many heritage providers recognise not only the financial advantages, but also the kudos that might be derived, a clear implementation gap appears to exist between the support expressed for environmental sustainability measures and their uptake. 
4. Sustainability policies and strategies exist for heritage resources and heritage attractions that are part of a national body or organisation but, in the Devon and Cornwall survey, many respondents reported that the policies and strategies had not made much impact on local practices.

5. Much depends, of course, on the effectiveness of a parent body in shaping and implementing sustainability policies. Thus, the National Trust has made much more of an impact with its 'green' policies than the Museums, Libraries and Archives Council with its 'Vision and Action Plan', or the Church with its 'Church and Earth' and 'Shrinking the Footprint' strategy. If sustainable management practices are to become more widespread across the entire visited heritage sector, there is a clear need to share and replicate the experience and approaches of the National Trust. A key question, however, is precisely how good practices can be effectively disseminated.

6. A critically important finding is that the data derived from the questionnaires show that only 31.8 per cent of those questioned had broken even or made a profit in the previous financial year; 68.2 per cent therefore operated at a loss. However, there are variations between the categories of heritage provider. Thus, while 55.6 per cent of the historic houses/castles cover their costs or make a profit, only 28.8 per cent of the historic churches are in a similar position. The failure to generate profits by so many of the examples of visited heritage included in this research clearly represents a very significant barrier to innovation in the implementation of more sustainable management practices. 
7. For some providers, financial 'shelter' is provided by their parent organisation. This kind of protection is afforded to Devon and Cornwall's National Trust properties included in this survey. By contrast, the 'diocesan share' that is levied on parishes by the Church of England means that the parent body takes revenue away from a great many of Devon and Cornwall's historic Anglican churches.

8. Schemes aimed at maximising income and turning losses into profits vary considerably from the identification of particular niche markets to broad-based strategies of diversification. It is noted, however, that the failure by a majority of providers to undertake systematic research or to understand their 'market segments' means that the scope to realise fully the opportunities that might exist to increase income and secure profitability is, in practice, very limited.

9. Responses to the Devon and Cornwall survey indicate that heritage providers are active in offering interpretational material and facilities that meet the perceived needs and demands of their visitors. However, it was clear that there is a noticeable emphasis on low-cost, 'passive' interpretational materials (leaflets, guidebooks, information panels, signage and labelling, and self-guided tours). Moreover, up-dating and improvement of materials by most providers is infrequent and rarely carried out by professionals. The quality of materials was often acknowledged to be fairly low. Rather fewer sites offer 'active' interpretation such as guided tours, media presentations, and models and interactive provision. 
10. As in the case of a lack of research regarding opportunities to secure new markets and thereby increase their income, few providers in this survey have carried out any careful or systematic research regarding the requirements of their existing visitors and many tend simply to depend on hunches and subjective assessments. Indeed, many do not regard it as particularly necessary to tailor facilities and the interpretation that is offered to the needs of any specific visitor group. However, the need to engage with their local community is frequently noted by respondents. 


\section{CHAPTER 5}

\section{CONCLUSION}

\section{Section 5.1 Outcomes in Relation to the Aims and Objectives of the}

\section{Research}

The overall aim of this research, articulated in Section 1.7 of the first chapter of the thesis, has been to contribute to a better and fuller understanding of sustainable development in the heritage sector, and the current application and implementation of sustainable management practices. In order to achieve this aim, six key research objectives were pursued, and these may be reiterated as:

1. Making an assessment of the levels of awareness of heritage managers of various sustainability issues, and their attitudes towards the adoption of sustainable management practices.

2. Establishing the extent of adoption, priorities accorded to, and the degree of implementation of sustainable management (environmental, sociocultural and economic).

3. Investigating perceptions and opinions amongst heritage managers about the potential benefits of, and problems and barriers to, the implementation of sustainable management. 
4. Evaluating the extent of commodification and the implications of such commodification or commercialisation for the sustainability of Devon and Cornwall's heritage sites.

5. Examining, where relevant, the role of larger parent organisations in the dissemination of good practices, the availability of guidance, and the sharing of investment costs between sites for the implementation of sustainable management practice.

6. Formulating a set of policy recommendations in relation to the key findings of the research project.

Within the context of an increasingly pervasive acceptance that sustainability imperatives and sustainable management practices should be integrated into almost every activity in which society engages, this thesis is the first to explore the extent to which the managers of a sample of visited heritage places in a region of England have acknowledged the importance of practising sustainability in their operations and put measures in place to achieve it. Moreover, while some earlier research on the adoption of sustainable management approaches in businesses generally, and tourism businesses in particular, tended somewhat narrowly to emphasise only environmental sustainability (i.e. the so-called 'greening' of business practices), in this research, a wider conceptualisation has been adopted. Thus, the interlocking character of environmental, economic and socio-cultural sustainability issues has been recognised and more recent theoretical concepts, such as corporate 
social responsibility and the triple-bottom-line approach, which both embrace a broad and interdependent notion of sustainability, have been examined.

The empirical investigation of the thesis breaks further new ground by focusing specifically on sustainability in the management of heritage places in Devon and Cornwall, a region which is immensely rich in heritage resources, but which has hitherto been generally somewhat neglected in analytical studies. Published data indicate the large contribution made by heritage attractions to the tourism economy of Devon and Cornwall. Both counties include their heritage as a prominent component in the construction of their identity and place marketing. Drawing on the plentiful body of descriptive accounts of heritage in Devon and Cornwall, the thesis offered a survey and overview of the range, character and quality of the resources that exist in the two counties. In conducting this survey, it became apparent that no single, fully comprehensive inventory exists of all the publicly visited (i.e. accessible) heritage sites in Devon and Cornwall.

Although it is recognised that, if the recommendations of the 2007 Heritage White Paper, and the terms of the 2008 draft Heritage Protection Bill are in future given effect, a new national system for listing and registering heritage places may be adopted, nothing of the kind existed in the period when this project was being carried out. A further major contribution of the research, therefore, has been the construction of a flexible heritage inventory tool. It was shown that the problems posed by the fragmentary and inconsistent character of existing sources of information can be overcome, and a standardised database, capable of being linked to a mapping package, could be produced. While the database was 'populated' in this research for only five Devon and 
Cornwall heritage categories, its wider capabilities were nonetheless demonstrated. The experience gained in creating the database for this particular research project provided a glimpse of the formidable scale of the future task which will face English Heritage when (and if) such a comprehensive listing is attempted for the whole country and for all types of heritage.

Compilation in this research project of the database of Devon and Cornwall visited heritage sites provided the starting point for a major empirical sample survey of opinions about, and the extent of the adoption of sustainable management practices in selected categories of heritage site in the two counties. A postal questionnaire survey elicited 416 usable responses (a return rate of 35.7 per cent) and the answers provided a basis for analysing current attitudes towards, and the practice of sustainable management in the case of historic houses/castles, museums and archives, and historic churches. No comparable survey of this kind, or on this scale, has previously been undertaken, and the findings therefore represent a new contribution to knowledge about the penetration of both the ethos, and the adoption of sustainability in particular parts of this country's heritage sector.

In gathering responses to the questionnaire survey, it became apparent that the strong curatorial and conservation drivers that motivate the managers and custodians of heritage in Devon and Cornwall meant that some felt a strong resistance to the idea that the quest to achieve sustainability should apply to their activities. Indeed, in a small number of cases, quite vehement hostility was 
articulated. ${ }^{36}$ The perceived tension between a desire, on the one hand, to protect at all costs the historical integrity of a heritage site and, on the other hand, societal pressures on managers to minimise the use of non-renewable resources, to respond better to the needs of their visitors, and to generate an income, proved to be particularly acute. This tension helps to explain the difficulties encountered in securing responses from some of the managers to whom the questionnaire was directed. Uncertainty and doubt on the part of heritage managers about the relevance of the sustainability agenda to their activities also explains in part the reticence encountered amongst managers who were asked to participate in follow-up, in-depth interviews.

\subsection{Significance and Contribution of the Key Findings}

Chapter 4 provided a preliminary review of the main results obtained from the questionnaire survey and interviews. However, the significance and contribution of the key findings will be discussed below in more detail in order to provide a basis for the proposal of a theoretical model of the current position and the development of a set of policy recommendations to assist further progress. Each of the key findings will now be linked back to the six main research objectives, given in Chapter 1 and reiterated at the start of this chapter, and links are made to the key ideas discussed in the literature review. Thereafter, future research proposals which build on the work reported in the thesis will conclude the chapter.

\footnotetext{
${ }^{36}$ This was expressed occasionally in very strongly worded letters of protest returned to the researcher instead of a completed questionnaire. Some correspondents pointed out forcefully that 'sustainability' and sustainable management are totally irrelevant in the context of heritage and that the two are not compatible.
} 


\subsubsection{Objective 1: Awareness of heritage managers of sustainability issues and attitudes towards the adoption of sustainable management practices.}

In relation to research objective one, which was 'to assess the awareness of heritage managers of sustainability issues, and their attitudes towards the adoption of sustainable management practices', the research indicated that many respondents believed themselves to be well aware of the broad sustainability agenda. A high percentage stated that they viewed environmental management as an important goal. Moreover, evidence was encountered that a good deal of attention is also paid to socio-cultural sustainability considerations at many of the sites in the survey.

However, a highly significant finding was that, although some of the benefits of implementing sustainable approaches, such as cost savings, appear to have been recognised by the majority of respondents, this awareness has not been translated into actions. An implementation gap therefore exists and many of the heritage managers in the sample are simply pursuing easy, inexpensive, lowimpact measures. Very little additional implementation is taking place. In fact, amongst the heritage providers who claim to have adopted 'green' measures, the data indicated that a majority have done little more than install low-energy light-bulbs or similarly unsophisticated and modest changes. This finding links to Henderson's (2007) assertion that fundamental tensions exist between commercial priorities and socio-environmental implementation.

When the managers were asked to describe the barriers to further implementation, over a third stated that they possessed insufficient knowledge 
about what more they could do. This absence of knowledge was reflected in the lack of coherent and strategic planning for sustainability which was encountered amongst the respondents. Not only have very few sites conducted a review of their sustainability or formulated a plan, even amongst those that do have a strategy, very few seemed to have been inclined to act upon it. These findings suggest that knowledge amongst heritage custodians may, in some instances, be limited to the traditional curatorial approach identified by Garrod and Fyall (2000) and later Aplin (2002).

The research showed, however, that those heritage sites belonging to a larger organisation, which is mainly the case for historic houses/castles, have been able to use the organisational knowledge base and sustainability frameworks of their parent body in order to make better-informed decisions and implement effective initiatives, an assertion supported in the literature by Kleindorfer, Singhal and Van Wassehove (2005). It was therefore amongst the more locally managed, volunteer-led heritage sites that a striking absence of even the most basic sustainability measures was encountered.

\subsubsection{Objective 2: Priorities accorded to, and implementation of, various kinds of sustainable management.}

In relation to research objective two, which was to 'establish the extent of adoption accorded to, and the degree of implementation of, sustainable management (environmental, socio-cultural and economic)', the research suggested that the priority accorded to the development and implementation of 
different sustainable management approaches varies, but is noticeably skewed towards socio-cultural sustainability. Of course, as the research focused exclusively on publicly visited heritage, it is no surprise to find that socio-cultural sustainability - responding to visitor needs - is privileged. This finding accords with assertions made in previous literature that the traditional curatorial approach at heritage sites focuses strongly on the ability to retain cultural significance (Garrod and Fyall 2000, Aplin 2002). It also lends support to Timothy and Boyd's (2003) contention that heritage providers regard the provision of correct and accessible interpretation as fundamental in attracting visitors.

In general, a surprisingly low priority was accorded to environmental sustainability. One of the most significant findings, however, was the low priority accorded to economic (i.e. financial) sustainability. Even though many respondents acknowledged that their sites were running at a loss, only a third of the managers in the sample thought that finding a remedy to their plight was a priority. However, those running National Trust properties were aware of the organisation's espousal of the '3BL' approach, which addresses economic, environmental, and socio-cultural sustainability in combination. In these cases, a more balanced approach to the priority accorded to each kind of sustainability was noted. By contrast, the acute financial marginality of some of the small museums included in the survey was reflected in the fact that relatively more of their managers prioritised only their economic sustainability. It may be noted that Henderson's (2007) research suggests that enterprises which are financially secure tend to be much better placed and more likely to explore the '3BL' approach. 
The significant point is that, while the imperative of attracting visitors to publicly accessible heritage, and catering for their needs, is almost universally acknowledged by their management, there is a startling failure, even amongst those who run the most unprofitable heritage attractions, to recognise the importance of addressing economic sustainability issues as a foundation for other forms of sustainability. For some it became clear that their future is highly precarious. In cases where a heritage site is economically unsustainable, a lack of funds for making investments meant that their socio-cultural and environmental sustainability was also at risk.

\subsubsection{Objective 3: Barriers to the implementation of environmentally} sustainable policies and/or financially robust management, and the delicate balance between public access and conservation/custodianship.

In relation to research objective three, which was to 'investigate perceptions and opinions about the potential benefits, problems and barrier in the implementation of sustainable management', four principal barriers were found to constrain heritage managers in the implementation of environmentally sustainable policies and/or the adoption of financially robust management. These barriers comprise practical issues, conflicts with conservation, the role of volunteers, and transport considerations.

(a) Practical issues: The high investment costs and the widespread lack of knowledge and expertise amongst those who manage heritage resources were seen frequently as the major barriers preventing the adoption of sustainable practices. Du Cross's $(2001,2008)$ assertion that heritage managers often 
make flawed decisions based on their own limited knowledge would therefore appear to be supported by the evidence produced in this research.

(b) Conflicts with conservation: Although many of the mangers in the survey reported that they are striving to improve their sustainability, major concerns were frequently expressed about the risk of damaging historic structures and collections. Sustainable management practices were thus seen to conflict with the conservation needs of the heritage in their custody. It was reported that lowenergy technologies can inflict serious damage on historic furnishings, fabrics and artefacts. Moreover, the visual intrusion, or structural impact of, for example, the installation of energy-efficient heating or solar panels was seen as unacceptable. Indeed, listed status often precluded the installation of any new energy-efficient equipment, and some heritage sites are located within protected landscapes, which also ruled out making intrusive changes to external structures. Previously published literature (e.g. Garrod and Fyall, 2000; Aplin (2002) has speculated that the dominance of traditional curatorial imperatives precludes heritage managers from adopting environmental practices which are feared to pose an unacceptable risk to heritage structures. This research has yielded firm empirical evidence that, in the case of a significant number of Devon and Cornwall heritage sites, such reticence does indeed exist.

It was notable however that, in the case of properties in the care of the National Trust, which enjoy access to centralised expertise, as well as the necessary finance, ways have been found to adopt low-energy technologies and other environmentally sustainable measures. In this research, further investigation revealed that higher-cost, energy-efficient lighting that does not pose a threat to 
delicate fabrics and artefacts, is obtainable, but its expense makes it unaffordable to all but a few sites. While the National Trust has secured an agreement with a manufacturer to supply low-UV, energy-efficient lighting at a considerable discount, smaller sites do not enjoy a similar advantage. These findings support the idea that different types of site are at different stages of a linear or iterative transformation model in which investment is a necessary precursor to progress towards sustainability (Roome 1992, Steger 1993, Walley and Whitehead 1994).

(c) Role of volunteers: The dearth of expertise and knowledge amongst the heritage providers found in the study reflected the heavy dependence of the sector on unpaid volunteerism. Categories such as the historic houses that employ higher numbers of paid, well-trained staff (even though the help of volunteers is important) are better able to respond to the sustainability agenda. Salaried staff tend to be more likely to access necessary training in the implementation of sustainable management, and to devise and carry through projects that seek to improve practice. In contrast, the limited number of paid and trained staff at museums/archives, and their almost entire absence from the historic churches, impacts very strongly on their ability to respond to the sustainability agenda.

Of course, properly trained, well-organised and well-informed, unpaid volunteers can sometimes make a vital contribution to the successful management of visited heritage. In this investigation, however, the reality was found often to be somewhat different. In line with the findings of research conducted by Jabbour and Santos (2009), volunteers reported that they lacked 
the time and awareness needed to identify and implement initiatives. Indeed, some respondents, especially those who care for historic churches, pointed out that heritage management was not, in fact, part of their main role. Jabbour and Santos (2009) argued that success in the management of an enterprise depended on the provision of suitable staff training; their suggestion seems strongly to be endorsed by the findings of this research.

(d) Transport considerations: A significant finding in the investigation is that managers of heritage recognise the conflict inherent in their quest to achieve sustainability at sites that rely on visitors who arrive by private car. Heritage sites located in other areas of the country where good public transport services exist are, of course, able to discourage the use of cars by visitors (and staff), but the relatively remote character of much of the heritage in Devon and Cornwall, poorly served by public transport, offers no such 'green' option. As anticipated, a sizeable proportion of respondents to the questionnaire picked out potential restrictions on the use of motor vehicles as potentially damaging to the quality of the visitor experience and some even saw such measures as a threat to the securing of income to fund conservation. Thus they felt that, by discouraging the use of private cars, they would reduce visitor numbers and thereby lose income. Such losses would be disastrous for some sites, cutting off funds and jeopardising operational viability. For some, the idea of 'green transport' was therefore seen emphatically as no advantage, but instead was regarded as a threat. 


\subsubsection{Objective 3: Perceptions and opinions about the benefits, problems and barriers to the implementation of sustainable management.}

This finding also relates to objective three, which was to 'investigate perceptions and opinions about the potential benefits, problems and barrier in the implementation of sustainable management'. The research findings suggested that opinions about the benefits, problems, and barriers associated with the implementation of sustainable management varied amongst the different heritage categories. Those running historic houses were the most likely to recognise the interconnections between the different forms of sustainability and to regard environmentally friendly practices as very important. Moreover, the managers of historic houses were the most likely to be concerned about constructing a good external image and responding to the wider expectations of society. However, this apparent awareness may be because these properties tended to be in the custody of the National Trust. In contrast, the managers of museums and archives and historic churches put most of their emphasis on caring effectively for their site, preserving its integrity and reducing costs. They tended to be much less concerned about constructing an externally positive image or appearing to be responsive to society's expectations.

Perhaps predictably, replies to the questions in the survey and the interviews indicated that cases in which there were professionally trained staff, and a better understanding of the barriers to the adoption of sustainable management, were much better placed to act on their knowledge to implement improvements. While many of the respondents from volunteer-led organisations possessed at least some awareness of the potential benefits (as well as the problems) of adopting sustainable management approaches, very few have done so. The 
clear distinction between the three categories of heritage surveyed in this study in their readiness to take-up of sustainable approaches appears to be significant, and further research of a similar kind involving other categories would be required in order to establish who the adopters and non-adopters are in other parts of the heritage sector, and to what extent they fit into Hass's (1996) model of linear adoption.

\subsubsection{Objective 4: The extent of commodification and its implications for} sustainability and heritage places that do not easily lend themselves to direct commodification.

In relation to objective four, which was to 'evaluate the extent of any commodification and its implications for sustainability at heritage sites', the investigation showed that the fuller commodification of heritage resources would offer a means by which financially marginal heritage sites might be able to improve their sustainability. However, few managers were found to be exploiting fully their opportunities to commodify the heritage in their care. In the few cases where opportunities were being taken, it was clear that income had been increased and investment in other sustainable initiatives (environmental and socio-cultural) had thereby been rendered feasible. The case studies highlighted in Chapter 4 showed that commodification initiatives, even those which were small scale, had led to improved sustainability or, at least, enabled innovation. It is therefore argued that opportunities for further commodification should be explored in those cases that currently operate at a loss, potentially incorporating one of the three commodification models proposed by Graham, Ashworth and Tunbridge (2000). The examples cited showed that income- 
generating schemes do not inevitably compromise the historical integrity of the heritage attraction and do not need to be complicated or expensive to initiate. It is contended that, while a few cases were found where opportunities to generate new income streams were very limited, for a majority, further commodification would certainly be possible by adopting the turnstile, the windfall gain, or the full commodification approach described by Graham, Ashworth and Tunbridge (2000). The means, for example, to encourage increases in visitor numbers, to sell goods, and to enhance the visitor experience could be identified with no detrimental impact on the conservation of the heritage concerned. Overall, however, the study has revealed that the managers of small-scale heritage resources in Devon and Cornwall only reluctantly engage in enterprise activity and an enterprise ethos was generally found to be lacking.

\subsubsection{Objective 5: The role of larger parent organisations in the implementation of sustainable management practices.}

In relation to objective five, which was to "examine the role of larger parent organisations in the dissemination of good practices, the availability of guidance, and the sharing of investment costs between sites for the implementation of sustainable management practice', a major finding was the significance of the role played by a parent organisation in shaping responses to the implementation of sustainable management at particular sites. The role comprises two aspects: investment finance and policy formulation. For some providers, the parent organisation provided a financial 'shelter', allowing the heritage site to operate with limited or no profit, while still actively engaging with 
socio-cultural and environmental issues. In contrast, the diocesan share that is levied on parishes by the Church of England means that the parent body drives the balance sheet of a great many of Devon and Cornwall's historic Anglican churches into the 'red', inevitably thereby limiting their ability to respond to environmental or socio-cultural sustainability agendas.

A parent body can also shape and implement sustainability policies, and offer training and guidance. Thus, the National Trust has made a significant impact on its Devon and Cornwall properties by introducing its 'green' policies. On the other hand, neither the Museums, Libraries and Archives Council, with its 'vision and action plan', nor the Church, with its 'shrinking the footprint' strategy, have been similarly successful. The latter bodies have proved much less effective in raising awareness and disseminating good practice. Their internal structure and interrelationships between the central body and sites in the localities is considerably weaker than that within the National Trust. It therefore appears that while organisations like the National Trust are able effectively to progress their heritage properties along the linear, or continuum, model proposed by Hass (1996), others appear to be much weaker in planning and disseminating good sustainable practices. If sustainable management practices are to become more widespread across the entire publicly visited heritage sector, there is a clear need to share and replicate the experience and approaches of the National Trust, which is now in the vanguard of both environmental and sociocultural sustainability initiatives in the heritage sector. 


\subsubsection{Objective 5: Evidence of existing dissemination of good practice, expertise and knowledge within and across the categories.}

This finding also links to objective five which was to 'examine the role of larger parent organisations in the dissemination of good practices, the availability of guidance, and the sharing of investment costs between sites for the implementation of sustainable management practice'. While the study revealed that there is some evidence of good practice and knowledge and expertise of sustainable management within the heritage sites surveyed, the means for sharing knowledge, both within and between the categories, appeared to be almost non-existent. Moreover, an awareness of how information about good practice could be accessed appeared to be absent. While the historic houses/castles, especially those belonging to larger organisations, reported that training was offered for both their paid staff and for volunteers, nothing similar was mentioned in the case of the museums and the churches. Some museum managers, exclusively those holding membership of the MLA, reported that extensive training on curatorial issues was available, and that ideas regarding good management practices were informally shared, on an ad hoc basis, within local groups. Much depended on the attitude and drive of the individuals involved and there was no evidence of any systematic provision of management advice or training.

In the case of those caring for historic churches, access to training, guidance and advice appeared to be minimal. While the informal and ad hoc exchange of ideas did occur in some cases, it also depended on the level of interest shown by particular individuals and groups. 
These findings suggest that there is considerable scope for the dissemination of good practice and the provision of basic training in economically, environmentally and social culturally sustainable management. The means by which dissemination of good practice and training might be achieved were not explored in the study, but it is clearly a pertinent issue about which further comment will be made in the next section of the chapter on policy recommendations.

\subsubsection{Objective 5: Modelling progress towards the sustainable} management of Devon and Cornwall's heritage resources

Two clear conclusions emerge from the explanation and analysis of the outcomes of the empirical survey that have been explained in the preceding sections of this chapter and these findings also link to objective five, which was to 'examine the role of larger parent organisations in the dissemination of good practices, the availability of guidance, and the sharing of investment costs between sites for the implementation of sustainable management practice'. First, there is considerable variation between sites in the extent to which they have either recognised the value of, or begun to adopt, a sustainable management approach. Second, there is broad evidence that the three heritage categories which were surveyed in this study are at different stages in their progress towards sustainable management. Drawing on the theoretical concept of a linear model of voluntary 'greening', outlined in the first chapter of the thesis, historic churches thus appear to be at a very early stage of adoption of all three kinds of sustainable management (environmental, socio-cultural, and economic). Moreover, it appears that there are major obstacles (such as the 
attitudes of their managers, their reliance on unpaid and inexpert volunteers, the burden of meeting the diocesan share, etc.) that will impede further progress. As a category, although there are some exceptions, museums and archives, appear to have advanced a little further than the historic churches. Fewer 'structural' barriers to action, such as the payment of a large subsidy to a parent organisation, or an unwillingness to accept that they manage a heritage attraction, appear to have impeded progress.

Although the sample in this study upon which the findings are based is small, and caution must therefore be exercised, the most 'advanced' category, in terms of sustainable management, seems to be the historic houses and castles. Certainly, those belonging to the National Trust appear to have recognised the concept of corporate social responsibility and to have adopted the triple-bottomline (3BL) sustainable management approach.

A tentative model of the current position of the three heritage categories in their progress towards sustainable management is proposed (Table 5.1). While it is recognised that this theoretical model offers a relatively crude 'fit' in explaining the detailed intricacies that have emerged from the responses to the questionnaire survey and interviews conducted in this study, it is nevertheless offered as a working summary and overview of the research project as a whole.

It is recognised that the achievement of further progress towards the sustainable management of heritage may well depend on the development of policies that will offer support and encouragement, and help to minimise the barriers that currently dissuade custodians from adopting new measures and 
approaches. More secure funding regimes also seem to be needed. Recommendations regarding the kinds of policies that may prove helpful are therefore outlined in the following section. 
Table 5.1 Modelling a progressive route to the sustainable management of

heritage

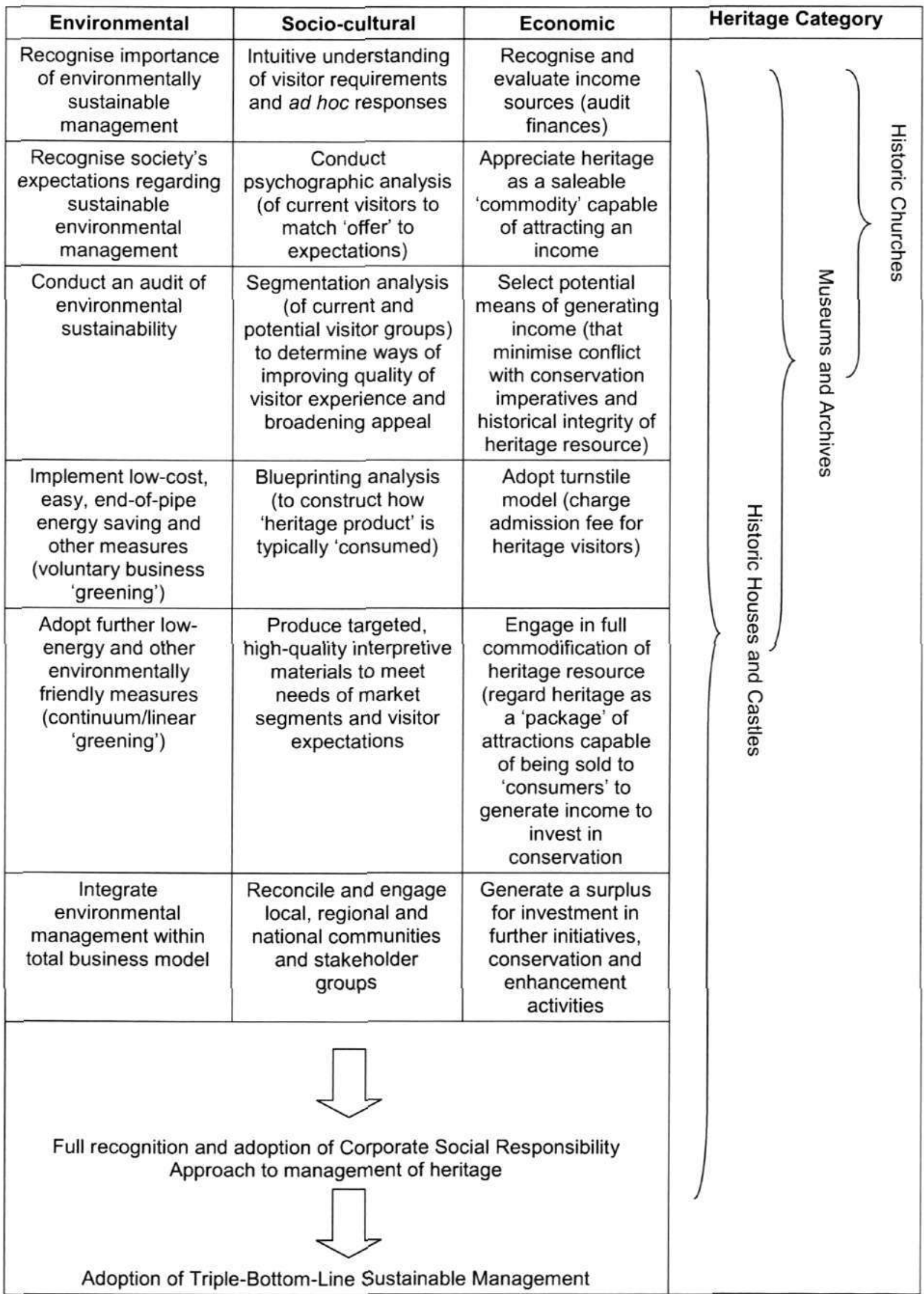

Source: Author 


\subsection{Policy Recommendations in relation to Key Research Findings}

This section addresses research objective six, which states that the research will 'formulate policy recommendation in relation to key research findings'. The policy recommendations presented here also, of course, link to they key findings presented in the preceding sections.

\subsubsection{Heritage networks}

The evidence assembled in this study indicates that existing frameworks for sharing expertise, knowledge and good sustainable practice within the heritage sector are limited. With the exception of the National Trust, which offers a model for high-quality professional training, and information sharing, other bodies appear to be much less active and effective. A key question is whether the practices of the National Trust are capable of being replicated across the entire sector. In the context of the museums/archives and historic churches categories, very considerable changes in the management training provision and remit of the Museums, Libraries and Archives Council, and the Church of England would be required. An alternative might be the establishment of new means to deliver training and to share good practice. A possible vehicle could be the formation of regional heritage networks, perhaps under the auspices of the National Trust, or English Heritage. While some types of heritage site already share good practice, albeit often in a piecemeal fashion, the creation of a properly constituted heritage network could act as a driver to articulate and share effective management practices, and to encourage those currently not engaged to access practical sources of knowledge and expertise. 
It is suggested that networks of this kind would benefit from a membership that encompasses more than one type of heritage, a service currently not available. While it is perceived that these networks would initially draw heavily on the expertise and knowledge of the larger heritage providers, broadening awareness and communication between members would gradually encourage greater engagement with the sustainable development agenda. Initially, in order to assess its potential, the heritage networks proposal would need to be piloted in a single defined area, possibly a county. In order to support the networks, to advertise meeting dates, and host useful information, a web site would be necessary. As yet, of course, the cost and feasibility of creating such a facility has not been established. However, it is untikely that charging for membership to the network would be a viable means of attracting interest, particularly from those who are currently the most economically marginal and the least engaged with sustainability.

Start-up funding for a network might be sought from English Heritage and the Heritage Lottery Fund. Engaging with stakeholders to establish the best means by which to share information, establishing county-wide and local networks, and demonstrating the benefits of such a system would then form a proposal through which on-going funding could perhaps be secured.

\subsubsection{Establishing the best model for 'governance' of heritage resources}

The study has shown that several different forms of governance currently exist in the publicly visited heritage sector. While only three types of heritage have been investigated in detail, evidence of varied practices was apparent. 


\section{(a) The Church of England}

The least successful body for the promotion of sustainable management appears to be the Church of England. Although it does have written policies on environmental sustainability, the research evidence suggested that the information is not effectively disseminated. Moreover, the Church has not devised a coherent position with regard to maximising opportunities to generate an income from heritage visitors. Communication between the churches in the survey and the Church of England at the centre was found to be limited. The requirement to pay the diocesan share was often crippling and there was no evidence of any coherent advice or guidance on the ways in which income might be increased.

Nevertheless, there are signs that the Church of England is seeking to address some of these deficiencies and improvements may well occur in future whereby better guidance will be offered to those responsible for the management of historic churches in relation to the provision of interpretation and promoting increases in heritage visiting. In 2006, in collaboration with English Heritage, the Church of England launched its 'Inspired' programme, with the aim of helping historic churches to access government funding to enable them to become more accessible to visitors. Designed to encourage churches to pursue heritage tourism in order to stem the rising costs of repairs and ensure a sustainable future for their buildings, the programme has so far supported a pilot project in Coventry city and across Warwickshire. Those who care for church buildings in these areas have been engaged to explore creative ways of welcoming visitors and to 'tell well-researched and more engaging stories to those who make visits' (Divine Inspiration 2010). Largely a web-based initiative, it offers free, online 
toolkits for churchwardens that explain how to best research and display their chosen interpretation, free training to any church staff from the area about how to manage and interpret their church, and guidance on welcoming visitors. The project also produces a newsletter that reports examples of best practice and includes tips on how to improve environmental and economic sustainability. Although it has been hailed as a flagship project by the Church Tourism Association, the Church of England and English Heritage, there currently appear to be no plans to build on it elsewhere in the country. However, it is an excellent example of what might be achieved in future in Devon and Cornwall.

In addition to the Inspired programme, the Church's 'Sacred Britain' campaign was set up in 2005 by the Churches Tourism Association and The Churches Conservation Trust. A major outcome was the formulation of a strategy for 2007-2009 that proposed a marketing and branding framework 'for the promotion of visits to churches and other places of worship of recognised heritage significance' (Sacred Britain 2008, 4). Priorities for action over the period were also identified. While not explicitly acknowledging links to psychographic and segmentation theories in the heritage tourism literature, the Sacred Britain strategy does highlight the need for churches to examine their market segments in order to target their interpretive provision. The strategy also focuses on examples of churches that have been able to generate revenue and design their offering in an authentic, welcoming and rewarding manner. The document is thus directed towards the implementation of the kind of socioculturally sustainable management that has been a central concern of this thesis. Although it may be criticised for offering little direct practical guidance, and it has so far made no impact at all in the cases of churches surveyed in this 
project, its existence is highly encouraging and its further development and adoption by the historic churches of the Southwest may well assist them in securing their financial future.

It is clearly significant that, in espousing these two initiatives, the Church of England is belatedly recognising that historic churches are a highly significant heritage attraction with huge potential for generating the much-needed extra income that can fund conservation and other management efficiencies. There was, however, no evidence at all of any awareness of either scheme in Devon and Cornwall, but prospects that the ideas and strategies may eventually percolate into the Southwest are obviously encouraging. This research has suggested that the Church of England, while striving to achieve sustainable management, is not yet successful in communicating with those who manage its precious historic sites in Devon and Cornwall. The added burden of the diocesan share means that the managers of historic churches are even gloomier about their ability to implement sustainable practices than might otherwise be the case. Their reliance on volunteer staff impacts negatively on their ability to engage with sustainable management improvements. It is therefore contended that the Church of England needs to re-double its efforts to communicate its new enthusiasm for sustainability and heritage tourism because, at the moment, very few historic churches in Devon and Cornwall have yet become either aware or practically engaged. 


\section{(b) The Museums, Libraries and Archives Council}

This study has shown that the Museums, Libraries and Archives Council $(\mathrm{MLA})^{37}$ has so far made more progress in promoting sustainable management practices in Devon and Cornwall than the Church of England. Respondents to the questionnaire indicated that the MLA had provided training in sustainable curatorial practices. In addition, the MLA claims to offer advice and funding to its members. In the 2009 strategy document entitled Leading Museums, A Vision and Strategic Action Plan for English Museum, the MLA provided an action plan for supporting excellence. The document highlighted the need for trained curators and managing agencies. It also encouraged the formation of entrepreneurial partnerships and focused on effectively meeting visitor needs. While is some respects the MLA represents a central source of assistance similar to the National Trust, its key document gave little or no guidance for curators or managers of individual sites on how any of the main goals can be achieved. Instead, local managers of museums and archives are expected to implement and develop their own policies. In addition, membership of the MLA entails the payment of a subscription fee, which in the case of smaller, marginal sites was regarded as prohibitive. As a result, it would appear that the museums and archives most in need of the services and support of the MLA are unable to access them.

A more inclusive approach to membership, perhaps by means of a one-year free trial, temporary membership, or an associate programme, would encourage more museums to engage with the training and knowledge available. It may

\footnotetext{
${ }^{37}$ It should be noted that news regarding the winding up of the MLA as part of the government's 'bonfire of the quangos' was announced at the point that the thesis was completed. The future impact of the loss of the MLA is, as yet, uncertain.
} 
also promote more informal sharing of good practice and the creation of informal but beneficial local networks.

\section{(c) The National Trust}

By far the most coherent and progressive form of governance targeted at achieving sustainable management is that of the National Trust. Unlike sites from other heritage types, the Trust's properties included in this study demonstrated knowledge of the priorities, policies and strategies of their organisation. In turn, Trust properties stood out in their adoption of sustainable management initiatives. Evidently, the drive to prioritise sustainability, and the way in which these messages were conveyed to staff within the organisation, were highly effective.

This well-established approach to sustainable governance is, inevitably, due at least in part to the National Trust's charitable status and independence from government. The Trust's income is not derived in the same way as other, government-supported, organisations (e.g. English Heritage). Membership subscriptions, donations and revenues derived from commercial operations provide a secure financial basis to support the Trust's priorities of conservation, custodianship, and sustainability. Although it is heavily dependent on volunteers, the National Trust also employs a core of highly professional staff, Its policies are underpinned by careful research and planning. Its ethos, values and clear strategic vision are shared across its entire workforce and there is a symbiotic relationship between the centre of the organisation, its regional headquarters and all the individual properties. The ability of the National Trust 
to recognise and embrace the sustainability agenda has made it a leader in the field.

Clearly, the strategies, practices, experience and staff expertise of the National Trust would benefit other heritage organisations. Elements of National Trust procedures are capable of being adopted by other heritage providers, such as improved communication and training. Whether or not the Trust itself might somehow lead initiatives across the country's entire heritage sector is open to question. Much could be learnt from a close examination of its activities but it would be unrealistic to expect all those who manage and care for heritage to be able to operate with the same degree of effectiveness and success as the National Trust.

\subsubsection{Management Training}

The evidence presented in the study suggests that a need exists to improve knowledge and understanding of sustainable management practices. In particular, the training of volunteers who manage publicly visited heritage sites would be beneficial. In cases where there is no provision of training by a parent organisation, some other means are needed. One possibility might be to secure funding to buy-in appropriate training from the National Trust. Pilot training sessions, potentially paid for through English Heritage or the Heritage Lottery Fund, might be another possibility. Gauging feedback from respondents to assess the usefulness and transferability of such training would need to be undertaken and, if found to be successful, the potential for rolling out the provision on a funded, or fee-based, approach could be explored. 
Another potential means by which training could be undertaken would be to create a 'champions scheme', whereby representatives from different heritage organisations would be trained in various management techniques; they would then replicate the training within their own organisations, thus reducing costs. This approach would also, of course, need to be piloted and its effectiveness assessed.

\subsubsection{Applying for Grants and Support}

The study revealed that many small sites find the process of applying for heritage grant funding to be complex, time-consuming, and often met with failure. Two possible means are suggested by which the process could be made easier. In the National Trust, all applications for grants and financial support are processed through a central point, which limits duplication and improves the Trust's ability to secure grants. ${ }^{38}$ Providing a central point of contact through which grant applications could be checked and submitted by each organisation would be one possible recommendation. Of course, this suggestion would potentially only benefit those heritage sites which belong to a parent organisation. However, such a service could provide valuable feedback on unsuccessful applications and act as a signposting facility for new, and underexploited, funding streams. The National Trust have apparently been able to ensure that applications from individual properties are submitted on a fair basis whereby no single site is permitted to bid for multiple funding streams and thus compromise the prospects of success for other bidders. If a similar

\footnotetext{
${ }^{38}$ This information was supplied in a personal communication from a National Trust representative.
} 
arrangement were to be adopted by other organisations, drawing on the experience of the National Trust would clearly be essential.

For sites that are not members of larger heritage organisations, an alternative approach would be needed. A web-based facility that detailed all the bodies from which heritage funding could be sought might prove valuable. Potentially, this kind of list could be incorporated into the English Heritage HELM site that was described earlier. Information on the eligibility criteria for making applications, the processes involved, and the success rate of applications would be helpful. The web site would need to be updated, perhaps quarterly, or twice each year. It would offer an inexpensive means of disseminating potentially very useful information.

\subsubsection{Improvements in access to Information on Sustainable Management}

While a completely comprehensive knowledge all of the diverse sources of information on sustainable management of heritage sties is not claimed, it was asserted in Chapter 1 of the thesis that practical heritage management literature appears to be somewhat limited. The bulk of the provision published from the 1990s onwards was aimed at museums and archives. It was usually generic in style and mostly offered advice for curators on museum planning and museum management. Examples included The Manual of Museum Management (Lord and Dexter 1997); The Handbook for Museums (Edson and Dean 1994); and Museum Management (Moore 1994). In some cases, more specific guidance, aimed at helping curators to tackle specific issues, was offered. For example, there was Developing staff resources for managing collections (CMN and 
VMNH 1996); and Environmental guidelines for museums and galleries (Cassar 1994).

After the 1990s, a shift in emphasis away from the more practical issues of management towards issues of social inclusion can be detected (Pollock and Zemans 2007). Advice on strategies for engagement (Cave 2007) became more prominent, reflecting newer perspectives emerging more widely across the heritage sector. However, it is clear that there was still little reference to other forms of sustainability, which focused instead on the role of authenticity and interpretation. In contrast to the guidebooks aimed at museum and archive management, comparable works for historic house and historic church managers were less abundant. Academic studies of the role of historic churches as heritage visitor attractions have been carried out. Doctoral theses produced at the University of York (Watson 2007), Nottingham Trent (Gibson 2004) and Exeter (Busby 2006) all focused on the characteristics of those who visited historic churches. Their findings have not, however, been translated into manuals that give practical advice to those who care for and manage heritage of this kind.

Both English Heritage and the National Trust currently provide on-line libraries of their own strategic and policy documents which are publicly accessible. The opportunity to expand these libraries to provide wider heritage management information, including examples of good practice, the strategic documents of other heritage organisations, and any other useful information, perhaps ought to be exploited. Alternatively, libraries of works of guidance could be incorporated into the additions to the HELM website, previously discussed. 
A single location for such information would obviously enhance the ability of heritage site managers to access guidance, and the quality and consistency of information could also be more effectively monitored. Once again, the effective implementation of this recommendation would rely on collaboration between heritage organisations, something that may need to be piloted to assess its practicability.

\subsubsection{Radical suggestions}

In addition to the more conventional recommendations suggested so far, a series of more radical ideas could be envisaged. One aim of articulating these ideas is to stimulate debate about how the long-term sustainability of heritage might be more satisfactorily assured.

(a) Introduce a tourism levy. Many of the recommendations put forward so far in this chapter would require funding. The results of the questionnaire survey and interviews indicated, however, that a very significant proportion of the heritage sites in the sample, do not currently operate at a profit; many make a loss. Even those which charge an admission fee often fail to cover their costs. Arguing from the standpoint that tourists and visitors to heritage attractions are not fully aware of the true cost of providing public access to historic sites, it may be that some kind of annual tourist levy or tourist tax should be introduced and the income thereby derived should be shared amongst all the custodians of places that contribute to the attractiveness of a region or locality. Though likely to be highly unpopular, and probably politically impossible to achieve, in 
discussing the need for such a levy, attention would be drawn to the fact that the true cost of maintaining heritage tends to be hidden from its consumers.

(b) Allocate a share of the community charge. A mantra emerging amongst those who have theorised the issue of authenticity and socio-cultural sustainability has been the desirability of achieving stronger community engagement with local heritage places and local heritage narratives. To date, however, theories of socio-cultural sustainability have failed to address the issue of who pays for the conservation and care of the heritage. A radical recommendation that a share of the local community charge should be dedicated to the maintenance of heritage resources might therefore be worthy of consideration. Again, increased finance could provide for the introduction of sustainable practices. Specific business sponsorship of a heritage place might also be sought. As in the case of the 'tourism tax' idea, the likelihood of winning political support for such a suggestion is clearly extremely low. However, simply discussing the idea would focus attention on the largely hidden costs involved in maintaining heritage.

(c) Increase entry fees. Against the background of one of the major findings of this study that many heritage sites, including those that charge an entrance fee, do not cover their expenses, admission charges could be levied at full economic cost. Such a strategy would be exceptionally high risk because visitors could well be completely deterred and the downward spiral thereby worsened. Many attractions, however, make no entrance charge for visits. If satisfactory means could be found to introduce a charge, for example in the case of historic churches, financial sustainability might well be secured. 
(d) Closing heritage sites/ restricting access. The final radical suggestion is that the main means by which the environmental sustainability of the site could be achieved would be to close the site completely to public access. The wear and tear upon heritage sites that is brought about by visitors imposes an additional burden that many simply cannot support. Such a drastic measure would have major social consequences; as Garrod and Fyall (2000) point out: the closure of public access to heritage undermines its relevance and brings about a loss of identity. However, such a suggestion would sharply focus attention on key issues and perhaps stimulate useful debate about the true costs involved in providing ready and cheap access to the nation's heritage.

\subsection{Critique of Research and Research Design}

As with all research, some limitations may be identified in a retrospective evaluation of the project. The limitations primarily involve methodological and conceptual issues, and geographical considerations; these are discussed below. In addition, time and cost factors inevitably imposed some constraints on the scope and scale of the research that could be undertaken.

\subsubsection{Methodological limitations}

It is acknowledged that the findings reported in this thesis relate to only three heritage categories. The intention was to embrace five categories but, as noted earlier, in two cases, too few responses to the empirical survey were in practice secured and a decision was therefore taken to base the enquiry on three types 
of heritage. While the three categories that were surveyed are extremely important elements of the heritage of Devon and Cornwall, it is acknowledged that, in order to have been sure that the sample provided fully representative evidence, it may be that a larger number of categories would have been desirable. However, because no satisfactory comprehensive listing of publicly visited heritage sites in Devon and Cornwall was found to exist, it became necessary to devote considerable time and resources to the construction of a suitable database from which to draw the sample for the survey. Indeed, an inventory tool was devised that had the capability of recording the extent and diversity of all accessible heritage sites in the study area. Although the time taken to develop and populate this database meant that compromise was necessary regarding the total number of categories that would be included in the subsequent sustainable management survey, it is argued that the inventory tool itself represents a valuable research contribution. Nevertheless, with the benefit of hindsight, it is clear that the inclusion of archaeological heritage sites and marine and maritime heritage sites amongst the selection of five categories for detailed analysis might usefully have been altered. As noted above, managers of sites in these two categories provided very few responses to the questionnaire survey. If the poor level of responses yielded by these categories could have been predicted, alternatives could have been sought. Moreover, the subsequent designation of the Mining World Heritage Site in west Devon and Cornwall, which took place after the selection of categories for inclusion in this research had been made, might suggest that the sustainable management of commodified Devon and Cornwall mining heritage sites should be surveyed. Any future study of the running of publicly visited heritage in the Southwest should certainly include historic mining sites though it must also be noted that, 
although the landscape archaeology of former mining activity is abundant, only a handful of locations are commodified heritage sites. Thus, the inclusion of mining heritage would not, in fact, have significantly increased the size of the sample examined in this research project. Even so, an expansion of the survey to embrace other key categories of heritage in the Southwest does represent an opportunity for further research in this field, a point discussed further in section 5.5.

When constructing the questionnaire for this research, it became evident that there was only very limited existing empirical research examining the implementation of socio-cultural, economic or environmental management at heritage sites. Indeed, gauging whether the heritage sites surveyed were achieving a lower or higher than expected level of implementation was difficult. This lack of existing research, specific to heritage sites, meant that the study needed to draw on a diverse range of comparators: from tourist sites to manufacturing businesses. However, because of the different characteristics of other commercial enterprises, such comparisons were not always entirely satisfactory in providing a reliable guide to the extent to which implementation at heritage sites is, or is not, meeting 'expected' or 'anticipated' levels. Inevitably, research that probes issues that have not been comprehensively examined before will encounter problems of this kind, and utilising the closest comparators represents the only realistic option. Notwithstanding such deficiencies, comparisons between the different types of heritage surveyed in this research and other enterprises in levels of adoption of sustainable management practices still provides a very useful baseline on which future research can build. 
When shaping the methodology for this research, a decision was taken to conduct a large-scale questionnaire survey first and, thereafter, in order to probe key issues still further, to undertake in-depth interviews. The approach had the merit of ensuring that key issues emerging from the questionnaire responses could be directly followed-up in the interviews. However, it is acknowledged that an alternative approach might have been to begin with the in-depth interviews and to use the findings thereby derived as the basis of questions posed in the wider survey. There are, of course, pros and cons involved in both approaches. In making a decision to gather questionnaire responses first and then pursue in-depth interviews, it should be noted that the survey was constructed after carefully consulting the discourses in existing literature. Thereafter, heritage management issues were discussed at length with a highly experienced professional National Trust employee. Pilot surveys were also used to ensure that the survey design was suitable for completion.

In retrospect, it could be argued that the usual notions of sustainability, when applied in the context of heritage, may have benefited from a fuller and perhaps more subtle articulation. Thus the broad sub-division of the concept of sustainability into socio-economic, economic and environmental aspects did not always prove directly applicable in the case of heritage sites. This problem is discussed further in Section 5.4.2 (below).

Another criticism might be that the managers of the heritage sites chosen for indepth interview were self-selecting. In other words, those who had indicated a willingness to participate in a follow-up interview provided a pool from which a 
small sample was chosen. Purists might suggest that interviewees should have been picked in a more random manner. However, in the early stages of devising the methodology, the advice of the representative from the National Trust was that securing agreement for interview within this sector would be extremely difficult due to the heavy time constraints usually experienced by managers. Compounding the issue was the relatively small sample of historic houses and castles. In a category where there are relatively few sites in total and the majority are owned by one or two key organisations, eliciting responses to the survey and agreements to be interviewed proved difficult. It is therefore suggested that the means employed in this research of securing willing interviewees was a pragmatic response to the realities of the difficulties that were encountered.

Overall, therefore, in spite of the problems encountered in gathering the data, and the omission of categories of heritage that it may have been desirable to include, a very good body of evidence was assembled. There is, of course, considerable scope to extend and develop the research further in the future which are discussed in detail below (Section 5.5).

\subsubsection{Conceptual Issues}

It has already been touched upon in this chapter that a certain degree of confusion was encountered amongst respondents to both the questionnaire and the interviewees regarding the concept of sustainability. In particular, it became clear when undertaking the pilot for the survey phase of this research that, 
amongst heritage custodians, there were different understandings of the terms socio-cultural sustainability and environmental sustainability. While the revised questionnaire sought to explain these terms more fully, it is nevertheless acknowledged that both in the questionnaire responses, and in the in-depth interviews, interpretations of the meanings of these terms remained inconsistent. While some providers, such as those belonging to the National Trust, made it clear that they work within an institutional framework within which the different types of sustainability are well-understood and the terms are frequently employed, for other heritage managers, the terminology seemed to be unfamiliar and evoked confusion. In particular, those speaking on behalf of historic churches were often unclear about the meaning of the terms and how they might be applied to their heritage site. Initially, in fact, it had been anticipated that the key obstacle might lie in defining socio-cultural sustainability; however, in reality, environmental sustainability proved to be the term that many struggled to understand. From the survey results and the indepth interviews it became clear that the main source of the confusion was an intermixing of the notion of 'being green' (i.e. a traditional interpretation of environmental sustainability), and the notion of sustaining the built fabric of an historic site into the future. With hindsight, although confusion of this kind has not occurred in studies exploring the sustainable management of other types of enterprise, it might perhaps have been expected to arise amongst those charged with the care of fragile historic resources. As the nature of this confusion only became fully evident towards the end of the research process, namely, when the questionnaires were being analysed and the interviews were underway, there was no realistic opportunity to re-format the enquiry in a way that drew a distinction between the two kinds of environmental sustainability 
that affect heritage management. If the project is extended in future, a key recommendation, however, would be that a differentiation is made between conserving (sustaining) the historic fabric of a heritage resource on the one hand, and introducing 'green' measures (to minimise its 'footprint' and make financial savings, etc.) on the other. Doing so would therefore require the subdivision of sustainability into four categories: socio-cultural, economic, environmental ('being green'), and environmental ('historic conservation'). It seems likely that a categorisation of that kind would avoid the need to disentangle the evidence in the manner that proved necessary at times in this research.

\subsubsection{Geographical limitations}

Limiting the extent of the study area in this project to the two southwest counties of Devon and Cornwall was justified in that the unique and rich character of their heritage merited a survey focused specifically on this area. However, the geographical extent of the research was in some ways also a drawback. The principal issues that arise when confining a survey to one particular English region is that some types of heritage are not very well represented. For example, there are only 50 publicly open historic houses and castles in Devon and Cornwall. Samples within categories of heritage are bound therefore to be numerically skewed. It may be that a survey of the sustainable management of historic houses and castles in a much larger area (thereby yielding a larger sample) should have been undertaken. In other words, the driving criterion for the selection of the sample might have been the categories of heritage rather than a geographical area. Clearly, this alternative approach ought to be 
considered if further research on the sustainable management of heritage is undertaken in future.

\subsubsection{Time and cost constraints}

As already noted, cost and time constraints restricted scope to increase the scale of the research beyond (initially) five categories of heritage. Additional time and financial resources would enable the project to be considerably extended and amplified to include other types of heritage. In undertaking a larger survey, postage and travel costs would, of course, be significant.

Additional time would also have made it possible for the inventory tool to be fully populated with all fifteen heritage categories, thereby making it of wider use for both academic and other purposes. As mentioned earlier in the thesis, the scope for the further development of the inventory tool is considerable and it would have been highly rewarding to have been able to have explored further some of the undoubted practical applications of the data that it already contains, as well as building in more information.

\subsection{Future Research}

In exploring attitudes towards, and the implementation of sustainable management practices at publicly visited heritage sites in Devon and Cornwall, this study has pioneered a new field of investigation in academic heritage studies. In doing so, however, no claim is made that a definitive set of 'answers' 
to all the questions about sustainable management has been provided. Much work remains to be done. There are many avenues for future research; some of the possibilities relate to the critical reflections on the research project that have been presented above. The main opportunities for future work will now be identified.

\subsubsection{Research in other regions}

The findings presented for Devon and Cornwall may, of course, not be typical of other regions or apply to the wider national picture. Future research therefore needs to explore similar questions in other areas of the country.

\subsubsection{Industrial heritage in Devon and Cornwall}

As noted above, since this research project commenced, a World Heritage Site has been designated in Cornwall and West Devon. This designation recognised the unique quality and importance of the mining landscapes of the Southwest. While the typology developed for this research identifies and categorises mining and industrial heritage, as already explained, the five categories selected for inclusion in the questionnaire survey were chosen and populated prior to the UNESCO designation. In retrospect, the inclusion of the small number of publicly accessible mining heritage sites would have been a valuable addition to this study. As a future avenue for research, sustainability issues for the industrial heritage category should be examined. 


\subsubsection{Historic houses and castles}

In Chapter 3, it was noted that the response rate to this investigation by the historic houses and castles category was low. Potential remedies to this problem have already been discussed. A higher response rate would, of course, have provided a stronger basis upon which to comment on the sustainable management practices at these types of sites. While steps were taken to address the potential weakness in the research by augmenting the questionnaire data with in-depth interviews, future research would benefit from expanding on the number of participants in this category in order to verify the conclusions that have been drawn. In addition to the possibility, discussed earlier, of drawing a sample of historic houses and castles from a larger geographical area, other survey techniques would perhaps need to be explored. For example, telephone interviews, or more one-to-one conversations, would probably need to be tried.

\subsubsection{Linear or progressive adoption of sustainable management}

In Chapter 1, attention was drawn to theories about the linear and iterative character of the process of adoption of environmental sustainability in the general business sector of the UK economy. It has emerged from this study that progress in the adoption of sustainable management by those who run heritage sites apparently lags behind that which has already been achieved in the world of commerce and business. Moreover, evidence was found that some heritage managers have yet to appreciate that environmental sustainability is either relevant or achievable in the context of the resources in their care. There is considerable uncertainty and even some hostility. However, the sustainable 
development agenda continues to rise in prominence and it would therefore be worthwhile to monitor progress in its adoption by heritage managers in the years ahead. Theories about the progressive and iterative adoption process could then be tested in a further survey of heritage providers to establish changes in management attitudes and in the levels of take-up of sustainable measures.

\subsubsection{Cross-cultural comparisons}

The desirability of comparing the findings derived for Devon and Cornwall with those for other parts of the country, and of extending the range of categories concerned to include industrial heritage, has already been mentioned. However, there is also a strong case for comparing sustainable management in this country's heritage sector with that practised in other countries. Indeed, it could well prove instructive to explore the differences and similarities in the uptake of sustainable practices in this country with those in the heritage sector of, for example, Germany or the Netherlands, where environmental sustainability is already more deeply embedded. Indeed, there would seem to be considerable scope for the development of comparative research both on the different approaches to the sustainable management of heritage sites across Europe and the evolution of European Union policies and support made available for the sustainable development of heritage resources. 


\subsubsection{Attitudes of the heritage visitors}

The present study focused attention on the opinions and actions of the providers and managers of visited heritage sites. It was thus a 'supply-side' study. Another avenue for future research would be to explore the 'demandside' by gathering the opinions and attitudes of heritage visitors. Such research could establish whether sustainable management practices increase (or maybe decrease) the popular appeal of heritage places, and whether the public's social conscience plays any part in the decisions they make as heritage visitors.

\subsubsection{Sustainable transport}

The sustainable transport dilemma faced by managers of heritage sites who are keen to become more sustainable was discussed in Chapter 4 and was summarised earlier in this chapter. Future research could be devised to explore more fully the complexities involved in achieving sustainable transport to heritage places located in remote rural areas. Future research might, for example, focus on the impact of limiting private transport, or facilitating other sustainable transport options. In this way, research could contribute both to the sustainable heritage and the sustainable transport agendas.

\subsubsection{The sustainability agenda and other key stakeholders}

A further potential investigation could explore the attitudes to, or 'knowledge' of, sustainable heritage amongst those who influence policy and decision making that affects the heritage sector. The opinions of politicians, planners, or tourism 
organisations could be ascertained and evaluated. The priority afforded to sustainable issues by funding organisations, such as the Heritage Lottery Fund could be examined. An investigation of the attitudes of heritage stakeholders may well shed light on why the heritage industry has not yet fully embraced the sustainable development agenda in the same way as other businesses.

\subsubsection{Evaluation of the costs and benefits of sustainable management}

One final possible area for future research would be to move away from merely studying perceptions regarding the barriers to, and motivations for, adopting sustainable management practices towards an objective assessment of the actual costs and benefits. Quantifying the financial impacts of sustainability could well play an important role in convincing providers to change their practices. At the very least, such work might help to eliminate the guesswork and conjecture that is so often involved in decisions about whether sustainable measures might prove worthwhile. 


\section{REFERENCES}

Aas, C., Ladkin, A. and Fletcher, J. (2005) Stakeholder collaboration and heritage management. Annals of Tourism Research, 32, (1) 28-48.

Aday, L. (1996) Designing and conducting health surveys. Jossey-Bass Publishers Inc. San Francisco Aplin, G. 2002. Heritage: Identification, conservation and management. Oxford University Press, Oxford.

Arentz, D. (1998) The Grand Tour. Nazraeli Press. Munich.

Ashworth, G. and Larkham, P. (1994). Building a new heritage: Tourism, culture and identity in the new Europe. Routledge, London.

Barker, N. (2007) The Bishop Phillpotts Library, Truro, The Book Collector, 54, (4), 439-500.

Barthel, D (1996) Historic preservation: Collective Memory and Historical Identity. Rutgers University Press. New Brunswick.

Beacham, P. (1980) Archaeology of Devon Landscape: Essays on Devon's Archaeological Heritage, Devon County Council Planning Department, Exeter.

Beacham, P. (1982) 'The Conservation of the Heritage', in: Beacham, P. (ed.) Devon's Heritage: Buildings and Landscape: A collection of essays on the conservation of Devon's environment, Devon County Council Planning Department, Exeter, 72-77.

Beacham, P. (2001) Devon Building: An introduction to local traditions, Devon Books, Tiverton.

Bell, S and Morse, S (1999) Measuring the immeasurable? London, Earthscan.

Black, J. (1992) The British Abroad: The Grand Tour in the Eighteenth Century. St Martins Press, New York.

Black, J (2003) Italy and the Grand Tour. Yale University Press. New Haven

Booker, F. (1967) Industrial Archaeology of the Tamar Valley, David \& Charles, Newton Abbot.

Borlase, W. (1754) Observations on Antiquities Historical and Monumental of Cornwall, W. Jackson, Oxford.

Borlase, W. (1758) Natural History of Cornwall, W. Jackson, Oxford

Brayshay, M. and Kelly, A. (1988) Forrabury Common, Near Boscastle, Cornwall, The Ecology of an Open Field, Journal of Environmental Management, 26, (4), 277-297. 
Brayshay, M. (1996) 'Introduction: The development of topographical writing in the South West', in: Brayshay, M. (ed.) Topographical Writers in South-West England, University of Exeter Press, Exeter, 1-33.

Brayshay, M. (2006), 'Landscapes of Industry', 'Urban Landscapes',

'Landscapes of Transport', in: Kain, R. (ed.) England's Landscape: The South West, English Heritage, Harper Collins, London, 131-154, 155-184, 185-206.

Breathnach, T. (2006) Looking for the real me: Locating the self in heritage tourism. Journal of Heritage Tourism. 1, (2) 100-120.

Brunsden, D. (2003) The Official Guide to the Jurassic Coast, Dorset and East Devon's World Heritage Coast: A Walk Through Time, Coastal Publishing, Wareham.

Busby, G (2002) The Cornish church heritage as a Destination Component. Tourism. 50, (4), 371-381

Busby, G. (2006) The Cornish church heritage as a tourism attraction: the visitor experience. Unpubl. PhD, University of Exeter.

Busby, G. \& Meethan, K. (2008) 'Cultural Capital in Cornwall: Heritage and the Visitor', In: Payton,P. (Ed.) Cornish Studies Sixteen, University of Exeter Press, Exeter, 146- 166. Butler, J. (1991-1997) Dartmoor Atlas of Antiquities, 4 volumes, Devon Books, Tiverton.

Caffyn, A (1998) Tourism, heritage and urban regeneration - community participation and power relationships in the Stirling Initiative. The Environment Papers. 1, (3). 25-38.

Caffyn, A and Lutz, J. (1999) 'Developing the heritage tourism product in multiethnic cities'. In: Timothy, D. (ed.) Critical Essays: managing heritage and cultural tourism resources. Volume 1. Ashgate, Aldershot.

Cannadine, D. (1995) 'The first hundred years'. In: H. Newby, Editor, The National Trust: The Next Hundred Years, The National Trust, London, pp. 1131.

Carlsen, J., Getz, D. and Ali-Knight, J. 2001. The environmental attitudes and practices of family businesses in the rural tourism and hospitality sectors. Journal of Sustainable Tourism. 9, (4) 281-297.

Cassar, M. (1994) Environmental guidelines for museums and galleries. Routledge. London

Cato, P., Waller, R., Sharp, L., Simmons, J and Williams, S. (1996) Developing staff resources for managing collections: An initiative cosponsored by The Canadian Museum of Nature and The Virginia Museum of Natural History. Virginia Museum of Nature History Special Publication Number 4. Martinsville

Cave (ed) (2007) Museum and Art Galleries: making existing buildings accessible. RIBA, London 
Chandler, J. (1993) John Leland's Itinerary: Travels in Tudor England ['Cornwall', 59-90; 'Devon', 103-126], Alan Sutton, Stroud

Chandler, J. (1996) 'John Leland the West country', in: Brayshay, M. (ed.) Topographical Writers in South-West England, University of Exeter Press, Exeter, 34-49.

Chaney, E. (1998) The Evolution of the Grand Tour: Anglo-Italian Cutlural Relations since the Renaissance, Frank Cass, London.

Cheung, S. (1999) The meanings of a heritage trail in Hong Kong. Annals of Tourism Research. 26, (3) 570-588

Cherry, B. and Pevsner, N (1989) The Buildings of England: Devon, Second Edn, Penguin Books, London.

Chhabra, D., Healy, R. and Sills, E. (2003) Staged authenticity and heritage tourism. Annals of Tourism Research. 30,(3) 702-719.

Choay, F. (2001). The Invention of the Historic Monument. Cambridge University Press. Cambridge

Christy, M. and Worth, R. H. (1922) The Ancient Dwarfed Oak Woods of Dartmoor, Report and Transactions of the Devonshire Association, 54, 291-342.

Church of England (2006a) Shrinking the Footprint [online] http://www.shrinkingthefootprint.org/campaign.php . Accessed June 2006

Church of England (2006): A Church Near You [online] http://www.achurchnearyou.com/ Accessed June 2006.

Church of England (2009) Church and Earth 2009-2016 [online]. http://www.shrinkingthefootprint.org/misc lib/cofe 7vp full.pdf . Accessed Sept 2009

Church of England (2010) The Church of England's Built Heritage [online] http://www.cofe.anglican.org/about/builtheritage. Accessed February 2010.

Claire, T. (1982) Archaeological sites of Devon and Cornwall. Moorland Publishing Ltd, Derbyshire.

Cohen, M. (1992) The Grand Tour: constructing the English gentleman in eighteenth century France, History of Education, 21 (3), 241-257.

Cole, D. (2004) Exploring the sustainability of mining heritage tourism. Journal of Sustainable Tourism. 12,(6) 480-494.

Creed, R. (2002) Richard Creed's journal of the grand tour, 1699-1700: the journey to Rome with the $5^{\text {th }}$ Eart of Exeter, 25 September to $23^{\text {rd }}$ December 1999: four months. Oundle Museum, Peterborough 
CSD (1999). Commission on Sustainable Development. Seventh Session, 19$30^{\text {th }}$ April, New York

Daily Telegraphy (2008) The National Trust sees the eco light [online] http://www.telegraph.co.uk/earth/3345054/The-National-Trust-sees-the-ecolight.html. Accessed July 2008.

Darlow, S. and Hunt, R. (2010) The Re-development of Cotehele Quay Museum, Rep. Trans. Devon. Assoc. Advmnt Sci., 142, forthcoming.

Davies, R. (2008) The Red Store. Lerryn, Cornwall, Journal of Architectural Conservation, 14, (3), 7-22.

DCMS \& English Heritage (2004) Review of Heritage Protection: the way forward. [Online]

http://www.culture.gov.uk/global/siteSearch/SearchResults.htm? SRH DB=Site Index\& SRH STYPE=SIMPLE\& SRH SearchString=heritage\& SRH Doctype =1. Accessed September 2005

DCMS (2006) Understanding the Future: priorities for England's museums. [online]

http://www.culture.gov.uk/images/consultations/cons uf prioritiesforenglandsm useums.pdf. Accessed June 2008

DCMS \& English Heritage (2007) Heritage Protection for the 21st Century White Paper. [online]

http://webarchive.nationalarchives.gov.uk/+/http://www.culture.gov.uk/reference library/consultations/1156.aspx Accessed December 2007

DCMS (2008) Draft Heritage Protection Reform Bill. [online] http://webarchive.nationalarchives.gov.uk/+/http://www.culture.gov.uk/reference library/publications/5075.aspx Accessed June 2009

Delafons, J. (1997) Politics and preservation: a policy history of the built heritage 1882-1996. E.\& F.N. Spon, London

Dartmoor National Park Authority (2004). Prehistoric Archaeology of Dartmoor. [online] http://www.dartmoor-npa.gov.uk/lab-archaeo.pdf. Accessed June 2009

Dietz, M. (2004) 'Itinerant Spirituality and the Late Antique Origins of Christian Pilgrimage'. In: Ellis, L. and Kidner, F. (eds) Travel, Communication and Geography in Late Antiquity: Sacred and Profane. Ashgate Publishing. Aldershot

Digance, J. (2003) Pilgrimage at contested sites. Annals of Tourism Research. 30, (1). 143-159.

Diocese of Coventry and English Heritage (2009) Divine Inspiration. [online] http://www.divine-inspiration.org.uk/ Accessed Sept 2009 
Directgov (2010) Conservation Areas and Advice [online] http://www.direct.gov.uk/en/HomeAndCommunity/Planning/PlanningPermission/ DG 10026179 Accessed March 2010

Donnachie, I. (2010) Studying local and regional history in Britain and Ireland: The Open University MA in History. Scottish Local History Journal, 78. 24-28.

Drummond, S. and Yeoman, I. (2003) Quality issues in heritage visitor attractions. Butterworth-Heinemann, Oxford.

Du Cros, H. (2001), A new model to assist in planning for sustainable cultural heritage tourism. International Journal of Tourism Research. 3, (2). 165-170

Du Cross, H. 2008. Too much of a good thing? Visitor congestion management issues for popular world heritage tourist attractions. Journal of Heritage Tourism. 2, (3) 225-238.

Dymond, D. (1986) Writing a Church Guide, London, Church House

Edmonds, R. (2005) The Jurassic Coast, Report and Transactions of the Devonshire Association, 137, 53-64.

Edson, G. \& Dean, D. (1994) The Handbook for Museums. Routledge. New York.

Edwards, J. and Llurdes I Colt, J. (1996) Mine and quarries: Industrial heritage tourism. Annals of Tourism Research. 23,(2) 341-363.

English Heritage (2005) 2005-10 English Heritage Strategy. [Online] http://www.english-heritage.org.uk/upload/pdf/Research Strategy.pdf.

Accessed June 2006.

English Heritage Images of England website [online] http://www.imagesofengland.org.uk Accessed June 2006

English Heritage Pastscapes website [online]. http://pastscape.englishheritage.org.ukJ. Accessed June 2006.

English Heritage (2006a) Biomass Energy and the Historic Environment [online] http://www.english-heritage.org.uk/publications/biomass-energy-historicenvironment/ Accessed July 2007

English Heritage (2006b) Heritage Counts 2006 England [online] http://www.english-heritage.org.uk/hc2006/ Accessed June 2007

English Heritage (2008a) Heritage Counts 2008 England [online] http://hc.english-

heritage.org.uk/upload/pdf/HC08 National Acc.pdf?1279012326 Accessed July 2009

English Heritage (2008b) Climate Change [online] http://www.englishheritage.org.uk/protecting/climate-change/ Accessed November 2008 
English Heritage (2008c) Micro Wind Generation and Traditional Buildings. [online] http://www.english-heritage.org.uk/publications/micro-wind-generationand-traditional-buildings/ Accessed January 2009

English Heritage (2008d) Micro-generation in the Historic Environment [online]. http://www.english-heritage.org.uk/publications/microgeneration-in-the-historicenvironment/ Accessed January 2009

English Heritage (2008e) Energy Conservation and Traditional Buildings. [online] http://www.english-heritage.org.uk/publications/energy-conservation-intraditional-buildings/

English Heritage (2008f) Conservation Principles, Policies and Guidance. [online] http://www.english-heritage.org.uk/publications/conservation-principlessustainable-management-historic-environment/ Accessed November 2008.

English Heritage (2010a) Historic Environment: Local Management. [online] http://www.helm.org.uk/server/show/nav. 19710 Accessed February 2010.

English Heritage (2010b) Listed Buildings [online] http://www.englishheritage.org.uk/protecting/heritage-protection/what-can-we-protect/listedbuildings/ Accessed March 2010

Enjoy England website [online] http://www.enjoyengland.com/ Accessed July 2006

Feehally, M. (1984) Helping the Stones to Speak: simple ways to tell visitors about your church, Kenilworth, Society for the Interpretation of Britain's Heritage.

Fotsch, P. M. (2004) Tourism's uneven impact: History on cannery row. Annals of Tourism Research. 31,(4) 779-800

Frankfort-Nachmias, C. and Nachmias,D. (1996). Research methods in the social sciences. Edward Arnold. London

Gale, T. (2007) The Problems and Dilemmas of Northern European Postmature Coastal Tourism Resorts, in: Agarwal, S and Shaw, G. (eds.) Managing Coastal Tourism Resorts: A Global Perspective, Channel View Publications, Clevedon, 21-39.

Garrod, B. and Fyall, A. (2000). Managing heritage tourism. Annals of Tourism Research. 27,(3) 682-708.

Garrod, B. and Fyall, A. (2001). Rejoiners and commentary: Heritage tourism: A question of definition. Annals of Tourism Research. 28, 1049-1053.

Gibson, R. (2004). The English parish church - its relationship to the heritage visitor attraction market. Unpubl. PhD, Nottingham Trent University. 
Goodridge, J. (2008) Tamar View, the Horn of Plenty, and the Devonshire Great Consolidated Mining Company, Report and Transactions of the Devonshire Association, 140, 227-244.

Goulding, C. (1998) Grounded theory: The missing methodology on the interpretivist agenda, Qualitative Market Research: An International Journal 2 (1) $50-57$.

Goulding,C. (1999) 'Interpretation and Presentation'. In: A. Leask and I. Yeoman, Editors, Heritage Visitor Attractions: An Operation Management Perspective, Cassell, London pp. 54-67.

Goulding, C. (2000) The Commodification of the Past, Postmodern Pastiche, and the Search for Authentic Experiences at Contemporary Heritage Attractions, European Journal of Marketing, 34 (7) 835-853.

Graham. B. and Murray, M.(1997) The spiritual and the profane: the pilgrimage to Santiago de Compostela, Ecumene, 4 (4) 389-409.

Graham, B. et al. (2000) The contested interpretation of heritage landscapes in Northern Ireland, International Journal of Heritage Studies, 2, (1 \& 2), 10-22.

Gray, T. (2000) Travels in Georgian Devon: the illustrated journals of the Reverend John Swete, 1789-1800, Devon Books, Tiverton.

Grinsell, L. (1970) Discovering Regional Archaeology South Western England. Shire Publications, Tring, Herts.

Haden, S., Oyler, J and Humphreys, J. (2009) Historical, practical, and theoretical perspectives on green management. Management Decisions. 47, (7), 1041-1055

Hale, A. (2001) Representing the Cornish: contesting heritage interpretation in Cornwall, Tourist Studies, 1, (2) 185-196.

Hale, A. (2002) 'Whose Celtic Cornwall? The ethnic Cornish meet Celtic spirituality' in: Harvey, D. C., Jones, R., Mclnroy, N., and Milligan, C. (eds) Celtic Geographies: Old Culture, New Times, 157-170.

Hall, C. (2007) Response to Yeoman et al: The fakery of 'The authentic tourist'. Tourism Management. 28, (4) 1139-1140

Hampton, M. (2005). 'Heritage, local communities and economic development'. In: Timothy, D (Ed). Critical essays: managing heritage and cultural tourism recourses, Volume 1. Ashgate, Aldershot.

Harden, R (undated) based on AECOM report for Church of England. [Online]. http://www.cofe.anglican.org/news/pr6109.html . Accessed April 2010

Handler, R. (1986) Authenticity. Anthropology Today, 2, (1) 2-4 
Harris, G. T. (1921) Ecological Notes on Wistman's Wood and Black Tor Copse, Dartmoor, Report and Transactions of the Devonshire Association, 53, 232-245.

Harris, H. (1968) The Industrial Archaeology of Dartmoor, David \& Charles, Newton Abbot.

Harvey, D. C. (2001). Heritage pasts and heritage presents: Temporality, meaning and the scope of heritage studies. International Journal of Heritage Studies. 7 (4) 319-338.

Harvey, D. (2006) 'Faith, Church and Landscape', in: Kain, R. (ed.) England's Landscape: The South West, English Heritage, Harper Collins, London, 75-88.

Harvey, D. (2006) 'Landscape as Heritage and Recreational Resource', in: Kain, R. (ed.) England's Landscape: The South West, English Heritage, Harper Collins, London, 207-228.

Harvey, D. (2008) 'The History of Heritage'. In: Graham, B. and Howard, P. (eds) The Ashgate research companion to heritage and identity. Ashgate Publishing. Aldershot. 19-35

Hass, J.L. (1996) Environmental ('Green') Management Typologies: An evaluation, operationalisation and empirical development, Business Strategy and the Environment, 5,(2), 59-68.

Havinden, M. and Wilkinson, F. (1970) 'Farming', in: Gill, C. (ed.) Dartmoor: A New Study, David \& Charles, Newton Abbot, 139-181.

Hellyer, A. (1986) 'Rare Plants in a Composed Setting: Rosemoor Gardens, Torrington, North Devon', Country Life, April, 982-984.

Henderson, J. (2007) Corporate social responsibility and tourism: Hotel companies in Phuket, Thailand, after the Indian ocean tsunami. International Journal of Hospitality Management, 26, (1), 228-239

Herbert, D. (2001) Literary places, tourism and the heritage experience. Annals of Tourism Research. 28. (3), 12-333.

Heritage Lottery Fund [online] http://www.hlf.org.uk/Pages/Home.aspx Accessed June 2009.

Hibbert, C. (1987) The English: A social history, 1066-1945. Graffton Books, London.

Historic Houses Association (2010) Inspirational Places - the value of Britain's historic houses: HHA's policy proposals for 2010 and beyond. [online] http://www.hha.org.uk/DB/policy-news/inspirational-places-the-value-of-britainshistori.html Accessed June 2010.

Hewison, R. (1987) The Heritage Industry. Britain in a climate of decline. London, Methuen. 
Hitchcock, M. and Darma Putra, N. (2005) The Bali Bombings: Tourism Crisis Management and Conflict Avoidance. Current Issues in Tourism, 8, (1) 62 - 76

Holbrook, A., Krosnick, J. and Pfent.A. (2007). 'The Causes and Consequences of Response Rates in Surveys by the News Media and Government Contractor Survey Research Firms.' In: James M. Lepkowski, N., Tucker,J. C., Brick, M., Edith, D., Leeuw, D., Japec, L., Lavrakas, P., Link, M., and Sangster, R. (eds) in Advances in telephone survey methodology. New York: Wiley.

Hoskins, W.G. (1973) English Landscapes. BBC. London

Herring, P. (2006) 'Cornish Strip Fields', 'Medieval Fields at Brown Willy, Bodmin Moor', in: Turner, S. (ed.) Medieval Devon and Cornwall: Shaping an Ancient Countryside, Windgather Press, Macclesfield, 44-77, 78-103.

Hoskins, W. G. (1954) Devon, reprinted edn, 1972, David \& Charles, Newton Abbot.

Hoskins, W. G. (1955) The Making of the English Landscape, Hodder and Stoughton, London.

Hoskins, W. G. (1978) One Man's England, BBC, London.

Howard, P. (2003) Heritage: Management, Interpretation, Identity, Continuum, London.

Hunter, C. (1997) Sustainable tourism as an adaptive paradigm. Annals of Tourism Research. 24, (4) 850-867

ICOMOS ICIP (2008) The ICOMOS Charter for the Interpretation and Presentation of Cultural Heritage Sites (Ename Charter) [online] http://www.enamecharter.org/downloads/ICOMOS Interpretation Charter EN 10-04-07.pdf Accessed July 2009

Jabbour, C. and Santos, F. (2009). Problems associated with voluntary work in a small not-for-profit organization: A case from Brazil. Management Research News, 32, (10), 921

James, N. D. G. (2007) Bicton Gardens Countryside Museum, Bicton Park, Exeter.

Jenkins, J. (1994) From acorn to oak tree: the growth of the National Trust 1895-1994. MacMillan. London.

Johannson, L. (1997) The challenge of implementing ISO 14001 for small- and medium- sized enterprises - surviving in the new global jungle. Environmental Quality Management. 7, (2) 9-19.

Johnson, P. (2000) Reflections on the gentle art of re-creating lost gardens, The Spectator, 284, 8944, 22-23. 
Johnson, P. and Thomas, B., (1995) 'Heritage as Busiess'. In: Herbert, D.T. (Ed) Heritage, Tourism and Society Mansell, London, pp. 170-190.

Kelly, F. (ed.) (1991) Medieval Art and Architecture at Exeter Cathedral, Conference Transactions 11, British Archaeological Association, London.

Kennedy, N. and Kingcome, N. (1998) Disneyfication of Cornwall - Developing a Poldark Heritage Complex, International Journal of Heritage Studies, 4, (1) 45-59.

Kleindorfer,P., Singhal, K. and Van Wassenhove, L. (2005). Sustainable Operations Management. Production and Operations Management. 14, (4) 482 - 492

Kolar, T. and Zabkar, V. (2010) A consumer-based model of authenticity: An oxymoron or the foundation of cultural heritage marketing? Tourism Management. 31, (5) 652-664.

Kotler, P. (1991) Marketing management: Analysis, planning, implementation and control. Prentice Hall, Englewood Cliffs, NJ.

Laithwaite, M. (1992) Victorian Ilfracombe: origins and architecture of a north Devon holiday resort, Devon Books, Exeter.

Lambert, D. and Lovie, J. (2006) All Rosy in the Garden? The Protection of Historic Parks and Gardens, Journal of Architectural Conservation, 12, (3) 5867.

Lambert, J. W. (1939) The Penguin Guides, No. 3: Cornwall, Penguin Books, Harmondsworth.

Landorf, C. (2009). A framework for sustainable heritage management: A study of UK industrial heritage sites. International Journal of Heritage Studies. 15,(6) 494-510.

Larkham, P. (1995) 'Heritage as Planned and Conserved'. In: Herbert, D.T. (Ed.), Heritage, Tourism and Society. Mansell, London, pp. 85-116.

Laws, E. (1998) Conceptualizing visitor satisfaction management in heritage settings: an exploratory blueprinting analysis of Leeds Castle, Kent, Tourism Management, 19, (6) 545-554

Leask, A. and Yeoman, I. (1999) Heritage visitor attractions: An operations management perspective. Casell, London.

Lee, Ki-Hoon (2009) Why and how to adopt green management into business organisations? The case study of Korean SMEs in manufacturing industry. Management Decisions, 47,(7), 1101-1121

Legg, R. (2002) The Jurassic Coast: Guide to the Devon and Dorset World Heritage Site, Dorset Publishing Company, Wincanton. 
Light, D. (1991) 'The development of heritage interpretation in Britain'. In Edwards, J. and Llurder I coit, J. C (1996) Mines and Quarries: Industrial Heritage Tourism. Annals of Tourism Research, 23, (2), 341-363

Light, D. (1995) 'Visitors' use of interpretive media at heritage sites'. In: Timothy, $\mathrm{D}(\mathrm{Ed})$. Critical essays: managing heritage and cultural tourism recourses, Volume 1. Ashgate, Aldershot.

Lord, B. and Dexter, G. (1997) Manual of Museum Management. The Stationary Office. London

Loveridge, F. L. (1939) The Penguin Guides, No 4: Devon, Penguin Books, Harmondsworth.

Lowenthal, D. (1985) The past is a foreign country. Cambridge University Press, Cambridge.

MacCannell, D. (1973). Staged authenticity: arrangements of social space in tourist settings. University of Chicago Press. Chicago.

Magean, A. \& Hulmes, R (2000) Appraisal of Conservation Area Character in England: progress and problems, International Journal of Heritage Studies, 6, (3), 245-67.

Mather, A. S. and Chapman, K. (1995) Environmental Resources. Longman Scientific \& Technical, London.

May, T. (Ed) (2001). Social research: Issues, methods and process. 3 ed Open University Press, Buckingham.

Mellor, A., (1991) 'Enterprise and Heritage in the Dock'. In: Corner, J. and Harvey, S. Editors, Enterprise and Heritage: Crosscurrents of National Culture Routledge, London, pp. 93-115.

Merritt, Q. (1998) EM into SME won't go? Attitudes, awareness and practices in the London borough of Croydon. Business Strategy and the Environment. 7,(2) 90-100.

Moore, K. (1994) 'Introduction: museum management'. In: Moore, K. (ed) Museum Management. Routledge. London

Moscardo, G. (1996). Mindful visitors: Heritage and tourism. Annals of Tourism Research, 23,(2). 376-397.

Mountford, E. P, Backmeroff, C. E. and Peterken, G. (2001) Long-term Patterns of Growth, Mortality, Regeneration and Natural Disturbance in Wistman's Wood, A High-Altitude Oakwood on Dartmoor, Report and Transactions of the Devonshire Association, 133, 227-262.

Museums, Libraries and Archives Southwest website [online] http://www.mlasouthwest.org.uk/ Accessed August 2009 
Museums, Libraries and Archives Council (2009) Leading Museums, A Vision and Strategic Action Plan for English Museum [online] http://www.mla.gov.uk/what/programmes/renaissance/ /media/Files/pdf/2009/M LA Museum ActionPlan final. Accessed August 2009

National Trust (2001) Rural Sustainability- A rural policy framework [online] www.nationaltrust.org.uk/main/w-rural01.pdf. Accessed October 2007.

National Trust (2006a) Towards sustainable land management [Online] http://www.nationaltrust.org.uk/main/w-pc-sustainable land managementfull report.pdf Accessed October 2007.

National Trust (2006b) 'Trust You', National Trust Magazine, September 2006, National Trust

National Trust (2007) Our Future [online] ttp://www.nationaltrust.org.uk/main/wtrust/w-thecharity/w-thecharity our-future-2.htm Accessed July 2007

National Trust (2009a) Environmental Impact Assessment [online] http://www.nationaltrust.org.uk/main/w-chl/w-countryside environment/w-

environmental practices/w-environmental science-impacts.htm. Accessed December 2009

National Trust (2009b) Environmental Principles: A statement of. [online] http://www.nationaltrust.org.uk/main/w-chl/w-countryside environment/wenvironmental practices/w-environmental principles.htm Accessed December 2009

National Trust (2009c) 'Trust You', National Trust Magazine, September 2009, National Trust

National Trust (2010) National Trust: About Us. [online] http://www.nationaltrust.org.uk/main/w-trust/w-thecharity.htm Accessed April 2010. Accessed March 2010

Natural England (2010a) Areas of Outstanding Natural Beauty [online] http://www.naturalengland.org.uk/ourwork/conservation/designatedareas/aonb/d efault.aspx Accessed March 2010

Natural England (2010b) Sites of Special Scientific Interest [online] http://www.naturalengland.org.uk/ourwork/conservation/designatedareas/sssi/d efault.aspx Accessed March 2010

Natural England (2010c) National Parks [online] http://www.naturalengland.org.uk/ourwork/conservation/designatedareas/nation alparks/default.aspx Accessed March 2010

Neuendorf, K. (2002) The Content Analysis Guidebook. Sage Publishing. London. 
Newman, P. (2006) Recording Dartmoor's Extractive Industries, Industrial Archaeology Review, 28, (2) 87-95.

Nuryanti, W. (1996) Heritage and postmodern tourism. Annals of Tourism Research. 23, (2) 249-260

O'Neil, M. (2008) Museums, professionalism and democracy. Cultural Trends. 17 , (4) 289-307.

Office of National Statistics (2001) [online] www.ons.gov.uk. Accessed June 2006

Oppenheim, A. N. (1999) Questionnaire design, interviewing and attitude measurement. Pinter, London and Washington.

Ordnance Survey Codepoint web-page [online] www.ordnancesurvey.co.uk/oswebsite/products/codepoint. Accessed June 2009.

Orwin, C. S. and Sellick, R. J. (1970) The Reclamation of Exmoor Forest, David \& Charles, Newton Abbot.

Overton, M. (2006) 'Farming, Fishing and Rural Settlements', in: Kain, R. (ed.) England's Landscape: The South West, English Heritage, Harper Collins, London, 109-130.

Palmer, C. (1998) From theory to practice: Experiencing the nation in everyday life. Journal of Material Culture, 3 (2), 175-199

Palmer, C. (1999). Tourism and the symbols of identity. Tourism Management. 20, (3), 313-321.

Palmer, C. (2003). Touring Churchill's England: Rituals of kingship and belonging. Annals of Tourism Research. 30,(2) 426-445.

Palmer, C. (2005) An Ethnography of Englishness: Experiencing Identity through Tourism. Annals of Tourism Research. 32, (1) 7-27

Pearce, S. (1996) Archaeological curatorship. Leicester University Press. London

Pearce, S. M. (1999) Material History as Cultural Tradition: A La Ronde, Exmouth, Devon, England, Material History Review, 50, 26-34.

Peel, L. (ed.) (2010) The National Trust Handbook 2010, National Trust, Swindon. 32-107

Pemble, J. (1988) The Mediterranean passion: Victorians and Edwardians in the South. Oxford University Press. Oxford.

Pevsner, N. (2002) The Buildings of England: Cornwall. Yale University Press. London 
Pollock-Ellwand, N., Miyamoto, M., Kano, Y. and Yokohari, M. (2009). Commerce and conservation: An Asian approach to an enduring landscape, Ohmi-Hachiman, Japan. International Journal of Heritage Studies. 15, (1), 223.

Poria, Y., Biran, A. and Reichel, A. (2006). Tourist perceptions: Personal V. Non-personal. Journal of Heritage Tourism. 1, (2) 121-132.

Prentice, R. (1993) Tourism and heritage places. Routledge, London.

Prentice, R., Witt, S. and Hamer, C. (1998) Tourism as experiences: The case of heritage parks. Annals of Tourism Research. 25, (1), 1-24

Prentice, R. (2004) Tourist familiarity and imagery. Annals of Tourism Research. 31,(4) 923-945

Pretes, M. (2002) Touring mines and mining tourist. Annals of Tourism Research. 29, (2), 439-456.

Pritchard, A. and Morgan, N. (2001) Culture, identify and tourism representation: marketing Cymru or Wales? Tourism Management. 22,(2) 167 179.

Rea, L. and Parker, R. (1997) Designing and conducting survey research. Jossey-Bass. California.

Riley, M. and Harvey, D. (2005) Landscape Archaeology, Heritage and the Community in Devon: An Oral History Approach. International Journal of Heritage Studies, 11, (4). 269 - 288

Rhoden, S., Ineson, M. and Ralston, R. (2009) Volunteer motivation in heritage railways: a study of the West Somerset Railway volunteers. Journal of Heritage Tourism, 4, (1) 19 - 36

Robb, J. (1998) The 'ritual landscape' concept in archaeology: a heritage construction. Landscape Research. 23, (2). 159 - 174

Robson, C (1993) Real World Research. Blackwell, Oxford

Roome, N. (1992) Developing environmental management strategies, Business Strategy and the Environment, 1, (1), 11-24.

Rowe, S. (1821) The Panorama of Plymouth or Tourist's Guide to the Principal Objects of Interest in the Towns and Vicinity of Plymouth, Dock, and Stonehouse, Rowes, Plymouth.

Rowe, S. (1848) A Perambulation of the Ancient Royal Forest of Dartmoor and the Venville Parishes: Or, A Topographical Survey of their Antiquities and Scenery, Exeter. This work was reprinted in 1985 as a facsimile by Devon Books, Exeter. 
Royal Mail: Postcode finder [online]

http://www.royalmail.com/portal/rm/postcodefinder;jsessionid=VQBJJJVW03DU QFB2IGVEQEQUHRAOWQ2K?catld=400145\&gear=postcode Accessed June 2006

Royal Mail: Address finder [online]

http://postcode.royalmail.com/portal/rm/addressfinder;jsessionid=ECB0X3UFFD XQ2FB2IGJFEOQ; jsessionid=ECB0X3UFFDXQ2FB2IGJFEOQ?catId=400145

\&catid $=$ \&gear $=$ postcode Accessed June 2006

Ryan, C (1995) Researching Tourist Satisfaction - issues, concepts, problems. Routledge, London.

Ryan, C. (1995) Evaluating the communication process between interpreter and visitor. Tourism Management. 6, (4) 295-303

Samuel, R., (1994) Theatres of Memory Verso, London.

Segadicki (2006) Managing intangible heritage at Tsodilo. Museum International. 58, (1-2), 31-40.

Shackley, M. (2001). Managing sacred sites: Service provision and visitor experience. Continuum, New York: London.

Shackley, M. (2006) Cost and benefits: The impact of cathedral tourism in England. Journal of Heritage Tourism, 1, (2) 133-141.

Shorter, H. H. (1938) Fields in Manaton Parish, Dartmoor, Antiquity, 12, 183189.

Smit, T. (2000) The Lost Gardens of Heligan, Indigo, London.

Smit, T. (2001) Eden, Bantam, London.

Smith, V. (1992) The Quest in Guest. Annals of Tourism Research. 19, (1) 1-17

Smith, L. (2006) Use of heritage. Routledge, London, New York.

Soane, J. (2002) Agreeing to differ? English and German conservation practices as alternative models for European notions of the built past. International Journal of Heritage Studies. 8, (3) 267-281

Spooner, G. M., Proctor, M. C. F., and Spooner, M. F. (1980) Changes in Wistman's Wood, Dartmoor: photographic and other evidence, Report and Transactions of the Devonshire Association, 112, 43-80.

Stanier, P. (2005) Cornwall's Industrial Heritage, Twelveheads Press, Truro.

Starn, R. (2002) Authenticity and historic preservation: towards an authentic history. History of the Human Sciences, 15, (1) 1-16 
StreetMap web based mapping resource [online] http://www.streetmap.co.uk accessed June 2006.

Steger, U. (1993) The greening of the board room: how German companies are dealing with environmental issues, in: Fischer, K. and Schot, J. Environmental Strategies for Industry, Island Press, Washington. 147-66.

Swarbrooke, J. (2002) The development and management of visitor attractions. Butterworth-Heinemann. Oxford

Thorne, R. (1980) Covent Garden market: its history and restoration. Architectural Press, London.

Thorne, R. (1982) 'The Chapels of Devon', in: Beacham, P. (ed.) Devon's Heritage: Buildings and Landscape: A collection of essays on the conservation of Devon's environment, Devon County Council Planning Department, Exeter, 54-65.

Tilden, F. (1977) Interpreting our heritage. University of North Carolina Press, Chapel Hill

Timothy, D.J. and Boyd, S. (2003) Heritage Tourism. Prentice Hall.

Timothy, D. J. and Boyd, S. W. (2006) Heritage tourism in the 21st century: Valued traditions and new perspectives. Journal of Heritage Tourism. 1, (1) 116

Todd, A. and Laws, P. (1972) The industrial archaeology of Cornwall. David and Charles, Newton Abbott.

Tourism Associates (1999) Valuing our environment: a study of the economic impact of conserved landscapes and the National Trust in the South West, West Country Tourist Board/Tourism Research Group, Exeter.

Tourism Concern website (2005) [online] http://www.tourismconcern.org.uk, accessed $21^{\text {st }}$ August.

Tunbridge, J. (1998) 'The question of heritage in European cultural conflict'. In: Graham, B (ed) Modern Europe: Place, Culture and Identity. Arnold, London. 236-260

Turner, R., Pearce, D. and Bateman, I. (1994) Environmental Economics An Elementary Introduction. Harvester Wheatsheaf. Hemel Hempstead.

Turner, S. (2004) The Changing Ancient Landscape: South-West England c.1700-1900, Landscapes, 5, (1) 18-34.

Turner, S. (2006) 'The Christian Landscape: Churches, Chapels and Crosses' in: Turner, S. (ed.) Medieval Devon and Cornwall: Shaping an Ancient Countryside, Windgather Press, Macclesfield, 24-43. 
UN (1994) Agenda 21. UN Department for Economic and Social Affairs.

Division for Sustainable Development. UN website at http://mww.un.org, accessed 19 August 2005

UNEP (2005). Making tourism more sustainable: a guide for policy makers. United Nations Environment Programme, Paris

Uriely, N., Israeli, A. and Reichel, A. (2002) Research notes: Heritage proximity and resident attitudes toward tourism development. Annals of Tourism Research. 29, (4), 859-862.

Uzzell, D. (1996) Creating place identity through heritage interpretation. United Kingdom Intellect Limited.

Veal, A. (1997) Research methods for leisure and tourism: a practical guide. Pitman

Vernon, J., Essex, S., Pinder, David and Curry, K. (2003). The 'greening' of tourism micro-businesses: Outcomes of focus group investigations in south east Cornwall. Business Strategy and the Environment. 12, (49), 49-69

Vernon, J., Essex, S., Pinder, D. \& Curry, K. (2005) Collaborative policymaking: local sustainable projects, Annals of Tourism Research, 32, (2), 325-345.

Vernon, J., Essex, S., \& Curry, K. (2005) 'Sustainable Rural Tourism Business Practice: Progress and Policy in South East Cornwall', in: Hall, D., Kirkpatrick, I. \& Mitchell, M. (Eds.) Rural Tourism and Sustainable Business, Channel View Publications, Clevedon, pp.323-350.

Visit Britain website [online] http://www.visitbritain.com/en/GB/ Accessed August 2009

VisitCornwall website [online] http://www.visitcornwall.com/ Accessed July 2006

VisitDevonandCornwall.com website [online]

http://www. visitdevonandcornwall.com/ Accessed July 2006

VisitDevon.co.uk website [online] http://mww.visitdevon.co.uk/site/areas-to-visit Accessed July 2006

Waitt, G. (2000). Consuming heritage: Perceived historic authenticity. Annals of Tourism Research. 27, (4), 835-862.

Walley, N. and Whitehand, B. (1994) It's not easy being green, Harvard Business Review, 72, (3), 46-52

Wang, N. (1999). Rethinking authenticity in tourism experience. Annals of Tourism Research. 26, (2), 349-370.

Warner, K. M. (2004) Showcasing and Treasuring Horticulture in Public Spaces, Horticulture: Art and Science for Life, 642, 101-107. 
Waterton, E. and Smith, L. (2008). Heritage protection for the 21st century. Cultural Trends. 17, 197-203

Watson, S. (2007) Church tourism: Representation and cultural practice. Unpubl. PhD, University of York.

West, S. and Ansell, J. (2010) 'A history of heritage'. In: West, S. (ed) Understanding heritage in practice. Manchester University Press. Manchester.

Wheeler, D., Shaw, G. and Barr, S. (2004) Statistical techniques in geographical analysis. David Fulton Publishers.

Williams, A.M. and Shaw, G. (1997) Riding the big dipper: The rise and decline of the British seaside resort in the twentieth Century. In: Shaw, $G$ and Williams, A.M. (eds.) The Rise and Fall of British Coastal Resorts, Pinter, London. 1-18.

Williams, M. (2001). 'Social survey: Design to Analysis'. In: May, T. (Ed) Social research: Issues, methods and process. Open University Press, Buckingham. 87-119.

World Commission on Environment and Development, (1987). Our Common Future. Oxford: Oxford University Press.

Yale, P. (1991). From tourist attractions to heritage tourism. Elm Publications, Huntingdon.

Yale, P (1998). From tourist attractions to heritage tourism. Second Edition. Elm Publications, Huntingdon

Yeoman, I., Brass, D. and McMahon-Beattie, U. (2007). Current issues in tourism: The authentic tourist. Tourism Management. 28, (4), 1128-1138.

Youings, J (1968) Tuckers Hall Exeter: The History of a Provincial City Company through Five Centuries, University of Exeter Press, Exeter.

Youings, J. (1996) 'Some Early Topographers of Devon and Cornwall', in: Brayshay, M. (ed.) Topographical Writers in South-West England, University of Exeter Press, Exeter, 50-61. 


\section{Appendices}

Content:

Appendix 1. Listed Building Status Explained

Appendix 2. Conservation Area Status Explained

Appendix 3. AONBs, SSSI and National Parks

Appendix 4. The Heritage Lottery Fund

Appendix 5. Quantitative Survey

Appendix 6. Survey Cover Letter

Appendix 7. Semi-Structured Interview Schedule

Appendix 8. Interview Transcripts A-H

394

Appendix 9. Publications

513 


\section{Appendix 1}

\section{Listed Building Status}




\section{Listed Building Status}

Reference was made in the thesis, especially in Chapter 2, to the fact that many important heritage buildings in Devon and Cornwall have 'listed status'. It was noted that, in all, Devon has 19,000 listed buildings, more than any other single county, and Cornwall has 12,490 . A brief explanation is provided here of the introduction of Listed Building status, the process of designation, and the meanings of the categories which are in use.

\section{The Introduction of Listed Building Status}

The Secretary of State for the Environment is required to compile lists of buildings of special architectural or historic interest, for the guidance of local planning authorities in the exercise of their own planning functions under the Town and Country Planning Act 1971.

The recognition of the need to provide legal protection for historically important structures dates to the passing in 1882 of the Ancient Monuments Protection Act, which afforded limited protection to the nation's key ancient monuments. 'Building preservation orders' that were meant to encompass a wider range of structures were introduced by the Town and Country Planning Act 1932. However, a major impetus to large-scale action occurred as a result of the widespread damage inflicted on buildings during the Second World War. Initially, the aim was to determine which highly valued historic buildings were sufficiently important to require reconstruction. Thereafter, the current system of listings was quickly 
developed whereby a broader remit was defined which was included in the 1947 Town and Country Planning Act. The Act introduced Listed Building Status and the first full historic buildings survey of England was carried out in the 1950 s and 1960s. As a result, Statutory Lists were compiled for all local authority areas. Revisions were made in 1970 to the criteria applied in selecting buildings for Listing and this triggered a re-survey in order to up-date the status of the entire stock of the nation's protected buildings. This re-survey of the whole country is only just nearing completion.

In 1990, the Planning (Listed Building and Conservation Areas) Act amended and refined the approach to granting planning permission for Listed Buildings, and a further amendment of this act in 2009 made English Heritage the responsible body for overseeing the compilation of the lists, and for the granting or revoking of listed building status.

\section{The operation of the Listed Building System}

Listed building status aims to protect buildings from inappropriate demolition or alteration. Listing aims to identify and protect buildings that:

helps us acknowledge and understand our shared history, It marks and celebrates a building's special architectural and historic interest, and also brings it under the consideration of the planning system so that some thought will be taken about its future (English Heritage 2010b). 
The drive of the listing system is fundamentally to protect older, less common, buildings in their original condition. Eligible buildings are graded to allow those that are older, or more precious, to be subject to stricter criteria. Buildings from later periods, such as those which are post-1945, need to be of exceptional importance to be accorded Listed Status. Those buildings that are listed but are are decaying are placed on English Heritage's Buildings at Risk Register.

The principles of applied in the selection of buildings for Listed Status were drawn up by the Historic Buildings Council (the functions of the former Historic Buildings Council for England are now carried out by the Historic Buildings and Monuments Commission (HBMC) and approved by the Secretary of State. They cover five groups:

1. All buildings built before 1700 which survive in anything like their original condition are listed.

2. Most buildings of 1700 to 1840 are listed, though selection is necessary.

3. Buildings erected between 1840 and 1914 are listed only if they possess definite quality and character. Selection would, for example, include the main works of principal architects.

4. For buildings erected between 1914 and 1939, those of exceptionally high quality are listed.

5. A few outstanding buildings erected after 1939 are listed

In choosing buildings, particular attention is paid to their special value as examples of certain types of structure or architecture, or their role in illustrating 
social and economic history (e.g. industrial buildings, railway stations, schools, hospitals, theatres, town halls, markets, exchanges, almshouses, prisons, mills, and factories); technological innovation or virtuosity (e.g. cast-iron structures, prefabricated buildings, or cases of the early use of concrete). An association with a well-known character or event can also be used to justify Listed Status. Finally, group or assemblage value can be important, especially where buildings together represent key examples of town planning (e.g. urban squares, terraces or model villages).

\section{The protection afforded by Listed Building status.}

A building designated as listed by English Heritage,

May not be demolished, extended or altered without special permission from the local planning authority which typically consults the relevant central government agency, particularly for significant alterations to the more notable listed buildings (English Heritage 2010b).

Some exemptions do exist, especially for churches that are currently in use for worship. However, English Heritage must be satisfied that, in these cases, the body in charge of a Listed Building is an organisation with its own agreed and approved procedures.

In cases where it is deemed necessary to intervene, English Heritage or the local authority can require a building's owners(s) to repair and maintain the building. If any of these requirements are not met, or demolition or alteration occurs without consent, then a criminal prosecution can be pursued. 
The different categories of Listed Building status

English Heritage categorises Listed Buildings in three classes: Grade I, Grade II* and Grade II. English Heritage describes these categories as

Grade I buildings are of exceptional interest, sometimes considered to be internationally important. Just 2.5 per cent of listed buildings are Grade I.

Grade II* buildings are particularly important buildings of more than special interest. 5.5 per cent of listed buildings are Grade II*.

Grade II buildings are nationally important and of special interest. 92 per cent of all listed buildings are in this class and it is the most likely grade of listing for a home owner.

Listing currently protects $c .500,000$ or so buildings. Because of the national and international importance, Grade I and $\mathrm{I}^{*}$ buildings may be eligible for English Heritage grants in cases where urgent major repairs are required.

Broadly the same situation obtains in Wales, where the statutory body is Cadw (which means 'Keep' in Welsh) and in Scotland, where the key body is Historic Scotland. In Northern Ireland, the Ulster Architectural Society is the responsible body. In both Scotland and Northern Ireland, instead of the categories: Grade I, $\mathrm{II}^{*}$ and II, the more logical Grades A, B and C are used. 
Appendix 2

Conservation Area Status 


\section{Conservation Area Status}

Reference has been made in the thesis to Conservation Areas as a means of protecting the built heritage of the two counties of the Southwest. It was noted that Devon and Cornwall together have 415 designated Conservation Areas. A brief explanation is provided here of the designation of such areas.

\section{Definition of Conservation Areas}

Government guidance documents describe conservation areas as

Places which are desirable to preserve as a result of their special architectural or historic interest ... [they are] areas that include important examples of our social, cultural and aesthetic history must be safeguarded from indiscriminate or ill-considered change (DirectGov 2010).

Many conservation areas contain one or more listed buildings; however, the designation often affords equal importance to the surroundings. Indeed, the role of the conservation area is to protect the 'whole place', including the built and natural environment. However, it is also recognised that conservation areas are dynamic, living communities, which 'must be allowed to change over time in order to remain vital and prosperous'. The central aim of designation as a conservation area is the protection of the character of that area for future generations. In cases where heritage places lie within conservation areas, of course, the protection they afford extends to the safeguarding of the heritage. 


\section{The Protection Afforded}

When a conservation area is designated for the protection of the natural and built environment, all new development proposals are judged according to criteria determine whether the changes will be sympathetic to the architectural and aesthetic qualities of the area. Local councils have the statutory power to control the changes in conservation area and they are required to pay particular attention to elements such as the scale of any proposed development, the concentration of buildings or features, the architectural design, and the building materials.

\section{Restrictions that Apply}

Guidelines for the statutory protection of conservation areas refer to five main elements.

1. Demolition of buildings - consent is required for the demolition in whole or part of any building and/or structure. Advice must be sought from the local authority if demolition is proposed.

2. Trees - Notice of felling, lopping or topping, or uprooting of trees within a conservation area must be made to the local authority. A minimum of six weeks notice in writing is required. 
3. Satellite dishes - Consent must be sought from the council when seeking to locate a satellite dish on chimney stacks, roof slopes or the front elevations of buildings in a conservation area.

4. New development - New developments are required to be designed to a high standard and to be sympathetic to the existing built environment. Developments must be seen to make a positive contribution to the enhancement of the character of the conservation area. All planning applications require additional information, over and above that normally expected when making a planning application, to explain how the proposed development fits in with the existing design and character of the conservation area.

5. Changes to existing buildings - All applications for building work in conservation areas are publicised, by local councils, at the site and in local newspapers. Building work that is regarded as sympathetic to the character of a conservation area is eligible to be considered but permission needs to be sought for alterations to roofs, cladding of buildings, and changes to the profile of a roof. 


\section{Appendix 3}

\section{AONBs, SSSIs and National Parks}




\section{Areas of Outstanding Natural Beauty (AONB)}

It was noted in the thesis that one key measure of the abundance in Devon of 'natural heritage' is that over 50 per cent of the county is covered by environmental designations. In addition to the National Parks of Dartmoor and Exmoor and the East Devon coastal World Heritage Site, these include five Areas of Outstanding Natural Beauty (AONBs). In Cornwall, the county's single AONB, first designated in 1959, comprises 12 separate areas; while 11 of these areas are coastal and estuarine; one is inland (Bodmin Moor).

Areas of Outstanding Natural Beauty (AONBs) are described by Natural England (2010a) as 'areas of high scenic quality that have statutory protection in order to conserve and enhance the natural beauty of their landscapes'. These valued landscapes are diverse and can include moors, meadows, wetlands, lowland and upland amongst others.

AONBs were first defined for designation under the terms of the 1949 National Parks and Access to the Countryside Act. This legislation afforded such area special protection from development. Under powers granted by the 2000 Countryside and Rights of Way Act 2000, Natural England assumed responsibility for the designation and statutory protection of AONBs. The 2000 Act provided new measures that detailed the role of local authorities in the care of AONBs. It also included instructions on the preparation of management plans for AONBs. The local management of AONBs is carried out in partnership by Natural England and the relevant local authorities. Sites usually have particular staff dedicated to them to ensure that technical advice and statutory protection is effectively delivered and co-ordinate. 
Natural England (2010a) defines the purpose and objectives of AONB designation as follows:

1. The primary purpose of an AONB designation is to conserve its natural beauty.

2. Although recreation is not an objective of designation, AONBs should be used to meet the demands for recreation as far as this is consistent with the conservation of natural beauty and the needs of agriculture, forestry and other users.

3. In pursuing the primary objective of the designation of an AONB, account should be taken of the need to safeguard agriculture, forestry, other rural industries and of the economic and social needs of local communities.

AONBs are similar in some ways to National Parks. However, they differ principally because they are not designed, or used, as areas for extensive outdoor recreation. Instead, AONB designation is aimed at the protection of those sites with unique or highly valued landscape qualities. The objective is to safeguard and enhance the natural beauty of such areas. While this

Taking Cornwall's AONB as a single case (even though it actually comprises 12 separate tracts of landscape), and Devon's five AONBs, the six cases in the two Southwest counties represent 18 per cent of England's total of 34 . 


\section{Sites of Special Scientific Interest (SSSI)}

Earlier in the thesis, it was noted that Devon currently contains 211 Sites of Special Scientific Interest (SSSIs), and there are some 166 SSSIs in Cornwall.

Natural England (2010b) describes Sites of Special Scientific Interest (SSSIs) as:

The country's very best wildlife and geographical sites ... [including] some of the most spectacular and beautiful habitats; wetlands teeming with wading birds, winding chalk rivers, flower-rich meadows, windswept shingle beaches and remote upland peat bogs.

Seen to be areas at risk from pressures for development, from climate change, and from the effects of inappropriate and unsympathetic land management, SSSI designation was provided for in the 1981 Wildlife and Countryside Act. This legislative protection was strengthened and further clarified in the 2000 Countryside and Rights of Way (CROW) Act and the 2006 Natural Environment and Rural Communities (NERC) Act 2006. These Acts empower Natural England to protect and manage the designated areas with the aim of sustaining them for the future.

There are now over 4,000 SSSIs in England 'covering around 7 per cent of the country's land area' (Natural England 2010b). The 377 sites in Devon and Cornwall thus account for almost 10 per cent of the national total. Many SSSIs are in private ownership and Natural England is therefore required to work with over 26,000 landowners and managers across the country in order to ensure that protection is afforded. Management approaches at the SSSIs are further complicated by the fact that more than 70 per cent are also designated as 
Special Areas of Conservation (SACs), Special Protection Areas (SPAs), National Nature Reserves (NNRs) or Local Nature Reserves (LNRs).

Designation as an SSSI indicates that an area contains the rarest, and most fragile examples of geology, flora, and fauna. The 2008 State of the Natural Environment Report stated that SSSIs also include extensive, rare, global environments such as peat bogs, maritime heath lands and limestone pavements.

As well as protecting diverse and unique habitats, SSSIs also offer visitors the opportunity to engage in sensitive recreational activities. The wider benefits of SSSIs have been investigated and research by Natural England (2010b) has shown that a range of functions are performed by the habitats in SSSIs. These include:

1. Healthy peat bogs and woodlands that are capable of locking up carbon and thus helping to tackle the effects of climate change.

2. Naturally functioning rivers, wetlands and their catchments reduce the risk of flooding in built-up areas and on agricultural land.

3. Coastal habitats, such as salt marshes and sand dune systems, provide effective natural defenses against rising sea levels. 


\section{National Parks}

Earlier in the thesis it was noted that Devon contains the whole of one (Dartmoor) of England 10 National Parks, and part of another (Exmoor). There are a further two National Parks in Scotland and three in Wales, making 15 in total in Great Britain.

National Parks are cherished and protected because use of 'their beautiful countryside, wildlife and cultural heritage' (English Nature 2010c). National Park areas do often include towns, villages, and farms. They are areas where people live and work.

Statutory provision for the designation of National Parks was made in the 1949 National Parks and Access to the Countryside Act. This Act defined two legal obligations in cases where a National Park was designated:

1. To conserve and enhance their natural beauty, wildlife and cultural heritage.

2. To promote opportunities for the public understanding and enjoyment of these special qualities' (Natural England 2010c)

These obligations are the responsibility in each National Park of a body known as a National Park Authority. Each National Park Authority employs between 50 and 200 paid staff as well as calling on the assistance of numerous volunteers. While National Parks promote recreation in a way that other types of protected landscape do not, they are nonetheless required to priorities conservation over recreational activities, thus ensuring that Parks are managed sustainably. National Park Authorities also have a duty to foster the economic and social well- 
being of the communities resident within the boundaries of a Park. These various obligations are addressed through the development of statutory National Park Management Plans. Each National Park is thus required to devise a Plan that sets out a five-year management strategy for their Park. With the aim of achieving social and economic wellbeing, local communities, landowners and other key stakeholders are actively engaged in the production of these Plans.

The earliest National Parks were designated in 1951 when the list included Dartmoor, together with Snowdonia, the Lake District and the Peak District. Exmoor National Park was designated three years later, in 1954. In both Dartmoor Exmoor National Parks, the outstanding scenic beauty, the richness of the wildlife, the abundance of history and heritage, and the opportunities afforded for the enjoyment of the environment as a recreational pastime combine in large tracts of landscape that are much cherished elements in the natural heritage of the Southwest. 
Appendix 4

The Heritage Lottery Fund 


\section{Heritage Lottery Fund}

In chapter 2 of the thesis, it was noted, as an example, that the disused Derriton railway viaduct in Holsworthy, which dates to 1898 , was restored as a footpath and cycle track with support from the Heritage Lottery Fund [HLF] in 2007. A brief explanation of HLF is given below.

Set up by Parliament in 1994, the HLF provides grants to local, regional and national heritage projects in the United Kingdom. The money to support these projects is sourced from the National Lottery. For each lottery ticket purchased, $28 p$ goes towards the support of a variety of projects aimed at benefiting local communities. National Lottery funding is divided between the HLF and other activities. The funds are allocated to 'good causes' as follows:

- Charities, health, education the environment, 50 per cent

- Sports, 16.67 per cent

- Arts, 16.67 per cent

- Heritage, 16.67 per cent (Heritage Lottery Fund 2010)

The HLF is administered by a non-departmental public body known as the National Heritage Memorial Fund [NHMF], which is accountable to Parliament through the Department of Culture Media and Sport. The NHMF distributes the heritage share of National Lottery monies to the various 'good causes'. Submitted projects are chosen, independently of government, by one of 14 adjudication panels. 


\section{Eligible Projects}

The HLF seeks to make grants to projects that 'sustain and transform a wide range of heritage ... with a lasting impact on people and place' (Heritage Lottery Fund 2010). The fund is accessible to a wide range of heritage types including: museums, historic houses, cultural traditions, natural heritage landscapes, parks and gardens and archaeological sites. The aim is to provide support that will sustain national and local heritage sites and resources for future use.

The HLF is the 'largest dedicated funder of the UK's heritage, with around $£ 180$ million a year to invest in new projects'. Moreover, it is regarded as one of the leading advocates and promoters of the value of heritage in modern-day living. To date, the HLF has supported more than 33,900 projects, allocating $£ 4.4$ billion across the UK as a whole. 


\section{Appendix 5}

\section{Quantitative Survey}




\section{Heritage in Devon, Cornwall and the Isles of Scilly: Research Survey}

Thank you for taking the time to fill in this questionnaire. The aim of these questions is to find out more about your historic/heritage site, its visitors and, in particular, how the site is managed and maintained. This questionnaire is divided into three sections. The first section comprises questions that will help me describe your site. The second section focuses on how you run the site and the challenges that have to be faced in order to achieve sustainability. The third section asks a few short questions about you.

\section{Section 1: $\quad$ About Your Site}

The following questions aim to provide a clear picture of the type of historic/ heritage site at which you work and provides the context for the following sections.

Q1 Please identify the main kind of heritage that describes your site. Please rank responses where 1 =primary function, $2=$ secondary function etc.

Religious Heritage site (churches) Marine and Maritime heritage Historic House and/or Castle Historic Park and Garden Heritage Arts and/or Crafts Centre Heritage festivals, Market, Fair Natural Heritage and Landscape Famous person influenced site

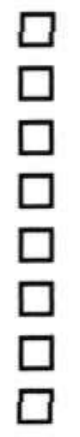

Archaeological site

Museum and Archive Industrial heritage Transport Heritage Heritage Theme park Military Heritage Science based heritage Other (please state).

If your site includes more than one category please comment

\section{Q2 When did you first open to the public?}

Date when first opened to the public:

\section{Q3 Please provide a brief description of the special historic features of your heritage site (tick all those that apply)}
Listed Grade 1
Listed Grade 2*
In an AONB
Listed Grade 2
In a SSSI
In a Conservation Area
In a National Park
Other special feature, please detail:

\section{Q4 Where is your historic/ heritage site located?}

Large urban area (city/ large town)

Small urban area (small town/ village)

Rural setting (surrounded by open countryside/ small clusters of housing)

Island based (not based on mainland Britain)

Other, please detail: 
Q5 Do you know of similar or complementary heritage sites within 5 miles?

No

Not sure

Yes, please name them:

Q6 What other attractions in your locality do you advertise/promote? (These may include any facilities that are of interest or value to your visitors, for example another heritage site, places to eat, etc.). Please name the other attractions below:

Q7 Which of the following best describes your organisation?

$\square$
$\square$
$\square$

Public Limited Company

Religious organisation

Other, please specify
Charitable organisation

Privately owned business

\section{Q8 Does your site form part of a larger organisation?}
Yes
No (If no, please go to question 10)

Q9 If yes, to which organisation does it belong?

Q10 Is your historic/heritage site managed and run by a single organisation, or managed in a partnership by several stakeholders?

$\square \quad$ Managed by a single organisation

$\square \quad$ Managed in partnership

If managed in partnership, please list the key stakeholders:

Q11 What facilities are offered at your historic/ heritage site? Please tick all that apply:

$\begin{array}{ll}\square & \text { Guided tours } \\ \square & \text { Self-guided tours } \\ \square & \text { Information leaflets } \\ \square & \text { Guide books } \\ \square & \text { Information boards } \\ \square & \text { Special exhibitions } \\ \square & \text { Other, please specify }\end{array}$

'Hands-on' activities with exhibits

Education rooms/ facilities

Talks/lectures (on/off-site to special interest groups)

Gift shop

Café/ restaurant

General amusements

Car park (if yes, please answer Q12)

Q12 Approximately how many car parking spaces are there at your site? 
Q13 How many people are employed at the historic/heritage site? (please tick, as appropriate)

\begin{tabular}{llll} 
Paid employees & \multicolumn{2}{c}{ Volunteers } \\
$\square$ & $1-2$ & $\square$ & $1-2$ \\
$\square$ & $3-5$ & $\square$ & $3-5$ \\
$\square$ & $6-10$ & $\square$ & $6-10$ \\
$\square$ & $11-20$ & $\square$ & $11-20$ \\
$\square$ & Over 20 & $\square$ & Over 20
\end{tabular}

\section{Section 2: Management of heritage sites}

The following questions ask about the number and type of visitors that you welcome to your historic/heritage site, and the facilities that you provide for them. In addition, there are questions about different environmentally friendly practices that might have been implemented at your site and the kinds of issues that arose in adopting them. My questions aim to provide an insight into the how social, financial and environmental sustainability issues are managed at your site.

\section{1: Visitors and Visitor Management}

Q14 When is your historic/heritage site open to visitors? (If parts of your historic/heritage site open at different times please tick the box that refers to the opening times of your primary use, as identified in Q1)
All year
Only on certain days
Seasonally
Not usually, or rarely, open to the public
Only on request

Q15 Approximately how many visitors come to your historic/heritage site each year?

Number of paying visitors (including members)

Number of non-paying visitors.

Q16 At your heritage site, on which of the following do you base your knowledge of visitors (i.e. their characteristics/geographic origins etc)?
$\square \quad$ Formal market research information
Informal information/ from experience
Don't know

Q17 From where are your usual visitors drawn? (if possible, please give an approximate percentage)

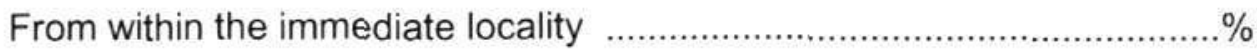

From within the rest of the county .......................................................

From within the rest of the Southwest ..............................................\%

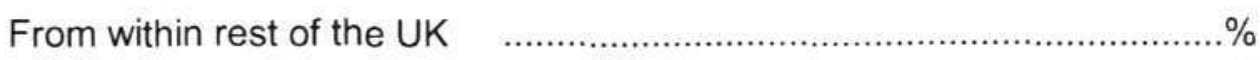

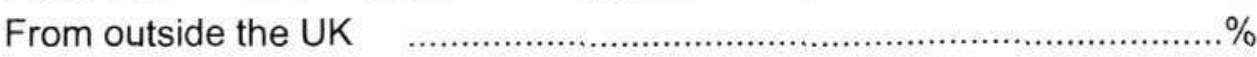


Q18 Using the categories below, could you describe your main visitor groups? (please rank from 1 = most frequent visitors, to 8 = least frequent)

People who just want a day out (Dip in and out of information)

People seeking lots of factual information (Deliberately visit well researched places)

Value seeking family groups (Like what they know)

Child orientated fun seekers (Want to be certain of a good time)

Frequent visitors (Regular day trippers seeking a new experience)

Families interested in learning (Enjoy adventure as a family)

Young experience seekers (Young with no children looking for interest/ challenge)

Other

Q19 Is interpretive information provided for visitors at your historic/heritage site?

$\begin{array}{llll}\text { Yes } & \square \quad \text { No, go to question 28 } \quad \square \quad \text { Don't know, go to question } 28\end{array}$

\section{Q20 What types of interpretive information do you provide?}

$\begin{array}{llll}\square & \text { Guided tours } & \square & \text { Information boards/panels } \\ \square & \text { Film/video presentations } & \square & \text { Signs/labels } \\ \square & \text { Self-guided audio tours } & \square & \text { Models/reconstructions } \\ \square & \text { Guide books } & \square & \text { Other, please specify } \\ \square & \text { Leaflets } & & \end{array}$

Q 21 In your opinion, which of the different ways of providing interpretive information works best? Please rank each method, 1 = most effective, 8 = least effective

$\begin{array}{lcc} & \begin{array}{c}\text { Cost effective } \\ \text { Guided tours }\end{array} & \begin{array}{c}\text { Offer best means to secure visitor attention } \\ \text { and interest } \\ \text { (Rank 1-8) }\end{array} \\ \text { Film/video presentations } & \square & \square \\ \text { Self-guided audio tours } & \square & \square \\ \text { Guide books } & \square & \square \\ \text { Leaflets } & \square & \square \\ \text { Information boards/panels } & \square & \square \\ \text { Signs/labels } & \square & \square \\ \text { Models/reconstructions } & \square & \square\end{array}$

Q22 In your opinion, which of the different ways of providing interpretive information, listed in Q20, exerts the least environmental impact?

Q23 Is your interpretive information designed for particular 'audiences'?

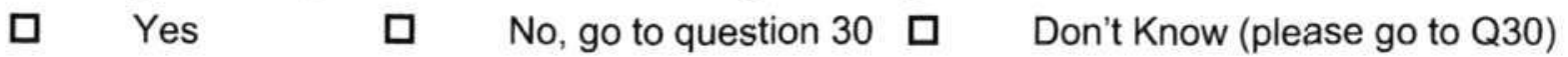


Q25 In your opinion, do any difficulties arise when trying to devise interpretive information for visitors with different expectations and requirements?

$\square \quad$ No $\quad \square \quad$ Yes, please give brief details

Q26 How frequently do you update or change your different interpretative materials? tick those that apply

Annually Every 2-5 years Over 10 years $\begin{gathered}\text { Not/Never } \\ \text { been updated }\end{gathered}$

Guided tours
Film/video presentations
Self-guided audio tours
Guide books
Leaflets
Information boards/panels
Signs/labels
Models/reconstructions

Q27 How is your interpretive material produced? Please tick those that apply
Designed/produced 'in-house'
Designed/produced by external professional
Other, please company

\begin{abstract}
Guided tours
Film/video presentations

Self-guided audio tours

Guide books

Leaflets

Information boards/panels

Signs/labels

Models/reconstructions
\end{abstract}

$\begin{array}{ll}\square & \square \\ \square & \square \\ \square & \square \\ \square & \square \\ \square & \square \\ \square & \square \\ \square & \square \\ \square & \square\end{array}$


Q28 Which groups exert influence on the interpretive information that you provide? (Please rank in order where $1=$ most important, $10=$ least important)

Shareholder/ investors

Visitors

Government

Focus groups

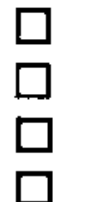

Pressure Groups

Environmental Groups

Local community

Other, please specify $\square \quad$ Employees

Suppliers

Press/ media

Q29 Do you provide for local/community groups to make use of the historic/heritage site? $\square$ No $\square$ Yes, if yes, please give brief details:

\section{Section 2.2: Environmental Management}

Q30 In your opinion, how important is it that your historic/heritage site operates in an environmentally friendly manner?

Very important Important Neither important or unimportant

Fairly unimportant Unimportant

Q31 If yes, what are the reasons that make it important to operate in an environmentally friendly manner? Please rank, 1 = most important reason; 7 = least important reason

$\square \quad$ It can save us money

$\square \quad$ It enhances our image

$\square \quad$ We have to do so to comply with legal requirements

$\square \quad$ It engenders a good ethos amongst employees and visitors

$\square \quad$ It responds to society's expectations

Other, please describe

Q32 Has your organisation reviewed the environmental performance of your operations? Yes, go to Q33 No, go to Q34

Q33 If yes, please answer the following questions:

(a) What form did the review take? (external audit/internal auditinformal actions)

(b) in what year did you review it?

(c) did you make any changes as a result of the review? $\square$ Yes $\square$ No

Q34 Does your organisation have an environmental sustainability strategy or policy?
Yes
No, go to question 36

Q35 If yes, in what year was the strategy/policy first introduced?

Please could you include a copy of your policy/strategy with your questionnaire return. 
Q36 Has your organisation implemented any of the following measures which might reduce the resource consumption of your operations?

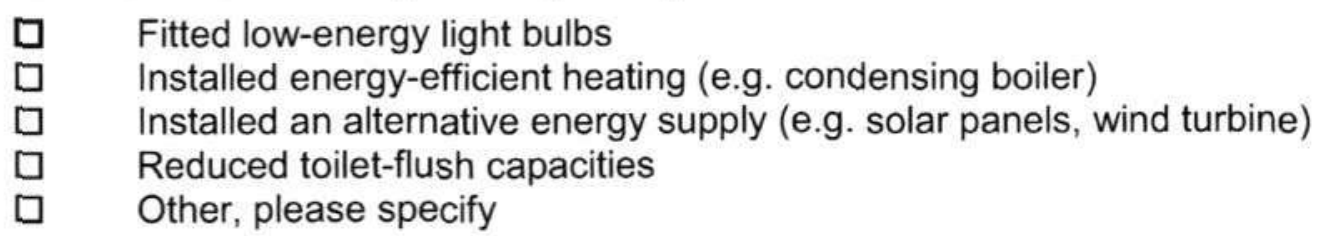

Q37 Has your organisation implemented any of the following measures which might reduce the waste produced by your operations?

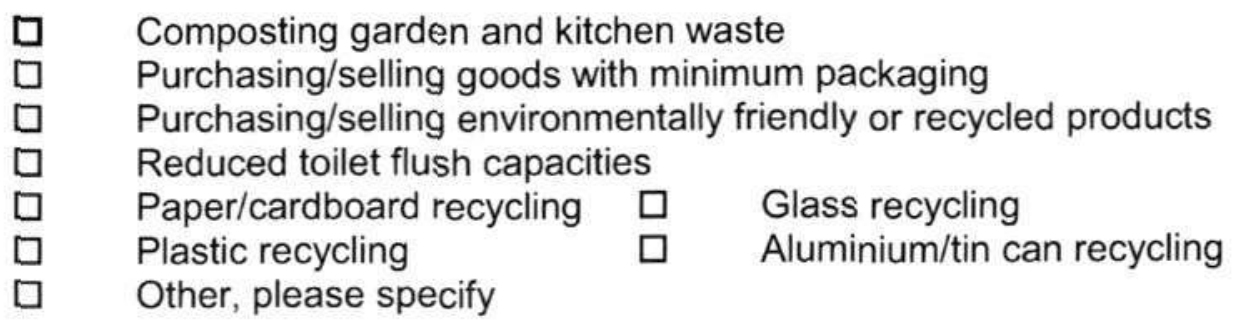

Q38 If you currently recycle paper/cardboard, glass, plastic and/or aluminium/tin cans, how do you dispose of the material?

$\begin{array}{ll}\square & \text { Local recycling bins or banks } \\ \square & \text { Local council collection service } \\ \square & \text { Other, please specify }\end{array}$

Q39 Have you implemented any of the following measures to help conserve the local environment or limit the pressure on your site?
Adopted measures to limit the number of people visiting your site at any one time
Restricted access to a particular part of your site
Created wildlife areas/haven on your site
Planted trees or other vegetation
Worked with local community on an environmental project, please specify

Other, please specify

Q40 Have you implemented any of the following measures which might help to support the local community?

Purchased/sold products and services produced locally

Encouraged visitors to use public transport to access your site

Encouraged visitors to cycle or walk to your site

Provided walking or cycling routes within your site

Communicated your environmental improvements to your visitors 
Q41 Did you experience any problems in introducing any of the measures listed in questions $36-40$ ?

Yes, go to question 42

No, go to question 43

Q42 If yes, what problems did you experience?

Q43 What do you consider to be the main barriers to the introduction of (further) environmentally friendly practices in your operation? Please rank, $1=$ most significant, $8=$ least significant

$\square$ No time to investigate

$\square$ Actions are not cost effective

$\square$ Lack of staff enthusiasm

$\square$ Do not know what more we could do

$\square$ Would impact adversely on the historical conservation of the site

$\square$ Other, please specify

Q44 In your view, what impacts do environmentally friendly measures have on the conservation of the heritage resource and the heritage tourism experience that you are able to offer?

\begin{tabular}{lcccccc} 
& \multicolumn{2}{c}{ Conservation of heritage resource } & \multicolumn{3}{c}{ Tourism experience } \\
Enhances & No change & Conflicts & Enhances & No change & Conflicts \\
Water efficiency & $\square$ & $\square$ & $\square$ & $\square$ & $\square$ & $\square$ \\
$\begin{array}{l}\text { Recycling and waste } \\
\text { management }\end{array}$ & $\square$ & $\square$ & $\square$ & $\square$ & $\square$ & $\square$ \\
$\begin{array}{l}\text { Local purchasing } \\
\text { policies }\end{array}$ & $\square$ & $\square$ & $\square$ & $\square$ & $\square$ & $\square$ \\
$\begin{array}{l}\text { Promotion of public } \\
\text { transport }\end{array}$ & $\square$ & $\square$ & $\square$ & $\square$ & $\square$ & $\square$ \\
$\begin{array}{l}\text { Restrictions on } \\
\text { private motor } \\
\text { vehicles }\end{array}$ & $\square$ & $\square$ & $\square$ & $\square$ & $\square$ & $\square$ \\
$\begin{array}{l}\text { Habitat conservation } \\
\text { measures }\end{array}$ & $\square$ & $\square$ & $\square$ & $\square$ & $\square$ & $\square$ \\
& & $\square$ & $\square$ & $\square$ & $\square$ & $\square$
\end{tabular}




\section{Section 2.3: Financial Management}

Q45 Please rank the sources of income of your organisation? (rank all that apply: $1=$ most important, $10=$ least important)

$\begin{array}{llll}\square & \text { Admission charges } & \square & \text { Membership subscriptions } \\ \square & \text { Donation } & \square & \text { National Lottery grants } \\ \square & \text { Regular Local Authority payments } & \square & \text { One-off Local Authority grants } \\ \square & \text { Media/ film use of sites as 'sets' } & \square & \text { Catering } \\ \square & \text { Retailing } & \square & \text { Conferences } \\ \square & \text { Other } & & \end{array}$

Q46 Taking into account all sources of income, in the last financial year, did your site generate a profit or surplus?

$\begin{array}{llll}\square & \text { Yes } & \text { No } & \square \quad \text { Don't know } \\ \square & \text { Prefer not to answer } & & \end{array}$

\section{Q47 What is the biggest area of expenditure at your site?}

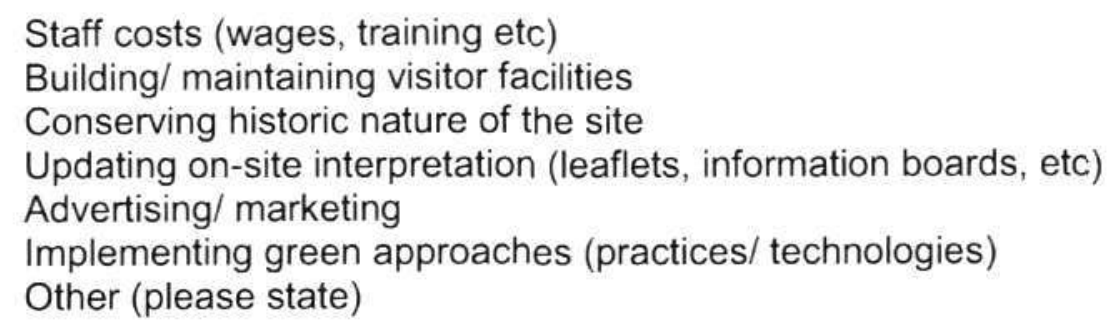

Q48 In your opinion, what are the main priorities for your operation?

Please rank 1 = greatest priority, 3 = least priority
$\square \quad$ Environmental sustainability (locally sourced material, green energy, recycling, etc.) Economic sustainability (income viability, profits)
Responding to your visitors' expectations and needs (i.e. achieving 'socio-cultural sustainability' (positive relationship with the local community, employing local people, reflecting local history, but also achieving wider appeal and acceptance).

\section{Section 2.4: Advice, Guidance and staff training}

Q49 In your experience are there any problems in trying to obtain information or advice on environmental (sustainability) issues?
$\square \quad$ Yes
No
Don't know
Unwilling to answer

Q50 Please name your main sources of advice on environmental sustainability issues (Please list) 
Q51 Has your business ever funded or arranged training and staff development either for yourself and/or for other employees regarding:

Environmentally friendly practices

$\begin{array}{ccc}\text { Yes } & \text { No } & \text { Don't know } \\ \square & \square & \square \\ \square & \square & \square \\ \square & \square & \square \\ \square & \square & \square \\ \square & \square & \square \\ \square & \square & \square\end{array}$

Income generation and profitability

Visitor management

Visitor profiling

Production of interpretive information

Local community engagement

Other, please specify

Q52 Which, if any, of the following act as a barrier to the organisation being able to provide training for you or other staff? (please tick as many boxes as apply)

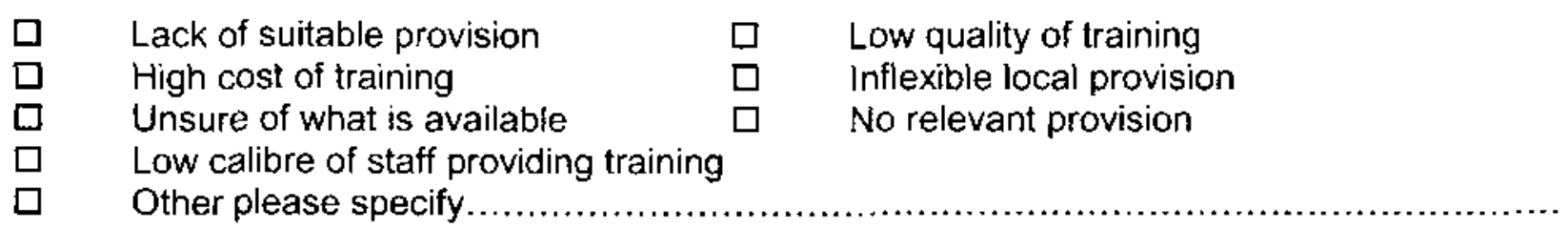

\section{Section 3: About you}

These questions are about your own role and responsibilities. The information you provide here will be useful to me as a context for your previous responses. Please be assured, I will respect confidentiality and no personal names will be disclosed without permission, and individuals will not be detectable from aggregated statistical or qualitative data.

\section{Q53 What is your full job title?}

Q54 Please rank your key responsibilities (Please rank as many as appropriate, $1=$ most important, 10 = least important)

To increase profitability

To maintain existing levels of income

To compete with other similar sites for a market share

To reduce environmental impacts on the site

To educate visitors and the local community in the historic value of the site

To provide a facility for use by the local community

To provide accurate and authentic interpretation for visitors

To attract tourist and visitors

To provide job opportunities for the local community

To manage existing employees

Other (please specify) 
Q55 Please indicate your age group and gender?

$\begin{array}{llll}\square & \text { Male } & \square & \text { Female } \\ \square & \text { Under 25 } & \square & \text { Between 25 and 34 } \\ \square & \text { Between 35 and 44 } & \square & \text { Between 45 and 54 } \\ \square & \text { Between 55 and 64 } & \square & \text { Over 64 }\end{array}$

Q56 How long have you worked for your current organisation?
$\square \quad$ Under a year
$\square \quad 1$ to 2 years
$\begin{array}{ll}\square & 2 \text { to } 5 \text { years } \\ \square & 10-20 \text { years }\end{array}$
$\begin{array}{ll}\square & 5-10 \text { years } \\ \square & 20+\text { years }\end{array}$

Q57 Was your previous job in a similar type of organisation?
口 Yes
$\square \quad$ This is my first job
No

Q58 Please indicate the highest qualification you hold (Please tick only one, i.e. the highest qualification you hold)

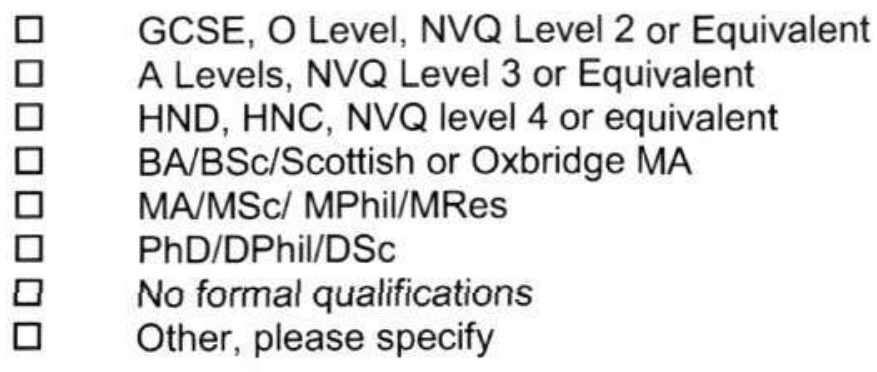

Q59 Would you consider participating further in my research by means of a short personal interview?
Yes
$\square \quad$ No
I would like to know more before saying yes

Q60 Would you like to receive information about the outcomes of my survey?
Yes
No

If yes to Q59 or Q60, please provide contact information in the space provided:

Thank you very much indeed for completing this survey. If in doubt about any of these questions, please do not hesitate to contact me by e-mail at susan.darlow@plymouth.ac.uk or on 07776074602

Please return the questionnaire to: University of Plymouth, FREEPOST

School of Geography. Plymouth. Devon PL4 8ZZ 


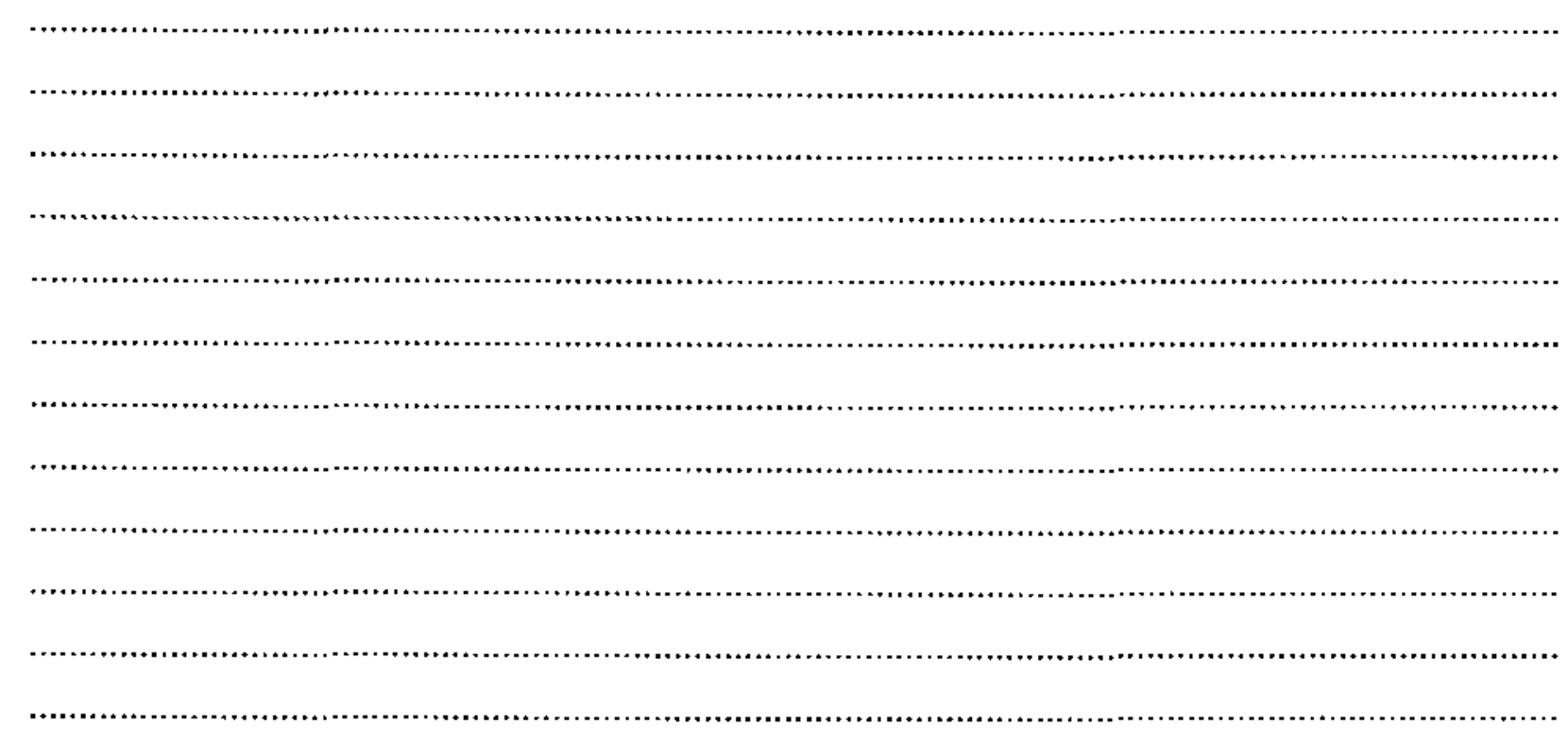


384 


\section{Appendix 6}

\section{Survey Cover Letter}




\section{Address of Heritage site \\ From Mail merge}

Dear (Insert name),

\section{RE: Heritage in Devon, Cornwall and the Isles of Scilly: Research Survey.}

As part of my $\mathrm{PhD}$ research at the University of Plymouth, I am investigating the exceptionally rich and varied range of heritage sites - accessible for the public to visit - in Devon, Cornwall and the Isles of Scilly. I am interested in what there is, how heritage sites are managed and operated, and whether those who run them think it is feasible to achieve a sustainable approach to their management. The results of this study will be valuable in identifying the opportunities for, as well as the limitations of, furthering the sustainability agenda in the heritage tourism sector and where further support and assistance might be secured. I would be extremely grateful if you could help me in my work by spending a short time to participate in my survey. Your responses will be anonymous and confidential.

The questionnaire has been designed to be completed by the appropriate manager or steward. Please complete the attached questionnaire and return it to me in the FREEPOST envelope provided. If, for any reason, you do not wish to complete the questionnaire, I would be grateful if you could return it to me in the FREEPOST envelope so that I know not to send you reminders.

If you have any concerns about any of these questions, please do not hesitate to contact me by e-mail at susan.darlow@plymouth.ac.uk or on 07776074602. I would be pleased to send you a summary of the results of the survey when completed if that would be of interest to you.

Thank you for your co-operation. Your support and assistance is much appreciated.

Yours sincerely,

\section{Susie Darlow \\ School of Geography \\ University of Plymouth

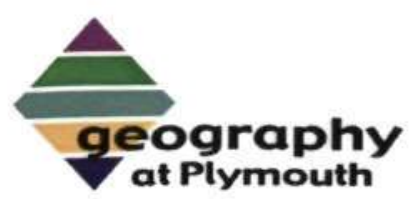




\section{Appendix 7.}

Semi-Structured Interview Questions 


\section{Interview Schedule}

\section{Those who have implemented sustainable management}

Q1 Taking everything into account, how would you prioritise/balance your sustainability goals?

1. Financial viability (Economic sustainability)

2. Providing access and interpretation (Social sustainability)

3. Environmental 'friendly' practices (green sustainability)

Q 2 For your heritage site, how do you feel these three kinds of sustainability blend or conflict?

You identify that you/ your organisation has implemented one/ a number of projects to make the site more sustainable (building on specific forms of sustainable management already undertaken...light green to dark green).

Q 3 Please can you describe the stages in introducing such measures.

\section{As a prompt:}

Was the action the initiative of one individual or corporate policy?

How raised and proceeded?

\section{Additional prompts:} change?

What processes did you have to go through to achieve desired

Who was involved (stakeholders, internal/ external)?

What worked particularly well?

What didn't work so well, what problems did you encounter?

What would you do differently next time?

Where there any constraints on what you were able to achieve?

Balance between maintaining integrity vs improved performance vs public opinion?

How were you able to monitor this process?

Q 4 Did these processes lead on to any further projects or changes in the way that you/ your organisation operate? 


\section{As a prompt:}

What led you/ your organisation to implement these changes? What were the key drivers/ pressures?

Did you feel that you/ your organisation had a choice in implementing these changes?

Are any of the following factors important in your/ your organisation's choice to implement these changes?

- Increased government pressure

- Increasing costs

- Pressure of public opinion

Q 5 What factors have exerted an influence on the way that you/ your organisation manage your resource? Are there any associated conflicts?

- Changing attitudes towards heritage - increased access and ownership

- Need to balance access with integrity of site

- Need to have both a local and national narrative

- The need to be more professional - in appearance and approach

- The need to buy into the local branding of the area (share a common identity)

Q6 What benefits has you/ your organisation gained from implementing these changes?

- Cost savings

- Meeting government requirements

- Improved public opinion - increased local ownership

Q7 Do you plan to implement any further projects in the future?

What are your motivations for implementing further projects? And what impact do you think they will have?

- Increased profitability,

- Better environmental performance

- Maintaining integrity of site

- Community buy in

- Commercial advantage/marketing edge

What factors might prevent you from doing this?

Q 8 Could you do more to become more socially sustainable (include brief description of social sustainability)? 


\section{As a prompt:}

What are the current barriers/ drivers?

Provision for local stakeholders to find a narrative that resonates with them as well the broader needs of visitors

Q 9 Do you aim to become more environmentally sustainable?

As a prompt:

What are the current barriers/ drivers?

- Promoting public transport

- Increasing recycling

- Reducing energy consumption

- Local sourcing produce

- Conserving habitats

Q 10 Do you think that changes in the current climate, for example increasing fuel costs, changing visitor expectations, changes in demand and attitudes towards heritage, and changes in government legislation are likely to drive you to implement projects like these in the future?

Q 11 If you were to undertake additional projects of this nature what would be the key messages that you carry forward from previous experience?

Q 12 Have you shared any of your good practice with other sites/ organisations?

As a prompt:

Through what forum?

\section{Those who have not implemented sustainable management}

In your questionnaire response you identify that, at present, your site/ organisation's key concern is not implementing projects to make the site more economically/environmentally/socially sustainable. What I would like to do is just explore a bit further what might be limiting or constraining any actions that you might like/want to take, but feel you can't (whether it's a matter of costs, the sensitivity of the site, the practicability of implementing any measures, whether you have considered any measure, and if so why they were rejected etc). 
Q1 What are the main pressure/ constraints that have led you/ your organisation to continue operating without implementing any projects such as .. include examples?

- Will reduce the integrity of the site

- Cost

- Lack of knowledge on what can be achieved

- Other duties more important

Q2 Would you/ your organisation consider implementing, or are you planning to implement, any type project (give examples) in the future? implement?

What type of projects do you think you would be most likely to

What are your motivations for implementing further projects?

And what impact do you think they will have?

- Increased profitability,

- Better environmental performance (climate, transport, energy etc)

- Maintaining integrity of site

- Community buy in

What factors might prevent you from doing this?

What would need to change in your organisation before you would be able to implementing something of this nature?

- Support/training

- Funding

- Agreement of stakeholders

- Examples of good practice from similar organisations/ sites

Q 3 Over recent years, it has been suggested that the way heritage is viewed by the public is changing from 'something only accessed by the elite' to 'a resourced accessible to everyone'. At your site, is the local community actively involved in the management of your site/ organisation?

In what way are they involved? (focus groups, volunteers)

Q 4 Do you think that any of the following factors have exerted an influence on the way that you/ your organisation manages you resource? Are there any recognisable conflicts?

- Changing attitudes towards heritage - increased access and ownership

- Need to have both a local and national narrative 
- The need to be more professional - in appearance and approach

- The need to buy into the local branding of the area (share a common identity)

Q 5 Could you do more to become more socially sustainable?

What are the current barriers/ drivers?

Provision for local stakeholders to find a narrative that resonates with them as well the broader needs of visitors

Q6 Do you think that changes in the current climate, for example increasing fuel costs, changing visitor expectations, changes in demand and attitudes towards heritage, and changes in government legislation are likely to drive you to implement projects like these in the future? 
Appendix 8

Interview A-H 
Please note that the transcripts included in this appendix are reported verbatim. Where quotes appear in the main report some have been corrected to reflect the change from spoken to written English. At no point has alteration to the content or meaning of the quotes been made.

Interview A

SD: Standard introduction requesting permission to record and providing an explanation of all ethically required statements

\section{Tape recording begins}

SD: I have got a series of questions, and I have been able to glean a lot of information for what you sent through to me, your responses to the survey and also the portfolio and also the results that you put in there. What I am largely going to be asking you about today is things you have implemented, how it works, what you would like to do in the future, the restraints and that sort of thing. And when I am talking about issues of sustainability I am don't just mean environmental, I also mean the obvious economic implications and also the socio cultural side, the keeping things relevant for people and stakeholder by in, that kind of thing. Shall I kick off then?

Int A: Go on fire away.

SD: I actually saw from your questionnaire response and your environmental portfolio that you have been implementing a number of things particularly in relation to reducing your electricity consumption?

Int A: Yes energy, its an energy hungry building, it's a Tudor house and the Tudors method of warming a house was just to throw a few extra logs on the fire. Which worked for them. It was an environmentally friendly way of warming the place for them, because the logs being thrown on the fire were current. So its not like you are digging of tons of oil or coal out of the ground that took millions of years to put there so ecologically it was a sound way of doing it. It was a cheap and cheerful way, it worked and it kept the building warmed and cooled through the seasons so it sort of breathed if you like. Unfortunately with things like modern day smoke detectors and the risk of fire especially in [name of town] and the fact that rooms would be left unattended where they throw logs on the fire they would only do that to occupied rooms, and there would be lots of servants round nearly all the time, that doesn't happen in the winter here. We have to heat the place in a different way. We can't use circulating water because of the risk, well A: you end up having to punch holes through ancient fabric - floors, ceilings, walls and screw things to the wall, and secondly there is the risk of a leak you know something going wrong, you get a leak and it pours water down, you damage ancient fabric and put the collection at risk at the 
same time. So you can't, where as somewhere like the guildhall had it done in the $19^{\text {th }}$ Century, sort of central heating put in in the $19^{\text {th }}$ early $20^{\text {th }}$ century, when they didn't even think of these things, its too late, its done. So they have got central heating but its never been put in here, so we are stuck with what we have got. And the only method that we can find that works and warms the place sufficiently and doesn't damage the fabric or anything else and doesn't set of the fire detectors and smoke alarms is Night storage heating which we do the cheapest way possible on economy 7 which is still very energy hungry through the winter, and this is the desperate situation that we are in with a museum, and an old building, a grade one listed building, that you have got to keep the building warm to prevent damaging damp forming, and condensation forming and hence damp and you ruin the building and the fabric and the collection itself. So you are stuck, you have got to heat it. And the worst of it is that the place is damn near empty, it isn't occupied during the winter so we are heating it for nothing, well apparently, and I can't find a better way of doing it. I have investigated, or I have been investigating, air to air heat pumps that might be a better method but again you need an outside wall which means holes in the walls and wires going through the walls, you've got to drill holes in walls to mount things on the walls and its going to look messy with all sorts of conservation issues. Our energy bills, I think I told you is..

\section{SD: $\quad 20 \%$}

Int A: Yes $20 \%$ that's $£ 2000$ a year. I mean we have just finished the season and taken $£ 10250$, we've got another 2 weeks of opening in December which might add another $£ 500$ if we are lucky, but $£ 200$, well $£ 180$ * 12 which is out direct debit, $£ 180$ a month which is $£ 2160$, which easily $20 \%$ if not more. It's a nightmare. The only other, by comparison things like lighting and dehumidifiers are..well they take a bit, we have a photocopier and various electrical appliances downstairs in the study centre but very little else, Kettle every now and then and the odd emersion heater every now and then for hand washing and washing dishes. The next biggest thing is probably, I don't know where I have put it, I probably worked out where all the energy went. About $£ 435$ goes on lighting, that's the other thing, lighting. Up till now, because of the nature of the collection, not so much the building, well bits of the building we have until now had to use incandescent lighting, halogen lighting, which again is very energy intensive. But commercial low energy lighting is florescent tube bent in several different directions, that's all it is. But it is very ultra violet heavy, a lot of UV content and you can't blast the collection. Clothes, materials and colours. It kills pigments, hardens materials and does lots of horrible things to paper things. You have to e very careful what you expose to UV light. Some things you get away with like wood, metal, unless its coloured or painted as you would kill the colour in it. I started investigating LED lighting and I am starting to get somewhere. With the help of this lady here, [names lady] she has been watching me and I have found some LED lighting which is starting to work and so she has agreed to fund one room, so she has ordered the bits for it and we are going to try 
LED lighting in one room and see if it works, and if it does we can gradually change over on a replacement basis and change over the whole museum with LED lighting where we can. That will cost...the UV content of the LED lights is actually zero, so it is less than the incandescent lighting or any other form of lighting. It is actually a measurable zero. [Names lady] actually came round last week, or week before, with a light meter and held it right up to the source and switched it to UV, and nothing! Absolutely zero.

SD: So it is actually better in terms of maintaining the integrity of the collection as well?

Int A: That's right, the only trouble is that they are not very bright, these lights, I think the technology has a long way to go yet, but it is sufficiently light that you just have to put in more of them to produce the same amount, or nearly the same amount, of light. Like a 50Watt halogen bulb I can only replace it with an LED of $35 \mathrm{~W}$, so ok I'll just put in 2 for one or one and a half. For every 2 halogens that I will replace I will put in 3 . But as they only draw $1,5-2 \mathrm{~W}$ compared to $50 \mathrm{Watts}$ I don't care. What is the odd Watt here or there.

SD: What process did you have to go through to get that in place, it probably stemmed from the outcome of your assessment which says you have done everything that you can possibly do to reduce it. Is that something that you based it on,

Int A: Yes that was the only process that drove it, $A$ it is financial, I have got to do something about the energy bill or the museum will fail financially, it is on a knife edge now, it always has been, it has always teetered on the edge of affordability. In a good year we can probably afford an extra exhibition or something special like redecorating a room or something, but we are living hand to mouth. Everything that pushes us over the edge on a regular basis, like these are a one off, sustainable costs and once electricity goes up it doesn't come down again, and electricity has just gone up massively. We actually caught EDF out, well they caught themselves out, we tried to change suppliers to a cheaper supplier. But EDF stopped it and said you can't, you need to read the small print in your...we haven't got a contract but it is what they call a rolling contract because we have a particular contract and after a year if flipped into their normal tariff and at the time they didn't want to loose the museum so they gave us a good tariff, last year they put it up a bit and so I started looking, but I didn't read the small print, its my own fault, and I was really angry with them as they had really ripped me off and put me in a bad place. The only way they could do it was to price fix it for a certain period and they fixed it to march 2009, and behold all the energy providers, including EDF, had to put up their energy providers dramatically way back in the middle of the year. And all of a sudden what I thought was a price hike a year ago has turned out to be our saviour, and they are stuck with their own low tariff, well relatively low tariff. But I'm aware of it now so come next march I will be ready for them to send me that letter. They give you a 6 week period to 
do something about it and then they close the window and you are stuck with them again for another 1 year period. So I am going to be on the look out.

SD: That is quite good then, in terms of you being able to get in there. When you came to look at fitting the LED lighting trial. Did you have to, it obviously came from the information from Envision, but who do you have to have approval from to do something like that?

Int A: Well I am an electronics engineer from previous experience so it was an obvious move. Every now and again I have my ear to the ground about new technology, though I don't have an MP3 player or anything modern like that, I'm not into gadgets. What I am on the look out for is energy saving, I have an interest in energy production and energy saving. For example I have just put in solar panels at home and that has been an eye opener, I will come on to solar panels for the museum in a minute, because I am outside the conservation area I could do it without planning permission. And they have been brilliant, I am astonished by what they produce. But the LED lighting side of it, I can put low energy lighting in at home as there is no UV penalty at home, except to some clothing and the dog and stuff but who cares, and low energy lighting is just about on a par with LED lighting. LED lighting depending on how you use it is probably a bit cheaper and the UV content is zero so its ideal for a museum.

\section{SD: But a higher initial set up cost?}

Int A: Oh god yeah! The cost for an incandescent light bulb is $56 p$ and they last for about a year. But at 56p who cares! But for the LED lighting one bulb was costing us $£ 18$ and the holder to put it in for experiment is costing $£ 7$ or $£ 8$. I was lucky we found a cheap source as $£ 7$ or $£ 8$ was the cheapest we could get. If you order them 10 at a time you get a price break so we are down to $£ 15$ or $£ 16$ a light bulb so I need to buy 10 which is $£ 150$ for 10 bulbs and then the light holders as well. Helena's budget is about $£ 200$ pounds so we are just covered for that room just there, where the window is, is the Victorian nursery, I will show you in a minute perhaps. I can show you one of the bulbs.

SD: Are they fairly unobtrusive the way they sit in there? You don't have to drill any holes or anything?

Int A: Yes, I did it in such a way that we didn't have to go to the huge expense of changing anything. We have mostly track lighting throughout the museum and it is good enough. I did most of this on line (shows picture on line).

\section{SD: Are they the type of ones that hang of the string?}

Int A: Well no, not quite .We have to MR16 which are the ones with the two little pins while the GU10s are the plug in and twist. These are 240 mains and these run on 12 volts. 


\section{SD: And so much more friendly to what you are trying to achieve then?}

Int A: Well, we have so many different types of lighting throughout the museum, it is mainly like this screw in type. But because these draw so little current that I decided that they wont work in the transformers that we have got. In one room we have these bulbs at 12 volts running at 50 watts which is ridiculously high current. The mathematics of electricity dictate that the lower the voltage the higher the current to give you a certain, the same light output, and they have to be transformed down anyway. Why they just didn't go for the normal bulb holders that would have taken the GU10 or something that would take a light bulb similar to that or a normal lightbulb, I don't know. It was done arbitrarily by the museum designer at the time, and I wish I had got involved in that at the time, and I failed, I wasn't thinking about that at the time. And if we look at these, these are the ones we are going for, the all purpose LEDs, and they have 35 watt, they are the approximate equivalent to 35 watt halogen so to get 50 watts equivalent, I will have to have 1.5 or 2 . I did in fact get 2 similar to that free of charge from a company in Germany on request. I mean these things are worth $£ 4$ or $£ 5$ each. I have trialled them in a different part of the museum and they work as well. SO where we have got 2 what's replacing 20 watts in a big case that takes 12 bulbs so where we had 240 watts we now have it replaced by 24 watts.

\section{SD: So quite a dramatic reduction then?}

Int A: Well its $10 \%$. It's worth doing and the bonus of 0 UV.

SD: In terms of the effect of the UV on the integrity of some of the displays is that a prescribed thing that you can't do? Is there guidance on that saying you can't?

Int A: Yes, [names lady] would tell you the exact levels, I can't begin to tell you what the prescribed level is but she was going round with a meter and saying 'Owww that's a bit high', or 'that bulb is chucking out a lot of ultra violet'. It is the amount of UV in the end that lands on the artefact. What we have done with the windows, you see all these tiny little lead pained windows they had a team going round the museum for two years running, ending the year before last, a team of little old ladies in their 70s and 80 s going up step ladders with the uv material filter films. They cut round it and you wet it and wet the window and you stick it on. It looked hideous with all the bubbles and you wanted to go and prick them with a pin and smooth it out but it dries flush with the glass and you can't see it.

\section{SD: Is it on there now?}

Int A: Yes but you can't see it. If you measure the UV in there, it cuts its down by $98 \%$, so in there where that one faces south the sun does that over 
there, and so the direct sunlight was quite a lot. Strangely there was more UV coming in through the side window which is north facing, and we couldn't work out why, but what I think it is is the white walls scattering it and magnifying it, as it collecting UV off all the small corners and making it worse with the rays going uni directional and scattered rays.

SD: So while that wasn't doing anything for reducing bills, it was there for the conservation and integrity of the resource?

Int A: Yes, I mean anything you do, I suppose rule of thumb is, you could say it is a general rule of conservation, don't make it worse, whatever you are going to do to try and reduce something or make something better, like we are going to try and reduce the electricity, energy cost of the building, don't do it at the cost of anything else, like changing all the bulbs for low energy and then blasting everything else with UV light. You mustn't do that, you must go the opposite way and not make matters worse. The NT are using Phillips master classic bulbs that use half the energy so a light equivalent of 60 watts is drawing 30 Watts. I wasn't enamoured with that as it is still 30watts and the bulbs were $£ 5$ each. So alright it is manageable and I could migrate over on a failure basis so I just swapped in the new ones, even if I ended up with a row of 4 old bulbs and 5 new ones rather than mixing, but I have already migrated the museum across from 75 watt bulbs to 60 watt bulbs, that was what I did first when I go into the museum as the light difference between 60 and 75 watts in negligible but the power consumption is huge and I though why! Lets change them all to $60 \mathrm{~W}$ and no one is going to know the different and we saved ourselves $60 \mathrm{w}$ per strip doing that, and that was 6 years ago but we have to go further. The heating element of the building takes $75 \%$ of that $£ 2000$ so the lighting and other things takes the rest, the $£ 500$ pounds loosely speaking. And the lighting is a big thing.

SD: I saw that you had managed to sneak in some insulation in the redoing of your roof.

Int A: Yes, that roof there at the north end, had to have all the slates taken off as all the nails had rusted, called nail sickness or nail rot or something, and all the slates were just slipping and sliding down the roof, and when it got windy they were going airborne and decapitating seagulls and things. So we had to have the whole roof stripped off, it was rebattened and at the same time they put felt in which was a good thing as it didn't have any felt before, and they put in as much insulation as they could get in without introducing a layer of damp or a layer that cut off the air flow

\section{SD: And without being identifiable from underneath I assume?}

Int A: Yes it is well hidden, its underneath the plastered attic that we have got and the slated roof. So looking at it now you wouldn't know that there was any insulation up there at all. And it was done under the 
supervision of the surveyor. That was the only thing that the conservation office said, either you can put in a conservation application which is hugely bureaucratic or you can do it under the supervision of the surveyor. We opted for the surveyor for a variety of reasons, not just because we were lazy and it was easier but because all the work got supervised. Not to the great please of the builder involved as he was up on the scaffolding every 5 minutes saying this isn't right or this little thing isn't right. But at the end of the day we got the perfect job. The roof was re-slated and we didn't lose too many slates in the process and the guys who did it, the actual roofers, signed their names in the lead as they were so proud of their work.

SD: So that is another example of where you have been able to address the issue of not having the building insulated without effecting the internal and external integrity. Is it very much a balance? As in the questionnaire that I sent you there was a question about how do you balance financial sustainability with environmental and social. And on your answers you said the main one was financial sustainability as you said at the beginning that you have struggled to stay open. Is that how it works with the social side? Maintaining the interpretation and local heritage for local people

Int A: The heritage side of it isn't an issue as it is so easy to do. People keep bringing things in, the volunteers keep displaying it and it runs itself. It doesn't cost us very much money. If you can't balance the books you have dead business, its not a business as such it is a non profit making organisation but you could argue that if the money coming out exceeds the money coming in you are bankrupt and it doesn't matter how much stuff is brought in it isn't going to get displayed and if it was displayed the public aren't going to get into see it. The perverse thing is if you stop the public coming into view it you cut off all your income, and this is the terrible thing about local small volunteer run museum, the size of ours, its crippling. Big museums get all the money thrown at them from DCMS, it is supposed to trickle down through them to us, and what do we get? Training!

\section{SD: Yes I read that in your response}

Int A: And what use is training, none, we have all done all the courses. Enough with the training, try something different, try buying us some electricity. But they don't do it like that, that isn't allowed.

SD: Do you think that is something that they think of, especially with the changes in the current economic climate, with fuel costs and things like that?

Int A: No I don't think so. Selfish reasons start to come in

SD: And that will presumable have a massive impact on your running here, the higher the prices? 
Int A: Yes no matter who we go with next year it's going to be massive, I don't know how we are going to cope with it, it is the great unknown. Depends on the size of the electricity bill and who can find to supply us. Another option is opening the museum all year round but that means having to persuade volunteers to come in over the cold winter months, and god knows they whinged enough last month as they were freezing in there even with the heating on. And of course you power usage goes up so what you gain, you don't necessarily gain enough income from people coming in. It is a bit hit and miss getting people in and you lose the opportunity to change exhibits, as the volunteers who change the exhibits would then have to do it in a different way by closing one room at a time and change a little bit here or there throughout the museum, they would have to work in a different way.

SD: Do you regularly change exhibits? Do you do it once a year or a couple of times a year?

Int A: It is usually on a whim, the ladies out there do the lion share of the work, they ask to do a such and such display. Last year they wanted a make and mend display, old clothes, how they were made, and how clever they were at getting so many different garments out of one piece of material. It was the height of sustainability in the Victorian era, even I am impressed and I haven't the slightest interest in clothing. There is a picture up there of a wedding couple. The wedding dress is then cut into pieces to make a christening gown, then there is a picture of them with the baby and beside it is the gown itself, it's made of silk. It is falling apart and rotting and simply because in the preservation process they used a heavy metal preserve so give it a kind of sheen, which is rotting it, where as silk would last for centuries but not in these circumstances. What tickled me was that you see this Victorian couple all young and energetic, and then you see the mum with the baby wearing the dress and you see the dress itself and you think that those people are all long dead but there is the dress. And the fact that it came out of the wedding dress. There is something else up there about how they intermixed different garments, it's incredible. When I was in Exeter yesterday I brought 5 pairs of jeans and I guarantee that they won't still be around in 10 years time.

SD: I saw again in the information that all of the visitors that come in are usually those who are walking past and are unlikely to visit again?

Int A: That's right

SD: Does that relate to your choice as to what you update, is it personal choice because there is no driver to update as no one comes in and sees the same thing every week

Int A: You very rarely get repeat visitors, for a variety of reasons, the assumption is that if they have been to [this] museum is that museums 
aren't going to change that much and we get people come in who say there were here 15-20 years ago and they all comment how much it has changed, they are surprised as their expectations are that it will look the same as it did 10-15 years ago. As long as people are attracted to the town and walk up the street we get a percentage coming in, either because there are attracted to it or because it is raining or because they have bored children that they want to entertain.

\section{SD: I saw that you have cut right back on your marketing}

Int A: We have cut that out completely

SD: Because you seemed to get more people when you didn't do it, rather strangely?

Int A: That was coincidental, perverse. It made no difference, it the first instance it saved us $£ 200$ and I got hell from the town Clarke, the lady that puts the guide together she was very much 'why don't you want to spend $£ 200$ with us?' and I could by $£ 200$ worth of electricity. In order to get that $£ 200$ back I would have to get in 200 pensioners at $£ 1$ or 133 other visitors. We'd be lucky to get 10 , and alright 10 is very nice but certainly not worth spending $£ 200$ on. So the marketing is a balance, you have to know that that advert will earn you back or you won't do it. But people don't beat a path to [this] museum; they come to the museum as a consequence of coming to [name of town].

SD: But you say in your information that that is good in terms of transport, as it means that it doesn't contribute to your environmental footprint.

Int A: A lot of people come up on the river, but having said that that isn't environmentally friend as 2-3 years ago I met the then owner of the boat company and he said his diesel costs were the $£ 128,000$ per year. Imagine the amount of diesel they are consuming, and that is the cheap stuff, the red diesel.

SD: In your responses you mentioned that you had plans for the future, you would like to do the solar panelling? And you would like to get the tourist information office in on the ground floor?

Int $A$ : Yes, that second one is very controversial at the moment we have mooted it before but got howled down by very vociferous trustees, and one of those trustees is also on the governing committee of the VIC. The bottom line is between you are $\mathrm{I}$ is that both the TIC and the museum are at risk of financial failure, the TIC first as they are very labour intensive, they have lots of staff and have to staff it Saturday. They are currently operating at low staff levels as one of them is off having a baby and the rules are that you can't sack her and replace her but that doesn't help the TIC, the rules are never levelled fairly at smaller enterprises. I am not saying we should sack her, I don't mean that at all, there is no fair way of doing it coss someone is going to lose 
out. And in this case the town is. The TIC is more at risk than we are but if they close we are in the front line, and with cost that the building takes to maintain, as the town council pays that and my wages and if the museum became financially unviable something would have to be done. I don't know what that something would be as we have a huge collection and you would have to put it somewhere, you wouldn't be able to just take it to the dump or hold an auction as the rules are that the MA rules are that you must not do that. So I don't know about that. What was the other one?

\section{SD: Solar panelling?}

Int A: Yes solar panelling. I have just fitted them to my roof at home. I have no experience of solar panelling, only the say so of other people. I haven't gone for the hot water ones because they are a bit of a waste as they just heat hot water. We got a little meter read out and it tells you what you are producing, and on a cloudy day like today I will be producing half a $\mathrm{KW}$ or maybe a little less but on a good day the peak of these things is about $2.6 \mathrm{KW}$ which translates at the end of the year into half our consumption, an half is worth having. Even now I am measuring it against what we use from the mains, what we use on a daily basis. Now I was given a tip off about a change in rules on listed buildings by one of the district councillors, [names councillor]. And I looked outside and thought that that roof is south facing, it isn't very big but it is south facing and all along there is as well and I thought we could get some solar panels um on there. I worked out we probably use 30,000 units a year $30,000 \mathrm{KWH}$ and the best I thought we could do was that I could probably get urr $1,000 \mathrm{kwh}$ out of it, and the science of it works out as if you were to actually measure the power that comes off the roof then subtract it from what you actually use because if you use it when the sun is shining then you actually benefit

\section{SD: It continually tops itself up?}

Int A: Yes, but in my case I don't know how I managed it, I did it with blind faith and I just blundered into this but Southern Electric have got this tariff where they pay you $20 p$ per unit and I actually buy it for there at the highest rate 18pence a unit for I am making a bit of money out of that and at the lowest rate 13pence a unit hang on so they are buying from me for more than I am buying it back so it actually pays for me to sell them all of my units and use as little of my own generated units as possible and to buy it back from them so the savings are actually working out more. The energy use itself will not alter very differently at all. For example if I can get $4000 \mathrm{KW}$ units of panels up on the roof compared to 30,000 its worth having it will be a large amount of solar panels.

\section{SD: And a large initial layout?}

Int A: Yeah, between you and me I paid 12-13 thousand pounds for my solar panels and I get 2.5 thousand pounds grant back um a non profit 
making organisation would get half back. Well it gets worse because I get a conservation officer in and he came with the man from English Heritage and normally I get on, we both do and individually get on well, but they were both being very obstructive, maybe they were showing off to one another and they said 'no we won't allow more than a couple of panels up there and it won't be worth it [Int A's name]', and I said 'why the criteria is that these panels can't be seen, and the only place you can see these panels from is here if you lie on the floor and look upwards', 'well there you go they can be seen' 'so for heavens sake [gives name], don't be stupid who is going to lie on the floor and look up and say oh that is terrible' and its modern, the roof material is modern, it isn't even 100 years old, and his definition of modern was $20^{\text {th }}$ century onwards so anything from 1900 onwards and this was replaced in the 1960s and so 'No [gives name] it is modern material', and this one they wouldn't allow any on. They were just being obstructive and we kind of fell out, and I used something that we had fallen out about a few years ago, a building that they had knocked down in [name of town] and I mentioned it and it became quite unprofessional.

\section{SD: So in terms of solar panels is that quite unlikely?}

Int A: I will wait for the law to change because the law is changing all the time because the pressure to introduce renewable energy in every respect is becoming very very urgent. At the moment you can put solar panels on the roof unless you are in a conservation area without planning permission, and even if you are in a conservation area you can put them on a building as long as they can't be seen from the main highway. It gets a bit sticky if it is a listed building, this is a grade 1 listed building so when I thought about it things like wind turbines are a no-no, you have to get planning permission for it even now, though I think that will change in April, so it should be allowed as long as you don't make a complete nuisance of yourself. Wind turbines don't work well in an urban area so sadly a non starter

\section{SD: And certainly not hydro electric?}

Int A: We investigated [name of town] weir as I know the owner of the weir, he brought it because at the time it was a liability as whoever owns it has to maintain it, and I approached him and said I had been looking at the old water turbine on the weir but the director of the [name of town] renewable energy society, and weirdly the previous owner got to hear about it rushed round his house and brought it back from him for something silly. And it meant it was now owned by a businessman who knew the real value of it and wants to sell it from as much as possible. So that will sit on it for a while. It wouldn't produce much electricity, it will probably net $£ 25,000$ of electricity a year, so it would power the school, all these things are worth having. I think the government idea is that every house with a south facing roof and every hillside where it wasn't a complete blemish where it really didn't matter, and every tall building even in a city could have a wind turbine it would probably 
produce half the electricity used by domestic users and that is a hell of a start.

SD: The last thing I was going to ask you quickly, is in terms of the good practice you are doing in terms of the lighting and solar panelling and things like that, what sort of forums do you share it through? Are you encouraged to share with the town council or other museums?

Int A: Yeah I talk to everybody, initially through the trust, the museum trust and the society I share it with them, they are the managing trust for the museum and I share it with them, they have given me a free hand to investigate it and have even given us a budget to buy some LED lamps, which I did $£ 150$ worth and tinkered with that. It was a lost leader if you like and might not have worked, some of them didn't work at all. The society aren't that interested but I keep them informed. My boss my immediate line manager who is the town clerk is interested as he is interested for other buildings even the guildhall and heaven forbid the civic hall and both buildings are concrete and consume an awful lot of energy. Museum wise, certainly through the museum groups, the Devon museum group, [names lady from group] says that some of the payback for the grant we are getting is that you stand up and talk about it at the Devon Museum group and the South Hams one, and I have the South Hams one tomorrow. So I have got a note there to take some LEDs along to show them.

\section{SD: So you are the pilot for it really?}

Int A: Yes, because I am interested. Not many people in the museum world are interested in energy conservation. It doesn't occur to them they just know it costs a lot of money and they don't even know how electricity works in the first place and well they just pay what it costs. My predecessors were a long line of women, and I'm not knocking women, they just simply didn't have an interest in electricity and when they were cold they would switch the heating on, they had it roaring away from September to May and then I came in and said look at this electricity bill and it hadn't been paid for 3 years, just an oversight by them and the electricity company. It was just a nightmare, and I had to change it so when it was a cold day and when it was unoccupied I just switched the heating off. I live nearby so if its going to be frosty or below 6 degrees centigrade I just come in and turn the heating on, as it is it runs probably 5 degrees above the ambient temperature outside unless it is really cold then it runs about 2 degrees above the temperature outside, coss it is open to atmosphere, we can't fit double glazing, there are massive gaps, look at the gaps around the door, it's not a door it's a gate. You don't stand a chance, you can hang curtains and there has been talk about polythene inside the windows temporarily in the winter to avoid heat loss, but you are wasting your time really. Though these panels around the side of the museum and you walk up the stairs in the morning when it is dark and you can see daylight through the panels. All you can do is keep the inside a bit 
above the outside temperature, we stand no chance in hell of keeping this building thermally, integrally tight. That's all your doing you are heating [name of town]. And it's the same with the dehumidifier as some areas you have to dehumidify, like the study centre as its paper records and the other one is the kitchen, every now and then when you see fish in the kitchen it's time to turn on the dehumidifier, but it sucks the water through the building but they are sucking the water out of [name of town].

SD: My final question is, do you think your personal interest in the environment and your knowledge of electricity has really helped made you interact more with issues of sustainability? Made you more prone to do things if you like?

Int A: Yeah, almost certainly. If you like, my skill and aptitude is towards energy conservation and it spills out into other aspects like how do people get to the museum, do they use renewable methods to get here, but that is secondary as they came to [name of town] for a different purpose and visited the museum as a secondary thing. And for things like that you could say we are one space removed from the initial journey and that is good as it means they are maximising the initial journey and getting the most from it. Um other things like our last survey, should be we educating the public, emphatically no! It touched a raw nerve, we are not here to educate people in best practice in how to live their lives, I can show them what we do and why but it is really up to them how they live their lives so draw a line, and some museum professionals are overstepping that line and becoming dictatorial and overstepping that line. And in [name of town] we have transition town [name of town] and the two things go side by side, I had someone in the office last week looking at things from the 50 s and 60 s to see how the war years and post-war year, which I just remember, and how we fed ourselves, and we had to because after the war Britain had had 5 years of trying to sustain itself and grow its own food, and people still went fairly hungry, they didn't starve but it was fairly heavy going and the last bit was run out of the land and every little bit of land was used and utilised and food wasn't wasted like it is today, $30 \%$ is thrown away! Its looking at how we did things then not necessarily to copy them but to see how through the process now project into the future, and what we are looking for is how is [name of town] going to look in 2030. It's the kids at local schools, what better use of kids imagination than having a look at the powered down urr oil independent community. And not because oil and energy use is evil but because we will have to be resilient and rely on our own resources for many of our needs, and I mean our needs not our wants. The needs are food shelter warmth, the wants are the luxuries. Those things we will interact for, and that is probably how the balance was in the 40s and 50s until it tipped over, and what better way of using the museum than using its resources which freeze the past and can look at it through into the future, I think it's a very good use of the museum. That's the use if you like and the sustainable nature of the museum and we could use most museums like that, as the sustainable path from the past to the future, 
as generations make exactly the same mistakes as previous ones. But that is the nature of the human race.

SD: I suppose the thing about museum is that you can continue to add to them and it will continue to build a heritage of the local area.

Int A: And that was another thing that annoyed me, I got a diversity questionnaire from the museum association or the MLA or I don't know where the source was but I got very tetchy about it. As they wanted to know what our ethnic mix was or whether we were trying to expand our ethnic mix of our audience, I mean for god's sake, this is a rural community that has had a Celtic ,Anglo-Saxon, Viking, Norman past, western European if you like and heavily agricultural, this is our heritage, this is what we display we haven't got another one, we don't have an ethnic heritage, there isn't one. Our ethnic population content is probably less than $1 \%$ but we do have a lot of visitors from overseas and all over the place and they come here to look at this heritage, the authentic [name of town] heritage, they haven't come to look at their heritage in the context of [name of town] they have come to look at [name of town] heritage. Because when I go somewhere else, Bristol, Birmingham etc there is an ethnic heritage and fine I will look at that but don't expect to extract the same level of ethnicity from [name of town] because it just doesn't exist. This survey specifically excluded the Celtic nations, so the welsh, the Cornish and they specifically excluded them in this survey in terms of Celtic identify, which is such a silly argument as if you follow the strands back we are all basically from the same race, the western Europeans, you can't say you are English or Celtic because there was a Celtic tribe called the Ingles. And the chance of you being totally Celtic or totally Pictish is totally ridiculous

\section{SD: And thank you, sorry to overrun by such a long time}

\section{INTERVIEW CLOSE}

SD: Standards thanks and re-emphasis of participant right to access transcript. 
Interview B

SD: Standard introduction requesting permission to record and providing an explanation of all ethically required statements

Tape recording begins

Int B: I think I wrote in the questionnaire that I found a bit difficult when it related to a church, some of the questions seemed like it was more for the paying public.

SD: Yes it was particularly difficult to target everyone and make it relevant to churches. What I have got is a couple of questions, having had a look at your questionnaire. In the questionnaire and this interview have referred a lot to sustainability and by that I don't just mean environmental changes, I also mean, in the case of churches, how you maintain your congregation and a resource for the community, and obviously economically with your running costs and things like that. From your questionnaire I can see you have implemented a number of measures, low energy light bulbs, recycling and also purchasing local products. So my first question is did you have to go through any particular process to get those things in place?

Int B: No not really, I mean each church has a parochial church council and some people take responsibility for the building and can decide to do things like change to low energy light bulbs. The recycling is quite easy as North Devon District Council provide for that you can tap into it and recycle quite easily. And they have a recycling depot so if you have any big items which we do as well, we have a trailer which we hitch up and can take things away.

$S D$ : Do you think it is quite important to be able to do things like that?

Int B: Yes, I think so. Most people in the church would be quite environmentally conscious if you like.

$S D:$ I read the shrinking the footprint document from the church of England, is that kind of approach ingrained?

Int B: No not really, I mean a lot of it is just off our own bat, and a lot of the congregation wouldn't know anything about that. The PCC would, it would reach down to them, but in terms of the congregation they probably wouldn't know anything about it to be honest

$S D$ : In terms of taking what you have done a bit further, is there anything that you are planning to do?

Int B: We have actually got a rebuilding and sort of maintenance project that we are trying to raise funds for at the moment, and when that happens 
the electrical side of things, being environmentally friendly bit will be part of that, but I guess that is on hold at the moment and so what we are doing is using energy saving light bulbs where we can. It's still not particularly energy efficient as we have chandeliers which have 6 light bulbs in each one, so when we do the reordering we will completely redesign all of that.

$S D$ : And do you have to take things into consideration like the grade one listing when doing things like that?

Int B: Yes we do, it actually isn't too bad on the inside of the church to be honest but we have to go through a process where you have to present what you do, essentially like the planning applications with the council. We do have to go that and it's looked at by a church architect for the detail and they inspect it. It then goes through the church council. But that's all been passed. With things like lighting they are pretty good on really.

$S D$ : Are there any other things that you would like to do but can't because of the listing?

Int B: I guess if we wanted to have our own way and you weren't restricted by the listing we could do a lot with not letting heat through the roof but that would be a big project as it would be redesigning the whole look of the church that honestly wouldn't be that practical. I am sure you are aware but a lot of these buildings aren't environmentally friendly as they aren't designed for that.

$S D:$ Is cost a limiting factor?

Int B: Yes, yes it is.

$S D$ : Because there is also the diocesan share?

Int B: Yes, and we also have this building project, and we don't get any funds from the church for that, we have to raise it ourselves and that's about $£ 250,000$.

\section{$S D$ : And is that raised locally from community and from businesses?}

Int B: We haven't had much luck with businesses actually. A lot of it is through the congregation really.

\section{SD: It must mean planning very far in advance then?}

Int B: It is, we are actually going out to tender at the moment, we have probably reached about two thirds of our target. So we are prepared to start. And the Exeter diocese will give us a loan, once we have raised $75 \%$ they will loan us the other $25 \%$ which is a very low interest loan of about $3 \%$ interest on that loan. 


\section{$S D$ : That way you can fundraise while it's being done?}

Int B: Yes that's right. And they expect it to be in five years, we are fairly confident, that if we have raised $75 \%$ we can raise the rest by year 5 .

\section{SD: Do you have income from visitors as well?}

Int B: Not at all, we are not really the sort of church that attracts visitors really. It is a Victorian church but we have a lot of, all I can say really is other churches have more value.

SD: Do you get people coming to look into their pasts?

Int B: Yes we do get that sometimes, and we do still have an open churchyard and people come to look around that, and they do sometimes ask to take a look around the church. But that is very minimal. In the summer we might get a couple of people a week on average but in the winter it's hardly any at all.

\section{$S D$ : So not enough to warrant guide books or leaflets or anything?}

Int B: No not at all, I mean we have thought about it, when people do come they are interested to know a little bit more and I think if we had them and we had a pot to raise money and you could put that in, it might attract some but there isn't a huge amount of interest.

$S D$ : So something you might consider but at the moment it's not really worth it.

Int B: No, not really worth investing in. I mean it's more for visitors who attend the church services I suppose because it's not just about the building but to let them know what we do. And for people coming into the area.

\section{$S D$ : Does the church do house wider activities than services?}

Int B: It has a church hall attached to it, which is also grade 1 listed and was built at the same time and that's used a lot, almost every day of the week. You have the scouts use it twice a week, we actually have what is called a drop in which is for homeless people and workshops that people can get involved in, that is open every days of the week except Sunday, then there is the Victorian History group and then of Friday and Saturday lunchtime there is another drop in. The AA use it one night a week for their group. The hall is used quite extensively but the church here isn't.

\section{$S D$ Are all of those groups locally based?}

Int B: Yes they are. They are all community based.

$S D$ : In the questionnaire when I asked how you prioritised your sustainable goals you said it was more about the social side. Bt 
not quite in the way I phrased it, Not in the sense of keeping a heritage site open to visitors. More about maintaining the church for the community?

Int B: Yes, I think that is what I found difficult in some of the questions as we don't have that audience if you like. Like [names a nearby church] church is right in the centre of town, by the shops so they can have it open all the time and probably get a lot of people in. But ours is out of the way of the town and unless you are part of the congregation it not really an attraction really.

\section{SD: Do you have a large regular congregation?}

Int B: I would say its about 100 . Over a 3 week period on average about 150 come.

SD: Is that a weekly service?

Int B: Yes, its every week, Every Sunday morning and sometimes in the evening too

SD: And with the lighting project that you are going ahead with, you mentioned that funding was a problem, but have you had any problems contracting people to do the work. Do you have to use a specialist?

Int B: We had to have a church architect. Every 5 years the church has to have an assessment to how much work they need, which is mandatory, and if there is any building work that needs to be done the architect advises whether it needs to be done within the year or can wait. A lot of design goes through that architect. We have just gone out to tender actually, and through tender we can choose whoever we want. But the design goes through the church architect

SD: Are there any restrictions with the loan?

Int B: No, no. We can choose whoever we want to. The church architect will probably have to come and inspect the work as its being done so they will pick on it if the contractor isn't doing it very well they pick up on that

SD: Is the assessment done centrally through the diocese?

Int B: Um, yes

SD: And that is every five year? And everybody across the diocese have it?

Int B: Yes all churches throughout the diocese of Exeter

SD: Do you get lot of information through that? 
Int B: You do get a proper run down of all the building work that needs attention; you do get a report back.

SD: Do they give you a guide to costing?

Int B: No they don't give you any idea of that at all, you have to find that out for yourself.

\section{SD: That sounds quite helpful though?}

Int B: Yes it is, and he will advise us as well, on annual maintenance checks that we should be doing putting in place.

SD: And are those annual maintenance checks carried out by the churchwardens?

Int B: Yes I suppose it is the churchwardens, but also the PCC largely. But I suppose it does come down to the churchwardens

SD: Is the PCC made up of elected members of the congregation so in that way you have the buy in of the congregation without having to tell everyone about it?

Int B: Yes, and once a year you have the annual general meeting and there will be a report of all those things and that is open not only to the congregation but to the general public.

SD: Apart from the annual maintenance check do you also pick up things throughout the year as they come up?

Int B: Oh yes, it seems to be ongoing really, as with all old buildings, especially without church hall. We have to look at it quite frequently. I wouldn't say we get a lot of vandalism but we do attract some because we are out of the way really.

SD: Do you have a separate budget for that?

Int B: We do have a maintenance budget but it basically comes out of general funds. The church office keep an eye on it but have access to some funds that we can go into if we need to.

SD: In terms of increasing fuel prices, does that have an impact on what you are trying to do?

Int B: It does really, and even hiring the hall out, I mean most of them are voluntary groups and if we have to increase charges it does make an impact, and some people might have to pull out as its too expensive.

SD: Do you find that when you are trying to implement new things you have to talk to people like English Heritage or does your architect do that for you? 
Int B: We have actually, and in fact for the last 3 years we have applied to English heritage for our maintenance budget but we not been successful. I mean it's a lot of work actually filling in forms

SD: And do you think that is because of the age and type of your church?

Int B: Yes I do, they also classed is as not urgent, and not in danger, apart from the tower which is also listed, which is in disrepair, but it's not attached to the church so it doesn't affect the church or church hall. It's a shame really because when it gets to the stage when it is in danger we probably won't be able to use the church.

\section{SD: Are you going to keep trying?}

Int B: Yes we will. Well we do try and do things differently but we haven't been successful

SD: In terms of, when the project is underway, and you are doing everything you can at the moment, what benefits do you think you will get from them?

Int B: Well the benefits are minimal at the moment, as its just keeping the building in repair really, it's just maintenance really. And some of the money is really for the tower, for the brickwork so it doesn't have an impact on what we do. But the reordering inside the church will and we hope once we have done that we will be able to use the inside of the church more and not just on Sundays but also for various voluntary work that we do.

\section{SD: Does your church have plumbing and that sort of thing?}

Int B: Yes we do

SD: Is that something you would think of upgrading in the future?

Int B: In the distance future yes, I mean we have had the heating done fairly recently, we had new heating up in about 8 years ago so I don't think we will be doing that again in the near future.

SD: Was that quite a long project?

Int B: No it didn't take too long actually. Again the hard work was finding funding and people to do it.

SD: Were you restricted in what you were able to do? No log burners or anything?

Int B: Yeah That's right, I suppose we were restricted in that it had to be something like what we already had. We did consider under floor 
heating but that we didn't have the money to do that and we needed new heating so we just went ahead and did that.

SD: Was that something that the architect identified?

Int B: No we just knew that the heating was not working properly and it was getting colder and colder really, it was just something we needed to do.

SD: And was that covered under your normal maintenance cost?

Int B: Yes

SD: So you have 2 ways really that you do it. The larger project have to be done by forward planning,

Int B: Yes and fund raising activities

SD: And the rest through the maintenance budget?

Int B: Yes

SD: Do you think that the maintenance budget will be effected in the future by things like increasing cost in heating?

Int B: Yes I think it will, it definitely has an impact. If energy prices go up by a third then that money, which is only from the congregation, if effected. We either have to collect more money or they have to find more money

SD: And you mentioned that there are 2 churchwardens and about 15 people on the PCC. Is that a pool of knowledge you can use?

Int B: The other churchwarden is an architect which is very helpful and we don't have any electricians but we do have contacts and one has a workshop so he can do things like repairing walls and things and he's prepared to do that for material cost as he is prepared to do that free of charge.

SD: And do you think that because you do the energy saving light bulbs and you do try to do that sort of thing, does that relate to the congregation being quite pro sustainability

Int B: Yes, definitely

\section{SD: And if there weren't would that be an issue?}

Int B: Um. It could be, if you were in a village, which we aren't, you might be concerned about the way it looks, the aesthetics which we aren't. We use it as a functional building and people are concerned about what we do in it and not the appearance at all. 
SD: Is that your key concern as a churchwarden? To keep it up and running for that purpose?

Int B: Yes definitely

SD: Rather than maintaining the heritage of the building?

Int B: Yes, and actually we would probably pull the tower down if we didn't have that restriction then we wouldn't have to worry about maintaining it for years to come.

SD: And if it gets to a dangerous state and affects your ability to use the church building what will you do then?

Int B: I think we will get funding actually. But if we didn't we would have move out actually, into a local school hall. I guess the long term problems with that would be that the church would go into even more decay. If you haven't got the congregation that is interested in keeping the church it is difficult.

SD: In terms of the project that the architect recommends you need doing, do you get advice and best practice from others?

Int B: Yes we do, we do have resources from the dioceses that we can tap into if we want to.

SD: And do you provide example to other people locally?

Int B: Yes locally we do, the church is actually meeting with up as well, in what is called the deanery synod, where most of the churches in North Devon would be represented, people from each PCC are represented and we can share what we do and where we have been successful.

SD: And does that give you further ideas for things you can do?

Int B: Yes, sometimes. Most people are doing the same thing but occasionally I mean [names nearby church], the big church, in town is into recycling in a big way and yeah it does allow you to tap into it and be encouraged.

SD: In terms of your main motivation for doing projects like that, you have said you would potentially move somewhere else altogether. Is your main motivation to stay in the building because it is a nice place to worship and does have historic value?

Int B: When we first looked at having the work done we did actually serious thinking about moving out, and the long term implications of another 20 years time. The key thing is that the church is still in the community and finding somewhere big enough. If it would mean moving out it wouldn't have that connection with the community. I mean without the church 
hall you wouldn't be able to have the workshops that we control ourselves. I guess its finding that facility within the community.

SD: Internal maintenance for the contents, is that an issue or do local people come in and help?

Int B: Very rarely really and I think that comes from being a town church, I guess in a village you get a better connection and people support it more, but that doesn't happen in a town really

SD: Is that because the make up of people is different, and more people are working?

Int B: Yes that right. There are only a few people that have time during the week, so yes I think that is a restriction

SD: Training wise, does the diocese provide courses on environmental issues or working with the community? Are you restricted in what you personally, or the other churchwarden are able to do?

Int B: Yes time is a big thing, we do have a church administrator who looks at things like that and follows things up. But it is difficult when you have full time work as well. It would be great to do, and I do know some churches where the wardens are retired and have more time. Time limited. The other one is the architect who is also busy.

SD: Do you find that being part time is an issue or are you able to concentrate more fully in the time you have available?

Int B: I guess it is more that things get missed actually as you aren't able to give it the time you should and in the PCC meeting you are able to cover a lot of that but it is difficult with volunteers who just help out. I guess things get missed and you can't do everything. And then it is just running the services and the actual practicalities of it.

SD: Do you see carrying on with that in the future; will it be a continual requirement to catch up with maintenance?

Int B: Yes I think it will. Once we have done this major project it will be less so as it should solve many of the problems that are present. It happens to be linked but I am sure it will be very much ongoing. And as a Victorian building its almost worse as they weren't built very well and sometimes requires more attention than buildings that have been there 8 or 900 years.

SD: Is there anything you would like to add? Do you feel that that covered most of the bits that you felt lacking in the questionnaire?

Yes I think it did 
Int B: I mean I think it's the funding side and we just don't have that, and all the money has to come from the congregation really

SD: Do you think that might change in the future because of the nature of the church or do you think it will stay?

Int B: I think it will stay actually, I think it will become a bigger problem actually I think the church doesn't have anything in general and they aren't as generous as they used to be. I think it will become harder for churches to have work done, I think we are fortunate that the church is able to keep going.

SD: I read about the diocesan share for staff costs and salaries, is that an issue, with reducing congregations?

Int B: No, it has been steady but I can't see that it will actually. I think we will keep the congregation actually, the hardest thing is perhaps the younger congregation, the building doesn't mean anything to them, there is no desire to keep the building going because it's a heritage site

SD: Do you think that would be different if you were in a Norman chapel or something?

Int B: No I think that will get harder as time goes on. Only a particular group are interest in that sort of thing and I think it will be harder and harder to maintain that interest

SD: I know you mentioned that you don't have any interpretation but do you think that would encourage members of the congregation to take a greater interest in the church building?

Int B: It may do, we thought about having to do that and writing about the building project but there was a discussion about the value of the building. I am not sure if it would or not really.

SD: Do you think they would move if there was another facility within the community?

Int B: Yes I'm sure that if there happens to be a building near where the church is then we would have left it. It is more about the community ties than the building ties.

SD: That's very interesting as in other types of heritage that is the total opposite

Int B: Well I think with the church like ours with lots of voluntary work, that is the area where people want to spend their money, in actually ministering to those in need and if the building is taking resources away from that. And I guess if you have somewhere like a school you have no responsibility except paying the rent and you know the time people 
spend on the building could go into doing some good in the community. I guess it is very difficult as you have a building that you want people to come to not because of the building. You know even the Victorian society, they were quite vocal about the changes that we wanted to do but again they weren't prepared to put any money into keeping it and they expect the congregation to keep a building like that going, its almost very one sided.

SD: That's been really helpful, thanks for you time.

Int B: If you wanted to see the church you are more than welcome, today you could see the outside but you have my telephone number if you want to come back and have a look around

SD: How long is it usually open?

Int B: Mainly at the weekend the church hall often has someone there, and we live very close to the church and can let you in.We also have a churchyard you can have a look around, we are actually considering handing that over to the council actually.

SD: What are the maintenance issues of that at the moment? Is it more about the mowing?

Int $B$ : It is and trees

SD: Are there a lot of old large trees?

Int B: Yes there is a whole line of large trees.

SD: And walls and things?

Int B: Yes the walls too which are falling down.

SD: I guess it isn't something you use regularly

Int B: That's right. I guess most of your activities are based in your church and hall

SD: Would the council just take that off you?

Int B: Yes I think so

SD: Could they build on it?

Int B: I don't think they could actually. But we don't really mind, we don't see the building as important, it is probably more important to the council.

INTERVIEW CLOSE

SD: Standards thanks and re-emphasis of participant right to access transcript. 


\section{Interview C}

SD: Standard introduction requesting permission to record and providing an explanation of all ethically required statements

\section{Tape recording begins}

Int C: The...we used to be just joined with [another] church. There are two sort of comparisons really. [The other] is bigger and that has the morning services and this has the evening or afternoon service. In the summer the evening service is quite well attended. We have sort of 40 some days and it drops down to a dozen or 15 at times In the summer we get a lot of visitors In the winter it is too dark then as we are candle lit, so we have one at 3 o'clock in the afternoon which is an awful time everyone wants to watch telly or something and we are down to about half a dozen or 9 people in the winter and its quite a problem., but in the summer we get quite a lot because of the candles and because people enjoy the actual book of common prayer service as a change or they like the traditional words so that's um, and we will keep that going as long as we possibly can do and there are, and now there are 4 parishes in the united Pentecost of [mernique (?)] which runs right up as far as culdrose airbase, that is in this parish still, um and so there are quite modern services in some churches and they are sort of old in this one. Umm the actual parish um I am, um, myself and my wife are the only people who actually live in [the village]

\section{SD: Oh, right.}

Int C: Ok, um, there are a huge number of holiday letting houses around, I mean we let...we converted the old farm buildings here into holiday flats and things. In the parish most people come across from the other side of the creek and um, and flats, um, a lot of these are second homes but a lot of people retire down here and then come to church, so it's quite...then die and others take their place, and I suppose over the years it is slowly diminishing, the number of people that come. I'm not sure what will happen in the long run really...um...what else do you want me to?

\section{SD: I was going to ask if you have had to have any work done on the church as obviously maintenance must be a big issue.}

Int C: Um, we have had the bells completely...we have really good bells, we get a lot of visiting ringers, they are really good bells, 8 bells and those were re-hung in um well I suppose we managed to make it into a millennium project but it um we finished it in about 2000 and um, it's over here, um in about 2001, um but that brings people to the church as well, visiting bands of ringers come through and if they come to Cornwall they will often come and ring there bells and also [names another local church] which is quite nearby and they will um go to those two churches. Um and that was I don't know, I think it was $£ 30,000$ on that, um and they also not so very long ago put a new roof on the 
tower, that must have been about 1990 I suppose, they put a new lead roof up there.

SD: Is the money that is collected to pay for that sort of thing, is that from the congregation?

Int C: Yes, the, the, the, bells we had a special appeal for urmmm which people, we got the money fairly quickly for in fact urm and I mean the money I mean we, our collection doesn't match our running cost, once you have paid the common fund, I mean the common fund is the problem. Um the, that seems to go on upwards all the time and we can't quite make that, I mean we are losing, we are slowly losing money all the time, although we have quite a bit of money in the bank still but ultimately it's going to go um, if we, I think we are quite fortunate really because in the summer we get a lot of the visitors who come here we tend to know because they come here year after year and at the end of the day if we looked like going belly up we could have a whip round and I am pretty certain they would keep us going which is quite nice but its, the problem isn't the summer its just what will happen in the winter months when you have got so few people here that ultimately the vicar will say that I'm not going to bother, you know.

\section{$S D: \quad$ So is that your main concern for staying open then?}

Int C: Yes, yes it is. What will happen in the winter services is...at the moment we have services every Sunday we have which we alternate between a 3 o'clock afternoon service and an 8 o clock holy communion umm the 3 o clock service we have an organ for and we are luck we have a good local organist and umm and we have got a damn good organ and that is brilliant um and that is in good nick as well, um but if no one is in church then it is not going to happen.

\section{SD: And do you have a rolling maintenance budget as well?}

Int C: No we don't, we just do things as we find them, I mean I'm just trying to think what. I mean next.... The church yard is virtually full yeah and it is run by the church and not the parish council or anything else and we are now in the throes of taking, I mean we have been given a piece of land fairly adjacent to the church, I mean its just behind here and that is going to cost an arm and a leg to fence off and create a proper entrance and everything else, and that is our next sort of big spend, and again we have got some money from umm benefactors which will certainly go half way towards paying for the whole thing and I would guess that if we want to, and we do want to, we will raise the funds um so that wont eat into the church money. I don't know what that is going to cost, probably about $£ 20,000$ l expect and that is going to happen.

\section{SD: Is that going to be an appeal or something?}

Int C: Yes, yes, I guess, we, we have cost best part of $£ 10,000$ I guess, and the local landlord has give the the land to the church, it's about an acre 
and a half I suppose. Umm you know, in fact that is another thing that keeps the church going, you have peoples weddings , I mean we don't have that many but it's a fabulous spot and people come by boat and go off and that sort of thing

\section{SD: And is that a good form of income generation?}

Int C: Oh yes it is, yeah it is important actually when you get down to it as we charge for all kinds of things, we charge for candles, the organ, and everything else, and it can be 2 or 3 hundred pounds and if you are going, if your weekly income is only about $£ 20$ then it um...

\section{SD: Then it must stack up?}

Int C: Yes, it does. We also have a... at Christmas we have a big carol service that fills up um and we sing carols, though I suppose a lot of churches do, and that is really well supported, and we have, we ring out the old year and ring in the new, and that isn't a service as such but there is a lots of people that watch that and there is a specific set service for new years eve but we tend to run it just for the bell ringers and its not um, yeah. And that seems to fill up. The millennium service we had in the church, you could only stand in the church I mean all the way through we must have just fit people in here I mean it was standing side by side, you couldn't sit down in here and that was quite spectacular and totally unexpected we didn't expect, but everyone chose just decided to just come, which was really nice. So about 360 people at that and it's just a [ ] really.

\section{SD: So events and the summer tourist trade are your main revenue source?}

Int C: Yes, that's right. We have the tedate service in august which is totally different to our normal service but its quite nice, its um, it is...do you know tedate service?

\section{SD: Yes}

Int C: And well its quite different to a normal service, not what I call a happyclappy service at all, it fits in with what I call, what we do normally and the money we get from that I think we send it to amnesty, um so we don't keep all the money that we generate by any means and um which I think is quite right, um.

\section{SD: And is the church used for anything beyond services?}

Int C: We sometimes get concerts

\section{SD: And bell ringing?}

Int C: Yes bell ringing practice every week and band and our ringers and local bands too. We used to do a lot more concerts than we do know, I 
mean, that was mainly done by visitors as well really, we had a group of people from Manchester who used to come down and people from the choral society and that sort of thing and they used to come, and they stopped coming down to Cornwall I think, I don't think they are going anywhere else um but they used to run all the recitals and that sort of thing, but we still have umm, probably one or 2 concerts a year which we do.

$S D$ : Do you think the income that you get from the tourists is fundamental?

Int C: Yes, absolutely, yes if it wasn't for that. And they wouldn't want to be called tourists, people who come down every summer and a lot of them have been coming down here for, they are $4^{\text {th }}$ or $5^{\text {th }}$ generation who either have been coming down to [the village] on holiday or have been to the surrounding area, and they come here with children and then the children grow up and bring their children and it goes on. And it's a dead regular thing which is why I am particularly nervous about dropping services and things as people say we shouldn't have services every Sunday and the second you don't have one, you, you, I mean people down know you have one at 630 on Sunday here then they won't come, and they won't come at all and you just lose it, and I think that is quite important too, to keep it going. And every now and again visitors will retire down here and then become big parts of the church um.

SD: And I notice that you have got heaters although you have candle lighting.

Int C: We do have electricity in the church so we aren't totally dependent on candles but the light is candles.

SD: Because you did say in the questionnaire that you have some energy efficient light bulbs and everything?

Int C: Yes, I mean, yes

SD: And do you just use the heating as and where necessary?

Int C: We keep it off as much as we can do.

\section{SD: Do you have to keep it on to maintain the fabric of the building?}

Int C: Yes, we put it on on a Friday so it runs Friday and Saturday so two nights a week, if there is something earlier in the week we put it on.

\section{SD: And is this the increased cost of electricity and everything?}

Int C: It's peanuts, yeah really. I don't know what we spend but it isn't a big issues. The big issue for keeping the thing going is the common fund really. 


\section{SD: Which covers the salary and the pensions of....}

Int C: The clergy yes, that's right, I think um we have had problems getting candles, they go up and down in price, I presume they are made in China or somewhere like that um, they were English and the price of those went through the roof at some point and then I think the company went bust and um that was a problem.

\section{SD: I presume they are a very specific size?}

Int C: Yes, yes they are. But its standard, so its not um. I'm trying to think of anything else cost wise, I mean the actual building is in good order umm, yes sooner or later there will be a big problem in the roof or something and then that will be horrendous.

SD: Do you have somebody who comes down from the diocese at all?

Int C: Yes, every five years we have an inspection yes.

SD: And is that...

Int C: It's called a quinquenial

\section{SD: And is that an architect that come down?}

Int C: Yes, he is not employed, he doesn't work directly for the church but he does a lot of work for the diocese and the guy who comes here is [gives name] from Truro but he would do, I don't know what proportion of Cornish churches but a lot of them, and he does the national trust as well. I mean he is looking for things like cracks in walls and the obvious things, I mean he doesn't do things like climbing on the roof and taking the slates off

SD: No

Int C: But if there is a big puddle on the floor...

SD: And does he give you an idea of the time scales that the work needs to be done in?

Int C: Yes, yes he does. I mean he'll say something like, if he finds the gutters are all blocked he will say that those need doing immediately you know, tomorrow. If you know there are branches in tree that they will need to be taken down in the next year and before he comes again in 5 years time you know all the []need replacing or something.

\section{SD: And do they come back and check that you have done it?}

Int C: Only at the end of the 5 years. Yeah. But you know the, the, parish council, or the church council, the parochial church council will have the report and the church wardens are meant to make sure it is carried 
out so the church council, if they are any good, will make sure it is done.

$S D$ : And is your main role maintaining the church or the congregation or does it have a wider remit?

Int C: Well its sort of the church warden...there is um. It is up to the church warden to maintain the fabric of the church as much as possible and if the church is going pair shaped the vicar would get involved but by enlarge they wouldn't want to they would hope the churchwardens would but it but it is very...ummm....we have got myself and another guy my age who is local and pretty able so between us both we have been able to get through most of it. But you do get churches where you can't get hold of churchwardens and where they are about 99 and that can be a problem.

SD: And when you do identify something that needs doing do you have to go to the church council to get permission.

Int C: Yes and if you um, you have got to be quite careful what goes in, major works require a faculty from the diocese um, you can't just go and put in a new alter or anything, I mean even a plaque on the wall you have to get permission for um and any sort of real difference to the church, it is usually straight forward but it can be tricky.

SD: And do you have to special work force, as well as special permission, to do work on the grade one listed....?

Int C: No, not necessarily. But you would have to have people who were capable of doing it yeah. We had problems here (indicates wall) this part of the church is much newer and the wall dropped down from this little bit. I don't know how long ago it was added but about 150 years ago, I don't know could be more. But the roof had started to come in and we just got a straight forward builder to redo it and it wasn't a specialist thing.

SD: And are there many principles that you have to abide by like not altering the historic structure or anything?

Int C: Yes, you have to be really sort of careful as far as what happens and you've got to you know you can't use ordinary emulsion, it has to be lime and stuff, and all the materials have to be good. And every now and again something does go wrong, like we had some pointing done in the tower about 30 years ago which was done with really hard cement which was totally wrong, it should be lime cement that should allow water through, although it goes dry so lime cement breathes while modern cement doesn't so that was a disaster.

\section{SD: And did you have to have that replaced?}


Int $\mathrm{C}$ : Yes we did. It stayed there for about 20 years and then we had some more work done, in fact funny enough, we had a recession, there was a firm called Trevaners which are now, not sure if they are still going, they might be, they might be part of $\mathrm{E}$. Thomas, but they had a group of skilled people, masons who they didn't want to sack, they wanted to keep so they did a lot of work here at the church for just cost price to keep their team together. And that worked really well.

\section{SD: So good for them and for you?}

Int C: Yes, if they had broken the team up, they didn't they kept the team together and they did lots of work for the National Trust and they were really good. They did quite a lot of pointing for the church and did the work on the tower.

SD: And do you think maintaining the historic integrity is key to maintaining visitor numbers

Int C: Yes I do and things like cleaning the brass, these are taken down twice a year and they are taken to bits, thousands of bits, and it's a two day job twice a year and we get people, and I have absolutely nothing to do with it, we get people who never come to church come in here and we have benches laid out, and we have people who sit here and people are doing their part for the church so it isn't just coming to worship.

\section{SD: So is there wider community involvement?}

Int C: Yes its not huge but there certainly is some you know and I think you know that they all feel ownership of the church which is good. And there aren't many people but you probably get 25 coming in or something like that and considering the winter congregation is only something like 10 or something like that, it is quite good.

SD: And in terms of striking a balance, for my research, I am looking at sustainability in a broad sense, so the economic which you have already mentioned, trying to maintain costs, the social which is trying to get people to keep coming here and engaging with the community, and the environmental so the real green stuff, like your energy saving light bulbs, so how do you think the balance is struck here?

int $\mathrm{C}$ : I don't know really, I, we could do a lot more in the church yard to make it more... mean at the moment we just strim everything flat and we could certainly do more with the churchyard to make it a. more attractive and $b$. there is lots of grasses and things that we could um....

\section{SD: Create a wild flower meadow or that sort of thing?}

Int C: Yes.

\section{SD: And is that a cost factor preventing you from doing that?}


Int C: No it's a time thing, just getting round to sorting it out.

\section{SD: And you identified in the questionnaire that this wasn't your main job? is that an issue?}

Int C: Yes it is an issue, it is odd, My grandfather was, I mean I am the third generation of churchwarden straight through, my grandfather was in the 1920s and I don't know how long he did it for but my father was churchwarden for donkeys years here and I have been church warden for about 10 years and there is a time limit now and you are supposed to come off after 5 years but because I have live here and I employ shipwrights in the boathouse and we actually do it, um that um I am not sure what will happen when I pack up and I think the vicar is keen that I, you can vote every year to wave the rules so you aren't compelled to quit, um and possibly they will carry on doing that with me unless I make a total....um and it's not that kind of thing, it's ok if you have other people who help which is what we have got, we have got really, the pcc of about 12 people and most people on the pcc will do things if you ask them too, like can you sort that and they will do it which is good and um.

SD: You mentioned about the churchyard and about the extra plots of land, are there any other projects that you have got coming up?

Int C: No, that would be, that would be a big project for us and we wont be able to do much else, I don't there is anything else at all. I mean you get things happen all the time, I mean we have got about 20 in the congregation and they don't change at all and quite recently the surveyor said that we had lovely tiles that you couldn't see because they were carpeted, lovely Cornish tiles and he said we need to get rid of the carpet but there were absolute ructions with the older people on the thing as they didn't like to see it change and they don't like change at all. And recently we moved the alter forward as we have a new lady vicar and she want to celebrate communion by facing the congregation not that way. But the book of common prayer says you have got to face east which is that way, so you need to stand with your back to the congregation, and as far as I am concerned it really doesn't matter, and I am quite keen to work with it but I mean if you really look at it is beautiful but its difficult its like walking in treacle almost.

SD: So it's about creating a balance between your current congregation that you are keen to keep while moving forward?

Int C: Yes, yes, as far as I am concerned we are lucky to have a vicar at all and if she is happier doing that its not a problem. At least we don't have a problem accepting a lady vicar. A number of churches um, especially traditional ones wouldn't do that, and there isn't a problem with that as far as it goes, but it is funny how small things become huge stupid issues. 


\section{SD: And are those the sort of issues that crop up more than any others?}

Not....i don't know. Its...

\section{SD: A risk of having an ageing population?}

Int C: Yes I mean that's its, its not a huge thing and we have got some good young people on the pcc who balance that sort of thing and that's good, and also just having people arriving from outside the community who retire down here with fresh views, they can put things in perspective which is also good.

\section{SD: I suppose you have to balance it again.}

Int C: That's it and it is extremely easy to upset somebody and if you only have a regular 12 people anyway you can't afford to do it, and we are extremely conscious of that, and so is the vicar in fact. But you do see churches that go completely pair shaped over that.

SD: And probably the final thing that I was going to ask was do you lock the church?

Int C: The church is open in, we unlock it at 8 o'clock in the morning when we start work and lock it again in the evening.

\section{SD: And is there an issue with crime?}

Int C: It's a thing we are always nervous of, someone did try to steal one of these (indicated brass candle support)

\section{SD: I did notice the padlocks actually}

Int C: And the fact that we have sensors on the top and a big alarm system set up and we were quite worried, in the last august September time when people were stripping the lead off roves and with candelabras you would just melt them but now the price of scrap has just dropped.

\section{SD: So you feel fairly safe at the moment?}

Int C: Yes we do at the moment, we did have one of these, when the organ was put in, we did have a spare one from there, so we did have a spare, but we are worried that if another one was taken it would affect the whole feel of the church

\section{SD: And is that more an issue in the summer with all the visitors?}

Int C: No I don't think so, they would either be stolen to order and that wouldn't be locals. We had a collection box outside the church broken into 3 or 4 years ago, so yes crime is an issue but its fairly low key and I think we gain much more having the church open. And we get, one of 
the, not everyone comes to the church []. We have 4 churches in this parish, they call it a united benefice and one of those churches is more or less in a field and they get no visitors and we get more so we are very lucky, and people do give money but we have noticed the last 10 months we used to get $£ 5, £ 10$ pound notes but people are struggling now and we get more $£ 1$ coins and 50 pence pieces. And its quite inevitable I know.

SD: And you have postcards and things do you have any books on the history of the church?

Int C: It's out at print at the moment, the current vicar has only been here a year and she is going to look at revamping that

SD: Are they quite popular in the summer?

Int C: Yes, in the summer season

INTERVIEW CLOSE

SD: Standards thanks and re-emphasis of participant right to access transcript. 


\section{Interview D}

\section{SD: Standard introduction requesting permission to record and providing an explanation of all ethically required statements}

\section{Tape recording begins}

Int Di: This is the church called st [gives name], and the diocese wanted to close the church and announced it was going to be closed and the community said no and so they have basically taken it back from the diocese, kept it open and somehow got a curate attached to the church, they pay their common fund to the diocese as normal and they recognise the bishop as their Bishop because there are some churches in Cornwall who do not agree with women priests and they have broken away from the diocese of Truro and I think they pay their common fund to the diocese but they don't recognise their bishop as the bishop of Truro and they have a bishops from out of the county

Int Dii: A flying bishop

Int Di: A flying bishop and he is their spiritual sort of leader

Int Di: Yes they appointed a flying bishop for these churches where women priests are not accepted.

Int Dii: And anyway, this church, this one church, and what they have done, they do a whole church calendar every year in advance and they have enough money to rewire the kitchen, they have got whist drives, social events, they serve tea every Sunday afternoon, they do lunch on Sundays and they have got the whole years concert to earn the money every year to run the church and they have an average of 35 in their congregation which is fantastic and he came to see our concert the other night because they are doing a similar concert, and this chap here, he does an Elvis

Int Di: ..Impersonation,

Int Dii: Yes he does Elvis,

Int Di: Elvis sings gospel, we had it here the other night

\section{SD: That sounds fantastic}

Int Dii: It's incredibly loud, you know how young people listen these days, you being a young person, but for me it was far too loud, we had to very large speakers on either side and it was very load. But very funny

Int $\mathrm{Di}$ : And we have these two people, one of whom has this implant in his head because he is hard of hearing, and I encouraged them to come, and told them to come and I sat them right at the front, said you sit over there 
Int Dii: Yes they were sitting here

Int Di: And then when they started it almost blew his sound system and they came and sat right back here, because he could hear it perfectly.

Int Dii: I did feel really sorry for him, but it was very funny at the time

Int Di: But um, you lead this little thing

Int Dii: Right I thought we..

Int Di: Ow.. just one more thing, the one thing that amazes me is that a little community like this can support and develop a building this big, and it is, I mean we have 6 churches in our cluster, the bishop has joined our parish with the one next door and we now have one priest and a paid curate as well as an unpaid one. And but this is the biggest of the 6 churches as far as seating capacity and in the height of the ceiling..

Int Di: Yes the height of the ceiling

Int Dii: And in another one of our churches, which I would say was very high church, I would say it is almost catholic and the ceiling..

Int Di: The bishop actually said in one of his sermons when he came that they had in fact ignored the reformation (laughs)

Int Dii: And there is a festival there twice a year, a very upmarket music festival which is wonderful because of their acoustics, but our acoustics here are better because their ceiling is at least $30 \%$ lower

Int Di: Yes, their pillars are quite short, aren't they

Int Dii: And this is just so big

\section{SD: And excellent stained glass windows as well}

Int Di: Well we'll come on to that

Int Dii: Yes, we'll get to that, that, is the oldest one in the Country not just Cornwall

Int Di: Yes, 1469 or 1489 it was actually put in and we have just restored it

Int Dii: There is a bit about it in there [indicated booklet]

SD: $\quad$ Yes, you did mention it in your questionnaire

Int Di: Right, carry on 
Int Dii: Right yes, this is in the booklet (indicates font) and its all lead lined inside and we think it probably leaked as its probably just a soak away because if you look at all the woodwork around here it is all wet and we think what we think will probably happen, its [int Dii's name] idea, is that it will have to be moved and the whole think re-dug

Int $\mathrm{Di}$ : I think it's a soak away there and what we think is happening is that when it rains the water comes up and is staining the floor because we want to get this floor resealed. It's a Victorian floor and I have just found a letter, as I have been going thought the other church wardens papers and there was a letter written in 1961 by the father in law of one of the oldest members of the congregation and I am assuming that he wrote about the time that the church was being renovated, in the 1860 s I would imagine, in the Victorian times and all the walls were plastered at the time and they took all the plaster off and re-pointed it all in Portland cement which was of course wrong because the building can't breathe any more. Unfortunately we have just re-plastered that corner again which was the previous churchwardens bee in his bonnet and that was done with lime mortar. And they took all the floors up underneath here apparently, then they put pitch in and then the blocks and then slate in here, and in the central isle he talks about, and he was only a boy at the time, he talks about when they took the floor up they found a body, because there are quite a few bodies buried underneath the floor, and he said it looked alright for a minute or two and then it suddenly collapsed into a cloud of dust from where they had exposed it to the air. And under that chapel at this end of it, and under that chapel there is apparently a crypt and he said he went down there as a boy and all the bodies are lying on shelves down there, but we don't know where the access is

Int Dii: Yes we don't know where the access is to it

Int $\mathrm{Di}$ : But he went down there when they were doing the floor and he said that umm men were....he said that men were not allowed inside church with hats on and he was told by someone working on the roof to come inside and get something and he forgot to take his hat off and as he was coming out the vicars were walking in and apparently the vicar was about to have a go at him when something happened, and it doesn't say what but there were holes in the floor, and it knocked the vicar into one of the holes in the floor, that was the reverent Avery, and he wrote all about this, and I found the original letter in the file, and that's the history that makes the people and the stories..

Int Dii: And Avery the vicar here in 1900 and 1911, and he put a window in which I will show you later, we can start here and walk round. That is a lantern cross which was found in the leat...At my house in 1937 and it was in pieces

Int Di: There are other leats...I mean it's called a lantern cross and there are other lantern crosses in Cornwall that are recorded as we had a man here who put a microchip on it as some of the heavy things like that 
stone there, its called the Ogham stone, with IUSTI its spelt IUSTI on it, was found and they think it is probably a memorial to a monk. And people are now stealing things like that. And there is microchip, and I suggested that he did that lantern cross as well

We could have put it in one of the holes here

Int Dii: It is about the size of a grain of rice, the microchip. Now this is [introduces someone by name] and [she] is the author of the booklet

Int Diii: Yes I just write it

\section{SD: And when did you write it? Was it quite recent?}

Int Diii: It was just after [previous writer] went, so 2 years ago, yeah about 2.5 years ago

Int Di: And Susan is writing a thesis about heritage in Devon, Cornwall and the Isles of Scilly

\section{SD: That's right}

int Diii: And what is it?

Int Dii: Yes, there isn't much recorded, there is a lot written about houses and...

SD: Museums. but very little on churches which is a shame as it think it's a very underused resource

Int Diii: Yes, oh yes

Int Di: So we are just going to do a circular tour, we have just started with the font which is in a terrible state

Int Dii: The church is really the basic history, it's the route of the basic history of the area. If you come into the bell tower, you can see, there is quite an interesting plaque that was put up in 1783 , this is really interesting this one.

Int Diii: There is one in st [unknown]

Int Di: But ours is much bigger

Int Dii: Yes we think this is the original but they think theirs is but I am sure that...

Int Dii: And the bells are rung every Sunday

\section{SD: And are the bells difficult to maintain?}


Int Di: Yes we have had to buy new sets of bell ropes as they do wear out. That is the ringing team have just renovated themselves all the wooden parts and all the moveable parts up there in the tower, and cleaned out all the floor and everything and it all looks really...

Int Dii: Yes, the bell ringers tend to be a law unto themselves, they don't actually attend the church services...

Int Di: Yes, they come in this door and they leave by this door

Int $\mathrm{Di}$ : It always amuses me that they don't stay for the service

Int Dii: They are not just [Village] people, the often come from other churches Yes, they are from Other churches

Int $\mathrm{Di}$ : And they practice every Wednesday evening for a few hours, and that is really nice. Well some people love it and some people hate it

Int Dii: The bells ringing on Wednesday night are really lovely, like a bit of old England really

Int Di: Right, lets move on. Do you want to ask us any questions?

SD: Yes, I am keen to find out about any work you have had done, like you were saying about the floors and so on...

Int Di: Yes but that was Victorian..

\section{SD: And whether you have any work planned?}

Int Dii: Oh yes, we have lots of ideas..

Int $\mathrm{Di}$ : And a lot of it relates to the sustainability that you are talking about...

Int Dii: Except that we haven't got the money

Int Di: ..Yes, [IntDii] and the previous church warden they re-did all the roofs Yes the roofs were all redone in the last 20 years..

Int Dii: But when you are raising money for roofs it isn't very exciting and they did a marvellous job. It did cost $£ 150,000$ but we did have grants from English Heritage to do it

\section{SD: And is that because you are grade one listed here?}

Int Di: Yes, and we had the bell tower roof re-leaded

Int Dii: Yes re-leaded

Int $\mathrm{Di}$ : And we found the timbers that supported it were rotten when they looked at it and that was done for $£ 14,000$ extra. And the two valleys, 
the south valley was done first and they found there that the timbers in the valley were rotten and they had to slice in oak which Is very expensive, we started off with an estimation of $£ 28,000$ and it went up to $£ 54,000$

\section{SD: And how much of that didn't you have to get from the community?}

Int Di: Umm we got $40 \%$ from English Heritage

Int Dii: And then the community have to kick in the rest

Int $\mathrm{Di}$ : We did lots of fundraising, I mean ever since I have been here, and I have been here 25 years, I have done nothing but fundraising to keep doing what want to do

Int Dii: And our most recent project is the window, and I will talk about that when we get over there and what we want to do, what we are working on now, and you can see all the mess (indicates lights), we started last week, we have had our first meeting with regard to rewiring the church, and obviously we will do the lighting and bring us into the $21^{\text {st }}$ century with electrical points and appropriate things like that because you know umm we, we, we need that because just to vacuum the church you need so many extension cords to get to one point and you know we, the vestry are there is a mess and we are thinking of putting a mezzanine floor there at the level of the window and moving the bell ringers, if we can get them to agree, to ring the bells one floor up. And my idea is to use the stairs here and cut an arch in there so you can come out, and that will create the space for a kitchen.

Int Di: Because what we really want um to comply with modern safety regulations, we are not complying to that in the way of umm, we offer coffee every morning after service and it isn't very hygienic at the moment

Int Dii: No

Int Di: As we use a bowl from up there (indicates bowl)

And we wash it up and put it down a drain outside and just use water from the tap which isn't very hygienic, so we want to move the vestry and the kitchen down here and possibly move the screens down here back

Int Dii: To where they came from, and you can see that this is the vestry in here and its very small (indicated vestry) and full of cupboards where we keep the cups and saucers and things like that, but as you can see it is very small.

SD: And do you have to strike a balance between what you can..

Int Di: Afford? 


\section{SD: Yes, and your income?}

Int $\mathrm{Di}$ : Yes I mean at the moment our income is $£ 18,000$ and out expenditure is $£ 21,000$ and so every year we lose between two and a half and three thousand pounds, and we have a limited amount of money in our deposit account. And that is going to be run out by two years time

\section{SD: And does that include any major work?}

Int Di: No, no major work

Int Dii: That's just general running costs

\section{SD: And is a large amount of that money going on the diocesan share?}

Int Di: Yes!

Int Dii: Yes

Int $\mathrm{Di}$ : Its, its, its, for this church it is disproportionally high for us to sustain, and as I said to you before, we had a funeral here before with about 300 people in it and the collection went to the RNLI and when you look at the diocesan schedule of fees all that money either goes to the diocese, or the vicar or the bell ringers or the organist or whatever and nothing comes to the church whatsoever and yet the church is required to be heated, dry, insured and here and it falls onto basically congregation, most of whom are on the PCC to raise the money to keep it open and we are having a bit of a battle

Int Dii: But the diocese this year have, very generously, reduced our common fund apportionment by $£ 43$ (sarcastically)

SD: And is that because you share...(Vicar)?

Int $\mathrm{Di}$ : And in the old days you used to get a vicar for each church

Int Dii: And we have suggested that now we have a vicar for our 6 churches that our common fund should be proportionally reduced, and he said, and this is the archdeacon 'good try [IntDii], but no'

Int $\mathrm{Di}$ : But the diocese, you know I think the cathedral should be glorious and the bishop should be on a throne and should live and be seen in an appropriate way, and an imperial way if you like, and we should contribute towards that but umm they have done some things in the diocese, umm like an original residence of the bishop of Truro was called Epiphany house, and they decided to move the bishop into a modern house outside Truro but they didn't sell the old one, they converted into offices 
Int Dii: Well first of all they had it as a retreat house, and it was looked after by the nuns wasn't it

Int D:i Yes

Int Dii: But it didn't, they didn't sell it and its all full of nice fabrics and upholstery and and so it's a nice place to go and have a meeting but next door is a school that is no longer a school that is diocesan house and that is stuffed with employees running the diocese so its like when you are seen to be green but you aren't green. It's like wind energy, it's debateable as to how much they have come into the $20^{\text {th }}$ century

Int Di: And is this relevant to you?

SD: Yes

Int Di: Yes, this is the point, its all about keeping the doors open, it's the point of her visit really

SD: Yes, and if the money is all being siphoned away is it preventing you from maintaining...?

Int Dii: Well it is preventing us from modernising and renovating

Int Di: Yes

Int Dii: We can just about maintain it, because we set up, about 12 years ago, [The church] Trust because...

Int Di: Which is in there (indicates leaflet) And friends of [The church] trust

SD: Yes, I saw the sign in the car park

Int Di: Which was set up particularly to help run, and maintain the fabric of the church so that we were able to raise money in the trust without having to take the money out of the church funds all the time. It hasn't been a smooth run actually.

Int Dii: And do you have to balance what you can do to modernise the church without changing the historic nature?

Int Di: Yes, definitely, oh yes, because you always have to go to English heritage

Int Dii: And when we did the window we went to about 7 different funding bodies as windows are eligible for more...

Int Dii: And English heritage...the preliminarily meetings involved English heritage and the specialist people in stained glass from the diocese and there was someone else who came from London who was very high class and I remember when I spoke he put me down like I was 
dirt, and I was very upset about that. But they were very high powered people who were interested in stained glass completely. And because it is a national treasure and not just a Cornish one. And I think the reason why that survived the reformation, when they came round smashing everything up is because you can't see it from the road, that's my theory and I don't think... because the one on the other side that you can see from the road got severely smashed and that one is actually older than this one at 1487 because it is what they call a Jessie window. Because he is holding the route of Jessie which you can see there. This one (indicates widow). And when the specialists come they are always more interested in the Jessie window and the fragments that are left...

\section{SD: Have you got all the fragments?}

Int $\mathrm{Di}$ : Not all of them no, we would like to have it redone but it would cost another $£ 40,000$

Int Dii: And this (indicated information boards) is the story of our window challenge and all the press cuttings

Int $\mathrm{Di}$ : We have got things from Fitzgerald lighting, which has now folded due to the credit crunch, but they used to send out a Christmas card every year from the lighting companies in Bodmin, and I went to see the chief executive, whose brother is a friend of mine, and to cut a long story short they produced enough Christmas cards to send to all their clients across the world and they used the window umm on the front and they had a really lovely shadowy image of the church is the back and it was glossy and must have cost a fortune to produce, they gave us 3000 to sell to raise money for the window...

Int $\mathrm{Di}$ : Yes we have lots of idea for raising money. And we have concerts with well known sopranos and baratones and so on and we had coffee morning, and our goal was $£ 51,000$ but actually we raised about $£ 64$ $£ 65,000$ and then that screen was not part of the orginal plan but crept in somehow and that was an additional $£ 7$ or $£ 8,000$ on top of the $£ 51,000$ so it came to $£ 59,000$ but we have had a lot of excitement as we have the windows that you can see and enjoy while roofs you just take for granted and...And it's been beautifully restored as you can see and they have double glazed it, so the outside of the window will never be damaged by the weather again

Int Di: And the actual weather does not touch this window from the outside And many of the panes had deteriorated because of the weather. This is an interesting one, (reads from tablet) 'this tablet was erected to the memory of George Butler Matthew something or other with all his letters, and he was the (can't hear word) to the emperor of Brazil.

Int Dii: And he is buried here. This chap that wrote the letter I was talking about was actually at his funeral as his father was one of the bearers 
(reading from inscription) and it says 'was interred in the churchyard at [this church] Cornwall where his ancestory originally lived'

\section{SD: That is interesting...}

Int Di: And this women Honour Webber, she gave one of our chalices to the church, and its in the bank, we have quite a consignment of stuff in the bank, one is Elizabeth the first, we have an ostrich egg mage out of glass on a silver base, they are all in the bank. And with the history society it would be nice to get them all out, clean them up and have an exhibition.

They don't look particularly brilliant as I have seen it. The Elizabethan chalice was, when I originally did the first phase of the roof, we had it values to see if it could do the roof and we had it values by Ben and they said that one of the chalices the Elizabethan one was worth $£ 30,000$ as the American market was so high at the time ad very interested in our historic things, but since then the value has decreased as they are no longer buying all that. But when you look at it all the silver tracing on the outside has warn off and because it is silver gilt it looks drab, it doesn't look anything. I wouldn't give you £10 for it.

Int Dii: This step up here, several churches in Cornwall have them, you may have heard of them, the story is that they had a man who walked along here to light all the candles.

Int $\mathrm{Di}$ : Here are the original bits,

Int Dii: Yes some parts are original

Int Di: It's got brass inserts you see as this part of the church used to be sectioned off and all of that, which is called a rood screen, all of that used to have a balcony wide enough to walk across and that was the stairs going up to it. And I imagine at some point health and safety will want us to put a wrought iron gate in there or something to stop kids going up there, I mean common sense has gone out the window really but they haven't made us do it yet

And there was a story that the organ was originally over there

Int $\mathrm{Di}$ : I think it was in that one over there

Int Dii: Really

Int Di: Yes because they moved it out of there when they put that altar in there

I knew it was moved but I don't know when that was moved? About 100 years ago? About 1912

Int Di: So yes, about 100 years ago

SD: Do you get a lot of people, like tourists and things coming to visit? 
Int $\mathrm{Di}$ : Yes, from all over the world.

SD: I saw in your questionnaire that you said most of them were from outside the UK

Int Dii: Yes, I have just been e-mailing, it's amazing isn't it, I have been emailing, because he has been here 3 times before, a man in Melbourne Australia who is researching his ancestors. And he tried the website that was on the [names nearby local church] page or something, I don't know because I am quite computer illiterate, I'm too old for all this rubbish, and he found that the e-mail address didn't work and I don't know what was wrong with it so I have got [gives name] to take a look and sort out what is wrong with it. And apparently my telephone number is on it so he range me from Melbourne and he was, he wanted to get permission to use some of the photos he had picked up in the church in a book he is writing about his family history

SD: That is interesting, so do that majority of people you get here come to research there family?

Int Dii: He's been here 3 times! Yes the majority of people, we have people form America and Canada. We had one particular family from America or Canada and she contacted us through the parish magazine and then the editor of the magazine and he contacted me as she lived in America as I did, in Illinois, as I did so then I contacted her and then she sent some money towards the window and some more money towards the path and we found some more of her family graves when we tidied up the churchyard and that is from a long way away so they look for their roots.

\section{SD: And do they make the journey here specifically to see the church or in transit to somewhere else?}

Int Di: Yes, they come particularly to see the church

Int Dii: And the window was...oh my god who put the heaters on?

Int $\mathrm{Di}$ I range them and asked them to turn them off last night!

Int Dii: Who did you ring?

Int Di: [gives name]

Int Dii: Our electric bill is going to be through the roof

Int $\mathrm{Di}:$...but the window was originally the east window and if you see a line in the wall there that was originally that end wall of the church and beyond it was a chapel and it actually brought the chapel into the church somehow and they moved the east window and put a new one in here, and if you look at the panel on the right hand side there is an 
architectural detail on the left so we think there would have been another panel and it would have been more symmetrical and wider. And the window talks about the last days of Christ's life but not as it is actually shown in the bible, it shows a bunch of actors going round Cornwall from Penryn college which is down near Falmouth, and these actors used to come round and act out what they called the passion

Int Dii: And called the [audinalia]

Int Di: And they would come and act out the stories there, and this window actually shows the actors acting out the plays rather than the stories from the bible themselves, this one for example is three panels up and three panels over and it shows Jesus, and they have a whip look in his hand and in the bible it says Jesus was scourged on his back but right there he is being scourged on his front the reason they did that was that if an actor is out there and he is being whipped on his back the audience can't see his facial expression and so it was on his front so the audience could see pain and that is what that shows. And then just down below they have a big monster and that is the jaws of hell, and when we restored that panel, the facial details of the people in it, I side hell were missing, and so what the window company were able to do is look at their records because the restore glass, they exclusively restore glass and they could work out from the shape of the person and work out who it was, then they were able to work out who it was and re-fire the window, and the middle panel, the man with the beard was Adam and Adam is obviously the world's first sinner and Jesus is trying to get the sinners out of the jaws of hell.

Int Dii: And here is the before and after, you can see

Int Di: Because it was all broken up, they put it all together

Int Dii: There is a piece of the dragon

Int $\mathrm{Di}$ : And then they put it all together and fired it as one piece of glass as it would have been originally. Just to repair it they put the lead in where the cracks occurred

\section{SD: It is fascinating what they can do really.}

Int Dii: Yes, they have one women who, in Norwich, who is an expert and she is an artist and she loved creating it and she has a lot of historical documents on how it would have been and she did a lot of work on it, the artistic part and she did a lot of work preparing the ,keeping as close as possible to original. She would have loved to do a new Jessie window but they had a look and said it would cost $£ 40,000$ to take it out, replace it and you can't quite see it but at the bottom there are some areas where it has come slightly forward and it gives a, a, umm what is that word?

Int Di: It circulates the air, yes it warms up with the sun. Can you see it? 


\section{SD: Yes}

Int $\mathrm{Di}:$ Yes the idea is that it doesn't get all condensated and dirty

Int Dii: Yes there are two panels in each of the bottom ones and the steel gauze to stop the bugs from getting in.

\section{SD: So kind of like historic environmental protection?}

Int Di: Yes, that's right

Int Di: That hole up there, that one over there, the middle one over there, that one there and up there. And outside rather than just a sheet of glass they cut that and leaded it to make it fit the big shape of the window, it was very expensive but it was obviously the way to go.

\section{SD: And the extra glazing obviously stops it from getting any damage from outside?}

Int Di: Yes, the, the new glass on the outside effectively becomes the window outside. So its double glazed

Int Dii: And all the coloured glass came from France and that was shipped to Exeter and all the white glass was English and they put it all together and then brought it down here again which in the late $15^{\text {th }}$ century is fascinating to know how they coordinated it when we have enough trouble today coordinating with the internet and mobile phones but they did it all. And in stained glass terms it's a national treasure. There are a few panels that are jumbled but that probably happened when they moved it and they could make any sense of what happened there or there but they were able to identify what it should have been with the original panels of the story but they couldn't actually reform it with the glass that was there, so maybe some of the glass had come from some other window

Int $\mathrm{Di}$ : And this panel here used to be down there but they moved it up higher to look more uniform

Int Dii: It represents the people who gave the money, it's a donor panel and represents the people who gave the money

Int Di: But they are beautiful colours aren't they? And these three big panels were originally the land owners weren't they

Int Dii: The middle one is the king at the time and I can't remember who that is, the one on the left which is backed by honeycombs is the [local family name], family and that one over there is the bear family the [local family name], family and then the blue panel was awaiting something because the [local family name], farnily married someone and it was waiting to be theirs, and then the red panel with the three 
bits that looks like Stonehenge that is the [local family name], and they were the main donors.

Int $\mathrm{Di}$ : We did actually manage to contact some of the people who are related

Int Dii: Yeah

SD: Fascinating, and in terms of restoring this was that priority wise with the roof....

Int $\mathrm{Di}$ : This was after the roof and yes the lead was deteriorated and...

Int iD: The south one was done in $1987 / 88$ and this one was done 10 years later in $97 / 98$

SD: And that was presumably because of financial issues

Int Dii: Yes we had to earn the money!

Int $\mathrm{Di}$ : And yes when we had done all the serious stuff to keep the building dry then this was necessary to maintain it from deteriorating any further and also we had some major movement in the walls and so part of the budget was to take out all the pointing and investigate and then you have an amount to solve the problem if it was A, B or C. And when they actually took the pointing out they looked in through cameras and that sort of stuff but then, then, re-pointing it in lime mortar as appose to Portland cement the problem has been solved and apart from a few hairline cracks which is usual in plaster we haven't had any big crack appear.

Int Di: And that's why we knew the window needed doing, and ever since I have lived here, because I have been secretary of the PCC for 25 years, there has always been a tell tail crack on this wall from signs of movement and it has only been miniscule and then of course there was, at this top corner the lead started to come apart and you could see daylight through it and that is when we decided that we needed to get some professionals to look at it to see what was wrong with it and what needed to be done.

\section{SD: And that decision is made by?}

Int Di: The PCC

\section{SD: And do you get advice and guidance from the diocese?}

Int Di: When we, the, the projects are initiated in the PCC but when it gets to a certain stage you need some professional advice and the next port of call is the diocese, and then they will say 'you have this company, this company and this company who have done windows in the diocese 
before' so you contact them but only one was able to do it as the others were tied up doing York minster and were tied up for years and umm so that's what we... Have you ever been to Wells cathedral?

\section{SD: Yes I have}

Int Di: It's wonderful isn't it? We actually visited this place in wells, its just round the back, it's just a little shacky place just round the back and we went into the cathedral to have a look at the glass there and it was beautiful, have you ever been, yes of course you have, he used to sing in the choir

Int Dii: Is there anything else you need to know? The information is all there

\section{SD: And is the information produced so that the local community know what is going on?}

Int Di: Yes, the only thing we didn't do, which I wanted to do, was have a board with a thermometer on it to show where we were

Int Dii: We did that for the roof

Int $\mathrm{Di}$ : Yes, and we communicated that sort of information through the parish magazine umm not on a monthly basis but when it was needed or when we needed to look ahead. Because obviously there is an art in fundraising, if you fundraise too quickly or you are seen to fundraise too quickly, it seems to diminish peoples enthusiasm to want to give and so you have to be creative in what you say, and 1 am involved in fundraising for another church and we are trying to raise $£ 1.5$ million, and we had an enormous surge to start with that we haven't communicated with the wider public because doing too well too soon they will say 'ok they are fine they don't need my money then' and we would rather have 100,000 people give $£ 50$ than go to trust funds and get $£ 60-70$ thousand pounds as because if they contribute they feel part of the process and its an important part of the community you know fundraising.

Int Dii: We don't really know how old it is but on here is a picture of King Charles in the oak tree and whether that is actually the time. And some people look at it and say oh it isn't really that old (Speaking over each other)

Int $\mathrm{Di}$ : This was actually, I can't think of the word, anyway man in tree, they thought the carver or the man that painted it might have been called man-in-tree or something like that

\section{SD: Ah}

Int Di: Might have been something like a play on words. 
Int Dii: And the cross keys is St Peter isn't it, it's carved into the tree. And this is the window that I wanted to show you, it isn't the oldest one (can't hear voice distorted). And over hear it says '[gives reverend's name], Vicar here in 1911'. And this this is a picture of St Peter with the cross keys, [this churches saint] with the Bear, there is a story about [this churches saint] having a boar or being able to control a boar, but the, the other story is that she had a pet bear but we don't know how true it is, about 400

Int $\mathrm{Di}$ : You see she wanted a chapel and the bear went and laid down and in the parody of...

Int Dii: Yes, Doco her brother said he would build her a church where the bear rested and apparently it was just here in the chapel, and that is why she has the church in her hand, rather lovely don't you think? Very sort of...I can't remember the name. And this is St James with his shell. And St Mary, the Blessed Virgin Mary I think it is Beautiful especially how they use the glass to depict the jewelled edge to the cloaks

\section{SD: Yes}

Int Dii: Really lovely isn't it?

Int Di: And originally the [raridoes?] here was high, you can see, look right up to the line in the glass so they had only bothered to put in stained glass up to there because the [raridoes] stopped at that height. And for some reason, lord knows why that was taken down, god knows what happened to it and then this one was built

Int $\mathrm{Di}$ : It's quite new

Int Dii: Yes, 1951

Int D:i The family that lived in my house, they put that up and they had previously put that one up in 1983

Int Dii: I don't like that one, I think its dull

Int Di: Yes, well its sort of... if it were cleaned it would be absolutely wonderful, I mean all this green (cleans a bit)

Int Dii: Really, Oh gosh yeah

Int $\mathrm{Di}$ : Someone said that this was Fern Jones, the way that their faces have been depicted, very Fern Jones don't you think?

SD: Yes, they are very sort of...

Int Dii: Romantic?

SD: Yes 
Int Dii: I think that they are lovely.

Int Di: But with regard to keeping the church...the congregation is small umm the burden of $£ 21,000$ a year rests on it. And we have a concert every year that makes anywhere between 1 and 3 thousand a year and [Intii] organises the fete which makes, averages $£ 3000$ a year..

3 and a half

Int Dii: Yes, 3 and a half a year and then the collections you know every Sunday which average...

Int Di: Between 50 and 90 as its 1500

Int Dii: ..and umm then

Int Di: We have visitors

Int Dii: Yes, we sell the cards at the back and then people give donations

\section{SD: Do you make a lot of money from tourist coming in?}

Int $\mathrm{Di}$ : Well, it's always better in the summer when we get quite a few people coming in on holiday. And it was quite good when we had the window because it was in the press all the time and then we would do something or buy something

Int Dii: But we don't get a huge amount

Int $\mathrm{Di}$ : No, not enough but we, we, really have a shortfall of about 2 and a half to $£ 3000$ a year which as we said, our savings, which were an overraising of funds from the roof were in the bank and you know it, you know, we have enough for 2009 and 2010 and then we are in trouble so we have got to try and get the rewiring done and the kitchen and then we need to have more events throughout the year more consistently to raise, to guarantee that the amount we raise plateaus at the $£ 3000$.

Int $\mathrm{Di}$ : But I think it is going to take at least 5 year to raise the money to do the kitchen and the electrics

Int Dii: Yes, yes

SD: And are you very badly affected by the cost of heating and lighting and so on?

Int Di: Yes, I mean we have just had our oil stolen.

Int Dii: £200 worth 
Int Di: Yes, and that cost rested with the congregation as we had to fill it up in order to have a funeral and then the money from the funeral went straight to the RNLI and we turned the heating on 24 hours before the funeral and then someone came and stole that and you know our electric bill and our oil bill are quite high, and you know apart from that our biggest bill which is the parish share to the diocese is the insurance, and you know you are locked into using ecclesiastical insurance because that's the was it is and you know um we have already had to increase our excess to a level where we would never make a claim, in order to keep our premium lower than they otherwise would be.

Int Di: Yes, we could claim for the oil that was $£ 200$ as the excess is a thousand

SD: Oh dear. So that is sort of...

Int Di: So it's only any use if there is a disaster

\section{SD: Tree through the roof or something?}

Int Di: Yes

Int Dii: They get you whichever way you turn

Int Di: Money for old rope really

Int Dii: These are quite nice, the angels are quite nice. [another volunteers name] has been taking photos of all the pieces around the church as we are just about to publish the new service booklets and they are going to be illustrated. And here is a good story about ah bringing ourselves into the $21^{\text {st }}$ century. Many years ago it was discussed that we should possibly take this screen out and use it at the back of the church for the kitchen and vestry idea. I simply suggested that we move the screen from that set of pillars to this set of pillars and take away the Victorian choir stalls, and therefore making a screen edged stage

\section{SD: Yes}

Int $\mathrm{Di}$ : And then we could move the vicars station up here or make it portable, and move the lectern up here and then make these portable and just sit there. And then you could just leave those there and use these from ecclesiastical carver or whatever. Then you would be in a position to, I have been dying to have in a symphony orchestra to have a fantastic concert, we cannot do it because we don't have the room for a 27 piece symphony orchestra where as if we had this room we could have them here, and that would make the sanctuary even more special and then we have the space here and we could wire it when we do the lighting for performances and stuff, then we could have regular, very up market, terrific, concerts that would then bring in the appropriate 
income. But everyone said 'Oh my god, over my dead body, those are the choir stalls, I used to sit in them when I was a...' but no-one sits in them, even when we had the cathedral choir for the rededication of the window they sat at the back near the organ so the organist could hear them sing and do the prompts. So its of no use at all and, I mean, you know, beautiful as it is it is only Victorian and you have to sacrifice something in order to look ahead. But then you could reduce the size, make them portable, have rings in, like sedan chairs and lift it up, you know so at least have flexibility.

\section{SD: And are people very interested in keeping it the same then?}

Int $\mathrm{Di}$ : The words we hear here, I would love it to be embroidered into a kneeler, 'but this is the way we have always don't it', and the way we have always done it means that we are losing three grand a year.

\section{SD Right}

Int Di: And that is a problem, and here is the thing about heating, they put in this well here, and one up there. And the chimney that goes out to the churchyard there, and they would like a fire out there to create a draft and they would like the boiler and it would suck the smoke through. There is the boiler there and then a set of steps going down through there and we had a cottage in the car park and the man used to lived there's sole job was to heat the church and keep the boilers running so when they put this system in, it is obviously a new radiator compared to the others we have got, they put it through where they used chimneys to run the pipes through so it has really been...

\section{SD: Fascinating, and that was done presumably with minimal impact?}

Int Dii: Yes that's right, yes.

Int Di: I was just explaining the heating system

Int Dii: And that, this is these statues

Int Di: Come and have a look... who brought this piece of carpet in? I wish they wouldn't, either get a new runner or don't bother, this old remnant isn't good enough. But apparently this came from the tower in Bodmin, at one time, and apparently $7 \mathrm{~s} 6$ they paid and they were, you know you can see part of the tree there you know.

Int Di: And what was the name of the man? Apparently he should be lying out like that but he is holding, it's the base of the tree of Jessie

SD: Yes, you can see him holding it there and the branches leading right up. So this was the one that was smashed?

Int Dii: Yes, or broken in transit, but when the desecrated the priory in Bodmin... 
Int Di: Yes, we don't know much about how it came to be here, but there again that is very dirty isn't it?

Int Di: And again, that was put in by the reverend [gives reverend's name] when he moved the altar, and that is Cornish granite and Cornish slate and the candles and the cross are made of Cornish copper. This altar so entirely Cornish.

SD: So even historically people have been trying to keep the theme of this church very original?

Int Di: Yes, yes

SD: That's really interesting. So in terms of lighting, what are you planning?

Int Di: Well we've only had a meeting this week to find out how we would go about communicating our needs to the lighting designer to put it on a computer to actually computer generate a set of drawings that will show the effects of our choices. Umm we aren't thinking of really changing the sources of our lights but we just need to enhance a few areas that are darker than they should be umm probably want obviously to bear in mind that we need to use energy saving bulbs and we would like to think we could reduce our electric bill long term by having the appropriate type of fitting and so on. Um the only major addition will be bringing power points to this point of the church so that we can plug our amplifiers in without blowing the fuses, and we have a crib here at Christmas and we need to plug that in and we have extension cords and we have a tree over there and we have extension cords and they are dangerous. And, and so, so we want to come into the $21^{\text {st }}$ century and beyond with a design and an execution that no one who is alive no will ever have to do anything to again

Int Dii: We have actually put in a hearing system, which not only allows the priest to have a mic here but also it has the facility for the people with hearing aids to be able to hear.

\section{SD: So it has a T Loop?}

Int Dii: Yes, that's right but unfortunately most of the congregation claim their hearing aids don't work or they forget them so they are none the wiser of what is going on um

Int $\mathrm{Di}$ : And people when they get into their 80 s sometimes can't cope with hearing aids and we have 2 of them here they can't cope with how to operate them and they just can't believe that what they are hearing is hearing, they just cant cope mentally with it

Int Di: The funniest story is that we had a concert in the church last year, it's so funny I just loose it when I think about it, and [names individual] 
Mum [gives name] was sitting next to me and she suddenly said 'oh my god my hearing aid has gone', and I said 'where is it?' and she said 'it must have fallen out' so anyway she reaches down and picks it up and says it won't fit I don't understand it and she had picked up a cocktail sausage that had been distributed during the intermission and she was trying to stick it into her ear and I said '[gives name], I don't think that is going to improve your hearing' and she said 'why' and I said 'because it's a sausage' she hadn't brought her hearing aid at all, she hadn't brought it with her

\section{SD: And so do you think the work that is being done to the hall and making that more accessible has made it....}

Int Di: Yes we can't believe what an improvement it has made, we can't believe that we didn't do it before, it took 2 year, or was it more than two years? From when the idea was put forward to actually getting it installed

Int Dii: You see the thing is the opportunity, and it's well known that the power of the committee is judged by its ability to say no. And progress is painfully slow, and also with a big committee you always have a handful of people who do the work and everyone else just sits there and feels important, and it becomes an important part of their social calendar

Int $\mathrm{Di}$ : And because this is Devon and Cornwall none of us are Cornish, we are all incomers and there are very few Cornish left, but they don't want anything changed, their attitude is over my dead body

\section{Yes, do you think that...}

Int $\mathrm{Di}$ : I can say this because I am from South Devon, but have spent a lot of time abroad and I admired my house for 10 years before it came on the market and when it did I said right I am packing everything in and I retired from everything, retired from work and moved here, and I come from South Devon, and there was a farmer, who was unfortunately murdered and I was unpacking and I was a bit depressed as I had just left my lovely life in America and I was a bit depressed and I went down to the pub and the only person that I knew, apart form my sister, who lives in Wadebridge was the landlord of the pub and so I went over there for a glass of wine, and after a while of hiding his beer thinking I was going to steal it, and he looked at me, he said 'are you the person that has brought the big house?' and I said 'yes', and he said 'ow I hear you are a rich American', and I said 'well that's not true, I'm English in fact I'm from the West country', 'oh are you from round here?' he said, 'I'm from South Devon' and he said 'oh that's much worse than coming from America'. So the first person I met I thought what am I in for, but he was winding me up and the next morning there was a parcel on my windowsill and my house is $14^{\text {th }}$ century so you step down into the front porch and down into the entrance hall, which is how they used to do it, I don't know why, I opened the door and this massive string bag about 
this high fell in through the door and landed on my feet, daffodil bulbs, hundreds of them and it was the farmer who had left it at the door. And he didn't even drive down my drive he parked at the end walked down and walked back so his land rover wouldn't make a noise, and I planted them, and as I say he was murdered and every year they come up and I think of him, it was a lovely thing to do and a terrible end for this interesting old Cornish man. Very few of the Cornish people in the parish actually do anything

Int Dii: Yes, they are very happy for us to come in and organise things, and they do heip a lot but they don't actually instigate, no

Int $\mathrm{Di}$ : And they say no a lot in the meantime

Int Dii: And over my dead body

Int $\mathrm{Di}$ : Yes, in fact our old vicar, who has retired, there was this lady, the second oldest lady on the PCC, she is only 89, anyway there was this subject on the agenda, and she said 'over my dead body' and someone else on the PCC said 'that could be arranged'. So it's like the vicar of Dibley

Yes when she was here, she has retired now but when she was here it was very much like the vicar of Dibley, she has terrible angina and the solution is alcohol, the angina has been accelerated by the cigarettes but its helped by the alcohol so she brings a little bottle to church, on day she dropped her handbag and the bottle rolled out, and it rolled across the floor and hit the central heating pipe and there was this awful thud roll, clunk. And when we had our new vicar I said to him 'just a word to the wise, if you hear a thud, roll, clunk it just means that Mrs $X$ has dropped her handbag and the whiskey bottle has rolled out'. 89 next week!

SD: In terms of maintaining a constant congregation number is that an issue?

Int Di: Yes, I mean its always low in the winter time, between 15 and 20.

Int Dii: With the family stuff we have had as many as 60 and with the concerts like Elvis doing the gospel stuff we had just over 80 and when we had our first gala concert with some well known sopranos we had

Int Dii: Yes a church full

Int Di: Yes just over 330 people, you know that is what we have to aim for, this gospel thing showed us that we have to do things like that more regularly and it made what $£ 560$ ?

Int Dii: $£ 558$, yes I banked it. We only charged $£ 6$ a ticket and we gave them refreshments afterwards free so it was very inexpensive. But it was a very good way of bringing things together. And half the fun of fund 
raising events isn't the financial but the community spirit and developing that community spirit.

Int Di: But the first three letters of fundraising is fun so we really should remember that. And it does work, we get lots of people coming to the fete, lots of families and we always advertise it as being a family, visitors, come for all the family.

\section{SD: And is that helpful in getting you new congregation members?}

Int D:i Well that is what the idea is but it doesn't really work, one of our younger members on the PCC, lives just over the road here and he started a family service and that developed into a parish party that we have once a month and that is very popular with the families and they are a lovely group aren't they

Int Dii: Yes

Int Di: And we had a pet day in January and they all brought their doggies and rabbits and cat baskets. And the vicar was here and they brought their pets up one by one and they blessed the child with their pet. It worked really well. We had about 60 people there.

\section{$S D: \quad$ So its about keeping it varied really?}

Int Dii: Yes, and about thinking of something new, you have to add new things

Int Di: But at the same time keeping the traditional things going, and while we don't use the book of common prayer for our morning service we have got a common worship sort of thing, we have communion every Sunday but we have some people in the parish that like the old, and they would come if we did. But I find it disappointing that in the church group it tends to bring out the worst in their personalities sometimes, rather than bringing out the best and um I wish we could all just...I mean you can understand religious wars as people are so passionately strong about it

Int Dii: We do have evensong here in the evening which a little group of people come to

Int Di: Yes, between 5 and 7 people. I think it is a shame there isn't more

\section{SD: So it sounds like you have quite a varied use really?}

Int Di: Yes, and the bishop wants us to have more, evening prayer once a week and morning service once a week

Int Dii: We don't have a morning service in the week at the moment

Int Di: No St Endellion, one of our..the church on top of the hill but they are a collegiate church 
Int Dii: Is there anything that you would like to ask us particularly?

SD: Well I was going to ask you about the balance actually, I mean you have said about the economic sustainability being the majority thing with that $£ 3,000$ being key. Is that the key one in terms of a balance between maintaining what the congregation want with balancing the needs of a historic church?

Int Di: Well, I would say that this church, I umm, have been here 10-12 year. This church has never withered at a challenge that it has met, it takes a while to go through the motions, by the time you go to faculty, decide on the fundraising, but this church has never faltered in recognising the need

Int Dii: And that is one of the things I can see, that hazards in putting in this electrical plan, as it has been mooted that with the decrease in congregation there is a possibility that this church will close in the next 15 year. Which horrifies us

Int Di: We look at it as a challenge. We want to park the idea in people's minds that if they don't support the church on a regular basis it won't be here for when they need it for the regular births, marriages and funerals and you don't have to be a member of the congregation but you should understand the need to contribute and I want to see something in the parish newsletter magazine to remind people at the time when we have our annual meeting to be very creative in writing an article to plan this seed in the minds of the readers about how much it costs to keep these doors open

Int Dii: About 10 or 15 years ago, I did actually put a notice up before the AGM that the church was going to close and we had a lot of people came because they didn't want the church to close, so you get the impression that they want to keep it but they don't actually want to put their hand in their pocket to help us to keep it going.

SD: And what would happen if it did, would everyone have to move to one of the other local churches?

Int Di: Well by the time it closes half the congregation would be dead anyway unless we get more people in

Int Dii: And that is half the problem that I was putting to you, unless we get people agreeing to a plan for heating and modernising, is there any point, if we have a kitchen going in is it actually going to be used? Are we looking because we want to do it now I mean is it viable?

\section{SD: But would not modernising be an additional reason to close?}

Int Di: And you can't have the events in it if you don't that bring in the money that you need to keep going. I mean If we could have the facilities and 
we could have 4 concerts a year producing $£ 3,000$ each, you know they do it elsewhere they have 300 people a night for 10 nights at Easter and 300 people a night for 14 nights in August, its been going on for 50 years and because of the festival, they have a friends organisation for the festival and an extended friends organisation for the church and the friends have either written a cheque for the $£ 20,000$ rewiring scheme but because of the existence of the festival the benefits are enormous. And while we shouldn't try and copy them we need to do something that we can do and sustain in order to take the pressure off because if you could develop a reputation, you could build on weddings etc and build on the fete and the parish suppers and build it up that way.

Int Dii: So as you can see we have lots of ideas about what we would like to do to modernise but it's the money

\section{SD: So it's the key factor then?}

Int Di: Also before the money issue its just as [IntDii] said, if we went to the PCC and said, right we are going to do we are going to do that we are going to put a mezzanine floor in and a kitchen and the total budget is $£ 100,000$ they would all go don't do it. You really have to sell it to them, so say the advantages of doing it are this and this and this and it will enable us to raise $£ 12,000$ a year in a good year towards the running of the church and in a good year that's the sort of income we need so we need to have the wiring upgraded and the kitchen to cater for these events.

\section{Int Dii: And for modern health and safety}

Int Di: And I was at a funeral at a church in Devon, my family church and they have a kitchen there and they had a funeral with 400 people and they brought in a catering company to use the kitchen and did a reception, a proper buffet lunch for 400 people and they paid the church hundreds and hundreds if pounds for the privilege of doing it rather than going to a local hotel.

I mean these landowners that donated the window we don't have people like that these days.But in those days when I was looking at the accounts form the early part of the 1900s the heating bill was $£ 117$ and 6 and our last oil bill for 500 litres was $£ 300$, and you don't put more than 500 litres in in case someone comes to steal it again

Int Di: And we have the coat of arms for King Charles because Cornwall was a royalist stronghold during the war and it has 1661, ours is particularly good coss it isn't too big and its in relief which is good as most of them are just painted onto a board. It could do with a good clean. I think 500 years ago this church must have been quite well endowered. They must have had some wealthy people who could by things like that. I always think ours is one of the best and it would be nice to have it cleaned. 
Int Dii: We had a great problem with this window, when we had high winds and heavy rain the whole thing leaked and we had to get a specialist man into do that to um seal it all um and clean it. And then we had a big gale about a year later and it still came in, all down the sides and we had to get him in again

Int Di: We have always been told that it isn't the church it's the people.

Int Dii: Yes it's the church and not the people

Int Dii: I think that those of us who are involved in the church would like it to continue especially while we are here and I think that we look at ourselves as, I can't think of the word, custodians, yes custodians so that we are sort of improving it to the best of our ability for the next generation to carry on, that's what's happened over the last 100 s of years

Int Di: I want to come into the church and feel minimised, I mean the architecture makes me feel about that big and I think we all need knocking down to where we really fit in things especially when you see what is going on in the world and the country, with the credit crunch and all the money that the bankers have been making for selling nothing, you know you get grounded when you sit here and look at the wonderful architecture and that is why cathedrals are so wonderful and enormous. It's the theatrical side and there has obviously been a need though out time to do that and its obviously defying all the rules, the old tried ways of life and we are obviously paying the piper now as we are deviating from well structured and laid out rules of society, and at the end of the day we are just animals, developed and well educated animals. And when you come here and take communion you feel uplifted.

Int Dii: I was a bit like should we have someone dressed as Elvis in here but I heard that he was good and he was good, it's about trying new things

Int Di: Well it's about a balance isn't it

Int Dii: Yes, that's right, we have become a very celebrity orientated consumer society and we need to recognise that to bring people into the church to use it because this guy that did Elvis said 'use your churches they are wonderful buildings' and he is right isn't he

Int Di: Yes

\section{INTERVIEW CLOSE}

SD: Standards thanks and re-emphasis of participant right to access transcript. 


\section{Interview E}

SD: Standard introduction requesting permission to record and providing an explanation of all ethically required statements

\section{Tape recording begins}

SD: What I am trying to get an idea of today is whether you have started any projects recently and whether your approach to managing the church is sustainable. And by that I mean environmentally sustainable which is what everyone associated with recycling, using environmentally friendly materials but also economically, so whether running costs are a problem and things like that and socially so maintaining congregations and providing information for visitors.

Int E: Yes fine

SD: In your questionnaire you identified that you already do a number of things, you recycle and you have a wildlife area...

Int E: Yes that's right, up in the top corner of your churchyard,

SD: And was that a specific project?

Int E: It's something that has evolved over time, and in fact my colleague who is the other church warden and who is looking after the flowers now set up a group and they decided to do a survey of the churchyard in general, of the flora and fauna initially and then it spread and they decided they would try and leave a corner of the church yard. Obviously this will eventually be taken over by graves etcetera but it is very much a wildlife sanctuary and that is something they keep a monitoring on all the time.

SD: Is there and annual monitoring?

Int E: Yes that's right.

SD: And was that just one persons idea that got taken forward?

Int E: It was something that just evolved I suppose from a group of people.

SD: And when you want to set up a project like that or the recycling is there a specific process you have to go through?

Int E: Not really, it's a fairly ad-hoc basis. We just get together with the congregation and ask for volunteers and take it from there

SD: And in terms of any larger projects have you done anything like putting in new heating or? 
Int E: No, we did about 4 year ago put in a new boiler which is much more efficient and has cut down the cost of our fuel bills, and we also put in these magnetic collars on the fuel pipes and things, if you have heard of those?

\section{SD: Are those the ones that tell you how much you are using?}

Int E: No they supposedly move the fuel along at a better pace and is supposedly cost saving, I think it probably is. And the boiler is much more efficient than it ever was before. The big problem is with a building like this you are listed and therefore what you actually can do is very limited. We explored the concept of solar panels but being in an area of outstanding natural beauty plus being grade 1 , um class one heritage, it's almost impossible to get those things off the ground. But we have got them in thought but whether we can actually put them into practice with the parameters which we have to operate in is very debateable.

SD: And is that because you can't physically do them or because if you were to do them they would be very expensive?

Int E: No, basically we haven't a position where we could put them that would be out of site of the public and therefore out of site of the area of outstanding natural beauty that we are in. And although the national trust is um also very forward thinking it is very difficult to get them to again put things on the horizon that don't blend as such.

SD: So very limited, I suppose, as there is access to the whole building?

Int E: Yes, we thought about the top of the tower and the valley between the two roves, which is there, but because of the contour of the slope it is totally visible from the top of the hill so anyone coming down there can see into the tower and the valley of the roof so again there is no where that is viable that we could put these things that would be out of sight without encroaching on the building structure.

SD: So if, it were, the legislation were to change in the future would yourselves and the PCC be willing to...

Int E: Yes, we've done a lot of research on this and we have looked at different situation around the country and at the moment our hands are tied.

SD: And would you say that your approach to managing the church does sort of take into account the environment..

Int E: Yes it does

SD: $\quad$...as far as possible.. 
Int E: Yes it does, because we've got the lighting that we now have on is low energy lighting, believe it or not, it's come on so much in the last couple of years which I am sure you are aware, so it's very hard to tell the difference, but it has made a lot of difference to the lighting, the bills, and recently we have stopped using, we until recently used to have the tower lit up at night which was quite costly, but we have restricted that now in conjunction with our advisors in the insurance company who say that it is not necessary and we have intruder lights now which come on and off in case any animal or person come near. So that saved us a lot of money and energy as well. And also we had lead stolen from the roof this time last year and they think it was probably an advantage to the theft to have it lit up all the time you know so now we don't. We are constantly rethinking these things all the time and contently looking for ways with which we can improve our efficiency because basically it boils down to money, and at the moment we need about $£ 1,800$ a week to run this church and anything we can do to reduce that cost is beneficial.

\section{SD: And is a large chunk of that as well going on the diocesan share?}

Int E: Yes, this year the diocesan share is, this year, somewhere in the region of $£ 54$ thousand, so just over a thousand a week. Probably about $£ 700$ a week we need for running costs as we are in an exposed area it is a very old building and it needs constant repair and maintenance

SD: Your maintenance budget is quite high then?

Int $E$ : It is now necessarily quite high, yeah.

SD: And in terms of sort of generating revenue, which is terrible as I know churches don't generate revenue, it is presumably from tourism and congregations? Things like that?

Int E: Basically our income comes from the congregation, planned given, where basically we can claim our $28 \%$ back on income tax and events, we have started doing a lot more social events now. In the last few weeks we had an open day here on a Saturday, followed by a barbeque, including the bishop's visits, which is the planned arrangement this year in the diocese. That raised a reasonable amount of revenue, and last weekend, our organist owns a fairly large estate down at the banks of the Yealm and we had an open day down there with cream teas and that raised some money for us, so you know it is constant social functions rather than anything else.

SD: And in the current climate with oil prices going up and everything becoming more expensive is that something that you will do more of in the future? 
Int E: We will probably, well it's a situation that we are in at the moment, we lost the full time vicar last year, he retired on ill health grounds and since then we have a part time priest in charge so an awful lot more comes down to the church wardens and we have decided that we want to reintegrate as it were with the parish and with the village and have a lot more social function, and we have noticed that the congregations have started to rise since we have done that, that is no reflection on the previous priest at all it is just the way we have operated.

SD: And are you sort of attracting more younger people and families that way?

Int E: We attract quite a lot of young people because we have a very big wedding number here, last year we had 72 weddings which is a bit too much as it is a lot of pressure of the people of the church and you don't have the same sort of time to deal with the parish. This year we are down to 54 and that's a happier balance. And in doing that it created revenue and it also brings the younger element into the church and we have now noticed that it has starting to snowball because those couples that get married a couple of years down the line bring their children back for baptisms so we do a tremendous amount of baptisms as well as weddings so it snowballs onwards and it creates a better parish environment it think.

SD: So in terms of maintaining your congregation you don't see any problems in doing that?

Int E: I don't see the problems with the congregation, no not at all.

SD: In terms of tourism do you, sort of, get lots?

Int E: We get lots of tourism but we don't make any money out of it as such. Because the church is open from 8 o'clock in the morning until about 5 o'clock at night, $4: 30$ or 5 o'clock at night. A bit less during the winter times obviously and we are on the coastal footpath as you are aware. We get a tremendous number of walkers coming in even on services on Sunday, we just get people on the footpath and just attending the service and then we never see them again, we don't know where they are from necessarily, we do have a visitors book but, you know, I have come down here during the day and there have been 20 or 30 people in here but no entries in the book, its an unknown factor which I did in fact say in the return. And we do know that we get people from all over Europe and I put an estimate in there at about 600 and I think that is a very conservative estimate because we probably do 600 children alone from school visits. Because we are in a happy position here where we have the [names visitor facility] centre, we have the national trust um nature reserve and the church, So it fills in their curriculum quite well as they come out for a full day and do all three.

SD: I suppose you also have the advantage of the fairly large car park at the bottom as well. 
Int $\mathrm{E}:$ Yes, yeah, yeah

\section{SD: Do you have any issues of access in terms of..}

Int E: Not really, we are totally surrounded by National Trust land, even the car park is national trust and our access route in is national trust, which we rent off them at a fairly peppercorn rent but no, um I wouldn't say with have problems with access except during the summer months which is very busy, particularly the marine centre and if we have weddings here sometimes the village nearly comes to gridlocked state, so that is you know that is that problems but other than that no.

SD: So in terms of information for tourists, you said in your questionnaire that you have leaflets

Int $\mathrm{E}$ : Yes, we have what we term as our book table at the back and we have the history of [this] church, we have got various postcards and various information relating to Christian Aid and various other items that we deal with and they go quite well. In fact, we have just got it at the printers now, it is an upgrade of the history of [this] church to incorporate newer things because this [indicates stain glass window] was put in in 2004 as the millennium window, so in fact that one [indicates other window] is term of the century 1902 to celebrate the millennium and this one is for the millennium 2004, it took us 4 years to get permission to put it in. [laughs]

SD: In terms of updating, you said you have it at the printers now for a newer version, but how often do you look at updating it?

Int $\mathrm{E}$ : We, look at it on a regular basis, but it depends on the sales, we have decided now that we want to try and do this every three years so that we get enough, um, booklets at a reasonable price because if you buy very smaller amounts its much more expensive and we worked out we have got a balance there and if we can update upgrade every very three years then we can buy in sufficient quantity to get rid of them in that time. And we are talking in terms of 2000 to 2 and a half thousand in that 3 year period.

\section{SD: So quite a high number then?}

Int $E$ : It's quite a high turnover, yeah

\section{SD: And is there someone taking money for those?}

Int $\mathrm{E}$ : No, it's purely on trust, purely on trust. We work totally on trust here, I don't think we lose out, I'm sure we don't. It's a bit of an unknown factor, I am sure there are people that do that. Also the car park, we have a little box there asking people to donate, some do some don't, and again it's based on trust. 
SD: So again at weekends you don't have any security issues or anything like that?

Int E: No, this is something that concerned us a great deal after we lost the lead on the roof last November and since then I have commission a survey by Devon and Cornwall constabularies crime prevention officer for the area and also our ecclesiastical insurance assessor and both of them were very happy with the level of security that we have. Again it's a balance of trust.

SD: I suppose there are always quite a lot of people around here.

Int E: Yes, yeah, it's a very hard situation to access really as you just take people as you find them and that's it.

SD: You mentioned earlier about urr money out to the diocese. And what do you get out of that apart from the time of the priest?

Int E: Basically it's a sharing arrangement, um, it is estimated on your congregation on a degree, and historic facts about the amount you can give to the diocese. You get a full time priest, we don't at the moment, but usually you would get a full time priest, and you get all the facilities of the diocese, legal and commercial whatever, and its worked out the we have $x$ number of parishes in the diocese and each one pays according to their means. It all goes into a big kitty and then comes back out again. In fact, the cost of clergy amounts to something like I think $78 \%$ or $80 \%$ and a lot of the extra are taken up by clergy pensions and I in fact I think we go over the diocesan quota by about $20 \%$ which has to be found from other sources within the diocese, rental and things like that so...

SD: In terms of advice and guidance that you can get from them, is that readily available?

Int E: Oh yes, that ranges across the whole field, whether that's religious, commercial, structural or whether its anything you can name its all covered by the diocese.

SD: In terms of the structural part of it do they actually send someone to you? With any frequency?

Int $E$ : Yes, in fact last week, we are required by law to have a check every 5 years, which we term quinquennial survey, which is every 5 years we have that survey by an accredited architect/surveyor within the diocese.

SD: And are those instantaneous changed that you have to make straight away?

Int E: No, they scale it, um, when they look at the situation they will say, this needs to be don't urgently, this needs to be don't in 12 months and this 
needs to be don't in 5 years. Umm, when we had the last one 5 years ago we had quite a lot of structural problems that we had to deal with and they have all been dealt with within that 5 year period.

\section{SD: And is that your responsibility as the church warden?}

Int E: Yes

SD: And also the PCC? Is that something you have to, if a big bit of work needs doing as money has to be allocated, do you have to go through a specific process?

Int E: Yes, we have to get the agreements from the parochial church council, we advice them and we tell them what we need, and we are in charge of the overall running of the church, and at the moment with the part time priest we are also in charge if the whole religious aspect of the church as well, and responsible for being sure services are carried out, funerals are dealt with, weddings are dealt with and so on.

SD: Quite a heavy work load then?

Int E: Yes, it's a very heavy work load, yeah.

\section{SD: As your post is voluntary?}

Int E: Yes, oh very much, yes. Totally voluntary, and as an example yesterday $I$ dealt with a funeral, and if you take the funeral as itself, umm, you have got to go through the undertakers, then you have to go through and make sure you have an organist, make sure you have a verger, make sure you have all the bits a pieces to go with it, so it is constant phoning around getting things organised and I had to deal with 2 wedding rehearsals and two weddings on the phone yesterday as well. IN fact I think I probably had between 20 and 30 in and out phone calls throughout the day just dealing with parish matters. In fact we have also got a film crew coming down to do some filming so I am dealing with that too. It is an awful lot of administration sometimes.

\section{SD: Do you get a lot of interest from film crew?}

Int E: This is the first time. Yeah, this is a one off, we have never had it before to my knowledge, but its again an income so um.

\section{SD: And are they using it as part of a set?}

Int E: Yes.

SD: Because I know it is quite common for them to use historic houses. 
Int E: Yes, this one is an adaptation of a Rosamund Pilchard novel. So again it is country life and country living, and that's the theme as far as we know, yeah.

SD: You are obviously very flexible about the means of income then?

Int $\mathrm{E}$ : We are flexible but we have to stick to agreed criteria. No, we vet everything very carefully and make sure it doesn't demean the church in any way shape of form. So we have to be very careful on that.

SD: So to make sure it doesn't interrupt the normal service and congregation?

Int $\mathrm{E}$ : Yes, we must make sure it doesn't intrude; it must run in parallel with and not take over from.

SD: In terms of your congregation are they, sort of, very attached to the church building? As well as the congregation.

Int $E$ : Yes we have a very good attendance and we have 3 services on a Sunday, at 8 o'clock we usually have 20-22 people for communion. Morning services at 1030 we have, let me see [looks in book], 80 . Easter communion was 200 plus. It's $75-80$ to 100 most of the time on the 1030 service usually, and then again its probably 20ish in the evening at 630 .

SD: So in terms of when you need a project doing, like your new window or something like that, are they, are all the congregation very supportive.

Int E: I would say they are very supportive, yeah, and not just the congregation but the parish in general.

SD: So very much integrated with your community in general as well which is a key part of the social part.

Int $\mathrm{E}$ : Yes, it's a very community minded village. Not everyone goes to church and some go to the local Baptist church in town for reasons for themselves. They have a strong youth community there which we don't, because we don't have any building facilities other than the village hall for events.

SD: And is that set away from here?

Int E: Yeah, yeah, so that presents some difficulties with the younger element, but for example the barbeque that I mentioned earlier we all finished off eating in here and we cooked in in the car park and all ended up sitting in here to eat and that was great. We do the same for harvest suppers and yeah.

SD: I suppose you could get anymore building in as you are quite.. 
Int E: Yes, we are out on a limb here, yes really out on a limb.

SD: Right, urm, I think we have answered a lot of the questions here which is good. So in terms of the social sustainability we have talked about the congregation and we have touched on some of the economic and environmental issues such as recycling. I would assume that your priority of these as a church would be, the social sustainability aspect of it, or is the economic very much the driver?

Int $E$ : No I think it all goes hand in hand, it is all linked very much together, I wouldn't say that the economic situation is the be all and end all. If we did had problems paying our quota to common fund the diocese would understand our reasons whatever, so no we aren't a commercial venture as such. In any way at all, so no I suppose the social side, the community, the social and community side are the main aspect.

SD: So are the all very supportive, with the recycling and stuff? Or is it more driven by you as an individual?

Int E: No, we have recycling points around the site and we don't pay for the south hams to deal with it but we do have some of the congregation take it in turns to come down a month at a time and the they pass it on to someone else and they dispose of it in their own way. And very often if needs be sort it so it is looked after that way. But also at the back of the church we have, let me think, spectacles, we recycle telephones, we have just stopped milk bottle tops as they are inundated with them apparently and can't cope any more, we do paper, we do anything like that, clothing we take in for the shekinah mission and other sources. Yeah we cover quite a lot of things in that respect.

SD: And obviously, like with the milk bottle tops, you have a lot of support,

Int E: Yes, I'm not joking, hundred weights

\section{SD: And have you got any forthcoming projects?}

Int E: Not at this moment in time, no, at this moment we are fairly level. We have got another survey scheduled for the church yard, umm, we did a little bit of it with the younger people on barbeque day but it is planned that as we come through to the beginning of summer then we will start to compare and check notes with what we have done over the last few years. And also its easier to do because once you get the longer evenings we get working groups of parishioners come down and do little odds and jobs and do little bits outside which is good.

\section{SD: So great enthusiasm in that way?}

Int E: Yes 
SD: Right, we have covered social, in fact we have covered quite a lot. So the management is through yourself as the driver at the moment. Are you looking to get a full time priest in?

Int $\mathrm{E}$ : I don't know, with the economic climate in the church at the moment in and in the country in general um I think it might be a little while before we do, there are certain factors here which are unique to this parish. As when we have had a full time priest before he has also been in charge of the naval establishment which used to be HMS Cambridge which closed 4 or 5 years ago now, and that lost us something like 12-14 hundred number of congregation and so that has to be taken into account when we think about another full time priest. So it is very difficult to think what the diocese is going to be looking at to provide with.

SD: In terms of that does that mean you have to take on a lot more personal responsibility and is that something that would you could arrange to have more churchwardens or something?

Int $\mathrm{E}$ : No, you are only allowed to have 2 church wardens and we serve on a yearly basis but its anticipated that when you take it on its for a minimum of three years but you are reselected every year and the most you can do it 23 year terms and you are supposed to stand down at the end of that 6 year term and um it's a good way that of making sure you get new ideas and new aspects coming through, but if the need arises as the situation is at the moment they might decide you can go on a further yearly basis, if you are willing to and if you are capable to for another couple of years after that but that has to be approved by the arch deacon and the diocese.

\section{SD: Is there a long line of people waiting to?}

Int E: No, not really, no. The big problem is now most people are in full time jobs and I am lucky enough to be retired, as is my colleague and we can afford the time and possibly the, I won't say the finance, but it doesn't come...you ...there is obviously an outlay as you are travelling around a great deal, but for somebody who is working full time to deal with the work load I mentioned yesterday with 2 weddings, a christening, a funeral, two lots of asked and the film crew, to accommodate that you wouldn't be able to work full time, because you would end up coming in at 9 o'clock in the evening after a full day of work. You won't be able to cope with that. It presents difficulties and I can see difficulties in the future, not just for the church but for any voluntary organisation.

\section{SD: As people are forced to work longer for financial reasons?}

Int E: Yes, yeah. 
SD: In terms of, harping back to the physical structure, because you are located in such a protected area and your building has such high listed status, is this the main barrier that stops you from doing things?

Int $\mathrm{E}$ : Yes, yeah, we do as much as we can, yes. Which is where we started off, we are limited but we do as much as we can. So we have low level, low energy lighting, we have the most efficient boiler we can get. We don't have double glazing because of the type of windows that we have got. You can see the structure here, you know, you can't upgrade it to bring it into the modern $21^{\text {st }}$ century so you do whatever you can and that's about it. Heating what I do thought out the winter is we have a time clock and what we try to do is keep it to an hour in the morning and an hour in the evening so it looks after the structure, we aren't interested in the people shall we say as they can put a coat on but the structure is going to be here for another 100 years so it needs protecting so just to keep the moisture content to a reasonable level is the main aim of the heating.

SD: Presumably if you need to re-plaster any walls or anything it would all have to be done in line with the grade one requirements?

Int $\mathrm{E}$ : Yes, oh yes, and the thing is you need a certain amount of damp within the structure, because if you start to put on excessive heating which we wouldn't do anyway, you would cause all sorts of problems with the wooden structure as it would all start to split, so you've got to keep that balance which ecologically is a good thing as it isn't using vast amounts of energy,

SD: So it lets you do your bit environmentally which maintaining the structure?

Int E: Certainly. That's right, yes.

SD: I think we have covered everything

Int E: Yes I think we have covered everything and more that I had down there.

SD: Oh and one think I remembered I was going to ask you quickly. Jumping back to it. In terms of you bringing in the lighting and the recycling is that practice that you share with anybody?

Int $\mathrm{E}:$ Yes, this is don't through the diocese as well, this is where you can get information. We have ....I can't remember the term he uses now but he is the chappy that looks after the whole object and aspect of ecology and energy saving within the diocese and goes around giving advice and brings out pamphlets every so often 
SD: And can he put you in touch with people who have already had it done and things like that?

Int E: Yes that's right

SD: That really was my final question; there is always one I forget to ask until the last minute. Once again, thank you very much for your time. I really do appreciate

\section{INTERVIEW CLOSE}

SD: Standards thanks and re-emphasis of participant right to access transcript. 
SD: Standard introduction requesting permission to record and providing an explanation of all ethically required statements

\section{Tape recording begins}

SD: What I am trying to do is find out if heritage sites, in particular churches, how they are managed and what aspects of sustainability come into the management process and by that I mean environmental sustainability, recycling, doing work in an environmentally friendly manner, social sustainability so basically maintaining a congregations and attracting tourists and economic so whether it's a...viable to keep going in the current economic climate and how you generate revenue and things like that.

Int F: Right ok

SD: And I aimed to cover most of that in my questionnaire but because I covered a range of heritage sites in that obviously not all the questions were appropriate to everybody.

Int F: Yes

SD: So that is what this phase of the process is for, and I am particularly talking to people from churches in an attempt to find out further detail about that sort of thing. Is that alright?

Int F: Yes, that's fine.

SD: Good, good, I have a range of questions. I saw you said in your questionnaire that you are in the process of putting in a new lighting system, or you are investigating doing that?

Int F: Yes

SD: And how are you going about doing that? Is there a specific process you have to go through?

Int F: Yes, if you have to do it in any church really, but especially if it's a grade one listed church like this you have to jump though an enormous number of hoops before you are allowed to do anything at all that impinges in any way on the fabric of the building, so with the lighting for example urrr we have to go through the whole process through the church of England faculties where you have to make an application to the diocesan advisory committee as it's called, setting out exactly what you are proposing to do, showing them detailed plans and so on, and they get very concerned for example if there are going to be wires visible or if you are going to nail something into the roof, or almost anything under the sun. And the DAC has amongst its members quite a 
wide range of specialists like a lighting specialist, and we are actually doing lighting and sound, to combine the project, and so all of those proposals have had to go to the full Diocesan advisory committee for a discussion then they have been referred onto the DAC lighting and sound specialists who have come to visit us in the church urr have made some suggestions on..we think this would be better here...or whatever we have then had to take those back to the company that we have asked to produce these plans, and there has been some direct discussions between the advisors and the company with us in the loop as well and urm once that has all been agreed and agreed with the advisors the revised plans have to go back to the DAC, which is the phase we are now at, and they have also got to be referred to the church architects...

\section{SD: Right}

Int F: Because obviously all churches will have architects, like all churches have to have a quinquenial inspection where we have a list to choose from of approved architects and the architects then...they are just asked for an opinions, they can't veto it or anything like that, they are just asked for an opinion, ummm and ok then you have to raise the money obviously, or you have to find the money maybe you have it already maybe you haven't, and then you get the green light and you can go, but you have just got to do it, having got the final faculty approval you have to do it within 12 months

\section{SD: Right}

Int F: As the faculty only lasts for 12 months so if you miss the deadline you have to go through the while process again. Which is one reason why things tend to get done rather slowly in the church of England but no we have got a number of faculties us at the moment, were also, we have got rather ambitious plans (coughs) for the whole new set of facilities in this area which consist of a new entrance, urr toilets, kitchen, urr and then an upstairs area as we have plenty of room going up here with urr a small meeting room and so on, urrm and that project is being called the arc because it will actually have the form of an arc and certainly that is a major project, we are looking at half a million pounds and we are looking at, clearly, we are going to have to get some grants.

SD: Yup,

Int F: To sustain that, coss clearly like most churches we don't have the fund for that.

\section{SD: And who would you go to for those grants, in the first place.}

Int $\mathrm{F}$ : We are exploring that at the moment, there are a range of possibilities, that ur, um lottery funding is particularly tight these days with the Olympic games coming up and lots of money being diverted urr in that 
that direction. It's fairly early days yet, we have the plans, we have been working with the architects for ur oh at least a year and a half if not two years and we have plans that have gone out to consultation with the congregation and we have had one or two fairly informal discussions with the DAC who have now approved the concept plans if you like, and the work will obviously be done in stages and the architects will just submit plans for particular aspects to the DAC sort of on kind of a drip feed basis, and that's quite a major thing as you have to move that font there. Now the font is the oldest thing in the church, it's a Norman font, and ummm so obviously English heritage get involved here as well and they can be very, very fussy and we have had some discussion with them as to whether we keep the base of the font, which we don't want to do or just put the font on its four feet as it were. And then you have got this lovely piece of Victoriana above it which personally I would happily put on the nearest bonfire, but for some strange reason the man from English heritage is quite fond of it umm but we want to put in a new font right at the intersection there between the west door there and the main entrance there, which theologically is a good place for it to be umm and we certainly can't have that monstrosity hanging down in that position

\section{SD: No}

Int F: So we are still arguing with the man from English heritage at the moment to see if we can just get rid of it, or as they suggested from English heritage 'wouldn't it look lovely hanging there?' above where we put the Easter garden and the crib over there, and I suppose it we have to put it somewhere it will be there, ah what we are hoping to do now is say that it has to be moved for health and safety reasons as it is over a hundred years old, it could drop off, and it weighs and awful lot, and it's a health hazard coss whenever there is a baptism the vicar has to stand at the top of the steps and he is holding a baby, or sometimes it's a bigger person, but its usually a baby and he has to climb up there and there is a real risk of banging heads on the beam. But I don't know it's just aside, that is just a side issue of course. So yes, we have a number of proposals like that, and we are hoping that in the next 5 years to bring in a new heating system. We have been looking at the possibility of some solar panels on the roof obviously once again English heritage wouldn't want any big solar panels visible from the outside but the particular design of the church means we could put them in the gullies (coughs) and no-body would see them unless they are flying overhead in a helicopter of if they are up on the roof.

\section{SD: So you are not overlooked from either side?}

Int F: No, no, no we have two sets of gullies that are completely internal and then those sets (indicates) that are external. That is a possibility but that is early days, we do have the, the chair of the parochial church council...the PCC the chair of the building group arrrm is very keen on green energy so he is having a look at those. 
SD: And has that sort of filtered through to the lighting and sound that you are having put in?

Int F: We are certainly considering that as the lighting is terribly archaic and ugly and very expensive to run, very expensive to run. And we estimate that with the lighting system that is being proposed the cost of lighting will be reduced by at least $70 \%$ as what we are having to pay, what we have to pay, at the moment. On the heating front we are still costing up what we will do... at the moment we have an oil fired boiler and we are costing up whether to stick with oil or switch to gas and that has been more of a financial consideration than anything else, and oil is actually not as expensive as it was whereas gas has gone up quite a bit, so there isn't a big difference between them. The big difference is however that we already have the oil, the supply system and tank everything like that as there is no gas in the building at all and that is going to involve tranches, and that then brings you into archaeologists running around making sure you aren't disturbing any bones and even though there are no doubt hundred of thousand of bones that have been scattered all over the place that have been messed up over the centuries, but if you have to go through that that is an expensive process, then you have the joys of drilling through very thick walls and English Heritage, once again, jumping up and down saying 'you can't do this you can't do that' and so I don't know which way that will do. I suspect, the latest thinking is I think to stick with oil, for reasons of simplicity I suppose, its urr, I don't know how much difference there is in terms of impact on the environment of either of them, (Coughs) and anyway that isn't as urgent as the lighting and the urr the arc. So they are our two major projects we are looking at, at the moment.

SD: And so in terms of looking at access to funding, you mentioned the heritage lottery one is a bit tight at the moment, do your congregation contribute a lot in terms off....

Int F: We are looking at having a major fundraising launch at the end of the summer beginning of the autumn, urr, and will undoubtedly get some money out of the congregation, and we are, our main concern is actually with funding from the congregation is to get in increase in the level of weekly giving because a church this size, this is the largest parish church in Cornwall, its expensive, its expensive to run and unfortunately a lot of people, a lot of regular church goers are just in the habit of urr time for the weekly giving here's a pound, or l'll be generous this week and put in two pounds, less than $20 \%$ of the congregation in terms of planned giving provide over $80 \%$ of the money that we get in week in week out on an annual basis and for the last few years we have been running on an operational deficit, and we have a small amount of reserves which are progressively being eaten away and we can't go on doing that much longer.

SD: And is that because a large amount of your income goes on the diocesan share? 
Int F: Yes, the so called common fund, that costs us a good umm $£ 30,000$ a year. $£ 30,000$ a year and yes some people in the congregation think that's ridiculous but I actually think it's good value for money as we are in a team ministry, but that means there are 4 churches in the team but it means we have 3 full time clergy, it means we have the full time clergy and one, two, two non stipendiary clergy and one, two, three, four alderman's in training who will all be staying, or three will be staying and will be non stipendiary and will be living here and staying here so we have quite a good team in that sense. We do obviously apart from the regular giving we are looking to raise money through other sources, we run quite a range of concerts (indicates booklet with concert details) we run a range of conferences over the course of the year and the that brings in a useful income stream, not an enormous one but a useful one certainly. And we um we do a big Christmas tree festival in December and that brings in everyone, everyone from the town every school and every sort of community organisation in the town, and some companies, bodies like the police and the fire brigade and so on. And they will all decorate a tree and we will have 60-70 quite big trees all around the church and all lit up. Its sends the electricity bill up for a couple of weeks but once again that will normally bring in a good $£ 5,000$ profit and we serve lunches and that sort of thing, so ah we have activities like that, and we try and put something on in the summer, some kind of event and we urr that brings in people. And as you can see behind us we have a small church shop, and we get a range of visitors coming in coss we are open from April to September everyday from 11 till 3 with stewards in here and so on. And we have leaflets here about the church in 5 different languages because we, we get a number of international visitors, in particular a lot of Germans, in some cases if we are really rushed we will have 4 coach loads of Germans all arriving at the same time and there are 200 of them all roaming around, German, Dutch, some French, some Spanish but they are all mixed otherwise, you get some Americans you get people who have discovered that their grandparents or great grandparents have were married here and they will make a point of coming and ur having a look. Sometimes they will buy things in the shop and sometimes they will leave donations on the way out.

\section{SD: Do you think the majority of you visitors are from quite a way away?}

Int F: Not the majority, no. The majority are from other parts of the UK. At a guess, I mean I don't think I could sit down and do the statistics, I mean we do record numbers on a daily basis but we obviously don't identify who's who, I mean you just know if there is a rush of Germans for example, I mean they are the only ones who tend to come in coach loads with a tour guide. The others are just individuals, who are on holiday here, and the weather plays a role, I mean if it's a dull rainy day you get more people coming in here than if it's a bright sunny day in the summer and everyone is heading off to the beach. I mean you get a sort of tourist who is going to be interested in the history of the 
church and the architecture and all that sort of thing clearly. But urr yeah, I would imagine at a guess $30 \%$ of the visitors would be international, over a year.

SD: Right, quite high then. And is that because you are based in an urban area and quite accessible?

Int F: Its accessible and its near, we are quite near the Eden project and we are quite near Llanhydrock House which is the most popular national trust house, and one of our team churches is at Llanhydrock house and now they get, that church gets an incredible stream of visitors from the house and umm I know the treasurer there and they have a small donations box on the wall there and umm in the summer the treasurer has to go in at least three times a week just to empty out the box.

\section{SD: Blimey}

Int $F$ : As it is just stuffed with money. I mean it varies, and attitudes vary as well, I mean we get quite a lot of Germans but the rarely put any money in.

\section{SD: Right}

Int F: And one reason so that, quite simply, is that in a lot of continental countries ummm France in the one I know best from my own work, the umm government, the state pays for all the maintenance and upkeep of churches.

\section{SD: I see}

Int F: Where as in this country the government doesn't give any and you are on your own as it were. And I suppose to some extent some of these visitors from abroad just assume that the funding of the church in this country is the same as their own, which it isn't.

SD: And is that why you have such and extensive shop, to maximise your income?

Int F: Yes that is too, it's not an enormous shop but it, it, it brings in a steady turnover and we are probably looking at, it varies from year to year, last year wasn't as good as the year before, urrm but we are looking at several thousand pounds profit coming out of that each year and it isn't much but every little helps, you need to maximise income as much as you can obviously.

\section{SD: And in terms of the leaflets how often are those updated?}

Int F: Not often enough. They really need to be worked on now, and my own feeling is that the leaflets that we have got, the text has been there for a long time, are extremely detailed and they really are for people who are seriously interested in church buildings, so you take one of those 
and you walk yourself round and you get detailed histories of this and that, and we have a separate leaflet that give you the details of all the window in the church

\section{SD: Right}

Int F: But a lot of visitors don't want that level of detail or so much dense text. I mean some do but it probably, I don't know if they are the majority and I don't know if they would take the time to actually read it while they are here. and so I am in favour of actually producing something that is a lot simpler with a lot less text, and keeping that for those who want it but having something that is a bit more umm user friendly and a bit more orientated to those tourist who are not interested in going into great depth with those aspects of the building, I mean we also try and promote [local town name] more generally as a tourist centre, we have some leaflets up there is you want to take one on your way out, about tourist attractions in [local town name] and that sort of thing... urrr we are a member of, I can't remember, it's on the wall up there. Ummm Visit Cornwall, which is an umbrella tourist organisation

\section{SD: And it has a website}

Int F: Yes we are on that one. We do run our own website, and have don't for a couple of years but it needs a good overhaul and we have got some presence there, some presence there at least.

SD: And do you have to have someone in to constantly stand with all of the merchandise?

Int F: Well when the church is open for visitors yes we have two stewards here and they can sell merchandise and welcome people and explain leaflets and answer questions, and yes we have a rota, right through the year for that. We do get visitors out of season as well but they have to go up to the rectory and ask someone to open the church and show me and recently and more recent we will of course.

\section{SD: And do you have it shut the rest of the time because of crime?}

Int F: Yes, it's I mean, there are mixed views on that one. I mean on balance I would like to leave it open during the day but not in the evenings and to do that yes when it is not really officially opened you would have to have all of this stuff (indicated shop) in lockable units clearly. Umm one of the advantages that we are looking at with the arc is that that will be able to be accessed through that door

\section{SD: Yes}

Int F: And it will give people the chance to have a look into the whole church as it will be glass and ummm the glass areas in it, but without being able to get into the building as a whole, and that has its own central heating 


\section{SD: Right}

Int F: So that we wouldn't have to have, in winter, the whole church being heated. And I think by the time we get to that stage we will just be able to leave that open during the day and then if people want to come into pray or just have a look they can without umm without umm without putting the whole security of the building at risk. I mean obviously we have valuables and the silver and we have got a safe. I mean over there we have [church's saints name] casket which was actually stolen back in the 19 ...early 1990 before my time but I mean that has its own separate alarm system, you could get a big sledge hammer and whack that glass as hard as you liked and it wouldn't have any impact on that at all, the outer bits look as though they are wood but they are in fact solid steel. And I wouldn't be worried about leaving that, about leaving that open. There are other things like those triptychs (check spelling), there is one hanging there and there is one and there, and they are $15^{\text {th }}$ century and they have been valued at about $£ 160,000$ each and some people say we shouldn't have those out as someone might be tempted to steal them and obviously the building is locked and closed and there are security alarms and if someone comes in without putting in the code and turning the alarms off like I did this morning then the alarm would go off and you have got 30 seconds effectively, and we had that tested a few years ago effectively when we had some kids throwing stones up against those windows, they wouldn't do it on that side as its too visible but that side is a lot less visible and we have had to spend $£ 30-40,000$ to put up steel guards on the windows to stop that happening arr but then you get little holes and birds sometimes fly in and set the alarms off, but anyway. No I think it would be better if the church could be open, open more so, and I mean the insurance company, the ecclesiastical say that yes in the day it's quite safe to be open in the day but in the balance the majority feeling at the moment that if there is no one in here then it should be locked so I'm afraid that what a lot of churches are doing these days

SD: And I saw on the sign outside that you offer quite a range of services, do you have any sort of problems maintaining your congregation?

Int F: No, I mean out main, on Sunday, I mean we have an 8 o'clock service from the Book of Common Prayer and that has a small regular congregation of about 20 and in the summer months you get the odd visitor coming into that as well but only occasionally. But the main service on Sunday is the 10 o'clock service umm and we rarely get less than 120 at that umm more sometimes, quite a few visitors again in the summer come to that service, umm obviously for big services, Easter, Christmas etc there can obviously be more, up to 300 . I mean we have got seating, with this seating we have 180 of these and we have another 160 so called rapid response chairs that we keep over here and can just wheel out uurrr and set up very quickly. We are obviously very lucky, or at least I think we are, in that we don't have fixed pews 
because that does mean that you can try out lots of different configurations for different services but also for events, I mean you can have an art exhibition for example and move a whole lot of chairs over to the side for instance and there is a lot of space and a lot of place in the middle. And we have had a couple of occasions when we have had the, going back 3,4 or 5 years now, we had the highways agency put on a big exhibition in here when they had to go into consultation about the arrr the new part of the A30 going over Goss Moor and they picked the church for the size and accessibility and the space and obviously if you have pews you are in a much tighter situation as to what you can do I mean even the choir stalls we are looking to get rid of at some stage because it maximises the flexibility of use. We are very keen to have the building used, and not just on Sunday for services but for a wide variety of community based uses.

\section{SD: You said in your questionnaire that you have a lot of schools coming in.}

Int F: We have a lot of schools coming in because on, I mean we provide, at Easter, I mean we have this thing called the Easter experience which, there is [a linked] church of England primary school has a special link with the church and I am biased because as well as being churchwarden here I am chair of the board of governors at that particular school. But all the schools, primary and secondary, came in for that and looked. But we get quite regularly during the year, we get one or two classes from a school coming in for a half day or a day, and sometimes we get people from [names local town] college coming in for two days even and doing all sorts of projects like art work, we have even had a maths class here where they come and measure up things, angles and heaven knows what, so yes we get a lot of umm school visits, certainly yes.

\section{SD: So in terms of community engagement you are quite far ahead?}

Int F: Yes, we are certainly very active, we are certainly very active yes.

SD: Excellent, and um in terms of managing the church and church hall, as a church warden are there two of you?

Int F: Yes, there are two church wardens, there are two church wardens and we each take lead responsibility for different areas, and I have yet another hat in that I am the executive officer for the whole of the [names local town] team ministry which means I chair the regular team weekly staff meeting for all the clergy in some ways I manage the clergy, although the team rector is effectively the boss, anything that is of a management nature or a financial nature, like clergy putting in claims for expenses, I am the one that approves it, for example so I have quite a major role in how things are managed and run yes. But in terms of the church wardens the other church warden's particular area of activity is with young people so she works more particularly with that. 


\section{SD: So she has the engagement side and you have more the..}

Int F: I have more the management side, both the management of resources and the management of clergy, then there is the PCC with the treasurer and the secretary and things and I certainly don't run the church office as such but I am more involved in strategic development, policy developments, umm trying to get the clergy to work effectively as a team, which isn't easy, not easy at all because umm a lot of clergy are like academics, as that's my background, and a lot of academics aren't team players because I am god's greatest gift to the world, I am brilliant and no-body tells me what to do academic freedom and off we go, and I'm not saying that this clergy is like that but some are and they have all got that little bit of independence in them and some need guidance to make them effective team players in that way.

SD: And as your priority as a churchwarden are you umm very much for maintaining the structure of the church or is the priority very much for maintaining the structure of the church or for maintaining the congregation and its religious role?

Int F: It's both, it's both, I mean the building is important clearly as it is an historic church and we certainly don't want to see it umm falling into ruin in any sense, but at the end of the day it's what goes on inside the building and outside the building as we do quite a lot of pastoral work and we run events fairly regularly in some of the estates in [the area], like every fortnight we will have a drop in Sunday lunch at one of the estates in the community hall or whatever it is called, on the other side of town. It's the whole thing if you want, in a way, I mean [this church] isn't an, what is commonly called an evangelical church, we are fairly high church, not extremely high but on Sunday we have incense and things like that which you won't find in a lot of the more evangelical churches but at the same time we are umm ahh we are a very inclusive church. I mean more than half of our clergy are women and we are very happy with that umm yup so um.

SD: And in terms being inclusive do issues of the environment come up often, I mean do you have anyone who drives that sort of thing, I mean you identified that you recycle and everything?

Int F: Yes we certainly recycle and we have one person who takes lead responsibility for that, I mean behind the organ there we have specific recycling bins and the main thing we recycle really is paper and you know every week we have news sheets, or one off orders of service, I mean where possible we do store them away and bring them out when the cycle comes round but you may have 2-300 copies of an order of service, which are of no use when the service is gone and they all get carefully, carefully recycled.

SD: And in terms of prioritising the balance, and you discussed working outside the church would the social aspects be your main concern, with economic and environmental? 
Int $\mathrm{F}$ : Yes probably, the economics you can't ignore as if the moneys not there you can't do anything, you can't maintain the building, you can't develop all the things you would want to, you can't do the pastoral work that you would want too.

\section{SD: And do you have a specific maintenance budget or do you tackle things as they come up.}

Int $\mathrm{F}$ : We do, we do, each year we produce an annual budget for the year ahead, and in that we will identify a sum for what you might call routine maintenance work and that's usually about $£ 10,000$ umm we do keep some reserves obviously in case something major and totally unexpected happens, and require pretty much immediate action, but obviously that isn't a limitless pot and so we have to be careful with that, but in general the new things we have got to generate the income or get grants because we can't rely on our own resources, not with the common fund payments that we have to make. The average running cost of the church are just week in week out paying for utilities, paying for clergy services, alter supplies and so on and so forth.

\section{SD: And have you been hit by the increase in utility prices?}

Int $\mathrm{F}$ : Oh yes

\section{SD: And has that had quite an impact?}

Int $\mathrm{F}$ : That certainly has yes, if anything it was worse a year ago than this year as umm the price of oil in particular for the heating, in a church of this size in the winter to get it heated you have to have the boiler really blasting, and it is just sucking up oil like no bodies business, and that was getting incredibly expensive. It's expensive but it has certainly come down from the level it was at. I mean oil has come down in price more than gas has, I mean the gas companies are quick to put the prices up but slower to drop them down and oil has come down much more significantly umm. Yeah I mean electricity is a factor obviously but at a time like this I am not bothering to put the lights on, I'm not bothering to put lights on now. When it's open to visitors we usually have one light on up there in the sanctuary but unless it's terribly dull then we put a few more on but for services we have it all on. And similarly for things like weddings and funerals we have it all on. And they also bring in a little bit of money, not a lot, umm as you have to give a lot of that to the diocese every time, but it brings in a little bit. Baptisms don't which is a shame as we do a lot of baptisms a year, we do about 100 baptisms, sometimes they will be slotted into the main services but quite often, like last Sunday we had one at 12 o'clock, one at $10^{\prime}$ clock and one at 2 o'clock, almost like a production like almost, and you do get the odd donation from people there but you know there are no... we don't charge any fees for that while we do charge fees for weddings and funerals. 
SD: And in terms of fulfilling you're, in terms of maintenance for the building and providing interpretation for visitors do you have any specific training for that sort of thing?

Int F: No, er, not.. I don't think anyone has had any...ur, I mean I suppose when I was working full time in a university in London, part of my role there was running commercial courses so I myself was quite used to going to major national exhibitions and so on and running a stand and so on, I may at that stage have been on some training at the university or been on some sort of basic course, and the principles translate over into any sort of work.

\section{SD: So more informal skills?}

Int F: Yes, there is no, no, no, any formal, we haven't done any formal training no

SD: Ok, lovely and now my very last questions as I can appreciate I am probably overrunning my time. Is about, well you mentioned the lighting and all the processes you had to go through, do you actually urrr, you said you were talking to the person at the DAC, do you get any advice and guidance from people who have already had it done or do you get the opportunity to share the practices you develop with other people? Or is it all centrally managed?

Int F: Well I mean you can identify, umm, you can go round. And I know the rector has done this on several occasions, you get to hear of certain people the advisors at the diocese will tell you to have a look at that church or this church where they have done this and in fact we all went over to Padstow because they have had new lighting put in and a whole team of us went over there and had a good look around, and decided we didn't like what they had done but that was aesthetically, rather than anything else, and it was fine for a church of that size but wouldn't have worked in a church as big as this, and yes, yes, and that is more informal to some extent, yes, we wouldn't just pick up the phone or go to the phone book and simply look at who can put some lights in for us and look at a name and leave it at that and in fact we umm we, we, we did get two different companies to come into the church and have a look, listen to what we were saying, and then make proposals, make proposals to us, and that is also for financial reasons to make sure we knew how much they were going to be charging but they did come up with some different ideas I must say and obviously umm we would normally do a little bit of internet research and have a look at what seems to be going on in other, in other churches elsewhere in the country.

\section{SD: So very much your responsibility to find out then?}

Int F: Yes, yes, very much so. No I mean we are left on our own in that sense, very much on our own in that sense, we can umm, the only 
rigorous area in which we are controlled is with the diocese and English Heritage in what we can and cannot do.

\section{SD: Are they quite restrictive?}

Int F: No I wouldn't say that, they are just very, very careful and it is a time consuming and laborious process, and umm no they are helpful, they are certainly helpful it has to be said, they can be fussy at times. But no on balance I think they are usually right in what they are saying, and they are as the name implies they are an advisory committee and their first role is to advise, I mean at the end of the day it is our decision, and it's a bit more complicated if you get English Heritage coming in, because they, in some areas, have the power of veto and of course they aren't allowed to do that full stop. And I don't imagine if the diocese were to strongly advise against something we would say tough your wrong and we are right and we are doing it, but they are amenable, amenable to argument and discussion, I have known them on a few things to say this isn't a good idea and then to change their mind. But there are not one of them, I have been down to some meetings and there are 20 or 30 of them sat around and you might have $\mathbf{2 0}$ or $\mathbf{3 0}$ different opinions to whether that's good or not good, so umm, and you listen and then umm they will eventually give you some written advice, they will give you written advice after the meeting and they give you a statement and you act from that, but umm no, I think on the whole it's a, it's a helpful process, but that applies to everything, like if you want to saw a branch off one of the trees outside, like we have to because this is also a conservation area and we have to go through all the civil authorities there in terms of getting some sort of forestry expert to come in and certify this and that, and that all has to go to the DAC as well for approval, and we, we, actually spend quite a lot of money on maintaining the churchyard but we do get some money there from the council from the town council and what used to be West Devon district council, but now obviously it is the unitary authority, Cornwall Council will take that over as this is a closed churchyard and has been since the 1850 s and that means that legally it is the council's responsibility to maintain the churchyard, but we agreed with them that we would run the work as we didn't think they would maintain it to a standard we would be happy with, so they just give us an annual grant which we supplement from our own funds and bring in external contractors you know to do grass cutting and strimming and all that, and its important, especially in a location like this church, to have the church yard looking like it is well looked after and maintained.

\section{SD: And so your main barrier to doing anything to the church. Is it the listed status or is it the cost?}

Int F: Oh it's the cost, it's the cost. No the listed status you can do things, like this concept of the Arc which is very, which is very modern, English Heritage are very pleased with, and it just, it just sits in here like a pod effectively and its not impinging in any way on the fabric of the building, the moment you start screwing things in....and we actually have got 
permission, we'll get permission to actually put a hole through above the door there so we can go through the wall there from the upper floor of the Arc into the Parvous (check spelling) rooms out there, which just gives us some extra office space or smaller meeting space or storage space or whatever so in that instance there they will say yes, because that isn't an external wall there and you have got the parvous rooms there the other side, and if you wanted to knock a hole through over there (indicates external wall) they would say no and that is fair enough with a $15^{\text {th }}$ century building and you can't really complain about that.

SD: Well I think that is all of the questions that I would like to cover, thank you very much for your time, is there anything that you would like to ask me?

Int F: What, what degree are you doing this for?

\section{INTERVIEW CLOSE}

SD: Standards thanks and re-emphasis of participant right to access transcript. 


\section{Interview G}

SD: Standard introduction requesting permission to record and providing an explanation of all ethically required statements

Tape recording begins

SD: It's very much about what type of site is out there, then it moves on to the three main types of sustainability, the economic in terms of financial viability, social sustainability in terms of maintaining visitor numbers that sort of thing, and then the environmentally friendly stuff that everyone associated with sustainability. But basically it was very light touch and I got a fairly good set of responses, mainly from churches and things and um, when it came to actually getting to my next bit which is sort of delving into projects and things I was a bit undersubscribed on the historic house front. But anyway, I have already spoken to a number of people from heritage churches..

Int G: And we can always put you in contact with people from other national trust properties if you want to do it in Devon and Cornwall? If you are interested?

SD: Yes, that's my study area, Devon, Cornwall and the Isles of Scilly, but obviously they are a bit harder to get to

Int G: And depending if you want to pick out garden sites or historic houses or anything like that we can probably give you the contacts, just too sort of say you could go and speak to these guys as well. And you say [name of another staff member] filled this out anyway?

SD: Well she actually proofed it for me in the first instance and put in what you've got and all that sort of thing. It did have quite a lot of questions in so I did feel a bit mean sending it to her after she had been so helpful.

Int G: I think in terms of the whole sustainable management of heritage it's quite a difficult dilemma especially for an organisation like the Trust as if you looked into sustainability in its very broadest sense our biggest Achilles heel is, you know, how do we make our money to make sure we can do conservation? Largely through the visitor coming here, how does the visitor get here? By car, $95 \%$ of visitors come by car. Well that's not the most sustainable way to you know, and I think that's our biggest Achilles heel as an organisation, we rely so heavily on those visitors, yet the way and the method that they get to our properties, and because of our isolated nature, most of the properties, like here, it's a real difficult dilemma and I don't know how we can really get round that you know at all of our properties, you know. And some of them do it very well, like greenway, that has just opened up, you can go or you pretty much have to go by river, because there is only about 10 parking 
spaces and there is a section 106 agreement that only allows a certain amount of traffic through the local area so it's, it's quite tight in terms of what you can and can't do, so it's about finding innovative ways of dealing with that in its broadest sense. How, what would you like to get out of this?

\section{SD: Well I have a series of questions.}

\section{Int G: That's fair enough}

SD: I am just interested in how you prioritise and balance the main types of sustainability and the projects that you, like the wetlands one you were talking about, how you, sort of, develop those projects and manage them to be sustainable. And whether the national trust as an organisation limits you, helps you, to act more or less sustainably in those projects.

Int G: Well I would say um that there is an awful lot about that, and I would say as an organisation we do go down that route, I think sometimes we have to be fairly careful about what we are choosing that's the most important and we do have an approach now that, certainly for the large projects we have a triple bottom line approach and we do look at it in terms of financial, environmental and social, and sometimes the environmental and social can come out way higher than the financial return and it still justifies it, in fact it justifies it more, I think the difficulty that we have got is that if you were talking to me about this 2 years ago I would probably be saying something different, but now, in a very tight financial time you have got to be really careful about some of these things and you might want to hold back certain projects that might be financially consuming but don't really return anything, when actually we've got to make sure as a charity, although we are a conservation charity we are a charity that has to make sure that we can financially go on into the future, and I think at the moment it's a bit more of a difficult dilemma but we are still holding our own because actually we have still got the visitors coming in and we still have the secondary spend to spend as so we actually have got that little bit of play there where we can still say that we can make an approach in a different way and make sure that we do concentrate on that triple bottom line approach saying that there is a justification on the social and environmental grounds, now the social is, the environmental is a bit of a no-brainer for us because of the type of organisation that we are, the social, I think is incredibly important because we have such large holdings in communities, and if we forget about our local communities that's really dangerous, really dangerous, and so for example the map there, that's, that's all the shaded bit and grey bit are parts of the estate, that gives you an idea, that's the house there so it's fairly sizeable, with the quay being this bit down here, and the mill down there, and those are the two sort of tariff areas but it is still massive actually in terms of the size and scale of the estate, you know, and we are actually in two parishes, over..this is the [local area name] over here and this is the [name of valley] Valley up here and so this is 
[names local parish] parish and this is [nearby town name] up here, so we are split between two parishes and the estate as a whole is fairly sizeable so I said its about 1300 acres, we've got 5 farms and we've got a number of small holdings but we've got about 90 cottages on the estate as well. Now the cottages were part of the endowment of the estate, so given to make sure we, you know, it would return rental income to go on, but also they are a money pit as well as they are $17^{\text {th }}$, $18^{\text {th }}$ century properties and they suffer with the same problems that other properties of that age suffer with and that's damp, you know, so, um, you know, they are not always in good shape and that's a really difficult dilemma for us and I would say that is one of our biggest problems at the moment, how we get round that issue of ensuring what does return an awful lot of money for us um those properties, that do return a good income, are up to a certain scratch and that our repairs and maintenance doesn't become more than the rental income that we are getting in and that's, in terms of how we ensure that that endowment really drives itself, that's important for us as a sustainable business, going forward. And we do need to look at ourselves as a business as well, we are in the leisure industry at the end of the day, as well as being a conservation charity, and if we lose that point we get into a very dangerous position I think because then we become very focused on ourselves rather than focused on the visitor and all the other things that drive our income, umm so I think as an organisation we do make sure that we try to um have a very sustainable approach to things, a lot of the project work we are doing now, um for example we are doing one down at the um mill which is focused on a hydropower scheme, so it's trying to say, well actually can we make the Mill as a complex a carbon neutral property by generating its own electricity from the power of, not necessarily the water wheel but the, leat and the water that feeds along that. Now that's been quite interesting as much as it has been an important project for the Trust I would say it's taken us 13 months to get an extraction license from the environment agency

\section{SD: Right}

Int G: So it's an incredible amount of time working with agencies that really, um, want to and should be backing projects like this, because they have a (unsure of word) themselves as well in terms of their approach and how they need to be supporting things like this. But it's been a real headache getting through all of those processes, just to get an increased extraction license, an extraction license we already have, but where we want to take more water to be able to power a hydro turbine that will then hopefully generate enough electricity to be running off the holiday cottages and the mill complex down there. And that one was um heavily supported externally as well, so some of these areas, we know we can get external funding as well because they hit all of the right criteria for a lot of funders as well, so there is always that encouragement and if that means that sometimes $10-20 \%$ of the project can come from within and we can get the rest external then, you know, again it's a no-brainer, we should be doing it and if it's got 
the criteria of something like that which is, you know, a very good thing that can hopefully generate enough power to power itself as a property in its own right, then its, its highly sustainable as well, fingers crossed. Um if it does generate what we wanted it to then it becomes quite sensible for us, and I understand there are a lot of projects I have seen nationally like that, you know, the trust as an organisation is a lot more focused on things like, you know, wood chip boilers, umm where can we install those, but also trying to make sure learn from where we have installed things, and the problems and the teething problems that they have and that's the benefit of being in a big organisation like this as usually you can find someone else who has already done it and they might go 'don't even touch it' or 'actually these are brilliant but these are the problems you will have on the way there that you need to be aware of'.

\section{SD: Are there lots of, sort of, forum for sharing best practice, do you, or do you have to ask around or?}

Int G: You usually have to ask around, there is not, the trust is trying to get better at sharing best practice, because in the past one of the things that we all want to make sure is that we don't re-invent the wheel, because if someone else has done it, you know let's not go through the pain of these things, lets learn from one another, and the benefit we have in an organisation like this is that you have property staff and then you have people based at the region, and so they will be in regional offices covering, so for example this region is Devon and Cornwall, you've got 11 regions or countries that form the Trust umm and the benefit is that usually someone within the region is tapped into head office, so although we might be at properties we might have, for example an environmental practices advisor that covers all of Devon and Cornwall, so knows what's going on at all the properties in Devon and Cornwall, he knows all of his other environmental practice advisor colleagues in every other region because they get together, and they have someone at head office who sees everything that is going on, so it's quite, you can go by quick process to get to someone to say 'have you done this somewhere before' who can then hop on to someone else and get it and 'have you done something like this?', 'yeah' and you can get the contact pretty quickly and I would say that's where we benefit of being the size and sometimes our processes can be a little bit slow and laborious but that is partly for a reason really, um it's to make sure that because we are, the core purpose of this organisation is about looking after incredibly beautiful special places most importantly forever and for everyone, now if looking after them forever looking at sustainability, now that's a pretty important thing, so you know trying to be able to do that you have to be very careful about what you want to do at a property, and a lot of what we try to do is make sure that it is reversible, ultimately reversible, so if we do, do, something, can it be whipped out, or is it something that is there and if we suddenly put on a canopy over hall court for example, as much as I would say that that is the wrong thing to do, if we were to do it how would we do it in a way that if we suddenly thought that this is all wrong 
and doesn't work we can whip it away. If we did something where we suddenly left large areas of the building irreparable or the rest of it then that doesn't fit with our criteria on how we do things.

\section{SD: Right}

Int G: So there is always a level of reversibility in there. I think our challenge sometimes is that because we are always trying to do so many things it is what emphasis you might put on certain things um at the moment I would say that really we need to come back to the daily operation being the vital area that we need to concentrate on. Partly, it's because where we can really drive the finance but it's also where we can drive down some of our other areas of work, so focusing on, like you say, where people always look towards the recycling and the green issues, but our electricity consumption, how do we reduce that? You know, when you are trying to drive a business but are trying to drive down things like electricity use, how do you do that? You know, because it, we do have criteria to say that, for example some of my targets are that in 2006 we established a baseline of our electricity consumption across this whole property and the challenge is to get it down by $10 \%$ on one year, $15 \%$ the next year, $20 \%$ the next year after that, on that original baseline so there are targets there that we are trying to achieve and that's on LPG, oil, electricity, the whole lot, eventually it will be on water consumption as well so um we are always trying to make sure that we can focus on the day operations, say how do we still drive the business but still get some of these areas of work down a bit that's pretty hard, in fact that's very hard

SD: And is that particularly an issue at the moment with increased oil costs and, I know they have gone down a bit recently, and higher electricity with less income?

Int G: Yes, I think, um, I think organisationally we are quite switched onto these things, I mean because we've got quite good contacts as well we do get certain people into talk to us. A classic one was a couple of years ago we had Patrick Holden from the soil association give a talk about Peak oil, and you know, the whole peak oil movement and the understanding of that, I mean, umm you know, it's a classic case of this will happen and we are doing nothing to really adapt and change, nothing at all and we really need to be doing something, and its only when people see that prices go through the roof they suddenly think ow something is happening, and I think we've have been having that conversation for a while but we need to step up our efforts in terms of what we are going to do to reduce that so we are trying to do that on as I said a fairly light touch basis for the moment, at the moment in terms of on a day to day basis but we are always having those discussions, two weeks ago I had our environmental practices guy out to say "look is there an opportunity to have a woodchip boiler up here at the house, should we be looking at ground source or air source heat pumps', you know there is always that desire to say 'how can we move this on in the next stage' and ultimately say 'can we knock out two of um these oil 
tanks, how do we get rid of them' because they pose an environmental risk in having them in the first place because if one leaks it's a massive environmental risk, and over and above that it's a finite resource that we are using so we have got to get to grips with these and on properties like this where you have a, a, substantial estate and quite a lot of woodland where you could use more actively and again that's a another discussion at a local level with local communities that might like woodland walks that might change quite drastically and the landscape could change quite drastically if we pursue something like this to say 'well actually you know what we need to clear these woodlands to start looking into a more sustainable method of managing our properties' and I think that's quite difficult for them really as you know we are in an AONB and you are also partly in a world heritage site, there are a lot of conversations that need to go on before we go down some of these routes um and I think there is this massive journey that we need to go on, not just organisationally because we are already on that journey but getting other people to buy into it as well as I think, I think there is this sort of um desire now from a lots of people, you feel they want to step away from the whole issue and that climate change isn't happening, you know people are no longer as interested I don't think at buying organic, they prefer to buy local, but organic, you know, it's expensive and it's not that, and more and more farmers are moving away from organic which is interesting, so that whole ethos, when finance starts to take the pinch a little bit it does effect everybody, and that's not to say for one minute that we stop our progress on those as we are still looking at how we can pursue some of these projects, some of them can't, you know, go any further until we have feasibility studies done on them, so if we wanted a woodchip boiler here we would have to produce enough from the estate to keep it going or where else could we keep it going from? Where is the demand? And you know, that's, that's more professional work, that's not something that I can sit down and cobble together, I could provide the information but the technicalities of it I don't know, so you know there are five/ten thousand pounds feasibility studies that need to be done there to get all that information together. But that, you know, isn't to say for one minute that we are stopping our thrust on that, in fact I would say we are pushing it quite hard.

SD: And are you able to drive that sort of thing from here or are you, do you have a lot of pressure from the national trust to take on projects, set baselines? Are you encouraged to set baselines or is it very much sort of driven from here?

Int G: Um, It's actually a bit of both I would say. If there are things that we know are right that we want to pursue from here then that's all right, However, there is, there are obviously things that will come from the centre, from head office that will be right, ok, some of our key performance indicators now, and that I will be measured on as a manager here, will be 'right [name], you have got to reduce your consumption here by $10 \%$ on that baseline', and the baseline is based 
upon 'right that's the amount of electricity we know you used in that year', so we are going to try and make a shift down from that

\section{SD: Yes}

Int G: But that is nationally, every property does have that challenge, $10 \%$ there, $15 \%$ from the year after, and it's not $10 \%$ over that $10 \%$ and $20 \%$ over that $15 \%$ its $15 \%$ on that baseline and $20 \%$ on that baseline so we are reducing a little bit over time, after a big jump in year one. So those are national targets which I think you have to have something driven from head office to say that we have got to make a real head start on this, and if, if I was setting my baseline and I said you know what I think $2 \%$ is about right for this year and then another property said, I'm going to keep it level, or you know I have a growth to my business so l'm going to go for $5 \%$ over you've got disparity all over the place with people being able to set their own criteria, that needs challenging, if people are, you know increasing their businesses and saying, 'you know what, I have a new catering outlet, there is no way I am going to get a $10 \%$ reduction' then we should be looking at what we are putting in there, are they the right fridges? Are they rated in the right way? Are we generating the heat from the fridges to plough back? Are we doing all the right green things to ensure that we try and cut down as much as we can? And I would say that you know with the project funding that we get, a lot of the time we are able to do that, um because we need to build it in and we need to make the business case financially stack up, to say, right, you know, originally to do this well we need $£ 50,000$ and if we are going to do it absolutely gold star we need $£ 80-100,000$ and if there is a business case behind it we can actually free up that money internally to be able to do that.

\section{SD: Right}

Int G: So there is more and more of a questions of as I say, larger projects now have this full triple bottom line approach, which although I say environmental, social and financial um there is um we have got a spider diagram which picks out different parts of what that TBL will be so you know, it might be purely money in, it might be community, so there are different things and you'll say depending on what success you might aim to achieve where you are now and where that project will take you on each of those 8-10 different areas. So you'll plot it and if, if the line starts to fall inside where we are now what's the purpose of doing it? So we really are trying to justify quite hard why we are making certain projects go forward. Um I would say that there are, there is a lot going on within the Trust at the moment where we are trying to push things more from the properties, to say 'can we achieve these targets? Actually should we be more realistic about target setting as well? Or are we setting targets too low? Can we do much better than that?' and that is where we at property level should be pushing back, and are pushing back to say 'no, no. no, we can do far better than that'. Um, some of it is very much down to us at property level so we might sort of say 'one of our targets is how are visitor rates there, visit here' and we 
have surveys that are carried out by Bournemouth university and one of our targets nationally, all properties, to when it's all fed in, to achieve an average of all visitors saying that they have had a very enjoyable visit, and actually that means that some people are going to overachieve and some people are going to underachieve, for example here, in my opinion, we should be able to get 4 out of 5 visitors saying they had a really good day out so then why don't we achieve $80 \%$ ? So there is always that drive from the property level to say 'you know what? We can do better than that.' Some of those more difficult ones, are like I say, the consumption, I mean when you know you are driving a business as hard as you can and there are opportunities in different place, and I mean the whole financial side is so important as, if the projects don't generate that level of income we are not going to have it ploughed back in to some of the projects we want to pursue. So if you are pushing the business that hard you have to think really carefully about how in earth you are going to see a reduction.

SD: And in terms of the factors that you have to consider in that spider diagram are they all measureable things? For example community engagement?

Int G: No, completely subjective. And that's almost where you need to have, what we have done before, properties have set their own triple bottom line, so they have done their own spider diagram and it's been facilitated, so somebody who, from head office is doing it on a regular basis who will sit down and challenge and say 'are you sure you are doing that?' and will say 'are you being realistic about it?' because it would be really easy if you were submitting a project to say, 'well, we are right lets draw a circle around the inside of all of that, and lets draw a big circle around the outside of that when we have done the project', you know it's, it is very subjective so you have got to be quite clear about what you are trying to achieve, and as I say be quite realistic about um whether it is the right thing to do, because if you're introducing a new catering outlet you are going to see some things like electricity consumption for example, dive inside last year's line, because how on earth are you going to be able to do it without seeing an increase in you electricity, without saving elsewhere and doing something quite dramatic. So, you do need to be realistic about how you do it but it is very subjective.

SD: Right, and in terms of getting funding for projects, you said earlier that there was a pot that you can draw certain percentages out of, and then it makes it more viable, um being part of the Trust do you think that makes it easier to get the funding?

Int G: Um, I think, that, that a lot of our problem internally is that we have an annual project bidding round, so come September time I have to submit my projects, and I submit an awful lot of projects, and I might get a small handful of them, so I have to prioritise very carefully on what I feel is the most important 4 or 5 , knowing that if I do submit, and you know, you could argue that this is a bit of naivety from me, that if I 
submit 20 projects I know I am only going to get 4 or 5 of them tops, so I have to be quite careful with the ones that I'm going for. We do have different categories, where if it goes over $£ 100,000$ it becomes a major project, um, and so that usually goes onto another level, another step so sometimes we also have restricted funds at properties so it might be where someone might have left a legacy or a particular donation that I can use during the course of the year, or it might be raffle aid money, or gift aid money that we have got and kept to one side and I can say 'well actually this is a fairly small project and I can actually get on and do it now' but I would say that having, I came from a very small charitable trust umm and I actually thought I would have so many more resources coming into an organisation like the National Trust, I have, I have far, far, more resources but I have got something on a far, far, bigger scale so you could say proportionally it's about the same, you know, the money that I have is much, much better, to be able to play with um, but the scale of this operation is so much bigger you never feel like you have enough, and there is so much more that you would like to do but you think so I can't do that either, so yes (coughs) [this site] as a property being part of the National Trust it does have massive benefits being part of the National Trust, but its all, it's all, you know um fairly comparable in terms of the operations you are running um you know I have so many more staff here that are high calibre than In my previous organisation that then the scale of that organisation was nothing in comparison to this one, so it, it's always quite hard knowing that you are a certain level with the financial investment bit that you can plough back in, it is better but we still have a long way to go. And I think, I think now there is a lot more, sort of, of an entrepreneurial look at how we can generate revenue ourselves, so is there a more natural manner, I, I don't particularly want to be waiting every year for an annual project bidding round to find out if I can get access to funding there will be times when I will want to access finding quite quickly that's not within my operating budget, so my day to day budget, that might be set aside into projects, how can I make sure I have larger sums of money? So I need to think quite laterally about how I raise money then, um that is outside of the main part of the trust, you know it might be something that I can say, ok right I can raise money this way but I want to make sure it is restricted and it is purely for me to draw on at [this site], it doesn't just go back into the central pot.

\section{SD: And do you, sort of, do fund raising activities then?}

Int G: We do. A lot of our fundraising is on a fairly small scale at the property so we do have things like pledger days and legacy days where we might invite people along, and you know, that tends to be led from the region and tends to be held around the region, so last year we had one here but before that I can't remember when we last had one here. Raffle income we keep at the property and that's a good one because obviously its led by the centre but you know you can win $£ 10,000$ as first prise but we keep the raffle money we make at the property and then head office double it, so the moment we go over $£ 200$ for every $£ 1$ of raffle ticket sales we get we get $£ 2$ from head office and that's 
money that we get to keep, so there are pockets of money outside of our operating that are quite important because we get to keep it at the property. Second hand book shop is a classic one, as we can keep that money and that will generate anywhere between $£ 8-10,000$ a year that we can keep at the property that doesn't go back into the general fund. Um, gift aid. We keep $80 \%$ of our gift aid money, so when you are asked at reception, this is the entrance price would you mind filling out a gift aid form, the money that we get back um we keep $80 \%$ of that so again its useful pockets of money that you can use. The other routes that we tend to go down is when we say, ok, we want to do, as I was saying earlier about this hydropower scheme down at the mill, we have got two people within the region, one is a grant manager and one is a donor development manager, and again they do different things but they are tapped into head office and we'll go to them and say 'look we really need to raise $£ 50,000$ for this particular project' and they will see who is the most suitable individual, company, charitable trust, to go away to and see if we get the money. And the reason the best way is to go through head office and the region on these things is that they can keep a check on everything that is coming in from the national trust and I do respect this, because as much as I know I want money at this property, if I was to stick in one application to someone, say the national lottery fund completely off my own back and something else comes in from a property in the North West and something else comes in from a property in the South East that we are all doing it from a property level and we are all saying that the National Trust thinks this is the most important project for you know now nationally for us to pursue, the National Lottery funding is going to go right so organisationally what are you saying is the most important thing, its haphazard, and so it is important organisationally that we know what is going where and we know what we are trying to find money for and who from as well. So, which is always difficult because at the time you have to take a bit of a hit on the chin and say 'alright, your project is more important than mine' and I hate doing that but you have to sort of say 'yes, you are right that is far more important and far more useful to us all as an organisation for you to do that project so yeah, you need to do it'. And so the fundraising is done on different levels, you can get fairly small sums of money from just the work we do here, but if you want to get larger sums then we have to engage our grants and donor managers to see how we can get money that way.

\section{SD: Right, and in terms of you operational budget, is that all centrally drawn?}

Int G: It's set by ourselves at the property, it's difficult because it is completely related to the visitor. It depends on the way that the property is set us and it can be a bit confusing. [this site] is a general fund property so any money that we make goes straight back into the general fund pot, any money that we need to take out also comes out of the general fund pot. Some properties, so if you take Killerton, near Exeter for example, um it depends on the way it was donated to the Trust, and Killerton is what we call a special trust in credit, which means it operates as a 
special businesses all on its own, any money that it generates it keeps, but any project that it wants to finance it has to finance itself. I can't go to the general fund as say 'I need $£ 150,000$ ' as it's a special Trust that is in credit and it should take from its own resources so it manages itself, pretty much as a small business by itself in the Trust.

\section{SD: Right}

Int G: On the flip side of special Trust's in credit there are special Trust's in debt so those properties that don't make a lot of money or generate not enough money to keep themselves going, they also take money from the general fund. It does mean that they build up this sort of almost like liability that in essence one day they need to pay back to the general fund.

\section{SD: Right}

Int G: And this is purely because of the way that they are set up or the way that they were donated to the Trust, so we are a general fund property but I would say that the majority of our turnover is generated from either the visitor or from the tenant, so where we get rental income. Our turnover every year is about $£ 1.9$ million um we generate about $£ 450,000$ from rent, we have 2 catering outlets which generate about $£ 480,000$ a year between the two, we have a shop which generates about $£ 350,000$, we have our art gallery which generates about $£ 140,000$, money through the door, admissions and member credit we get as well, we generate about $£ 350,000$ from that um, we also do recruitment, so we try and encourage paying visitors to become members of the National Trust and that generates money back for the property of about $£ 35,000$ a year so you have got you know a heavy proportion of the income we generate is based on the visitor and as I say from rental income as well, I mean we do get money from other sources but the sort of...oh and holiday cottages as well, we do have a number of holiday cottages on the estate, so we do generate money from all of those different areas, so it is largely visitor driven, very heavily visitor driven but if we were to suddenly find that another foot and mouth happened and we had to close the estate or something like that we would then, if we were generating a deficit instead of a surplus every year we would then be taking our money from the general fund pot and saying right we need help now, and that is how we would be funding it.

\section{SD: Right, Ok so it's a balance over a period of highs and lows really?}

Int G: We are a property that generates quite a good surplus every year which makes it back into the general fund, and so, for example last year we generated a surplus of about $£ 530,000$ which is a good amount, you know half a million to go back into the region, but you have to remember that 4 out of every 5 National Trust properties don't generate an income because you know coastline, countryside, they all have wardens, they all have areas that we need to look after and costs 
that we incur but they don't actually generate an income unless you have a car park you know on a stretch of coastline and you can generate money from the pay and display.

\section{SD: Like the Wembury one?}

Int G: Like Wembury or Godreavy, there are quite a few around as the Trust owns quite a lot of coast line around Devon, I think it's, in percent quite a substantial area um but a lot of those areas don't generate money, so we have got to work out ways of paying for them, so it is important that [this site] as a money generating property makes as much as it can to support those other areas and you know we've got an office to support, the regional office and the advisors team that will help us to achieve what we need to achieve but as an entity the regional office doesn't generate and income so we have to be sure we can support those staff over there as well.

SD: And what is your largest area of expenditure from your operational budget?

Int G: Wages

\section{SD: Wages?}

Int G: Yeah

SD: And do you have people coming to, sort of, monitor the actual building and tell you what you need doing on a regular basis?

Int G: Yes, we have what we call quinquennial surveys so we have quite large reports every five years, they are supposed to be every 5 years or so, that are fairly in-depth analysis of the house, and um so we will know what work needs doing over a 5 year period and then we can phase it as well. And out direct labour is planned more importantly, we have a direct labour and building team, and we are quite lucky that we do have a building team that we can call upon quite rapidly, you know if we have problems here we can call on them fairly sharp-ish, and that's because we have 90 cottages on the estate as well and we have to look after those, we are getting a bit better at doing condition reports on those as well to say, look what needs doing. We do have a fairly large spreadsheet that looks at all of those 90 cottages to see what needs doing over than 5 year period and what priority are they, priority one needs doing in the next 2 years, priority 2 needs doing in the next 5 year, priority 3 really needs doing in the next 10 years and that's what we call backlog work, it's not improvement it's just backlog that we need to do. Um the bottom line there comes to about £1.2 million, so there's a hell of a lot of work that needs to be done on those cottages to make sure they are up to a good standard. Um what we would like to do as well is that when we do that backlog work that we do do a level of improvement as well, so for example we might for example have loft insulation so think and people are burning oil and burning electricity 
through night stores and things, whatever it might be, it's just disappearing, and if we are going to go into a property and say look the kitchen and bathroom needs doing and some of the slates are coming off the roof, we need to go in to do that but we should also be building in to say right let's stick in loft insulation, let's check it all over, lets' be sure that we can help tenants reduce some of their costs by what we might put in there as well rather than just burning it. Because I think where as I was talking about the electricity baseline that we have got, that's for this property and when I mean the property I mean the areas that we have immediate control over. It doesn't include tenanted properties so those 90 priorities we can't actually influence ourselves, I mean we could if we put in loft insulation and tried to reduce it that way, but I think we do need to be looking at how we have that overall cut, is there a way we could do a district central heating system so that it doesn't impact on the mansion here but it might be in the small hamlet of [names local hamlet] where there are 15-20 cottages where if we could have a biomass system that would be big enough that we could feed out to all of those cottages that really cuts all of their consumption as well. So there are different ideas on what we can do and how we can do it, but it's, you know, it's a pretty hefty task getting on top of all of that.

SD: Yes, and is the quinquennial survey done by an architect or a surveying team?

Int G: Yes, it's done by a surveying team that will go around and have a full check, and they would probably go around with [names another staff member] so that she knows on the house what work needs doing and then we'll have a check over at the Barn Restaurant as well, and those are the two grade 1 listed buildings, so yeah, we will have a proper check on those, so yeah its basically done by specialists.

SD: And your building team, I presume they are specialists in, I mean do they have skills in historic house rebuilding like wrought iron making? Or is that something you have to outsource when you need to do things like that?

Int G: There are some things that we have to outsource we've got for example a stonemason I mean some of them are just very good general builder, I mean exceptional, but we do have a stonemason, we've got a carpenter, a painter and decorator and things like that um and some of them, I mean they know the mix of lime mortar that they need to be using so I would say that they are builders with very very good conservation and heritage skills.

\section{SD: Right}

Int G: So they are very much tailored towards this sort of building rather than a new build 
SD: So they are, sort of, already contemplating the historic aspect when building something or doing a project?

Int G: Absolutely, yup, yup

SD: Right, in terms of interpretation for visitors and engaging the community, which you sort of mentioned earlier, um do you, are the community involved in making decisions about what is displayed at new projects?

Int G: Um, only so far as some of the bigger projects, I mean the discovery centre was a classic example as there was a heavy involvement from people there, quite few tenants got involved there and volunteers so it was a, how do you feel about this? I think these things are always very difficult because the more you open it up the more indecisive things can become, I mean if you make a decision, you can make a decision fairly quickly yourself but if you don't stand to check it against people you don't know necessarily that it is the right one, the more people you consult the more difficult it can become because everybody has an opinion or a view on the best way of presenting something and you are never going to please everybody all of the time so try to get a consensus is probably the best way of doing it but recognising, and I think [another staff member] is fairly good at this with the focus group is that please be mindful that we aren't going to make radical changes but we want to check it against you to see how you feel about it and if there is anything that you think we are massively missing here you know tell us but it's not a discussion forum where we are going to sit here for 3 or 4 hours making sure that we pick out every little last detail, let's just make sure we are getting the right stuff together. So, um, I think we get, we have got better at that community engagement, and we try to do more of it, so we do, do open days, you know, we did it with the Hydro scheme so we said look we'll hold I think 2 or 3 open days come along and we put poster up in the local area and adverts in the Parish news to say look if you want to come along and find out more about this. And part of it is because you usually get really interesting questions coming out of it and really interesting points where you know we hadn't really thought of that. And so there is really a massive benefit of doing that but at the same time you do get to a point where we have got to continue that we make sure that we drive this forward so we've got to play it quite careful at times as well I think, depending on how the scale and size and interest of a project, that can help us dictate what level of consultation we might do, if it's an interpretation board in the garden we can make that decision very quickly and get on with it, I don't think there needs to be massive consultation on that, We'll speak to out manning officer, we'd speak to the garden team, you know there might be a couple of visitors that will sort of day how this works and what works best but we will fit that sort of thing into the style that we are starting to use throughout the property and we can make those decisions quickly, it's the big projects that I would say we've got to be doing more of. 
SD: Right, and are you, is the interpretation you provide based on, local knowledge or is that something that is driven from the centre as I know you have um particular groups that you aim interpretation at,

Int G: Yes,

\section{SD: I can't remember what they are called..}

Int G: The curious minds and the explorer families and so on

SD: Yes, which are they centrally chosen things or are they locally driven as well?

Int G: The, the, they are segments that we know as an organisation because of what we are dealing with and the types of properties that we have, we know, there was a lot of work done to say how we segmented people and it's not by their a, b1, c1 sort of categorisation its by their motivations so people can become different groups, so for example curious minds might be the normal types of groups that you see around the National Trust, you know, 45 plus, quite interested, got a bit of time on their hands and got a bit of disposable income, quite interested in properties like this, and explorer families which is exactly as it says, and it can be that a couple that are coming round as a curious mind can be looking after their grandkids and become an explorer family as their motivation are quite different. So it's not where that person is constantly a B1 and they remain in that categorisation and will always be that, it's about looking at their motivations are for coming here, and although that it totally driven centrally as a piece of work as a property we are trying to define which of those categories, the 7 different segments, which of those are we attracting and therefore how do we target a lot of our work, at those, and a lot of our interpretation and the visitor experience at those individuals, and a lot of those that are commonly found at properties and are found here are curious minds, explorer families and the out-and-about-ers, I put myself as an out-andabout-er as I tend to when I go somewhere I like to mooch around and I don't always like to have a lot of information shoved in my face, I just like to pick up snippets and it's like right, that's great let's move on now. Those, those, those sort of different segments, it is aimed at those and we will always have those particular groups in mind, it's not for one minute to say we are going to forget about everyone else, it's to say actually you know what we have to be aware that that is a high proportion of the people who are coming here, let's make sure we generate the interest for them and hopefully they will pass the word on when there not here, and they talk to friends as well and we can generate a lot of interest like that. And I think now, I mean we need to be looking at interpretation as well in terms of its widest possible sense in terms of how we do it, so it's not just an interpretation panel in the garden it's about how we engage with visitors as well and that's a big element of what we need to do, it's the manner in which we get people interested, and all the time the best way is through personal contact, it 
means so much more if somebody tells you something that is really interesting rather than you reading something on an interpretation panel, and it will sink in, and if it is done in the right way it can make or break the visit so you know, that whole personal contact is really important now and so that's how we do it.

SD: And your, sort of, motivation for updating, changing interpretation, is that to retain the visitors, attracting new people or is it really a means of managing people around the site more effectively, or a mix of them all?

Int G: Yeah, I would say it's a mixture of all of that actually. It is about ensuring that we pitch information at the groups that we get but making sure that if we felt that we were seeing an increase in explorer families is that information right for that particular audience as well, is it pitched at a level where it crosses over those barriers. The discovery centre was a classic example where I felt this worked really well, it was pitched at a certain level but if you want that extra information there were folders tucked underneath where you can dig deeper and you can find out far more detail if you want that level of information, and that was layering the information as much as possible and umm, I think that works pretty well, but I think that the interpretation that we did is always aimed at a mix of all of those trying to make sure that we do, um, have the, that we are pitching it at the right people that are coming here but also broadening it out for the people that aren't coming here. But at the same time knowing that we need to manage those people around the property, so some of the, the newer welcome sheets, the welcome leaflets, is more about managing people's expectations a little bit more, and every year we might tweak that so we might say sort of say that actually we have done a risk assessment saying we really should be telling people about the ponds, and to do that maybe we can put that on the back of the welcome leaflet just to say please be mindful of the fact that you are with children you might want to supervise them, so that might be something that we might want to add in at a later date and um it is a mix of all of those and we do thoroughly understand that we do have to um manage people pretty carefully as this property generates visitors of around 95-100,000 visitors a year and you can't personally handle every one in every different area so there is a degree of management that is required by signage or interpretation or leaflets, or whatever it might be so we do need to think about all those elements quite carefully I think.

SD: And is all the interpretation reviewed regularly or is it sort of time frames, like for the leaflets you might look at every year...?

Int G: Yeah, things like the leaflets we have to look at on an annual basis I think there are some things that we are always looking at, can we improve that, can we make it better? And there are some areas where we might say that is fine for now let's just leave that, the discovery centre is done and we might add in there but let's see what comes back from the visitor, as time goes on have we missed something and 
we can get that from speaking to our volunteers and we try to encourage that sort of discussion, of what the visitor is actually telling us and we can be led by that to a certain extent, you know the danger is that we can be led by ourselves and we desperately want to tell people every last snippet of information in a highly intellectual way that bores the visitor stupid and we have got to be really careful not to do that.

\section{SD: And so you monitor it on a number of different levels?}

Int G: Yeah, I would say so and it probably sounds a bit haphazard the way we do it but to a certain degree it probably is, I mean for example comment cards are a classic one of how we try and gather information and we get something from that consistently comes up then we will say right, ok we need to do something about that in the closed season, let's make sure that we cover that one off and provide that information, I think there is always a desire from certain teams to make sure that they have certain information out there on a regular basis, the whole engagement agenda, how we engage our visitors more and get them to understand our work more deeply so they don't just see us as superficially, oh you look after these big stately homes and that's it, it's well how do we go about it and partly to try and encouraging people to be members and understand that membership isn't just a season ticket, as much as it might be treated like that, it's not just a season ticket, you are buying into a cause and this is the cause underneath it and this is why it costs us so much to do this work because we have to be really careful about it, and trying to explain that if we are going to try and look after these places forever for everyone then we have got to be really careful about how we do that because they won't last for every if we just let everyone use them in a particular way so we've got to be quite careful about it, so we do look at it on a bit of an ongoing basis but annually we do get back certain survey information that allows us to interrogate it a bit better the comment cards are a classic one and the Bournemouth survey that we carry out is another one that we can sort of say, are we getting it right? There are certain questions on those surveys like the presentation of the life and times, at that property, what was it like and was it any good? And if that sort of percentage starts to drop drastically we can think, ok we are starting to move away from some of that information which is quite important, let's go back to it and revisit it. So it's almost like on an ongoing basis but we can pick out certain information annually, when we need to.

SD: I have just looked at my watch and realised just how much I have overrun by

Int G: Don't worry if there is more stuff that you want to get out of it, as I don't mind

SD: We have covered quite a lot, but is there anything that you think I have missed that is particularly important to you here or the Trust as a whole? 
Int G: Um no I think the one thing that I would say is don't underestimate the whole point of some of these dilemmas that your are sort of researching now, that are at the heart of what we do, I mean how do we make sure that we become sustainable as an organisation, and as much as I can give you the view from a property perspective, from a national level there are a certain number of things that we are trying to do to make sure we do this, like I mentioned electricity consumption, we are trying to cut that um one of the biggest things for us at the moment is to achieve a $20 \%$ net gain nationally so that we are always generating more money than we are spending every year because if we don't do that then we get into a spiral of oh my god we are going downhill and as a charity that is set up to look after these places in perpetuity sustainability is absolutely at the crux of what we have to do, and the charity commission too don't want to see us going belly up they want us to survive into the future, obviously, naturally there is a push there to make sure that, you know the finance has to drive a lot of what we do actually and um I think everybody understand that, it's not just down to the guys in catering or the shop making the money because the guys in the house and the guys in the garden know that they are spending it and they know that if they can't make it they can't spend it, so there is always that understanding that conservation is really at the heart of what we do but we have got to make sure that we have to make ourselves financially ship shape as well and again Rachel may have told you this, that we do have a strategy, a national strategy that focuses the mind quite clearly I think, to make sure we are achieving certain criteria and there are 4 elements in that strategy um, financing our future, so achieving that $20 \%$ net gain, ensuring that the amount of money that we are spending is slightly less that they money that we are making, um improving and tracking our conservation and environmental performance so we know where we are at, have we got a full understanding of our assets, are we looking after them in an appropriate way, um are we always improving the knowledge that we have got in improving those assets as well and um investing in our people are our third important strand, if we don't get the people right and we don't develop and manage our staff and our volunteers in a sustainable way because they are absolutely fundamental to achieving everything else so that is an important area for us, and then fourthly which is one of the most important areas for us is engaging our supporters, so how do we do that engagement agenda better so that people can feel as though they are almost part of the organisation that we are part of, and I think that is one of the hardest elements as I think the trust has a perception externally and we have got to make a massive perception shift, I mean when I joined the trust nearly 4 years ago um I was, I knew I wanted to work at [this site], I loved the place and I loved the people but I had a perception in my mind of what the National Trust was like and what it was about and it was more what it's like that troubled me so I said to my boss can I have the weekend to think about it, thanks for offering me the job but I still need the weekend to think about it, because I had in my mind that the organisation was a bit Victorian, a bit backwards, a bit slow, and I always had had in my 
mind that they only sell lavender in the shops and that sort of stuff of, I had stereo typed it as an organisation and I had to think quite carefully about it and on Monday morning it was yes of course but I wanted to be in an organisation that 1: was challenging and 2 : challenged me and that would be quite forward thinking and when you get into the organisation you realise that it is all of those things it is very forward thinking, it is very open and they listen a lot, but that's not the perception that exists externally I don't think so there is a massive massive shift there of the perception that people have of this organisation and it think we would make massive in-roads into other things if we could make that shift in perception. And so those are the 4 elements that drive us and I think that sustainability sits at the heart of all of that really because we have to be, there are something's that do that aren't sustainable, you know but that whole issue of forever, for everyone means that we have to work out a way to be sustainable going forward otherwise we just won't exist, we aren't like a business, we can't afford to go bankrupt, what happens to all of these massive assets if the trust dissolves, you know, it's a huge number or properties that we own and look after, and land, and so that whole issue of sustainability is really at the heart of the purpose of this organisation.

\section{SD: And do you think the national trust is sort of a lead organisation in terms of managing heritage?}

Int G: Yes, I do and I think it is seen as that as well actually, there are a lot of other national trusts that have sprung up in other countries um and now there is an international national trust organisation and its seen that they national trust for England, Wales and Northern Ireland over here is seen as the mother trust really, a lot of people use us to come along and say how do you go about it and how do you do it, Saturday I had a couple of people from Newport, Rhode Island sitting with me asking how do you do it, how do you go about it and it sounds like we are in a very similar position to them organisationally with where we are at but there is international recognition that we are seen as standards are very high and what we are trying to achieve is always very high as well the danger is that it lets you down as a fool if you are seen as being always up there and you don't always have the finance to keep you up there you have to let some things go and those might be the things that are picked on, we might be doing everything else very well but it might be that $10 \%$ of things that we are struggling with that are picked on as hang on a minute you aren't whiter than white are you where as actually we always have in mind yes, but we know where we want to be, we know what our aspiration is and we do want to whiter than white but it's just getting there and we need to be realistic about how long it's going to take us to get there and you know there are some projects that we need to be looking at here that we need to look at as a 10-15 year project and that might be beyond my time of being here but we need to have that vision, I mean Wicken Fen which is another national trust property in the east of England, that is a 100 year vision and you know that is where we do have a bit of a foot hold because we are separate in a way where we are looking after these places for ever and we can 
have these huge vision of these places years and years on because the property will still be here and it will still be looked after by the trust so we can have that very, very, long term visioning. As much as our strategies and plans at the moment look over 3 years we can look over a much, much, longer period of time.

SD: And does the Trust allow you to be quite innovative in approaches that you take?

Int G: I think more so now, I think if I had been in the trust 10 years ago I would have said not so much um but not I would say it is far, far, more. And as I was saying earlier there is this level of drive to have more entrepreneurialism to sort of say are there more natural ways of thinking how we can do these things and I think when we do them we are much more responsive as an organisation to say that we need to share that information now about what is brilliantly well done and yeah where we can learn something from that because we didn't do it right, and we need to learn something from our best practice and our bad practice, you know because we need to put our hands up and say, you know we did that really bloody awfully but we need to learn from that and usually when someone does something badly the last thing you want to do is share it with people but we need to get better at doing that as well. To share that information and say don't fall into the trap of doing this, this, and this because it doesn't work, don't try to re-invent the wheel on that one, so we do need to be good at sharing best practice and bad practice, but I would say now that we are being freed up a lot more to be innovative at properties and lead the way and actually we can push our organisation and our regional colleagues, and head office to say we would rather do this and we want to do it this way because we think it will bring these benefits rather than it being the other way round and head office telling the region to do something and the region saying oh god right ok can you all do this at these properties, and in a way that is one of the challenges organisationally at the moment, is how we take that pyramid of the organisation and flip it round, so actually it being head office there, coming out regionally to properties there we turn it round so actually properties are innovative and want to do it this way and we need the help from the region and it means we need this from the centre and head office to deliver it that's quite a challenge in this organisation.

\section{SD: That's brilliant that's all my questions. Thanks you very much}

Int G: If you do want any other contacts you have my e-mail address, and just say who is the person at that property that you want to get in contact with, I am more than happy to let you know anything like that, and help more in any way we can as well.

\section{SD: General discussion}

Int G: Which is really interesting now as over the weekend they were saying that museums are going to have to look at charging again as they are 
just not surviving, a lot of museums just aren't surviving as the funding just isn't working the way that they had hoped, yeah it is coming full circle and I think that is where we benefit from being outside the government to be honest, I like the fact that we are a separate charity, I wouldn't like us to be part of the government and it means that we are in theory completely non political and means that we don't have a trend either way and we can step back from it all and watch others doing things and just get on with our core work.

In the 4 years that I have been in the trust the shift is quite dramatic and quite drastic, and I wouldn't underestimate how much of that has come down from the director general recognising the direction, and [gives name], I think is incredibly high calibre and brilliant, and it sounds as though the right person is really driving this and understands where the organisation needs to go and when this new strategy was introduced, I think it was in 2007, for me it was a bit of a 'well that's what we should be about as an organisation' and it was easy for me to do coming in from the outside to say that's what I would believe this organisation should be about, if I wasn't involved in the organisation. So yes, it has seen quite a shift.

And I mentioned that there is a hell of a lot of training going on about staff and volunteers about how do we make sure we are more receptive, so rather than being, a volunteer in the corner with their hands behind their back staring avidly at anyone that comes through the door its more about smile, say hello, read the body language understand that if somebody doesn't know what they are looking at and actually wants to know but doesn't want to ask you might want to step in and say well actually that is that, this is how it is put together and this is how we clean it and then know when to step away as well. So not holding someone in a room talking at them, so read the body language, there is a lot of training going on around that and so with our room guides being there for security as well they are very much there for the visitor, and that is quite a shift, you know 10 years ago it would have been telling people not to touch this and making sure everything was secure but that becomes more of an undertone of what the role is about and now it's much more about how you can get closer to those visitors and how you can engage with them as well.

\section{INTERVIEW CLOSE}

\section{SD: Standards thanks and re-emphasis of participant right to access transcript.}


Interview H

SD: Standard introduction requesting permission to record and providing an explanation of all ethically required statements

\section{Tape recording begins}

Int $\mathrm{H}$ : Well this is a listed building. The council owns the building, [town name] Council. So we are not responsible for the outside they have to up keep that. We are responsible for the inside and we rent that from the council on a long lease. Ok. We have a shortage of space as you will find out. We have quite a large number of artefacts photographs and things about [town name] which has a long history and so we are always looking for more space. But unfortunately we don't want to move as this is a prime site and we get a lot of visitors, 10,000 a year, on and off but its more or less stable now at 10,000, which we certainly wouldn't get if we were tucked away in a side street so we don't want to move, so the only possibility at the moment is to extend upstairs but that is a privately owned flat, or leased from the council so they don't want to lose that and we can't have it. So basically we have three rooms, the kings room where king Charles the second came in 1870 to entertain the corporation, and we have quite a lot of things about that, then there is room two there where there are lots of models of ships and things and other things of historical interest. And room three which was the subject of a big project that we did three years ago to completely renew that room and make it in to the Henley study, named after a certain William Henley who was a Victorian gentleman in [town name], who was a self made man and who did a lot of research, scientific research and all sorts and there are lots of his things there which were originally in a separate museum called the Henley Museum that used to be across the road there and that has now moved in here and that was, well the council was responsible for that and the building became derelict or in a bad state so they agreed to bring it in here, so we are responsible for looking after all of those artefacts in that room and the council give us some money to help us with it, and so our income come mainly from people coming in who pay and also the council gives us a sum every year for the Henley and it gives us a reduced, you know, special rent, if you like, not the commercial rent that we would have to pay and that is how we manage to break even, we are supposed to break even and we do that actually at the moment quite well. With the stable number of people we do alright, not to bad at all. So we are hoping actually that we might be able to proceed to phase two of this new project which is to do room 1 and 2 , now that we have done room 3 . These two rooms, I mean they are fairly old now, the cabinets and things date from the 50 s and they aren't up to date and there are all sorts of things that we would like to do but perhaps the first thing is to come and look.

\section{SD: Thanks that would be lovely}


Int $\mathrm{H}$ : This is a little exhibition by the way that is on temporarily about Dartmouth Pottery. It used to be operating from Warfleet which is just down the road Its now closed unfortunately but this is a selection of what they did, that people are interested in.

\section{SD: Is this a temporary exhibition? How long has it been here?}

Int $\mathrm{H}$ : This particular one well you know about 6 months I suppose, I don't know how long they want to keep it but it's a brilliant place for it. So it's a bit of [town name] History. Here is a bit more of [town name] history [indicated maps on wall] shows how it grew there is the plot this was originally was a bit pool on the tidal river, it was eventually filled in and bits added and it was reclaimed and now it is like this. It still tends to flood around here when there had been a torrent of rain

\section{SD: Oh dear}

Int H: Right room 1. As you see these are old cabinets. As you can see we have quite a lot in here. A lot of the stuff is quite low down and you can't see it very well so one of the ideas for phase two of the project is to have new cabinets with an island in the middle of the room with some models on it, you know, the bigger models. And outside a sort of series of cabinets all the way round that would indicate the history of [town name] chronologically as you go round. That would be the idea anyway.

\section{SD: Is that something you are hoping to do in the very near future?}

Int $\mathrm{H}$ : Well, we are trying to get some money together and Devon County have given us an offer of about half the money that we need, and we can offer some money from our own resources, but we still need another $£ 10,000$ or so to get started. And if we can't get that, because it's difficult at the moment, we might have to separate it into 2 parts and do this room first and that room later.

SD: And what sort of process do you have to go through to start a project like that, do you have to get specific approval?

Int $\mathrm{H}$ : Well the Council have to approve of course but they already approved in principle. Otherwise it's up to us but we have to find the money and if it were a matter of changing any of the walls or anything, which it isn't really, we would have to get listed building approval of course, we did for the other project actually, we had to take away a small part of the room but I will show you that in a minute. Right so have a look around. We have got quite a lot of paintings on the wall that are probably worth something.

SD: And are all the artefacts donated by local people or people in general? 
Int $\mathrm{H}$ : That's right, I have to say donated quite a long time ago and while our records show where a lot of them came from we just don't know where some of it came from but we have got the catalogue, one of my jobs actually has been to catalogue it all on the computer so we have got well over 3000 items now. It's quite a job to get them all done.

\section{SD: And are they all on display?}

Int $\mathrm{H}$ : No they aren't all on display, that is another thing to explain. Obviously we have a reserve of things that we don't have the room to display and they are kept in a room called the Jessie room, it's at the other end of this Butterwalk, it's not accessible to the public except you know by appointment. It's called the Jessie room because it has a very fine ceiling, plaster ceiling, showing the Jessie Tree, you know Christ's er..And it's a unique item this ceiling; it's the only one like it. It's not generally known that. We could make something of that, I think. The problem is the access to it, getting the access without a) upsetting the rest of the store and $\mathrm{B}$ ) you know providing someone to look after it. Because someone needs to be here when its open obviously but they can't be there at the same time.

\section{SD: Do you continually get artefacts coming in?}

Int H: Yes, every month of two you get one or two things. Yes. Sometimes we have to say "no we have no space", or "it's not directly relevant to us" but usually we take it on.

SD: Does that give you a lot of options on changing your displays quite often?

Int $\mathrm{H}$ : Yes, that's the idea, the curator does try to shift things around a bit, but probably not as much as we might because it is all extra work. But that is the idea yes, so eventually we see most things. But there are a few things in there that aren't so attractive or are in a bad state so they don't get shown you see.

SD: Yes, indeed. And in terms of updating the information to go with it is that something that you try and do quite regularly?

Int $\mathrm{H}$ : Well, we try. As you can see there are labels everywhere saying what everything is but it is a job to do that. And the catalogue has a little...information on it, we use a software package developed especially for museums that seems to be quite good and so they ask you to put in text about things.

SD: Is that quite handy if you want to put something out?

Int $\mathrm{H}$ : Yes, that's right.

\section{SD: Do you get a lot of repeat visitors in?}


Int H: Most of the visitors, to be fair, are repeat visitors. Who come for for instance Torquay on holiday and they come from Torquay to Kingswear on the Steam train and across the river, get a boat and go up and down the river, maybe to Totnes and get the bus back to Torquay, so a circular trip.

\section{SD: Right, so mainly people who haven't been here before?}

Int H: Yes, mainly people who come in here first, on the way. But we do get some people coming back. Particularly people doing research or people interested in the Navel aspects of [town name], because [town name] College is here you see.

\section{SD: Do you get a lot of people with family interests?}

Int $\mathrm{H}$ : Yes, we get quite a lot of people with Children, that is why we would really like a few more things for children to operate. There are a few things they can operate, some little steam engines and things like that. There isn't much in here that children can operate, they can see all the models and they do like those.

\section{SD: So you are really trying to appeal to a wide audience then?}

Int $\mathrm{H}$ : Yes, a fairly wide audience, you can see the numbers...I have some figures in there. Obviously there are quite a lot of senior citizens as they come on their trips and also quite a lot of children, especially in the summer.

\section{SD: And are you open all year round?}

Int H: Yes, it's open all through the year but at reduced hours. So 10 until 5 in the summer but in the winter that is October till March then that is only open 11 till 2 I think. But every day of the week.

\section{SD: So that would explain why you have such good visitor numbers?}

Int H: Yes, that's true I think. You know we have thought about changing that as it needs people to be here, I mean [names volunteer] is here most of the time, but mainly in the mornings, she can't be here all the time. We have a rota of stewards who have to be contacted who are arranged to come and hand tickets out and supervise.

\section{SD: How many people do you have on at any one time?}

Int H: Usually two but sometimes only one

\section{SD: So do you have any issues with crime or anything like that?}

Int $\mathrm{H}$ : Well we have had one or two teenagers who cause problems but not many. And we do have a security button that you can press if you have a problem, It rings in the next door shop and there are one or two burly 
lads in there who would come and sort it out. But one or two of the older ladies you know could be worried about things like that.

SD: And I notice that you have your blinds down, is that part of the....

Int $\mathrm{H}$ : Yes, that's part of the conservation, the light is so reduced. I'm not an expert on conservation but we do have a man who is one of the trusties who is a recognised curatorial advisor and can advice on that. And our curator who isn't here today is aware of what has to be done.

SD: I see you have got lots of lighting around. Does it add up to quite a large electricity bill?

Int $\mathrm{H}$ : Yes, the electricity bill went up quite a bit when we did the Henley there, and of course you might have heard the loud speaker at the bottom of the stairs. That has attracted quite a few visitors.

SD: So are you balancing electricity out with visitors in?

Int $\mathrm{H}$ : Yes that's right. We do have to consider that but the main thing Is to get the visitors in and look after the artefacts, we can't afford not for it to be done properly.

SD: Do you have low energy light bulbs?

Int $\mathrm{H}$ : Yes, that is the idea I think. I mean these are all out of date and that is one of the reasons for the project.

SD: Will that all be wrapped up in the project?

Int H: Yes, yes it will. Would you like to come and see the next room? There is a mixture of large models, I mean we haven't got room for all of them, and small things in these cabinets...all sorts of things.

SD: Do you try and keep it all very varied in each room?

Int $\mathrm{H}$ : Yes, and you have got all of these things which are of historical interest. This was [town name] in 1864. Useful things and all sorts of things that people can study if they know what to look for. All sorts of old ships. So there we are, that is that. And over there is the WWII cabinet with lots of things in.

SD: And are you going to do the same sort of thing in here?

Int $\mathrm{H}$ : Yes, that's right. We want to have a separate little corner for WWII which we haven't made much of, as that's a bit of a mess at the moment really. Everything jumbled up and people have tried to write little labels for as well but it's hard to work out what everything is.

SD: Again you said that the other room was going to be done in chronological order Is that the same in here? 
Int $\mathrm{H}$ : Yes, that's right. There will be a section for that and a section for these dresses, used by Governor Holdsworth who was one of the leading lights of [town name], he basically controlled the place, you know. So that is a bit of history as well. And over here we have got early trading links. That was a model of Noss and that used to be one of the main ship building areas on the river. Newfoundland fish trade, that was important for [town name].

SD: Do you get a lot of local people coming in to have a look?

Int H: Yes, you do, but again once they have been and seen it they tend not to come back. This is one of the models that children can put a coin in and see it working.

SD: I see you have knots as well, they must be fairly popular?

Int H: Yes, sometimes they mess those up. And you have got lots of pictures of historical interest. And more things that they can operate.

SD: Is it spaced out at different height for different visitors??

Int H: No, it's a jumble isn't it, I don't know if you thing it's something we could improve a lot, I mean I don't like it very much.

SD: Well its interesting because you have fitted a lot in.

Int $\mathrm{H}$ : This is one of the famous people from [town name]. Thomas Newcomen who invented steam trains and got them working in Mines before Watt took over and invented the watt engines.

SD: You said that you have two stewards on at any one time. Do they stand in the rooms helping people?

Int H: Well they should really be around in the office or near the office so that they can give the tickets out, because people could come up the stairs and you wouldn't see them, you know. But if there are two of us, one can wander round the other rooms.

\section{SD: Do you get a lot of people asking you for additional information?}

Int $\mathrm{H}$ : Yes, quite often in the course of the afternoon you might get two or three people asking questions. You are supposed to know the answer but if you don't you can always write them down and get them sent.

SD: You do have a lot of models don't you?

Int $\mathrm{H}$ : This is another interesting model of [town name] during the war, you can see all the ships here.

SD: You have a lot about the changing face of Dartmouth haven't you? 
Int $\mathrm{H}$ : Yes, that's right. There is quite a bit of chronological history. I mean this goes with the WWII stuff over there.

SD: And in terms of the things you display is it all very much local history?

Int $\mathrm{H}$ : Yes

SD: I mean I see you have things over there on the fishing trade, are international people who come in very interested in that?

Int $\mathrm{H}$ : Yes, quite a few Americans come and you know, they are interested in knowing about the Newfoundland fishing trade. And there is another [town name] of course renamed [town name] in Nova Scotia. And people have come from there as they know that there is a [town name] here and they swap stories about the two [town name].

SD: I suppose they are very interested in the old days of British history anyway because of the colonial connection?

Int $\mathrm{H}$ : Yes, another thing is that the Pilgrim Fathers who eventually sailed from Plymouth stopped here on the way and we have got a model of the Mayflower and a list of the passengers. And people ask us about that sometimes.

SD: So you have got quite a lot of interactive exhibits then?

Int $\mathrm{H}$ : Yes, well in this room anyway, the children like those. We have got things here as well that would interest the girls perhaps, it's a dolls house, a big Victorian thing

SD: Again was that a donation?

Int $\mathrm{H}$ : Yes a lady that used to live in one of the local houses donated this, based on what she remembered I think or something like that. She had all the stuff about it but I don't know the details. But you see there is a wide variety of things because people tend to donate things like this. Ok? So let's go to the next room, room three. This is a nice collection of paintings done by a lady in 1839 showing all sorts of views of [town name]. Must be worth something as well. This is of interest too, these tapestries on the wall are done by local ladies, they must have spent a lot of time on that.

SD: Were these actually of the time, so were they made in 1944 as well?

Int $\mathrm{H}$ : Yes, that's right.

SD: That's amazing I suppose that is another conservation issues with the lights as they still look very new. 
Int $\mathrm{H}$ : Yes, that's right, and I think it's a good place for them

SD: Have these been up for a long time or are they changed?

Int $\mathrm{H}$ : I'm not sure, at least 10 years I think. As long as I can remember. In fact 1994 I think for the 50 year anniversary. Somewhere it should tell you, perhaps it doesn't. I'm almost sure they were done in 1994. Now this is the Henley room I mentioned. This is the one that has been redone to look like a Victorian gentleman's room and its full of all the things that Henley used to have. In the separate Henley Museum.

\section{SD: And when way all of this put in?}

Int $\mathrm{H}$ : About 3 or 4 years ago now, in 2005 I think it was. We employed a professional company, Image Makers who did this sort of thing and they did a very good job I think.

SD: And did they take all the interpretation that was in the existing museum and change it all to fit in?

Int $\mathrm{H}$ : They produced all this [indicates interpretation panel] based on what we told them and on what they found out, you know. We had a lady as well who was working for the Museum who was a curator at one time and she knew a lot about the history of it and um, you see some of these books are quite valuable, this is the Geneva bible, first published 1560.

SD: I mean you said in here that you had to get some permission to change?

Int $\mathrm{H}$ : Yes, we did have a little room here that was a little library, and that had to be taken away to make room for all of this but that wasn't a problem as it was only a partition wall not one of the original walls.

SD: And in terms of attaching light fittings and things like that did you need permission?

Int $\mathrm{H}$ : I don't think we needed that and if we did need permission we got it easy enough.

SD: And in terms of changing the walls did you have to have permission? Did you get English Heritage in?

Int H: Somebody did come along but they didn't have any concerns with it as far as I remember.

\section{SD: Are they more concerned with the facade?}

Int H: Yes, they are, yes. Much more yes, 
SD: I assume they wouldn't let you do solar panels on the roof or anything like that?

Int $\mathrm{H}$ : No, we haven't discussed that but there is a thought.

SD: Is that something that you would consider in the future?

Int $\mathrm{H}$ : [Laughs] And are people at other heritage sites trying that?

SD: I know some of the smaller ones where energy bills are an issue are considering it.

Int $\mathrm{H}$ : I think I might have problems getting it approved but it's a thought.

SD: And when you come to do a project is your first port of call the council as they own the building?

Int $\mathrm{H}$ : Yes, I suppose so. And also the district council who are responsible for planning proposals and approvals.

SD: And they try and help you to keep going, developing and running?

Int $\mathrm{H}$ : Yes, I mean with these things it was in the will of [names benefactor] that these things have to be on public display in perpetuity. And he gave some money for that so the council felt necessary to show these even when that old building became unusable

SD: You said that you were using this room as a library before hand, did moving this collection here mean that you can only display less of your artefacts?

Int H: Most of the books are now in the Jessie room, the store room and some of them are in the office. The whole of this room wasn't a library, only a small part of it. It was only really the people who are members of the museum that knew what was in there or used it.

SD: So it was quite good for you as a museum to make this room more user friendly?

Int $\mathrm{H}$ : Yes

SD: And with the current financial situation do you thing that is having an impact on your visitor numbers?

Int $\mathrm{H}$ : We were worried about that last year when numbers were going down a little but I think it has come back up again this year, there are more visitors staying in England now than there were, and I mean we get 10,000 visitors a year which is quite a good number for a small museum, and as long as that continues we will be ok.

SD: And do you have a lot of volunteers? 
Int $\mathrm{H}$ : We have about 300 on our list who pay subscriptions and of those some are too old to do steward duties. But we have around 150-200 who do stewards duties.

\section{SD: So a very high number, are they all local?}

Int H: Yes, they are all local, of course they are. They have to be as it's so difficult to park here and being able to walk is an advantage.

\section{SD: So who would you say are your main tourist groups?}

Int $\mathrm{H}$ : The main tourists groups would be those coming from Torquay on the circular tour, those visiting [town name] on a day tour maybe in a car, they will spend an hour or so here and then an hour or so in the shops. If it's raining they will come in here.

\section{SD: And in terms of marketing, what do you do?}

Int $\mathrm{H}$ : There are leaflets. We have a marketing man who tried to produce these things every now and then. We have a website which is supposed to publicise our new things like the display of pottery. And periodically we have an exhibition about D-day and about the armada and you know one or two artefacts from that.

SD: So quite a drive for marketing, does that help with visitor numbers?

Int $\mathrm{H}$ : Yes, I think so, I think it is important to have some help with publicity or people wouldn't know we exist.

\section{SD: When did the loud speaker go in?}

Int $\mathrm{H}$ : That was part of this project here, we spoke to Image makers and asked what we could do to publicise this better and that was one of their idea, it works very well. It can get a bit boring if you stand there for 5 hours and listen time after time. But I think it's a good thing.

SD: And do a lot of people come here specifically to visit the museum or are they usually here for another reason?

Int $\mathrm{H}$ : The majority probably don't come here on purpose they are usually walking past and think "ah there is the museum lets go in and see what they have got" sort of thing particularly if it is raining. There is probably a minority that know there is a museum and it has a lot of historical things and the kids would like to see some of these things and so they come.

SD: And you said about updating the other two rooms, is that something that you will be doing immediately? 
Int $\mathrm{H}$ : We would hope to do that next winter obviously its best to do a project like that which would involve a lot of moving things when there aren't a lot of people visiting and when the hours are shorter so you have time to do it when there aren't people wandering around so probably from October onwards.

SD: Would you try and do both rooms at the same time?

Int $\mathrm{H}$ : Yes, simpler to do it both at the same time, because otherwise I don't know where we would put everything.

SD: Right I think we have covered everything I have already asked about visitor numbers..

Int $\mathrm{H}$ : Yes, we have enough, it would be nice to have a few more but we have enough.

SD: The one thing that I probably haven't asked is about how you balance being environmentally friendly, maintaining an income and conserving the integrity of the artefacts.

Int $\mathrm{H}$ : Yes we have to do that, that's the top priority really I think. I mean as a museum we are officially accredited with rules and conservation and catalogues and things like that. And we got through that last year and we are now one of the accredited museums and not everyone is so for that of course we need to have rules and things like that

SD: And obviously maintaining visitor number is important to you. When you change rooms do you have rules of what you can change?

Int H: Yes, if it's in a bad state you have to be very careful with it. And if it's something that needs special light we have to have the right light for it.

SD: Right so really prioritising the conservation of that?

Int H: Yes, that's right.

SD: Ok I will leave it there, thank you very much for your time.

\section{INTERVIEW CLOSE}

SD: Standards thanks and re-emphasis of participant right to access transcript. 
Appendix 9

\section{Publications}




\title{
Constructing heritage geographies: Mapping valued sites in Devon and Cornwall
}

\author{
Susie Darlow \\ School of Geography
}

\begin{abstract}
Possessing almost a third of England's scheduled monuments the Southwest is rich in heritage resources. Tourism contributes over $£ 4.6$ billion to the regional economy and 'heritage tourism' is a growing component. Surprisingly, no comprehensive inventory of the region's heritage resources exists and there is certainly no source that enables spatial distribution or the characteristics of heritage to be explored. As part of a study into sustainable management of visited heritage, this study presents both the case for, and the means employed in, the construction of the region's first comprehensive, searchable database of heritage sites designed to facilitate mapping and detailed analyses. Demonstrating the methodology through two examples museums and churches - the creation of an inventory tool, and mapping using GIS, will be explained. Applications of the research will be considered. Finally, the inventory as a platform for the empirical and theoretical exploration of the sustainable management of heritage resources will be highlighted.
\end{abstract}

Introduction

This paper addresses two significant challenges that face those seeking to study the geography of heritage tourism. The first challenge is defining precisely the meaning of heritage: what should be included, and what should not. The second challenge is to establish the location of all manifestations of heritage falling within an acceptable definition and to enter details in an inventory that is capable of underpinning further applied investigations. These challenges are explored within the context of Southwest England.

Defining and mapping the heritage of the Southwest region is important for a number of reasons. The region's heritage and historic resources are diverse, extensive and distinctive. Moreover, the concentration of heritage in the Southwest is the highest in England, and includes four (UNESCO) World Heritage Sites, 16.5 percent of national conservation areas (2005), a third of scheduled monuments $(6,846), 22$ of England's 42 registered historic wrecks, and fourteen Areas of Outstanding Natural Beauty covering 37 per cent of the region's area (English Heritage, 2006). The Southwest is also an appropriate focus for this study because of its thriving tourist industry, relying in no small part on visits to heritage resources. A National Trust survey showed that visits linked to the region's conserved landscapes account for $£ 2,354$ million annual tourist spend, and providing support for 972,000 jobs (43 percent of tourism-related jobs in the region), contributing $£ 4.6$ billion to the regional economy.

This wealth of resources and their contribution to employment and the regional economy reinforces the justification for developing a workable classification for Southwest's heritage and a new, comprehensive inventory of the location and character of the region's accessible heritage sites. 
2 Purpose of Research - The value of Mapping Visited Heritage

This paper comprises three main elements. First, the challenge of defining and categorising heritage resources is addressed. A critical assessment is offered of existing classifications, revealing both their variability and their lack of clarity and precision. None is deemed entirely appropriate for the Southwest's heritage and, as a result, a new hybrid model for the classification of 'visited' heritage in the Southwest is developed. Second, this paper discusses challenges faced in the development of a comprehensive inventory capable of providing information on the location and manifestation of heritage in the study area. The methodological processes employed in the creation and population of a robust and searchable database are described. To illustrate the way key problems involved in developing this kind of research tool have been solved, the particular challenges encountered in populating the 'churches' and 'museum' categories of heritage are presented. Third, consideration of potential applications of the searchable inventory of the Southwest's visited heritage and points to its use in an empirical exploration of sustainable management practices amongst providers of heritage tourism resources in the region.

\section{Classifying the Southwest's Visited Heritage}

Several models for classifying heritage have been proposed in recent years. Each model rests on the implicit assumption that heritage can be assigned to a discrete category. In practice, it is clear that some kinds of heritage may legitimately be assigned to more than one category. The development of a robust classification is not easy. For the purpose of this research the broad definition of heritage proposed by Graham, et al. $(2000,2)$ is employed. Graham defines heritage as a 'selective valuing (or using) of aspects of the past'. The term heritage is not synonymous with 'the past' or with 'history'. Instead, heritage refers to aspects of the past that are selected and valued by particular individuals and groups. In the context of that definition, this research focuses on visited heritage resources and therefore involves places or objects that are normally accessible to the general public.

In reviewing different typologies of heritage resources proposed by previous authors, it is clear that each model is more relevant to particular areas and meets the requirements of its proposers. Generally, existing classifications presented in the literature are based on the current or historic use of the resource. Important examples of existing classifications include those developed by Prentice (1993) and Yale (1998). Prentice defines a wieldy list of 23 different categories of 'heritage attraction' (Table 1) while Yale's classification comprises a more manageable eleven (Table 2). It should be noted, however, that Prentice aimed to classify tourist attractions and his typology therefore incorporates some categories that may not be considered heritage. Yale's classification is, by contrast, confined to heritage tourism resources and might be thought more appropriate as the basis for classifying visited heritage resources in Southwest England. However, Yale's classification has not been borrowed wholesale for this research because it incorporates several broad and generalised categories that do not allow for sufficiently clear separations to be achieved between certain kinds of heritage that are prominent in the study area. 

Business

\section{Table 1: Typology of Attractions}

\begin{tabular}{|c|c|}
\hline Type of Attraction & Description \\
\hline Natural History attractions & $\begin{array}{l}\text { including nature reserves, nature trails, aquatic life displays, rare breeds centres, } \\
\text { wildlife parks, zoos, butterfly parks, waterfowl parks; geomorphologic and geological } \\
\text { sites, including caves, gorges, cliffs and waterfalls. }\end{array}$ \\
\hline Science based attractions & $\begin{array}{l}\text { including science museums, technology centres, 'hands on' science centres, } \\
\text { 'alternative' technology centres. }\end{array}$ \\
\hline $\begin{array}{l}\text { Attractions concerned with } \\
\text { primary production, }\end{array}$ & $\begin{array}{l}\text { including agricultural attractions, farms, dairies, farming museums, vineyards; fishing, } \\
\text { mining, quarrying, water impounding reservoirs. }\end{array}$ \\
\hline $\begin{array}{l}\text { Craft centres and craft } \\
\text { workshops }\end{array}$ & $\begin{array}{l}\text { attractions concerned with hand made products and processes, including water and } \\
\text { windmills, sculptors, potters, woodcarvers, hand worked metals, glass makers, silk } \\
\text { working, lace making, handloom weaving, craft 'villages'. }\end{array}$ \\
\hline $\begin{array}{l}\text { Attractions concerned with } \\
\text { manufacturing industry }\end{array}$ & $\begin{array}{l}\text { attractions concerned with the mass production of goods, including pottery and } \\
\text { porcelain factories, breweries, cider factories, distilleries, economic history museums. }\end{array}$ \\
\hline Transport attractions, & $\begin{array}{l}\text { including transport museums, tourist and preserved railways, canals, civil shipping, } \\
\text { civic aviation, motor vehicles. }\end{array}$ \\
\hline Socio-cultural attractions & $\begin{array}{l}\text { prehistoric and historic sites and displays, including domestic houses, social history } \\
\text { museums, costume museums, regalia exhibitions, furnishings museums, museums } \\
\text { of childhood, toy museums. }\end{array}$ \\
\hline $\begin{array}{l}\text { Attractions associates with } \\
\text { historic persons }\end{array}$ & including sites and areas associates with writers and painters. \\
\hline Performing arts attractions, & including theatres, street-based performing arts, performing arts workshops, circuses. \\
\hline Pleasure gardens, & including ornamental gardiens, period gardens, arboreta, model villages. \\
\hline Theme parks & $\begin{array}{l}\text { including nostalgia parks, 'historic' adventure parks, fairytale parks for children (but } \\
\text { excluding amusement parks, where the principle attractions are the exciting rides and } \\
\text { the like). }\end{array}$ \\
\hline Galleries & principally art galleries. \\
\hline Festivals and pageants & $\begin{array}{l}\text { including historic fairs, festivals 'recreating' past ages, countryside festivals of 'rural' } \\
\text { activities. }\end{array}$ \\
\hline Fieldsports & traditional fieldsports, including fishing, hunting, shooting, stalking. \\
\hline Stately and ancestral homes & including palaces, country houses, manor houses. \\
\hline Religious attractions, & including cathedrals, churches, abbeys, priories, mosques, shrines, wells; springs. \\
\hline Military attractions & $\begin{array}{l}\text { including castles, battlefields, military airfields, naval dockyards, prisoner of war } \\
\text { camps, military museums. }\end{array}$ \\
\hline Genocide monuments & $\begin{array}{l}\text { sites associated with the extermination of other races or other mass killings of } \\
\text { populations. }\end{array}$ \\
\hline Towns and townscape, & principally historic townscapes, groups of buildings in an urban setting. \\
\hline Villages and hamlets & principally 'rural' settlements, usually of pre-twentieth century architecture. \\
\hline $\begin{array}{l}\text { Countryside and treasured } \\
\text { landscapes }\end{array}$ & $\begin{array}{l}\text { including national parks, other countryside amenity designations; 'rural' landscapes } \\
\text { which may not be officially designated but are enjoyed by visitors. }\end{array}$ \\
\hline $\begin{array}{l}\text { Seaside resorts and } \\
\text { 'seascapes', }\end{array}$ & principally seaside towns of past eras and marine 'landscapes'. \\
\hline Regions & $\begin{array}{l}\text { including pays, lande, counties, or other historic or geographical areas identified as } \\
\text { distinctive by their residents or visitors. }\end{array}$ \\
\hline
\end{tabular}




\section{Table 2: Heritage tourism attractions}

\begin{tabular}{|c|c|}
\hline Type & Attractions included \\
\hline The museums & $\begin{array}{l}\text { Local museums (comprehensive and specialist), History and archaeology museums, } \\
\text { science and technology, natural history, ethnography, open-air, film/ photography, } \\
\text { fine arts, industrial heritage, historical/ literary, archaeology, children and toys, } \\
\text { military, transport, specialist, private collection }\end{array}$ \\
\hline Stately homes & Stately homes, Castles, places and gardens, the royal family, royal parks, \\
\hline Religious Heritage & $\begin{array}{l}\text { British cathedrals, churches, special events, redundant churches, chapels, } \\
\text { churchyards and cemeteries, abbeys and priories, ruins. }\end{array}$ \\
\hline Other historical attractions & $\begin{array}{l}\text { Archaeological sites, ancient monuments, Military manoeuvres sites, listed buildings, } \\
\text { conservation areas, heritage centres, heritage trails and guided walks, homes of the } \\
\text { famous, historic public buildings, British battlefield sites, other monuments }\end{array}$ \\
\hline The Arts & $\begin{array}{l}\text { Art galleries, art displays, temporary exhibitions, works of art in situ, the crafts, } \\
\text { theatres, plays, musical entertainment, dance companies, cinemas, art festivals }\end{array}$ \\
\hline Industrial heritage & $\begin{array}{l}\text { Mines and quarries, the mills, wind and watermills, the public utilities, other industrial } \\
\text { remains, model towns, dockland revival schemes, the potteries, engineering projects }\end{array}$ \\
\hline Transport heritage & $\begin{array}{l}\text { The railways, railway museums, stations, other buildings, other leisure possibilities, } \\
\text { the canals, ships, roads and road transport, carriages, veteran and vintage cars, } \\
\text { public transport, road structures, air }\end{array}$ \\
\hline Countryside attractions & $\begin{array}{l}\text { National parks, AONB, SSSI, Nature reserves, country parks, Coastal scenery, } \\
\text { Heritage coasts, marine nature reserves, forest and woodland, forest parks, } \\
\text { community parks, paths and trails, mountains, caves, water attractions, }\end{array}$ \\
\hline Wildlife attractions & $\begin{array}{l}\text { Zoos, Aquaria, Safari parks, animal encounters, wildfowl and wetland trust reserves, } \\
\text { Falconry centres, other bird attractions, rare breed farms, city farms, heavy horse } \\
\text { attractions, trout farms, butterfly farms, local wildlife trusts, other specialist wildlife } \\
\text { attractions }\end{array}$ \\
\hline Miscellaneous attractions & $\begin{array}{l}\text { Waxworks, leisure and theme parks, seaside resorts and piers, towns, spa towns, } \\
\text { shops, film and television studios, }\end{array}$ \\
\hline Events attractions & $\begin{array}{l}\text { Traditional ceremonies, sports events, festivals of music, drama and film, food and } \\
\text { drink festivals, flower and garden festivals, religious events, political events, markets, } \\
\text { illuminations, circuses. }\end{array}$ \\
\hline
\end{tabular}

Source: Adapted from Yale 1998

In a further refinement in approaches to classifying heritage, Timothy and Body (2003) suggest that resources should be divided into two groups: tangible and intangible. Tangible heritage resources comprise those that are fixed and immoveable, such as buildings or historically important landscapes, and those that are portable, such as museum objects. Intangible heritage includes, for example, customs and ceremonies to which value is attached. Table 3 summarises Timothy and Boyd's classification and gives examples of resources meeting the criteria defined for each category within their classification.

Table 3: Timothy and Boyd Classification of resources

\begin{tabular}{|c|c|}
\hline Tangible resources & Intangible resources \\
\hline A: Tangible immovable resources: & - Value \\
\hline - $\quad$ Buildings & - $\quad$ Customs \\
\hline - $\quad$ Rivers & - $\quad$ Ceremonies \\
\hline - Natural areas & - $\quad$ Lifestyles \\
\hline B: Tangible moveable resources & $\begin{array}{l}\text { - experienced such as festivals, arts and } \\
\text { cultural events }\end{array}$ \\
\hline - Objects in museums & \\
\hline - Documents in archives & \\
\hline
\end{tabular}

Source: Adapted from Timothy and Boyd (2003) pp. 3

While Timothy and Boyd's approach is not adopted directly in this research, in highlighting the importance of an intangible kind of heritage, their work points 
to the need to allow for manifestations of cultural heritage in the classification devised for the Southwest. The region-specific inventory has many categories that could be transferable to other regions however the incorporation of a marine-specific category is of particular importance to this study area. Ideas drawn from a range of existing classifications have been incorporated in the scheme proposed for use in this research (Table 4). At inception, it was recognised that a particular heritage resource might belong in more than one of the sixteen proposed categories. A demand imposed on the database included a facility for recognising that some resources and sites might be double (or even triple) counted. In certain kinds of analysis, the fact that a resource is counted several times (within different categories) will be desirable. However, the database must also be capable of counting absolute populations. These and other demands imposed on the inventory tool are described in the next section.

Table 4: Southwest Heritage classification

\begin{tabular}{|c|c|}
\hline Category & Description \\
\hline Natural resources & $\begin{array}{l}\text { Resources/ Sites and attractions in which natural landscapes and nature form } \\
\text { the basis of the resource }\end{array}$ \\
\hline Human landscape resources & $\begin{array}{l}\text { Other landscape features affected by human influence/ includes other non } \\
\text { designated treasures landscapes }\end{array}$ \\
\hline Industry & $\begin{array}{l}\text { All resources/sites/ displays and museums linked to Industry including impact } \\
\text { of industry on society }\end{array}$ \\
\hline Transport & $\begin{array}{l}\text { All resources/sites/ displays and museums linked to Industry including impact } \\
\text { of Transport on society }\end{array}$ \\
\hline Socio cultural & $\begin{array}{l}\text { Resources/ sites/ museums/ displays which demonstrate human existence in } \\
\text { defined periods of history, incorporating archaeology of different eras }\end{array}$ \\
\hline $\begin{array}{l}\text { Palaces, houses parks and } \\
\text { gardens }\end{array}$ & $\begin{array}{l}\text { including ornamental gardens, period gardens, arboreta and including } \\
\text { palaces, country houses, manor houses. }\end{array}$ \\
\hline Famous person influenced sites & $\begin{array}{l}\text { A site or resources viewed as having value due to its inferred or actual } \\
\text { relationship to a historic person or persons }\end{array}$ \\
\hline Regions, settlements and buildings & $\begin{array}{l}\text { Principally historic townscapes and grouped buildings in urban and rural } \\
\text { areas. Focus on architecture, built environment, and geography of settlement }\end{array}$ \\
\hline Marine environment & $\begin{array}{l}\text { All heritage resources and attractions based within the marine environment } \\
\text { (beach to national offshore extent) }\end{array}$ \\
\hline Military resources & $\begin{array}{l}\text { Including castles and fortifications, battlefields, military airfields, naval } \\
\text { dockyards, prisoner of war camps, military museums displays, exhibitions and } \\
\text { memorabilia resources. }\end{array}$ \\
\hline Religious sites & $\begin{array}{l}\text { Including cathedrals, churches, abbeys, priories, mosques, shrines, wells, } \\
\text { springs. }\end{array}$ \\
\hline Science based attractions & $\begin{array}{l}\text { Including science museums, technology centres, 'hands on' science centres, } \\
\text { 'alternative' technology centres. }\end{array}$ \\
\hline Theme parks & $\begin{array}{l}\text { Including nostalgia parks, 'historic' adventure parks, fairytale parks for children } \\
\text { (but excluding amusement parks, where the principle attractions are the } \\
\text { exciting rides and the like). }\end{array}$ \\
\hline Arts and Crafts & $\begin{array}{l}\text { Including theatres, street-based performing arts, performing arts workshops, } \\
\text { circuses, art galleries and attractions concerned with hand made products and } \\
\text { processes, including water and windmills, sculptors, potters, woodcarvers, } \\
\text { hand worked metals, glass makers, silk working, lace making, handloom } \\
\text { weaving, craft 'villages'. }\end{array}$ \\
\hline $\begin{array}{l}\text { Festivals, fieldsports, markets and } \\
\text { fairs }\end{array}$ & $\begin{array}{l}\text { Including historic fairs, festivals 'recreating' past ages, countryside festivals of } \\
\text { 'rural' activities. Traditional fieldsports, including fishing, hunting, shooting, } \\
\text { stalking. }\end{array}$ \\
\hline Museums & $\begin{array}{l}\text { Museums based on or hosting specific or generalised historic displays. Can } \\
\text { be seen as an aspect of every category rather than a classification of its own. }\end{array}$ \\
\hline
\end{tabular}




\section{Creating an inventory tool}

Several processes are involved in the creation of a database capable of interrogation. To allow searching and interrogation, the database must contain recognisable classifications: locational data, and details about the resources. Given the income and employment benefits derived from its visited heritage resources, the lack of any significant previous research establishing the full extent, geographical location, and character of the Southwest's heritage is surprising. However, the lack of an existing comprehensive, searchable, publicly accessible inventory tool presents an opportunity for the development of a system allowing researchers, education providers and heritage managers more readily to find information concerning regional resources. It is suggested that the methodology developed in the context of the Southwest will be broadly transferable to other regions. The inventory will allow potential users to identify groups of heritage resources according to their characteristics, management styles, by particular features, or geographical location.

Some listings of heritage resources do currently exist and these provide fragmentary information that has been drawn upon in this research. For example, English Heritage and the National Trust are both primary providers of information relating to the heritage that they own or manage. While these organisations publish information on a large range of resources that the public can access, their data are often limited in detail. While an address is often provided, precise spatial information is frequently missing. The generally limited amount of detail given in existing inventories means that searching below the generic 'type' of resource is not possible and searches relating to specific characteristics, styles or features are not facilitated. Undoubtedly, the publicly accessible listings of the National Trust and English Heritage are designed to inform tourists and visitors and not designed to allow for intensive interrogation of the kind envisaged in this research.

Much information about other heritage resources in the Southwest can also be gathered by means of intensive on-line and library searching but, it should be noted, that to assemble a detailed picture of all examples of any particular group of resources, scores of different sites and publications must be consulted. To this task must be added that of searching for locational details such as postcodes and grid co-ordinates. The need for a single comprehensive database is clearly compelling.

\subsection{Formatting an inventory tool}

The desire to create an accessible tool, capable of being interrogated and useful at a range of different levels imposed a number of key demands. Above all, the database must be functional, use readily available software (of the kind that other general users would be able to operate), and have an accessible 'front end'. Although hosting the tool in Microsoft Excel has the attraction of ease of use and wide familiarity, the option was rejected. The Excel format provides neither the 'front end' functionality nor the ability to lock the original dataset to prevent the corruption of its contents. Microsoft Access was instead considered a better choice because this software is not only reasonably easy for computer-literate users to navigate and interrogate, but also offers the functionality necessary to create the inventory tool.

In order to test the robustness of the tool during development, heritage museums and heritage (Anglican) places of worship in the Southwest were 
chosen as pilot categories. Museums and churches together pose a wide range of methodological challenges likely to be encountered across the range of heritage categories that will be introduced to populate the datasets. The primary problem encountered in the population of both datasets is that neither the museums nor the churches categories represent data provided directly either by English Heritage or any other major listing agency. The population of both the museum and church datasets was made even more complex by a range of category specific and generic factors. The varying ease of addressing these complexities is described below. It should be noted that both of these heritage resource categories falls within a spectrum of complexity that will be encountered in the population of all later categories.

\subsection{Processes: populating the inventory}

The complexity of the process used to populate the inventory is demonstrated in Figure 1. It charts the processes from the initial identification of sources of information through the population of the inventory, to the creation of mapped categories of data. Constant reexamination of the sources used and the resultant information, as well as revisions of database format, were necessary as work progressed. The complexity and length of the process is intrinsically linked to the complexity of the information sources and the availability of basic locational data. 


\section{Business}

Figure 1: Process of Inventory creation

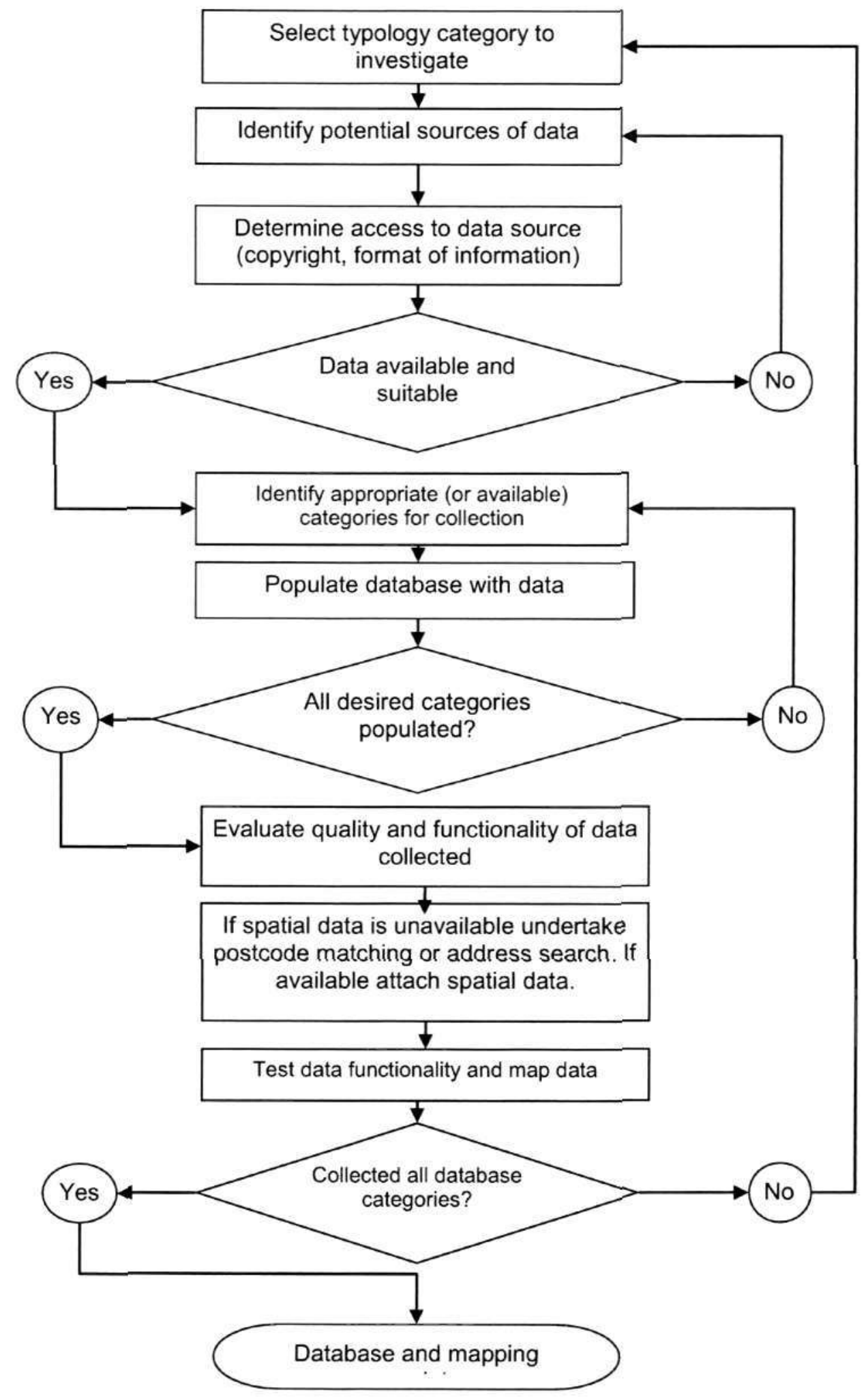


4.3 Creating heritage geographies: barriers to constructing geospatial information

Problems inherent in the creation of spatially referenced information have been academically documented. While examples cited here do not deal directly with the particular problems associated with mapping heritage, they are nevertheless important in demonstrating the general challenges that must be overcome in the construction of spatial information databases. Research by Batcheller et al. (2007, 47-65) shows that GIS based representation has emerged as 'an important tool in the analysis of spatial phenomena' and 'has been mirrored by the evolution of the data models underpinning such systems' but that it is the decision about 'which to employ for a given application' that is the most complicated. Thus the complexity involved in the 'intelligent selection' of an appropriate solution forms a barrier to creating databases linked to mapping. In the context of constructing heritage geographies, the intelligent selection involved (1) a search for electronic data on eastings and northings (to be imported to the main database as well as any spatial GIS package potential user might wish to use) and (2) a means of holding maps of heritage resources for users of the database who might not themselves have ready access to GIS software.

Cartwright (2007) identifies further problems experienced when developing geographical information resources. He suggests that sourcing information and spatial data is difficult and argues that these barriers can be overcome only by developing a unique '(geo)information realization resource' based upon user-defined requirement. His ideas are adopted in this research and the processes involved in translating heritage information into a format that can be spatially accessed will now be discussed using the case studies of museums and churches. 


\section{Case Studies: populating the inventory}

\subsection{Case Study 1: Museums - a low-complexity example}

Museums can contain a number of diverse kinds of visited heritage in the sense that the building that houses the museum might be a valued building, and the various collections housed inside might be individually valued (Figure 2).

Figure 2: Plymouth Museum, Plymouth: A museum with layered heritage significance. The Plymouth museum holds extensive and diverse displays of heritage giving it significant heritage significance. Additionally, the building has significant heritage value in its own right.

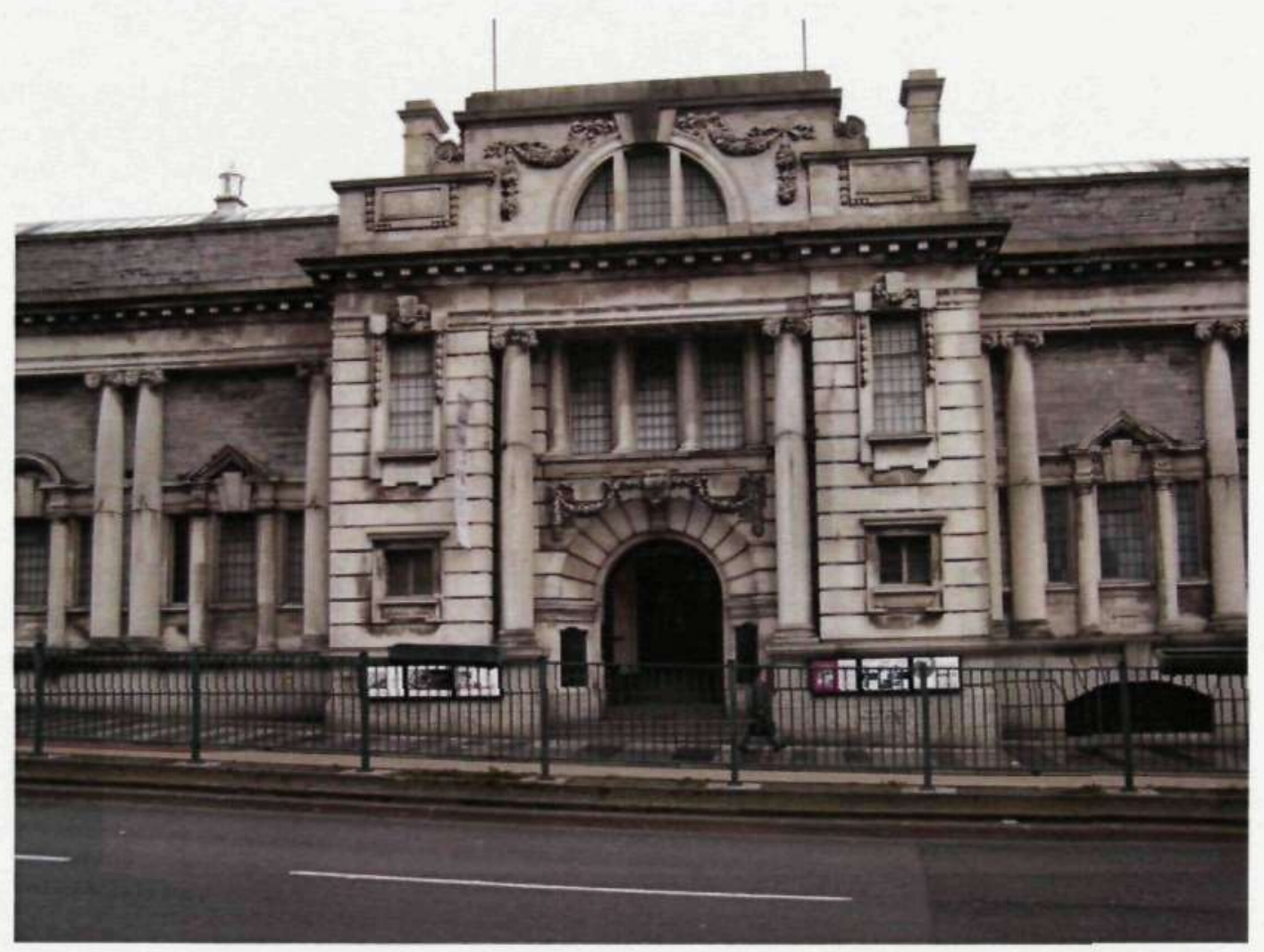

Heritage museums are an example of a low-complexity dataset; the reasons are that a single source of data exists that lists all the region's museums, the total number of heritage museums in Devon, Cornwall and the Isles of Scilly (183 museums) is relatively small, and detailed descriptive information for each museum was easily obtained. The construction of the database for this particular category was therefore straightforward. However, it should be noted that this information was not available for download or extensive interrogation, and it was necessary to transcribe the information into the Access database. In the case of museums, information shown in Table 6 was encoded: 
Table 6: Types of data on Museums available for transcribing and encoding into database tool

\section{Categories available for database encoding}

\begin{tabular}{|l|}
\hline Name of Museum \\
\hline Ownership of Museum \\
\hline Description of function of Museum \\
\hline Address of Museum \\
\hline Postcode of Museum \\
\hline Website of Museum \\
\hline e-mail address contact of Museum \\
\hline
\end{tabular}

To secure accurate spatially referenced information, further web-based resources were drawn upon to populate any 'missing' addresses. This task required the conversion of postcode information (available through web resources, such as www.streetmap.co.uk) into grid-reference data for entry into the database. Once created, the data were capable of being mapped using ArcGIS software. Figure 3 demonstrates the mapping output possible from the museums dataset.

Figure 3: Spatial representation of the museum database category

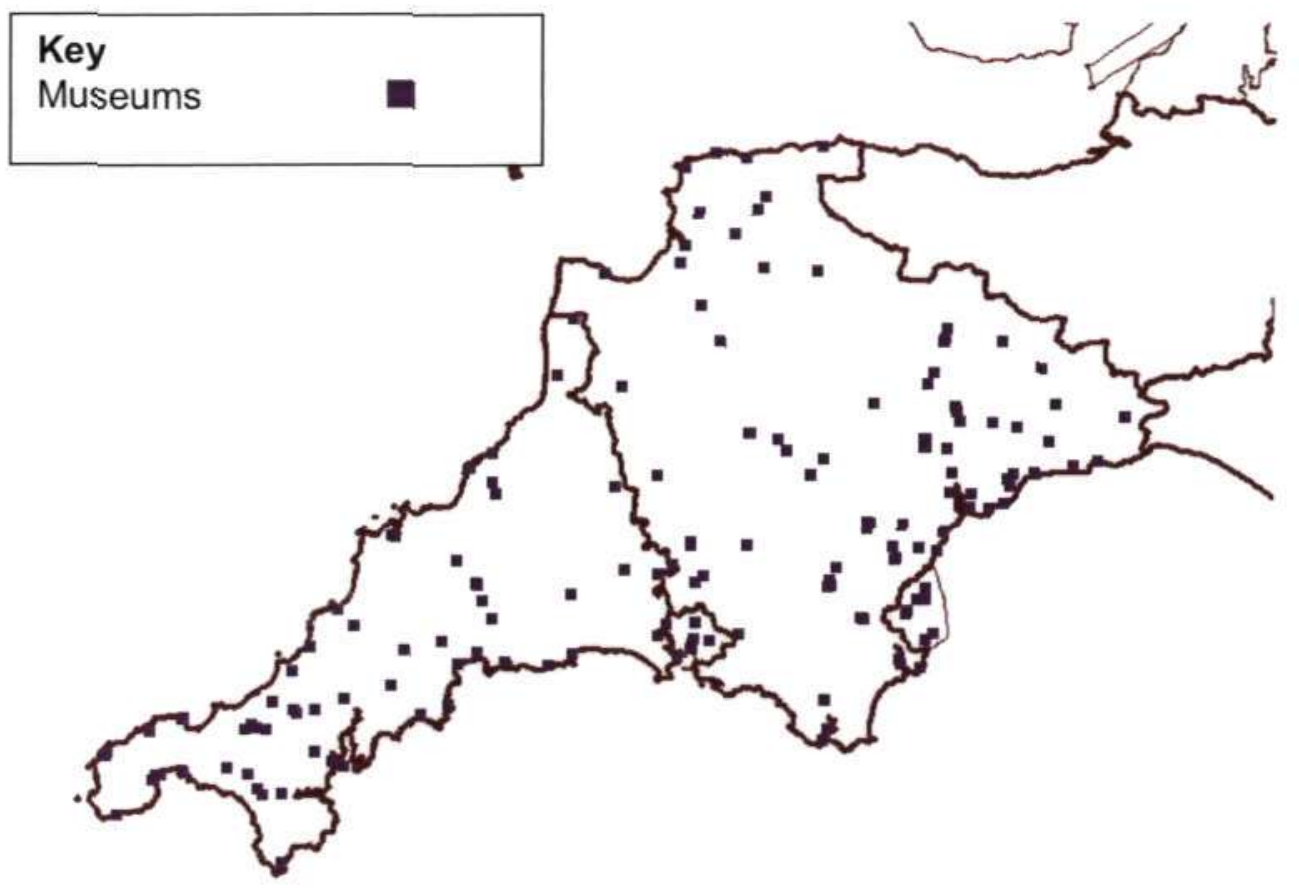




\subsection{Case Study 2: Churches - a high-complexity example}

In contrast to the museum dataset, the gathering of detailed information on heritage churches was highly complex.

Figure 4: St Andrew's Church, Aveton Gifford: A church with layered heritage significance. The original church comprised a cruciform medieval church until destroyed during a World War II bombing. The church was rebuilt in a copy of the original medieval form but has additional heritage significance due to its value as an example of post war reconstruction.

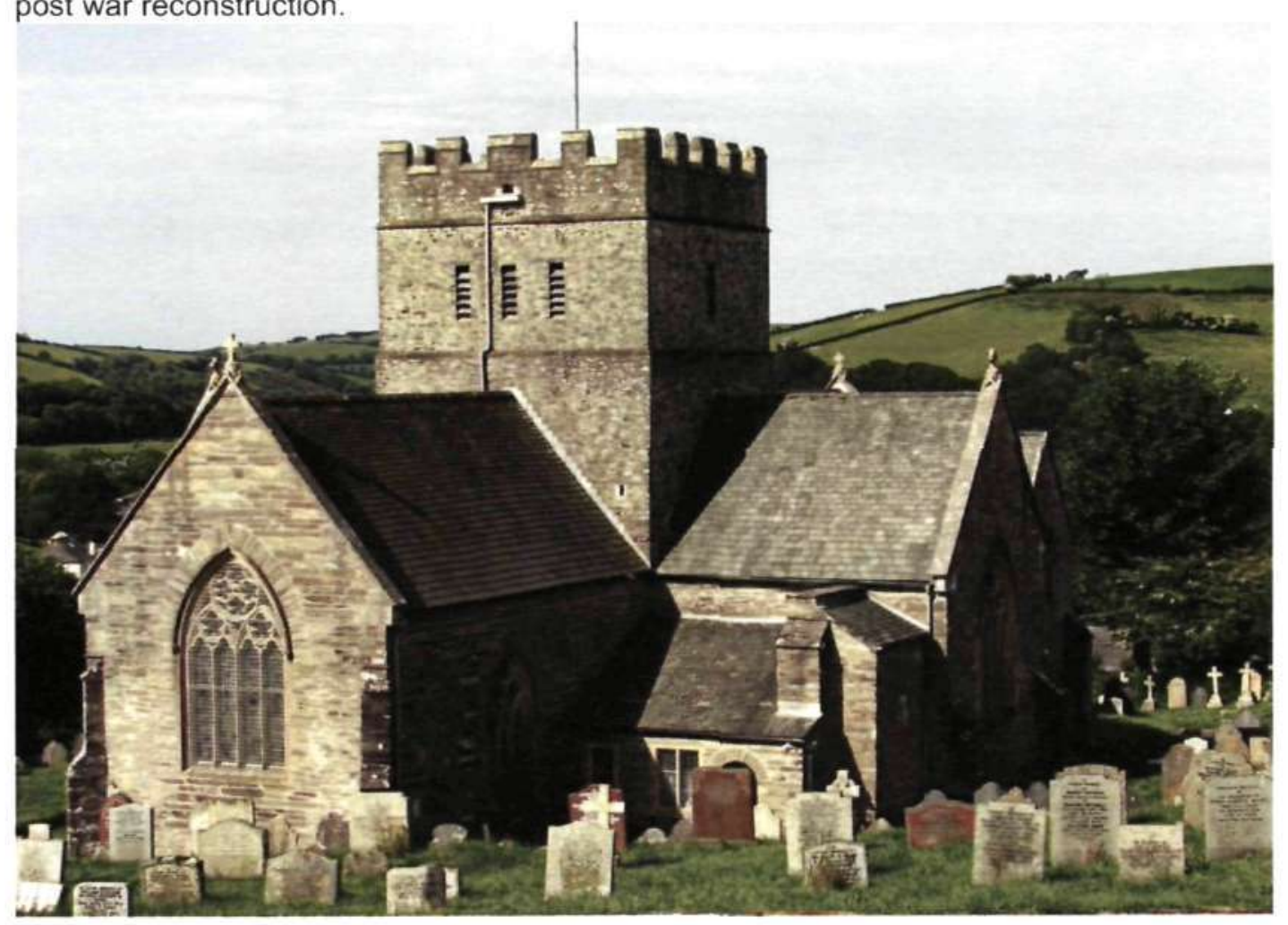

An initial problem is the large number of cases (929 churches in Devon and Cornwall). However, the prime complexity factor is the absence of a single source of detailed information about heritage churches. It was essential to combine information drawn from a range of sources. Foremost amongst these are the diocesan directories of the Church of England, which were used as a starting point. These directories are available only in hard copy, and contain limited and inconsistent information (Table 7).

Table 7: Types of church based data contained in the diocesan directory available for transcribing and encoding into database tool

\section{Categories available for database encoding}

\begin{tabular}{|l|}
\hline Details of parish names \\
\hline The name of the specific church \\
\hline The name and address of the clergy representing the church. \\
\hline
\end{tabular}


Information in the directories about the heritage attributes of individual churches is very limited. Supplementing this source was essential if the level of detail and quality of data required in the inventory was to be met. The Church of England's on-line facility 'A Church Near You (ACNY)' provides limited further data and this was exploited wherever possible. In the case of churches within Cornwall (Truro Diocese), for example, some postcodes and additional detail about the heritage character of churches is provided. Nevertheless, when a cross-check was made between the information contained in the ACNY resource and English Heritage listings, inaccuracies and inconsistencies were revealed. The fragmented nature of sources of information and suspicions about the reliability of data held in some listings meant that further research was essential.

English Heritage published information on all churches with 'listed' status and this source was employed to cross-reference and identify heritage churches, and to fill in as much 'missing' information as possible. Moreover, additional cases were added to the inventory comprising redundant church buildings that have 'listed' status.

Assigning spatial references churches posed a further level of complexity. It proved very difficult in a significant number of cases to establish the postcode assigned to the building. The easy conversion of postcodes into grid references was thereby precluded. To overcome the problem, a two-stage solution was found that pinpointed the precise locations of all the churches. First, the Royal Mail address finder was used wherever possible to access the full postal address of churches. Where a full address could be assigned, there was an associated postcode. Second, in cases where only address fragments were available, the facility offered by the www.streetmap.co.uk web-site to assign a 'nearest postcode' was used. Thereafter, it was possible to use the same method employed in the case of museums to assign unique grid references to each heritage church in the inventory. Figure 5 demonstrates the mapping output possible from the churches dataset.

It should be noted here that heritage places of worship of other Christian denominations and other religions are likely to be added to the inventory in future. A further layer of complexity to the data collection process is likely to be encountered as no single resource provides the necessary information. 
Figure 5: Spatial representation of the museum database category

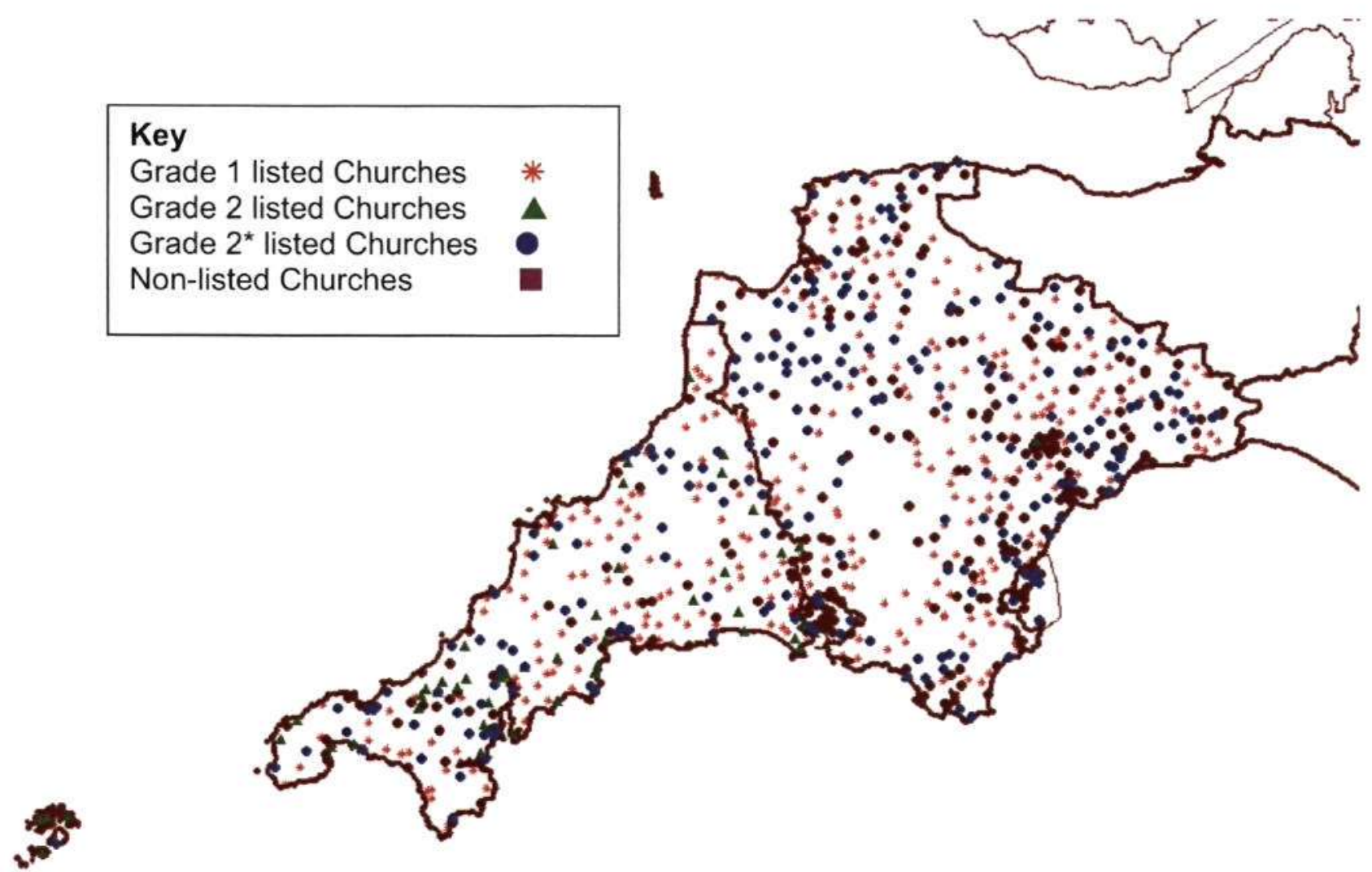

The importance of spatially referenced information has already been highlighted. Accurate grid references (easting and northing information) are essential for the production of maps of heritage features. As noted above, webbased map finder software was used to assign unique grid references to the centroid of each postcode. This was straightforward in all cases where postcodes could be established. In those cases where a 'nearest postcode' was assigned, it may be noted that the pinpoint accuracy of any locational maps produced from the data will be compromised. However, when mapping at the regional or sub-regional scales, the impact is less important. It is acknowledged that for certain applications, the incorporation within the inventory of some approximated grid references may impact adversely on a user's ability to find a site. A warning, and associated 'risk' distance from resource, will need to be identified in the final database where necessary.

\section{Research applications of the database}

The creation of the inventory of the Southwest's heritage, with its facility for searching and interrogating the information represents the first stage in an academic research project focusing on the sustainable management of heritage. It is also recognised that the database will offer the opportunity for other practical applications. 
7.1 Practical contribution of the inventory and its use as a platform for researching the sustainability of heritage resources

A research tool of the kind described in this paper - drawing together information from a diverse range of existing sources and displaying it in a way that can be easily accessed and mapped - offers a number of practical uses. The inventory is likely to be of value for educational purposes, for those devising policy, or simply for visitors who may wish to identify interesting places to visit. Further practical applications that can be envisaged include interrogation of the database by the managers of heritage resources who wish to identify similar, complementary, or contrasting providers that exist in close proximity. The inventory may provide a basis for networking, clustering and the sharing of good practice.

Above all the data gathered in the inventory will provide a vital platform for the core investigation of this research project which focuses on the sustainable management of visited heritage sites. The aim is to identify the techniques that mitigate not only detrimental environmental impacts of the heritage sites themselves, but also their political, economic and socio-cultural impacts. This empirical research will be used as the basis of an academic inquiry, and also has the potential to inform heritage managers, policy makers and educators.

\subsection{Theoretical contributions}

Deriving information on sustainable management practices and building this into the inventory will allow the identification of a sample of heritage providers who will be studied in depth. Management styles will be examined within a context of behavioural theory and drawing, for example on Plog's psychographic analysis (the 'Lifestyle and Activity Level Preferences Model'). Similarly Laws' Blueprinting Analysis will be employed as a methodology to test the theory that heritage resource managers who run their enterprises in a sustainable way, do so as a result of a conscious understanding of the interconnections that exist in the operation of their enterprise. Finally, Moscardo's theoretical work on 'Mindful and Mindless' actors will be explored in the context of the sustainability of the management approaches at heritage resources. The inventory will also underpin research on the spatial dispersion and clustering of resources that will draw on the theories of Porter (1998) and Novelli (2005).

\section{Conclusions}

This paper presented the case for the development of a regional typological classification of heritage and the associated need for a comprehensive listing of visited heritage resources. The lack of a comprehensive source of information regarding heritage in the Southwest - a fact that is surprising in light of the region's rich and diverse resource base and the economic dependence on income derived from domestic and international tourist visits - strongly justifies the work that is being undertaken. The challenges posed by the need to classify and list heritage resources in a way that allows for data to be searched and sorted have been outlined. At the same time, the considerable advantages that will flow from the completed listing have been 
established. It is argued that the database will be highly functional, fully linked to locational data, and searchable in a flexible manner. The practical value of the inventory tool for a range of heritage stakeholders also demonstrates the applied value of this research. Finally, the role of the tools described in this paper as the platform for empirical and theoretical explorations of sustainability issues in relation to heritage resource management in the Southwest has been highlighted.

\section{References}

Batcheller et al. (2007) 'The Performance of Vector Oriented Data Storage Strategies in ESRl's ArcGIS', Transactions in GIS. 11 (1), pp. 47-65

Cartwright. et al. (2007) 'Realizing the Literate Traveller', Transactions in GIS, 11(1), pp. 47.

Church of England: 'A Church Near You' website [online] hittp://www.achurchnearyou.com/

English Heritage: Heritage Counts [online] http://www.english-heritage.org.uk/hc2006/

English Heritage: Images of England [online] http://www.imagesofengland.org.uk

Graham, B. et al. (2000) 'The contested interpretation of heritage landscapes in Northern Ireland', International Journal of Heritage Studies, 2, 1 \& 2, pp. 10-22.

Laws, E. (1998) 'Conceptualizing visitor satisfaction management in heritage settings: an exploratory blueprinting analysis of Leeds Castle, Kent', Tourism Management, Vol $19,6,545-554$

Moscardo, G. (1996) Mindful Visitors: Heritage and Tourism. Annals of Tourism Research, Vol.23, No. 2, pp 376-397

Novelli, Marina, ed. (2005) Niche Tourism: Contemporary issues, trends and cases. Amsterdam: Elsevier.

Plog, S (1990) Vacation Places Rated, Fielding Worldwide, California

Porter, M. (1998) Clusters and the new economics of competition. Harvard Business Review. November-December

Prentice, R. (1993) Tourism and heritage attractions, London, Routledge

Royal Mail: Postcode finder [online]

http://www.rovalmail.com/portal/rm/postcodefinder;isessionid=VQBJJJVW03DU QFB2|GVEQEQUHRAOWQ2K? catld $=400145$ \&gear=postcode

StreetMap web based mapping resource [online] http://www.streetmap.co.uk

Timothy, D. and Boyd, S. (2003) Heritage Tourism, Prentice Hall. pp.36-9 and 99-103.

Yale, P. (1991) From Tourist attractions to Heritage Tourism. Elm Publications.

Huntingdon. 


\title{
The Re-development of Cotehele Quay Museum
}

\author{
Susie Darlow \\ School of Geography, Earth and Environmental Sciences, University of Plymouth, PL4 \\ BAA
}

and

Rachel Hunt

Cotehele, St Dommick, Cornwall, PL12 6TA

\begin{abstract}
Cotehele occuples a 1300-acre estate, on the Cornwall side of the River Tamar and compnses an historic house, formal and informal gardens, woodlands and orchards, a mill and a rver quay Owned by the Edgcumbe famly since 1353, it was transferred to the National Trust in 1947. The ongmal Quay Museum, operated in partnership with the National Mantime Museum, was first opened in 1982 in an old bulding known as 'Cap'n Bull's Storehouse' However, visitor numbers had slumped and, in 2007, a project called Cotehele Quay 'By the River' was devised to re-mvent the museum and increase its appeal The East Cornwall Regeneration Project, supported by the EU's Objective 1, contributed $£ 65,000$ of funding, and another $£ 10,000$ was provided by the Natronal Trust The National Maritime Museum offered 300 hours of expert curatonal time The arm was to redevelop the museum to fell the story of the thriving communty and industral economy of the Victorian era, and to explain the importance of the River Tamar through the ages Considerable local participation by the local community and a range of other stakeholders in devising the new museum was encouraged and the renamed Discovery Centre was finally completed in May 2008. Within the context of the socio-cultural sustainability of hertage, this paper describes both the Discovery Centre project and an evaluation exercise to gauge its success that was carried out by the authors following the museum's re-launch. Although further montoring will be needed in future to test whether the Discovery Centre maintains its appeal, it is argued that the re-making and remvention of the Cotehele Quay Museum, with its prominent emphasis on consuitation and inclusiveness, is an important example of a new approach $m$ the sustamable management of hertage
\end{abstract}

\section{INTRODUCTION}

In recent years, there has been a growing recognition of the need for a sustainable approach to the management of heritage, whereby both the intrinsic integrity of a historic property is protected, and the income-generating potential and appeal of the resource is maximised Major custodians of heritage properties, such as the National Trust, which since its formation in 1895 has played a key role in the conservation and protection of historically important landscapes and buildıngs, increasingly prioritıse sustainability as an objective in the way that heritage is cared for, 
displayed and made accessible to the public. ${ }^{1}$ This paper considers the processes and outcomes of the recent redevelopment of the Quay Museum on the Cotehele Estate, a large National Trust property in Southwest England. Although located on the Cornwall side of the River Tamar, Cotehele is, of course, very easily accessible to Devon residents; indeed, the property attracts visitors from across Britain and overseas. It will be argued that, in the re-making the Quay Museum, the Trust sought a broadly sustainable outcome whereby the key issues of economic viability, social acceptability, and even environmental friendliness were paramount. In particular, an examination will be made of the role of community and key stakeholder engagement in recreating this resource at Cotehele, and an evaluation will be presented of the success of the newly renamed quayside 'Discovery Centre' since the project was completed in 2008.

\section{BACKGROUND LITERATURE}

A limited body of literature exists that focuses on whether heritage sites can be made more sustainable and, if they can, how this might be achieved. Three main kinds of sustainability have been considered. These are economic sustainability ${ }^{2}$, socio-cultural sustainability ${ }^{3}$ and environmental sustainability. ${ }^{4}$ However, the literature on heritage tends to be dominated by studies of socio-cultural sustainability, particularly focusing on the success or otherwise of heritage interpretation and the degree to which authenticity has been achieved.

Studies of heritage presentation regard interpretation as a means of achieving sustainable management. ${ }^{5}$ Discussions about interpretation have focused on its effects on education at, and management of, heritage sites. In particular, interpretation as a means of guiding visitors appropriately to different areas of a site, thereby minimising their impact on a potentially vulnerable resource, has been considered by several authors. ${ }^{6}$ It has been argued that interpretation that (1) reinforces the perceived authenticity of a heritage site, (2) effectively appeals to its target audiences, (3) offers opportunities to connect to different narratives, and (4) is easily capable of renewal or refreshment, delivers socio-cultural sustainability. ${ }^{7}$

Studies that have focused on socio-cultural sustainability nevertheless allude to inextricable links with economic sustainability issues. Thus, in order to remain financially viable, a heritage resource must retain the interest and engagement of the paying public as successful interpretation creates economic as well as socio-cultural sustainability. ${ }^{8}$ However, research on the economic sustainability of heritage goes further and explores the notion of heritage resources as commodities that can be sold to well-defined markets. ${ }^{9}$ Such studies debate the problems of striking a balance between the demand to achieve a profit, i.e. economic sustainability, and the need to protect the integrity of often very fragile resources ${ }^{30}$.

Some authors have pointed to a dearth of work that integrates sustainability research to develop comprehensive recommendations for the effective management of heritage ${ }^{11}$. However, while gaps may exist in the scholarly literature, in recent years, heritage providers in this country, such as the National Trust, have developed an unrivalled practical experience of the sustainable management of their properties. Indeed, innovative approaches have been evident for several years. ${ }^{12}$ It may be argued therefore that heritage providers are more advanced in their approach than published literature suggests.

\section{SUSTAINABILITY IN THE NATIONAL TRUST}

As already noted, since its inception in 1895, the National Trust has been strongly associated with the conservation and preservation of heritage properties. The founders of the Trust saw the organisation as a 'guardian for the nation of ... threatened coastline, countryside and buildings'. ${ }^{13}$ While it may be argued that the notion of sustainability has always been implicit in the work of the 
National Trust, since the early 1990s, its framework documents, assessments, reports and strategies have increasıngly given explicit emphasis to the goal of sustainability Now ownıng 248 hectares (612,000 acres) of beautiful countryside in England, Wales and Northern Ireland, over 700 miles of coastline, and more than 200 butldings and gardens of outstanding interest and Importance', the Trust today is one of the country's largest managers of heritage With a current membershıp totallıng 3.5 mıllıon, some 12 million visıtors each year to tts pay-fóf-entry properties, and an estimated 50 million to its open arr properties, it is hardly surprising that sustainable management is seen as profoundly important. ${ }^{14}$ The National Trust's 1992 Environmental impact Assessment statement, and an associated document on environmental principles, Towards Sustainable Land Management (2005), together encapsulate sustainable management policies for both natural and built heritage in its own words, the National Trust seeks the 'cultural, economic, social and environmental interests of people today while planning for the wellbeing of future generations'. ${ }^{15}$ Indeed, between 2003 and 2007, in consultation with English Hertage and the Department of Culture Media and Sport (DCMS), the National Trust was engaged in a project to provide better guidance and support to all those Involved in the sustainable management of England's historic environment ${ }^{16}$

Dependence on entrance fees and membership subscriptıons, to cover operational costs, means that the National Trust's economic sustatnabılity is inextricably linked with ensurnng that its properties are also socially sustanable. In this context, social sustainability simply means that the presentation of heritage properties to the visiting public and all additional facilties must be acceptable, responsive and attractive both to new visitors and existing members ${ }^{17}$ Recognisıng that an economically sustainable income depends on offering a soclally sustainable product, the National Trust undertook new research to Identıfy its key audience groups, between April and July 2006 The Trust noted that visitor numbers were 'vital to our bottom line 49 per cent of our new members are recruited at pay-for-entry properties and our membership income - at $£ 102$ million thıs year $-\mathbf{1 5}$ our largest source of income ${ }^{\prime 18}$ The arms of the investıgation were twofold first, to Identify new visitors who might potentially be attracted to their sites and thereby generate further income, and second, to engage more effectively with their existing visitor groups Retaining the interest of all visitors, especially those who become subscribing members, is seen as a major priority in building 'a deeper relationship with supporters .. we want people to go home from a day out at a National Trust property inspired, enriched and enthusiastic about their expersence And to achieve this, we need to find out what they want' ${ }^{19}$

By indıcating how to target recruitment-drives for new members, the 2006 survey also serves as a management tool for each individual property A clearer understanding of the characteristics of visitor groups derived from the study thus provides information which helps in meetıng visitor needs and expectations In particular, the survey enables local and regional National Trust teams to

- Better target events and interpretation

- Develop more relevant retall and caterıng products

- Plan more targeted communications

- Introduce new campaigns that engage visitors to the Natıonal Trust's cause ${ }^{20}$ 
The research identified 'segments' or target audiences by dividing them, not by age, income or status, but by their motivations for visiting (Table 1). Clearly, the three most prominent target segments, at a national scale, are: the 'Out and About', the 'Explorer Families' and the 'Curious Minds' groups. Property managers have been asked to identify the two segments most appropriate to their local circumstances and to seek ways in which visitors drawn from these groups might be increased.

The National Trust has thus developed explicit strategies and policies that place it in the vanguard of those who seek the sustainable management, including the maximisation of income, of heritage properties. This study of the refurbishment and re-creation of the old Quay Museum on the Cotehele Estate provides an excellent case study of the practical implementation of these centrally driven strategies and policies. The sections which follow offer a brief background of the site, the story of the Quay Museum, the redevelopment project, and an assessment of the redesigned 'Discovery Centre' since its opening in 2008.

Table 1. Summary of characteristics of the of National Trust's seven visitor segments.

\begin{tabular}{|c|c|c|c|}
\hline 'Segment' Name & $\begin{array}{l}\text { Number of people in } \\
\text { segment nationally }\end{array}$ & They visit because... & Areas of interest \\
\hline Explorer families & 7.7 million & $\begin{array}{l}\text { 'they want an active and } \\
\text { stimulating experience' }\end{array}$ & Castles and ruins \\
\hline Out and About & 8.7 million & $\begin{array}{l}\text { 'we offer them something to } \\
\text { do' }\end{array}$ & $\begin{array}{l}\text { Picturesque towns and } \\
\text { villages, art and architecture }\end{array}$ \\
\hline Curious Minds & 5.6 million & $\begin{array}{l}\text { 'we provide a source of mental } \\
\text { stimulation to stretch their } \\
\text { active minds.' }\end{array}$ & $\begin{array}{l}\text { Well researched placed and } \\
\text { people stories }\end{array}$ \\
\hline $\begin{array}{l}\text { Young experience } \\
\text { seekers }\end{array}$ & 1 million & $\begin{array}{l}\text { 'they want to see awe-inspiring } \\
\text { things' }\end{array}$ & $\begin{array}{l}\text { Exercise and a challenge - } \\
\text { ending in the pub }\end{array}$ \\
\hline Home and family & 4.9 million & $\begin{array}{l}\text { 'we are a special family treat } \\
\text { for school or bank holidays' }\end{array}$ & Shopping and entertainment \\
\hline Kids first families & 3.8 million & 'they want to be entertained' & Country parks and estates \\
\hline Live life to the full & 3.1 million & $\begin{array}{l}\text { 'we can satisfy their thirst for } \\
\text { knowledge and quest for } \\
\text { escapism' }\end{array}$ & $\begin{array}{l}\text { Stately homes areas of } \\
\text { special interest }\end{array}$ \\
\hline
\end{tabular}

Source: compiled from information available from the National Trust, 2006. ${ }^{21}$

\section{HISTORICAL BACKGROUND COTEHELE ESTATE AND QUAY}

Cotehele House sits within a 1300 acre estate, spreading west from the Cornwall banks of the River Tamar. The estate, now containing the house, garden, extensive woodlands, orchards, a mill, and the riverside quay, was owned by the Edgcumbe family from 1353 until 1947, when the property was transferred to the National Trust. Dating mainly between 1485 and 1539, the house occupies a level site, high above the river. It is an exceptionally fine Tudor house, which contains 
an extensive collection of textıles and furniture. The bulding is set within beautiful formal and Informal gardens (Fig 1)

During the estate's early history, the Tamar, via the Quay, was the main means of access to the estate Today, however, visitors mainly arrive by car, some travel by rallway to Calstock and walk to the property; and modest numbers take the seasonally operated ferry trip from Calstock From the mid-nineteenth to the early twentieth centuries, an industrial hub developed and expanded around Cotehele Quay, bringing local employment and considerable revenue to the Edgcumbe estate. Fishıng, tın and arsenıc minıng, lime burning and market gardenıng vielded products that were transported down-river by Tamar barges The level of activity centred on Cotehele's Quay in that period contrasts starkly with the tranquility of the property and its waterfront today. Nevertheless, the remains of former industry, trade and river traffic represent an important heritage resource on the estate.

The National Trust's own surveys show that many visitors to Cotehele focus their trip solely on the historic house and the fine surrounding gardens, rather fewer visit other places of Interest on the estate, such as the mill (24 6 per cent) and the quayside Before the Museum refurbishment was undertaken, it was clear that those visitors who ventured down to the waterfront would not necessarly discover its existence Cotehele's Quay offers attractive catering faciltties, Including the Edgcumbe Arms tearoom providıng lunches and teas; a kıosk which serves light refreshments, drinks and ice-cream, the Shamrock, a restored sailıng barge; and a private canoe htre facility There are walks beside the ruver and the conserved lime-burning kilns as well as places to watch birds, have a pıcnıc, or sit and enjoy views of the river and the surrounding landscape Although centrally located on the Quay, the original Museum, developed by the National Trust in partnershıp with the Natıonal Maritıme Museum and opened in 1982 in the c 1910 building known as 'Cap'n Bıll's Storehouse', was not staffed and lay outside the tariff area of the main property (FIg 2). With a large car park nearby for which no fee is levied (donations are requested), it might be supposed that visitor numbers to the Museum would be high Anecdotal and observational evidence indicated the reverse, however, possibly due the fact that the bulding housed a museum was not particularly obvious to passing visitors

\section{VISITORS TO THE QUAY MUSEUM 2005-2007}

For more than twenty years after its opening, no systematic surveys were made of the frequency and character of visitors to the Museum. Lacking this information, it was impossibie accurately to gauge its success or fallure However, beginning in 2005, observations have been made of the type of visitor and patterns of use. Thus, Cotehele volunteers regularly undertook the monitoring work and the results thereby gathered indicated that the Museum attracted mainly local visitors and just a few industrial history and maritime history enthusiasts This evidence suggested that the level of detail, and nature of content provided in the displays had farly narrow appeal Analysis of the observations, made by the volunteers and Cotehele staff, indicated that the Museum was poorly signposted both at the Quay and elsewhere on the estate, it was simply overlooked by many visitors Moreover, the entrance to the Museurn was not obvious and could not be seen from the tea shop or kiosk - places where the majority of Quay visitors always congregate. Many of the exhibits, created in 1982, had become shabby and dated Although all the interpretative texts accompanying displays in the old Museum were well-written and informative, they were clearly rather old-fashioned, excessively detatled, and rather unappealıng, especially for children. Even though no detalled visitor statıstics were regularly collected, the low level of donations retrieved from the 'honesty box' located at the Museum's entrance reinforced the view that both visitor numbers and satisfaction levels were very low. 
The old Quay Musuem thus met few of the Trust's aims: it was free to enter and therefore not economically sustainable, it had only modest socio-cultural appeal, and it could not be described as sustainable in environmental terms. A decision about its future was required. The fate of the Museum rested on a new project called Cotehele Quay 'By the River'.

\section{COTEHELE QUAY 'BY THE RIVER' PROJECT}

Launched in 2007, the National Trust's Cotehele Quay 'By the River' project aimed to revitalise and reinvent the Quay Museum, and to enhance the setting and information about the Shamrock sailing barge, which is moored nearby. The project also aimed to incorporate consideration of the National Trust's national and local priorities developed as a result of the key audience research undertaken in 2006 . Some $£ 65,000$ of funding was contributed by the East Cornwall Regeneration Project (ECRP) through EU Objective 1 and a further $£ 10,000$ was provided by the National Trust. In addition, the National Maritime Museum pledged 300 hours of curatorial time for this and associated projects. The plan devised for the project envisaged the Museum's refurbishment between November 2007 and June 2008.

The aim was to redevelop the existing Quay Museum around two key themes. First, the story of the thriving community and industrial economy of the Victorian era needed to be told. Second, the importance of the River Tamar through the ages should be illustrated. Both themes were to be brought to life through a narrative that highlighted the families and individuals who had depended on the river, the industrial and agricultural activities of the valley, and the rich wildlife of the Tamar. Specific objectives were defined in the project remit:

- To provide thought-provoking interpretation to a wide audience including those with no previous knowledge of the Tamar Valley.

- To provide interactive interpretation and exhibits to 'humanise' the visitor experience, enabling visitors to relate to people who once lived in the area.

- To serve as a signpost encouraging visits to other sites to the rest of the estate including Cotehele Mill, the wider Tamar Valley, and the Cornish and west Devon mining landscapes which have recently been awarded World Heritage Site status.

- To use existing exhibits and information where appropriate.

Each objective reflected a desire to increase visitor numbers and create a socially sustainable visitor attraction. Through the effective use of a range of interpretive media, the project focused on widening the Museum's appeal to new audiences. For example, telling the story of the immediate area enabled local visitors to appreciate their connection with the surrounding landscape and its history. While visitors from further afield may not share in the intimacy of nearby associations, the Museum's narrative about place offers both meaningful insights about the unique World Heritage Site status of the area, but also the scope to compare the Tamar Valley's past with heritages encountered elsewhere. Interpretation capable of appealing to a wide audience was central to the National Trust's strategy. The research undertaken at Cotehele House showed that the existing key audience comprised the 'Explorer Families' and 'Curious Minds' groups. The redeveloped Quay Museum was thus aimed at local and national visitors who belong to these categories. 


\section{THE PROJECT PROCESS AND THE ROLE OF COMMUNITY PARTICIPATION}

A striking feature of the redevelopment of the Quay Museum has been the extensive consultation with key partners and representatives from the local community, the estate's tenants, and regular visitors to Cotehele. The process commenced in early 2007 when a team of 'key players' was established by Cotehele staff comprisıng members from the ECRP, the Tamar Valley Area of Outstanding Natural Beauty (AONB), Natıonal Trust regıonal representatives, exhıbıtion specialısts Gamble Fearon Partners, and John Graves the Trust's Curator of Ship History In addition, advice was sought on curatorial and conservation issues from the wider Natıonal Trust and from the National Maritime Museum in order to ensure that the local community and other interested parties could be actively engaged in the process, people were encouraged to join a focus group to examıne, discuss and question the ideas put forward by the key player team Local residents, Natıonal Trust volunteers, local busıness people, educatıon providers and a representative of the University of Plymouth were thus involved Members of the focus group were in fact selected from amongst those who attended one or both of the initial consultation events held in July and August 2007, which were organised to gauge opinions about the old Museum and its displays, and to share tdeas about how it could be redeveloped. ${ }^{22}$

The intial consultations proved critıcal in identifyng key explanatıons for the underuttlisation of the old Museum and how the proposed 'Discovery Centre' might be made more attractive Several innovative methods were employed to elicit views and ideas For example, 'tral's of interest', focusing on community histories and the Quay's and the Tamar Valley's Industrial pasts, were used to guide partıcıpants through prospective ideas about interactive displays and gauge responses Partıcipants were also asked to assess the exıstıng displays and models and point out how they might be improved and whether some should be elıminated; this assessment was achieved by asking people to place 'post-it' note messages anonymously on each display about which they wished to comment The content of all the 'post-it' notes was assiduously recorded, but they were then left on the displays to allow later visitors to add their own opınıons and comments Finally, a questionnaıre was circulated to ensure that all opınıons had been captured

Although disappointed by the small number of people attending the consultation events, partly explained by poor weather, key themes had nonetheless begun to emerge

- The old Museum's displays contaned far too much text

- Lighting was thought to be inadequate

- Space withın the Museum was limıted and the displays were too cramped

- The focus of the displays needed to be sharper

- The displays needed to retain (and improve) their relevance.

- Ways to engage chtldren and young people were lackıng.

- Artefacts that could be touched/handled were lackıng

- The existıng 'shıppıng office' tableau should be retained, but needed improvement.

- The old Museum had topological models, but more would be desırable. 
Following the consultation events and the gathering of this public feedback, the key player team began the redesign of the Museum. On-going input and comments from the focus group contributed at all stages of the design process.

Design companies were invited to tender and the exhibition specialists, Gamble Fearon \& Partners, were appointed. The National Trust's own labour team and a number of individuals, including electrical contractors and asbestos-removal experts, undertook much of the remodelling and refurbishment of the Museum. The review and revision of existing interpretive information within the Museum was completed by National Trust staff in partnership with the National Maritime Museum. Research was undertaken and new texts were written. These draft texts were then carefully scrutinised and reviewed by the focus group and feedback was incorporated where appropriate. Models and interactive resources were designed for incorporation in the new displays.

A diversity of opinions was expressed by members of the focus groups as the design work proceeded. For example, some members felt strongly that the newly drafted texts sacrificed too much of the important detail that had been conveyed by the displays of the old Museum, arguing that socio-cultural sustainability for particular groups was being lost as a result of the modifications. A decision was therefore taken to transcribe all the existing detailed information and to make it available in bound-volume form in the Museum for those who might be interested.

Some of the existing topological models were retained, though sometimes moved to new positions, and new ones were added to appeal to a new potential audience. Interactive features were incorporated into the design, especially aimed at children and young people. These included two replica salmon, 20-lb and $30-1 \mathrm{~b}$ in size, a wildlife activity-wall containing tactile, natural exhibits (Fig. 3), oral history listening posts, and a curtain of postcards for children to add to by drawing their favourite part of the estate.

\section{DISCOVERY CENTRE EVALUATION}

The renamed Discovery Centre was finally completed in May 2008 and officially launched at an event at the end of that month. To gauge the success of the project, it was decided by the authors of this paper that an evaluation exercise should be carried out. A questionnaire survey of visitors was therefore devised to be carried out by volunteers based at the Discovery Centre in October and November 2008. The aim of the survey was to probe views on the relevance, attractiveness and appropriateness of the Discovery Centre and to explore where respondents came from and whether they would visit the Centre again. To gauge whether the Discovery Centre had become more established, and remained socio-culturally sustainable, a further study was carried out in the summer of 2009.

In addition, a record was also kept of the number of visitors to the Discovery Centre from its opening in August until the end of October 2008 and for the eight-month opening period of 2009. Unfortunately, however, recording tended to be sporadic because the Discovery Centre is not usually staffed; frequency of observations thus depended on the availability of volunteers. However, comment cards completed by visitors in the first three-month-period augmented the questionnaire data about how the new facility was being received in the early weeks after its launch.

Estimated total numbers suggest that over 12,000 visitors came to the Discovery Centre in the first three months after its re-opening (Table 2). Unfortunately, no data exist on visitor numbers to the old Quay Museum; however, figures recorded since the redevelopment suggest a considerable improvement in interest. Set against the 15,671 visitors recorded overall at Cotehele in August 2008, the estimated 6,529 who went into the Discovery Centre represent a healthy 41.7 
The Re-development of Cotehele Quoy Museum - Transcript (awating final version)

per cent share of the tota! Visitor numbers decreased steadily from August to October reflectıng the transition from 'peak-season' to 'off-season'

Table 2 Discovery Centre visitor figures August- October 2008

August September October

\begin{tabular}{lccc}
\hline Total number of visitors recorded & 2738 & 1440 & 769 \\
Number of days recorded & 13 & 12 & 12 \\
Dally average & 211 & 120 & 64 \\
\hline Estumated visitor numbers to Cotehele for the month & 6529 & 3600 & 1987
\end{tabular}

Source Data collection carried out by National Trust volunteers

Nevertheless, an estımated monthly average of 4,039 visıtors is encouraging Indeed, over a complete eight-month season, the Trust might expect over 32,000 visitors to its Discovery Centre In fact, when these figures were revisited at the end of the opening period in 2009, it was reported that approximately 32,880 people had visited the Centre This figure indicated that, in its second year, the Discovery Centre was able to maintain the visitor numbers recorded from its initial period of opening It seems aimost certain that the Discovery Centre is attracting a greater volume of visits There is evidence therefore appeared to confirm that a socially sustannable heritage attraction had been established

For the moment, however, as the centreplece generatıng increased interest in the Quay, the riverfront area and the outer reaches of the estate, the new Discovery Centre is offering support for the economic sustannablity of Cotehele as a whole indeed, since the opening of the refurbished museum, the percentage of visitors who have ventured to the more remote parts of estate has increased For example, visitors to both the house and garden and the mill have increased from 266 per cent in 2008, to 346 per cent in 2009 These statistics suggest that signposting and transferring of visitors around the site have Improved

An analysıs of responses to the 2008 and 2009 visitor questionnarre surveys provides important clues on whether the Discovery Centre is realising its full potential It is, of course, acknowledged that further monitoring in the years ahead of visıtor numbers to the Centre, and their responses to the experience on offer, will be necessary. Such repeat surveys have the potentral to indicate the point at which the displays in the Discovery Centre might be in need of further refreshment

Questionnaire respondents were asked how much tıme they had spent in the Discovery Centre, whether they would visit again, and whether they had heard about the Centre before their arrival at Cotehele ( $\left.F_{1 g} 4\right)$. Regarding time spent, some 262 per cent of 2008 respondents stayed for 15 minutes, another 28.6 per cent reported a stay of 30 minutes; and only 72 per cent stayed longer than $\mathbf{4 0}$ minutes Those who had spent longest in the Centre tended to be visitors with children 'Explorer Families', 'Kids first Famulies, and 'Curious Minds' These findings suggest clearly that in its early weeks following the re-launch, the Centre was reaching its target audience (Explorer Families and Curıous Minds) Moreover, the 2009 survey revealed that a higher percentage of visitors had stayed at the Centre for longer perıods. Of these, 171 per cent stayed longer than 40 minutes, while some 229 per cent stayed 20 mınutes and 257 per cent stayed for 
30 minutes. The figures suggest that interest in the Centre's displays and interactive activities had increased since the site was first opened in 2008.

Asked if they would come back for another visit, 90.5 per cent of all 2008 respondents said 'yes'; the remainder said 'maybe'. In fact, all of the 'Explorer Families' said they would visit again, and 92.3 per cent of the 'Curious Minds' would also return. Some 83.9 per cent of 2009 respondents also said yes they would come back for another visit. This slight decrease in responses may reflect the fact that some of the 2009 respondents had probably already visited the Centre on more than one occasion. Thus, while the evidence suggests that socio-cultural sustainability was being achieved and, to a large extent, maintained, there is a longer-term risk that numbers may fall as return visitors feel that they have 'already seen' the Discovery Centre displays.

Of those surveyed in 2008, a quarter were aware in advance of their arrival at Cotehele of the existence of the new Discovery Centre. Amongst those responding to the repeat survey in 2009 , it was found that only 20.6 per cent claimed to have prior awareness of the Centre. While the findings in general have suggested that the new signposting within the estate is successful in drawing visitors to the quayside attraction, it seems that more effective and sustained external promotion and advertising will be needed to inform people of the Centre's existence and appeal. Indeed, this conclusion is further reinforced by visitors' answers to questions about which areas of Cotehele they were planning to visit on the day surveyed. As fig. 5 shows, the gardens, the house, and the mill were the three most-frequently mentioned attractions, and the prime motivation for the majority of visits in both 2008 and 2009.

Visitors who responded to both of the questionnaires were also asked for their views on the relevance, interest, and appropriateness of the displays in the Discovery Centre. When asked specifically about the content of the Discovery Centre in the original survey, responses were largely positive. All of those who replied agreed that the Discovery Centre contains a wide range of interesting and relevant material. Its appeal appears to have met with greatest approval amongst the 'Explorer Families' category. The 2009 survey data, which show that 94.2 per cent of respondents agreed that the Centre has a wide range of interesting, indicate that its initial appeal has continued.

Some 83 per cent of respondents from the 2008 survey agreed or strongly agreed that the interactive nature of the information had enhanced their visit. Of the remainder, all were drawn from categories of visitor that do not include children. Questions were asked to ascertain whether the quantity of information in the new Centre is too little, or too much. Although some 12.5 per cent of the 'Out and About' visitors, and 5 per cent of the 'Curious Minds', felt more information would be desirable, these percentages are relatively low and, amongst other groups, a clear majority felt that the balance was about right. The patterns of response remained the same in the 2009 survey where 81.4 per cent agreed, or strongly agreed, that the amount of information on display was about right.

2008 respondents were asked whether the Discovery Centre omitted topics that should have been included. Only those groups of visitors that do not include children gave responses which sought the inclusion of more topics. Thus, only 7.3 per cent of the 'Out and About'; and 4.9 per cent of the 'Curious Minds' said they would have liked more. A clear majority overall was happy with the coverage of topics. In 2009, this finding was replicated and 85.8 per cent of respondents were satisfied with the coverage of topics.

Opinions about whether the Discovery Centre provides a good representation of local and national heritage were also sought. Almost 93 per cent of 2008 respondents felt that local heritage was well represented, while 88.6 per cent of 2009 respondents felt the same. Regarding national heritage, 88.1 per cent of the 2008 respondents agreed or strongly agreed that it is well represented; but, in 2009 , the figure had fallen to 67.2 per cent. However, a further 24.3 per cent 
neither agreed nor disagreed with the statement, suggestıng that strong dissatısfaction remained low Previous research Iiterature points to the importance of the local community identifying with a heritage site, interpretation must appeal to both local and non-local visitors, offering a narrative whıch appeals to both groups to engender a feeling of inclusiveness ${ }^{23}$ The successful achievement of this kind of broad appeal is the key to achieving socio-cultural sustainability

The visitors responding to the 2008 questionnaire comprised 77 per cent from within Devon and Cornwall and another 5 per cent from the rest of Southwest England, 13 per cent from another part of Britain, and 5 per cent were from overseas ( $\mathrm{Fig} \mathrm{6)} \mathrm{These} \mathrm{patters} \mathrm{were} \mathrm{almost}$ exactly replicated in the 2009 questionnaire survey The data indıcate a strong local interest both in the Cotehele estate and in the new Discovery Centre There is, apparently, a sense of ownership of Cotehele's heritage amongst the residents of Devon and Cornwall Local people, of course, represent a stable source of support, even in the off-season when natıonal and international visttor levels are lower

\section{CONCLUSION}

The redevelopment of the Cotehele Quay Museum as the new Discovery Centre in August 2008 represents a model for the effective use of community and stakeholder engagement in the development of socio-culturally sustainable displayed heritage and the sustainable redevelopment of a building with associated heritage value The attitude of inclusiveness that characterised the entire process, the use of consultation events and the role of residents, regular visitors and specialists in the re-creation of the centre has resulted in a resource that, following its re-launch, had wide appeal to visitors and engendered strong support from the local community. The results of the questionnaire surveys reported in this paper indicate clearly that the Discovery Centre was being viewed by visitors as relevant, interesting, and representative of both local and national heritage Projected numbers, based on actual visitor figures (August-October 2008) suggested that the Centre would potentrally attract over 40 per cent $(30,000)$ of those who visit Cotehele durung a typical year Data from the full season in 2009 indicated that these projected numbers were not only met, but-exceeded If the forecast numbers continue to be met, the improved links between the Quay area and the rest of the estate will contınue to be strengthened Improved visitor flows around Cotehele's various attractions will undoubtedly contribute to the environmental sustarnability of Cotehele, whereby the pressure of numbers will be more effectively spread Further research and monitoring will be needed in future to test whether these conclusions remain true over a longer period of time The long-term socio-cultural sustainability of a visitor attraction is one of the greatest challenges that confront managers of heritage resources. Nevertheless, the re-makıng and reinvention of the Cotehele Quay Museum as the Discovery Centre, with its prominent emphasıs on consultation and inclusiveness, appears to have been a success story of considerable importance in the field of sustainable heritage management

\section{REFERENCES}

i National Trust, 2009. Devon and Cornwall Newsletter, Sprung, 4; National Trust, 2004. More than a canary in the mine, in http $/ /$ www.forumforthefuture org/greenfutures/ /articles 601898 (accessed: 25 January 2009); National Trust, 2006 Sustainable Hertage? in: http //www forumforthefuture org/greenfutures/articles/602482 (accessed 
25 January 2009); National Trust, 2003. Saving the energy for change, in: http://www. forumforthefuture.org/ greenfutures/articles/601579 (accessed: 25 January 2009); National Trust, 2009. Environmental Practices, in: http://www.nationaltrust.org.uk/ main/w-chl/w-countryside_environment/w-environmental_practices.htm (accessed: 19 January 2009); National Trust, 2007. Planning for a Sustainable Future, in: http://w ww.nationaltrust.org.uk/main/w-pwp-0807.pdf (downloaded: 19 January 2009).

2. Leask, A. and Yeoman, I., 1999. Heritage visitor attractions: an operations management perspective (Casell, London); Drummond, S and Yeoman, I., 2003.Quality issues in heritage visitor attractions (Butterworth-Heinemann, Oxford).

3. Cheung, S., 1999. The Meanings of a Heritage Trail in Hong Kong. Annals of Tourism Research, 26, 3, 570-88; Hale, A., 2001. Representing the Cornish: contesting heritage interpretation in Conrwall. Tourist Studies, 1 , 2, 185-96; Palmer, C., 2003. Touring Churchill's England: Rituals of Kingship and Belonging. Annals of Tourism Research, 30, 2, 426-45; Pretes, M., 2002. Touring Mines and Mining Tourists. Annals of Tourism Research, 29, 2, 439-56; Fotsch, P. M., 2004. Tourism's Uneven Impact: History on Cannery Row. Annals of Tourism Research, 31, 4, 779 800; Uriely, N., Israeli, A. and Reichel, A., 2002. Research Notes: Heritage Proximity and Resident Attitudes Toward Tourism Development. Annals of Tourism Research, 29, 3, 859-62.

${ }^{4}$. Fyall, A., Garrod, B. and Leask, A., 2003. Managing visitor attractions: New directions (Butterworth-Heinemann, Oxford).

5. Pretes, op. cit., 439; Palmer, op. cit., 426; Fotch, op. cit., 779; Uriely, op. cit., 859.

6. Moscardo, G., 1996. Mindful Visitors: Heritage and Tourism. Annals of Tourism Research, 23, 2, 376-97; Pretes, op. cit., 439-56; Palmer, op. cit., 426.

7. Moscardo, op. cit., 376; Plog, S., 1990. Vacation Places Rated (Fielding Worldwide, Redondo Beach, California); Fotch, op. cit., 779; Pretes, op. cit., 439; Uriely, op. cit., 859-62; Hale, op. cit., 185-90; Cheung, op. cit., 570-88.

8. Hale, op. cit., 185-96; Cheung, op.cit., 570-75.

9 Leask, op cit.

${ }^{10}$. Drummond, op. cit., 1.

${ }^{11}$. Miller, G., 2001. Corporate responsibility in the UK tourism industry, Tourism Management, 22, 589-98; Swarbrooke, J., 1995. The Development and Management of Visitor Attractions (Butterworth-Heinemann, Oxford).

${ }^{12}$. National Trust, 2009. Environmental Practices, in: http://www.nationaltrust.org.uk/ main/w-chl/w-countryside_environment/w-environmental_practices.htm (accessed: 19 January 2009).

${ }^{13}$. National Trust, 2009. The Charity: The History of the Trust, in: http://www.national trust.org.uk/main/w-trust/w-thecharity/w-history_trust.htm (accessed: 19 January 2009).

${ }^{14}$. ibid.

${ }^{15}$. National Trust, 2001. Rural Sustainability: A rural policy framework, in: http://www. national trust.org.uk/main/w-rural01.pdf (downloaded: 19 January 2009).

${ }^{16}$. HMSO., 2007. Heritage White Paper (the consultation formed the basis of a White Paper).

${ }^{17}$. National Trust., 2006. Trust You, Newsletter, September, 4-5.

${ }^{18}$.ibid., 2.

${ }^{19}$. ibid.

${ }^{20}$. ibid.

21 . ibid. 
${ }^{22}$. These events took place on a weekday evening and during the day of a weekend in July 2007.

${ }^{23}$. Hale, op. cit., 190; 195-6.

\section{List of Captions}

Figure 1. The Cotehele Estate from the air (source: courtesy of Barry Gamble).

Figure 2. The Quay Museum building, Cotehele estate (source: National Trust, 2007).

Figure 3: A plan of the proposed wildlife activity wall used in the Discovery Centre design process, now installed in the Discovery Centre (source: National Trust 2008. Original design produced by Colin Fearon).

Figure. 4. Responses to the Visitor Participation Survey: prior knowledge of the new Discovery Centre by different Trust visitor groups.

Figure 5. Cotehele attractions that respondents planned to visit (data from both the 2008 and 2009 surveys).

Figure 6. The origins of the 2008 survey respondents.

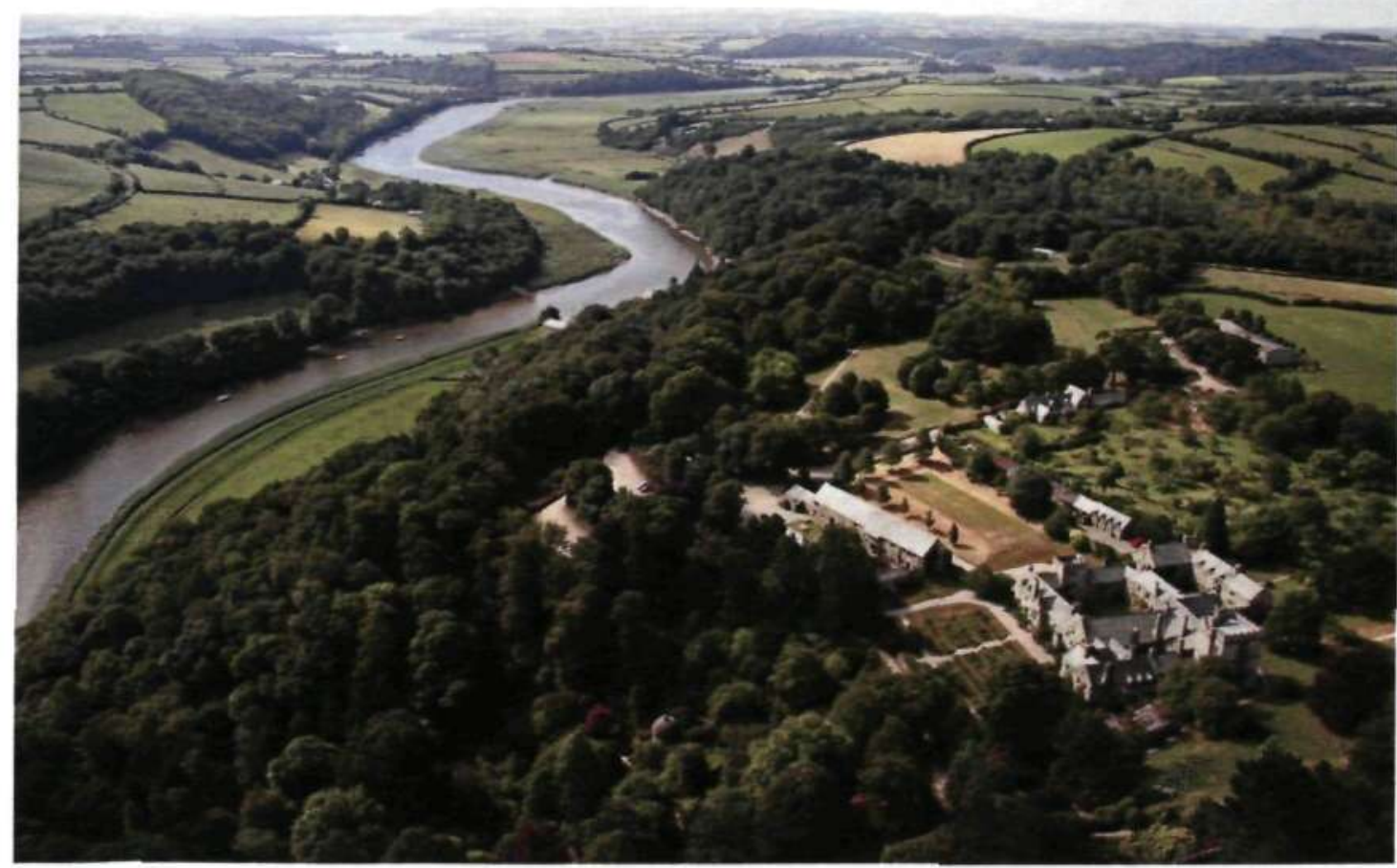

Figure 1 


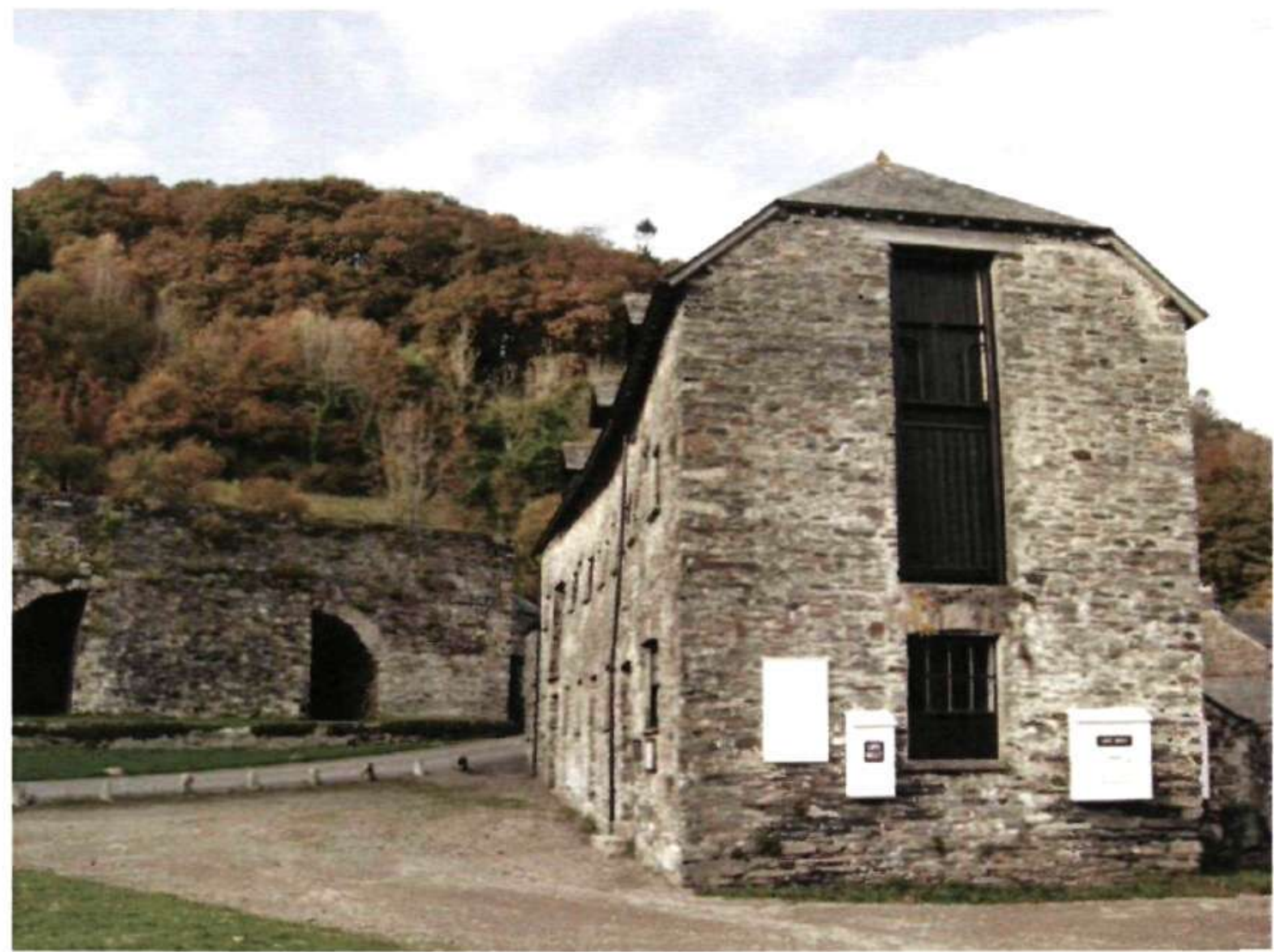

Figure 2 
The Re-development of Cotehele Quay Museum - Transcript (awaiting final version)

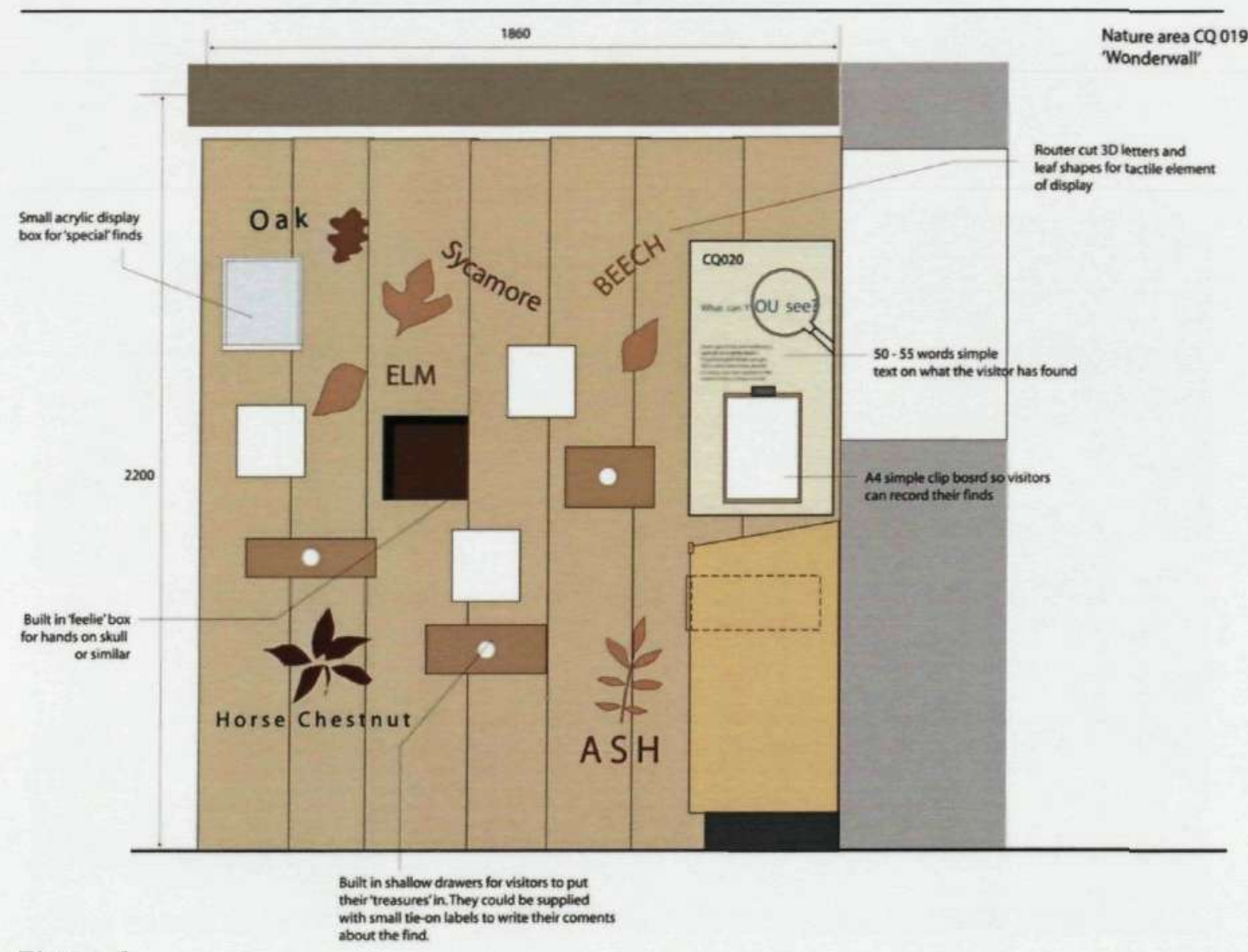

Figure 3

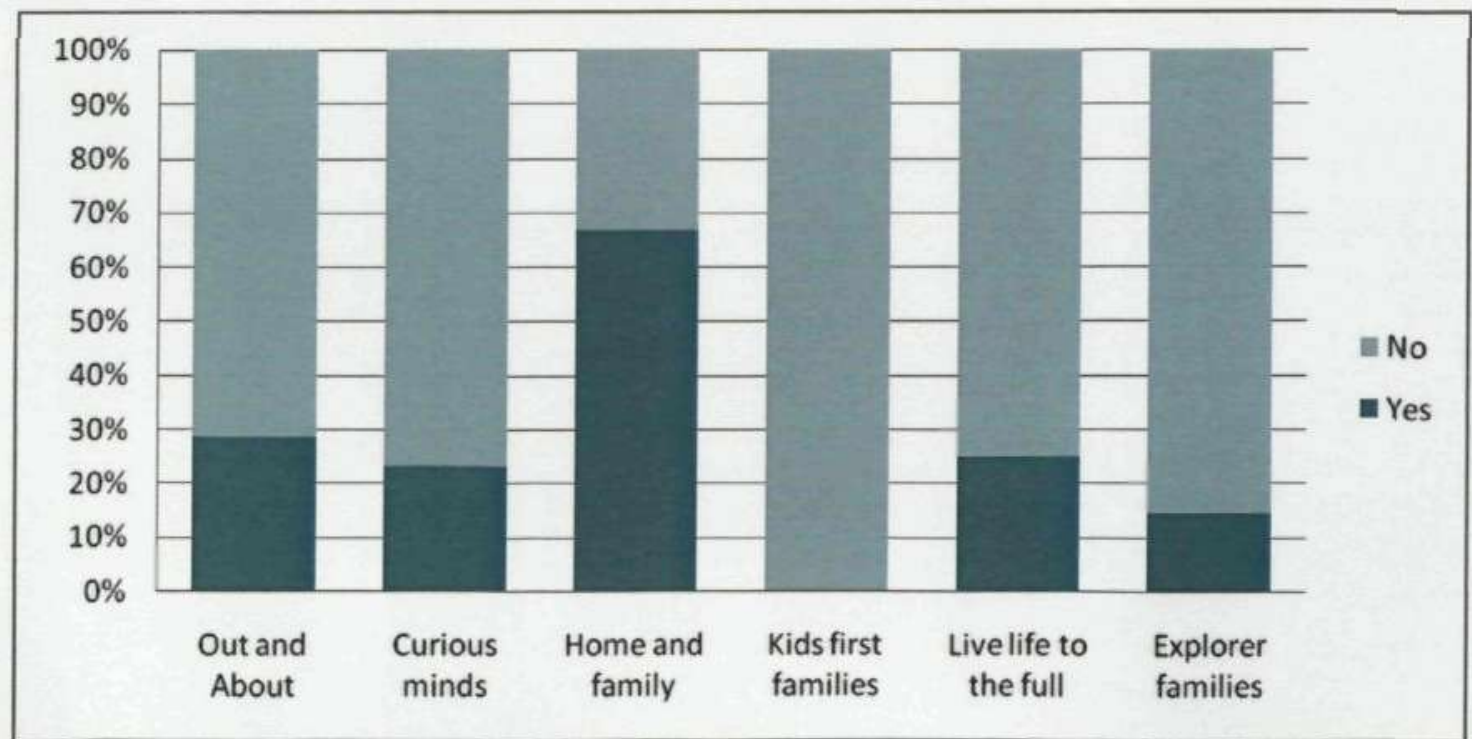

Figure 4 
The Re-development of Cotehele Quay Museum - Transcript (awaiting final version)

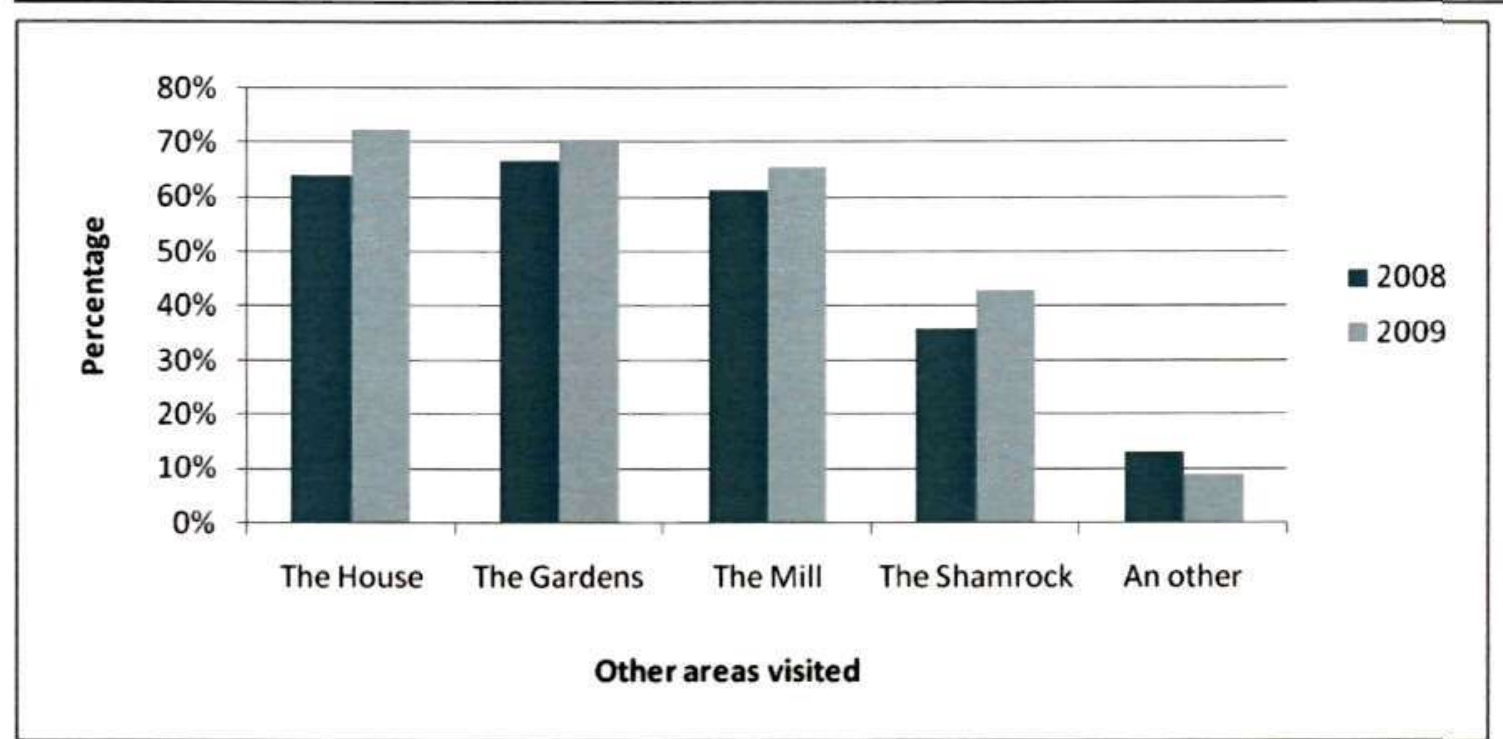

Figure 5

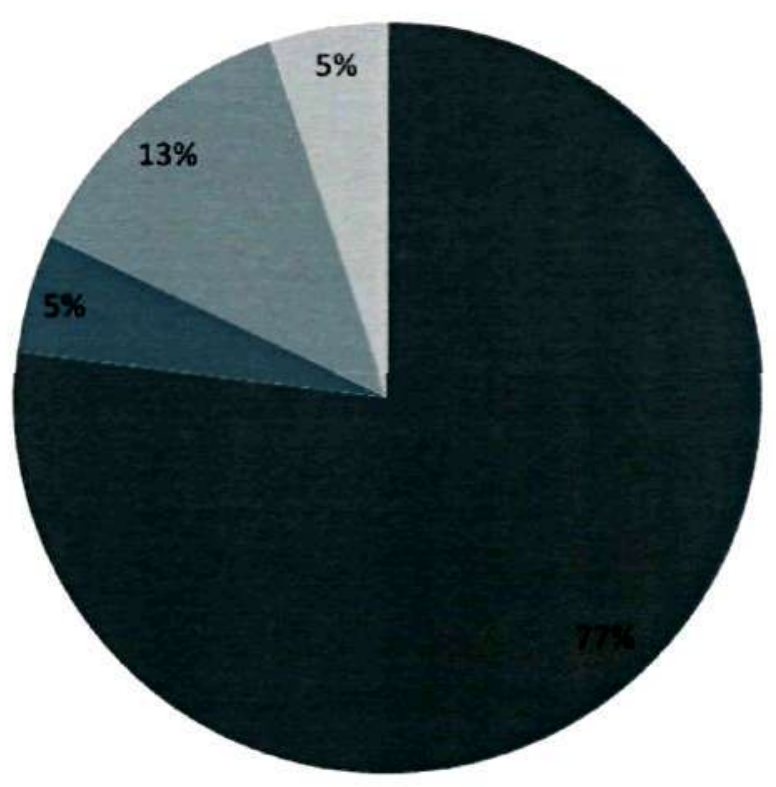

- Locally (Devon and Cornwall)

- Regionally (elsewhere in Southwest)

Nationally (Elsewhere in Britain)

= Internationally (outside UK)

Figure 6 